\title{
THERMAL NUMERICAL ANALYSIS OF VERTICAL HEAT EXTRACTION SYSTEMS IN LANDFILLS
}

\author{
A Thesis \\ presented to \\ the Faculty of California Polytechnic State University, \\ San Luis Obispo \\ In Partial Fulfillment \\ of the Requirements for the Degree \\ Master of Science in Civil and Environmental Engineering \\ by \\ Michael T. Onnen \\ June 2014
}


(C) 2014

Michael T. Onnen

ALL RIGHTS RESERVED 
COMMITTEE MEMBERSHIP

TITLE:

Thermal Numerical Analysis of Vertical Heat

Extraction Systems in Landfills

AUTHOR:

Michael T. Onnen

DATE SUBMITTED: June 2014

COMMITTEE CHAIR: James Hanson, Ph.D., PE

Professor of Civil and Environmental Engineering

COMMITTEE MEMBER: Nazli Yesiller, Ph.D.

Director of Global Waste Research Institute

COMMITTEE MEMBER: Garett Hall, Ph.D., PE

Professor of Civil and Environmental Engineering 


\section{ABSTRACT}

Thermal Numerical Analysis of Vertical Heat Extraction Systems in Landfills

\section{Michael T. Onnen}

An investigation was conducted to determine the response of landfills to the operation of a vertical ground source heat pump (i.e., heat extraction system, HES). Elevated landfill temperatures, reported various researchers, impact the engineering performance of landfill systems. A numerical model was developed to analyze the influence of vertical HES operation on landfills as a function of climate and operational conditions.

A 1-D model of the vertical profile of a landfill was developed to approximate fluid temperatures in the HES. A 2-D model was then analyzed over a 40 year time period using the approximate fluid temperatures to determine the heat flux applied by the HES and resulting landfill temperatures. Vertical HES configurations simulations consisted of 15 simulations varying 5 fluid velocities and 3 pipe sizes. Operational simulations consisted of 26 parametric evaluations of waste placement, waste height, waste filling rate, vertical landfill expansions, HES placement time, climate, and waste heating.

Vertical HES operation in a landfill environment was determined to have 3 phases: heat extraction phase, transitional phase, and ground source heat pump phase. During the heat extraction phase, the heat extraction rate ranged from 0 to 2550,310 to 3080 , and 0 to $530 \mathrm{~W}$ for the first year, peak year, and last year of HES operation, respectively. The maximum total heat energy extracted during the heat extraction phase ranged from 163,000 to $1,400,000$ MJ. The maximum 
difference in baseline landfill temperatures and temperatures $0 \mathrm{~m}$ away from the HES ranged from 5.2 to $43.2^{\circ} \mathrm{C}$. Climate was determined to be the most significant factor impacting the vertical HES.

Trends pertaining to performance of numerous variables (fluid velocity, pipe size, waste placement, waste height, waste filling rate, vertical landfill expansions, HES placement time, climate, and waste heating) were determined during this investigation. Increasing fluid velocity until turbulent flow was reached increased the heat extraction rate by the system. Once turbulent flow was reached, the increase in heat extraction rate with increasing fluid velocity was negligible. An increase in the heat extraction rate was caused by increasing pipe diameter. Wastes placed in warmer months caused an increase in the total heat energy extracted. Increasing waste height caused an increase in the peak heat extraction rate by $43 \mathrm{~W} / \mathrm{m}$ waste height. Optimum heat extraction per $1 \mathrm{~m}$ of HES occurred for a $30 \mathrm{~m}$ waste height. Increasing the waste filling rate increased the total heat energy extracted. Heat extraction rates decreased as time between vertical landfill expansions increase. Total heat energy extracted over a 35 year period decreased by approximately $21,500 \mathrm{MJ} /$ year for every year after the final cover was placed until HES operation began. For seasonal HES operation, the total heat energy obtained each year differs and the fourth year of operation yielded the most energy. Wet Climates with higher heat generating capacities yielded increased heat extraction rates. Maximum temperature differences in the landfill due to the HES increased by $16.6^{\circ} \mathrm{C}$ for every $1 \mathrm{~W} / \mathrm{m}^{3}$ 
increase in peak heat generation rate. When a vertical HES was used for waste heating, up to a $13.7 \%$ increase in methane production was predicted.

Engineering considerations (spacing, financial impact, and effect on gas production) for implementing a vertical HES in a landfill were investigated. Spacing requirements between the wells were dependent on maximum temperature differences in the landfill. Spacing requirements of 12, 12, 16, and $22 \mathrm{~m}$ are recommended for waste heating, winter-only HES operation, maximum temperature differences in the landfill less than $17^{\circ} \mathrm{C}$, and maximum temperature differences in the landfill greater than $17^{\circ} \mathrm{C}$, respectively. A financial analysis was conducted on the cost of implementing a single vertical HES well. The energy extracted per cost ranged from 0.227 to $0.150 \$ / \mathrm{MJ}$ for a $50.8 \mathrm{~mm}$ pipe with a $1.0 \mathrm{~m} / \mathrm{s}$ fluid velocity and a $50.8 \mathrm{~mm}$ pipe with a $0.3 \mathrm{~m} / \mathrm{s}$ fluid velocity, respectively. A vertical HES could potentially increase revenue from a typical landfill gas energy project by $\$ 577,000$ per year. 


\section{ACKNOWLEDGMENTS}

I would like to thank my advisor, Dr. Jim Hanson, for his countless hours devoted to providing guidance and advice throughout this research project. I would also like to thank Dr. Garrett Hall for his guidance on numerical modeling and his time and resources running my simulations. I would like to thank Dr. Nazli Yesiller and Dr. Garett Hall for serving on my thesis committee. I would like to thank Kevin Kopp for his contributions to this research during his participation in the National Science Foundation REU site at Cal Poly. This work would not be possible without the previous work of Wei-Lien Liu, Nicolas Oettle, and Janelle Marinos. I would also like to thank the Global Waste Research Institute for their support of my education. I would like thank my parents for their support of me through my education. I would also like to thank Sophya Lim for her support throughout the process. 


\section{TABLE OF CONTENTS}

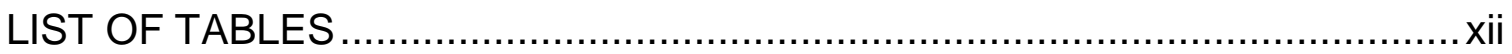

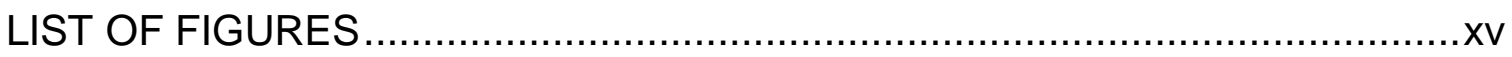

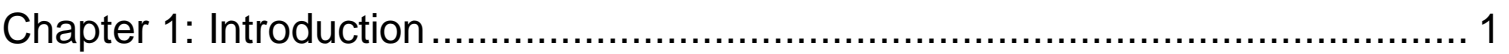

Chapter 2: Literature Review ................................................................. 4

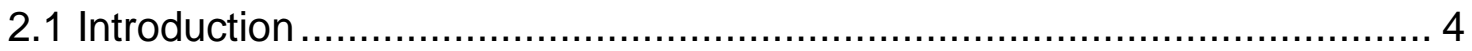

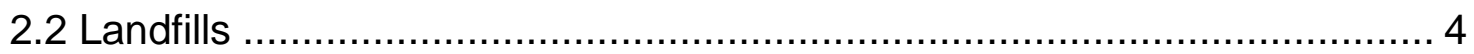

2.2.2 Landfill Containment Systems …................................................. 4

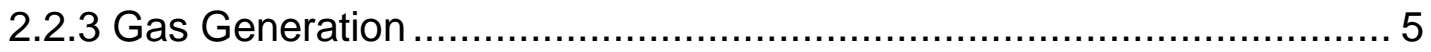

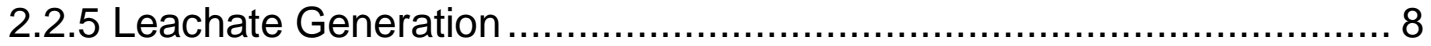

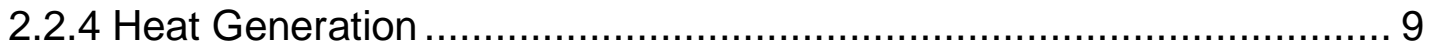

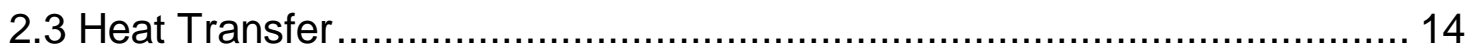

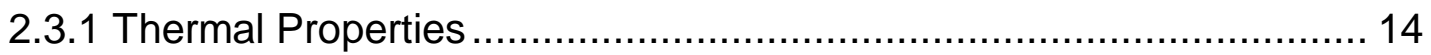

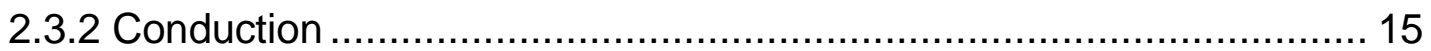

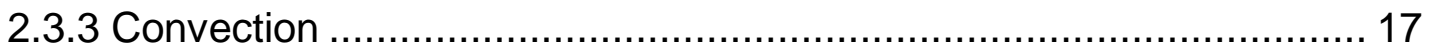

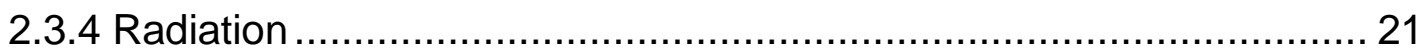

2.4 Finite Element Analysis of Conductive Heat Transfer............................. 23

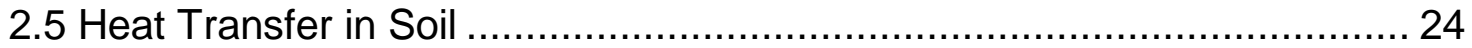

2.5.1 Ground Surface Heat Transfer .............................................. 25

2.5.2 Near Surface Ground Temperatures ......................................... 28 


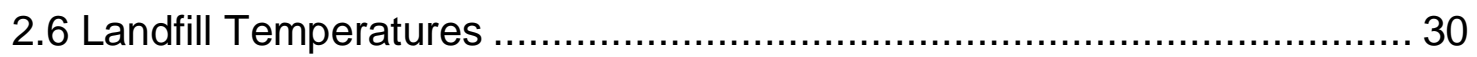

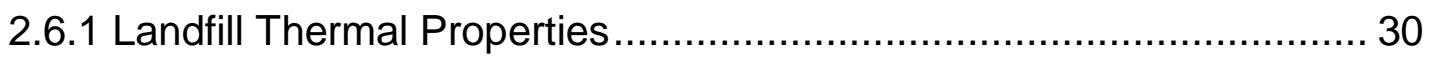

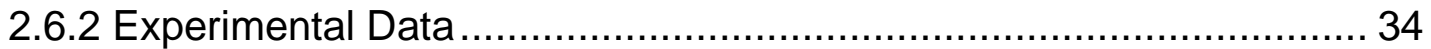

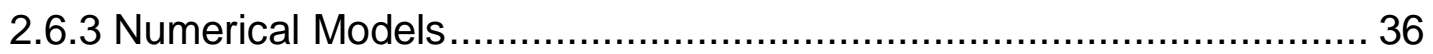

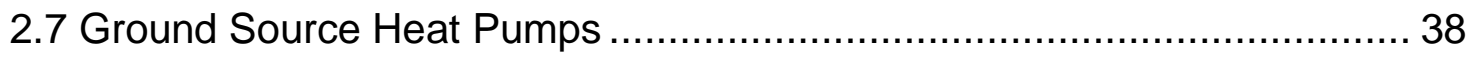

2.7.1 Ground Source Heat Pump Configurations.................................... 39

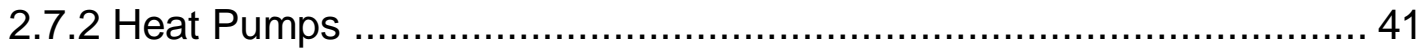

2.7.3 Seasonal Heat Storage ......................................................... 42

2.7.4 Ground Source Heat Pump Efficiency ......................................... 42

2.8 Ground Heat Exchanger Analytical Models ......................................... 46

2.8.1 Kelvin Line Source Theory …................................................... 46

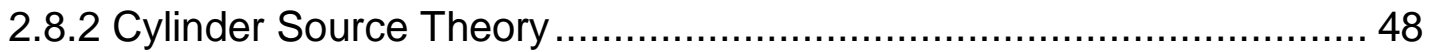

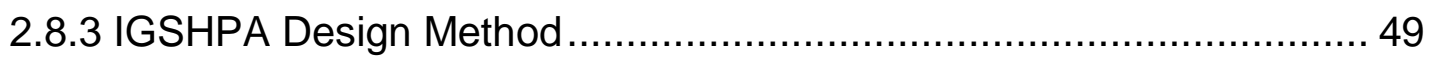

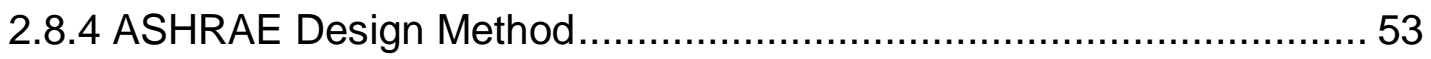

2.9 Ground Heat Exchanger Numerical Models ........................................ 54

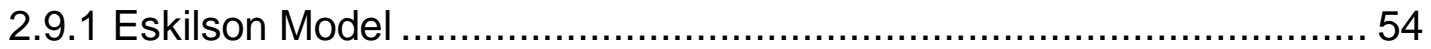

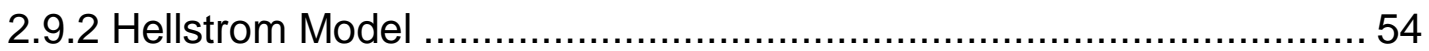

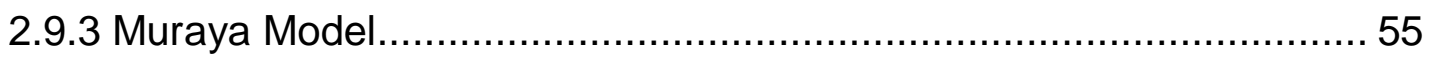

2.9.4 Rottmayer, Beckman and Mitchell Model....................................... 56

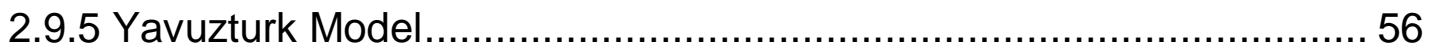




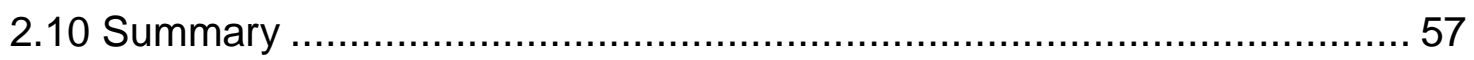

Chapter 3: Numerical Modeling Methodology ............................................... 59

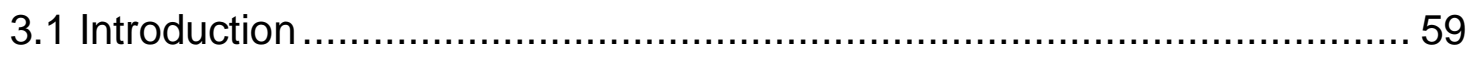

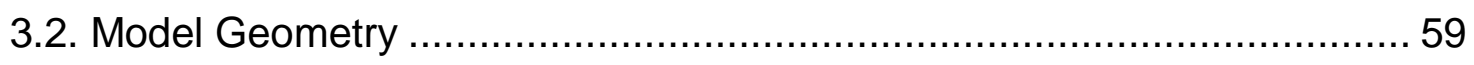

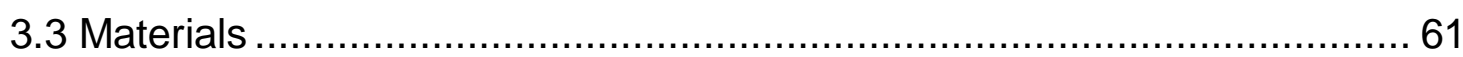

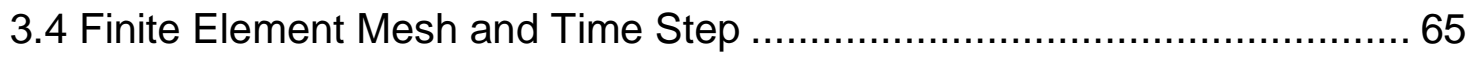

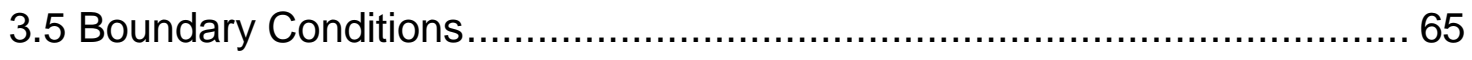

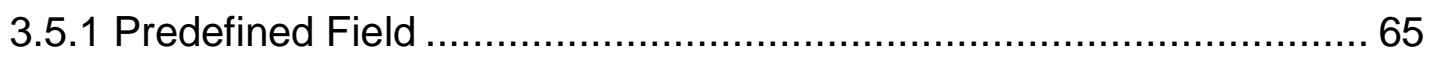

3.5.2 Ground Surface and Far Field Boundary Conditions .......................66 66

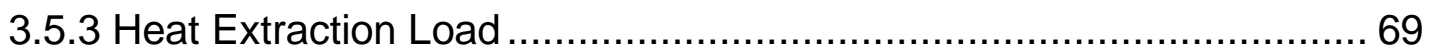

3.6 Heat Extraction Test Program ……............................................. 75

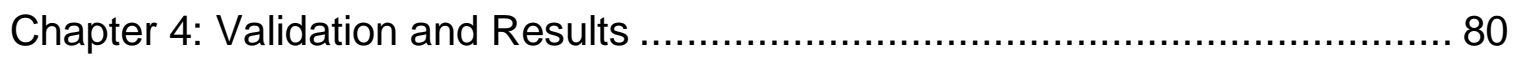

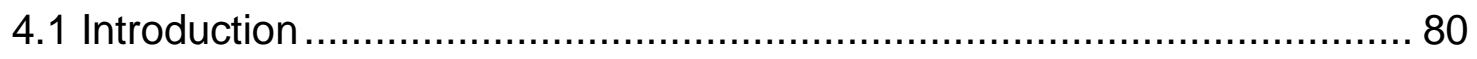

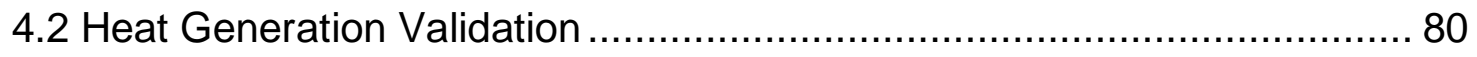

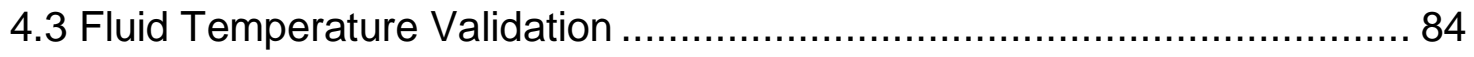

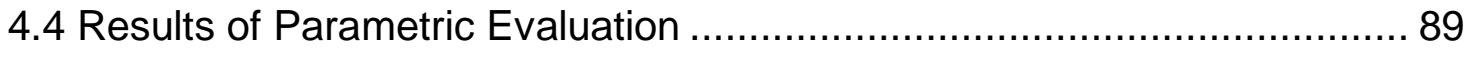

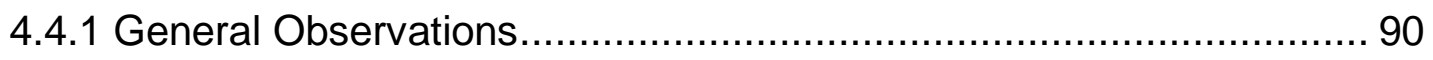

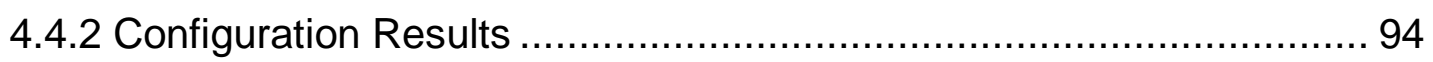

4.4.3 Year-Round Waste Placement Results ...................................... 106 
4.4.4 Seasonal Waste Placement Results

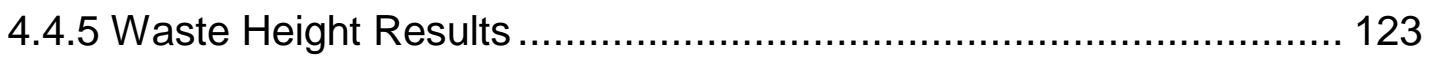

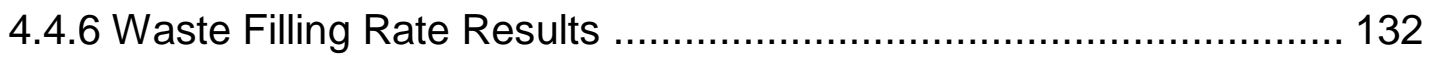

4.4.7 Vertical Landfill Expansion Results ............................................. 140

4.4.8 HES Placement Time Results ................................................ 149

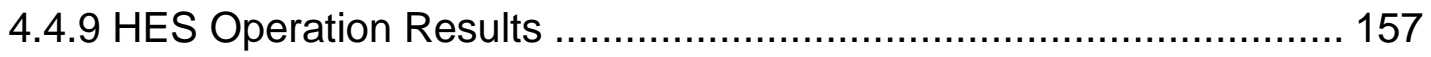

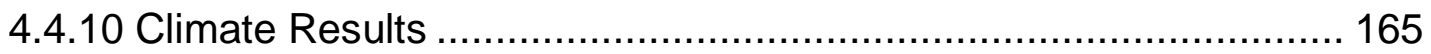

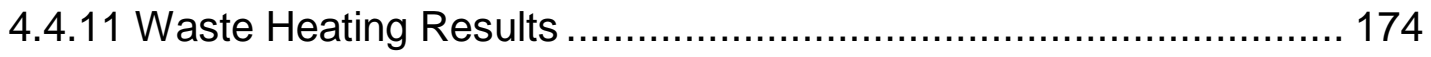

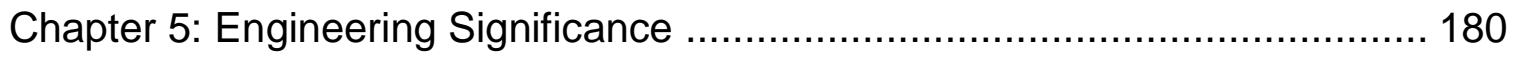

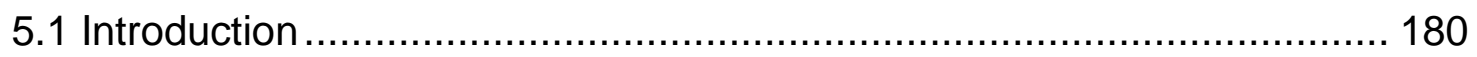

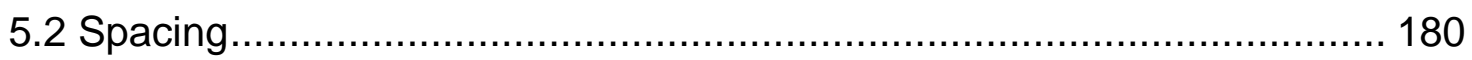

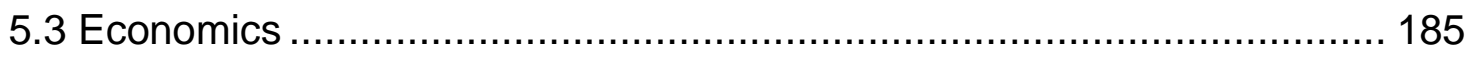

5.4 HES Effect on Gas Production .................................................... 189

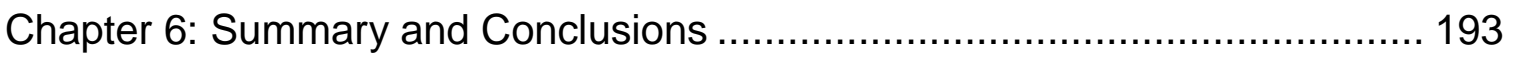

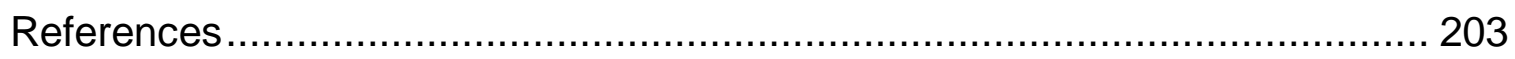

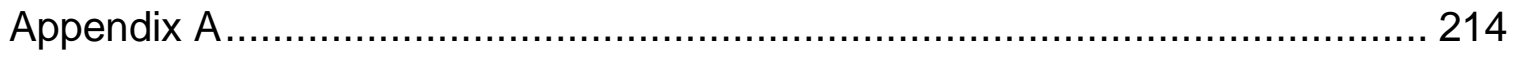




\section{LIST OF TABLES}

2.1 Heat Generation Potential of Waste .............................................. 11

2.2 Summary of Pipe Flow Forced Convection Relationships ..................... 20

2.3 Ground Surface Temperature Parameters ........................................ 28

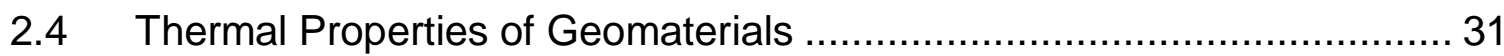

2.5 Soil Thermal Properties Determined by Liu (2007) .............................. 32

2.6 Waste Thermal Properties …………….......................................... 34

3.1 Thermal Properties of Materials Used in the Model............................... 62

3.2 Heat Generation Factors for Sites Used in Modeling ............................ 64

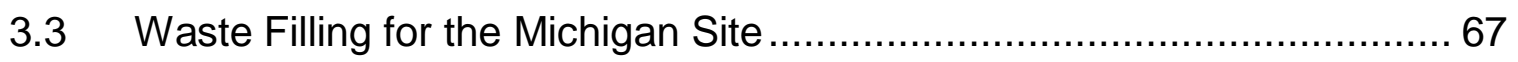

3.4 Ground Surface Temperature Parameters and Mean Annual Earth

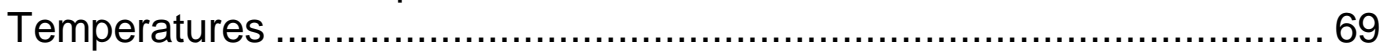

3.5 Properties of the Circulation Fluid and Water..................................... 70

3.6 Configuration Simulations ….......................................................... 77

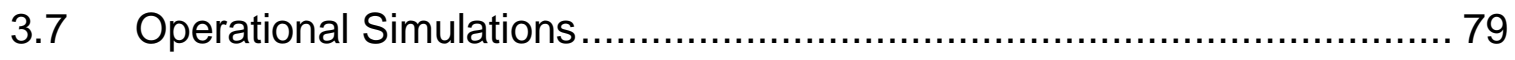

4.1 Convective Heat Transfer Results .................................................... 91

4.2 Temperature Results for Different Configurations $0 \mathrm{~m}$ away from the

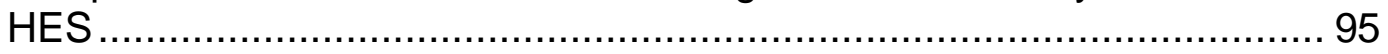

4.3 Heat Extraction Configuration Results ............................................. 99

4.4 Expected Range of Heat Extraction Rates for Configuration Simulations ................................................................................. 100

4.5 Peak Baseline Temperatures at Locations for Different Waste Placement Start Months............................................................... 107

4.6 Temperature Results for Different Waste Placement Start Months

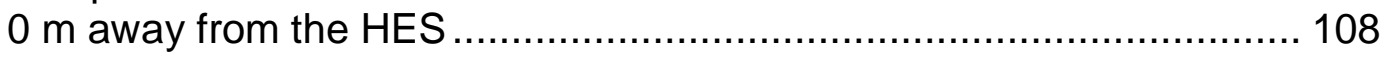

4.7 Year-Round Waste Placement Heat Extraction Results ....................... 113 
4.8 Expected Range of Heat Extraction Rates for Year-Round Waste

Placement Simulations

4.9 Peak Baseline Temperatures at Locations for Different Seasonal Waste Placements

4.10 Temperature Results for Different Seasonal Waste Placements $0 \mathrm{~m}$ away from the HES.

4.11 Seasonal Waste Placement Heat Extraction Results.

4.12 Expected Range of Heat Extraction Rates for Seasonal Waste

Placement Simulations

4.13 Peak Baseline Temperatures at Locations for Different Waste Heights

4.14 Temperature Results for Different Waste Heights $0 \mathrm{~m}$ away from the HES

4.15 Waste Height Heat Extraction Results 128

4.16 Expected Range of Heat Extraction Rates for Waste Height Simulations

4.17 Peak Baseline Temperatures at Locations for Different Waste Filling Rates

4.18 Temperature Results for Different Waste Filling Rates $0 \mathrm{~m}$ away from the HES

4.19 Waste Filling Rate Heat Extraction Results ..................................... 137

4.20 Expected Range of Heat Extraction Rates for Waste Filling Rate Simulations

4.21 Peak Baseline Temperatures at Locations for Different Vertical Landfill Expansions

4.22 Temperature Results for Different Timing of Vertical Landfill Expansions $0 \mathrm{~m}$ away from the HES

4.23 Vertical Landfill Expansion Heat Extraction Results ........................... 146

4.24 Expected Range of Heat Extraction Rates for Vertical Landfill Expansion Simulations

4.25 Peak Baseline Temperatures at Locations for Different HES

Placement Times 
4.26 Temperature Results for Different HES Placement Times $0 \mathrm{~m}$ away

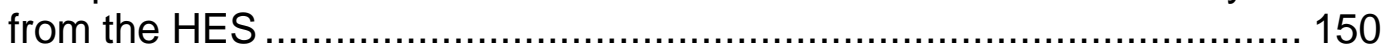

4.27 HES Placement Time Heat Extraction Results.................................. 154

4.28 Expected Range of Heat Extraction Rates for HES Placement Time

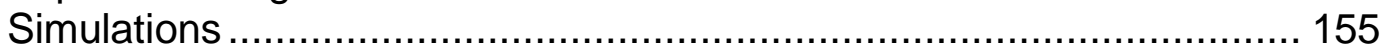

4.29 HES Operation Heat Extraction Results........................................... 162

4.30 Expected Range of Heat Extraction Rates for HES Operation Simulations 163

4.31 Peak Baseline Temperatures at Locations for Different Climates.......... 166

4.32 Temperature Results for Variable Climates $0 \mathrm{~m}$ away from the HES .... 166

4.33 Climate Heat Extraction Results ………...................................... 171

4.34 Expected Range of Heat Extraction Rates for Climate Simulations....... 172

5.1 Pipe Diameter and Fluid Velocity Simulations Zone of Influence Results 182

5.2 Operational Simulations Zone of Influence Results............................ 184

5.3 Costs of Components for a Single Vertical HES Well.......................... 186

5.4 Costs for Pipe Diameter and Fluid Velocity Simulations ...................... 188 


\section{LIST OF FIGURES}

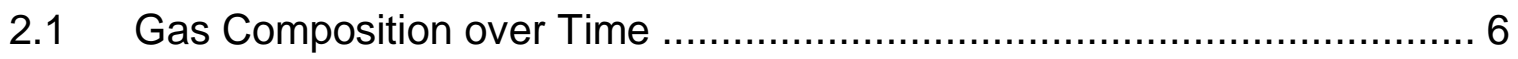

$2.2 \quad$ Heat Generation Function .................................................................... 13

2.3 Temperature Dependence of Heat Generation ................................... 14

2.4 Ground Surface Temperature Phase Lag ....................................... 27

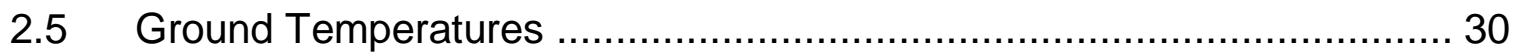

2.6 Temperature Variation with Depth ................................................ 36

2.7 Ground Source Heat Pump System ............................................... 40

2.8 Schematic of Modeled Ground Source Heat Pump.............................. 45

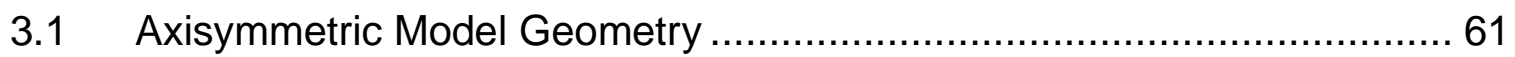

3.2 Heat Generation Function Dependent on Time and Temperature.......... 64

3.3 Schematic of Axisymmetric Model Boundary Conditions and Loads ....... 75

4.1 Heat Generation Functions for Michigan Cell B and Cell D .................. 81

4.2 Comparison of Predicted and Measured Temperatures at Michigan

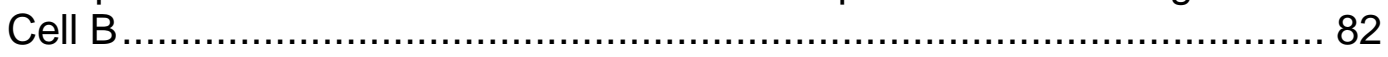

4.3 Comparison of Predicted and Measured Temperatures at Michigan

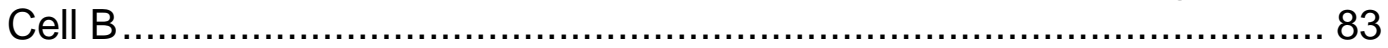

4.4 Example Minimum Fluid Temperatures........................................... 84

4.5 Example Maximum Fluid Temperatures......................................... 85

4.6 Change in Temperature over Time Due to Heat Generation .................. 86

4.7 Heat Extraction Rates at Different Weighted Averages

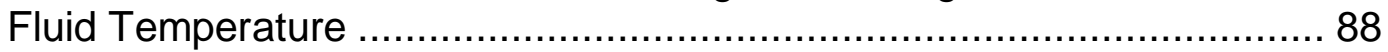

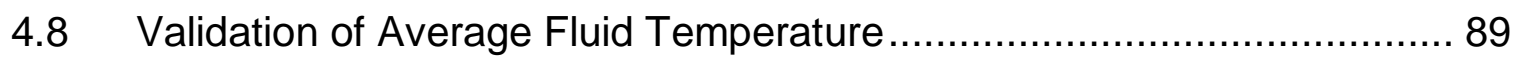

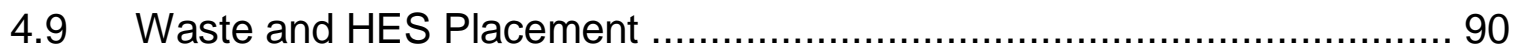


4.10 Radial Temperatures Away from HES . 92

4.11 Temperature Results: $25.4 \mathrm{~mm}$ Diameter Pipe $0.3 \mathrm{~m} / \mathrm{s}$ Fluid Velocity (Template Landfill Model)

4.12 Vertical Temperature Results: $25.4 \mathrm{~mm}$ Diameter Pipe $0.3 \mathrm{~m} / \mathrm{s}$ Fluid Velocity (Template Landfill Model)

4.13 Heat Extraction Rates from 25.4 mm Diameter Pipe at Various Fluid Velocities

4.14 Annual Average Heat Extraction Rates from 25.4 mm Diameter Pipe at Various Fluid Velocities 101

4.15 Heat Extraction Rates from $38.1 \mathrm{~mm}$ Pipe at Various Fluid Velocities .. 102

4.16 Annual Average Heat Extraction Rates from $38.1 \mathrm{~mm}$ Diameter Pipe at Various Fluid Velocities. 102

4.17 Heat Extraction Rates from 50.8 mm Diameter Pipe at Various Fluid Velocities 103

4.18 Annual Average Heat Extraction Rates from 50.8 mm Diameter Pipe at Various Fluid Velocities 103

4.19 Heat Extraction Rates with Fluid Velocity for Various Pipe Sizes 104

4.20 Annual Average Heat Extraction Rates with Fluid Velocity for Various Pipe Sizes. 104

4.21 Impact of Fluid Velocity on Peak Heat Extraction Rates .................... 106

4.22 Impact of Pipe diameter on Peak Heat Extraction Rates..................... 106

4.23 Temperature Results: Year-Round Waste Placement June Start......... 110

4.24 Vertical Temperature Results: Year-Round Waste Placement June Start.

4.25 Heat Extraction Rates for Year-Round Waste Placement Starting on Different Months

4.26 Annual Average Heat Extraction Rates for Year-Round Waste Placement Starting on Different Months 
4.27 Annual Average Heat Extraction Rates for Year-Round Waste

Placement Starting on Different Months.

4.28 Impact of Year-Round Waste Placement Time on Maximum

Temperature Difference

4.29 Temperature Results: Summer-Only Waste Placement..................... 119

4.30 Vertical Temperature Results: Summer-Only Waste Placement .......... 120

4.31 Heat Extraction Rates for Seasonal Waste Placement ...................... 122

4.32 Annual Average Heat Extraction Rates for Seasonal Waste

Placement.

4.33 Temperature Results: 45 m Waste Height ...................................... 126

4.34 Vertical Temperature Results: 45 m Waste Height ........................... 127

4.35 Heat Extraction Rates for Different Waste Heights ............................. 129

4.36 Annual Average Heat Extraction Rates for Different Waste Heights .... 130

4.37 Effect of Waste Height on Peak Heat Extraction Rate........................ 131

4.38 Peak Heat Extraction Rate for 1 m Length of HES ............................ 131

4.39 Temperature Results: 5 m/year Waste Filling Rate ........................... 135

4.40 Vertical Temperature Results: 5 m/year Waste Filling Rate ................. 136

4.41 Heat Extraction Rates for Different Waste Filling Rates ...................... 138

4.42 Annual Average Heat Extraction Rates for Different Waste Filling

Rates

4.43 Effect of Waste Filling Rate on Total Heat Energy Extracted ............... 140

4.44 Schematic of Vertical Landfill Extraction Simulations ......................... 141

4.45 Temperature Results: 5 Years between Original Waste Placement

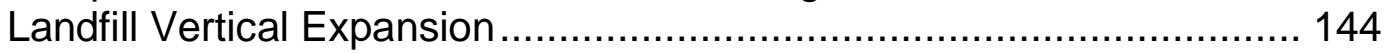

4.46 Vertical Temperature Results: 5 Years between Original Waste

Placement and Landfill Vertical Expansion 
4.47 Heat Extraction Rates for Vertical Landfill Expansions. 147

4.48 Annual Average Heat Extraction Rates for Vertical Landfill Expansions

4.49 Effect of Vertical Landfill Expansions on Peak Heat Extraction 149

4.50 Temperature Results: HES Placement 1 year after Cover Construction

4.51 Vertical Temperature Results: HES Placement 1 year after Cover Construction 153

4.52 Heat Extraction Rates for Different HES Placement Times ................. 155

4.53 Annual Average Heat Extraction Rates for Different HES Placement Times. 156

4.54 Effect of HES Placement Time on Total Heat Energy Extracted ........... 157

4.55 Temperature Results: Winter-Only HES Operation ............................ 160

4.56 Vertical Temperature Results: Winter-Only HES .............................. 161

4.57 Heat Extraction Rates for Different HES Operational Times ................ 163

4.58 Temperatures over a 1 Year Time Period .......................................... 164

4.59 Heat Extraction Rates over a 1 Year Time Period............................... 165

4.60 Total Heat Energy Extracted for Each Year after HES Placement ........ 165

4.61 Temperature Results: British Columbia Climate................................ 169

4.62 Vertical Temperature Results: British Columbia Climate ..................... 170

4.63 Heat Extraction Rates for Different Climates.................................... 172

4.64 Annual Average Heat Extraction Rates for Different Climates.............. 173

4.65 Effect of Heat Generation Rate on the Maximum Temperature Difference.....

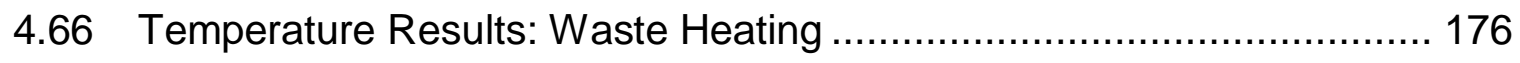

4.67 Vertical Temperature Results: Waste Heating …............................... 177 
4.68 Heat Extraction Rates during Waste Heating .................................. 178

4.69 Annual Average Heat Extraction Rates during Waste Heating .............. 179

5.1 Horizontal Spacing Configurations ....................................................... 180

5.2 Impact of Fluid Velocity on Cost Effectiveness of an HES for Different

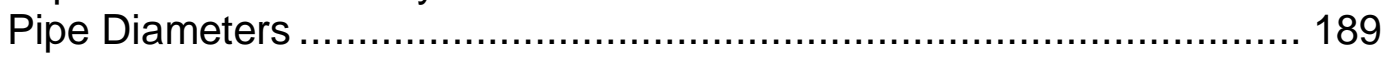

5.3 Impact of Pipe Diameter on Cost Effectiveness of an HES for Different

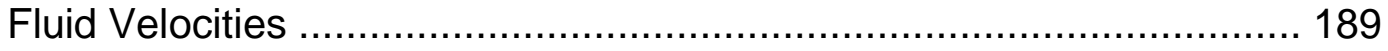

$5.4 \quad$ Increase in Gas Production Due to Waste Heating ............................. 191

A.1 Temperature Results: $25.4 \mathrm{~mm}$ Diameter Pipe $0.01 \mathrm{~m} / \mathrm{s}$ Fluid Velocity. 214

A.2 Vertical Temperature Results: $25.4 \mathrm{~mm}$ Diameter Pipe $0.01 \mathrm{~m} / \mathrm{s}$ Fluid

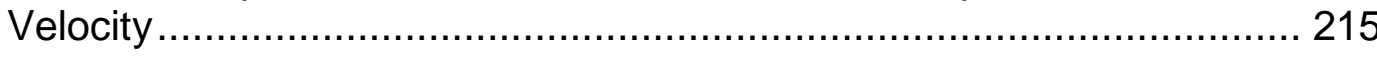

A.3 Temperature Results: $25.4 \mathrm{~mm}$ Diameter Pipe $0.1 \mathrm{~m} / \mathrm{s}$ Fluid Velocity... 216

A.4 Vertical Temperature Results: $25.4 \mathrm{~mm}$ Diameter Pipe $0.1 \mathrm{~m} / \mathrm{s}$ Fluid

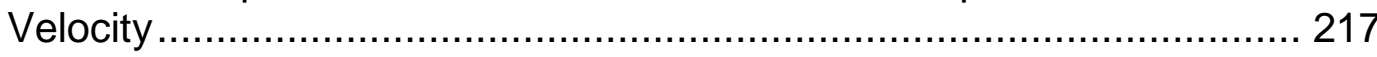

A.5 Temperature Results: 25.4 mm Diameter Pipe 0.6 m/s Fluid Velocity... 218

A.6 Vertical Temperature Results: $25.4 \mathrm{~mm}$ Diameter Pipe $0.6 \mathrm{~m} / \mathrm{s}$ Fluid

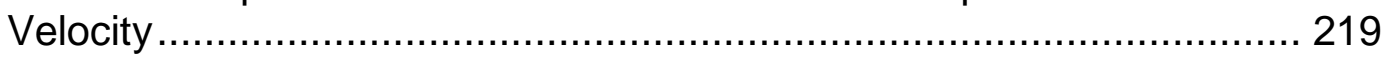

A.7 Temperature Results: 25.4 mm Diameter Pipe 1.0 m/s Fluid Velocity ... 220

A.8 Vertical Temperature Results: $25.4 \mathrm{~mm}$ Diameter Pipe $1.0 \mathrm{~m} / \mathrm{s}$ Fluid

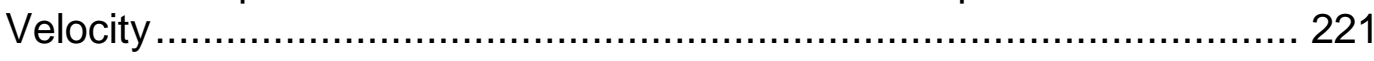

A.9 Temperature Results: $38.1 \mathrm{~mm}$ Diameter Pipe $0.01 \mathrm{~m} / \mathrm{s}$ Fluid Velocity. 222

A.10 Vertical Temperature Results: $38.1 \mathrm{~mm}$ Diameter Pipe $0.01 \mathrm{~m} / \mathrm{s}$ Fluid Velocity 223

A.11 Temperature Results: $38.1 \mathrm{~mm}$ Diameter Pipe $0.1 \mathrm{~m} / \mathrm{s}$ Fluid Velocity... 224

A.12 Vertical Temperature Results: $38.1 \mathrm{~mm}$ Diameter Pipe $0.1 \mathrm{~m} / \mathrm{s}$ Fluid Velocity 225

A.13 Temperature Results: $38.1 \mathrm{~mm}$ Diameter Pipe $0.3 \mathrm{~m} / \mathrm{s}$ Fluid Velocity... 226 
A.14 Vertical Temperature Results: $38.1 \mathrm{~mm}$ Diameter Pipe $0.3 \mathrm{~m} / \mathrm{s}$ Fluid Velocity.....

A.15 Temperature Results: 38.1 mm Diameter Pipe 0.6 m/s Fluid Velocity ... 228

A.16 Vertical Temperature Results: $38.1 \mathrm{~mm}$ Diameter Pipe $0.6 \mathrm{~m} / \mathrm{s}$ Fluid Velocity. 229

A.17 Temperature Results: 38.1 mm Diameter Pipe 1.0 m/s Fluid Velocity ... 230

A.18 Vertical Temperature Results: $38.1 \mathrm{~mm}$ Diameter Pipe $1.0 \mathrm{~m} / \mathrm{s}$ Fluid Velocity. 231

A.19 Temperature Results: 50.8 mm Diameter Pipe 0.01 m/s Fluid Velocity. 232

A.20 Vertical Temperature Results: $50.8 \mathrm{~mm}$ Diameter Pipe $0.01 \mathrm{~m} / \mathrm{s}$ Fluid Velocity. 233

A.21 Temperature Results: 50.8 mm Diameter Pipe 0.1 m/s Fluid Velocity... 234

A.22 Vertical Temperature Results: $50.8 \mathrm{~mm}$ Diameter Pipe $0.1 \mathrm{~m} / \mathrm{s}$ Fluid Velocity. 235

A.23 Temperature Results: 50.8 mm Diameter Pipe 0.3 m/s Fluid Velocity... 236

A.24 Vertical Temperature Results: $50.8 \mathrm{~mm}$ Diameter Pipe $0.3 \mathrm{~m} / \mathrm{s}$ Fluid Velocity 237

A.25 Temperature Results: 50.8 mm Diameter Pipe 0.6 m/s Fluid Velocity... 238

A.26 Vertical Temperature Results: $50.8 \mathrm{~mm}$ Diameter Pipe $0.6 \mathrm{~m} / \mathrm{s}$ Fluid Velocity 239

A.27 Temperature Results: 50.8 mm Diameter Pipe 1.0 m/s Fluid Velocity ... 240

A.28 Vertical Temperature Results: $50.8 \mathrm{~mm}$ Diameter Pipe $1.0 \mathrm{~m} / \mathrm{s}$ Fluid Velocity.

A.29 Temperature Results: Year-Round Waste Placement January Start..... 242

A.30 Vertical Temperature Results: Year-Round Waste Placement January Start . 243

A.31 Temperature Results: Year-Round Waste Placement March Start 
A.32 Vertical Temperature Results: Year-Round Waste Placement March Start...

A.33 Temperature Results: Year-Round Waste Placement April Start ......... 246

A.34 Vertical Temperature Results: Year-Round Waste Placement April Start.

A.35 Temperature Results: Year-Round Waste Placement May Start.......... 248

A.36 Vertical Temperature Results: Year-Round Waste Placement May Start.

A.37 Temperature Results: Year-Round Waste Placement July Start .......... 250

A.38 Vertical Temperature Results: Year-Round Waste Placement July Start.......

A.39 Temperature Results: Year-Round Waste Placement August Start ...... 252

A.40 Vertical Temperature Results: Year-Round Waste Placement August Start 253

A.41 Temperature Results: Year-Round Waste Placement September Start.

A.42 Vertical Temperature Results: Year-Round Waste Placement September Start ..... 255

A.43 Temperature Results: Year-Round Waste Placement October Start..... 256

A.44 Vertical Temperature Results: Year-Round Waste Placement October Start 257

A.45 Temperature Results: Year-Round Waste Placement November Start . 258

A.46 Vertical Temperature Results: Year-Round Waste Placement November Start 259

A.47 Temperature Results: Year-round Waste Placement December Start .. 260

A.48 Vertical Temperature Results: Year-Round Waste Placement December Start 261

A.49 Temperature Results: Winter-Only Waste Placement 262 
A.50 Vertical Temperature Results: Winter-Only Waste Placement ............. 263

A.51 Temperature Results: 15 m Waste Height ...................................... 264

A.52 Vertical Temperature Results: 15 m Waste Height ............................ 265

A.53 Temperature Results: 15 m/year Waste Filling Rate .......................... 266

A.54 Vertical Temperature Results: 15 m/year Waste Filling Rate ............... 267

A.55 Temperature Results: 15 years between Original Waste Placement

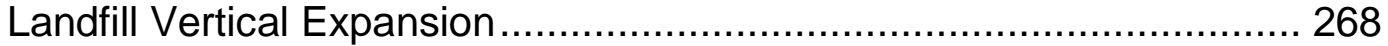

A.56 Vertical Temperature Results: 15 years between Original Waste Placement Landfill Vertical Expansion ............................................... 269

A.57 Temperature Results: HES Placement 5 years after Cover

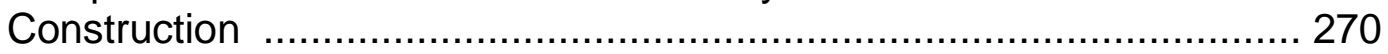

A.58 Vertical Temperature Results: HES Placement 5 years after Cover

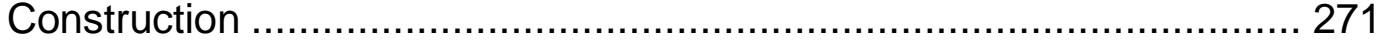

A.59 Temperature Results: Alaska Climate …....................................... 272

A.60 Vertical Temperature Results: Alaska Climate ................................. 273

A.61 Temperature Results: New Mexico Climate ..................................... 274

A.62 Vertical Temperature Results: New Mexico Climate …....................... 275 


\section{Chapter 1: Introduction}

Of the 250 million tons of Municipal solid waste (MSW) produced in 2011, 134 million tons were landfilled (US EPA 2013). MSW consists of: paper and cardboard $(28.0 \%$ by weight), food $(14.5 \%)$, yard trimmings (13.5\%), plastics (12.7\%), metals (8.8\%), rubber, leather, and textiles (8.2\%), wood $(6.4 \%)$, glass (4.6\%), and other materials (3.3\%) (US EPA 2013). MSW is generated by residential, commercial, institutional, construction and demolition, municipal services, and treatment plant source (Sharma and Lewis 1994).

Landfills are engineered containment facilities designed to keep harmful substances within waste isolated from the environment. To prevent the spread of contaminants, containment systems (bottom liner and cover liner) are placed around the waste mass. The containment systems are regulated by the United States Environmental Protection Agency (US EPA) along with state and local agencies.

Waste undergoes decomposition in the landfill resulting in gas generation, leachate generation, and heat generation. Significantly increased temperatures within the landfill (compared to surrounding ground temperatures) have been reported. Temperatures within the landfill have a potential to affect the geotechnical aspects of the waste (shear strength, hydraulic conductivity, compressibility), the liner systems, as well as the gas generation rate.

Waste at elevated temperatures may provide a potential source of heat for operations throughout the landfill (for example heating of buildings, heating of nearby green houses, and preventing leachate freezing in leachate recirculation 
systems). One method to capture this heat is a ground source heat pump. Ground source heat pumps are proven cost effective systems used to transfer heat between the ground and a structure. A ground source heat pump has the potential of effectively extracting heat for use near the landfill site as well as transferring heat within the landfill to improve the engineering performance of the landfill.

The principal objective of this investigation is to determine the potential effects of operation of a vertical ground source heat pump at a landfill. This investigation is part of broad investigation to quantify temperatures in landfills and their effects on landfilling operation. A numerical model was developed to investigate the effect of a ground source heat pump on MSW landfills. The model was applied at four climate regions (Alaska, British Columbia, Michigan, and New Mexico) for various ground source heat pump configurations and landfill operation conditions.

The relevant background technical knowledge pertaining to the development of the model is presented in Chapter 2. Research covering landfill design, landfill thermodynamics, pipe flow thermodynamics, and ground source heat pumps are discussed. Model formulation and the numerical test program for a vertical HES in a landfill environment is described in Chapter 3. A 1-D model of a vertical profile of a landfill was developed to approximate the fluid temperatures in the ground source heat pump. A 2-D axisymmetric model was developed to determine the effect of the ground source heat pump on landfill temperatures and heat extraction rates. Validation and results of the numerical 
analysis are presented in Chapter 4. A validation of the heat generation rate as well as the ground source heat pump fluid temperatures was conducted. Results of the 2-D axisymmetric model for both temperature and heat extraction rates are discussed. The engineering significance of operating a ground source heat pump in a landfill is presented in Chapter 5. The suggested spacing distance, financial costs, and the potential effect on gas production rate are discussed. Summary and conclusions from the numerical analysis are presented in Chapter 6. Results of the simulations are presented in graphical form in Appendix A. 


\section{Chapter 2: Literature Review}

\subsection{Introduction}

Relevant technical content pertaining to the application of ground source heat pumps in landfill environments is presented in this chapter. The order of topics discussed in this chapter is as follows: landfills, heat transfer, finite element analysis of conductive heat transfer, heat transfer in soil, landfill temperatures, ground source heat pumps, ground source heat pump analytical models, and ground source heat pump numerical models.

\subsection{Landfills}

Landfilling is a common waste disposal method, wherein waste is disposed in an engineered containment facility (Yesiller and Shackelford 2011). A description of landfill containment systems as well as the three main byproducts of landfilling are described in this section. The three byproducts of MSW landfills are: gas generation, leachate generation, and heat generation.

\subsubsection{Landfill Containment Systems}

A landfill containment system is comprised of a bottom liner and a cover liner (Yesiller and Shackelford 2011). Containment systems are designed to protect the environment from chemicals in the landfill (Sharma and Lewis 1994) and are generally configured as a layered system comprised of earthen and geosynthetics components.

The base of bottom liner typically consists of either $0.6 \mathrm{~m}$ of compacted

clay liner $(\mathrm{CCL})$ or a geosynthetic clay liner $(\mathrm{GCL})$ (Yesiller and Shackelford 
2011). A geomembrane is placed over the CCL or GCL to produce a composite liner system (Sharma and Lewis 1994). Typically, $0.3 \mathrm{~m}$ of granular leachate collection material with a geotextile separation layer between the liner and the waste mass exists over the geomembrane (Yesiller and Shackelford 2011).

Similar to the bottom liner, the cover liner containment system is a layered system comprised of earthen and geosynthetic components. A protective soil layer is placed directly over the waste with a filter and drainage layer overlying the protective layer (Qian et al. 2002). Overlying the drainage layer is a barrier layer made from clay or geosynthetics (Yesiller and Shackelford 2011). Another

drainage layer for precipitation is placed above the barrier layer (Qian et al. 2002). The ground surface consists of a protective soil layer with vegetation (Yesiller and Shackelford 2011).

\subsubsection{Gas Generation}

A byproduct of waste decomposition is gas generation. Gas is generated as a result of organic material decomposing into methane $\left(\mathrm{CH}_{4}\right)$ and carbon dioxide $\left(\mathrm{CO}_{2}\right)$ (Qian et al. 2002). Gases that typically exist in landfill gas are nitrogen $\left(\mathrm{N}_{2}\right)$, oxygen $\left(\mathrm{O}_{2}\right)$, hydrogen $\left(\mathrm{H}_{2}\right)$, carbon dioxide $\left(\mathrm{CO}_{2}\right)$, and methane $\left(\mathrm{CH}_{4}\right)(\mathrm{McBean}$ et. al 1995). Landfill gas composition has been determined to vary over time and gas generation can be divided into 5 distinct phases (Figure 2.1): aerobic (Phase I), aerobic/acid generation (Phase II), transition to anaerobic (Phase III), anaerobic (Phase IV), and transition to stabilization (Phase V) (Qian et al. 2002). Aerobic and anaerobic decomposition of glucose can be described by Equation 2.1 and Equation 2.2, respectively (Yoshida et al 1996): 


$$
\begin{aligned}
& \mathrm{C}_{6} \mathrm{H}_{12} \mathrm{O}_{6}+6 \mathrm{O}_{2} \rightarrow 6 \mathrm{CO}_{2}+6 \mathrm{H}_{2} \mathrm{O} \\
& \mathrm{C}_{6} \mathrm{H}_{12} \mathrm{O}_{6} \rightarrow 3 \mathrm{CO}_{2}+3 \mathrm{CH}_{4}
\end{aligned}
$$

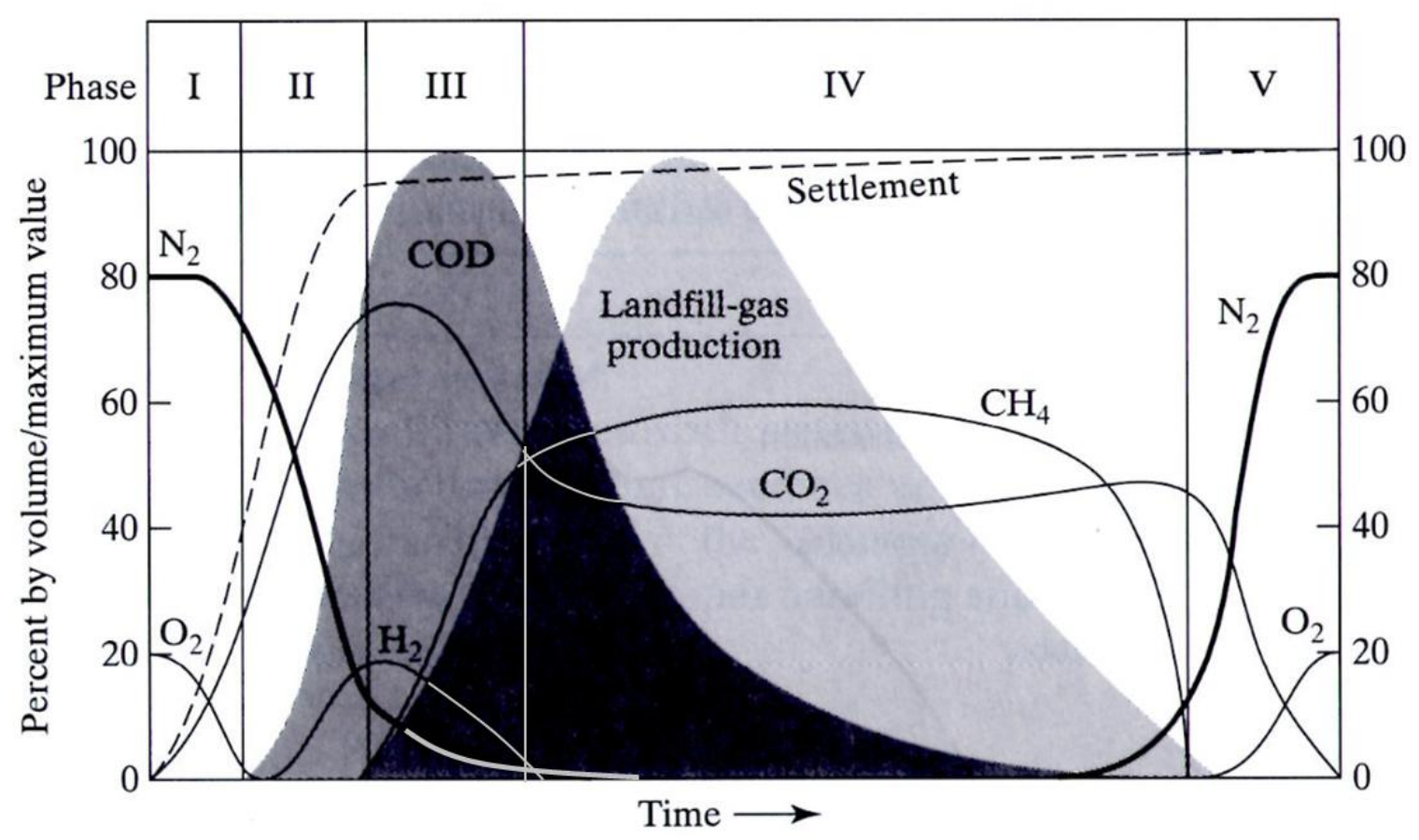

Figure 2.1: Gas Composition over Time (Qian et al. 2002)

Gases that were determined to be initially present in landfill gases were consistent with typical air and were comprised of nitrogen $\left(\mathrm{N}_{2}\right.$ at $\left.80 \%\right)$ and oxygen $\left(\mathrm{O}_{2}\right.$ at $\left.20 \%\right)$ (Qian et al. 2002). The aerobic phase was determined to end when no oxygen is present in landfill gas (McBean et. al 1995). The aerobic/acid generation phase was determined to span the time from the beginning of acid generation to the peak of acid generation (Qian et al. 2002). The transition to anaerobic phases was determined to occur from the peak acid generation, until $\mathrm{CO}_{2}$ and $\mathrm{CH}_{4}$ concentrations stabilize (Qian et al. 2002). The anaerobic phase was determined to consist of $\mathrm{CO}_{2}$ and $\mathrm{CH}_{4}$ at stable concentrations (McBean et. al 1995). Researchers have determined that average 
landfill gas compositions consist of $37 \%$ to $45 \% \mathrm{CO}_{2}$ and $50 \%$ to $60 \% \mathrm{CH}_{4}$ by volume during the anaerobic phase (Eklund et al. 1998, Themelis and Ulloa 2007, Hanson et al. 2005a). The transition to stabilization phase was determined to occur as landfill gases return to initial concentrations (Qian et al. 2002).

Factors determined to affect gas generation in landfills include: moisture content, waste composition, nutrient content, bacterial content, $\mathrm{pH}$, particle size of waste, and temperature (McBean et. al 1995, Qian et al. 2002). Temperature was determined to be important because optimum temperature for the two different methanogenic bacteria groups (mesophilic bacteria and thermophilic bacteria) differ (McBean et. al 1995). Optimum temperature ranges for mesophilic and thermophilic bacteria were determined to be 30 to $35^{\circ} \mathrm{C}$ and 40 to $65^{\circ} \mathrm{C}$, respectively (Hartz et al. 1982). Optimum temperatures for methane generation were determined to be $30^{\circ} \mathrm{C}$ to $40^{\circ} \mathrm{C}$. Temperatures below $15^{\circ} \mathrm{C}$ and above $70^{\circ} \mathrm{C}$ were determined to severely diminish methane generation (Tchobanoglous et al. 1993).

A method for quantitatively determining the effect of temperature on gas production was suggested by Hartz et al. (1982) based on temperature effects on chemical reactions. The Hartz et al. (1982) method is presented in Equation 2.3.

$$
\begin{aligned}
& k_{T_{2}}=k_{T_{1}} \mathrm{e}^{\frac{E a\left(T_{2}-T_{1}\right)}{R T_{2} T_{1}}} \\
& \text { Where: } \\
& k_{T_{1}}=\mathrm{CH}_{4} \text { production rate at temperature } 1\left(\mathrm{~m}^{3} / \mathrm{d}\right) \\
& k_{T_{2}}=\mathrm{CH}_{4} \text { production rate at temperature } 2\left(\mathrm{~m}^{3} / \mathrm{d}\right)
\end{aligned}
$$




$$
\begin{aligned}
& E_{a}=\text { energy of activation }(\mathrm{kcal} / \mathrm{mol}) \\
& T=\text { temperature }(\mathrm{K}) \\
& R \quad=\text { ideal gas constant }=1.987 \times 10^{-3} \mathrm{kcal} /(\mathrm{K} \mathrm{mol})
\end{aligned}
$$

Using five different samples from various locations within the U.S., Hartz et al. (1982) were able to determine the energy of activation, $E_{a}$. Immediate temperature effects on gas production were best estimated using an $E_{a}$ value of $23 \mathrm{kcal} / \mathrm{mol}$, while long term predictions were best estimated with an $E_{a}$ value of $20 \mathrm{kcal} / \mathrm{mol}$ (Hartz et. al 1982).

\subsubsection{Leachate Generation}

A byproduct of landfill operation is leachate (contaminated liquid present in landfills) generation. Factors influencing the quantity of leachate are: precipitation, surface run-off, infiltration, and waste conditions (waste composition, waste moisture content, and waste density) (Qian et al. 2002, Renou et al. 2008). Factors that affect the characteristics of leachate include: solid waste composition, waste age, operational conditions of the landfill, climate, hydrological conditions in the vicinity of the landfill, and conditions within the landfill (chemical conditions, biological conditions, moisture content, temperature, $\mathrm{pH}$, and degree of stabilization) (McBean et. al 1995).

Leachate quantity and characteristics have been determined to vary with time (McBean et al. 1995). Younger landfills were determined to have greater quantities of dissolved biodegradable organics than older landfills (Qian et al. 2002). Pollutants that exist in leachate were determined to be dissolved organic 
material, inorganic material, heavy metals, and xenobiotic organic compounds (Kjeldsen et al. 2002). Concentrations of the contaminants in leachate were determined to be 1000 to 5000 times greater than concentrations in groundwater (Kjeldsen et al. 2002).

The five phases of a landfill have been determined to contribute to differences in leachate (McBean et al. 1995). Aerobic decomposition occurs in Phase I and ends when all available oxygen is used (McBean et al. 1995). Anaerobic and facultative bacteria break down cellulose, putrescible materials, and soluble compounds (volatile fatty acids) in Phase II and III (McBean et al. 1995, Renou et al. 2008). Slower growing methanogenic bacteria consume organic compounds to produce methane and carbon dioxide in Phase IV (McBean et al. 1995). Decomposition ends, leading to a consistent leachate composition in Phase V. Leachate produced during Phase II, III, and IV was determined to have a biological oxygen demand (BOD) greater than 10,000 $\mathrm{mg} / \mathrm{L}$, a ratio of $\mathrm{BOD}$ to chemical oxygen demand $(\mathrm{COD})$ greater than 0.7 , and a pH between 5 and 6 (Qian et al. 2002, Kjeldsen et al. 2002).

\subsubsection{Heat Generation}

A byproduct of waste decomposition is heat generation. Heat generation results from the biochemical process of decomposition of organic matter in MSW. The microbial activity responsible for gas generation is also responsible for heat generation (McBean et. al 1995). Heat generation was determined to be higher during aerobic decomposition than anaerobic decomposition (Qian et al. 2002). Heat generation has been evaluated based on the biochemical decomposition, 
combustion of waste, and empirical values and values are presented in in Table 2.1.

El-Fadel et al. (1996a) developed a heat generation model based on net acetic acid generation. Heat generation was attributed to the formation of carboxylic acids (acetic, propionic, butyric, etc.), so heat generation was determined to be proportional to acetic acid formation (El-Fadel et al. 1996a). A proportionality constant was applied to the acetic acid formation rate to determine the net heat generation rate (El-Fadel et al. 1996a).

Yoshida et al. (1996) developed a heat generation model based on relationship between the gas generation rate and heat produced by the chemical reaction producing gas. The heat produced from the stoichiometric equations was determined to be $460 \mathrm{~kJ} / \mathrm{mol}^{-\mathrm{O}_{2}}$ for aerobic decomposition and $45 \mathrm{~kJ} / \mathrm{mol}$ $\mathrm{CH}_{4}$ for anaerobic decomposition (Yoshida et al. 1996). The consumption rates of $\mathrm{O}_{2}$ and production rates of $\mathrm{CH}_{4}$ were then used to determine the heat of biological decay of waste (Yoshida et al. 1996).

Lefebvre et al. (2000) developed a heat generation model based on microbial aerobic decomposition. Heat generation was calculated as the temperature difference at a given time at a depth of $0.5 \mathrm{~m}$ and initial temperature at a depth of $0.5 \mathrm{~m}$ (Lefebvre et al. 2000). 
Table 2.1: Heat Generation Potential of Waste (Yesiller et al. 2005)

\begin{tabular}{|c|c|c|c|c|}
\hline Reference & Heat Generation Reported & $\begin{array}{l}\text { Equivalent } \\
\text { Heat } \\
\text { Generation } \\
\left(\mathrm{MJ} / \mathrm{m}^{3}\right)\end{array}$ & $\begin{array}{l}\text { Decomposition } \\
\text { Conditions }\end{array}$ & Analysis Approach \\
\hline Pirt (1978) & $\begin{array}{c}1,520 \mathrm{kcal} / \mathrm{kg} \text { glucose } \\
(6,369 \mathrm{~kJ} / \mathrm{kg}, 1,147 \mathrm{~kJ} / \mathrm{mol}- \\
\left.\mathrm{O}_{2}\right)\end{array}$ & NA & Aerobic & $\begin{array}{c}\text { Aerobic digestion of } \\
\text { glucose }\end{array}$ \\
\hline Pirt (1978) & $\begin{array}{c}0.09 \mathrm{kcal} / \mathrm{kg} \text { glucose }(377 \\
\mathrm{J} / \mathrm{kg} \text { glucose, } 68 \mathrm{~J} / \mathrm{mol}- \\
\left.\mathrm{CH}_{4}\right)\end{array}$ & NA & $\begin{array}{l}\text { Anaerobic } \\
\text { digestion }\end{array}$ & $\begin{array}{c}\text { Complete conversion of } \\
\text { organic fraction to } \mathrm{CO}_{2} \\
\text { and } \mathrm{CH}_{4}\end{array}$ \\
\hline Rees (1980b) & $\begin{array}{c}25.5 \text { to } 1,097 \mathrm{MJ} / \mathrm{m}^{3} \text {-year } \\
\text { [Rate] }\end{array}$ & NA & $\begin{array}{c}\text { Aerobic, } \\
\text { depending on } \\
\text { water content } \\
\end{array}$ & Aerobic metabolism \\
\hline $\begin{array}{l}\text { Tchobanoglous } \\
\text { et al. (1993) }\end{array}$ & $\begin{array}{c}5.45 \mathrm{GJ} / \mathrm{t} \\
(5,450 \mathrm{~kJ} / \mathrm{kg})\end{array}$ & $5,450^{1}$ & Anaerobic & $\begin{array}{c}\text { Complete conversion of } \\
\text { organic fraction to } \mathrm{CO}_{2} \\
\text { and } \mathrm{CH}_{4}\end{array}$ \\
\hline $\begin{array}{l}\text { Tchobanoglous } \\
\text { et al. (1993) }\end{array}$ & $11,600 \mathrm{~kJ} / \mathrm{kg}$ & 11,600 & $\begin{array}{c}\text { Complete } \\
\text { decomposition }\end{array}$ & $\begin{array}{c}\text { Proximate analysis and } \\
\text { calorimetry }\end{array}$ \\
\hline $\begin{array}{l}\text { El Fadel et al. } \\
\quad(1996 a)\end{array}$ & $\begin{array}{c}244.5 \mathrm{kcal} / \mathrm{mol}-\text { organic } \\
\text { material converted }(755 \\
\mathrm{kcal} / \mathrm{kg} \text { cellulose, } 3163 \\
\mathrm{~kJ} / \mathrm{kg} \text { cellulose) }\end{array}$ & NA & Anaerobic & $\begin{array}{l}\text { Enthalpy of reactants of } \\
\text { the stoichiometric } \\
\text { biochemical reaction }\end{array}$ \\
\hline $\begin{array}{l}\text { El Fadel et al. } \\
\qquad(1996 a)\end{array}$ & $\begin{array}{c}61 \mathrm{kcal} / \mathrm{mol}-\mathrm{CH}_{4} \text { produced } \\
\left(256 \mathrm{~kJ} / \mathrm{mol}^{-} \mathrm{CH}_{4}\right)\end{array}$ & $1.38^{2}$ & Anaerobic & $\begin{array}{c}\text { Enthalpy of products of } \\
\text { the stoichiometric } \\
\text { biochemical reaction }\end{array}$ \\
\hline $\begin{array}{l}\text { El Fadel et al. } \\
(1996 a)\end{array}$ & $\begin{array}{c}26 \mathrm{kcal} / \mathrm{mol}^{-} \mathrm{CH}_{4} \text { produced } \\
\left(109 \mathrm{~kJ} / \mathrm{mol}^{-} \mathrm{CH}_{4}\right)\end{array}$ & $0.59^{2}$ & Anaerobic & $\begin{array}{c}\text { Stepwise biochemical } \\
\text { reactions }\end{array}$ \\
\hline $\begin{array}{l}\text { Zanetti et al. } \\
\quad(1997)\end{array}$ & $900 \mathrm{~kJ} / \mathrm{Nm}^{3}$ & 0.9 & Aerobic & $\begin{array}{l}\text { Enthalpy of reactants of } \\
\text { biochemical reactions } \\
\text { validated with field data }\end{array}$ \\
\hline $\begin{array}{l}\text { Lefebvre et al. } \\
\text { (2000) }\end{array}$ & $10 \times 10^{3} \mathrm{~kJ} / \mathrm{m}^{3}$ & 1.0 & Aerobic & $\begin{array}{l}\text { Heat accumulation in } \\
\text { refuse }\end{array}$ \\
\hline $\begin{array}{l}\text { Yoshida and } \\
\text { Rowe (2003) }\end{array}$ & $460 \mathrm{~kJ} / \mathrm{mol}^{-\mathrm{O}_{2}}$ & $1.61^{3}$ & Aerobic & $\begin{array}{c}\text { Biological decomposition } \\
\text { (equivalent glucose) }\end{array}$ \\
\hline $\begin{array}{l}\text { Yoshida and } \\
\text { Rowe (2003) }\end{array}$ & $\begin{array}{l}4.67 \mathrm{~J} / \mathrm{m}^{3} \mathrm{~s} \\
\text { [Rate] }\end{array}$ & NA & Aerobic & $\begin{array}{l}\text { Biological decomposition } \\
\text { (equivalent glucose) }\end{array}$ \\
\hline $\begin{array}{l}\text { Yoshida and } \\
\text { Rowe (2003) }\end{array}$ & $43.5 \mathrm{~kJ} / \mathrm{mol}-\mathrm{CH}_{4}$ & $0.23^{2}$ & Anaerobic & $\begin{array}{c}\text { Biological decomposition } \\
\text { (equivalent glucose) }\end{array}$ \\
\hline $\begin{array}{l}\text { Yoshida and } \\
\text { Rowe (2003) }\end{array}$ & $\begin{array}{l}0.218 \mathrm{~J} / \mathrm{m}^{3} \mathrm{~s} \\
\text { [Rate] }\end{array}$ & NA & Anaerobic & $\begin{array}{l}\text { Biological decomposition } \\
\text { (equivalent glucose) }\end{array}$ \\
\hline SFOE (2004) & $11,900 \mathrm{~kJ} / \mathrm{kg}$ & 11,900 & $\begin{array}{c}\text { Complete } \\
\text { conversion }\end{array}$ & $\begin{array}{c}\text { Energy released during } \\
\text { combustion }\end{array}$ \\
\hline Davies (2004) & $9,200 \mathrm{~kJ} / \mathrm{kg}$ & 9,200 & $\begin{array}{l}\text { Complete } \\
\text { conversion }\end{array}$ & $\begin{array}{l}\text { Energy released during } \\
\text { combustion }\end{array}$ \\
\hline Gibbs (2004) & $9,500 \mathrm{~kJ} / \mathrm{kg}$ & 9,500 & $\begin{array}{c}\text { Complete } \\
\text { conversion }\end{array}$ & $\begin{array}{c}\text { Energy released during } \\
\text { combustion }\end{array}$ \\
\hline \multicolumn{5}{|c|}{$\begin{array}{l}\text { calculated assuming waste composition provided by United States EPA (2003), } \rho \text { waste }=1,000 \mathrm{~kg} / \mathrm{m}^{3}, \mathrm{molecular} \text { fractions } \\
\text { outlined in Tchobanoglous et al. (1993) } \\
{ }^{2} \text { calculated assuming Ideal Gas Law applies, } \rho \text { waste }=1,000 \mathrm{~kg} / \mathrm{m}^{3} \text {, gas production }=200 \mathrm{~m}^{3}(\mathrm{gas}) / \mathrm{m}^{3}(\text { waste }) \text {, } \\
\text { gas composition }=60 \% \mathrm{CH}_{4} \\
{ }_{3} \text { calculated assuming a waste porosity }=0.4 \text {, oxygen fraction of gas in waste in as-placed condition }=21 \% \\
\mathrm{NA}=\text { direct conversion not applied as sufficient details related to waste composition and/or timing of } \\
\text { processes were not provided in the original reference }\end{array}$} \\
\hline
\end{tabular}


Liu (2007) developed a method for determining heat generation based on an empirical equation dependent on time and temperature. Waste heat generation was modeled using an exponential growth and decay function with time (Hanson et al. 2008). The function was empirically calibrated to four landfill sites (Alaska, British Columbia, Michigan, New Mexico) and was given as:

$$
\begin{aligned}
& H G=A\left(\frac{t}{B+t}\right)\left(\frac{C}{C+t}\right) e^{-\sqrt{\frac{t}{D}}} \\
& \begin{aligned}
\text { Where } & \\
H G & =\text { heat generation }\left(\mathrm{W} / \mathrm{m}^{3}\right) \\
T & =\text { temperature }\left({ }^{\circ} \mathrm{C}\right) \\
t & =\text { time (days) } \\
A & =\text { peak heat generation factor }\left(\mathrm{W} / \mathrm{m}^{3}\right) \\
B, C & =\text { time factor (days) } \\
D & =\text { decay factor (days) }
\end{aligned}
\end{aligned}
$$

Wetter climates were determined to have higher peak heat generation rates (Hanson et al. 2008). The heat generation functions with time are presented in Figure 2.2. 


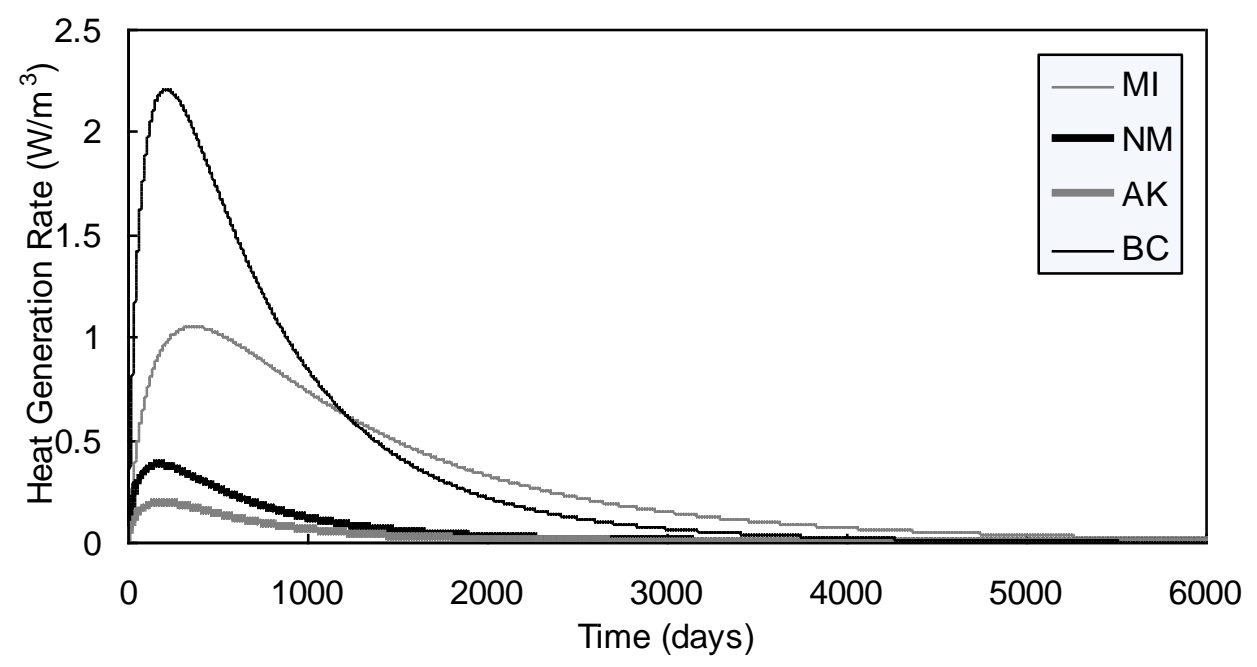

$\mathrm{AK}=$ Alaska, $\mathrm{BC}=$ British Columbia, $\mathrm{MI}=$ Michigan, $\mathrm{NM}=\mathrm{New}$ Mexico

Figure 2.2: Heat Generation Function (Liu 2007)

The heat generation rate was affected by the temperature of the waste. Microbial activity is temperature dependent (Hartz et al. 1982), so the heat generating capacity of waste is a function of temperature as well as time (Hanson et al. 2008). To account for the temperature dependence, the heat generation function with time was scaled with temperature (Liu 2007). Heat generation below $0^{\circ} \mathrm{C}$ and above $80^{\circ} \mathrm{C}$ was assumed to not occur, while peak heat generation was assumed to occur between $30^{\circ} \mathrm{C}$ and $50^{\circ} \mathrm{C}$ (Hanson et al. 2013). Heat generation function with time was linearly interpolated between zero and peak heat generation (Liu 2007). The temperature dependence of the heat generation functions is presented in Figure 2.3. 


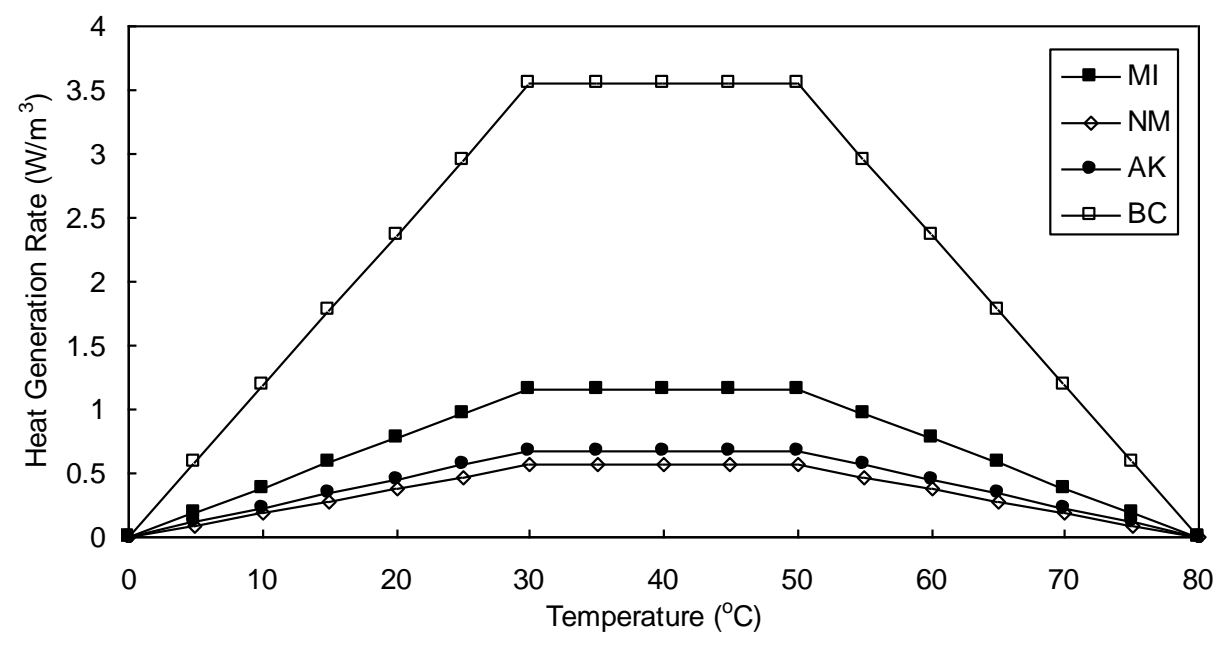

Figure 2.3: Temperature Dependence of Heat Generation (Liu 2007)

\subsection{Heat Transfer}

Heat transfer theory quantifies the movement of heat energy as a result of differences in temperature. Heat energy typically flows from hot to cold (i.e., high to low energy) using the principles of thermodynamics (Holman 1997). Thermal properties as well as the principal mechanisms of heat transfer (conduction, convection, and radiation) (Holman 1997, Mills 1999, Kumar and Sah 2004) are further discussed in this section.

\subsubsection{Thermal Properties}

Thermal properties required for analyzing heat transfer are thermal conductivity, heat capacity, and thermal diffusivity. Experimental values of thermal properties for different materials have been widely reported (e.g., Bolz and Tuve 1973).

Thermal conductivity is the proportionality constant between a given area, the thermal gradient across the area, and the heat transfer rate (Equation 2.6) 
(Carslaw and Jaeger 1959, Holman 1997, Mills 1999). Thermal conductivity varies with temperature, though for engineering purposes a single representative value for the expected temperature range is generally selected (Holman 1997, Mills 1999).

Heat capacity is the heat energy required to raise the temperature of a unit mass of a given material by a unit of temperature (Carslaw and Jaeger 1959, Holman 1997, Mills 1999, Kumar and Sah 2004, Morgan and Shapiro 2008).

Units of $\mathrm{J} /(\mathrm{kg} \mathrm{K})$ or $\mathrm{J} /\left(\mathrm{m}^{3} \mathrm{~K}\right)$ are used for heat capacity, $c$, or volumetric heat capacity, C, respectively (Carslaw and Jaeger 1959, Holman 1997, Mills 1999).

Density, thermal conductivity, and heat capacity are combined into the term thermal diffusivity (Holman 1997, Mills 1999):

$$
\alpha=\frac{k}{\rho c}
$$

Where:

$$
\begin{aligned}
& \alpha=\text { thermal diffusivity }\left(\mathrm{m}^{2} / \mathrm{s}\right) \\
& k=\text { thermal conductivity }(\mathrm{W} /(\mathrm{m} \mathrm{K})) \\
& \rho=\operatorname{density~}\left(\mathrm{kg} / \mathrm{m}^{3}\right) \\
& c=\text { heat capacity }(\mathrm{J} /(\mathrm{kg} \mathrm{K}))
\end{aligned}
$$

\subsubsection{Conduction}

Conduction represents the process of physical transfer of energy from a hot region to a cold region on a molecular or subatomic scale (Holman 1997, Mills 1999). In landfills, conduction occurs between waste particles due to temperature differences in the landfill. The material properties determine the rate 
at which heat is transferred (Carslaw and Jaeger 1959, Holman 1997, Mills 1999, Kumar and Sah 2004, Morgan and Shapiro 2008). Thermal conductivity is used to satisfy equilibrium between the heat transfer rate and the temperature gradient (Carslaw and Jaeger 1959, Holman 1997, Mills 1999). The steady state relationship in one dimension is termed Fourier's law for heat conduction (Carslaw and Jaeger 1959, Holman 1997, Mills 1999, Kumar and Sah 2004, Morgan and Shapiro 2008):

$$
\begin{aligned}
& q=-k A \frac{\partial T}{\partial x} \\
& \begin{aligned}
\text { Where: } \\
q=\text { heat transfer rate }(\mathrm{J} / \mathrm{s}) \\
k=\text { thermal conductivity }(\mathrm{W} /(\mathrm{m} \mathrm{K})) \\
A=\text { area }\left(\mathrm{m}^{2}\right) \\
T=\text { temperature }(\mathrm{K}) \\
x=\text { distance }(\mathrm{m})
\end{aligned}
\end{aligned}
$$

Often, it is necessary to determine the temperature within a material over time. Some materials also generate heat, so a more general heat conduction equation is required. The general 3-D transient heat transfer equation is presented in Equation 2.7 (Carslaw and Jaeger 1959, Holman 1997, Mills 1999):

$$
\frac{\partial T}{\partial t}=\alpha\left(\frac{\partial^{2} T}{\partial x^{2}}+\frac{\partial^{2} T}{\partial y^{2}}+\frac{\partial^{2} T}{\partial z^{2}}\right)+\dot{Q}_{h g}
$$

Where:

$$
T=\text { temperature }(\mathrm{K})
$$




$$
\begin{aligned}
t & =\text { time }(\mathrm{s}) \\
\alpha & =\text { thermal diffusivity }\left(\mathrm{m}^{2} / \mathrm{s}\right) \\
\dot{Q}_{h g} & =\text { volumetric rate of heat generation }\left(\mathrm{W} / \mathrm{m}^{3}\right)
\end{aligned}
$$

\subsubsection{Convection}

Convective heat transfer represents the process of heat transfer in a fluid caused by fluid motion (Holman 1997, Mills 1999). In landfills, convection occurs as leachate flows through the waste mass. Convection is caused by a physical transfer of energy that is influenced by fluid motion (Kumar and Sah 2004). Two types of convection exist: forced and natural (Holman 1997, Mills 1999, Kumar and Sah 2004). Forced convection arises when a fluid moves due to external forces such as water flowing through a pipe (Holman 1997, Mills 1999, Kumar and Sah 2004). Natural convection arises from changes in density as a fluid undergoes heat transfer (Holman 1997, Mills 1999, Kumar and Sah 2004), such as heating water in a pot.

In convective heat transfer, heat energy migrates within the fluid (Mills 1999). For pipe flow, the convective heat transfer rate to the fluid is a function of the heat capacity of the fluid, the temperature at different locations along the pipe (Holman 1997):

$$
\begin{aligned}
& q=\dot{m} c\left(T_{1}-T_{2}\right) \\
& \begin{aligned}
\text { Where: } & \\
q & =\text { heat transfer rate }(\mathrm{J} / \mathrm{s}) \\
\dot{m} & =\text { mass flow rate }(\mathrm{kg} / \mathrm{s})
\end{aligned}
\end{aligned}
$$




$$
\begin{aligned}
& c=\text { heat capacity }(\mathrm{J} /(\mathrm{kg} \mathrm{K})) \\
& T_{1}=\text { temperature at position } 1(\mathrm{~K}) \\
& T_{2}=\text { temperature at position } 2(\mathrm{~K})
\end{aligned}
$$

Equation (2.8) can be manipulated to be a function of the bulk fluid temperature in the pipe and the temperature of the pipe surface (Holman 1997):

$$
\begin{aligned}
& q=h A\left(T_{w}-T_{b}\right) \\
& \begin{aligned}
\text { Where: } \\
\qquad=\text { heat transfer rate }(\mathrm{W}) \\
h=\text { convection heat transfer coefficient }\left(\mathrm{W} /\left(\mathrm{m}^{2} \mathrm{~K}\right)\right) \\
A=\text { total surface area of heat transfer }\left(\mathrm{m}^{2}\right) \\
T_{w}=\text { pipe wall temperature }(\mathrm{K}) \\
T_{b}=\text { bulk fluid temperature }(\mathrm{K})
\end{aligned}
\end{aligned}
$$

The convection heat transfer coefficient is dependent on the characteristics of the fluid flow (Holman 1997, Mills 1999, Kumar and Sah 2004). The fluid flow and material parameters required to calculate the convection heat transfer coefficient are the Reynolds number and Prandtl number. Reynolds number and Prandtl number can be calculated for a known flow condition and fluid (Holman 1997, Mills 1999). Reynolds number and Prandtl number can be determined using Equation 2.10 and Equation 2.11, respectively (Holman 1997, Mills 1999).

$$
R e_{d}=\frac{\rho u d}{\mu}
$$


Where:

$$
\begin{aligned}
R e_{d} & =\text { Reynolds number } \\
\rho & =\text { density }\left(\mathrm{kg} / \mathrm{m}^{3}\right) \\
u & =\text { velocity of fluid }(\mathrm{m} / \mathrm{s}) \\
d & =\text { diameter of pipe }(\mathrm{m}) \\
\mu & =\text { dynamic viscosity }(\mathrm{kg} /(\mathrm{m} \mathrm{s}))
\end{aligned}
$$

$$
\operatorname{Pr}=\frac{c_{p} \mu}{k}
$$

Where:

$$
\begin{aligned}
\operatorname{Pr} & =\text { Prandtl number } \\
c_{p} & =\text { heat capacity }(\mathrm{J} /(\mathrm{kg} \mathrm{K})) \\
\mu & =\text { dynamic viscosity }(\mathrm{kg} /(\mathrm{m} \mathrm{s})) \\
k & =\text { thermal conductivity }(\mathrm{W} /(\mathrm{m} \mathrm{K})
\end{aligned}
$$

To calculate the convection heat transfer coefficient, the Nusselt number must be determined. Empirical relationships between the Nusselt, Pandtl, and Reynolds numbers have been developed and are summarized in Table 2.2 (Holman 1997, Mills 1999, Kumar and Sah 2004). As equations in Table 2.2 are empirical equations, specific conditions (geometry, Reynolds numbers, and Prandtl numbers) are required for the equations to be valid (Holman 1997). A Reynolds number value of 2300 was determined to be the threshold between laminar flow (less than 2300) and turbulent flow (greater than 2300) (Holman 1997, Mills 1999). 
Table 2.2: Summary of Pipe Flow Forced Convection Relationships (adapted from Holman 1997)

\begin{tabular}{|c|c|c|}
\hline Equation & Restrictions & Reference \\
\hline$N u=0.023 \operatorname{Re}^{0.8} \operatorname{Pr}^{n}$ & $\begin{array}{c}\text { Turbulent Flow, } \\
\mathrm{n}=0.4 \text { for Heating } \\
\mathrm{n}=0.3 \text { for Cooling } \\
0.6<\operatorname{Pr}<100, \\
2500<\operatorname{Re}<1.25 \times 10^{5}\end{array}$ & $\begin{array}{l}\text { Dittus and } \\
\text { Boelter } \\
(1930)^{*}\end{array}$ \\
\hline$N u=0.0214\left(R e^{0.8}-100\right) \operatorname{Pr}^{0.4}$ & $\begin{array}{c}0.5<\operatorname{Pr}<1.5 \\
10^{4}<\operatorname{Re}<5 \times 10^{6}\end{array}$ & $\begin{array}{c}\text { Gnielinski } \\
(1976)\end{array}$ \\
\hline$N u=0.012\left(R e^{0.87}-280\right) P r^{0.4}$ & $\begin{array}{c}1.5<\operatorname{Pr}<500 \\
3000<\operatorname{Re}<10^{6}\end{array}$ & $\begin{array}{l}\text { Gnielinski } \\
(1976)\end{array}$ \\
\hline$N u=0.027 \operatorname{Re}^{0.8} \operatorname{Pr}^{0.33}\left(\frac{\mu}{\mu_{w}}\right)^{0.14}$ & Turbulent Flow & $\begin{array}{l}\text { Sieder and } \\
\text { Tate (1936) }\end{array}$ \\
\hline$N u=0.036 \operatorname{Re}^{0.8} \operatorname{Pr}^{0.33}\left(\frac{d}{L}\right)^{0.055}$ & $\begin{array}{l}\text { Turbulent Flow } \\
\text { Entrance Region }\end{array}$ & $\begin{array}{l}\text { Nusselt } \\
(1931)^{\star}\end{array}$ \\
\hline$N u=\frac{\left(\frac{f}{8}\right) \operatorname{RePr}}{1.07+12.7\left(\frac{f}{8}\right)^{0.5}\left(\operatorname{Pr}^{0.66}-1\right)}\left(\frac{\mu}{\mu_{w}}\right)^{n}$ & $\begin{array}{c}\text { Turbulent Flow } \\
\mathrm{n}=0.11 \text { for } \mathrm{T}_{\mathrm{w}}>\mathrm{T}_{\mathrm{b}} \\
\mathrm{n}=0.25 \text { for } \mathrm{T}_{\mathrm{w}}<\mathrm{T}_{\mathrm{b}} \\
0.5<\operatorname{Pr}<2000 \\
10^{4}<\operatorname{Re}<5 \times 10^{6} \\
0.8<\frac{\mu}{\mu_{w}}<40\end{array}$ & $\begin{array}{l}\text { Petukhov } \\
(1970)\end{array}$ \\
\hline$N u=3.66+\frac{0.0668\left(\frac{d}{L}\right) \operatorname{RePr}}{1+0.04\left[\left(\frac{d}{L}\right) \operatorname{RePr}\right]^{0.66}}$ & Laminar Flow & $\begin{array}{l}\text { Hausen } \\
(1943)^{*}\end{array}$ \\
\hline$N u=1.86(\operatorname{RePr})^{0.66}\left(\frac{d}{L}\right)^{0.33}\left(\frac{\mu}{\mu_{w}}\right)^{0.14}$ & Laminar Flow & $\begin{array}{l}\text { Sieder and } \\
\text { Tate (1936) }\end{array}$ \\
\hline \multicolumn{3}{|l|}{$\begin{array}{l}f=\left(1.82 \log _{10} R e-1.64\right)^{-2} \\
N u=\text { Nusselt number } \\
R e=\text { Reynolds number } \\
P r=\text { Prandtl number } \\
\mu=\text { dynamic viscosity of fluid }(\mathrm{kg} /(\mathrm{m} \mathrm{s})) \\
\mu_{w}=\text { dynamic viscosity of water }(\mathrm{kg} /(\mathrm{m} \mathrm{s})) \\
d=\text { diameter of pipe }(\mathrm{m}) \\
L=\text { length of pipe }(\mathrm{m}) \\
{ }^{*} \text { as reported by Holman (1997) }\end{array}$} \\
\hline
\end{tabular}


Nusselt number can be determined using an appropriate equation from Table 2.2 and then used to calculate the convection heat transfer coefficient using Equation 2.12 (Holman 1997, Mills 1999).

$$
\begin{aligned}
& N u_{d}=\frac{h d}{k} \\
& \text { Where: } \\
& N u_{d}=\text { Nusselt number } \\
& h=\text { convection heat transfer coefficient }\left(\mathrm{W} /\left(\mathrm{m}^{2} \mathrm{~K}\right)\right) \\
& d=\text { diameter of pipe }(\mathrm{m}) \\
& k \text { = thermal conductivity }(\mathrm{W} /(\mathrm{m} \mathrm{K}))
\end{aligned}
$$

Once the convective heat transfer coefficient is determined, then convective heat transfer rate can be calculated using Equation 2.9.

\subsubsection{Radiation}

Thermal radiation represents the process of heat transfer from electromagnetic radiation that arises from the temperature difference between two surfaces that are not physically connected (Holman 1997, Mills 1999, Kumar and Sah 2004). Thermal radiation occurs in the 0.1 to $100 \mu \mathrm{m}$ wavelength range (Holman 1997, Mills 1999).

The amount of energy absorbed by a body is dependent on the reflectivity and shape of the object (Holman 1997). Some of the energy that reaches a surface is reflected, some is absorbed by the surface, and some is transmitted to the surroundings (Kumar and Sah 2004). An object that absorbs all thermal 
radiative energy is called a black body (Mills 1999). The energy radiated by a black body is given by Equation 2.13 (Holman 1997):

$$
E_{b}=\sigma T^{4}
$$

Where:

$$
\begin{aligned}
E_{b} & =\text { Energy radiated by a black body }\left(\mathrm{W} / \mathrm{m}^{2}\right) \\
\sigma & =\text { Stefan-Boltzmann constant }=5.669 \times 10^{-8}\left(\mathrm{~W} /\left(\mathrm{m}^{2} \mathrm{~K}\right)\right) \\
T & =\text { Temperature }(\mathrm{K})
\end{aligned}
$$

A gray body refers to an object that does not does not absorb all thermal radiative energy (Holman 1997). The emissivity of a gray body is defined as the ratio of the energy radiated by the gray body to the energy radiated by a black body at the same wavelength and temperature. Emissivity has been determined experimentally for different materials (Mills 1999).

Shape of surfaces impacts the amount of radiation heat transfer between two surfaces. Shape factors have been experimentally determined between two surfaces with different geometries. The overall heat transfer rate can be calculated by (Holman 1997):

$$
\begin{aligned}
& Q_{12}=A_{1} F_{12}\left(E_{g 1}-E_{g 2}\right) \\
& \text { Where: } \\
& Q_{12}=\text { heat transfer rate from surface } 1 \text { to surface } 2(\mathrm{~W}) \\
& A_{1}=\text { area of surface } 1\left(\mathrm{~m}^{2}\right) \\
& F_{12}=\text { shape factor from surface } 1 \text { to surface } 2
\end{aligned}
$$




$$
\begin{aligned}
& E_{g 1}=\text { Energy radiated by a surface } 1 \text { gray body }\left(\mathrm{W} / \mathrm{m}^{2}\right) \\
& E_{g 2}=\text { Energy radiated by a surface } 2 \text { gray body }\left(\mathrm{W} / \mathrm{m}^{2}\right)
\end{aligned}
$$

\subsection{Finite Element Analysis of Conductive Heat Transfer}

Finite Element analysis (FEA) is a numerical analysis method for solving field problems by discretizing a continuous space into predetermined elements. For FEA of heat transfer, the differential equation for heat transfer is transformed into an integral expression that can be solved in the discretized space (Cook et al. 2002). FEA is an approximation of a field variable through piecewise integration (Cook et al. 2002); as such, FEA results are usually approximate. Increased accuracy of a solution can be obtained by increasing the discretization of a space. Element size and shape is defined by nodes. Elements are connected to each other by nodes (i.e., nodes are shared by different elements). An arrangement of nodes and elements representing a particular space is defined as a mesh (Cook et al. 2002).

Each node can be assigned one or several degrees of freedom. Temperature represents the degree of freedom for heat transfer analysis. The physical properties of a space influence the conductivity matrix and the heat capacity matrix. Several methods (variational and weighted residual) are available for finite element formulation to solve for temperatures for given heat flux loads (Cook et al. 2002). The results of the finite element formulations for conductive heat transfer can be given as (Cook et al. 2002):

$$
[C]\{\dot{T}\}+[K]\{T\}=\left\{R_{B}\right\}+\left\{R_{Q}\right\}
$$


Where:

$$
\begin{aligned}
& {[C]=\text { heat capacity matrix }} \\
& \{\dot{T}\}=\text { derivative of temperature with respect to time vector } \\
& {[K]=\text { thermal conductivity matrix }} \\
& \{T\}=\text { temperature vector } \\
& \left\{R_{B}\right\}=\text { heat flux vector } \\
& \left\{R_{Q}\right\}=\text { heat generation vector }
\end{aligned}
$$

\subsection{Heat Transfer in Soil}

All three forms of heat transfer (convection, conduction, and radiation) occur in soils. Conduction occurs at the contact points between the soil particles (Kaviany 1995). Convection occurs as fluids and air move through the soil particles, transferring heat between the fluid and soil particles (Andersland and Ladanyi 1994, Kaviany 1995). Radiation occurs when radiant heat energy is absorbed or emitted by the soil particles (e.g., solar radiation) (Jumikis 1966). In general, conduction is the primary mode of heat transfer in soils (Mitchell and Soga 2005).

Soil is a matrix of particles, fluids, and voids each with different thermal properties, so bulk thermal properties (i.e., thermal properties of the matrix) are used to analyze heat transfer in soil (Andersland and Ladanyi 1994). Heat capacity for soil can be calculated by summing the heat capacity of the soil constituents as presented in Equitation 2.16 (Jumikis 1966).

$$
c_{s} \rho_{s}=c_{m} \rho_{d}+c_{w} \rho_{d} \frac{w_{w}}{100}
$$


Where:

$$
\begin{aligned}
& c_{s}=\text { heat capacity of soil }(\mathrm{J} /(\mathrm{kg} \mathrm{K})) \\
& \rho_{s}=\text { density of soil }\left(\mathrm{kg} / \mathrm{m}^{3}\right) \\
& c_{m}=\text { heat capacity of mineral constituents }(\mathrm{J} /(\mathrm{kg} \mathrm{K})) \\
& \rho_{d}=\text { dry density of soil }\left(\mathrm{kg} / \mathrm{m}^{3}\right) \\
& c_{w}=\text { heat capacity of water }(\mathrm{J} /(\mathrm{kg} \mathrm{K})) \\
& w_{w}=\text { moisture content }(\%)
\end{aligned}
$$

\subsubsection{Ground Surface Heat Transfer}

Air and ground surface temperatures can be modeled as an idealized sinusoidal function with a period of one year (Andersland and Ladanyi 1994, Labs 1981). Surface temperatures are related to air temperatures, yet differ in amplitude, mean temperature, and timing of peak temperatures (Andersland and Ladanyi 1994, Labs 1981). Some of the factors that cause the difference in the amplitude and mean temperature are vegetation, snow cover, drainage, soil properties, and topography (Karunaratne and Burn 2004).

To determine the difference in temperature between the air and ground temperatures, relationships have been established using dimensionless surface $n$-factors (Labs 1981, Romanovsky and Osterkamp 1995, Smith and Riseborough 1996, Hanson et al. 2010). The surface $n$-factor is a ratio of the air to ground freeze and thaw indices and is given by Equation 2.17 and Equation 2.18, respectively (Andersland and Ladanyi 1994).

$$
n_{f}=\frac{I_{s f}}{I_{a f}}
$$


Where:

$$
\begin{aligned}
& n_{f}=\text { surface } n \text {-factor for freezing } \\
& I_{s f}=\text { ground surface freezing index } \\
& I_{a f}=\text { air freezing index }
\end{aligned}
$$

$$
n_{t}=\frac{I_{s t}}{I_{a t}}
$$

Where:

$$
\begin{aligned}
& n_{t}=\text { surface } n \text {-factor for thawing } \\
& I_{s t}=\text { ground thawing index } \\
& I_{a t}=\text { air thawing index }
\end{aligned}
$$

Surface $n$-factors have been experimentally determined for different materials that represent common topographic surfaces (Andersland and Ladanyi 1994). The ground and air freezing and thawing indices can then be used to determine the difference in amplitude and mean temperature between ground and air temperatures (Labs 1981). Hanson et al. (2010) reported a formulation for daily $n$-factors that produces a refined prediction of ground surface temperatures.

Phase lag represents the difference in timing of the peak and minimum air temperature and peak ground temperature (Andersland and Ladanyi 1994). Peak and minimum ground surface temperatures occur at later dates than air peak and minimum temperatures (Andersland and Ladanyi 1994). This phase lag can be theoretically calculated by assuming that the primary heat transfer method is 
solar radiation (Labs 1981). The day with the minimum amount of solar radiation is winter solstice (December 21) and the day with the maximum amount of radiation is summer solstice (June 21) (Labs 1981). The theoretical phase lag was calculated to be 45.6 days ( $\left(\frac{1}{8}\right.$ cycles of a year) (Labs 1981, Carslaw and Jaeger 1959). Analysis of temperature field data determined that the phase lag constant falls between 26 and 45 days (Labs 1981). The difference in timing between peak air and ground temperatures are presented in Figure 2.4.

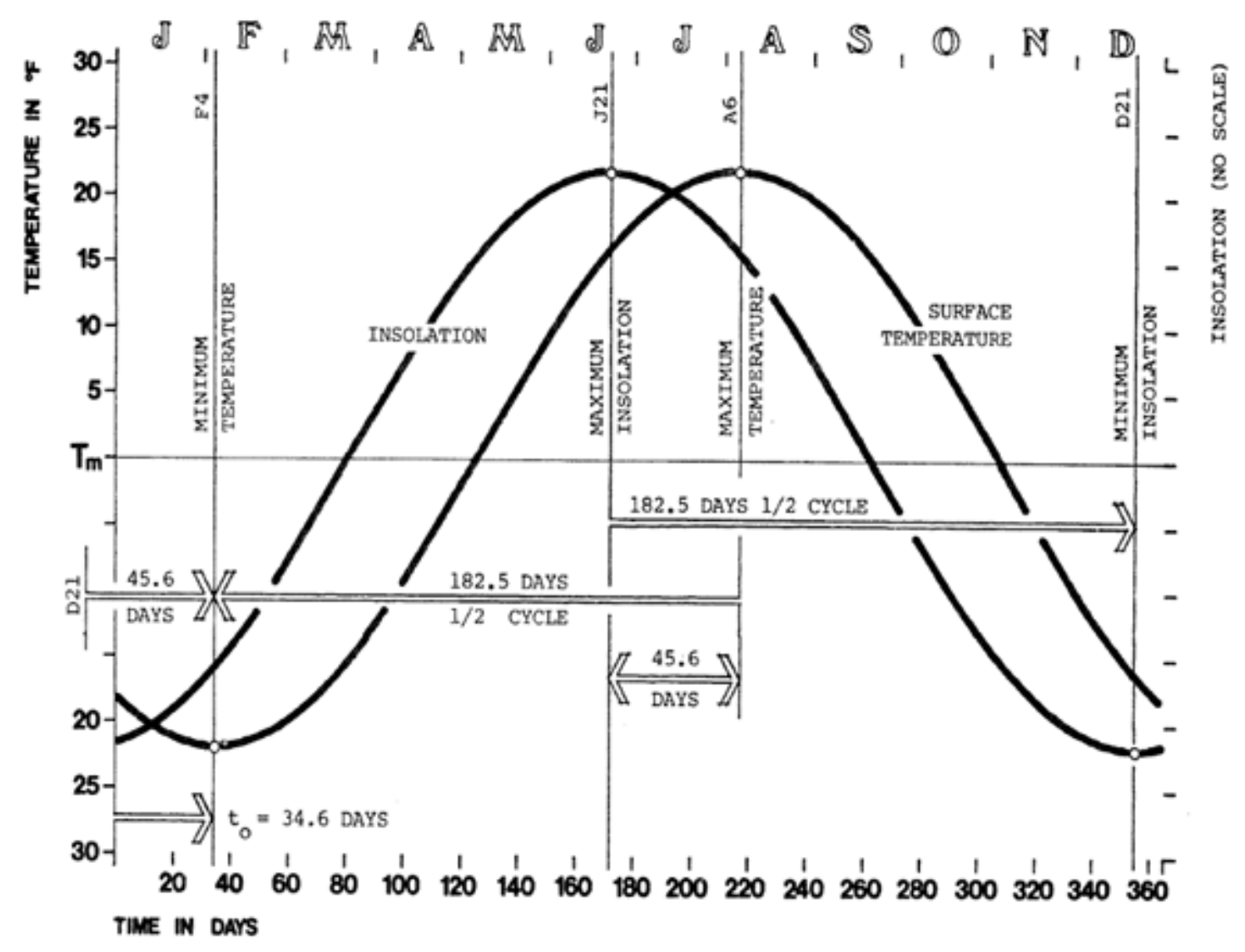

Figure 2.4: Ground Surface Temperature Phase Lag (Labs 1981) 
Site specific surface temperatures were determined for four landfill sites in North America (Liu 2007). Surface temperature data were analyzed and a sinusoidal curve fit was determined for surface temperature functions at each site for ground surfaces over soil and waste (Liu 2007). Surface $n$-factors were calculated from the temperature data over soil and waste for each of the four sites (Oettle 2008). Mean surface temperatures were higher over the waste than over in situ soil without underlying waste (Yesiller et al. 2005). The parameters for the sinusoidal functions are presented in Table 2.3.

Table 2.3: Ground Surface Temperature Parameters (Hanson et al. 2008)

\begin{tabular}{|c|c|c|c|c|}
\hline Parameter & Alaska & $\begin{array}{c}\text { British } \\
\text { Columbia }\end{array}$ & Michigan & $\begin{array}{c}\text { New } \\
\text { Mexico }\end{array}$ \\
\hline Mean Soil Temperature, $T_{m}\left({ }^{\circ} \mathrm{C}\right)$ & 5.4 & 12.1 & 12.3 & 19.0 \\
\hline Soil Temperature Amplitude, $A_{s}\left({ }^{\circ} \mathrm{C}\right)$ & 13.4 & 11.0 & 17.3 & 12.0 \\
\hline Thawing $n$-factor $($ soil) & 1.15 & 1.07 & 1.23 & 1.24 \\
\hline Freezing $n$-factor $($ soil) & 0.53 & NA & 0.91 & NA \\
\hline Mean Cover Temperature, $T_{m}\left({ }^{\circ} \mathrm{C}\right)$ & 6.6 & 17.3 & 13.0 & 20.0 \\
\hline Cover Temperature Amplitude, $A_{s}\left({ }^{\circ} \mathrm{C}\right)$ & 14.3 & 12.0 & 16.6 & 12.0 \\
\hline Thawing $n$-factor (waste) & 1.31 & 1.53 & 1.27 & 1.31 \\
\hline Freezing $n$-factor (waste) & 0.48 & NA & 0.56 & NA \\
\hline
\end{tabular}

\subsubsection{Near Surface Ground Temperatures}

Surface temperatures directly influence the near surface earth temperatures. In general, earth temperatures are constant at depths greater than $15 \mathrm{~m}$ (Bose 1983). The amplitude of the surface sinusoidal function decreases exponentially with depth which can be expressed by Equation 2.19 (Andersland and Ladanyi 1994):

$$
A_{z}=A_{s} \exp \left(-z \sqrt{\frac{\pi}{\alpha p}}\right)
$$


Where:

$$
\begin{aligned}
& A_{z}=\text { temperature amplitude at depth } z\left({ }^{\circ} \mathrm{C}\right) \\
& A_{s}=\text { temperature amplitude at ground surface }\left({ }^{\circ} \mathrm{C}\right) \\
& z \quad=\text { depth beneath ground surface }(\mathrm{m}) \\
& \alpha \quad=\text { soil thermal diffusivity }\left(\mathrm{m}^{2} / \mathrm{s}\right) \\
& p \quad=\text { period }(\mathrm{s})
\end{aligned}
$$

Ground temperatures are within the envelope determined by the temperature amplitude with depth (Labs 1981). The temperature profile varies with both depth and time within the period of the sinusoidal function (Andersland and Ladanyi 1994). A temperature profile with depth is presented in Figure 2.5. Temperature can be determined at any depth and time of the year using Equation 2.20 (Labs 1981):

$$
\begin{aligned}
& T_{z, t}=T_{m}+A_{z} \sin \left(\frac{2 \pi t}{p}-z \sqrt{\frac{\pi}{\alpha p}}\right) \\
& \begin{aligned}
\text { Where: } \\
T_{z, t}=\text { temperature at depth } z \text { and time } t\left({ }^{\circ} \mathrm{C}\right) \\
T_{m}=\text { mean annual earth temperature }\left({ }^{\circ} \mathrm{C}\right) \\
A_{z}=\text { temperature amplitude at depth } z\left({ }^{\circ} \mathrm{C}\right) \\
p=\text { period }(\mathrm{s})[1 \text { year in seconds }] \\
t=\text { time measured from start of period }(\mathrm{s}) \\
z=\text { depth beneath ground surface }(\mathrm{m}) \\
\alpha=\text { soil thermal diffusivity }\left(\mathrm{m}^{2} / \mathrm{s}\right)
\end{aligned}
\end{aligned}
$$




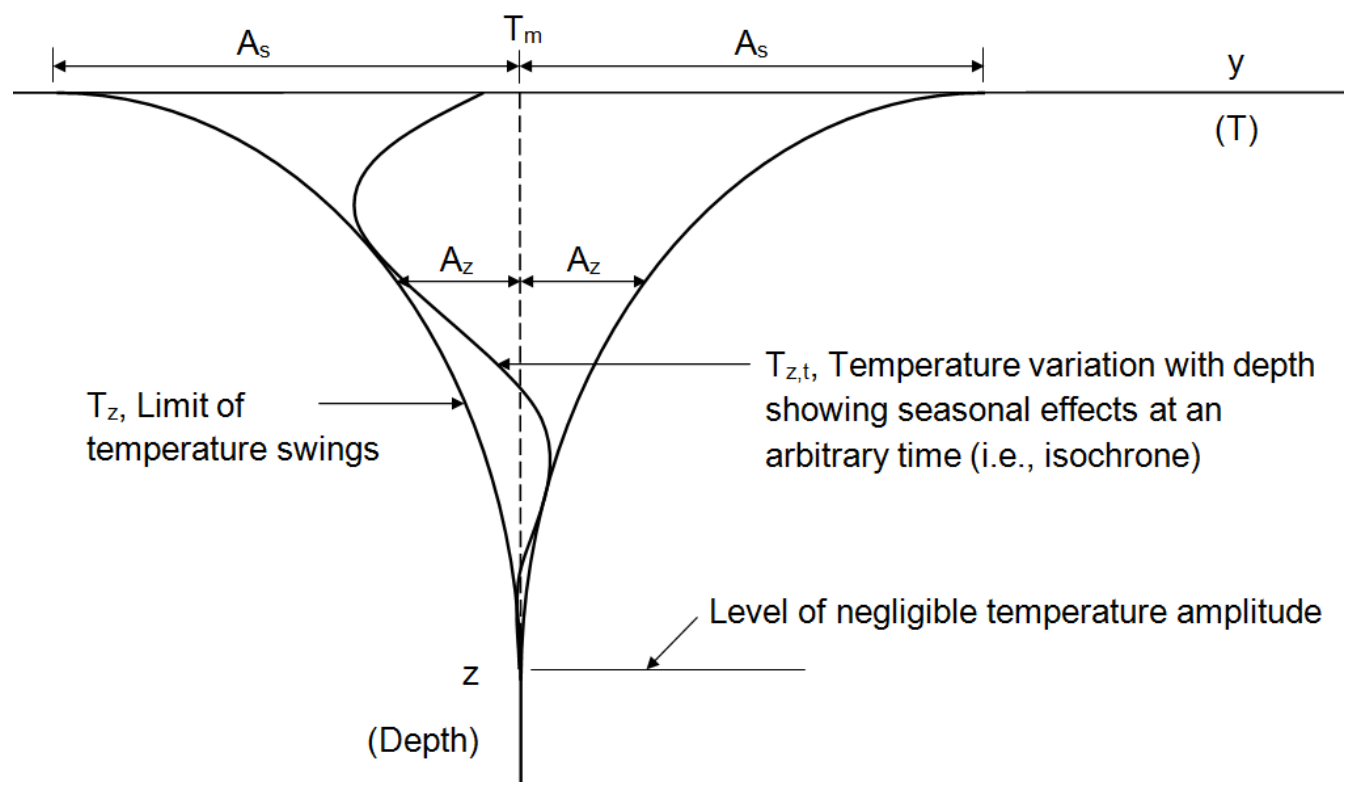

Figure 2.5: Ground Temperatures (Adapted from Andersland and Ladanyi 1994)

\subsection{Landfill Temperatures}

By adapting earth surface heat transfer theories to incorporate heat generation of waste, models have been established to determine temperatures in landfills. Landfill thermal properties, recorded landfill temperature data, and landfill numerical models are further discussed in this section.

\subsubsection{Landfill Thermal Properties}

To better understand landfill temperatures, quantifying soil and waste landfill thermal properties (unit weight, heat capacity, and thermal conductivity) was necessary. Thermal properties of waste have not been well documented, but are necessary to analyze and evaluate the thermal performance of landfills.

Soil thermal properties are dependent on mineralogy, density, gradation, moisture content, and time (Mitchell and Soga 2005). Increasing moisture content and density were determined to increase thermal conductivity of soil 
(Mitchell and Soga 2005). Thermal properties of some geomaterials are presented in Table 2.4 .

Table 2.4: Thermal Properties of Geomaterials (Mitchell and Soga 2005)

\begin{tabular}{|c|c|c|}
\hline Property & Material & Value \\
\hline \multirow{3}{*}{$\begin{array}{c}\text { Thermal Conductivity } \\
(\mathrm{W} /(\mathrm{m} \mathrm{K}))\end{array}$} & Water & 0.02 \\
\cline { 2 - 3 } & Shale & 1.56 \\
\cline { 2 - 3 } & Granite & 2.76 \\
\hline \multirow{2}{*}{ Heat Capacity } & Soil & $0.25-2.50(\approx 1.70)$ \\
\cline { 2 - 3 }$(\mathrm{kJ} /(\mathrm{kg} \mathrm{K}))$ & Water & 4.19 \\
\cline { 2 - 3 } & Minerals & 0.71 \\
\hline
\end{tabular}

Site specific soil thermal properties were determined by Liu (2007) for four landfills located in Alaska, British Columbia, Michigan, and New Mexico. Volumetric heat capacity values for the soils were calculated by summing the volumetric heat capacity of the mineral and water components using equation 2.16 (Liu 2007). Thermal conductivity was determined by analyzing field temperature data and solving for the thermal diffusivity (Liu 2007). Liu (2007) determined best-fit sinusoidal curves to temperature data at different depths. Using the difference in amplitudes at different depths, Liu (2007) was able to determine thermal diffusivity using Equation 2.20. Thermal conductivity could then be back-calculated by using the volumetric heat capacity and the thermal diffusivity (Liu 2007). The soil properties determined by Liu (2007) are presented in Table 2.5. 
Table 2.5: Soil Thermal Properties Determined by Liu (2007)

\begin{tabular}{|c|c|c|c|c|}
\hline Property & Alaska & $\begin{array}{c}\text { British } \\
\text { Columbia }\end{array}$ & Michigan & New Mexico \\
\hline$\gamma_{\text {soil }}\left(\mathrm{kN} / \mathrm{m}^{3}\right)$ & 20.5 & 16.7 & 21.0 & 17.7 \\
\hline$k_{\text {soil }}\left(\mathrm{W} / \mathrm{mK}^{3}\right)$ & 2.5 & 0.7 & 2.4 & 1.0 \\
\hline$C_{\text {soil }}\left(\mathrm{kJ} / \mathrm{m}^{3} \mathrm{~K}\right)$ & 2800 & 1300 & 1800 & 3100 \\
\hline$\alpha_{\text {soil }}\left(\mathrm{m}^{2} / \mathrm{s}\right)$ & $9.0 \times 10^{-7}$ & $4.9 \times 10^{-7}$ & $1.3 \times 10^{-6}$ & $3.3 \times 10^{-7}$ \\
\hline
\end{tabular}

MSW unit weights are difficult to determine due to variability in composition (McBean et al. 1995). Waste composition is affected by seasonal differences in waste generation, large objects present in waste, and regional commerce and industry (McBean et al. 1995, Oweis and Khera 1998). Unit weight of waste can be estimated either in the field or in laboratory settings (Dixon and Jones 2005). Field methods include using survey data and landfill records, collecting "undisturbed" samples, excavating large scale test pits, gamma ray logging of boreholes, or replacement density in boreholes (Oweis and Khera 1998, Dixon and Jones 2005, Zekkos 2006). Laboratory tests include small and large scale measurements of representative waste and summation of the individual components of waste (Oweis and Khera 1998, Dixon and Jones 2005). Unit weights of MSW have been reported to range from 5 to $15 \mathrm{kN} / \mathrm{m}^{3}$ (Oweis and Khera 1998, Dixon and Jones 2005, Zekkos 2006).

Waste volumetric heat capacity can be determined by summing the individual volumetric heat capacity of MSW components, as given by Equation 2.21 (Yoshida et al. 1996). 


$$
C_{w}=\sum_{i=1}^{n} x_{i}\left(C_{i}\right)
$$

Where:

$$
\begin{aligned}
& C_{w}=\text { volumetric heat capacity of waste }(\mathrm{J} /(\mathrm{kg} \mathrm{K})) \\
& x_{i}=\text { proportion of } \mathrm{i} \text {-th component of waste by weight } \\
& C_{i}=\text { volumetric heat capacity of } \mathrm{i} \text {-th component of waste } \\
& \\
& (\mathrm{J} /(\mathrm{kg} \mathrm{K}))
\end{aligned}
$$

Liu (2007) calculated volumetric heat capacity for the waste was calculated using the US EPA (2003) data for waste composition and summing the individual volumetric heat capacities using Equation 2.21 (Liu 2007). Other researchers have used experimental laboratory data (Lefebvre et. al 2000) of exhumed wastes or assumed values (Zanetti et al. 1997, Houi et al. 1997) of volumetric heat capacity.

To determine the phase lag associated with waste, Liu (2007) analyzed temperature at different depths in waste and determined best-fit sinusoidal temperature curves to the different depths. The lag times were then compared and thermal diffusivity was calculated (Liu 2007). Thermal conductivity of the waste was then calculated by multiplying the volumetric heat capacity by the thermal diffusivity (Liu 2007). Lefebvre et al. (2000) experimentally determined thermal conductivity from samples taken from a landfill. Thermal conductivity was assumed for landfill heat transfer modeling purposes by Zanetti et al. (1997) and Houi et al. (1997). Thermal properties as reported in literature are presented in Table 2.6. 
Table 2.6: Waste Thermal Properties (Adapted from Oettle 2008)

\begin{tabular}{|c|c|c|c|}
\hline Reference & $\begin{array}{l}\text { Thermal } \\
\text { Conductivity } \\
(\mathrm{W} /(\mathrm{m} \mathrm{K}))\end{array}$ & $\begin{array}{c}\text { Volumetric Heat } \\
\text { Capacity } \\
\left(\mathrm{kJ} /\left(\mathrm{m}^{3} \mathrm{k}\right)\right)\end{array}$ & $\begin{array}{l}\text { Thermal Diffusivity } \\
\qquad\left(\mathrm{m}^{2} / \mathrm{s}\right)\end{array}$ \\
\hline $\begin{array}{c}\text { Yoshida et al. } \\
\text { (1997) }\end{array}$ & $\begin{array}{c}0.53\left(k_{\mathrm{e}}\right) \\
0.18\left(k_{\text {series }}\right) \\
1.57\left(k_{\text {parallel }}\right)\end{array}$ & $3.3 \times 10^{3}$ & $\begin{array}{c}1.6 \times 10^{-7}\left(k_{\mathrm{e}}\right) \\
0.5 \times 10^{-7}\left(k_{\text {series }}\right) \\
4.7 \times 10^{-7}\left(k_{\text {parallel }}\right)\end{array}$ \\
\hline $\begin{array}{c}\text { Zanetti et al. } \\
\text { (1997) }\end{array}$ & 0.0445 & $2.2 \times 10^{3}$ & $0.2 \times 10^{-7}$ \\
\hline Houi et al. (1997) & 0.3 & $2.2 \times 10^{3}$ & $1.4 \times 10^{-7}$ \\
\hline $\begin{array}{l}\text { Lefebvre et al. } \\
(2000)\end{array}$ & 0.1 & $1.9 \times 10^{3}$ to $3 \times 10^{3}$ & $0.8 \times 10^{-7}$ to $2.2 \times 10^{-7}$ \\
\hline Liu (2007) & $\begin{array}{l}0.3(\mathrm{AK}) \\
1.5(\mathrm{BC}) \\
1.0(\mathrm{MI}) \\
0.6(\mathrm{NM})\end{array}$ & $\begin{array}{l}1.0 \times 10^{3}(\mathrm{AK}) \\
2.2 \times 10^{3}(\mathrm{BC}) \\
2.0 \times 10^{3}(\mathrm{MI}) \\
1.2 \times 10^{3}(\mathrm{NM})\end{array}$ & $\begin{array}{l}3.0 \times 10^{-7}(\mathrm{AK}) \\
7.0 \times 10^{-7}(\mathrm{BC}) \\
5.0 \times 10^{-7}(\mathrm{MI}) \\
5.0 \times 10^{-7}(\mathrm{NM})\end{array}$ \\
\hline
\end{tabular}

$\mathrm{AK}=$ Alaska, $\mathrm{BC}=$ British Columbia, $\mathrm{MI}=$ Michigan, $\mathrm{NM}=$ New Mexico

\subsubsection{Experimental Data}

Studies have been conducted to determine the magnitude of temperatures in landfills caused by heat generation of waste. Landfill temperatures at depths greater than $15 \mathrm{~m}$ were determined to be unaffected by surface temperature fluctuations (McBean et al. 1995). Maximum temperatures observed were $70^{\circ} \mathrm{C}$ and higher temperatures were generally observed in landfills with waste heights greater than $40 \mathrm{~m}$ (McBean et al. 1995).

Liner temperatures have been investigated by researchers (Yoshida and Rowe 2003, Hanson et al. 2005b, Oettle 2008, Yesiller et al. 2008). Landfill bottom liner temperatures were observed to be between $35^{\circ} \mathrm{C}$ and $45^{\circ} \mathrm{C}$ (Yoshida and Rowe 2003). Hanson et al. (2005b) reported bottom liner temperatures of $30^{\circ} \mathrm{C}$ under five year old waste. Cover liner temperatures were determined to vary seasonally and were mostly impacted by surface temperatures (Yesiller et 
al. 2008); however, heat generation characteristics of waste were also determined to influence liner temperatures (Oettle 2008).

Landfill waste temperatures have been investigated by numerous researchers (Yoshida and Rowe 2003, Yesiller and Hanson 2003, Hanson et al. 2005b, Yesiller et al. 2005, Hanson et al. 2006 Hanson et al. 2012). Temperatures of waste mass were observed in excess of $50^{\circ} \mathrm{C}$ (Yoshida and Rowe 2003) and $60^{\circ} \mathrm{C}$ (Yesiller and Hanson 2003). Stable waste temperatures were observed at depths greater than $8 \mathrm{~m}$ (Hanson et al. 2005a). The rate of temperature increase was determined to be higher for placement of younger wastes than older wastes (Hanson et al. 2005a). Waste placement temperature and waste age was determined to greatly impact landfill temperatures (Yesiller and Hanson 2003). Waste temperature data with time and depth is presented in Figure 2.6. 


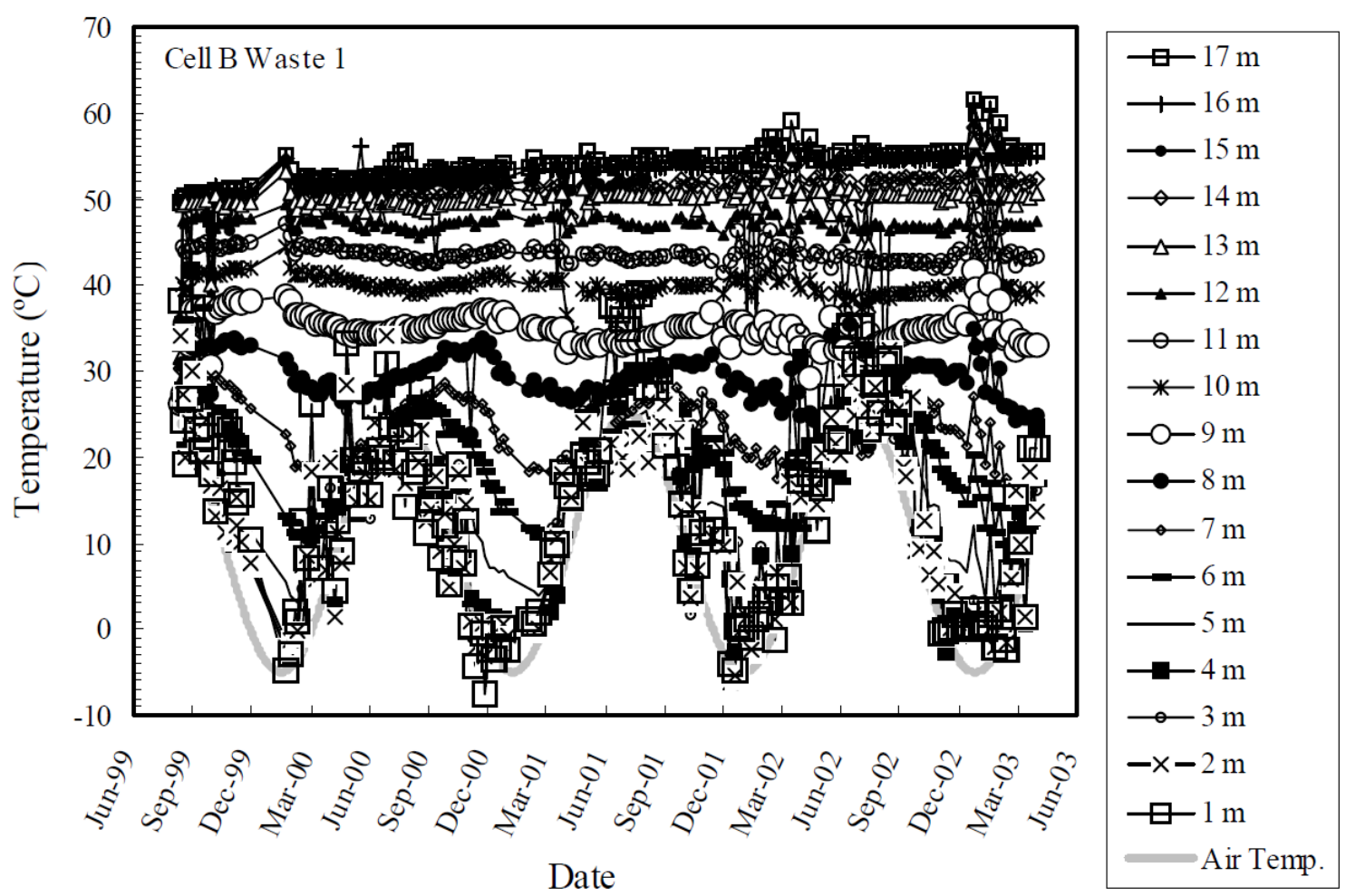

Figure 2.6: Temperature Variation with Depth (Yesiller and Hanson 2003).

\subsubsection{Numerical Models}

To further investigate landfill temperatures, several numerical models of landfill temperatures have been developed. The heat generation was simulated differently in each numerical model. El-Fadel et al. (1996b) developed a numerical model of the Mountain View Controlled Landfill Project in California, USA. An integrated gas generation, gas transport, and heat generation model was used to simulate the landfill (El-Fadel et al. 1996b). Landfill thermal properties (density, heat capacity, and thermal conductivity) were calculated as weighted averages of the solid, liquid, and gas phases present in the landfill. The acetic acid formation rates were used to determine heat generation (El-Fadel et al. 1996a). 
Lefebvre et al. (2000) developed a numerical model of landfill in southern France. A 1-D heat transfer model was established assuming constant thermal properties and constant biogas infiltration rates (Lefebvre et al. 2000). Oxygen concentrations within the waste were assumed to be uniform (Lefebvre et al. 2000). Temperatures in the model increased as oxygen diffused from the surface and was consumed due to aerobic decomposition (Lefebvre et al. 2000).

Yoshida and Rowe (2003) developed a numerical model of the Tokyo Port Landfill. A 1-D model was established to investigate liner temperatures in the landfill whereas the model consisted of two cells and the native soil (Yoshida and Rowe 2003). The landfill model was built up over time and the top $1 \mathrm{~m}$ from the surface was assumed to undergo aerobic decomposition (Yoshida and Rowe 2003). The waste below the top $1 \mathrm{~m}$ was assumed to undergo anaerobic decomposition (Yoshida and Rowe 2003). Heat generation was determined by the gas generation rate and the heat produced by the aerobic or anaerobic chemical reaction (Yoshida and Rowe 2003).

Liu (2007) developed a numerical model of four landfill sites in North America: Alaska, British Columbia, Michigan, and New Mexico. A 1-D finite element (Abaqus version 6.5) landfill temperature model was developed based on data obtained at four sites. The model consisted of a cover liner, waste, bottom liner, and subgrade (Hanson et al. 2013). Site specific data was used to simulate the materials (Table 2.5 and Table 2.6) and boundary conditions (Table 2.3). Heat generation was simulated using Equation 2.4 and calibrated to site temperature data (Liu 2007). The far field boundary condition was set to the site 
specific mean annual earth temperature (Table 2.3) (Hanson et al. 2013). Far field boundary was determined to be $75 \mathrm{~m}$ below the waste mass, which was established by analyzing the temperature change at different depths for a period of 30 years (Liu 2007).

Each heat generation model for waste was calibrated to the specific site that was simulated. Each model was effective at modeling the temperatures that occurred in at the site simulated. Only the Liu (2007) heat generation model accounted for the temperature dependence of heat generation.

\subsection{Ground Source Heat Pumps}

Due to the growing costs of fossil fuels, a need exists to provide cost efficient alternative sources of energy. One such potential supply of low cost thermal energy is ground source heat pumps (Bose 1983). Ground source heat pumps transfer heat to/from the ground to heat/cool associated structures using thermodynamic principles (i.e., heat flows from warmer locations to cooler locations). Ground source heat pumps can be utilized to either heat or cool a building, depending on relative temperature of the subsurface and desired building temperature (Bose 1983, Kavanaugh and Rafferty 1997). Buildings can be cooled as a result of thermal energy flowing from the building to the ground in warmer months and heated as a result of thermal energy flowing from the ground to the building in cooler months. 


\subsubsection{Ground Source Heat Pump Configurations}

Configurations of ground source heat pumps include: closed loop (groundcoupled) heat pumps, open loop (groundwater) heat pumps, and surface water heat pumps (Bose 1983, Kavanaugh and Rafferty 1997, Omer 2008, Phetteplace 2007). Closed loop heat pumps circulate water through a closed loop pipe system, open loop heat pumps utilize native groundwater to circulate through the system, while surface water heat pumps use thermal energy stored in surface water to modify the temperature of a building (Kavanaugh and Rafferty 1997, Omer 2008, Phetteplace 2007). Closed loop heat source pumps are much more common than open loop heat pumps and surface water heat pumps due to the thermal properties of rock (Younis et al. 2010).

Ground source heat pumps can be implemented in either a vertical or horizontal arrangement (Bose 1983, Kavanaugh and Rafferty 1997, Omer 2008). Horizontal configurations are generally easier to install than vertical configurations; however, vertical configurations are preferable when area of land is constrained or when rock layers are close to the surface (Younis et al. 2010).

Selection of a ground source heat pump configuration has been determined to be dependent on groundwater conditions, land available, and the earthwork costs (Younis et al. 2010). Groundwater conditions have been determined to greatly influence ground source heat pumps (Kavanaugh and Rafferty 1997). Economic viability of a ground source heat pump has been determined to depend on the overall configuration of the ground source heat pump. Building demands have been concluded to control the size and scope of 
the of the ground source heat pump system (Bose 1983, Kavanaugh and Rafferty 1997).

The basic elements of a closed loop ground source heat pump system consist of a ground heat exchanger, heat pump, and radiator (Figure 2.7). The ground heat exchanger is responsible for heat transfer between the ground and the pipe system, while the radiator system allows for heat transfer to the building. In some climates, ground source heat pumps cannot deliver all of the heating energy required for a building, so hybrid systems using other sources to heat the fluid in the system can be more economically feasible (Pertzborn et al. 2011). Other components can be added to augment the heating capacity of ground source heat pumps. Wang et al. (2010) included a solar collector to a ground source heat pump system and demonstrated improved efficiency. Boiler systems can also be added to supply additional heat to the system (Park et al. 2012).

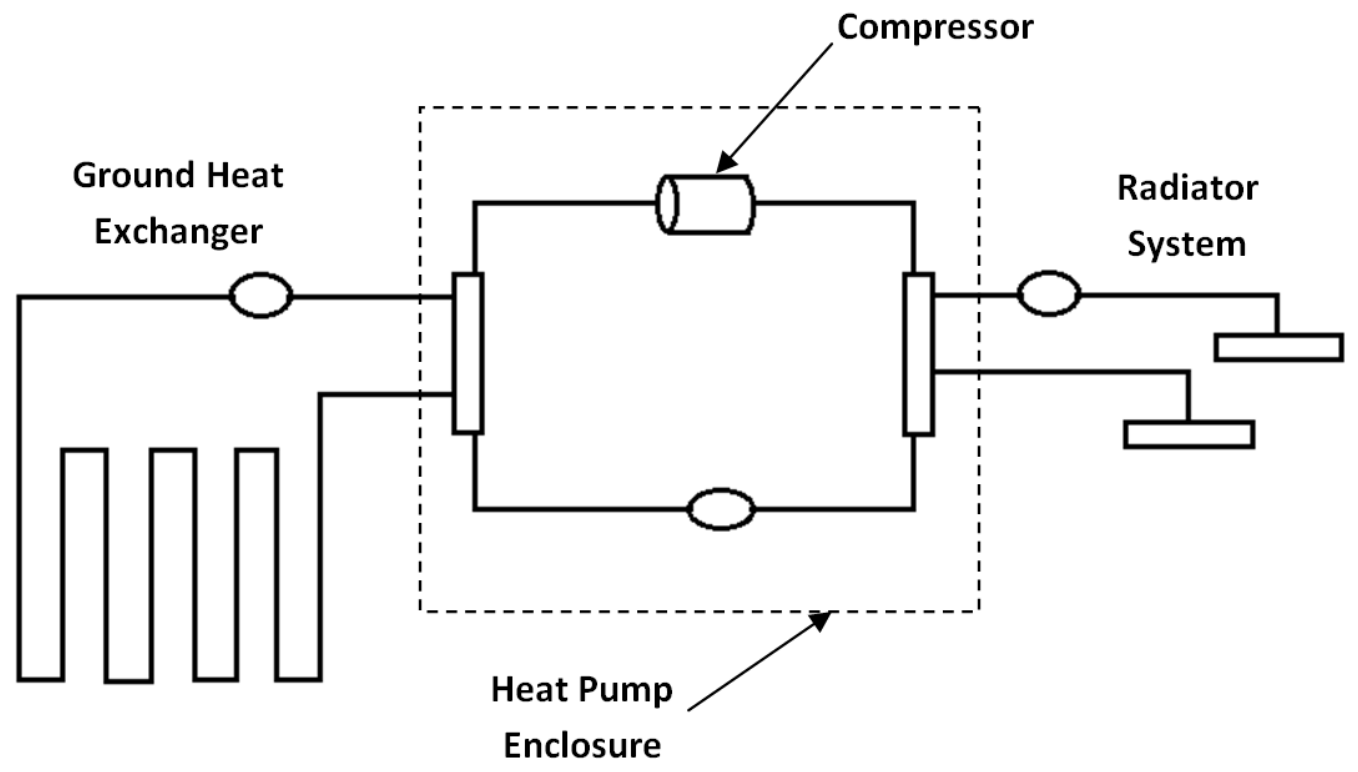

Figure 2.7: Ground Source Heat Pump System (Adapted from Omer 2008). 


\subsubsection{Heat Pumps}

While heat naturally flows from hot to cold, heat can be forced to flow from cold to hot with the addition of energy. A heat pump is a thermodynamic system used for heating purposes in which heat energy is transferred from a colder region to a warmer region with the addition of energy usually in the form of electricity (Sauer and Howell 1983). The heat pump system is comprised of four components: evaporator, expansion valve, condenser, and compressor (Kumar and Sah 2004). A refrigerant fluid flows in a circuit between the four components transferring heat from the cold region to the hot region (Reay and MacMichael 1979).

The refrigerant flows from the evaporator to the compressor, to the condenser, through the expansion valve, and then back to the evaporator. Heat is transferred by the system due the temperature gradients and pressures involved with each component. First, low pressure fluid flows into the evaporator and evaporates, absorbing heat from the cold region (Sauer and Howell 1983). The low pressure vapor then flows to a compressor, which uses electricity, and becomes high pressure vapor (Sauer and Howell 1983). The high pressure vapor then flows to the condenser emitting heat to the hot region when the vapor turns into a high pressure liquid (Sauer and Howell 1983). The fluid then returns to a low pressure liquid after the fluid passes through the expansion valve (Sauer and Howell 1983). 


\subsubsection{Seasonal Heat Storage}

In cooler months, heat energy flows from the ground to the building, while in warmer months heat energy flows from the building to the ground. During warm seasons, thermal energy can be stored in the ground for use later during colder months (Reuss et al. 1997). The system influences the surrounding ground temperatures (i.e., heating the building causes the ground temperature to decrease, while cooling the building causes ground temperature to increase) (Pertzborn et al. 2011). In climates where the number of heating days (days in which the building requires heating) exceeds the number of cooling days (days in which the building requires cooling), differences in the amount of energy being stored during the warmer months and the amount being withdrawn during the cooler months can cause a thermal imbalance that can affect system efficiency over time (Wang et al. 2010). In climates where heating and cooling days are approximately equal, ground source heat pumps can act as a seasonal energy storage system (Phetteplace 2007). Seasonal heat storage systems was determined to have storage efficiencies (the quotient of amount of energy supplied into the ground and the amount of energy absorbed from the ground) up to $70 \%$ (Reuss et al. 1997).

\subsubsection{Ground Source Heat Pump Efficiency}

The principles of mass and energy balance can be used to analyze ground source heat pumps. The amount of energy obtained from a ground source heat pump depends on: thermal properties of the soil, thermal properties of the circulating fluid, flow rate of the fluid, flow rate of the air circulating in the 
building, and the amount of electrical energy supplied to the system (Hepbasli et al. 2003, Inalli and Esen 2004, Ozgener and Hepbasli 2007). Heat flow from each component of the ground source heat pump has been given as (Ozgener and Hepbasli 2007):

$$
\begin{aligned}
& \dot{Q}=\dot{m} c_{p}\left(T_{o}-T_{i}\right) \\
& \begin{aligned}
\text { Where: } & \\
\dot{Q} & =\text { heat transfer rate }(\mathrm{J} / \mathrm{s}) \\
\dot{m} & =\text { mass flow rate }(\mathrm{kg} / \mathrm{s}) \\
c_{p} & =\text { heat capacity }(\mathrm{J} /(\mathrm{kg} \mathrm{K})) \\
T_{o} & =\text { temperature out of system component }(\mathrm{K}) \\
T_{i} & =\text { temperature into system component }(\mathrm{K})
\end{aligned}
\end{aligned}
$$

Electrical energy utilized to power the ground source heat pump system can be monitored and a coefficient of performance (COP) can then be calculated using Equation 2.23 (Phetteplace 2007).

$$
\begin{aligned}
& C O P=\frac{U_{t}}{I_{e}} \\
& \text { Where: } \\
& C O P=\text { coefficient of performance } \\
& U_{t}=\text { useful thermal effect }(\mathrm{J}) \\
& I_{e}=\text { purchased energy input rate }(\mathrm{J})
\end{aligned}
$$

The useful thermal effect represents heat transfer rate to the building and the purchased energy input rates represents the electricity requirements for the 
system components. Electricity costs directly affect the overall economic feasibility of the system, so ground source heat pumps may not be effective heating solutions in locations with high electricity rates (Singh 2002). In general, a ground source heat pump system will have a COP of 3 to 4 (Omer 2008).

The COP was determined to be affected by the location of the ground source heat pump and COP generally increased as latitude increased (Pertzborn et al. 2011). In addition, COP was determined to not be constant, but time dependent. Spring and fall yielded higher COP values than summer or winter (Stafford 2011). The time of day also was determined to affect the amount of energy extracted. The configuration Hepbasli et al. (2003) investigated was determined to extract the most heat between 9:00 AM and 10:00 AM.

Ozgener and Hepbasli (2007) analyzed a ground source heat pump configuration using the principles of energy balance to determine the COP. The energy balance equation was given as:

$$
Q+\sum \dot{m}_{\text {in }} h_{\text {in }}=\dot{W}+\sum \dot{m}_{\text {out }} h_{\text {out }}
$$

Where:

$$
\begin{aligned}
Q & =\text { heat transfer rate }(\mathrm{W}) \\
\dot{m}_{\text {in }} & =\text { mass flow rate input }(\mathrm{kg} / \mathrm{s}) \\
h_{\text {in }} & =\text { specific enthalpy input }(\mathrm{J} / \mathrm{kg}) \\
\dot{W} & =\text { rate of work or power }(\mathrm{W}) \\
\dot{m}_{\text {out }} & =\text { mass flow rate output }(\mathrm{kg} / \mathrm{s}) \\
h_{\text {out }} & =\text { specific enthalpy output }(\mathrm{J} / \mathrm{kg})
\end{aligned}
$$


The ground source heat pump investigated by Ozgener and Hepbasli (2007) consisted of two separate pipe circuits: the ground heat exchanger circuit and the heat pump circuit (Figure 2.8). The ground heat circuit was comprised of the ground heat exchanger and a pump, while the heat pump circuit was comprised of a compressor, air cooled condenser, capillary tube, and another pump (Ozgener and Hepbasli 2007). To prevent fluid freezing in winter, water and $20 \%$ by weight ethylene glycol mixture was used as the fluid in the ground heat exchanger circuit (Ozgener and Hepbasli 2007). R-22 fluid was circulated in the heat pump circuit to maximize the heat transfer rate to the building (Ozgener and Hepbasli 2007).

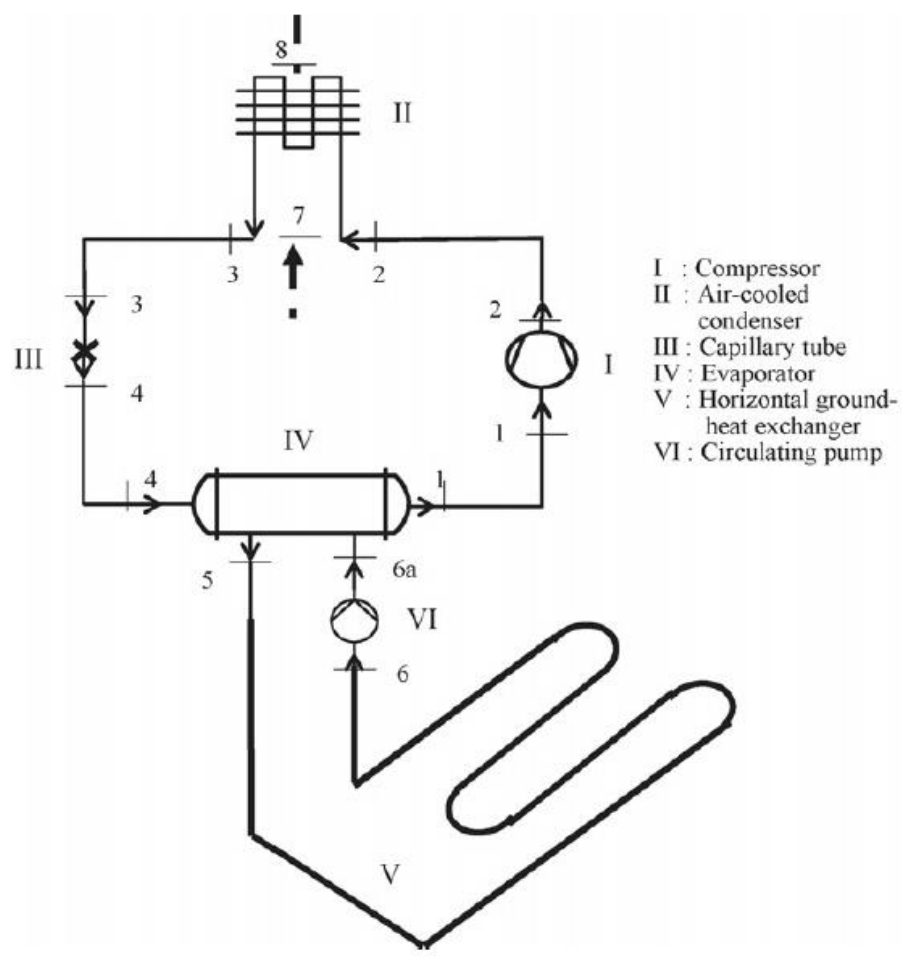

Figure 2.8: Schematic of Modeled Ground Source Heat Pump (Ozgener and Hepbasli 2007). 
Heat energy extracted from the ground was determined experimentally and applied as an energy rate per length of ground heat exchanger. The COP for the total system was then calculated using the equation:

$$
\begin{aligned}
& C O P_{\text {sys }}=\frac{\dot{Q}_{\text {cond }}}{\dot{W}_{\text {comp }}+\dot{W}_{\text {pumps }}+\dot{W}_{f c}} \\
& \text { Where: } \\
& C O P_{s y s}=\text { coefficient of performance for the entire system } \\
& \dot{Q}_{c o n d}=\text { heat rejection rate for the condenser }(\mathrm{kW}) \\
& \dot{W}_{\text {comp }}=\text { rate of work into the compressor }(\mathrm{kW}) \\
& \dot{W}_{\text {pumps }}=\text { rate of work into the pumps }(\mathrm{kW}) \\
& \dot{W}_{f c}=\text { rate of work into the fan for the air cooled condenser }(\mathrm{kW})
\end{aligned}
$$

The results of the analysis yielded a COP of the total system of 2.72 (Ozgener and Hepbasli 2007).

\subsection{Ground Heat Exchanger Analytical Models}

Several methods for analytically determining the heat transfer for a ground heat exchanger have been developed. Kelvin line source theory and cylinder source theory are presented in this section. The IGSHPA design method and ASHRAE design method are also described in this section.

\subsubsection{Kelvin Line Source Theory}

Kelvin line source theory was utilized to develop analytical solutions for ground source heat pumps (Ingersoll 1948, Hart and Couvillion 1986). The Kelvin line source theory treats the ground as an infinite medium and the ground 
heat exchanger as an infinite line (Yavuzturk 1999). Kelvin line source theory was given as (Yang et al. 2010):

$$
T-T_{i}=\frac{q}{4 \pi k} \int_{\frac{r^{2}}{4 \alpha t}}^{\infty} \frac{e^{-u}}{u} d u=\frac{q}{4 \pi k} I(X)
$$

Where:

$$
\begin{aligned}
T & =\text { temperature of ground at distance } r \text { away }\left({ }^{\circ} \mathrm{C}\right) \\
T_{i} & =\text { initial temperature of ground }\left({ }^{\circ} \mathrm{C}\right) \\
q & =\text { heating rate per length of line source }(\mathrm{W} / \mathrm{m}) \\
k & =\text { thermal conductivity }(\mathrm{W} /(\mathrm{m} \mathrm{K})) \\
r & =\text { radial distance from line source }(\mathrm{m}) \\
\alpha & =\text { thermal diffusivity }\left(\mathrm{m}^{2} / \mathrm{s}\right) \\
t & =\text { time from start of operation }(\mathrm{s}) \\
u & =\text { integration variable } \\
I(X) & =\text { Solution to integral }
\end{aligned}
$$

The solution to the integral, $I(X)$, has been calculated and approximations to the solution are available (Ingersoll 1954, Hart and Couvillion 1986). The Kelvin line source theory was most accurate for small pipes and short timeframes of up to a few months (Yavuzturk 1999, Yang et al. 2010). Heat flow for the Kelvin line source theory occurred only in the radial direction and does not take vertical heat transfer into account (Yang et al. 2010). Thermal resistance of the borehole was neglected in the Kelvin line source theory (Yavuzturk 1999). 


\subsubsection{Cylinder Source Theory}

Carslaw and Jaeger (1959) established an analytical solution to the heat transfer rate of a cylindrical heat source. The method employed an exact solution of the heat transfer equation of an infinitely long cylinder in an infinite medium (Carslaw and Jaeger 1959). The solution was given as (Carslaw and Jaeger 1959):

$$
\begin{aligned}
& T-T_{i}=\frac{q}{k} G(y, p) \\
& \text { Where: } \\
& y=\frac{\alpha t}{r_{0}} \\
& p=\frac{r}{r_{0}} \\
& T=\text { temperature }\left({ }^{\circ} \mathrm{C}\right) \\
& T_{i}=\text { initial temperature }\left({ }^{\circ} \mathrm{C}\right) \\
& q=\text { heating rate per length }(\mathrm{W} / \mathrm{m}) \\
& k=\text { thermal conductivity }(\mathrm{W} /(\mathrm{m} \mathrm{K})) \\
& \alpha=\text { thermal diffusivity }\left(\mathrm{m}^{2} / \mathrm{s}\right) \\
& t \quad=\text { time }(\mathrm{s}) \\
& r_{o}=\text { radius of cylinder }(\mathrm{m}) \\
& r \quad=\text { radial distance from cylinder }(\mathrm{m}) \\
& G(y, p)=\text { function of radial distance and time }
\end{aligned}
$$

The solution to the function $G(y, p)$ was developed and values were established for different values of $p$ (Ingersoll 1954, Kavanaugh 1985). The 
radius of the cylinder can be set to the ground heat exchanger borehole radius ( $p$ $=1$ ) and heat transfer can be calculated into the borehole (Yang et al. 2010).

\subsubsection{IGSHPA Design Method}

The International Ground Source Heat Pump Association (IGSHPA) has developed a method for designing ground source heat pumps (Bose 1983). The design method is valid for both vertical and horizontal ground heat exchangers (Bose 1983). The design procedure accounts for both heating and cooling cycles of the ground source heat pump (Bose 1983). Before the ground heat exchanger is designed, seasonal earth temperatures must be determined (Bose 1983). Also, the pipe diameter, material, and configuration must be selected (Bose 1983). Additionally, the minimum and maximum tolerable fluid temperatures for the heat pump performance curve must be selected (Bose 1983). The IGSHPA design method was formulated based on experimental data acquired from three horizontal and five vertical experimental ground source heat pumps (Bose 1983).

The ground source heat exchanger design begins with the calculation of the pipe and soil thermal resistances (Bose 1983). Pipe resistance is determined by (Bose 1983):

$$
R_{p}=\frac{1}{2 \pi k_{p}} \ln \left(\frac{D_{o}}{D_{i}}\right)
$$

Where:

$$
\begin{aligned}
& R_{p}=\text { pipe resistance }\left(\left(\mathrm{ft}{ }^{\circ} \mathrm{F}\right) / \mathrm{Btuh}\right) \\
& k_{p}=\text { thermal conductivity of the pipe }\left(\mathrm{Btuh} /\left(\mathrm{ft}{ }^{\circ} \mathrm{F}\right)\right) \\
& D_{o}=\text { outer diameter of the pipe }(\mathrm{ft})
\end{aligned}
$$




$$
D_{i}=\text { inner diameter of the pipe (ft) }
$$

The soil resistance was determined to be dependent on the time required for the ground heat exchanger to reach steady state (Bose 1983). Time to steady state is calculated as (Bose 1983):

For horizontal configurations:

$$
t=\frac{1.78 D^{2}}{\alpha}
$$

For vertical configurations:

$$
t=\frac{H^{2}}{9 \alpha}
$$

Where:

$$
\begin{aligned}
t & =\text { time to reach steady state (day) } \\
D & =\text { horizontal ground heat exchanger depth (ft) } \\
\alpha & =\text { thermal diffusivity ( } \mathrm{ft}^{2} / \text { day) } \\
H & =\text { vertical ground heat exchanger depth (ft) }
\end{aligned}
$$

Soil resistance also depends on whether the system is configured horizontally or vertically (Bose 1983):

For horizontal configurations:

$$
\begin{aligned}
& R_{S}=\frac{1}{k_{S}}\left(0.644+\frac{1}{4 \pi} \ln \left[\frac{\alpha t}{R_{o}^{2}}\right]\right) \text { for } \frac{\alpha t}{D^{2}} \leq 1.78 \\
& R_{S}=\frac{1}{2 \pi k_{S}} \ln \left(\frac{2 D}{R_{o}}\right) \text { for } \frac{\alpha t}{D^{2}} \geq 1.78
\end{aligned}
$$


For vertical configurations:

$$
\begin{aligned}
& R_{S}=\frac{1}{k_{S}}\left(0.644+\frac{1}{4 \pi} \ln \left[\frac{\alpha t}{R_{O}^{2}}\right]\right) \text { for } t \leq \frac{H^{2}}{9 \alpha} \\
& R_{S}=\frac{1}{2 \pi k_{S}} \ln \left(\frac{H}{2 R_{o}}\right) \text { for } t \geq \frac{H^{2}}{9 \alpha}
\end{aligned}
$$

Where:

$$
\begin{aligned}
R_{S} & =\text { soil thermal resistance }\left(\left(\mathrm{ft}{ }^{\circ} \mathrm{F}\right) / \mathrm{Btuh}\right) \\
k_{S} & =\text { thermal conductivity of the soil }\left(\mathrm{Btuh} /\left(\mathrm{ft}{ }^{\circ} \mathrm{F}\right)\right) \\
\alpha & =\text { thermal diffusivity }\left(\mathrm{ft}^{2} / \text { day }\right) \\
t & =\text { time to steady state (day) } \\
R_{O} & =\text { outer radius of the pipe }(\mathrm{ft}) \\
D & =\text { horizontal ground heat exchanger depth }(\mathrm{ft}) \\
H & =\text { vertical ground heat exchanger depth }(\mathrm{m})
\end{aligned}
$$

The difference between seasonal ground temperatures and minimum and maximum fluid temperatures for the heat pump must be calculated. For heating, the temperature difference in heating, $T_{H D}$, is the difference between the minimum earth temperature and the minimum tolerable fluid temperature of the heat pump (Bose 1983). For cooling, the temperature difference in cooling, $T_{C D}$, is the difference between the maximum earth temperature and the maximum tolerable fluid temperature for heat pump (Bose 1983).

The run fraction (ratio of heating/cooling demands to heating/cooling capacity) must also be determined to calculate the required length of pipe 
needed (Bose 1983). The run fraction ranges from zero to one and is calculated by comparing monthly demand to the hourly design load (Bose 1983). In addition to determining the run fraction, the COP for the heat pump must be determined (Bose 1983). The length of pipe in the ground required can then be calculated (Bose 1983):

For Heating:

$$
L_{H}=\frac{12,000\left(\frac{C O P-1}{C O P}\right)\left(\frac{R_{p}}{N}+R_{S}(f)\right)}{T_{H D}}
$$

For Cooling:

$$
L_{C}=\frac{12,000\left(\frac{C O P-1}{C O P}\right)\left(\frac{R p}{N}+R_{S}(f)\right)}{T_{C D}}
$$

Where:

$$
\begin{aligned}
L_{H} & =\text { length per ton of heating required (ft/ton) } \\
L_{C} & =\text { length per ton of cooling required (ft/ton) } \\
C O P & =\text { coefficient of performance for the heat pump } \\
R_{p} & =\text { pipe resistance }\left(\left(\mathrm{ft}{ }^{\circ} \mathrm{F}\right) / \mathrm{Btuh}\right) \\
R_{S} & =\text { soil resistance }\left(\left(\mathrm{ft}{ }^{\circ} \mathrm{F}\right) / \text { Btuh }\right) \\
N & =\text { number of pipes }(\text { i.e., } 2 \text { for vertical u-loop, } 1 \text { for single layer } \\
& \text { horizontal) } \\
f & =\text { run fraction } \\
T_{H D} & =\text { heating temperature difference }\left({ }^{\circ} \mathrm{F}\right) \\
T_{C D} & =\text { cooling temperature difference }\left({ }^{\circ} \mathrm{F}\right)
\end{aligned}
$$


A ton of cooling (or heating) is a quantity of energy equal to 12,000 Btuh (3.52 kW) (Bose 1983). The required lengths can then be determined by multiplying $L_{h}$ and $L_{c}$ by the number of tons of heating or cooling needed (Bose 1983). The length used is the longer of the heating and cooling lengths determined in analysis (Bose 1983).

\subsubsection{ASHRAE Design Method}

The American Society of Heating, Refrigerating and Air-Conditioning Engineers (ASHRAE) developed a design method for vertical ground source heat pumps. This method is based on heat transfer in an infinite cylinder developed by Carslaw and Jaeger (1959) (as reported by Kavanaugh and Rafferty 1997). The first step in performing any ground source heat pump design is to determine the configuration, piping, and heat pump to be used (Kavanaugh and Rafferty 1997). The designer must determine: ground temperature, thermal resistance of the borehole, thermal resistance of the ground, part load factor (the design load divided by the peak load), the short-circuit heat loss factor, annual average heat transfer to the ground, heat hump inlet temperature, heat pump outlet temperature, and thermal interference from adjacent borehole (Kavanaugh and Rafferty 1997). The length of borehole needed to heat and cool the building can then be calculated (Kavanaugh and Rafferty 1997). The longer of the two lengths calculated should be the length used in construction (Kavanaugh and Rafferty 1997). 


\subsection{Ground Heat Exchanger Numerical Models}

Several numerical models have been developed to analyze the heat transfer process in ground heat exchangers. Ground heat exchanger models were developed for soil and do not consider the possibility of heat generation of the material surrounding the ground heat exchanger. Both 2-D and 3-D models have been formulated and the following models are presented herein: Eskilson (1987), Hellstrom (1991), Muraya (1995), Rottmayer, Beckman and Mitchell (1997), Yavuzturk (1999), and Li and Zheng (2009).

\subsubsection{Eskilson Model}

Eskilson (1987) developed a model of a ground heat exchanger using $g$ functions (dimensionless temperature response factors). A radial-axial finite difference model was established to determine the temperature response for a single borehole for a unit heat pulse (Eskilson 1987). The resulting temperature response was then applied using superposition to varied horizontal spacing configurations of boreholes to determine the thermal response of multiple boreholes (Eskilson 1987). A $g$-function was then developed by nondimensionalizing the temperature response with time (Eskilson 1987). Heat extraction and rejection rates as a function of time can then be determined using the $g$-function and multiples of the unit heat pulse (Eskilson 1987).

\subsubsection{Hellstrom Model}

Hellstrom (1991) developed a model to determine the effects of multiple ground heat exchangers for seasonal heat storage. The model was comprised of 
two regions, the local region and the global region (Hellstrom 1991). The local region consisted of the volume directly around the borehole (Hellstrom 1991). A 1-D radial numerical solution was used to determine the local region heat transfer for short time scale thermal variations near the borehole (Hellstrom 1991). For long time scales, the heat flux in the local region is said to be constant with time and was calculated analytically (Hellstrom 1991). Temperatures in the global region were solved using a 2-D finite difference model. The global region was treated as a transient problem with thermal energy accumulation (Hellstrom 1991). Temperatures in the ground formation were determined by superimposing the local region short time scale, the local region steady state heat flux, and the global region temperature difference (Hellstrom 1991).

\subsubsection{Muraya Model}

Muraya (1995) developed a model to determine the heat transfer between the two legs of a single u-loop. A 2-D finite element model was used to determine the heat transfer between the legs of the u-loop (Muraya 1995). Different borehole geometrical configurations, backfill materials, soil properties, u-loop temperatures, and far field temperatures were simulated with the desired goal of determining the effectiveness of the ground heat exchanger (Muraya 1995). The most efficient selection of backfill was determined to depend on the borehole geometry (Muraya 1995). 


\subsubsection{Rottmayer, Beckman, and Mitchell Model}

Rottmayer, Beckman, and Mitchell (1997) developed a 2-D finite difference model representing a $3 \mathrm{~m}$ vertical section of borehole. Vertical heat transfer within the $3 \mathrm{~m}$ section was neglected, but the boundary conditions between sections were coupled (Rottmayer et al. 1997). The $3 \mathrm{~m}$ sections were used to account for changes in fluid temperature with depth (Rottmayer et al. 1997).

\subsubsection{Yavuzturk Model}

Yavuzturk (1999) developed a 2-D finite volume model to simulate a vertical ground heat exchanger. The model was established to determine the short time step thermal response of a ground heat exchanger (Yavuzturk 1999). Parametric evaluations of varying pipe sizes, pipe spacing, and borehole geometry were conducted and the short time step response of ground heat exchanger determined (Yavuzturk 1999). The response was presented in terms of a short term response factor, $g$-function (Yavuzturk 1999), similar to the long term response factor developed by Eskilson (1987)

\subsubsection{Li and Zheng Model}

Li and Zheng (2009) developed a 3-D unstructured finite volume model of a vertical ground heat exchanger. A triangulation mesh was utilized in the horizontal plane to accurately simulate the interior of the borehole (Li and Zheng 2009). Heat transfer between the two legs of the u-loop was accounted for because the interior geometry of the borehole was accurately simulated (Li and 
Zheng 2009). The vertical profile was divided into many layers to account for the change in fluid temperature with depth ( $\mathrm{Li}$ and Zheng 2009). Time steps of an hour were utilized for accuracy because of layering of vertical profile ( $\mathrm{Li}$ and Zheng 2009).

\subsection{Summary}

This chapter provided an overview of the necessary literature required to model a vertical heat extraction system (HES) in a landfill environment. Landfills are common waste containment facilities for MSW. Over time, MSW decomposes producing leachate, gas, and heat. Heat transfer within landfills due to ground surface temperatures and heat generation from decomposing waste has been studied and modeled numerically. Heat transfer has also been numerically modeled in ground source heat pumps in soil.

The Liu (2007) heat generation model of temperatures accounted for both the time and temperature dependence of heat generation. Other heat generation models did not account for the temperature dependence of heat generation. Therefore, the Liu model (2007) was used as a framework for the current investigation.

To develop a model of a ground source heat pump in a landfill environment, a new method must be devised because the current models available are insufficient for landfill environments. Specifically, current models cannot account for the thermal conditions, including heat generation, in landfills. Significant heat transfer in the vertical direction occurs in landfills. Current ground heat exchanger models are not able to properly account for amount of 
vertical heat transfer in a landfill. Due to the temperature dependence of heat generation, the HES temperatures and waste temperatures significantly impact each other. A model of a vertical HES in a landfill environment must be able to account for significant vertical temperature differences, as well as the coupled behavior of the HES and waste temperatures. To solve this problem, a 2-D axisymmetric model, with the axis of symmetry around the HES, was developed. 


\section{Chapter 3: Numerical Modeling Methodology}

\subsection{Introduction}

The numerical methodology for modeling a ground source heat pump in a municipal solid waste landfill environment is detailed in this chapter. A finite element analysis was conducted to simulate a single vertical heat extraction system (HES). The model simulated a single u-loop well in a municipal solid waste landfill using the finite element software Abaqus 6.11-2. Material properties, model geometry, model mesh, time steps, boundary conditions, loads, and the testing program are described in this chapter.

First, a 1-D numerical model of a vertical profile of a landfill was used to verify the waste heat generation function. Then, a 1-D numerical model of a vertical profile of a landfill was used to determine the thermal load applied by a vertical HES. Finally, a 2-D axisymmetric model was developed to determine the resulting heat energy extracted from an HES and the temperature difference in the waste mass caused by a vertical HES. Numerical models were developed for varying configurations and operational conditions in four climate regions in North America.

\subsection{Model Geometry}

First, a 1-D model was developed to determine the vertical thermal and temporal variations in a landfill due to the decomposition of waste. Four climatic sites around North America were simulated: Alaska, British Columbia, Michigan, and New Mexico. The model was comprised of a cover liner, waste, bottom liner, and subgrade. The cover extended from the ground surface to $1 \mathrm{~m}$ below the 
ground surface. Beneath the cover was waste, which varied in depth based on the site. The waste depths for Michigan Cell B and Cell D (used for model verification) were obtained from site records and were 32 and $31.5 \mathrm{~m}$, respectively. The waste heights for the sites representative of Michigan climate were $15 \mathrm{~m}, 30 \mathrm{~m}$, and $45 \mathrm{~m}$. A waste height of $30 \mathrm{~m}$ was used for the Alaska, British Columbia, and New Mexico climates. The bottom liner extended $1 \mathrm{~m}$ below the waste and the subgrade extended to a depth of $74 \mathrm{~m}$ below the base of the bottom liner. A depth of $75 \mathrm{~m}$ below the waste mass was required to allow for less than $0.1^{\circ} \mathrm{C}$ change in mean annual earth temperature at the vertical far field boundary (Liu 2007).

Then, a 2-D axisymmetric model was developed to determine the temperature influence of a vertical HES in a landfill environment with the axis of symmetry around the HES. The model was comprised of a cover liner, waste mass, bottom liner, subgrade, and HES. The resulting vertical profile of the model was consistent with the 1-D model. The radial distance from the center of the HES to the radial far field boundary was $80 \mathrm{~m}$. The radial distance from the center of the HES to the radial far field boundary was determined using the same criterion as the depth required below the waste mass. The HES is located on the axis of symmetry and extends from the ground surface to $3 \mathrm{~m}$ to above the bottom liner. Backfill was placed next to the HES along the axis of symmetry. The backfill extended radially $0.5 \mathrm{~m}$ from the axis of symmetry and vertically from the surface of the model to a depth of $3 \mathrm{~m}$ above the bottom liner. The axisymmetric model geometry is presented in Figure 3.1 . 


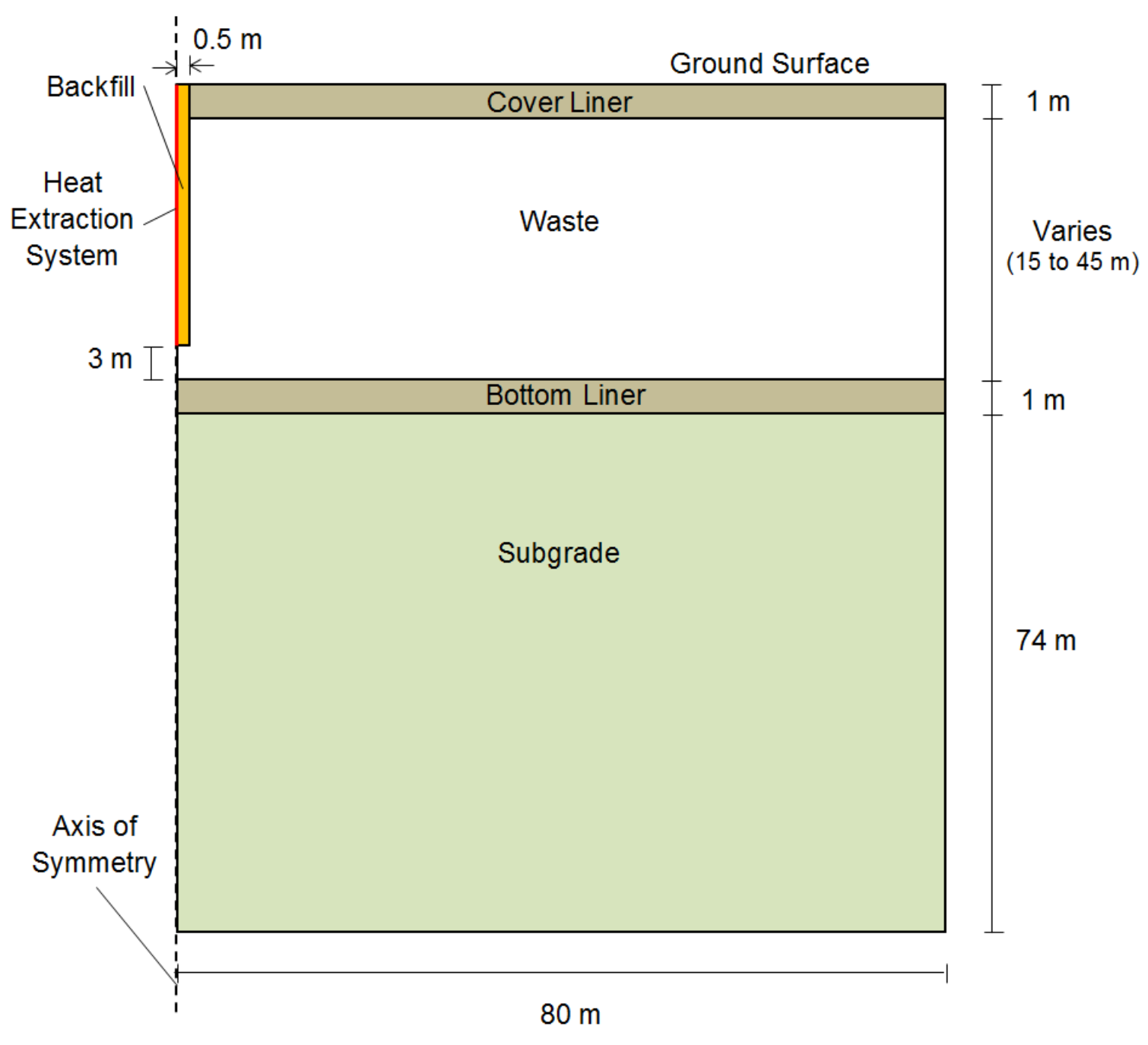

NOT TO SCALE

Figure 3.1: Axisymmetric Model Geometry

\subsection{Materials}

The materials simulated in the model were native soil, waste, and gravel backfill. The liners and subgrade were comprised of soil with site specific properties for the four climactic conditions. Soil properties were used to model the cover and bottom liners because these components are comprised primarily of soil. Geosynthetic components in the liners did not significantly impact the thermal response of the liner due to their thin configuration (Hanson et al. 2013). 
The waste was modeled using site specific waste properties. The backfill was modeled as gravel and thermal properties from literature were used.

Liu (2007) determined the material properties of the waste and soil at four test sites representing different climatic regions in North America. Material properties needed for the model were density $(\rho)$, heat capacity $(c)$, and thermal conductivity $(k)$. The material properties for the four sites are summarized in Table 3.1.

Table 3.1: Thermal Properties of Materials Used in the Model (Hanson et al. 2008, Hanson et al. 2013, Bradley and Zarling 1991)

\begin{tabular}{|c|c|c|c|c|}
\hline Property & Alaska & $\begin{array}{c}\text { British } \\
\text { Columbia }\end{array}$ & Michigan & $\begin{array}{c}\text { New } \\
\text { Mexico }\end{array}$ \\
\hline$\rho_{\text {soil }}\left(\mathrm{kg} / \mathrm{m}^{3}\right)$ & 2140 & 1800 & 2090 & 1700 \\
\hline$c_{\text {soil }}(\mathrm{J} /(\mathrm{kg} \mathrm{K}))$ & 840 & 1720 & 1340 & 760 \\
\hline$k_{\text {soil }}(\mathrm{W} /(\mathrm{m} \mathrm{K}))$ & 2.4 & 1.0 & 2.5 & 0.7 \\
\hline$\rho_{\text {waste }}\left(\mathrm{kg} / \mathrm{m}^{3}\right)$ & 530 & 1000 & 1000 & 760 \\
\hline$c_{\text {waste }}(\mathrm{J} /(\mathrm{kg} \mathrm{K}))$ & 1890 & 2200 & 2000 & 1590 \\
\hline$k_{\text {waste }}\left(\mathrm{W} /(\mathrm{m} \mathrm{K})^{3}\right)$ & 0.3 & 1.5 & 1.0 & 0.6 \\
\hline$\rho_{\text {gravel }}\left(\mathrm{kg} / \mathrm{m}^{3}\right)$ & 1900 & 1900 & 1900 & 1900 \\
\hline$c_{\text {gravel }}(\mathrm{J} /(\mathrm{kg} \mathrm{K}))$ & 1000 & 1000 & 1000 & 1000 \\
\hline$k_{\text {gravel }}(\mathrm{W} /(\mathrm{m} \mathrm{K}))$ & 2.2 & 2.2 & 2.2 & 2.2 \\
\hline
\end{tabular}

An empirical model for heat generation (Hanson et al. 2013) using a logarithmic growth and decay function with time was utilized as the heat generation function. Because the amount of heat generated is a function of temperature, a temperature dependent function was used (Figure 3.2). Optimum heat generation was assumed to occur between 30 and $50^{\circ} \mathrm{C}$ and no heat generation was assumed occur at temperatures less than $0^{\circ} \mathrm{C}$ and greater than 
$80^{\circ} \mathrm{C}$ (Hanson et al. 2013). The heat generation rate was linearly interpolated between the optimum and zero heat generation (Hanson et al. 2013). The temperature dependent function can be mathematically described as:

For $30^{\circ} \mathrm{C}<\mathrm{T}<50^{\circ} \mathrm{C}$ :

$H G=A\left(\frac{t}{B+t}\right)\left(\frac{C}{C+t}\right) e^{-\sqrt{\frac{t}{D}}}$

For $T<0^{\circ} \mathrm{C}$ or $T>80^{\circ} \mathrm{C}$ :

$H G=0$

For $0^{\circ} \mathrm{C}<\mathrm{T}<30^{\circ} \mathrm{C}$ :

$H G=\left(\frac{T}{30}\right) A\left(\frac{t}{B+t}\right)\left(\frac{C}{C+t}\right) e^{-\sqrt{\frac{t}{D}}}$

For $50^{\circ} \mathrm{C}<T<80^{\circ} \mathrm{C}$ :

$H G=\left(\frac{80-T}{30}\right) A\left(\frac{t}{B+t}\right)\left(\frac{C}{C+t}\right) e^{-\sqrt{\frac{t}{D}}}$

Where:

$$
\begin{aligned}
H G & =\text { heat generation rate }\left(\mathrm{W} / \mathrm{m}^{3}\right) \\
T & =\text { temperature }\left({ }^{\circ} \mathrm{C}\right) \\
t & =\text { time (days) } \\
A & =\text { peak heat generation factor }\left(\mathrm{W} / \mathrm{m}^{3}\right) \\
B, C & =\text { time factor (days) } \\
D & =\text { decay factor (days) }
\end{aligned}
$$




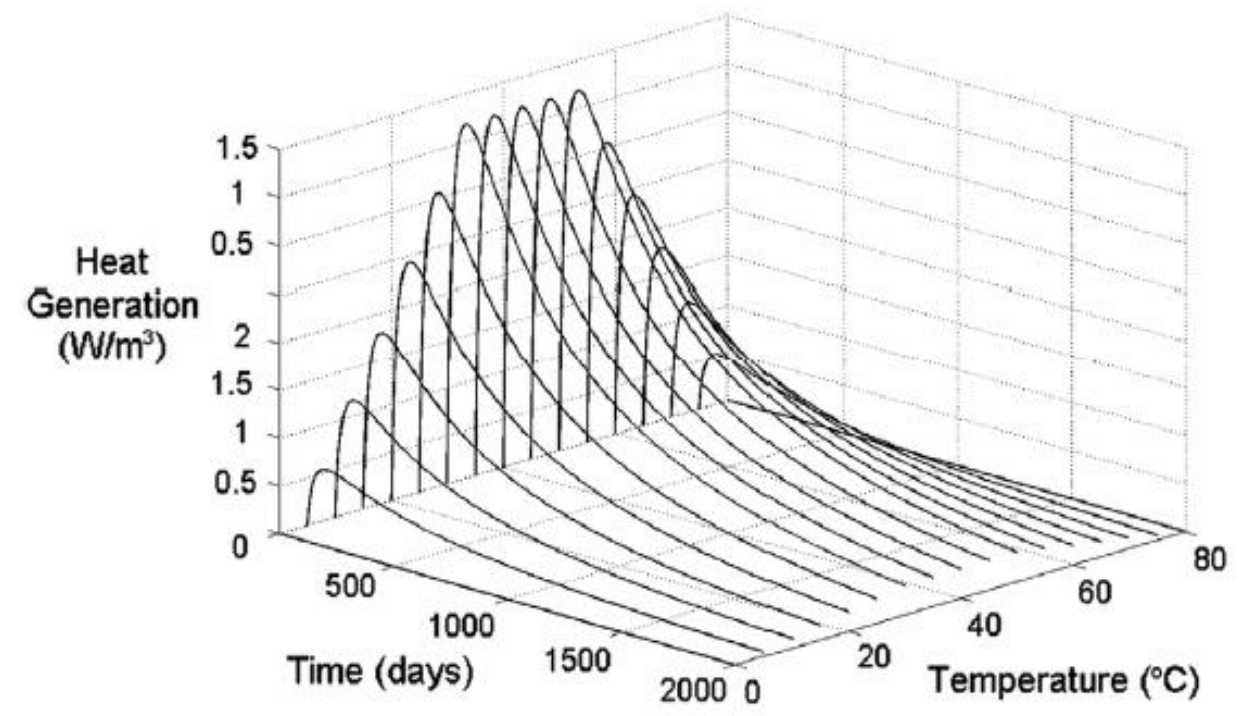

Figure 3.2: Heat Generation Function Dependent on Time and Temperature

The empirical heat generation factors determined by Liu (2007) were applied to landfills in representative Alaska, British Columbia, New Mexico, and Michigan climatic conditions (Table 3.2). The heat generation factors for Michigan Cell $D$ were used for the Michigan site because Michigan Cell D contained municipal solid waste operated under typical conditions while Michigan Cell B had differing waste composition (the inclusion of significant construction and demolition waste) and operational conditions, which included leachate recirculation (Hanson et al. 2013).

Table 3.2: Heat Generation Factors for Sites Used in Modeling (Hanson et al. 2008, Hanson et al. 2013)

\begin{tabular}{|c|c|c|c|c|c|}
\hline Factor & Alaska & $\begin{array}{c}\text { British } \\
\text { Columbia }\end{array}$ & $\begin{array}{c}\text { Michigan } \\
\text { Cell B }\end{array}$ & $\begin{array}{c}\text { Michigan } \\
\text { Cell D }\end{array}$ & New Mexico \\
\hline $\mathrm{A}\left(\mathrm{W} / \mathrm{m}^{3}\right)$ & 7 & 130 & 104.5 & 4.88 & 75 \\
\hline $\mathrm{B}$ (days) & 1200 & 2000 & 5000 & 50 & 5000 \\
\hline $\mathrm{C}$ (days) & 1200 & 2000 & 5000 & 5000 & 5000 \\
\hline $\mathrm{D}$ (days) & 90 & 80 & 120 & 180 & 50 \\
\hline
\end{tabular}




\subsection{Finite Element Mesh and Time Step}

Mesh size and time step are related to each other and a smaller element size requires a smaller time step. The following relationship was used to define the minimum time step for a given element size (Abaqus 2011).

$$
\begin{aligned}
\Delta l<\sqrt{\frac{6 k \Delta t}{\rho c}} & \\
\text { Where: } & \\
\Delta l & =\text { typical element dimension }(\mathrm{m}) \\
\Delta t & =\text { time step }(\mathrm{s}) \\
k & =\text { thermal conductivity }(\mathrm{W} /(\mathrm{m} \mathrm{K})) \\
\rho & =\text { density }\left(\mathrm{kg} / \mathrm{m}^{3}\right) \\
c & =\text { heat capacity }(\mathrm{J} /(\mathrm{kg} \mathrm{K}))
\end{aligned}
$$

A typical element size of $0.5 \mathrm{~m}$ was selected to ensure numerical stability. Using the thermal properties determined at the sites, an appropriate time step was determined to be 1 day. The 1-D model used $0.5 \mathrm{~m}$ linear, two-node elements, while the axisymmetric model used $0.5 \mathrm{~m}$ linear, four-node quadrilateral axisymmetric elements.

\subsection{Boundary Conditions}

\subsubsection{Predefined Field}

The entire model was set to mean annual earth temperature for the 1-D predefined field. A preliminary axisymmetric simulation was needed to determine the predefined field for the axisymmetric model. This preliminary simulation had 
the vertical profile of the one dimensional model and the same horizontal size as the axisymmetric model. The preliminary simulation modeled subgrade equilibrium, stepped waste filling, and the ongoing heat generation until the placement of the vertical HES. The results of the preliminary simulation were used as the predefined field for the 2-D axisymmetric model.

\subsubsection{Ground Surface and Far Field Boundary Conditions}

The simulated landfill was built up over time by adjusting the height of the surface temperature boundary condition in a stepwise progression. The boundary condition was first applied to all elements above the bottom liner subgrade for ten years to allow the subgrade and bottom liner to attain thermal equilibrium. The ground surface boundary was stepped upward by the waste filling rate with predetermined waste heights until the surface boundary condition reached the final ground surface level set for the model. The stepped waste filling at the Michigan Cell B and D cells was consistent with field data and is summarized in Table 3.3. 
Table 3.3: Waste Filling for the Michigan Site

\begin{tabular}{|c|c|c|c|c|}
\hline & \multicolumn{2}{|c|}{ Cell B } & \multicolumn{2}{c|}{ Cell D } \\
\hline & Date & Height $(\mathrm{m})$ & Date & Height $(\mathrm{m})$ \\
\hline Waste lift 1 Placement & $3 / 6 / 1994$ & 5.0 & $4 / 5 / 2003$ & 3.5 \\
\hline Waste lift 2 Placement & $7 / 15 / 1994$ & 5.0 & $7 / 3 / 2003$ & 3.0 \\
\hline Waste lift 3 Placement & $6 / 8 / 1995$ & 3.0 & $7 / 19 / 2003$ & 3.5 \\
\hline Waste lift 4 Placement & $12 / 8 / 1995$ & 3.0 & $7 / 24 / 2003$ & 3.0 \\
\hline Waste lift 5 Placement & $2 / 6 / 1996$ & 2.0 & $8 / 23 / 2003$ & 3.0 \\
\hline Waste lift 6 Placement & $5 / 26 / 1996$ & 4.0 & $9 / 23 / 2003$ & 3.0 \\
\hline Waste lift 7 Placement & $1 / 17 / 1997$ & 4.0 & $10 / 24 / 2003$ & 3.0 \\
\hline Waste lift 8 Placement & $5 / 1 / 1997$ & 3.0 & $11 / 23 / 2003$ & 3.0 \\
\hline Waste lift 9 Placement & $10 / 16 / 1997$ & 3.0 & $3 / 25 / 2004$ & 1.0 \\
\hline Waste lift 10 Placement & NA & NA & $6 / 23 / 2004$ & 2.0 \\
\hline Waste lift 11 Placement & NA & NA & $8 / 9 / 2004$ & 2.5 \\
\hline Cover Placement & $5 / 14 / 1999$ & 1.0 & $3 / 12 / 2006$ & 1.0 \\
\hline
\end{tabular}

The surface temperature was dependent on both climatic condition and presence of waste beneath the surface. A sinusoidal function with a period of one year was used to define the temperature variations of the ground surface. The theoretical coldest day for the ground is February $4^{\text {th }}$ while the theoretical hottest ground temperatures are obtained on August $6^{\text {th }}$ (Labs 1981). The sinusoidal function used was:

$$
T(t)=T_{m}+A \cos \left[\omega\left(t-t_{o}\right)\right]
$$

Where:

$$
\begin{aligned}
T(t) & =\text { temperature at any given time } t\left({ }^{\circ} \mathrm{C}\right) \\
T_{m} & =\text { average surface temperature }\left({ }^{\circ} \mathrm{C}\right) \\
A & =\text { ground surface temperature amplitude }\left({ }^{\circ} \mathrm{C}\right) \\
\omega & =\text { frequency }(1 / \mathrm{s})=\frac{2 \pi}{365 \text { days in seconds }}=1.992385 \times 10^{-7} \\
t & =\text { time }(\mathrm{s}) \\
t_{o} & =\text { phase constant }(\mathrm{s})
\end{aligned}
$$


The presence of underlying waste caused an increase in the average temperature and changed the amplitude of the ground surface temperature function (Yesiller et al. 2008). To account for the change in ground surface temperature, two sets of parameters were used for each site (Hanson et al. 2013) One set of parameters was used for the ground surface above the subgrade, while the other was used for ground surface temperatures overlying the waste and the cover (Hanson et al. 2013). The ground surface parameters for the different sites are summarized in Table 3.4.

The far field boundary condition for the 1-D model was applied at the bottom of the subgrade. The boundary condition represented mean annual earth temperatures. Mean annual earth temperatures were calculated (Liu 2007) and are presented in Table 3.4.

In the 2-D axisymmetric model, the vertical boundary condition consisted of mean annual earth temperature was applied $80 \mathrm{~m}$ from the axis of symmetry at the bottom of the subgrade and a zero heat flux condition (no heat flux in the vertical direction at the boundary) was applied at other locations along the bottom of the subgrade. The radial far field boundary condition (zero heat flux in the radial direction) was applied along the entire depth of the model at a distance of $80 \mathrm{~m}$ away from the axis of symmetry. 
Table 3.4: Ground Surface Temperature Parameters and Mean Annual Earth Temperatures (Liu 2007, Yesiller et al. 2005, Hanson et al. 2008, Hanson et al. 2013)

\begin{tabular}{|c|c|c|c|c|}
\hline Parameter & Alaska & $\begin{array}{c}\text { British } \\
\text { Columbia }\end{array}$ & Michigan & New Mexico \\
\hline Soil $T_{m}\left({ }^{\circ} \mathrm{C}\right)$ & 5.4 & 12.1 & 12.3 & 19.0 \\
\hline Soil $A\left({ }^{\circ} \mathrm{C}\right)$ & 13.4 & 11.0 & 17.3 & 12.0 \\
\hline Waste $T_{m}\left({ }^{\circ} \mathrm{C}\right)$ & 6.6 & 17.3 & 14.6 & 20.0 \\
\hline Waste $A\left({ }^{\circ} \mathrm{C}\right)$ & 14.3 & 12.0 & 16.6 & 12.0 \\
\hline $\begin{array}{c}\text { Mean Annual Earth } \\
\text { Temperature }\left({ }^{\circ} \mathrm{C}\right)\end{array}$ & 5.4 & 12.1 & 12.3 & 19.0 \\
\hline $\begin{array}{c}\text { Annual Precipitation } \\
(\mathrm{mm})\end{array}$ & 408 & 1,167 & 835 & 240 \\
\hline
\end{tabular}

\subsubsection{Heat Extraction Load}

The heat extraction load was modeled as an applied load along the simulated vertical HES. The load represents heat transfer rate caused by fluid flowing in a closed loop pipe circuit in the HES.

\section{Determination of Fluid Temperature}

The fluid temperatures were required to determine the amount of heat gain or loss along the length of the HES. The fluid temperatures impacted the waste temperatures while the waste temperatures impacted the fluid temperatures. Because the waste and fluid temperatures were dependent on each other and both were unknown, the fluid temperatures were estimated. An envelope of maximum and minimum possible fluid temperatures was developed. Numerous weighted averages of the maximum and minimum fluid temperatures were simulated. Weighted averages were then compared to the expected heat extracted from the vertical HES using the IGSHPA Design Method (Bose 1983). An appropriate weighted average was then selected to apply to all the models. 
To arrive at a maximum possible fluid temperature, a 1-D model of the landfill with heat generation was developed. The one dimensional model was used to establish a vertical temperature profile every month for 40 years after the cover liner was placed. Average fluid temperatures were then established with depth by mathematically calculating the progression of the fluid incrementally down and then up the length of the HES.

The circulation fluid was modeled as $20 \%$ propylene glycol and $80 \%$ water by mass. The $20 \%$ propylene glycol fluid to prevent freezing at the lowest expected ground temperatures. The thermal properties of propylene glycol circulation fluid compared to water are presented in Table 3.5.

Table 3.5: Properties of the Circulation Fluid and Water (Bolz and Tuve 1973, Holman 1997)

\begin{tabular}{|c|c|c|}
\hline Property & Circulation Fluid & Water \\
\hline $\begin{array}{c}\text { Density, } \rho \\
\left(\mathrm{kg} / \mathrm{m}^{3}\right)\end{array}$ & 1016 & 999 \\
\hline $\begin{array}{c}\text { Thermal Conductivity, } k \\
(\mathrm{~W} /(\mathrm{m} \mathrm{K}))\end{array}$ & 0.5 & 0.59 \\
\hline $\begin{array}{c}\text { Heat capacity, } c \\
(\mathrm{~J} /(\mathrm{kg} \mathrm{K}))\end{array}$ & 4020 & 4190 \\
\hline $\begin{array}{c}\text { Dynamic Viscosity, } \mu \\
\left((\mathrm{N} \mathrm{s}) / \mathrm{m}^{2}\right)\end{array}$ & $3.10 \times 10^{-3}$ & $1.2 \times 10^{-3}$ \\
\hline $\begin{array}{c}\text { Kinematic Viscosity, } v \\
\left(\mathrm{~m}^{2} / \mathrm{s}\right)\end{array}$ & $3.05 \times 10^{-6}$ & $1.2 \times 10^{-6}$ \\
\hline
\end{tabular}

Using a given pipe diameter and fluid velocity, the mass flow rate and convective heat transfer coefficient were calculated. The mass flow rate was calculated as (Munson et. al. 2009): 


$$
\dot{m}=\rho V A_{c}
$$

Where:

$$
\begin{aligned}
\dot{m} & =\text { mass flow rate }(\mathrm{kg} / \mathrm{s}) \\
\rho & =\text { density of fluid }\left(\left(\mathrm{kg} / \mathrm{m}^{3}\right)\right. \\
V & =\text { velocity of fluid }(\mathrm{m} / \mathrm{s}) \\
A_{c} & =\text { cross-sectional area of the pipe }\left(\mathrm{m}^{2}\right)
\end{aligned}
$$

To determine the convective heat transfer coefficient, first the Reynolds $(R e)$ and Prandtl $(P r)$ numbers were calculated. Then, an appropriate correlation with the Nusselt $(\mathrm{Nu})$ number was selected:

For Laminar Flow (Hausen 1943 as reported in Holman 1997), $R e<2300$

$$
N u=3.66+\frac{0.0668\left(\frac{d}{L}\right) \operatorname{RePr}}{1+0.04\left[\left(\frac{d}{L}\right) \operatorname{RePr}\right]^{0.66}}
$$

For Turbulent Flow (Sieder and Tate 1936), Re>2300

$$
\begin{aligned}
& N u=0.027 \operatorname{Re}^{0.8} \operatorname{Pr}^{0.33}\left(\frac{\mu}{\mu_{w}}\right)^{0.14} \\
& \begin{aligned}
\text { Where: } \\
N u=\text { Nusselt number } \\
R e=\text { Reynolds number } \\
P r=\text { Prandtl number } \\
\mu=\text { dynamic viscosity of fluid }(\mathrm{kg} /(\mathrm{m} \mathrm{s})) \\
\mu_{w}=\text { dynamic viscosity of water }(\mathrm{kg} /(\mathrm{m} \mathrm{s}))
\end{aligned}
\end{aligned}
$$




$$
\begin{aligned}
& d=\text { diameter of pipe }(\mathrm{m}) \\
& L=\text { length of pipe }(\mathrm{m})
\end{aligned}
$$

Using the calculated Nusselt number, the convective heat transfer coefficient was determined. The convective heat transfer coefficient was then used to calculate the temperature of the fluid along the length of the HES. Temperatures from the 1-D model were obtained at every node (i.e., every 0.5 m) for the entire length of the HES. The surface area of the pipe, which depended on the pipe size, was calculated for each $0.5 \mathrm{~m}$ section of pipe. The temperature of fluid entering the HES was prescribed to be equal to mean surface temperature of the soil. The fluid temperature was then calculated in 0.5 $m$ increments along the length (i.e., down then up the length of the well). The pipe wall was assumed to have the same temperature as the vertical temperature profile from the 1-D model. By combining Equations 2.8 and 2.9, the fluid temperature was calculated down and up the length of the pipe:

$$
T_{n}=\frac{h A_{s}\left(T_{m n}-T_{n-1}\right)}{\dot{m} c}+T_{n-1}
$$

Where:

$$
\begin{aligned}
T_{n} & =\text { temperature at increment } n\left({ }^{\circ} \mathrm{C}\right) \\
T_{n-1} & =\text { temperature at increment } n-1\left({ }^{\circ} \mathrm{C}\right) \\
T_{m n} & =1-\mathrm{D} \text { model temperature at same depth as increment } n\left({ }^{\circ} \mathrm{C}\right) \\
h & =\text { convection heat transfer coefficient }\left(\mathrm{W} /\left(\mathrm{m}^{2} \mathrm{~K}\right)\right) \\
A_{s} & =\text { surface area of the pipe in increment } n\left(\mathrm{~m}^{2}\right) \\
\dot{m} & =\text { mass flow rate }(\mathrm{kg} / \mathrm{s})
\end{aligned}
$$




$$
c=\text { fluid heat capacity }(\mathrm{J} /(\mathrm{kg} \mathrm{K}))
$$

The temperatures at equivalent depths from both pipes (i.e., the downward flow pipe and the upward flow pipe) were then averaged to determine the fluid temperature at a given depth. A fourth-order polynomial was developed to describe the fluid temperature as a function of depth. The process of determining the fourth-order polynomial was repeated every 30 days from the placement of the vertical HES to 40 years after the cover was placed.

To determine the minimum fluid temperatures, a 1-D model of the landfill without heat generation was developed. The 1-D model was simulated for ten years after the placement of the cover liner to allow for the temperatures to reached thermal stasis. A vertical temperature profile was made for every month for the last year of the model. The same method used to determine the maximum fluid temperatures was used to determine the minimum fluid temperatures. The minimum fluid temperature was calculated for a single year and the results were repeated on annual basis beginning from the placement of the vertical HES to 40 years after the placement of the cover. Then, weighted averages between the maximum fluid temperature and minimum fluid temperature for a given date were developed.

\section{Applied Heat Extraction Load}

Once the convective heat transfer coefficient and fluid temperatures were calculated, the heat flux load representing the vertical HES was determined. The fluid temperature calculated for each 30 day period was applied for the duration 
of the corresponding 30 day period. The pipe temperature was assumed to be the equal to the 2-D axisymmetric model temperature at the same depth, $0 \mathrm{~m}$ away from the HES. The heat flux load was then calculated using Equation 3.8:

$$
\begin{aligned}
& Q=h A_{s}\left(T_{f x}-T_{m x}\right) \\
& \begin{aligned}
\text { Where: } \\
Q=\text { heat transfer rate for } 1 \mathrm{~m} \text { length of } \mathrm{HES}(\mathrm{W}) \\
h=\text { convection heat transfer coefficient }\left(\mathrm{W} /\left(\mathrm{m}^{2} \mathrm{~K}\right)\right) \\
A_{s}=\text { surface area for } 1 \mathrm{~m} \text { length of pipe in the } \mathrm{HES}\left(\mathrm{m}^{2}\right) \\
T_{f x}=\text { fluid temperature at depth } z\left({ }^{\circ} \mathrm{C}\right) \\
T_{m x}=\text { model temperature at depth } z\left({ }^{\circ} \mathrm{C}\right)
\end{aligned}
\end{aligned}
$$

The boundary conditions and loads applied to the axisymmetric model are presented in Figure 3.3. 


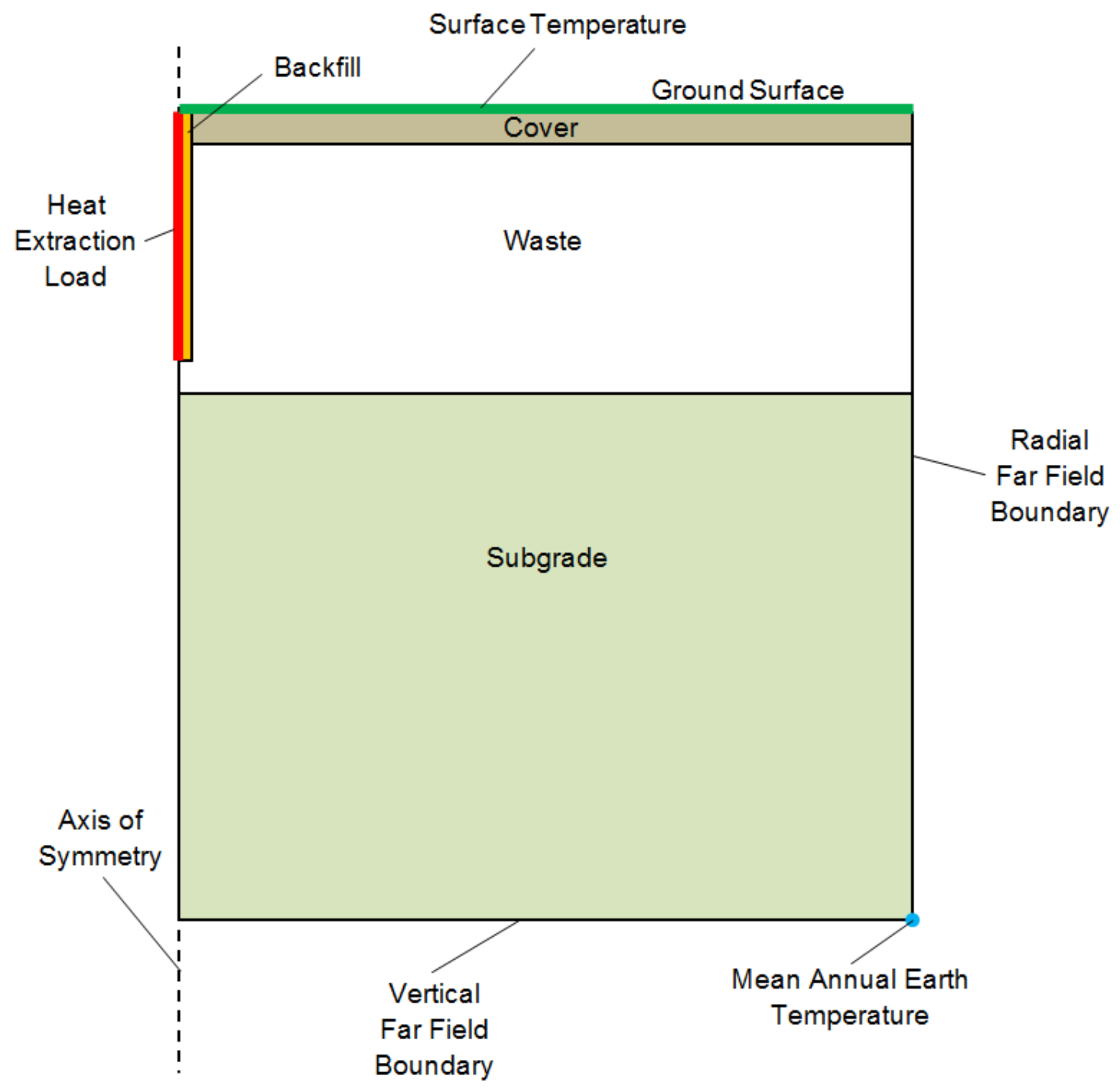

Figure 3.3: Schematic of Axisymmetric Model Boundary Conditions and Loads

\subsection{Heat Extraction Test Program}

The heat generation functions for the waste were validated by modeling Cell $B$ and $D$ at the Michigan landfill. The 1-D model was used to conduct the validation. The fluid temperatures were validated using the 2-D axisymmetric model. A single u-loop with fluid velocity of $0.3 \mathrm{~m} / \mathrm{s}$ and a $25.4 \mathrm{~mm}$ pipe diameter was used to calculate the heat transfer rate because fluid flow was turbulent. Multiple fluid temperature weighted averages were tested. The appropriate fluid 
temperature weighted average was selected by comparing the heat transfer rate from the model to the IGSHPA design method (Bose 1983) for designing ground source heat pumps.

Different configurations of the vertical HES and operational conditions were tested in the axisymmetric models. The configurations investigated variable fluid velocity and pipe diameter. The operational conditions investigated variable waste placement times, waste height, waste filling rate, HES placement time, vertical landfill expansions (i.e., piggyback expansion), HES operation, climate, and waste heating.

Fifteen configuration simulations were developed by investigating all combinations of fluid velocity and pipe diameter for a single u-loop. The pipe configurations were tested at a site representing Michigan climate with $30 \mathrm{~m}$ waste at $20 \mathrm{~m} /$ year filling rate. Waste placement began on the theoretical coldest ground surface temperature day (February 4). The fluid velocities used were $0.01,0.1,0.3,0.6$, and $1 \mathrm{~m} / \mathrm{s}$. The pipe diameters used were $25.4,38.1$, $50.8 \mathrm{~mm}$. The configuration simulations are presented in Table 3.6.

The subsequent 26 operational simulations were tested using a template landfill model and varying only one parameter. The typical model consisted of: $0.3 \mathrm{~m} / \mathrm{s}$ fluid velocity, $25.4 \mathrm{~mm}$ pipe size, $30 \mathrm{~m}$ waste height, $20 \mathrm{~m} /$ year waste filling rate, year-round waste placement beginning on February $4^{\text {th }}$, HES placement 1 day after cover was placed, year-round HES operation, and no vertical landfill expansions. 
Table 3.6: Configuration Simulations

\begin{tabular}{|c|c|c|}
\hline Simulation & Fluid Velocity $(\mathrm{m} / \mathrm{s})$ & Pipe Diameter $(\mathrm{mm})$ \\
\hline 1 & 0.01 & 25.4 \\
\hline 2 & 0.1 & 25.4 \\
\hline 3 & 0.3 & 25.4 \\
\hline 4 & 0.6 & 25.4 \\
\hline 5 & 1 & 25.4 \\
\hline 6 & 0.01 & 38.1 \\
\hline 7 & 0.1 & 38.1 \\
\hline 8 & 0.3 & 38.1 \\
\hline 9 & 0.6 & 38.1 \\
\hline 10 & 1 & 38.1 \\
\hline 11 & 0.01 & 50.8 \\
\hline 12 & 0.1 & 50.8 \\
\hline 13 & 0.3 & 50.8 \\
\hline 14 & 0.6 & 50.8 \\
\hline 15 & 1 & 50.8 \\
\hline
\end{tabular}

The year-round placement investigation was comprised of 12 simulations starting on the fourth of every month. Waste was placed on December 19 and March 19 for winter placement and on June 19 and September 19 for summer placement. The winter-only and summer-only waste placement allowed for 3 months between placements and 1.5 months between the coolest and warmest ground temperatures.

Waste heights of 15,30 , and $45 \mathrm{~m}$ were simulated for the Michigan site. The same filling rate was used for each waste height simulation (i.e., the $45 \mathrm{~m}$ waste height simulation had the longest filling time and the $15 \mathrm{~m}$ waste height simulation had the shortest waste filling time). Waste filling rates (i.e., vertical accumulation of waste mass) of 5,12 , and $20 \mathrm{~m} /$ year were simulated (i.e., 6 years of filling for the $5 \mathrm{~m} /$ year rate, 2.5 years of filling for the $12 \mathrm{~m} /$ year rate, and 1.5 years of filling for the $20 \mathrm{~m} /$ year filling rate). Waste filling rate simulations 
divided the total waste height into $5 \mathrm{~m}$ lifts placed at equal time intervals over the waste filling time period. The total waste height was divided into $2.5 \mathrm{~m}$ lifts at equal time intervals over the waste filling time period for the $5 \mathrm{~m} /$ year waste filling rate, so the waste was not placed at the same time every year. If the waste was placed at the same time every year, the temperatures in the landfill would be skewed due to placement temperature being the same for all lifts.

Vertical landfill expansions of 5 years and 10 years after intermediate cover was placed were investigated. Vertical landfill expansion simulations were comprised of two sections of $15 \mathrm{~m}$ of waste each. Waste filling in each $15 \mathrm{~m}$ lift was consistent with waste filling of the typical model. A meter of soil was placed in between the two sections representing intermediate cover.

The HES was operated both year-round and only in the winter. Winter HES operation occurred from December 19 to March 19 (heat extraction was set to 0 from March 19 to December 19 for winter HES operation).

The four climate sites (Alaska, British Columbia, Michigan, and New Mexico) were simulated using site specific material properties, heat generation, surface temperatures, and mean annual earth temperatures. The Alaska site was used to investigate waste heating. Waste heating was simulated by selecting the inlet fluid to be $50^{\circ} \mathrm{C}$ as opposed to mean surface temperature of the soil. Each operational simulation is presented in Table 3.7 with the values of the different operational parameters. 
Table 3.7: Operational Simulations

\begin{tabular}{|c|c|c|c|c|c|c|c|}
\hline Simulations & Climate & $\begin{array}{l}\text { Waste } \\
\text { Height } \\
(\mathrm{m})\end{array}$ & $\begin{array}{l}\text { Waste } \\
\text { Filling } \\
\text { Rate } \\
(\mathrm{m} / \mathrm{y})\end{array}$ & $\begin{array}{c}\text { Waste } \\
\text { Placement }\end{array}$ & $\begin{array}{c}\text { HES } \\
\text { Placement } \\
\text { after Cover } \\
\text { Placement }\end{array}$ & $\begin{array}{c}\text { HES } \\
\text { Operation }\end{array}$ & $\begin{array}{l}\text { Vertical Landfill } \\
\text { Expansions } \\
\text { (years after } \\
\text { intermediate } \\
\text { cover) }\end{array}$ \\
\hline 16 & MI & 30 & 20 & YR-Jan & 1 day & YR & NA \\
\hline 17 & $\mathrm{Ml}$ & 30 & 20 & YR-Mar & 1 day & YR & NA \\
\hline 18 & MI & 30 & 20 & YR-Apr & 1 day & YR & NA \\
\hline 19 & MI & 30 & 20 & YR-May & 1 day & YR & NA \\
\hline 20 & MI & 30 & 20 & YR-Jun & 1 day & YR & NA \\
\hline 21 & MI & 30 & 20 & YR-Jul & 1 day & YR & NA \\
\hline 22 & MI & 30 & 20 & YR-Aug & 1 day & YR & NA \\
\hline 23 & MI & 30 & 20 & YR-Sep & 1 day & YR & NA \\
\hline 24 & MI & 30 & 20 & YR-Oct & 1 day & YR & NA \\
\hline 25 & MI & 30 & 20 & YR-Nov & 1 day & YR & NA \\
\hline 26 & $\mathrm{Ml}$ & 30 & 20 & YR-Dec & 1 day & YR & $\mathrm{NA}$ \\
\hline 27 & MI & 30 & 20 & WO & 1 day & YR & NA \\
\hline 28 & MI & 30 & 20 & $\mathrm{SO}$ & 1 day & YR & NA \\
\hline 29 & $\mathrm{Ml}$ & 15 & 20 & YR-Feb & 1 day & YR & $\mathrm{NA}$ \\
\hline 30 & MI & 45 & 20 & YR-Feb & 1 day & YR & NA \\
\hline 31 & $\mathrm{MI}$ & 30 & 5 & YR-Feb & 1 day & YR & NA \\
\hline 32 & MI & 30 & 12 & YR-Feb & 1 day & YR & $\mathrm{NA}$ \\
\hline 33 & MI & 30 & 20 & YR-Feb & 1 day & YR & 5 \\
\hline 34 & $\mathrm{MI}$ & 30 & 20 & YR-Feb & 1 day & YR & 15 \\
\hline 35 & $\mathrm{MI}$ & 30 & 20 & YR-Feb & 1 year & YR & NA \\
\hline 36 & $\mathrm{Ml}$ & 30 & 20 & YR-Feb & 5 years & YR & NA \\
\hline 37 & MI & 30 & 20 & YR-Feb & 1 day & WO & NA \\
\hline 38 & AK & 30 & 20 & YR-Feb & 1 day & YR & $\mathrm{NA}$ \\
\hline 39 & $B C$ & 30 & 20 & YR-Feb & 1 day & YR & NA \\
\hline 40 & NM & 30 & 20 & YR-Feb & 1 day & YR & NA \\
\hline 41 & AK & 30 & 20 & YR-Feb & 1 day & YR-Hot & NA \\
\hline
\end{tabular}

$\mathrm{AK}=$ Alaska climate

$\mathrm{BC}=$ British Columbia climate

$\mathrm{MI}=$ Michigan climate

$\mathrm{NM}=$ New Mexico climate

YR-XXX = year-round placement - month placement started

$\mathrm{SO}=$ Summer placement only

$\mathrm{WO}=$ winter-only placement

$\mathrm{YR}=$ year-round operation

YR-Hot = year-round operation with waste heating

$\mathrm{NA}=$ does not apply 


\section{Chapter 4: Validation and Results}

\subsection{Introduction}

Results of the numerical models are presented in this chapter. Validation of the heat generation function and fluid temperatures in the vertical HES are provided in this chapter. Results of temperature distribution and heat extraction caused by the application of a vertical HES to a landfill also are presented in this chapter. The order of topics covered in this chapter is as follows: heat generation validation, fluid temperature validation, and results of parametric evaluation.

\subsection{Heat Generation Validation}

A 1-D model of heat generation Michigan Cells D and B was developed and compared to field data at different depths. Waste placement sequence and heights for Michigan Cells B and D were presented in Table 3.3. Identical material properties and boundary conditions were simulated in both cells. Different heat generation functions were applied to Cell D and Cell B to account for differences in operational conditions, such as waste composition and leachate recirculation (Hanson et al. 2013).

The heat generation functions employed in Cell D and Cell B are presented in Figure 4.1. The peak heat generation rates for Cell B and Cell D were $1.16 \mathrm{~W} / \mathrm{m}^{3}$ and $1.52 \mathrm{~W} / \mathrm{m}^{3}$, respectively. The time required to reach peak heat generation for Cell B and Cell D was 360 days and 87 days, respectively. The total amounts of energy generated by waste for Cell B and Cell D were 174 $\mathrm{MJ} / \mathrm{m}^{3}$ and $104 \mathrm{MJ} / \mathrm{m}^{3}$, respectively. 


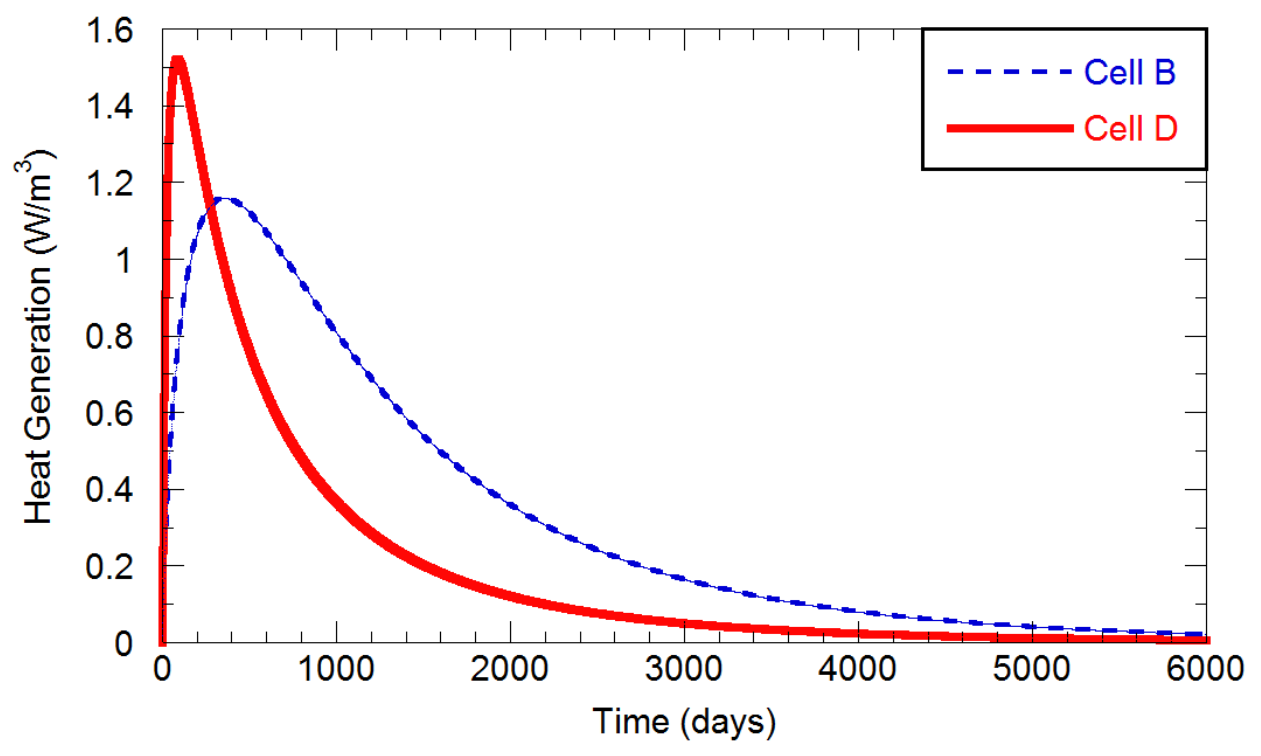

Figure 4.1: Heat Generation Functions for Michigan Cell B and Cell D (Hanson et al. 2013)

The results of the predicted and measured temperatures are presented in Figure 4.2 and Figure 4.3 for Cell B and Cell D, respectively. Time zero indicates the start of field data measurement. Temperature measurements for Cell B began 90 days after cover placement (Table 3.3). Temperature measurements for Cell $D$ began 473 days before waste was placed and continued during waste placement.

Predicted model temperatures were $\pm 2^{\circ} \mathrm{C}$ for cell $\mathrm{B}$ and $\pm 5^{\circ} \mathrm{C}$ for Cell $\mathrm{D}$ from the measured field temperatures (most temperatures were within $\pm 2^{\circ} \mathrm{C}$ for Cell D). In general, higher variations from predicted temperatures were obtained at shallow depths due to variable daily surface temperatures. Cell D had higher variations from predicted temperatures than Cell $B$ because data was acquired during waste placement. The variable surface temperatures that influenced 
waste temperatures at time of waste placement caused a higher degree of variability throughout Cell D than Cell B.
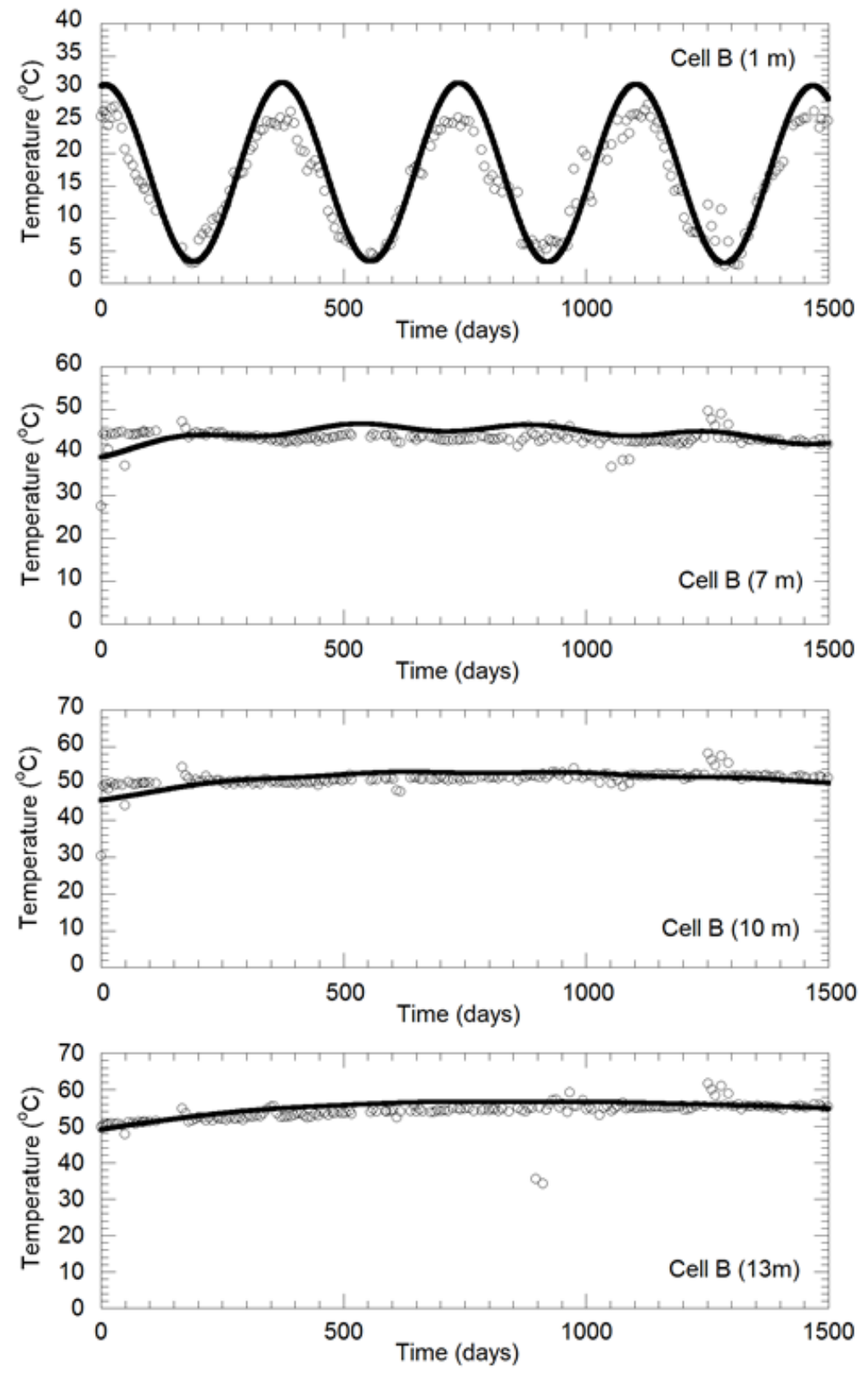

Predicted Temperatures $\quad \circ \quad$ Measured Temperatures

Figure 4.2: Comparison of Predicted and Measured Temperatures at Michigan Cell B (Hanson et al. 2013) 

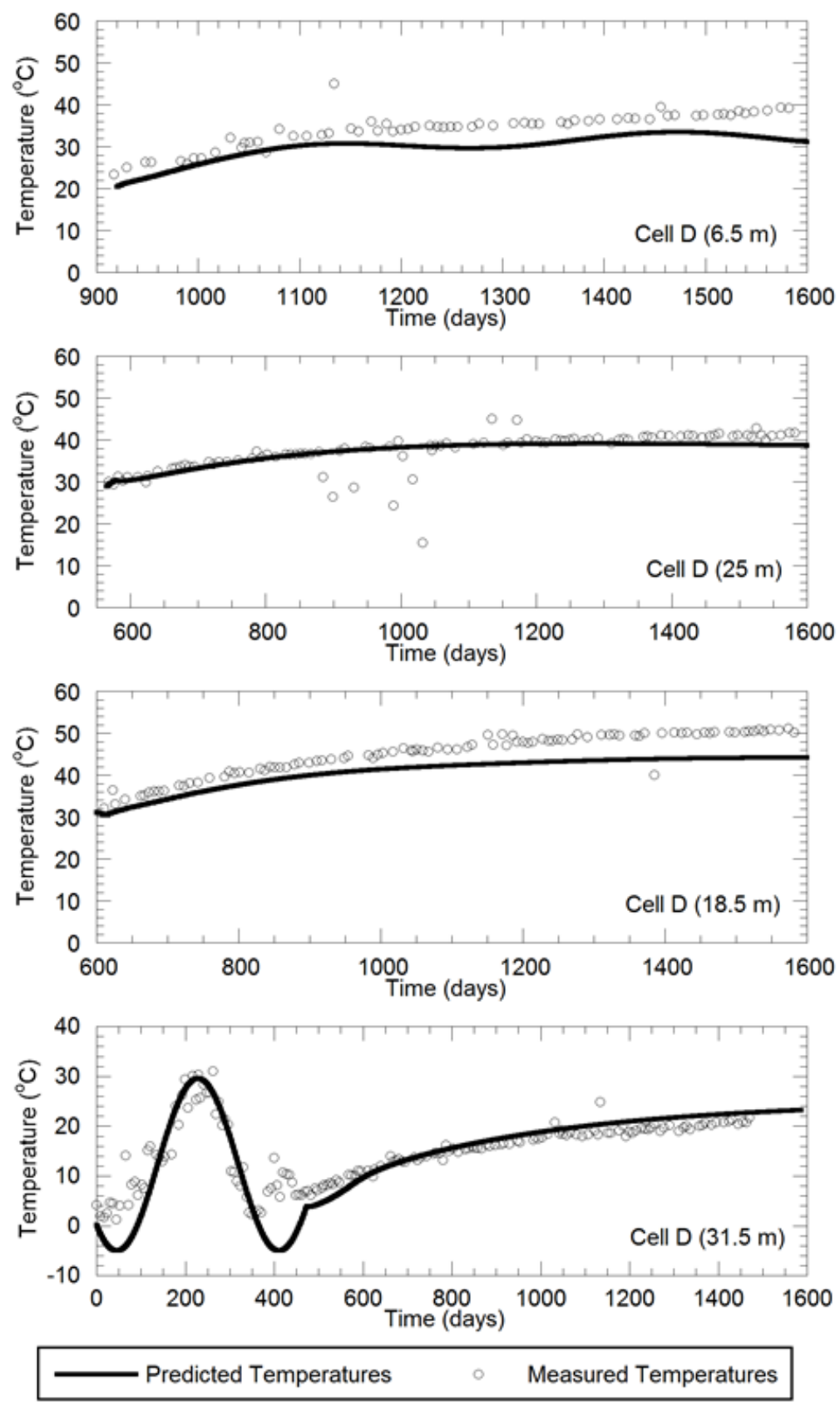

Figure 4.3: Comparison of Predicted and Measured Temperatures at Michigan Cell B (Hanson et al. 2013)

Higher temperatures were predicted in the center of the waste mass away from the top and bottom liners. Cell B had higher temperatures than Cell D at central depths in the waste with field temperatures reaching $56^{\circ} \mathrm{C}$ and $42^{\circ} \mathrm{C}$ for 
Cell B and Cell D, respectively. Seasonal fluctuations in temperature were most noticeable at shallow depths and decreased with depth. The phase lag of the sinusoidal seasonal temperature fluctuation increased with depth.

\subsection{Fluid Temperature Validation}

Several different weighted averages of the minimum to maximum fluid temperature were determined using the method outlined in Chapter 3. Minimum fluid temperatures were determined by calculating fluid temperatures in the HES with no heat generation present in the landfill. Maximum fluid temperatures were determined by calculating fluid temperatures in the HES with heat generation present in the landfill. Examples of the minimum and maximum average fluid temperatures in the vertical HES are presented in Figure 4.4 and Figure 4.5, respectively.

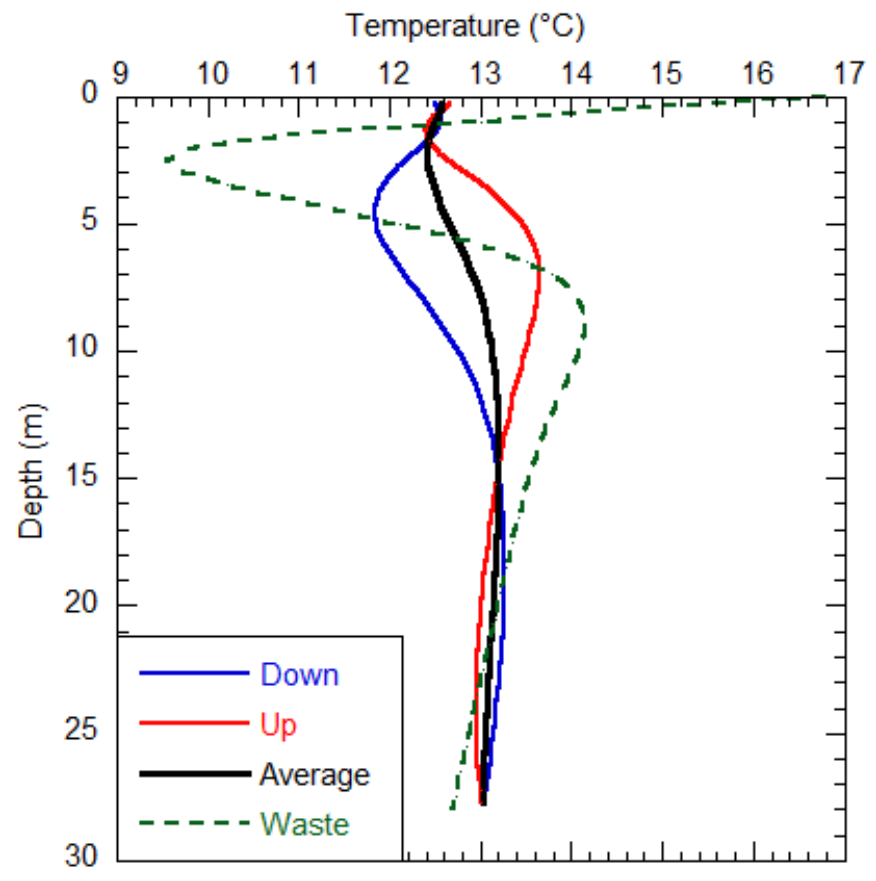

Figure 4.4: Example Minimum Fluid Temperatures 


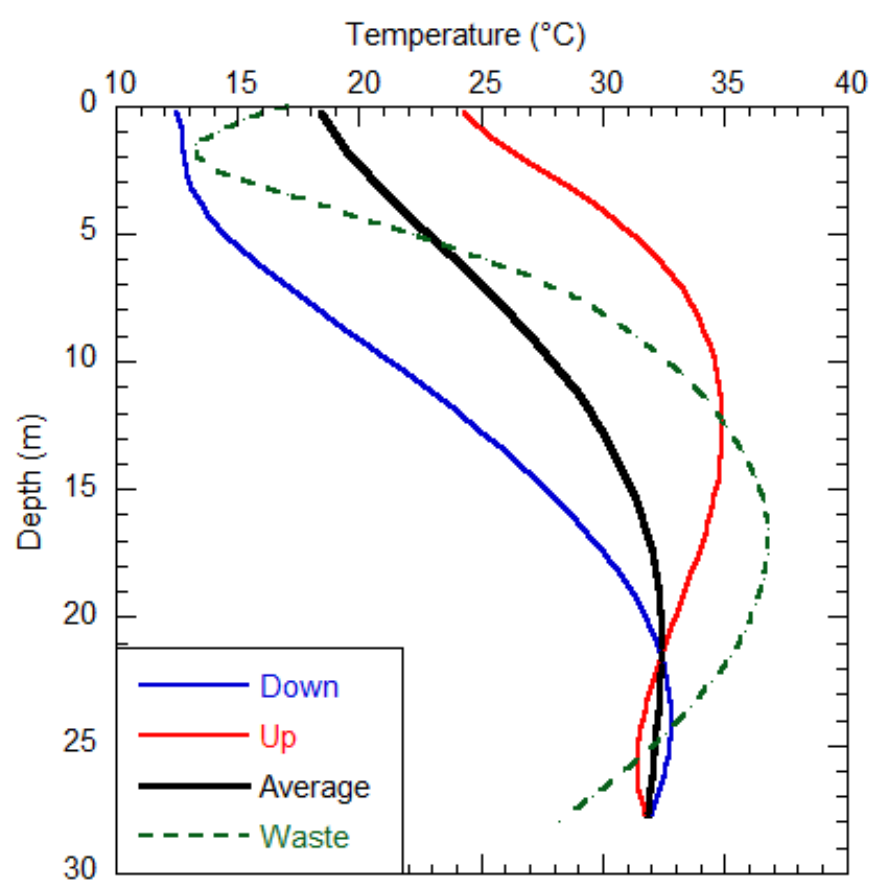

Figure 4.5: Example Maximum Fluid Temperatures

To verify the fluid temperature weighted averages, a calculation of the expected amount of energy from the HES was made. The IGSHPA design method (Bose 1983) for designing ground source heat pumps was used to determine the expected heat extraction rate.

First, the change in temperature of the native ground temperature due to the heat generation of the waste was required. The difference in temperature between the 1-D landfill model with heat generation applied and without heat generation applied was determined for a 5-year period starting after the placement of the cover. A 5-year period was determined to be sufficient as peak heat extraction occurred within the 5-year period. A second order polynomial curve fit was used to represent the change in temperature (Figure 4.6). 


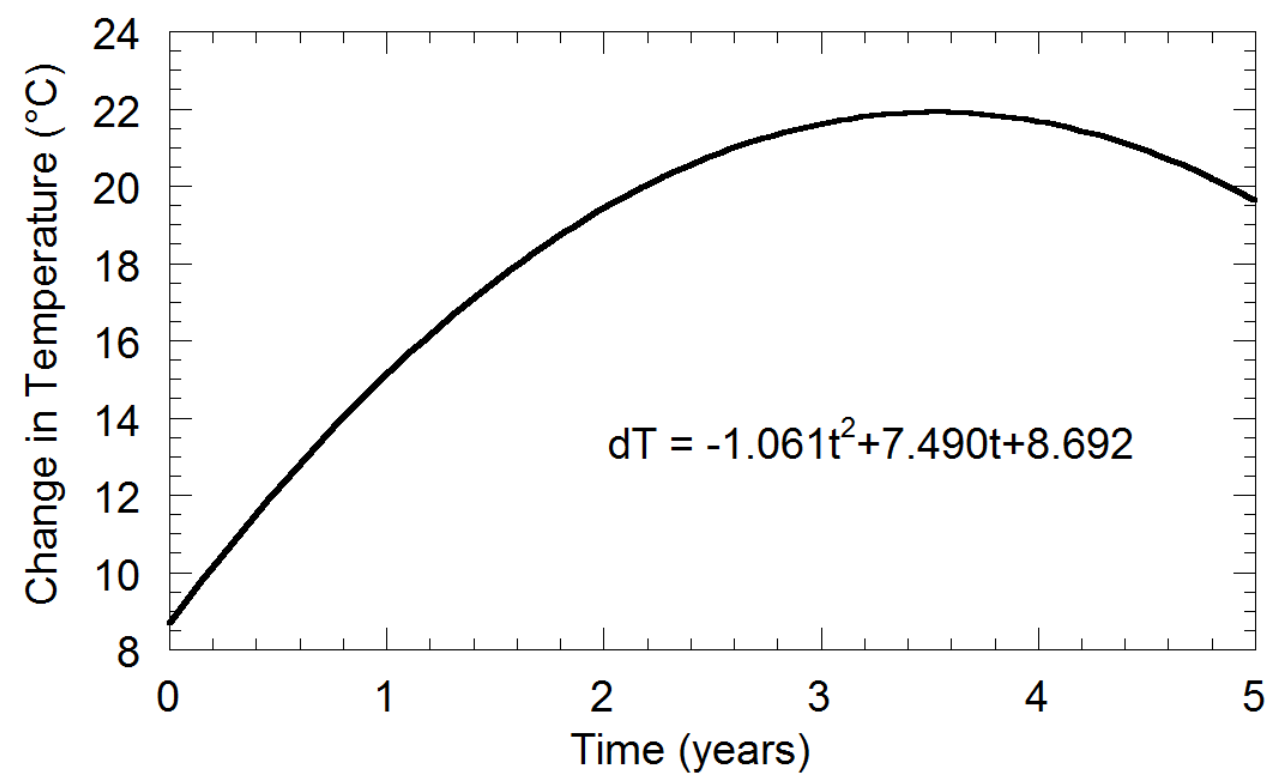

Figure 4.6: Change in Temperature over Time Due to Heat Generation

Using the second order equation, the change in temperature due to heat generation was calculated for the 5-year period. The minimum and maximum weighted average temperatures along the length of the HES from the 1-D model without heat generation were $12.4^{\circ} \mathrm{C}$ and $14.8^{\circ} \mathrm{C}$, respectively. The equation to calculate length of borehole required for the IGSHPA design method (Bose 1983) was modified to determine the heat extraction rate from the HES:

$$
Q=\frac{L\left(T_{S}+d T-T_{m f}\right)}{\frac{R p}{N}+R_{S}(f)}
$$

Where:

$$
\begin{aligned}
Q & =\text { heat transfer rate }(\mathrm{W}) \\
\mathrm{L} & =\text { length of borehole }(\mathrm{m}) \\
T_{S} & =\text { waste temperature }\left({ }^{\circ} \mathrm{C}\right) \\
d T & =\text { change in temperature due to heat generation }\left({ }^{\circ} \mathrm{C}\right)
\end{aligned}
$$




$$
\begin{aligned}
T_{m f} & =\text { minimum temperature of the fluid for the heat pump }\left({ }^{\circ} \mathrm{C}\right) \\
R_{p} & =\text { pipe resistance }\left(\left(\mathrm{m}^{\circ} \mathrm{C}\right) / \mathrm{W}\right) \\
R_{S} & =\text { waste resistance }\left(\left(\mathrm{m}^{\circ} \mathrm{C}\right) / \mathrm{W}\right) \\
N & =\text { number of pipes }(\text { i.e. } 2 \text { for vertical u-loop, } 1 \text { for single layer } \\
& \text { horizontal) } \\
f & =\text { run fraction }
\end{aligned}
$$

The pipe and soil resistances were given by Equations 2.28 and 2.34, respectively. The minimum fluid temperature of the fluid for the heat pump depends on the heat pump but is often between $0^{\circ} \mathrm{C}$ and $4.4^{\circ} \mathrm{C}$ (Bose 1983); therefore, a mean value of $2.2^{\circ} \mathrm{C}$ was selected. The run fraction can range from 0 to 1 and an operating range of 0.6 to 0.9 was selected. Using the minimum waste temperature, maximum waste temperature, the assumed minimum fluid temperature, and the selected run fraction operating range, a range of expected heat extraction rates from the HES were determined over the first 5 years. The minimum expected energy from the HES was calculated to be $526 \mathrm{~W}$ and the maximum expected energy was calculated to be $1424 \mathrm{~W}$.

Once the expected heat extraction rates were calculated, the heat extraction rates from the 2-D axisymmetric model for the different weighted averages were compared to the expected heat extraction rates. The heat extraction rates from the 2-D axisymmetric model were calculated by summing the heat flux into the HES along the length of the HES. Multiple fluid temperature weighted averages were simulated (Figure 4.7). The fluid temperature weighted average of $10 \%$ maximum fluid temperature and $90 \%$ minimum fluid temperature 
fell within the bounds of the maximum and minimum expected energy calculated for first 5 years (Figure 4.8): thus, the weighted average fluid temperature representing $10 \%$ maximum fluid temperature and $90 \%$ minimum fluid temperature was assumed to be valid for all simulations.

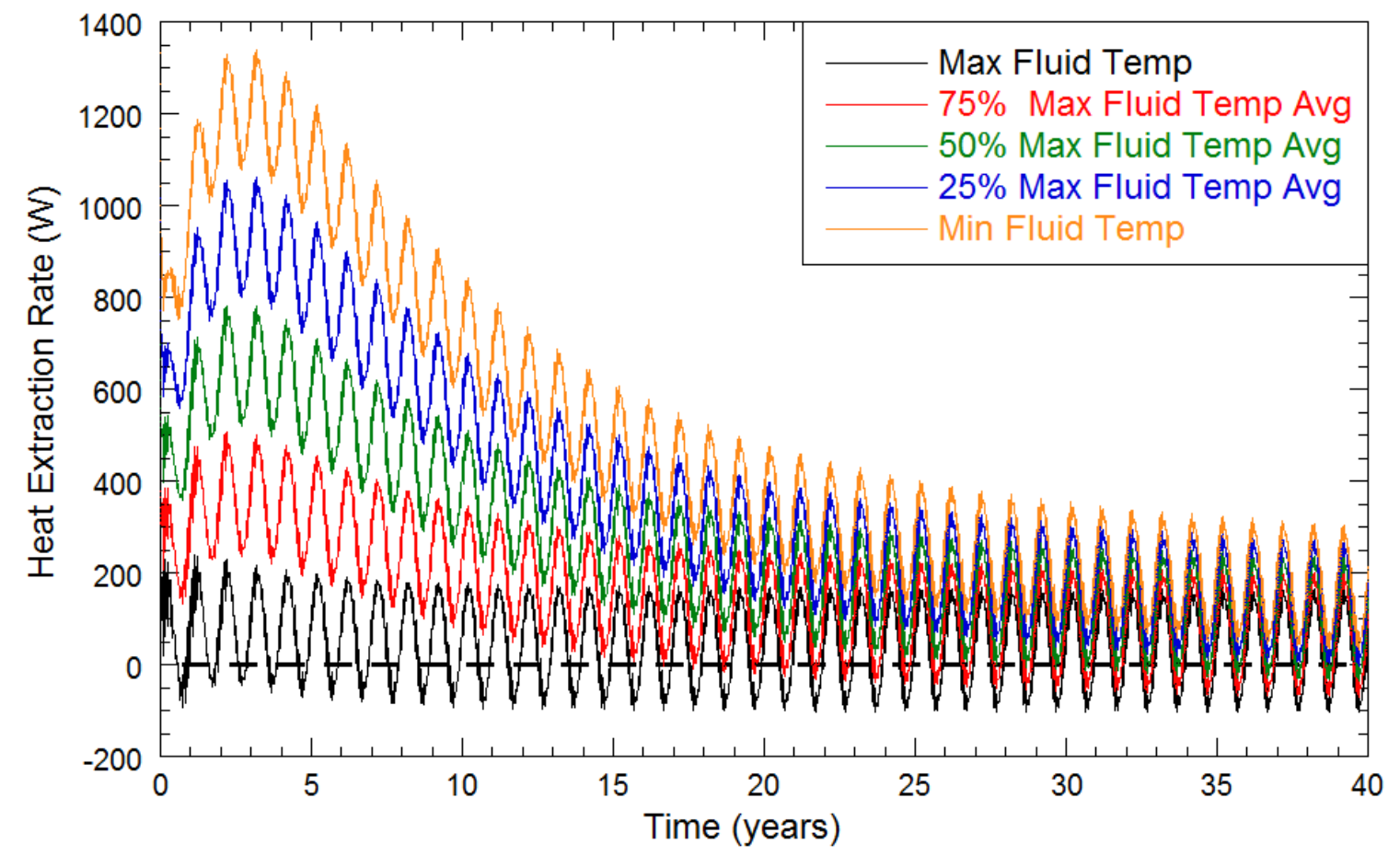

Figure 4.7: Heat Extraction Rates at Different Weighted Averages Fluid Temperature 


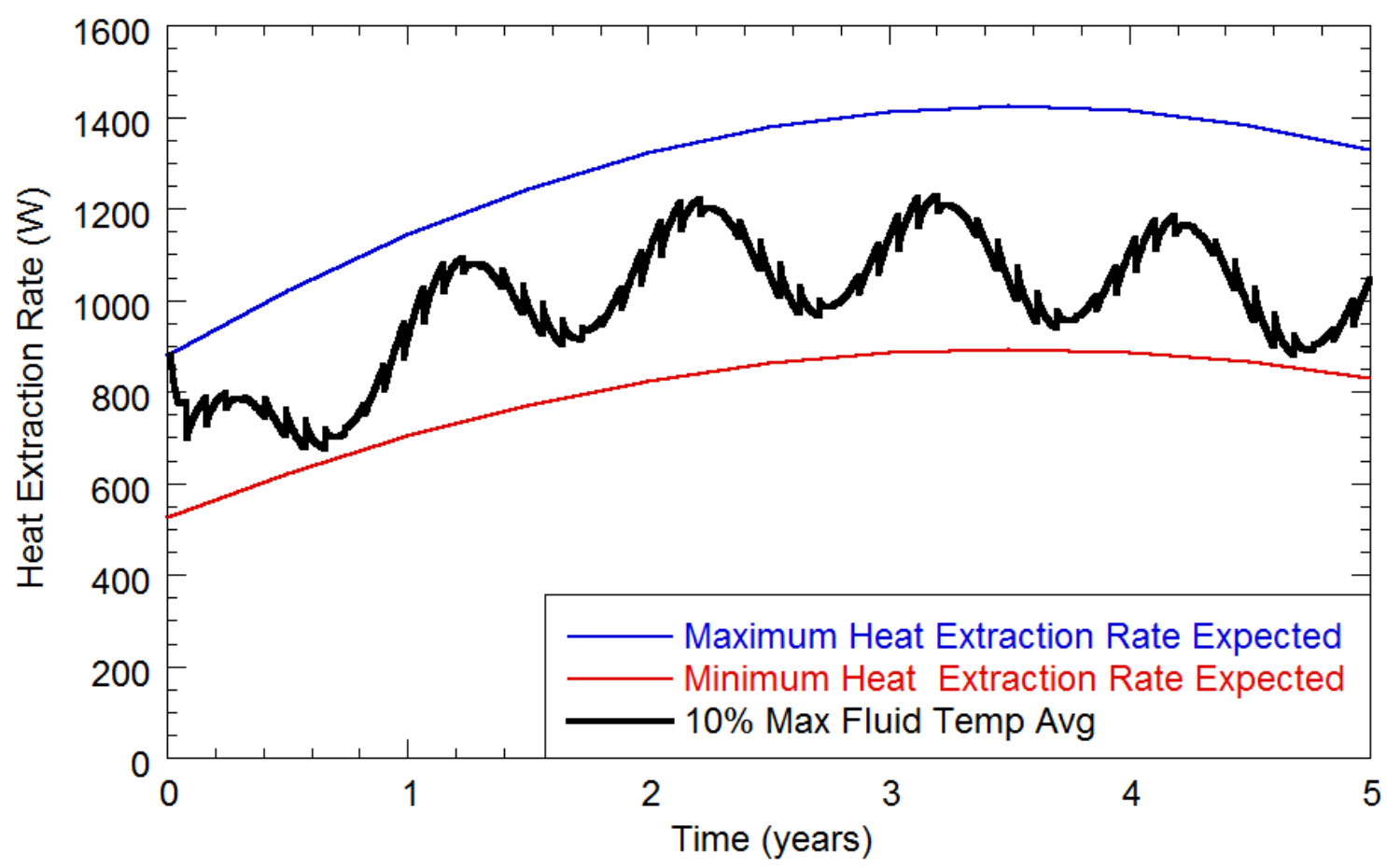

Figure 4.8: Validation of Average Fluid Temperature

\subsection{Results of Parametric Evaluation}

The temperature distribution and vertical HES heat extraction results are presented in this section. All models were simulated until 40 years after the cover was placed because radial far field boundary temperatures were within $5^{\circ} \mathrm{C}$ of mean annual earth temperatures at the end of the 40 year period and computational time was acceptable. For all heat extraction graphs and temperature graphs, time 0 indicates the initiation of HES operation (Figure 4.9). Parametric evaluation was conducted on a template landfill model, changing one parameter. The template landfill conditions included use of $25.4 \mathrm{~mm}$ pipe diameter, $0.3 \mathrm{~m} / \mathrm{s}$ fluid velocity, start of waste placement in February, $30 \mathrm{~m}$ waste height, $20 \mathrm{~m} /$ year waste filling rate, initiation of HES operation 1 day after final cover placement, year-round operation of the HES, and Michigan climate. 


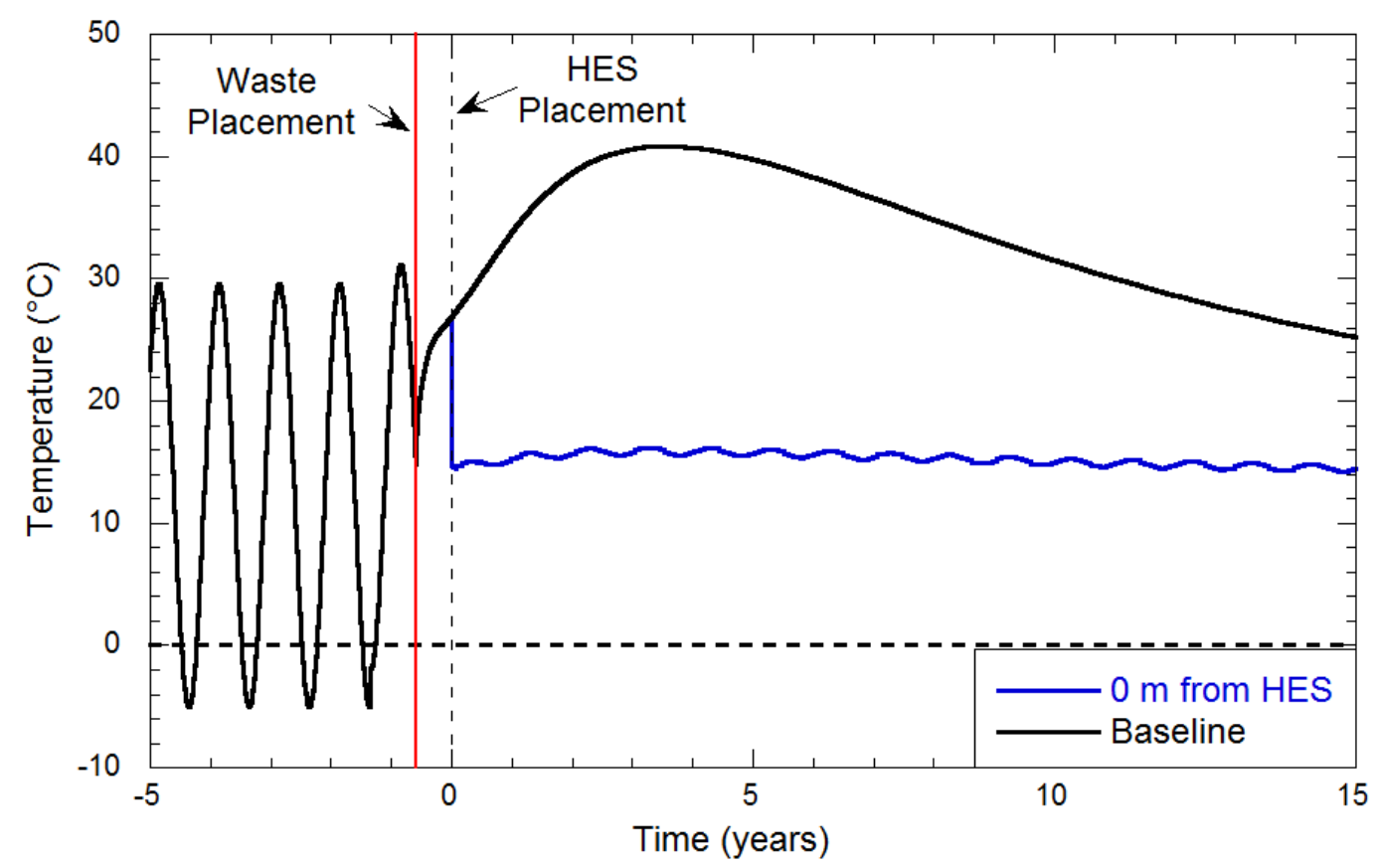

Figure 4.9: Waste and HES Placement

\subsubsection{General Observations}

The predicted general trends of heat transfer coefficients, temperatures, and heat extraction rates can be applied to all simulations. The landfill temperatures and vertical HES heat extraction rates were determined to be dependent on the convective heat transfer parameters. The resulting convective heat transfer coefficients for the 41 simulations are presented in Table 4.1.

Laminar fluid flow yielded similar convective heat transfer coefficients at different flow rates. Once turbulent flow was reached, convective heat transfer coefficients increased with increasing fluid velocity. Increasing pipe diameter caused a decrease in heat transfer coefficients for a given fluid velocity. 
Table 4.1: Convective Heat Transfer Results

\begin{tabular}{|c|c|c|c|c|c|}
\hline Simulations & $\begin{array}{c}\text { Pipe } \\
\text { Diameter } \\
(\mathrm{mm})\end{array}$ & $\begin{array}{c}\text { Velocity } \\
(\mathrm{m} / \mathrm{s})\end{array}$ & $\begin{array}{c}\text { Flow } \\
\text { Condition }\end{array}$ & $\begin{array}{c}\text { Flow } \\
\text { Rate } \\
(\mathrm{L} / \mathrm{s})\end{array}$ & $\begin{array}{c}\text { Convective Heat } \\
\text { Transfer } \\
\text { Coefficients } \\
\left(\mathrm{W} /\left(\mathrm{m}^{2} \mathrm{~K}\right)\right)\end{array}$ \\
\hline 1 & 25.4 & 0.01 & Laminar & 0.0051 & 72 \\
\hline 2 & 25.4 & 0.1 & Laminar & 0.0507 & 72 \\
\hline 3 & 25.4 & 0.3 & Turbulent & 0.152 & 926 \\
\hline 4 & 25.4 & 0.6 & Turbulent & 0.304 & 1613 \\
\hline 5 & 25.4 & 1.0 & Turbulent & 0.507 & 2427 \\
\hline 6 & 38.1 & 0.01 & Laminar & 0.0114 & 48 \\
\hline 7 & 38.1 & 0.1 & Laminar & 0.114 & 48 \\
\hline 8 & 38.1 & 0.3 & Turbulent & 0.342 & 854 \\
\hline 9 & 38.1 & 0.6 & Turbulent & 0.684 & 1487 \\
\hline 10 & 38.1 & 1.0 & Turbulent & 1.140 & 2238 \\
\hline 11 & 50.8 & 0.01 & Laminar & 0.0203 & 36 \\
\hline 12 & 50.8 & 0.1 & Laminar & 0.203 & 36 \\
\hline 13 & 50.8 & 0.3 & Turbulent & 0.608 & 806 \\
\hline 14 & 50.8 & 0.6 & Turbulent & 1.216 & 1404 \\
\hline 15 & 50.8 & 1.0 & Turbulent & 2.027 & 2113 \\
\hline $16-41$ & 25.4 & 0.3 & Turbulent & 0.152 & 926 \\
\hline
\end{tabular}

Simulated cover liner temperatures were mostly influenced by ground surface seasonal temperature fluctuations and the only noticeable temperature difference in the cover liner temperature occurred $0 \mathrm{~m}$ away from the HES. Temperatures along the length of the HES displayed seasonal variations. The seasonal variations arose from temperatures near the ground surface being transported to depth by the operation of the HES. Bottom liner temperatures were not significantly impacted by the presence of the HES.

Waste temperatures were affected by the operation of the vertical HES. The effects of the HES on landfill temperatures were most pronounced at locations within a radial distance of approximately $11 \mathrm{~m}$ from the HES. 
Temperatures approached baseline temperatures (i.e., radial far field temperatures not affected by the HES) asymptotically as distance away from the HES increased (i.e., the largest temperature differences in the radial direction were closest to the HES) (Figure 4.10). Seasonal variation in temperature decreased with increasing radial distance from the HES.

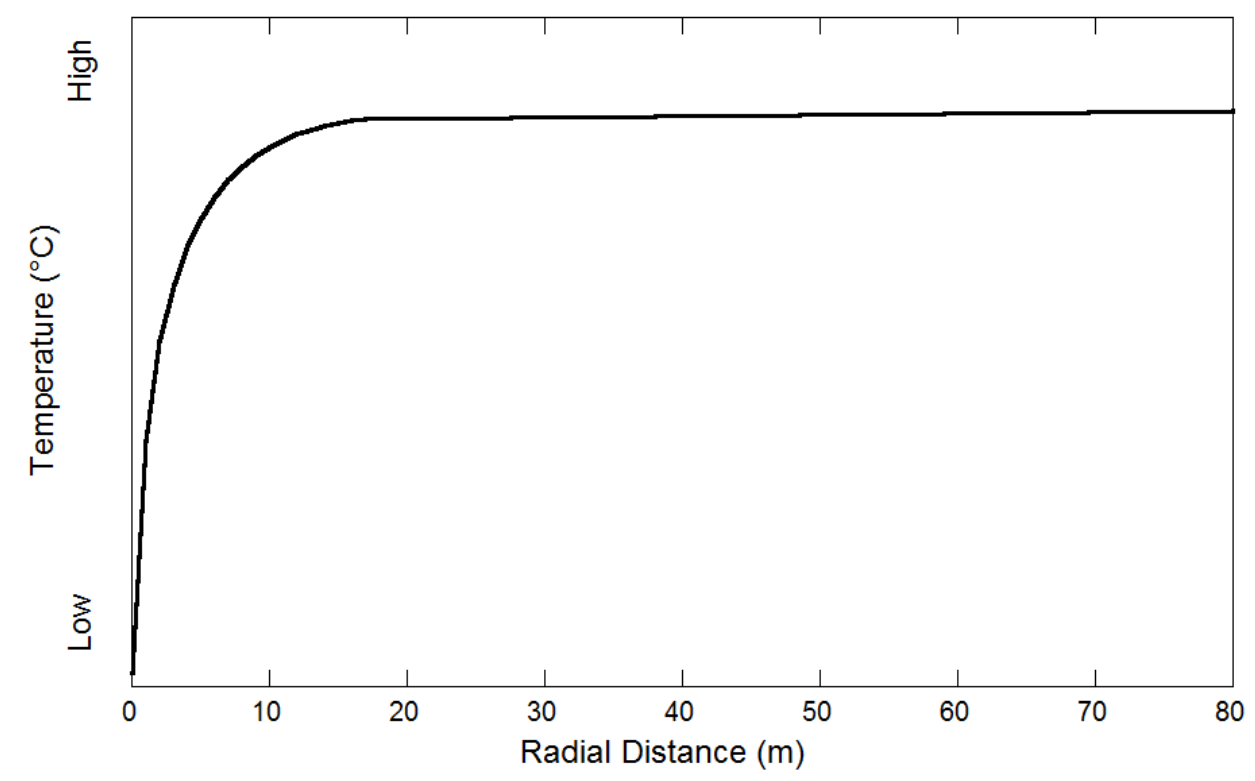

Figure 4.10: Radial Temperatures Away from HES

Temperature data over time is presented in the following sections for the cover liner, shallow depth, middle depth, great depth, and bottom liner locations. Shallow, middle, and great depth were $0.25,0.5$, and $0.75 \%$ of the total waste height, respectively. Average temperatures reported in the subsequent sections are average temperatures over the entire modeling time of the operation of the HES. Vertical temperature profiles are presented at the time of maximum difference between baseline temperatures and temperatures $0 \mathrm{~m}$ away from the HES. 
Heat extraction rates varied over long time scales and seasonally. For long time scales, differences in heat extraction rates from the vertical HES can be divided into 3 phases: heat extraction phase, transitional phase, and ground source heat pump phase. The heat extraction phase consists of solely heat extraction from the waste. The transitional phase represents the period from heat extraction to typical ground source heat pump operation. The ground source heat pump phase operates in both heat extraction and rejection modes depending on the season (heat extracted in winter and heat rejected in summer). Total heat energy extracted was calculated either by summing the total amount of heat energy extracted in the heat extraction phase or the amount extracted in a period until 40 years after cover was placed.

During the heat extraction phase, annual maximums of heat extraction rates occurred in summer and annual minimums of heat extraction rates occurred in the winter. Inlet fluid temperatures remained constant, so maximum heat extraction rates occurred in summer due to higher ground surface temperatures and minimum heat extraction occurred in winter due to lower ground surface temperatures in the winter.

The elapsed time to maximum temperature difference and time to peak heat extraction rate differ because the elapsed time to maximum temperature difference occurs for a single point in the landfill and the time to peak heat extraction rate is dependent on the temperature difference between fluid temperatures and temperatures $0 \mathrm{~m}$ away from the HES along the length of the 
HES. Longer elapsed time to maximum temperature difference yields a longer time to peak heat extraction rate, however no correlation between the two exists.

A period of approximately 30 days after the initiation of vertical HES operation was required for the heat extraction to reach thermal stasis. Thermal stasis was defined as the period in which model temperatures became proportional to the simulated fluid temperatures in the heat extraction load. Analysis and results presented in this section do not include this startup period due to the high degree of temperature and heat flux variability. Throughout this analysis, positive values represent heat extraction, while negative values represent heat rejection.

\subsubsection{Configuration Results}

The 15 configuration simulations (varying pipe diameter and fluid velocity) were simulated using the template landfill model (outlined in Chapter 3) and varying 5 fluid velocities and 3 pipe sizes. Temperature results, heat extraction results, and trends for the configuration simulations are discussed in this section.

Peak baseline temperatures for the configuration simulations were 29.6,

$35.1,40.8,36.1$, and $23.9^{\circ} \mathrm{C}$ for the cover liner, shallow depth, middle depth, great depth, and bottom liner locations, respectively. Temperature results of the various vertical HES configurations are summarized in Table 4.2.

Varying fluid velocity did not significantly change the impact the HES had on temperatures within the landfill. Higher fluid velocities yielded lower temperatures near the HES. Different fluid velocities had a much smaller impact on landfill temperatures once turbulent flow was reached (a change of $-0.1^{\circ} \mathrm{C}$ at 
the HES for every $0.3 \mathrm{~m} / \mathrm{s}$ increase in fluid velocity). The maximum difference between the temperature at the HES and baseline temperatures for fluid velocities representing turbulent flow were higher than those of laminar flow.

Table 4.2: Temperature Results for Different Configurations $0 \mathrm{~m}$ away from the HES

\begin{tabular}{|c|c|c|c|c|c|c|c|c|}
\hline 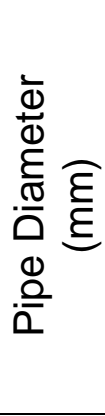 & $\begin{array}{l}\frac{7}{0} \\
\frac{0}{0} \\
\frac{0}{0} \\
\frac{0}{0} \\
\frac{0}{3} \\
\frac{1}{4}\end{array}$ & 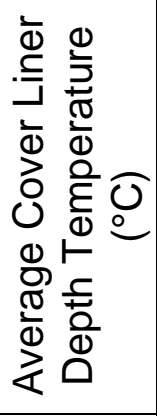 & 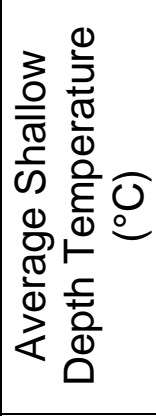 & 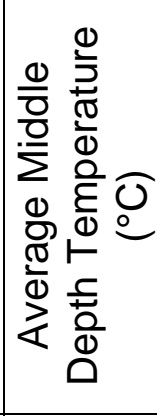 & 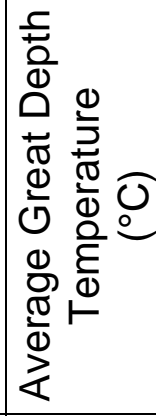 & 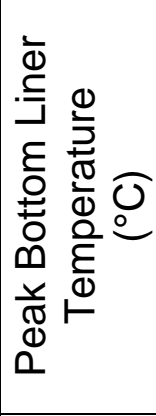 & 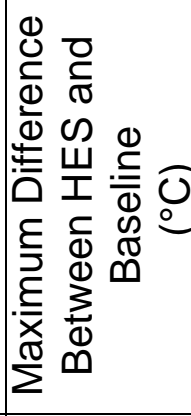 & 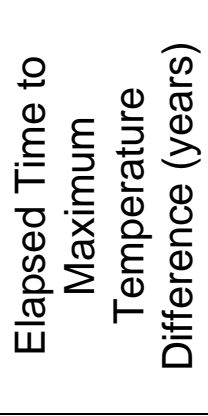 \\
\hline \multirow{5}{*}{25.4} & 0.01 & 14.1 & 15.5 & 16.0 & 15.7 & 22.3 & 21.2 & 3.5 \\
\hline & 0.1 & 13.7 & 14.5 & 15.0 & 15.0 & 22.2 & 23.1 & 3.8 \\
\hline & 0.3 & 13.6 & 14.3 & 14.4 & 14.3 & 22.1 & 25.2 & 3.7 \\
\hline & 0.6 & 13.6 & 14.2 & 14.3 & 14.3 & 22.0 & 25.5 & 3.7 \\
\hline & 1.0 & 13.6 & 14.1 & 14.3 & 14.2 & 22.0 & 25.7 & 3.7 \\
\hline \multirow{5}{*}{38.1} & 0.01 & 14.0 & 15.2 & 15.8 & 15.7 & 22.3 & 21.7 & 3.8 \\
\hline & 0.1 & 13.5 & 14.1 & 14.6 & 14.6 & 22.2 & 23.6 & 3.8 \\
\hline & 0.3 & 13.5 & 14.0 & 14.2 & 14.2 & 22.0 & 25.9 & 3.7 \\
\hline & 0.6 & 13.5 & 13.9 & 14.1 & 14.1 & 22.0 & 26.2 & 3.7 \\
\hline & 1.0 & 13.5 & 13.8 & 14.0 & 14.0 & 22.0 & 26.3 & 3.7 \\
\hline \multirow{5}{*}{50.8} & 0.01 & 13.9 & 14.9 & 15.5 & 15.6 & 22.3 & 22.2 & 3.8 \\
\hline & 0.1 & 13.3 & 13.9 & 14.4 & 14.4 & 22.1 & 23.9 & 3.7 \\
\hline & 0.3 & 13.4 & 13.8 & 13.9 & 14.0 & 22.0 & 26.3 & 3.7 \\
\hline & 0.6 & 13.4 & 13.7 & 13.8 & 13.8 & 22.0 & 26.6 & 3.7 \\
\hline & 1.0 & 13.4 & 13.6 & 13.7 & 13.8 & 22.0 & 26.7 & 3.7 \\
\hline
\end{tabular}

Varying pipe diameter did not significantly change the impact that the HES had on temperatures within the landfill. Larger pipe sizes yielded lower temperatures near the HES (approximately $0.2^{\circ} \mathrm{C}$ decrease at the HES for every $12.7 \mathrm{~mm}$ greater in pipe diameter). In contrast, the maximum difference between 
the temperatures $0 \mathrm{~m}$ away from the HES and baseline temperatures was impacted by the pipe size. An increase of approximately $0.5^{\circ} \mathrm{C}$ in the maximum difference between temperatures $0 \mathrm{~m}$ away from HES and the baseline temperatures was predicted for every $12.7 \mathrm{~mm}$ increase in pipe diameter.

Maximum landfill temperatures were determined to occur at a depth of $15.5 \mathrm{~m}$ into the $30 \mathrm{~m}$ deep waste mass. Temperatures did not significantly change (less than $5^{\circ} \mathrm{C}$ change in temperature) along the length of the HES for turbulent flow, however laminar flow caused a maximum of $11^{\circ} \mathrm{C}$ change in temperature along the length of the HES. Simulated temperatures increased to within $5^{\circ} \mathrm{C}$ of baseline temperatures $2 \mathrm{~m}$ directly below the HES. Temperatures at the cover liner, shallow-depth, middle-depth, great-depth, and bottom liner locations are presented in Figures 4.11 for the $25.4 \mathrm{~mm}$ pipe diameter with 0.3 $\mathrm{m} / \mathrm{s}$ fluid velocity. The vertical temperature profile results at the time of maximum difference between HES and baseline temperatures are presented in Figure 4.12 for the $25.4 \mathrm{~mm}$ pipe diameter with $0.3 \mathrm{~m} / \mathrm{s}$ fluid velocity. Additional plots for all other configuration simulations are presented in Appendix A. 

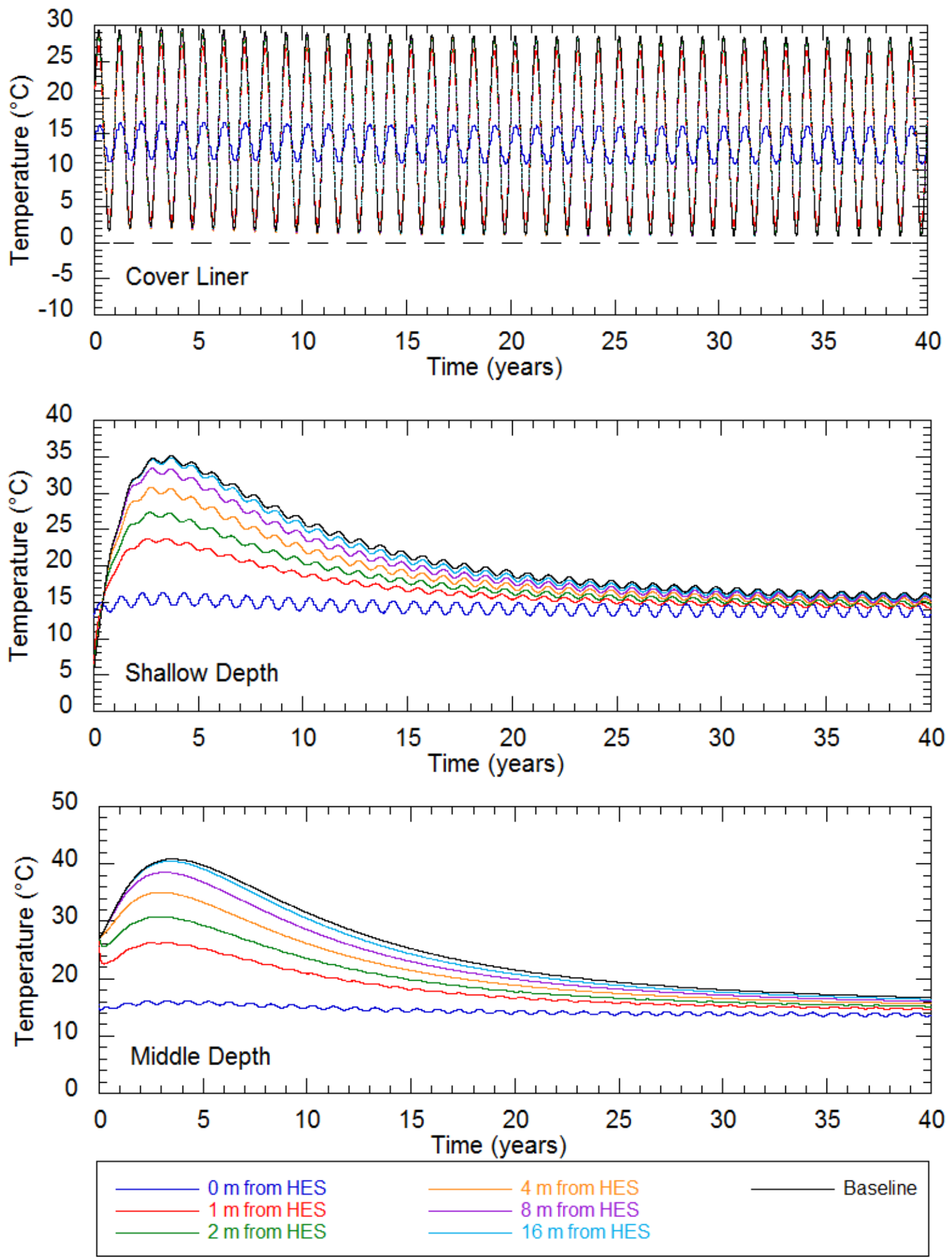

Figure 4.11a: Temperature Results: $25.4 \mathrm{~mm}$ Diameter Pipe $0.3 \mathrm{~m} / \mathrm{s}$ Fluid Velocity (Template Landfill Model) 

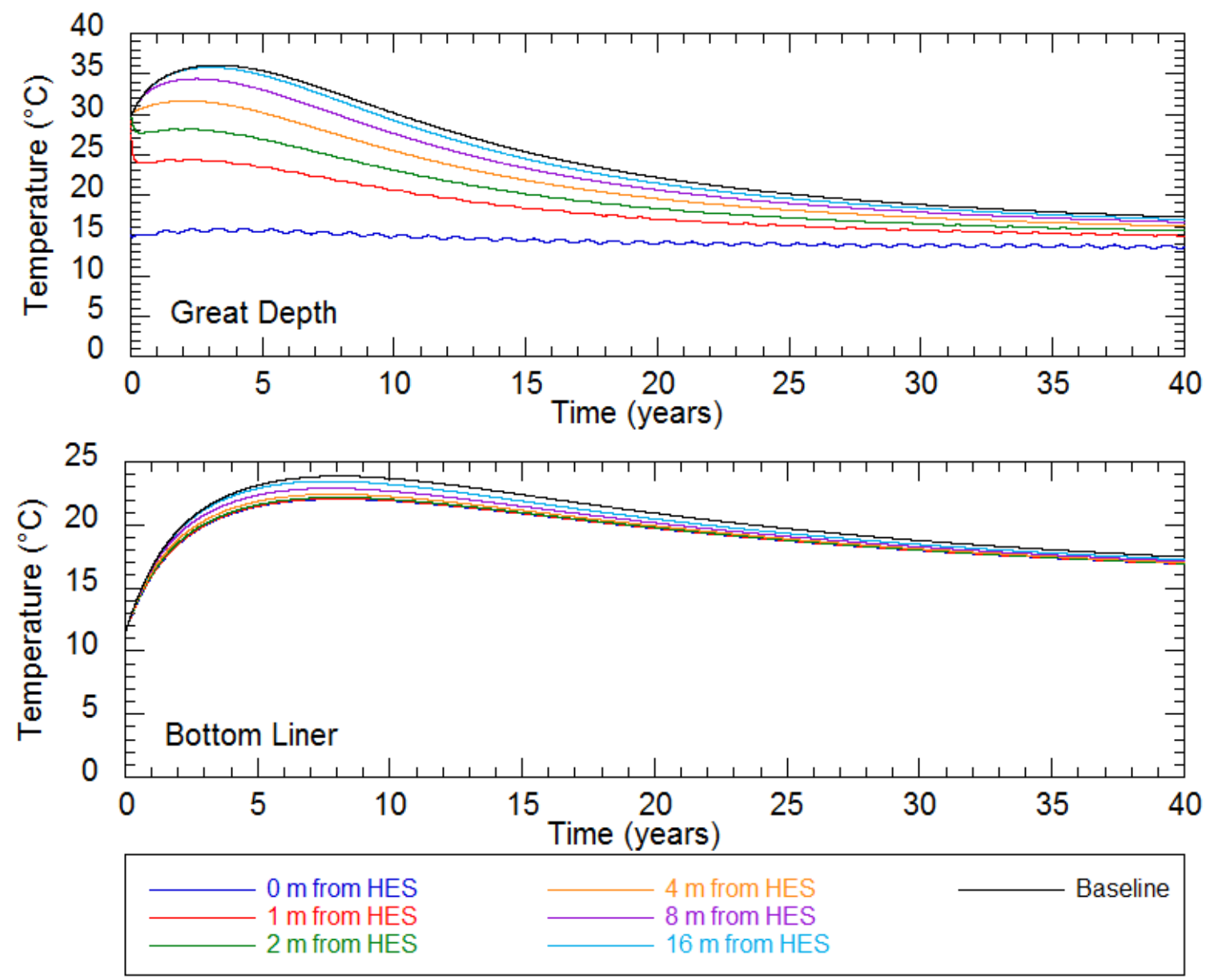

Figure 4.11b: Temperature Results: $25.4 \mathrm{~mm}$ Diameter Pipe $0.3 \mathrm{~m} / \mathrm{s}$ Fluid Velocity (Template Landfill Model)

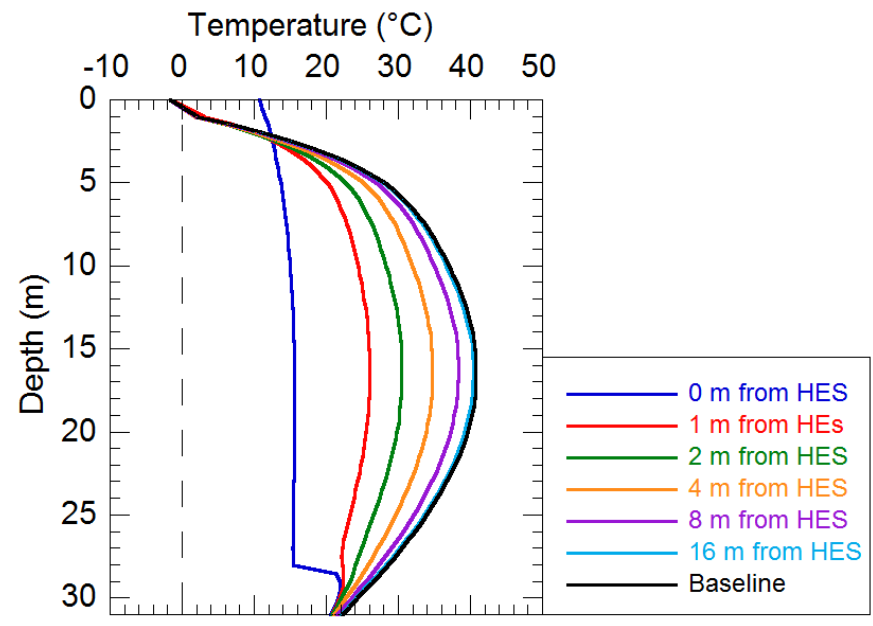

Figure 4.12: Vertical Temperature Results: $25.4 \mathrm{~mm}$ Diameter Pipe $0.3 \mathrm{~m} / \mathrm{s}$ Fluid Velocity (Template Landfill Model) 
The heat extraction results of the various vertical HES configurations are summarized in Table 4.3. The maximum total heat energy extracted for each pipe diameter was associated with the $1 \mathrm{~m} / \mathrm{s}$ fluid velocity and the minimum total heat energy extracted for each pipe diameter was associated with the $0.01 \mathrm{~m} / \mathrm{s}$ fluid velocity. Increased pipe diameter also caused an increase in the amount of heat energy extracted. The range in expected heat extraction rates for the configuration simulations are presented in Table 4.4. For the configuration simulations, total heat energy extracted over a 40 year period ranged from 468,800 to $606,500 \mathrm{MJ}$. The peak heat extraction rate occurred 3.1 to 3.2 years after initiation of HES operation. The average seasonal heat extraction rate amplitude ranged from 83 to $160 \mathrm{~W}$.

Table 4.3: Heat Extraction Configuration Results

\begin{tabular}{|c|c|c|c|c|c|}
\hline $\begin{array}{c}\text { Pipe } \\
\text { Diameter } \\
(\mathrm{mm})\end{array}$ & $\begin{array}{c}\text { Velocity } \\
(\mathrm{m} / \mathrm{s})\end{array}$ & $\begin{array}{c}\text { Peak Heat } \\
\text { Extraction } \\
\text { Rate }(\mathrm{W})\end{array}$ & $\begin{array}{c}\text { Time To } \\
\text { Peak } \\
\text { (years) }\end{array}$ & $\begin{array}{c}\text { Average } \\
\text { Seasonal } \\
\text { Amplitude }(\mathrm{W})\end{array}$ & $\begin{array}{c}\text { Total Heat } \\
\text { Extracted* } \\
(\mathrm{MJ})\end{array}$ \\
\hline \multirow{4}{*}{25.4} & 0.01 & 1000 & 3.1 & 83 & 468,800 \\
\cline { 2 - 6 } & 0.1 & 1100 & 3.2 & 110 & 530,000 \\
\cline { 2 - 6 } & 0.3 & 1230 & 3.2 & 140 & 561,100 \\
\cline { 2 - 6 } & 0.6 & 1240 & 3.2 & 145 & 568,000 \\
\cline { 2 - 6 } & 1.0 & 1250 & 3.2 & 147 & 572,500 \\
\hline \multirow{4}{*}{38.1} & 0.01 & 1030 & 3.2 & 95 & 480,800 \\
\cline { 2 - 6 } & 0.1 & 1150 & 3.2 & 122 & 560,200 \\
\cline { 2 - 6 } & 0.3 & 1260 & 3.2 & 149 & 577,600 \\
\cline { 2 - 6 } & 0.6 & 1280 & 3.2 & 152 & 585,300 \\
\hline \multirow{4}{*}{50.8} & 1.0 & 1290 & 3.2 & 154 & 590,600 \\
\cline { 2 - 6 } & 0.01 & 1050 & 3.2 & 100 & 495,300 \\
\cline { 2 - 6 } & 0.1 & 1180 & 3.2 & 129 & 575,600 \\
\cline { 2 - 6 } & 0.3 & 1290 & 3.2 & 154 & 592,500 \\
\cline { 2 - 6 } & 0.6 & 1300 & 3.2 & 157 & 600,400 \\
\hline
\end{tabular}

* over a 40 year period 
Table 4.4: Expected Range of Heat Extraction Rates for Configuration Simulations

\begin{tabular}{|c|c|c|c|c|c|c|c|}
\hline \multirow[t]{2}{*}{$\begin{array}{c}\text { Pipe } \\
\text { Diameter } \\
(\mathrm{mm})\end{array}$} & \multirow[t]{2}{*}{$\begin{array}{c}\text { Velocity } \\
(\mathrm{m} / \mathrm{s})\end{array}$} & \multicolumn{2}{|c|}{$\begin{array}{l}\text { Heat Extraction } \\
\text { During 1st year } \\
\text { of Operation } \\
\text { (W) }\end{array}$} & \multicolumn{2}{|c|}{$\begin{array}{c}\text { Heat Extraction } \\
\text { During Year of } \\
\text { Peak Heat } \\
\text { Extraction (W) }\end{array}$} & \multicolumn{2}{|c|}{$\begin{array}{l}\text { Heat Extraction } \\
\text { During Last } \\
\text { Year of } \\
\text { Operation }^{\star}(\mathrm{W})\end{array}$} \\
\hline & & Max & Min & Max & Min & Max & Min \\
\hline \multirow{5}{*}{25.4} & 0.01 & 780 & 530 & 1000 & 830 & 200 & 50 \\
\hline & 0.1 & 830 & 630 & 1100 & 880 & 270 & 50 \\
\hline & 0.3 & 950 & 680 & 1230 & 940 & 290 & 20 \\
\hline & 0.6 & 960 & 680 & 1240 & 950 & 300 & 20 \\
\hline & 1.0 & 960 & 690 & 1250 & 950 & 300 & 20 \\
\hline \multirow{5}{*}{38.1} & 0.01 & 780 & 560 & 1030 & 830 & 220 & 40 \\
\hline & 0.1 & 860 & 650 & 1150 & 910 & 300 & 60 \\
\hline & 0.3 & 960 & 690 & 1260 & 950 & 310 & 20 \\
\hline & 0.6 & 970 & 700 & 1280 & 960 & 320 & 20 \\
\hline & 1.0 & 980 & 700 & 1290 & 960 & 320 & 20 \\
\hline \multirow{5}{*}{50.8} & 0.01 & 800 & 580 & 1050 & 840 & 240 & 40 \\
\hline & 0.1 & 880 & 660 & 1180 & 920 & 310 & 60 \\
\hline & 0.3 & 980 & 700 & 1290 & 970 & 320 & 20 \\
\hline & 0.6 & 990 & 710 & 1300 & 970 & 330 & 20 \\
\hline & 1.0 & 1000 & 710 & 1310 & 980 & 340 & 20 \\
\hline
\end{tabular}

* last year is year 40

The $50.8 \mathrm{~mm}$ pipe diameter with a fluid velocity of $1.0 \mathrm{~m} / \mathrm{s}$ was determined to have maximum heat extraction rates, average seasonal amplitude, and total heat energy extracted. The $25.4 \mathrm{~mm}$ pipe diameter with a fluid velocity of 0.01 $\mathrm{m} / \mathrm{s}$ was determined to have the minimum heat extraction rate, average seasonal amplitude, and total heat energy extracted. The heat extraction rates and annual average heat extraction rates at different velocities for the $25.4,38.1,50.8 \mathrm{~mm}$ diameter pipes are presented in Figures 4.13 through 4.18. The heat extraction rates and annual average heat extraction rates for different pipe are presented in Figure 4.19 and 4.20 , respectively. 


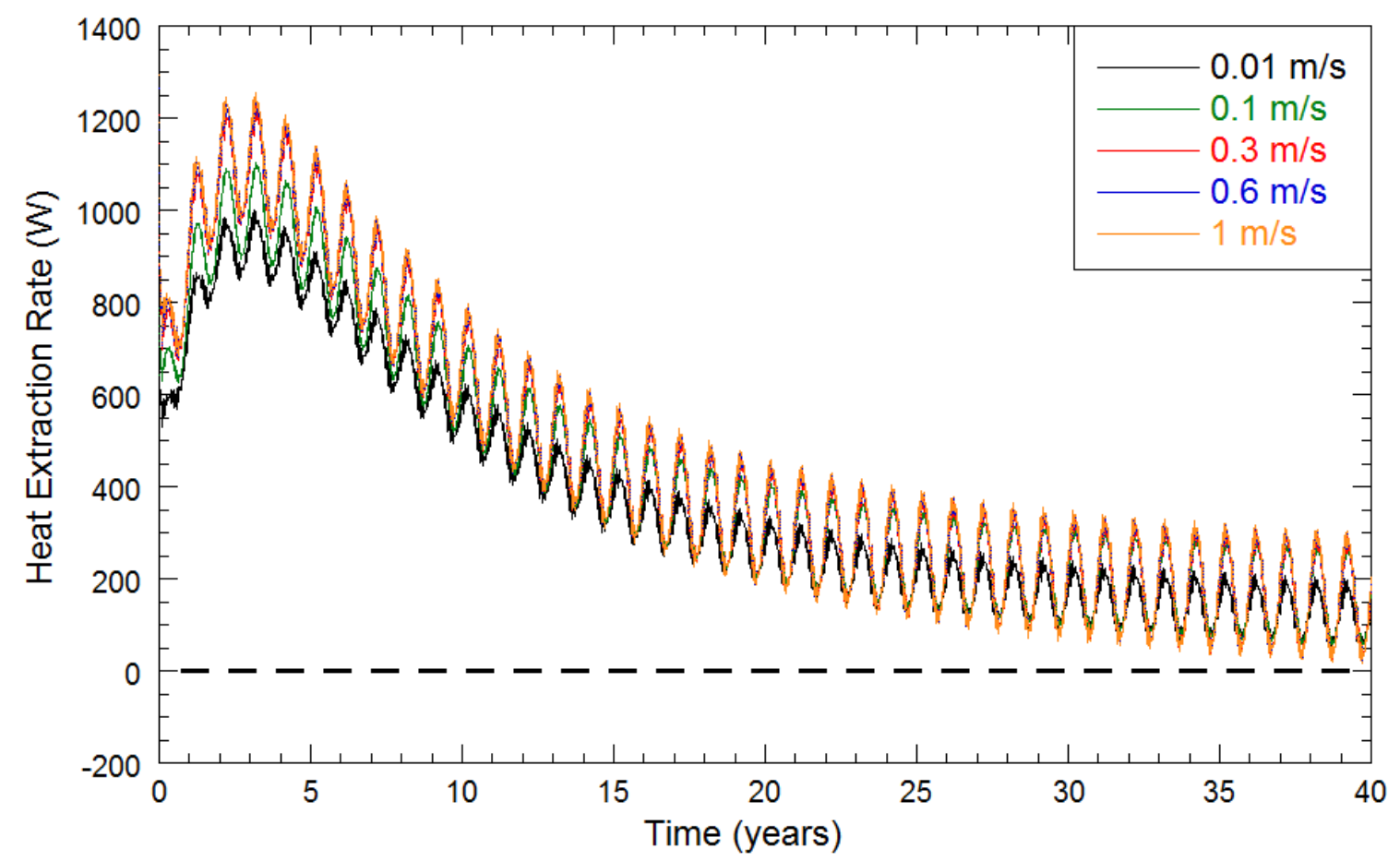

Figure 4.13: Heat Extraction Rates from $25.4 \mathrm{~mm}$ Diameter Pipe at Various Fluid Velocities

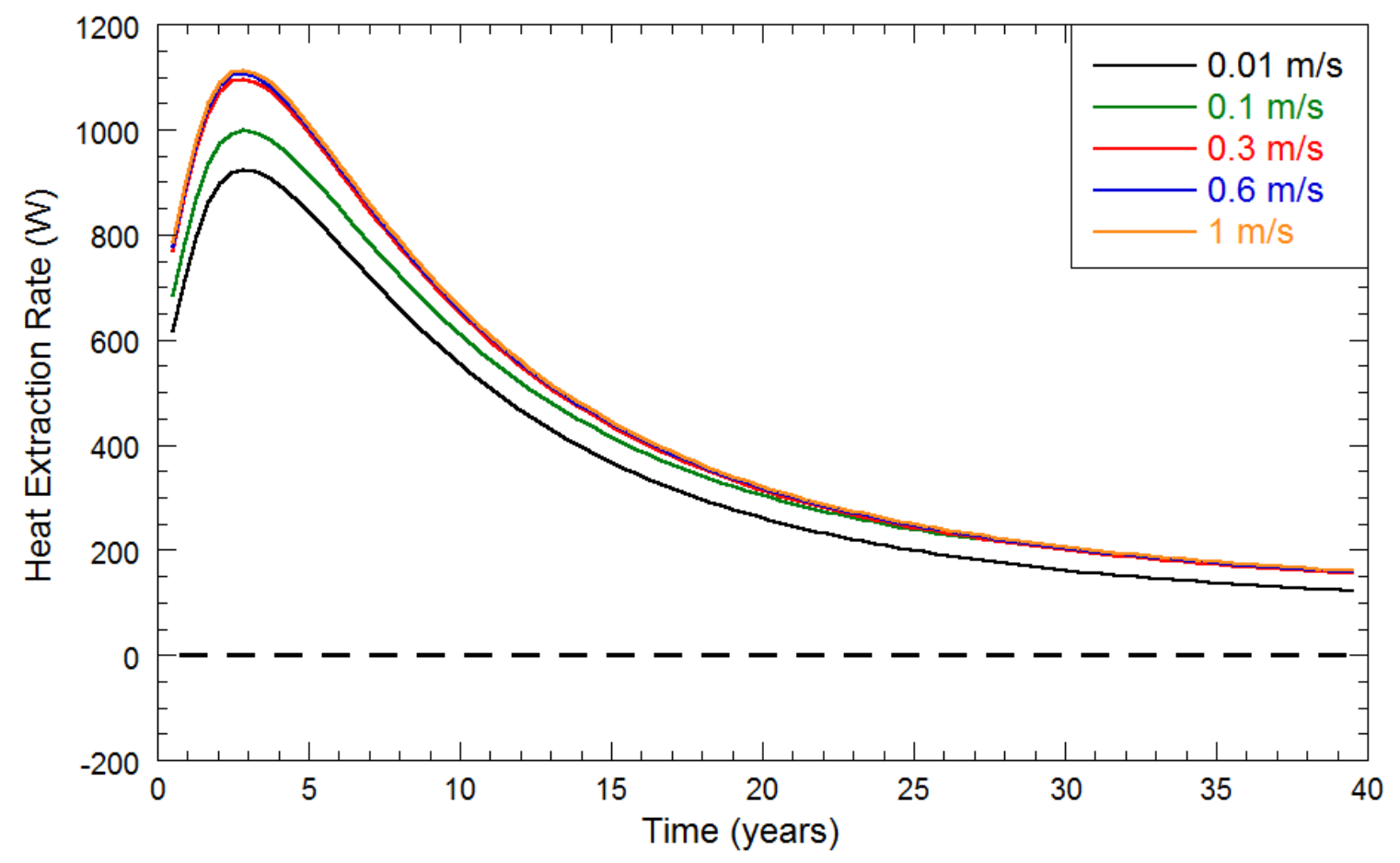

Figure 4.14: Annual Average Heat Extraction Rates from $25.4 \mathrm{~mm}$ Diameter Pipe at Various Fluid Velocities 


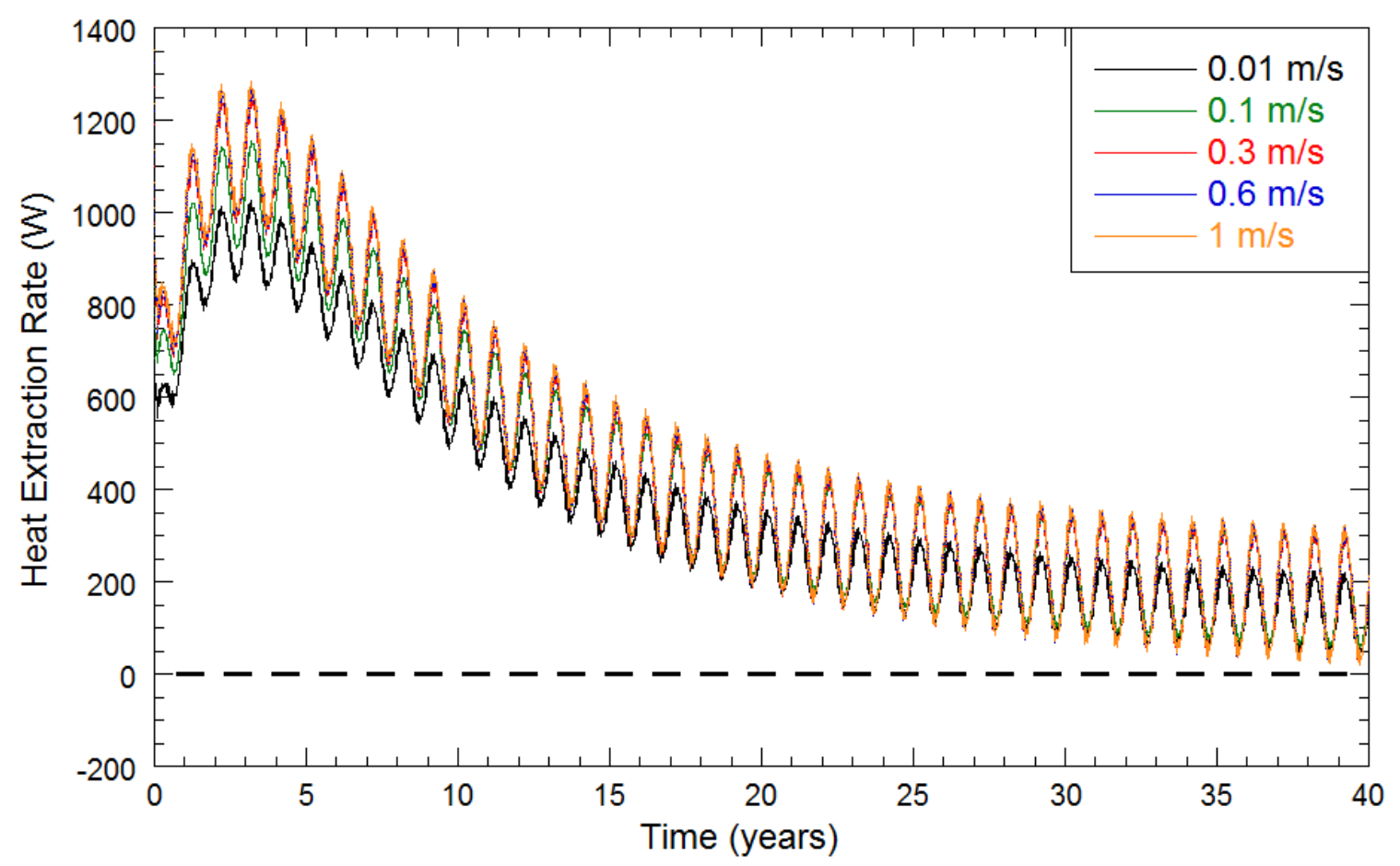

Figure 4.15: Heat Extraction Rates from $38.1 \mathrm{~mm}$ Diameter Pipe at Various Fluid Velocities

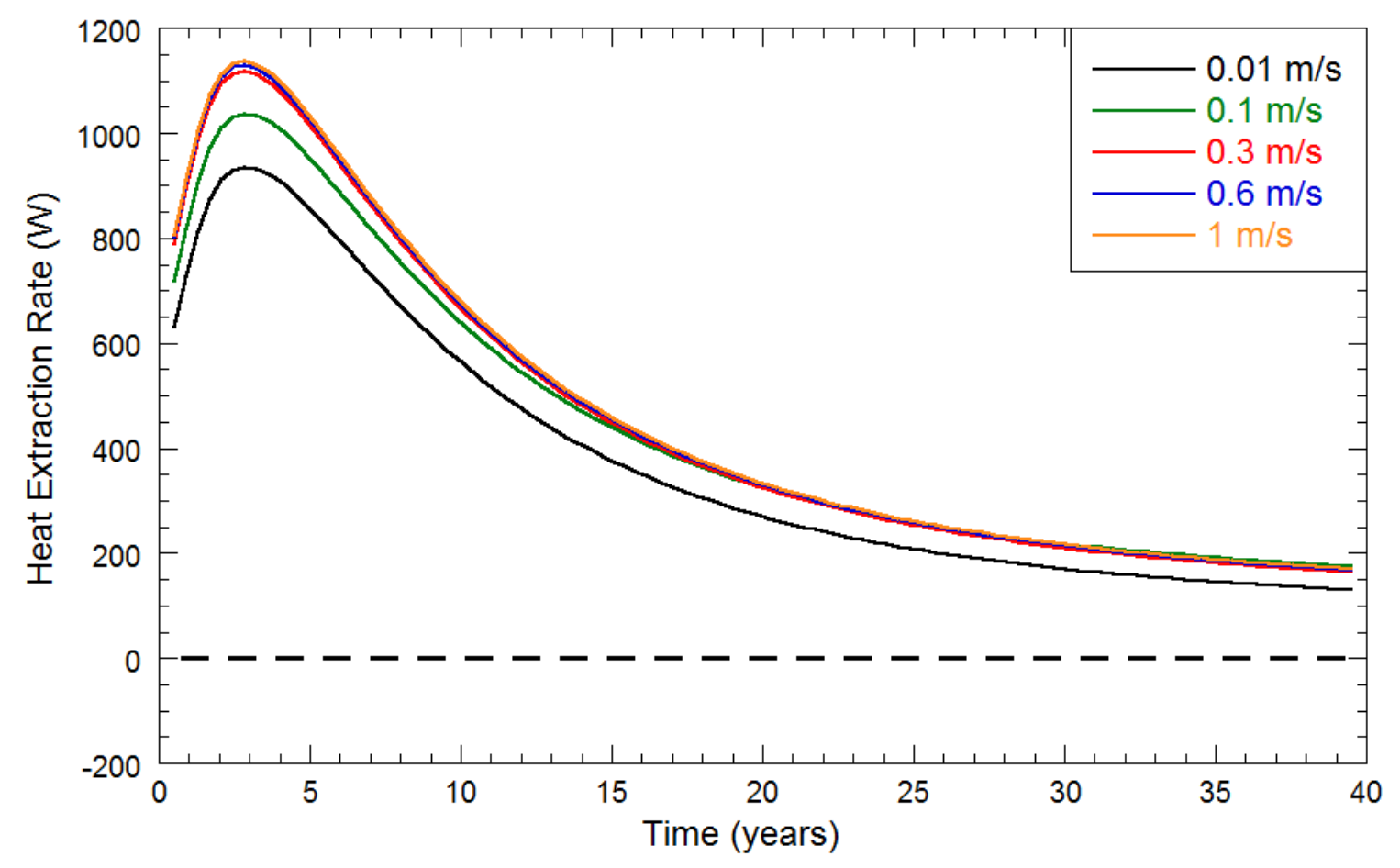

Figure 4.16: Annual Average Heat Extraction Rates from $38.1 \mathrm{~mm}$ Diameter Pipe at Various Fluid Velocities 


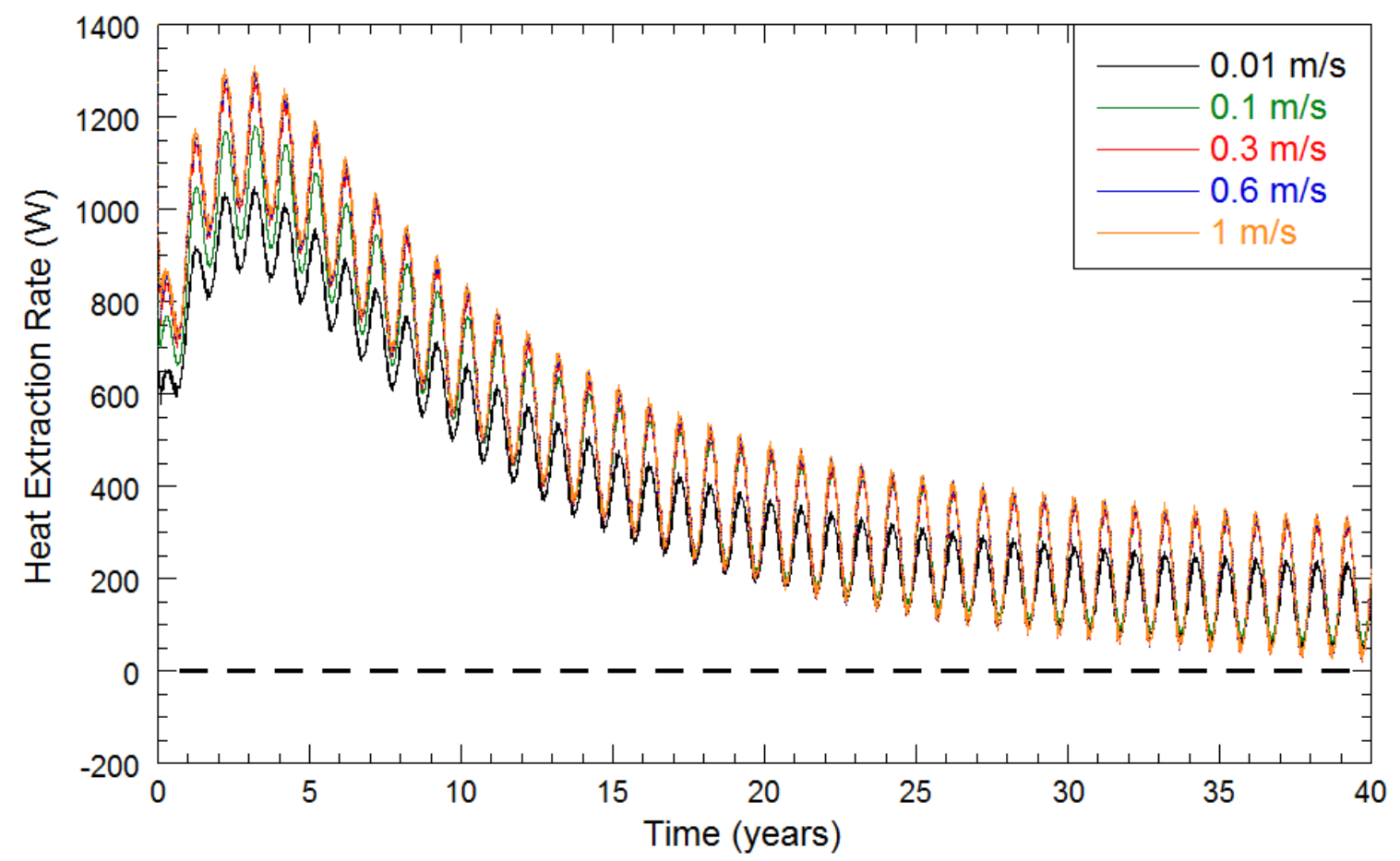

Figure 4.17: Heat Extraction Rates from 50.8 mm Diameter Pipe at Various Fluid Velocities

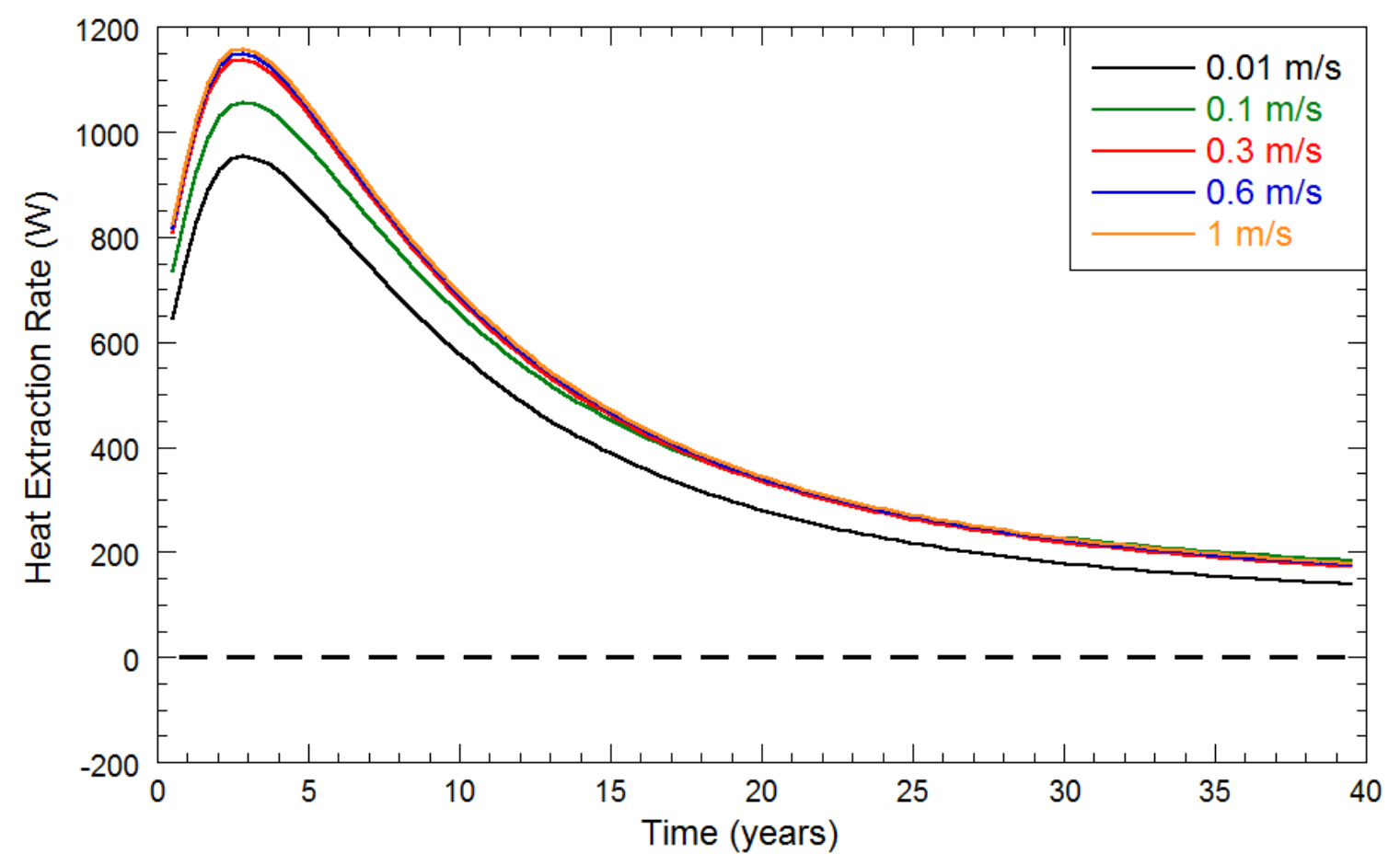

Figure 4.18: Annual Average Heat Extraction Rates from $50.8 \mathrm{~mm}$ Diameter Pipe at Various Fluid Velocities 


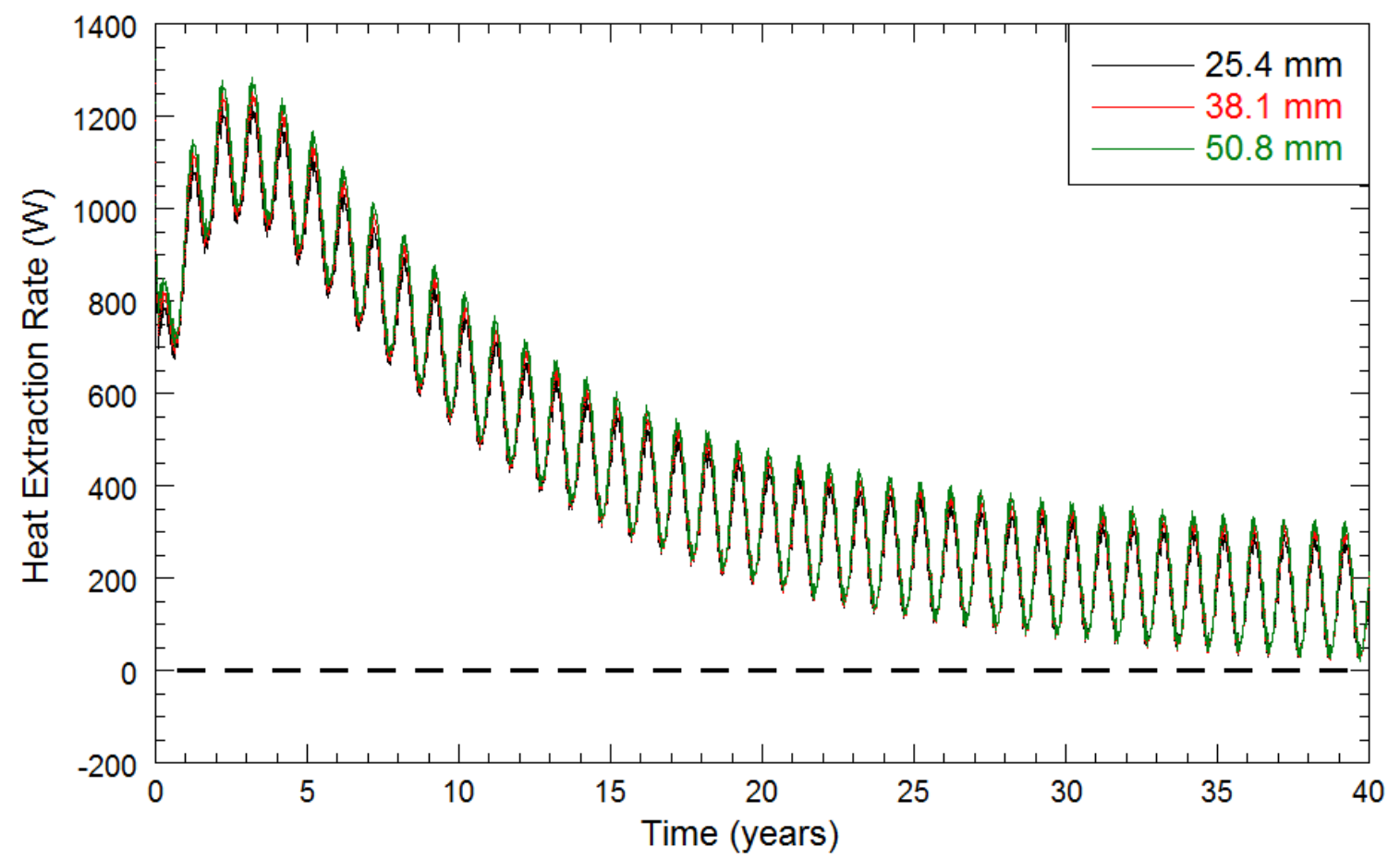

Figure 4.19: Heat Extraction Rates with Fluid Velocity for Various Pipe Sizes

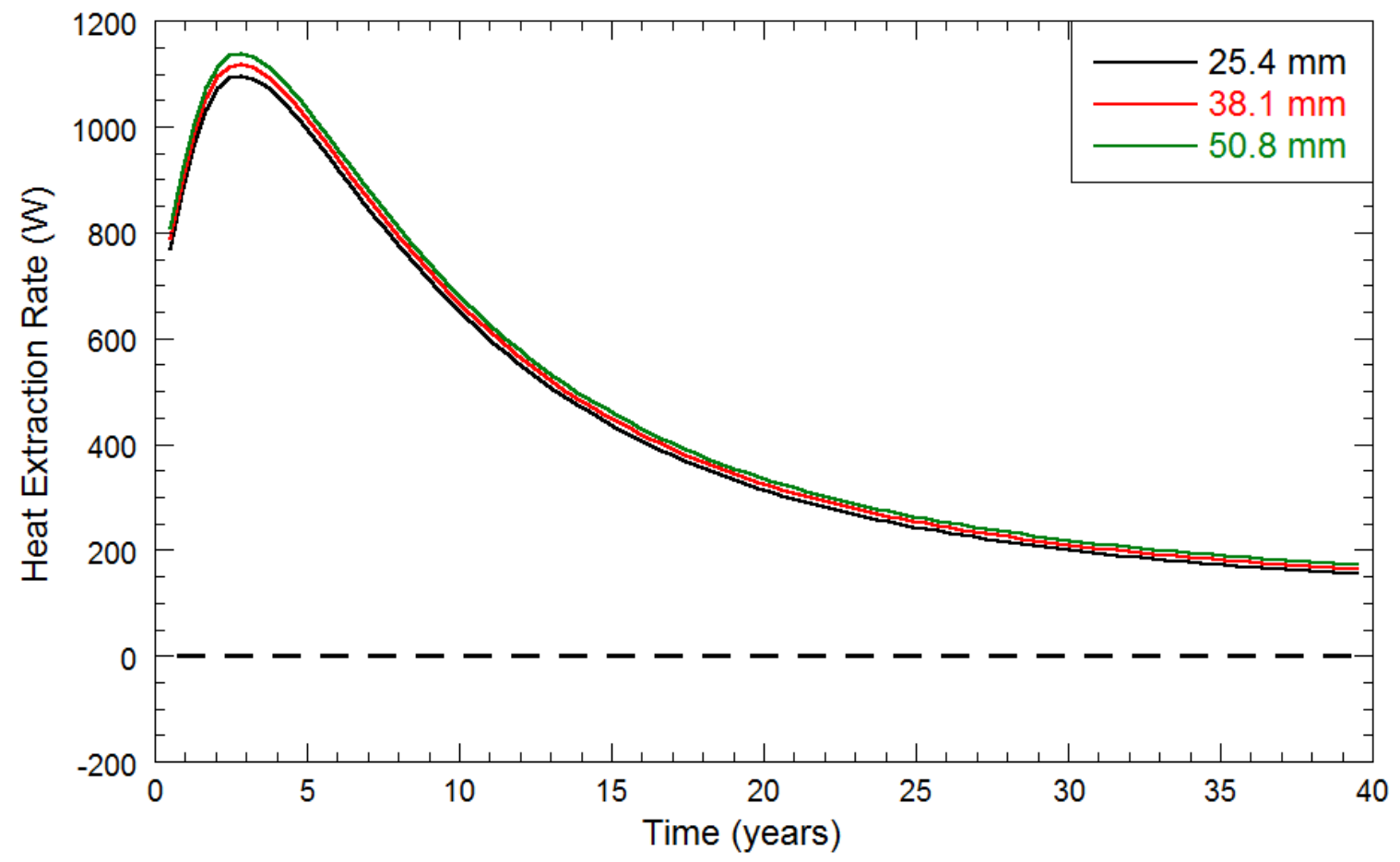

Figure 4.20: Annual Average Heat Extraction Rates with Fluid Velocity for Various Pipe Sizes 
Fluid velocity was determined to have a significant impact on heat extraction rates. Average seasonal amplitude of heat extraction rates increased with increasing fluid velocity. Turbulent flow yielded significantly higher heat extraction rates than laminar flow. Once turbulent fluid flow was reached, increasing fluid velocity beyond this point reduced the increase in extraction rates. For laminar flow, an increase in fluid velocity caused an increase in peak heat extraction rate of approximately $805 \mathrm{~W} /(\mathrm{m} / \mathrm{s})$. For turbulent flow, an increase in fluid velocity caused an increase in peak heat extraction rate of approximately $33 \mathrm{~W} /(\mathrm{m} / \mathrm{s})$. The difference in peak heat extraction rates between different velocities are presented in Figure 4.21.

Pipe diameter was determined to have an impact on heat extraction rates. Larger pipe diameters yielded higher heat extraction rates and greater total heat energy extracted. Peak heat extraction rates increased linearly at a rate of $31 \mathrm{~W}$ per $\mathrm{mm}$ increase in pipe diameter. The difference in peak heat extraction rates between different pipe sizes is presented in Figure 4.22. The combined analyses presented in Figures 4.21 and 4.22 demonstrated that fluid velocity had a significantly greater impact than pipe diameter on heat extraction rates. 


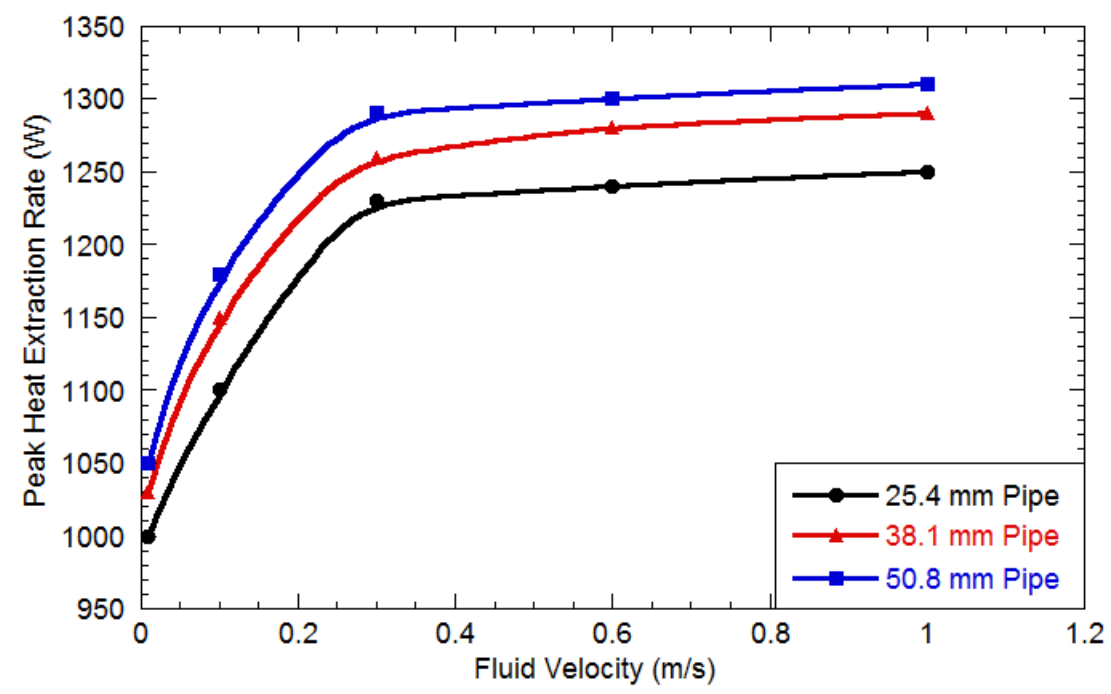

Figure 4.21: Impact of Fluid Velocity on Peak Heat Extraction Rates

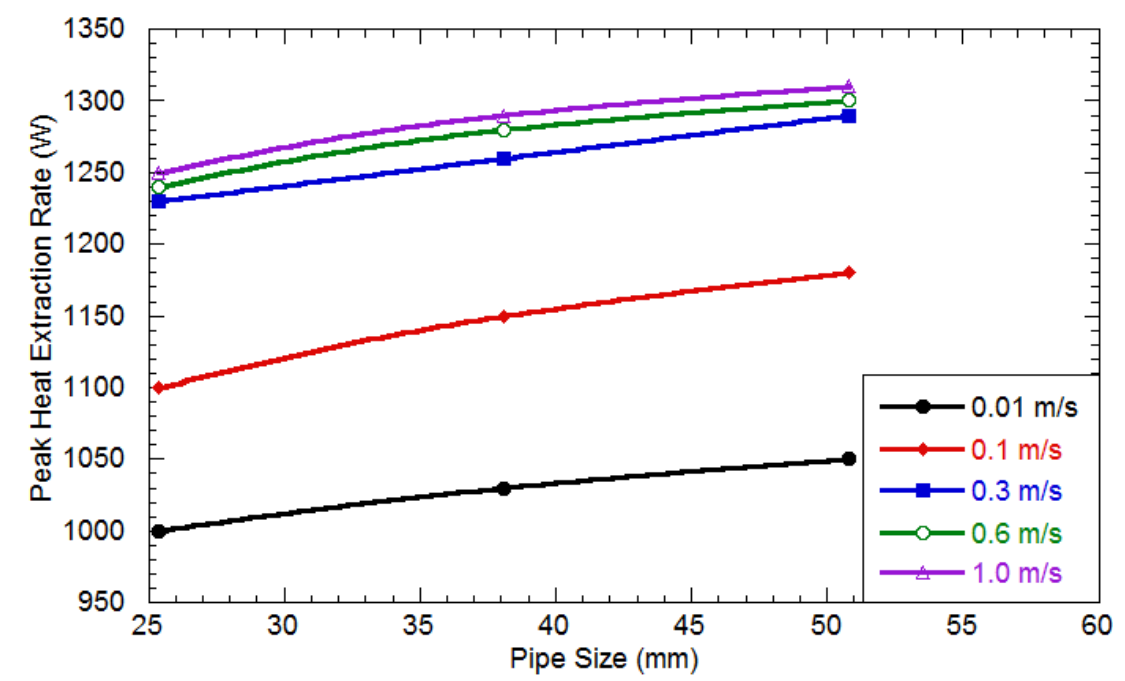

Figure 4.22: Impact of Pipe diameter on Peak Heat Extraction Rates

\subsubsection{Year-Round Waste Placement Results}

Year-round waste placement simulations were conducted on the template landfill model and only the waste placement starting month was varied. Waste was placed year-round for 12 simulations wherein waste placement was initiated each month of the year. Temperature results, heat extraction results, and trends 
for the year-round waste placement simulations are discussed in this section. Peak baseline temperatures and temperature results of the year-round waste placement simulations are summarized in Tables 4.5 and 4.6, respectively.

Table 4.5: Peak Baseline Temperatures at Locations for Different Waste Placement Start Months

\begin{tabular}{|c|c|c|c|c|c|}
\hline $\begin{array}{c}\text { Waste } \\
\text { Placement } \\
\text { Start } \\
\text { Month }\end{array}$ & $\begin{array}{c}\text { Peak } \\
\text { CL Temp } \\
\left({ }^{\circ} \mathrm{C}\right)\end{array}$ & $\begin{array}{c}\text { Peak } \\
\text { SD Temp } \\
\left({ }^{\circ} \mathrm{C}\right)\end{array}$ & $\begin{array}{c}\text { Peak } \\
\text { MD Temp } \\
\left({ }^{\circ} \mathrm{C}\right)\end{array}$ & $\begin{array}{c}\text { Peak } \\
\text { GD Temp } \\
\left({ }^{\circ} \mathrm{C}\right)\end{array}$ & $\begin{array}{c}\text { Peak } \\
\text { BL } \\
\text { Temp } \\
\left({ }^{\circ} \mathrm{C}\right)\end{array}$ \\
\hline January & 30.1 & 39.2 & 43.8 & 36.8 & 24.1 \\
\hline February & 29.6 & 35.1 & 40.8 & 36.1 & 23.9 \\
\hline March & 30.3 & 35.8 & 41.5 & 37.0 & 24.7 \\
\hline April & 31.1 & 36.8 & 42.4 & 37.9 & 25.6 \\
\hline May & 30.4 & 38.2 & 43.2 & 38.5 & 26.4 \\
\hline June & 30.6 & 39.4 & 48.9 & 39.0 & 27.0 \\
\hline July & 30.5 & 40.2 & 44.2 & 39.0 & 27.2 \\
\hline August & 30.3 & 40.2 & 43.9 & 38.3 & 26.7 \\
\hline September & 30.2 & 39.6 & 43.3 & 37.4 & 25.9 \\
\hline October & 30.0 & 38.3 & 42.5 & 36.4 & 24.9 \\
\hline November & 29.8 & 37.0 & 41.6 & 35.5 & 24.1 \\
\hline December & 29.7 & 35.9 & 41.1 & 35.2 & 23.6 \\
\hline
\end{tabular}

Temperatures along the length of the HES were not significantly impacted by year-round waste placement beginning on different months. The maximum difference between baseline temperatures and temperatures $0 \mathrm{~m}$ away from the HES occurred when waste placement began in July and the minimum difference between baseline temperatures and temperatures $0 \mathrm{~m}$ away from the HES occurred when waste placement began in February. 
Table 4.6: Temperature Results for Different Waste Placement Start Months $0 \mathrm{~m}$ away from the HES

\begin{tabular}{|c|c|c|c|c|c|c|c|}
\hline $\begin{array}{c}\text { Waste } \\
\begin{array}{c}\text { Placement } \\
\text { Start } \\
\text { Month }\end{array}\end{array}$ & $\begin{array}{c}\text { Avg. } \\
\mathrm{CL} \\
\text { Temp } \\
\left({ }^{\circ} \mathrm{C}\right)\end{array}$ & $\begin{array}{c}\text { Avg. } \\
\mathrm{SD} \\
\text { Temp } \\
\left({ }^{\circ} \mathrm{C}\right)\end{array}$ & $\begin{array}{c}\text { Avg. } \\
\mathrm{MD} \\
\text { Temp } \\
\left({ }^{\circ} \mathrm{C}\right)\end{array}$ & $\begin{array}{c}\text { Avg. } \\
\text { GD } \\
\text { Temp } \\
\left({ }^{\circ} \mathrm{C}\right)\end{array}$ & $\begin{array}{c}\text { Peak } \\
\text { BL } \\
\text { Temp } \\
\left({ }^{\circ} \mathrm{C}\right)\end{array}$ & $\begin{array}{c}\text { Maximum } \\
\text { Difference } \\
\text { Between } \\
\text { HES and } \\
\text { Baseline } \\
\left({ }^{\circ} \mathrm{C}\right)\end{array}$ & $\begin{array}{c}\text { Elapsed } \\
\text { Time to } \\
\text { Maximum } \\
\text { Temperature } \\
\text { Difference } \\
\text { (years) }\end{array}$ \\
\hline January & 13.7 & 14.4 & 14.5 & 14.4 & 22.2 & 25.9 & 3.0 \\
\hline February & 13.6 & 14.3 & 14.4 & 14.3 & 22.1 & 25.2 & 3.7 \\
\hline March & 13.6 & 14.3 & 14.5 & 14.4 & 22.7 & 25.8 & 3.7 \\
\hline April & 13.7 & 14.4 & 14.5 & 14.4 & 23.6 & 26.6 & 3.7 \\
\hline May & 13.7 & 14.4 & 14.6 & 14.5 & 24.4 & 27.3 & 3.6 \\
\hline June & 13.7 & 14.4 & 14.6 & 14.5 & 25.0 & 27.9 & 3.5 \\
\hline July & 13.7 & 14.4 & 14.6 & 14.5 & 25.1 & 28.2 & 3.4 \\
\hline August & 13.7 & 14.4 & 14.6 & 14.5 & 24.7 & 27.9 & 3.4 \\
\hline September & 13.7 & 14.4 & 14.6 & 14.4 & 23.9 & 27.4 & 3.3 \\
\hline October & 13.7 & 14.4 & 14.5 & 14.4 & 23.0 & 26.7 & 3.2 \\
\hline November & 13.6 & 14.3 & 14.5 & 14.3 & 22.2 & 25.9 & 3.1 \\
\hline December & 13.6 & 14.3 & 14.4 & 14.3 & 21.8 & 25.3 & 3.0 \\
\hline
\end{tabular}

Time required to reach the maximum temperature difference for yearround waste placement was longest when waste placement began in February, March, and April. Time required to reach the maximum temperatures difference for year-round placement was shortest when waste placement began in December and January.

Maximum landfill temperatures (at the time of maximum difference between HES and baseline temperatures) were determined to occur at depths between 14.5 and $16 \mathrm{~m}$ into a $30 \mathrm{~m}$ deep waste mass. Temperatures did not change significantly (less than $5^{\circ} \mathrm{C}$ change in temperature) along the length of the HES. Simulated temperatures increased to within $5^{\circ} \mathrm{C}$ of baseline temperatures within $2 \mathrm{~m}$ directly below the HES. Temperatures at the cover liner, 
shallow-depth, middle-depth, great-depth, and bottom liner locations are presented in Figure 4.23 for the waste placement starting in June. The vertical temperature profile results at the time of maximum difference between HES and baseline temperatures are presented in Figure 4.24 for the waste placement starting in June. Additional plots for all other year-round waste placement simulations are presented in Appendix A. 

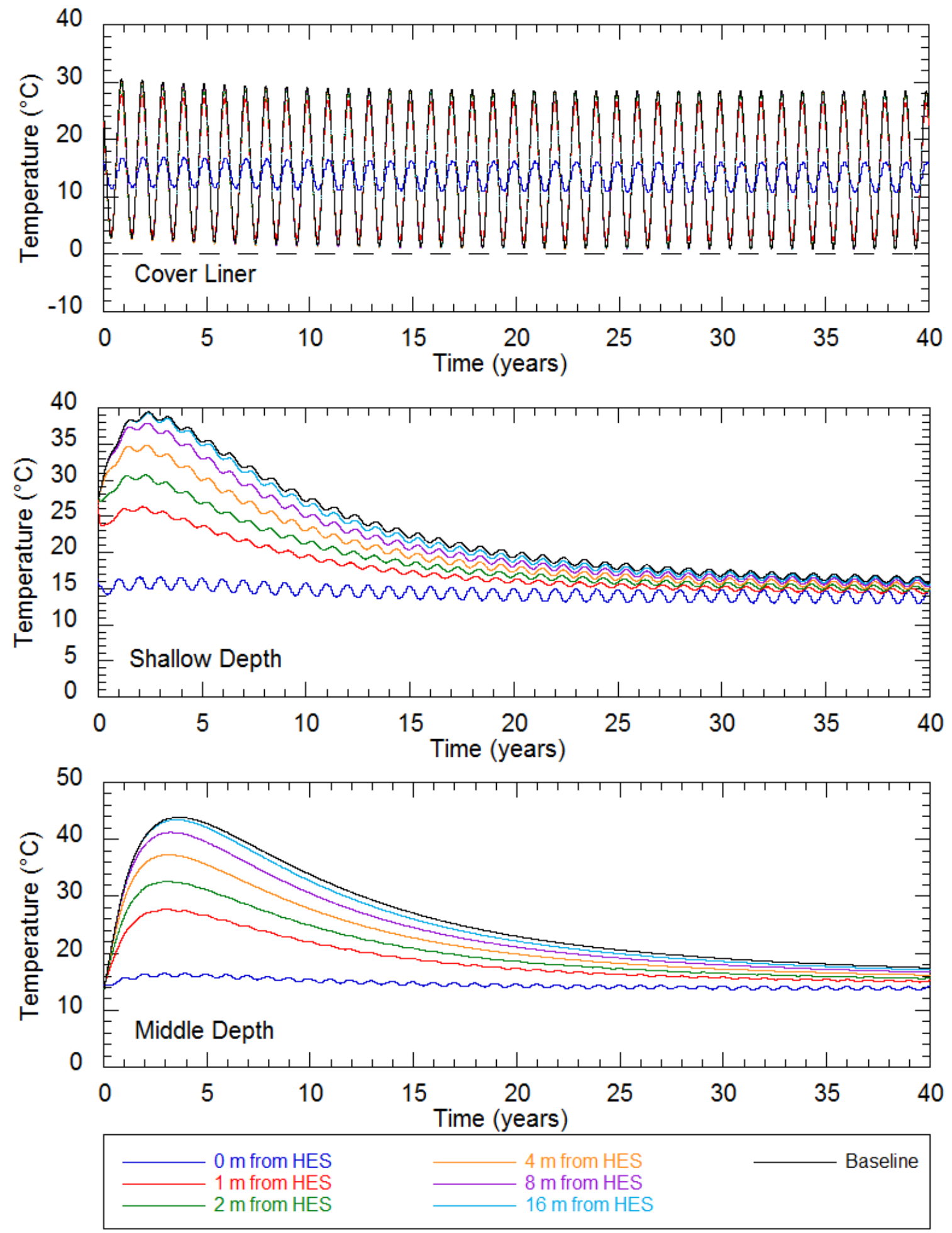

Figure 4.23a: Temperature Results: Year-Round Waste Placement June Start 

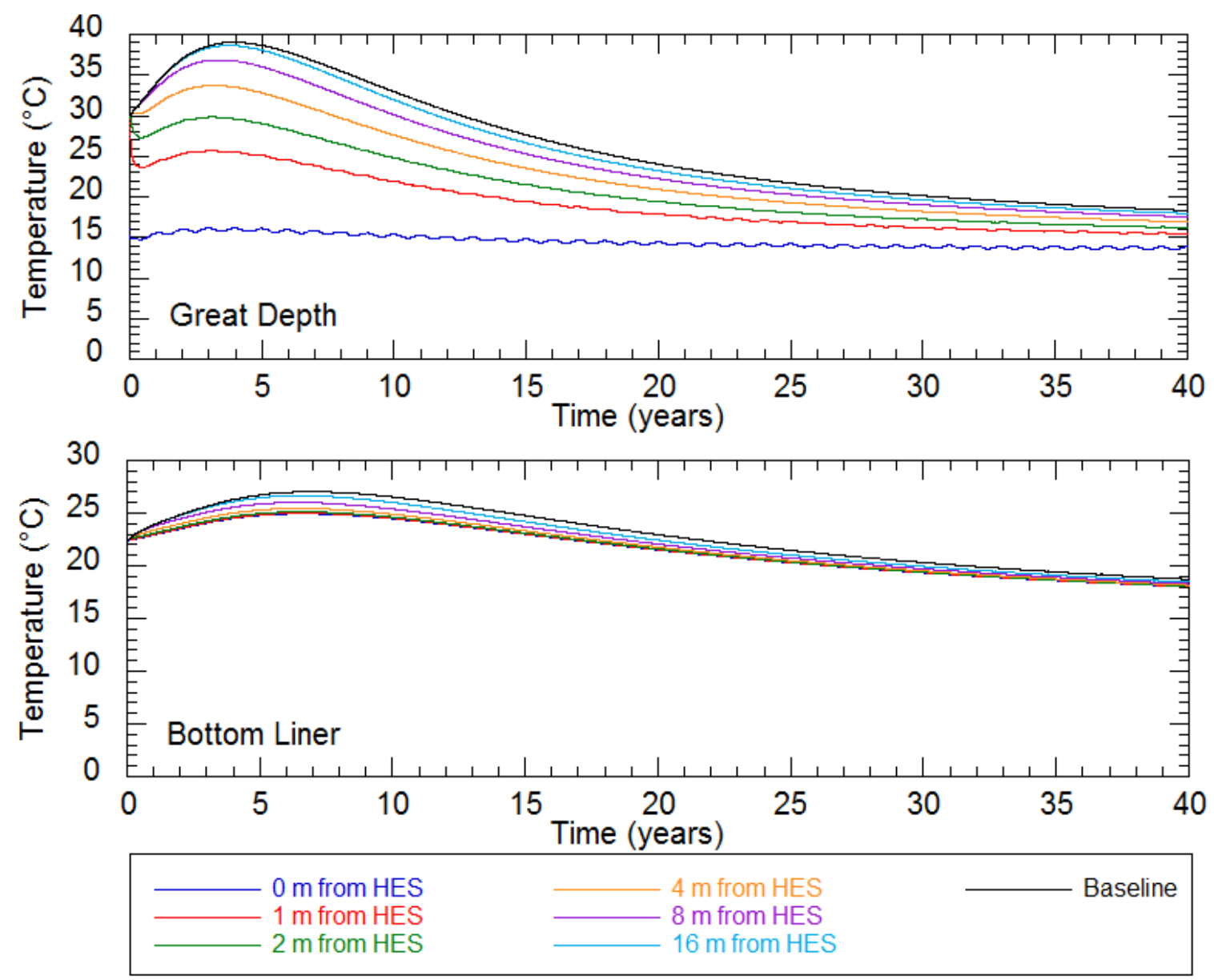

Figure 4.23b: Temperature Results: Year-Round Waste Placement June Start

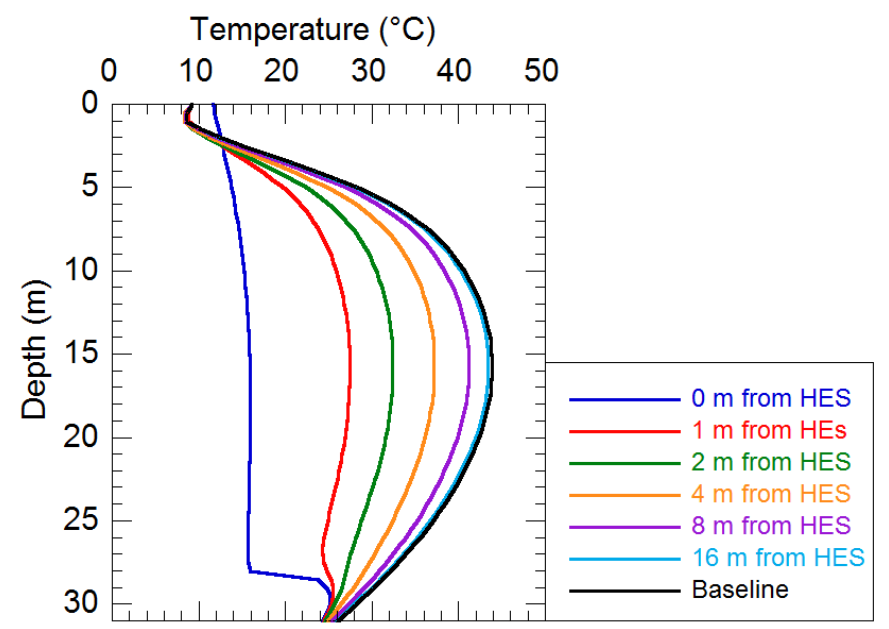

Figure 4.24: Vertical Temperature Results: Year-Round Waste Placement June Start 
The heat extraction results for the year-round waste placement simulations are presented in Table 7. The maximum and minimum heat extraction rates occurred for the year-round waste placement simulation with waste placement beginning in July and December, respectively. The range in expected heat extraction rates for the year-round waste placement simulations are presented in Table 4.8. Minimum and maximum total heat energy extracted were determined to be 554,700 and 661,700 MJ over a 40 year period, respectively. The time to peak heat extraction rate ranged from 2.4 to 3.2 years after start of HES operation. The annual average heat extraction rate amplitude ranged from 132 to $157 \mathrm{~W}$. The heat extraction rates for four year-round waste placements at four representative starting months are presented in Figure 4.25. Annual average heat extraction rates are presented in Figures 4.26 and 4.27. 
Table 4.7: Year-Round Waste Placement Heat Extraction Results

\begin{tabular}{|c|c|c|c|c|c|}
\hline $\begin{array}{c}\text { Waste } \\
\text { Placement } \\
\begin{array}{c}\text { Starting } \\
\text { Month }\end{array}\end{array}$ & $\begin{array}{c}\text { HES } \\
\text { Start }\end{array}$ & $\begin{array}{c}\text { Peak Heat } \\
\text { Extraction } \\
\text { Rate (W) }\end{array}$ & $\begin{array}{c}\text { Time To } \\
\text { Peak } \\
\text { (years) }\end{array}$ & $\begin{array}{c}\text { Average } \\
\text { Seasonal } \\
\text { Amplitude } \\
(\mathrm{W})\end{array}$ & $\begin{array}{c}\text { Total Heat } \\
\text { Extracted* } \\
\text { (MJ) }\end{array}$ \\
\hline January & May & 1360 & 2.3 & 143 & 599,000 \\
\hline February & June & 1230 & 3.2 & 140 & 561,100 \\
\hline March & July & 1270 & 3.1 & 144 & 585,200 \\
\hline April & August & 1320 & 3.0 & 144 & 613,100 \\
\hline May & September & 1360 & 3.0 & 139 & 637,300 \\
\hline June & October & 1400 & 2.9 & 134 & 656,800 \\
\hline July & November & 1410 & 2.8 & 132 & 661,700 \\
\hline August & December & 1390 & 2.7 & 133 & 648,400 \\
\hline September & January & 1360 & 2.6 & 137 & 626,400 \\
\hline October & February & 1310 & 2.5 & 144 & 597,700 \\
\hline November & March & 1280 & 2.5 & 157 & 571,000 \\
\hline December & April & 1230 & 2.4 & 143 & 554,700 \\
\hline
\end{tabular}

* over a 40 year period

Table 4.8: Expected Range of Heat Extraction Rates for Year-Round Waste Placement Simulations

\begin{tabular}{|c|c|c|c|c|c|c|}
\hline $\begin{array}{c}\text { Waste } \\
\text { Placement } \\
\begin{array}{c}\text { Starting Month } \\
\text { January }\end{array}\end{array}$ & $\begin{array}{c}\text { Heat Extraction } \\
\text { During 1st year } \\
\text { of Operation } \\
(\mathrm{W})\end{array}$ & \multicolumn{2}{|c|}{$\begin{array}{c}\text { Heat Extraction } \\
\text { During Year of } \\
\text { Peak Heat } \\
\text { Extraction }(\mathrm{W})\end{array}$} & \multicolumn{2}{|c|}{$\begin{array}{c}\text { Heat Extraction } \\
\text { During Last Year } \\
\text { of Operation } \\
\text { (W) }\end{array}$} \\
\cline { 2 - 7 } & Max & Min & Max & Min & Max & Min \\
\hline January & 1060 & 860 & 1360 & 1080 & 300 & 20 \\
\hline February & 950 & 680 & 1230 & 940 & 290 & 20 \\
\hline March & 1070 & 720 & 1270 & 980 & 300 & 30 \\
\hline April & 1160 & 770 & 1320 & 1030 & 310 & 40 \\
\hline May & 1220 & 800 & 1360 & 1100 & 320 & 40 \\
\hline June & 1240 & 810 & 1400 & 1140 & 320 & 50 \\
\hline July & 1230 & 760 & 1410 & 1150 & 320 & 50 \\
\hline August & 1160 & 660 & 1390 & 1130 & 320 & 50 \\
\hline September & 1060 & 550 & 1360 & 1090 & 310 & 40 \\
\hline October & 960 & 470 & 1310 & 1030 & 300 & 40 \\
\hline November & 860 & 410 & 1280 & 980 & 310 & 10 \\
\hline December & 800 & 450 & 1230 & 970 & 290 & 20 \\
\hline
\end{tabular}

* last year is year 40 


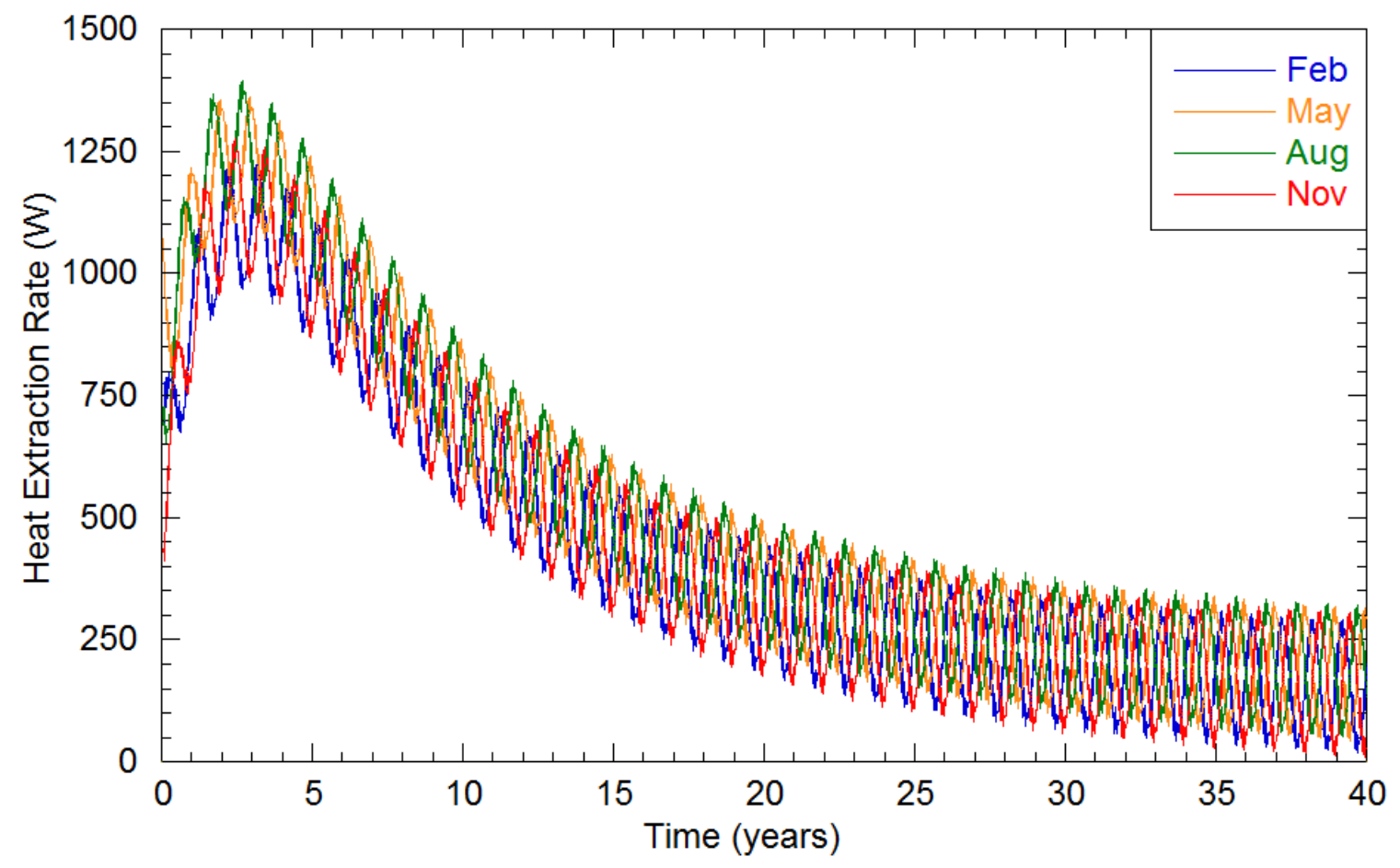

Figure 4.25: Heat Extraction Rates for Year-Round Waste Placement Starting on Different Months

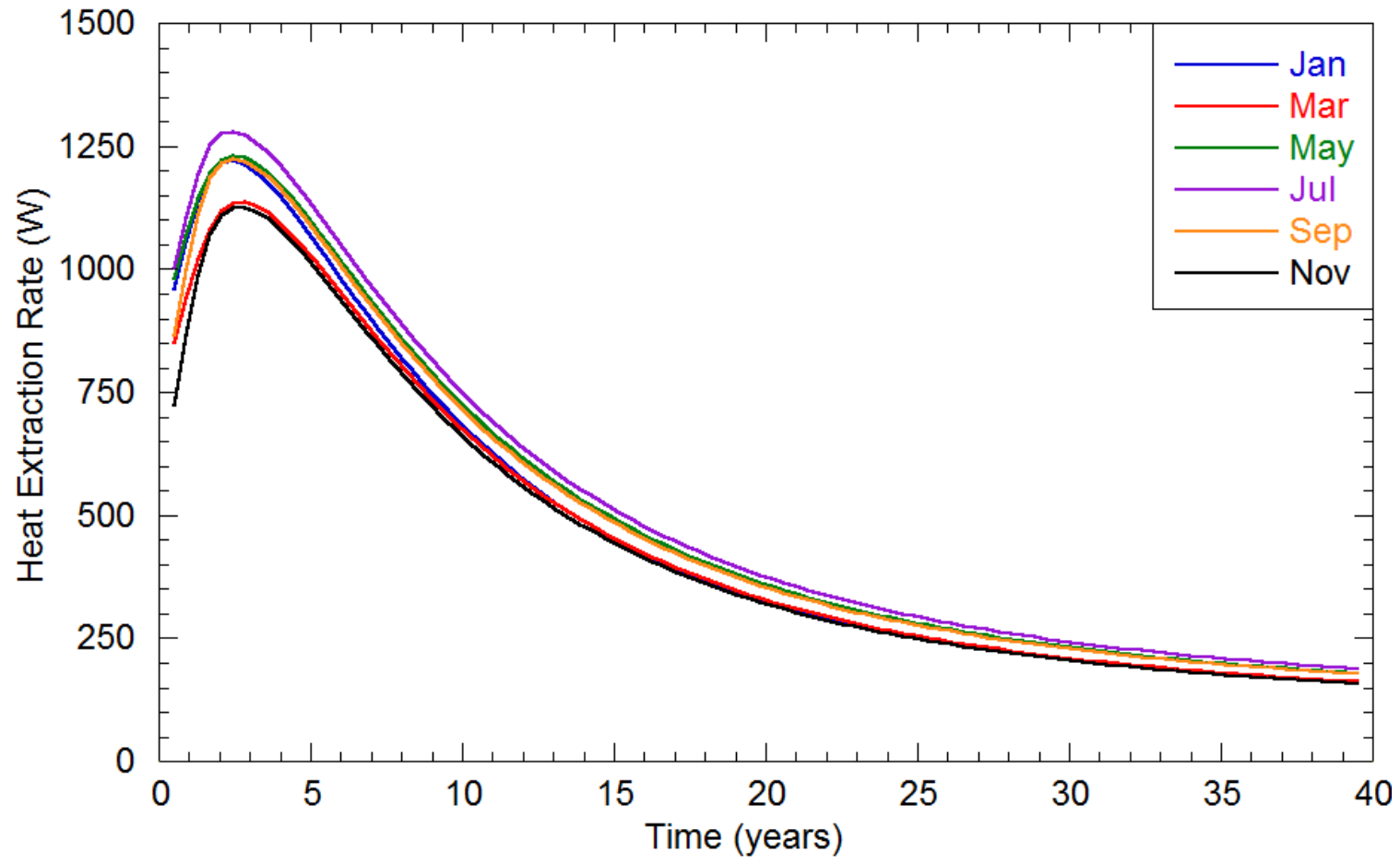

Figure 4.26: Annual Average Heat Extraction Rates for Year-Round Waste Placement Starting on Different Months 


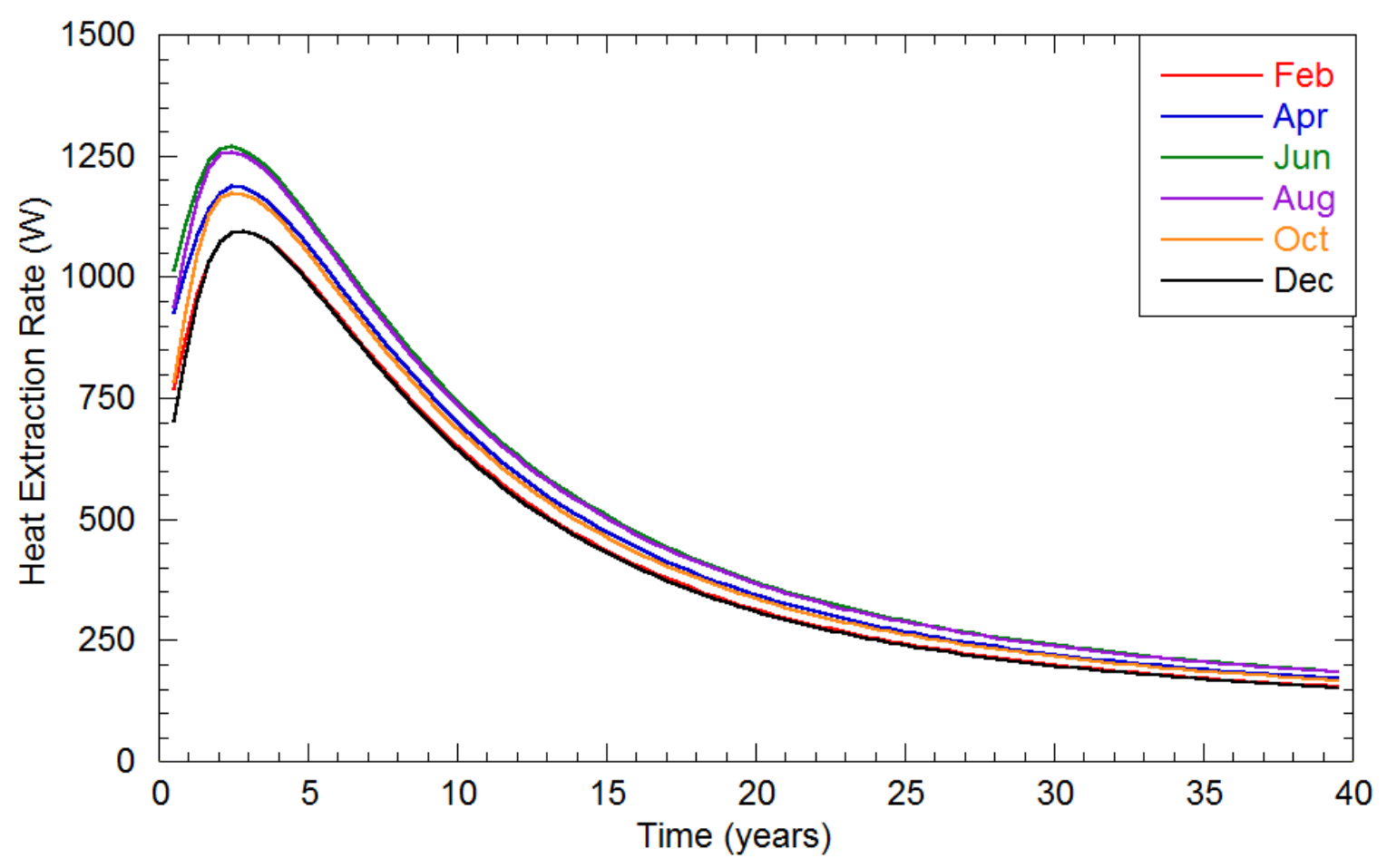

Figure 4.27: Annual Average Heat Extraction Rates for Year-Round Waste Placement Starting on Different Months

Different starting months for year-round waste placement had little effect on the temperatures near the HES. Higher simulated baseline temperatures were obtained when waste was placed in warmer months. Placement before peak seasonal temperatures coupled with final placement near mean seasonal temperatures lead to higher overall landfill temperatures. Due to temperatures near the HES not significantly changing and baseline temperatures changing with depth based on the month of waste placement, maximum difference in temperature between baseline temperatures and temperatures $0 \mathrm{~m}$ away from the HES exhibited the same trend as maximum baseline temperatures (Figure 4.28). 
The total heat energy extracted from year-round waste placement was dependent on the temperature of waste at placement. The simulations for different waste placement starting dates with the highest maximum temperature difference yielded higher heat extraction rates and total heat energy extracted.

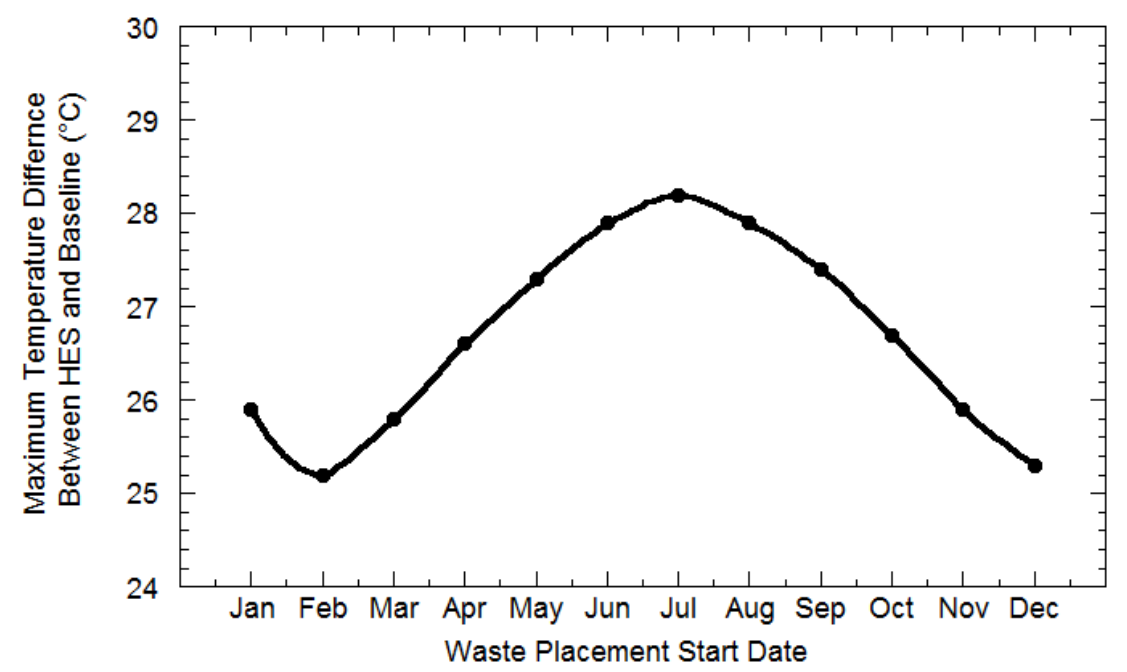

Figure 4.28: Impact of Year-Round Waste Placement Time on Maximum Temperature Difference

\subsubsection{Seasonal Waste Placement Results}

Seasonal waste placement simulations were conducted on the template landfill model and only the season in which waste placement occurred was varied. Simulations were conducted in which waste placement occurred in only winter and only summer as outlined in Chapter 3. Temperature results, heat extraction results, and trends for the seasonal waste placement simulations are discussed in this section. Peak baseline temperatures and temperature results of the seasonal waste placement simulations are summarized in Tables 4.9 and 4.10 , respectively. 
Table 4.9: Peak Baseline Temperatures at Locations for Different Seasonal Waste Placements

\begin{tabular}{|c|c|c|c|c|c|}
\hline $\begin{array}{c}\text { Waste } \\
\text { Placement }\end{array}$ & $\begin{array}{c}\text { Peak } \\
\mathrm{CL} \mathrm{Temp} \\
\left({ }^{\circ} \mathrm{C}\right)\end{array}$ & $\begin{array}{c}\text { Peak } \\
\text { SD Temp } \\
\left({ }^{\circ} \mathrm{C}\right)\end{array}$ & $\begin{array}{c}\text { Peak } \\
\text { GD Temp } \\
\left({ }^{\circ} \mathrm{C}\right)\end{array}$ & $\begin{array}{c}\text { Peak } \\
\text { MD Temp } \\
\left({ }^{\circ} \mathrm{C}\right)\end{array}$ & $\begin{array}{c}\text { Peak } \\
\text { BL Temp } \\
\left({ }^{\circ} \mathrm{C}\right)\end{array}$ \\
\hline Year-Round & 29.6 & 35.1 & 36.1 & 40.8 & 23.9 \\
\hline Winter-Only & 29.0 & 24.0 & 21.6 & 24.6 & 17.1 \\
\hline $\begin{array}{c}\text { Summer- } \\
\text { Only }\end{array}$ & 30.8 & 46.1 & 43.9 & 51.0 & 29.4 \\
\hline
\end{tabular}

Table 4.10: Temperature Results for Different Seasonal Waste Placements $0 \mathrm{~m}$ away from the HES

\begin{tabular}{|c|c|c|c|c|c|c|c|}
\hline $\begin{array}{c}\text { Waste } \\
\text { Placement }\end{array}$ & $\begin{array}{c}\text { Avg. } \\
\text { CL } \\
\text { Temp } \\
\left({ }^{\circ} \mathrm{C}\right)\end{array}$ & $\begin{array}{c}\text { Avg. } \\
\text { SD } \\
\text { Temp } \\
\left({ }^{\circ} \mathrm{C}\right)\end{array}$ & $\begin{array}{c}\text { Avg. } \\
\text { MD } \\
\text { Temp } \\
\left({ }^{\circ} \mathrm{C}\right)\end{array}$ & $\begin{array}{c}\text { Avg. } \\
\text { GD } \\
\text { Temp } \\
\left({ }^{\circ} \mathrm{C}\right)\end{array}$ & $\begin{array}{c}\text { Peak } \\
\text { BL } \\
\text { Temp } \\
\left({ }^{\circ} \mathrm{C}\right)\end{array}$ & $\begin{array}{c}\text { Maximum } \\
\text { Difference } \\
\text { Between } \\
\text { HES and } \\
\text { Baseline } \\
\left({ }^{\circ} \mathrm{C}\right)\end{array}$ & $\begin{array}{c}\text { Elapsed } \\
\text { Time to } \\
\text { Maximum } \\
\text { Temperature } \\
\text { Difference } \\
\text { (years) }\end{array}$ \\
\hline Year-Round & 13.6 & 14.3 & 14.4 & 14.3 & 22.1 & 25.2 & 3.7 \\
\hline Winter-Only & 13.5 & 13.9 & 13.9 & 13.7 & 16.4 & 10.5 & 4.9 \\
\hline $\begin{array}{l}\text { Summer- } \\
\text { Only }\end{array}$ & 13.8 & 14.6 & 14.8 & 14.7 & 27.0 & 34.4 & 2.5 \\
\hline
\end{tabular}

Temperatures $0 \mathrm{~m}$ away from HES were approximately $1^{\circ} \mathrm{C}$ lower for waste placement only in winter than waste placement only in summer for middle and great depths. The maximum difference between temperatures at the HES and baseline temperatures were highest when waste placement began in summer months and lowest when waste placement began in winter months. Placing waste only in winter resulted in the time to maximum temperature difference to increase significantly as compared to year-round placement, while placing waste only in summer decreased the time to maximum temperature difference as compared to year-round placement. 
Maximum landfill temperatures (at the time of maximum difference between HES and baseline temperatures) were determined to occur at depths between 14 and $16 \mathrm{~m}$ in a $30 \mathrm{~m}$ deep waste mass. Temperatures did not significantly change (less than $5^{\circ} \mathrm{C}$ change in temperature) along the length of the HES. Simulated temperatures increased to within $5^{\circ} \mathrm{C}$ of baseline temperatures $2 \mathrm{~m}$ directly below the HES. Temperatures at the cover liner, shallow-depth, middle-depth, great-depth, and bottom liner locations are presented in Figure 4.29 for summer-only placement. The vertical temperature profile results at the time of maximum difference between HES and baseline temperatures are presented in Figure 4.30 for summer-only placement. Additional plots for winter-only waste placement simulations are presented in Appendix A. 

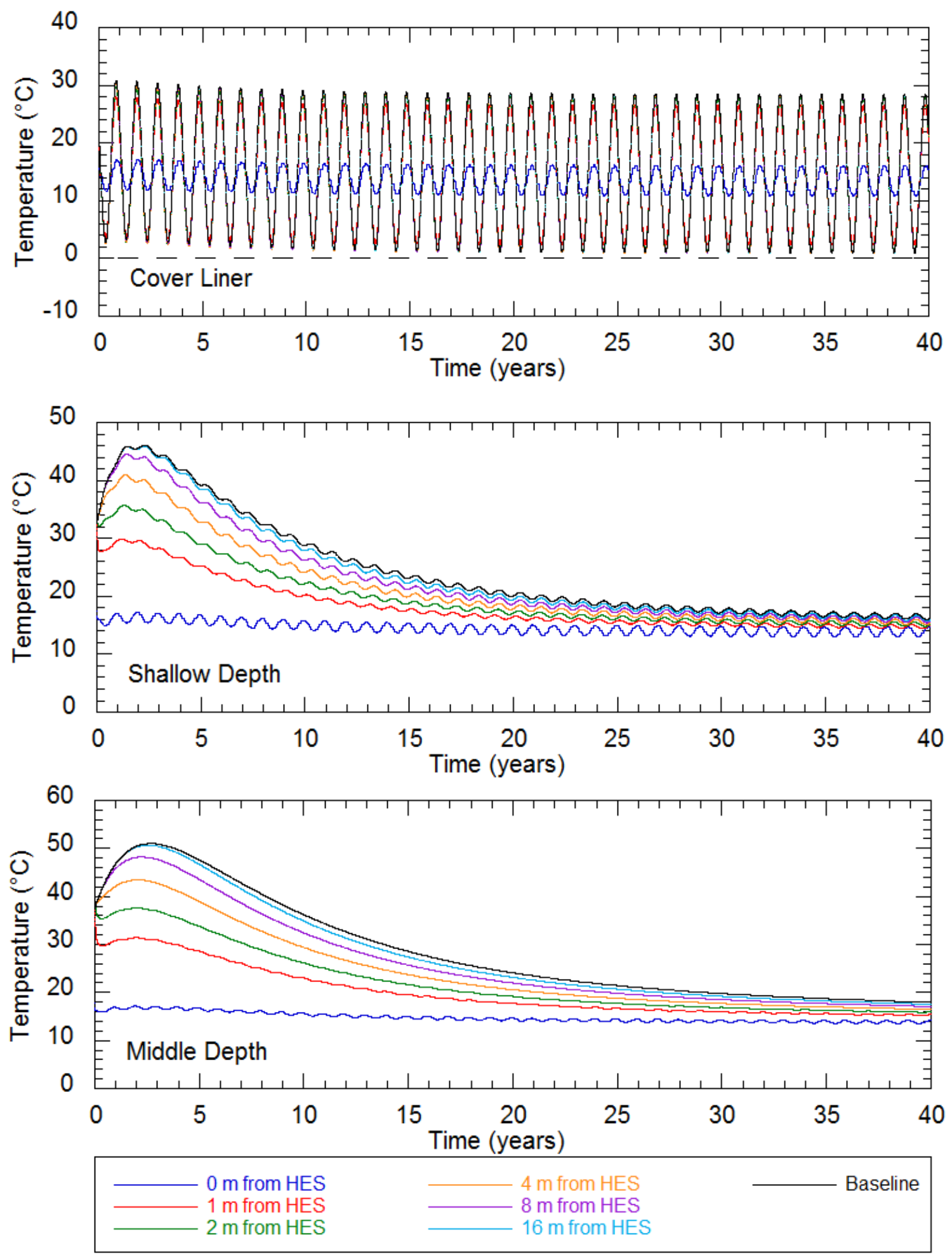

Figure 4.29a: Temperature Results: Summer-Only Waste Placement 

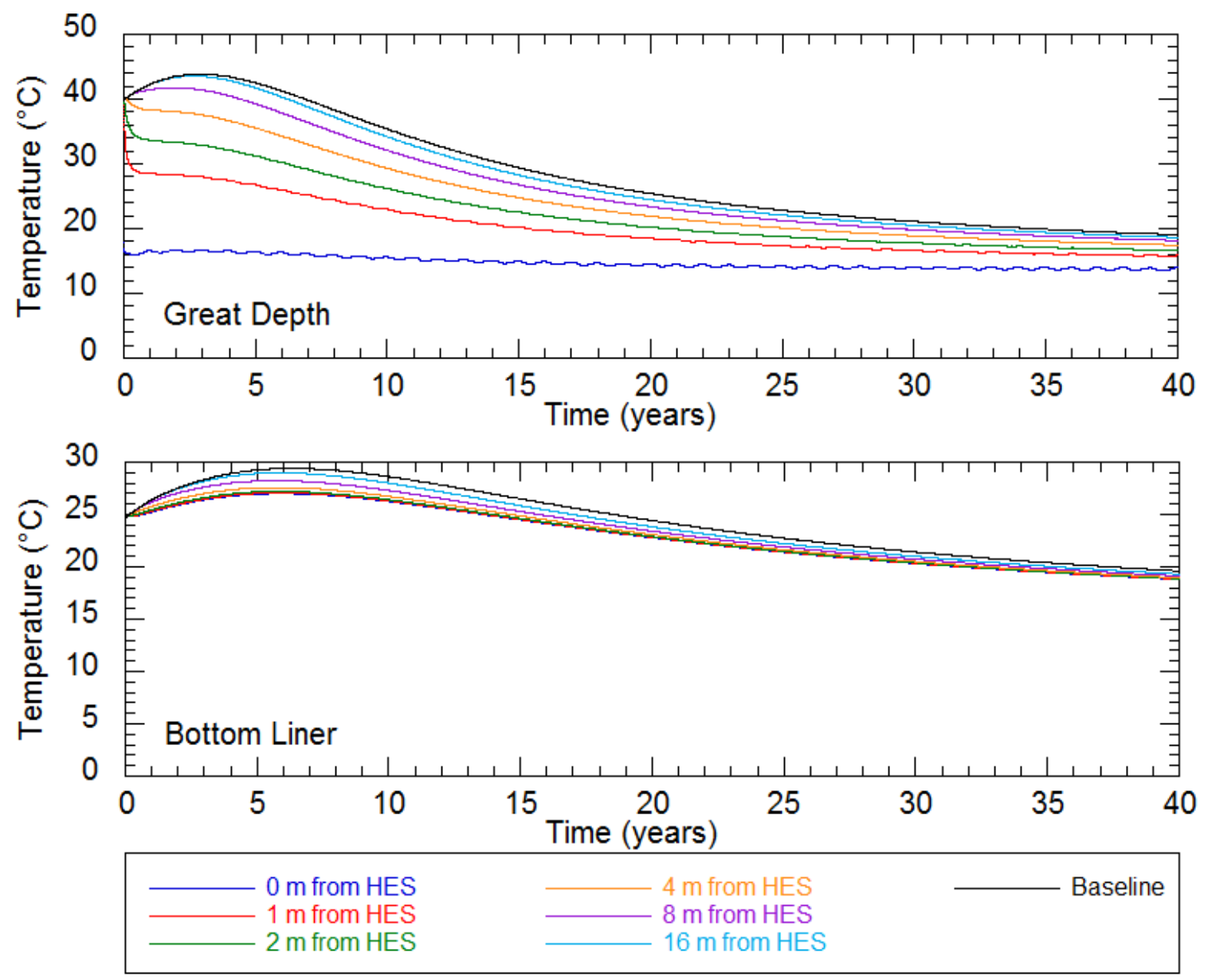

Figure 4.29b: Temperature Results: Summer-Only Waste Placement

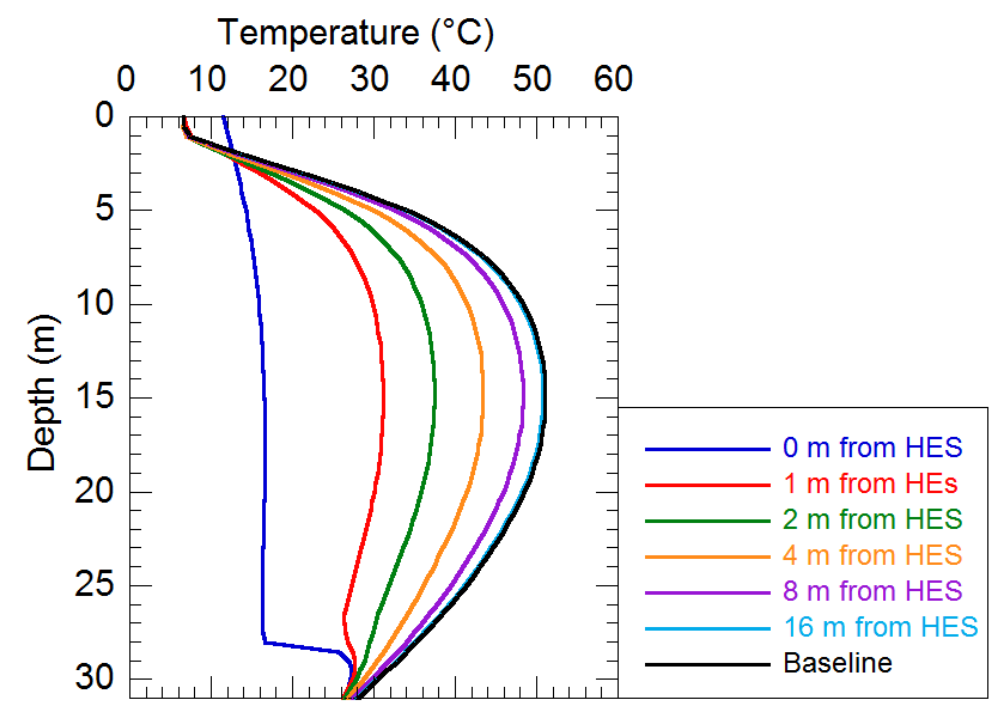

Figure 4.30: Vertical Temperature Results: Summer-Only Waste Placement 
The heat extraction results for the seasonal waste placement simulations are presented in Table 4.11. Winter-only waste placement simulations yield lower heat extraction rates than year-round or summer-only waste placement simulations. The range in expected heat extraction rates for the seasonal waste placement simulations are presented in Table 4.12. Maximum total heat energy extracted was determined to be $766,900 \mathrm{MJ}$ over a 40 year period. Minimum total heat energy extracted was determined to be $206,900 \mathrm{MJ}$ after a 24.7 year period. The heat extraction phase for the winter-only waste placement simulation lasted for 24.7 years and therefore, the total heat energy was calculated only for the heat extraction phase. The peak heat extraction rate occurred 1.8 to 4.3 years after start of HES operation. The average seasonal heat extraction rate amplitude ranged from $139 \mathrm{~W}$ to $140 \mathrm{~W}$. The heat extraction rates and annual average heat extraction rates for seasonal waste placement simulations are presented in Figure 4.31 and 4.32, respectively.

Table 4.11: Seasonal Waste Placement Heat Extraction Results

\begin{tabular}{|c|c|c|c|c|}
\hline $\begin{array}{c}\text { Waste } \\
\text { Placement }\end{array}$ & $\begin{array}{c}\text { Peak Heat } \\
\text { Extraction } \\
\text { Rate (W) }\end{array}$ & $\begin{array}{c}\text { Time To } \\
\text { Peak } \\
\text { (years) }\end{array}$ & $\begin{array}{c}\text { Average } \\
\text { Seasonal } \\
\text { Amplitude (W) }\end{array}$ & $\begin{array}{c}\text { Total Heat } \\
\text { Extracted } \\
\text { (MJ) }\end{array}$ \\
\hline Year-Round & 1230 & 3.2 & 140 & 561,100 \\
\hline Winter-only & 590 & 4.3 & 140 & $206,900^{\mathrm{a}}$ \\
\hline Summer-only & 1750 & 1.8 & 139 & 766,900 \\
\hline
\end{tabular}

* over a 40 year period

${ }^{a}$ the heat extraction phase occurred for only 24.7 years 
Table 4.12: Expected Range of Heat Extraction Rates for Seasonal Waste Placement Simulations

\begin{tabular}{|c|c|c|c|c|c|c|}
\hline \multirow{2}{*}{$\begin{array}{c}\text { Waste } \\
\text { Placement }\end{array}$} & \multicolumn{2}{|c|}{$\begin{array}{c}\text { Heat Extraction } \\
\text { During 1st year } \\
\text { of Operation } \\
(\mathrm{W})\end{array}$} & \multicolumn{2}{|c|}{$\begin{array}{c}\text { Heat Extraction } \\
\text { During Year of } \\
\text { Peak Heat } \\
\text { Extraction }(W)\end{array}$} & \multicolumn{2}{|c|}{$\begin{array}{c}\text { Heat Extraction } \\
\text { During Last Year } \\
\text { of Operation } \\
(\text { W) }\end{array}$} \\
\cline { 2 - 7 } & Max & Min & Max & Min & Max & Min \\
\hline Year-Round $^{*}$ & 950 & 680 & 1230 & 940 & 290 & 20 \\
\hline Winter-only $^{\mathrm{a}}$ & 190 & 0 & 590 & 310 & 270 & 0 \\
\hline Summer-only & 1720 & 1470 & 1750 & 1490 & 340 & 70 \\
\hline
\end{tabular}

* last year is year 40

${ }^{a}$ the heat extraction phase occurred for only 24.7 years

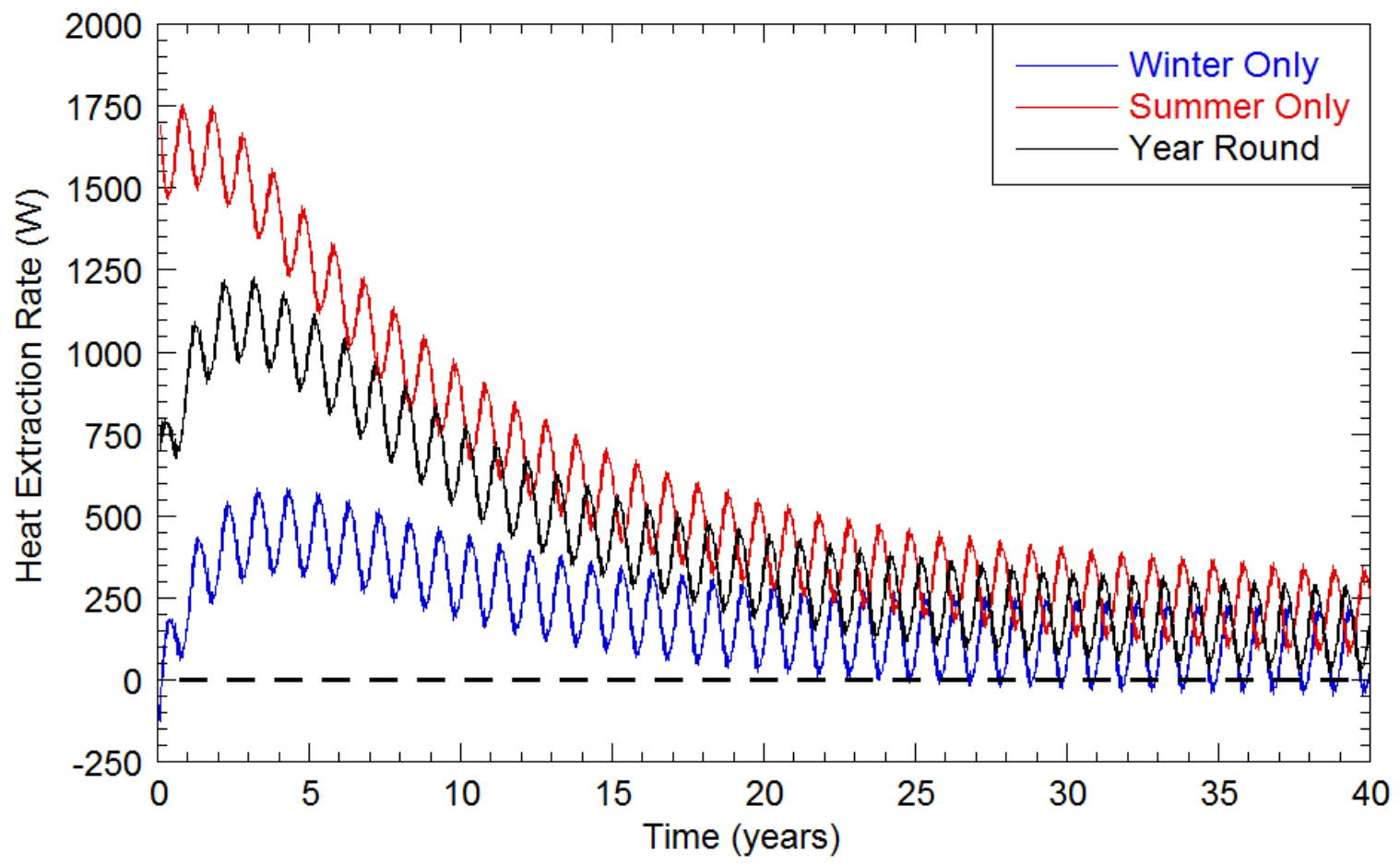

Figure 4.31: Heat Extraction Rates for Seasonal Waste Placement 


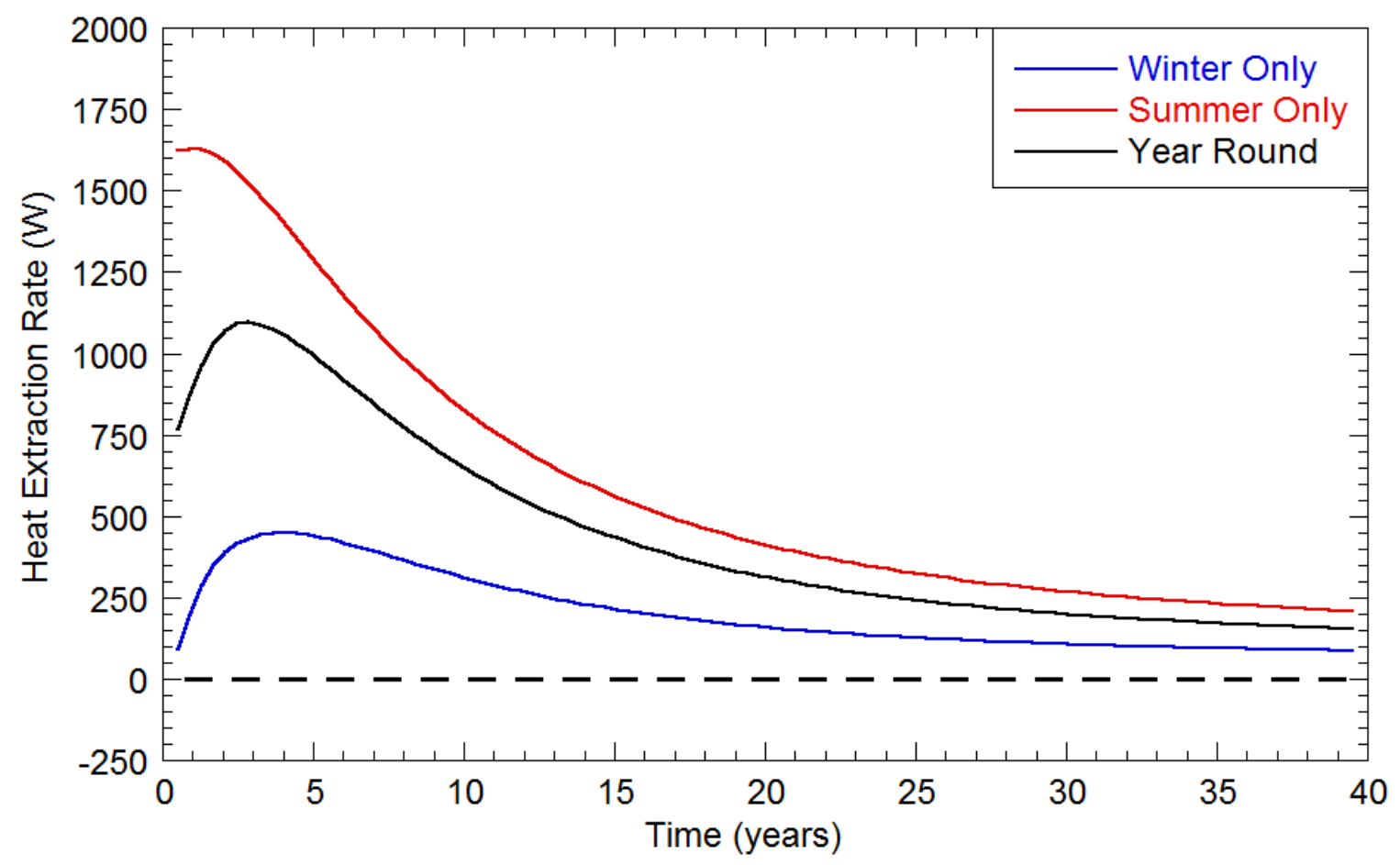

Figure 4.32: Annual Average Heat Extraction Rates for Seasonal Waste Placement

Waste placement only in winter caused temperatures in the landfill to be lower than temperatures from summer-only waste placement because the temperatures of the waste at the onset of heat generation are lower in winter than summer. The lower temperatures in the winter-only waste placement compared to the summer-only waste placement resulted in the lower temperatures $0 \mathrm{~m}$ away from the HES, lower heat extraction rates, and lower total heat energy extracted than summer-only waste placement.

\subsubsection{Waste Height Results}

Waste height simulations were conducted on the template landfill model and only the waste height was varied. Three waste heights were simulated: 15, 30 , and $45 \mathrm{~m}$. Temperature results, heat extraction results, and trends for the 
waste height simulations are discussed in this section. Peak baseline temperatures and temperature results of the waste height simulations are summarized in Tables 4.13 and 4.14, respectively.

Table 4.13: Peak Baseline Temperatures at Locations for Different Waste Heights

\begin{tabular}{|c|c|c|c|c|c|}
\hline $\begin{array}{c}\text { Waste } \\
\text { Height } \\
(\mathrm{m})\end{array}$ & $\begin{array}{c}\text { Peak } \\
\mathrm{CL} \mathrm{Temp} \\
\left({ }^{\circ} \mathrm{C}\right)\end{array}$ & $\begin{array}{c}\text { Peak } \\
\text { SD Temp } \\
\left({ }^{\circ} \mathrm{C}\right)\end{array}$ & $\begin{array}{c}\text { Peak } \\
\text { MD Temp } \\
\left({ }^{\circ} \mathrm{C}\right)\end{array}$ & $\begin{array}{c}\text { Peak } \\
\text { GD Temp } \\
\left({ }^{\circ} \mathrm{C}\right)\end{array}$ & $\begin{array}{c}\text { Peak } \\
\text { BL Temp } \\
\left({ }^{\circ} \mathrm{C}\right)\end{array}$ \\
\hline $15 \mathrm{~m}$ & 30.3 & 32.7 & 30.8 & 26.0 & 19.9 \\
\hline $30 \mathrm{~m}$ & 29.6 & 35.1 & 40.8 & 36.1 & 23.9 \\
\hline $45 \mathrm{~m}$ & 29.1 & 33.7 & 42.5 & 40.5 & 24.8 \\
\hline
\end{tabular}

Increasing waste height caused an increase in the temperatures along the length of the HES. The highest average temperatures along the HES occurred in the middle of the waste mass. Temperatures increased by approximately $0.5^{\circ} \mathrm{C}$ per $15 \mathrm{~m}$ of waste height increase at shallow, middle, and great depths.

Table 4.14: Temperature Results for Different Waste Heights 0 m away from the HES

\begin{tabular}{|c|c|c|c|c|c|c|c|}
\hline $\begin{array}{l}\text { Waste } \\
\text { Height } \\
\text { (m) }\end{array}$ & $\begin{array}{c}\text { Avg. } \\
\text { CL } \\
\text { Temp } \\
\left({ }^{\circ} \mathrm{C}\right)\end{array}$ & $\begin{array}{c}\text { Avg. } \\
\text { SD } \\
\text { Temp } \\
\left({ }^{\circ} \mathrm{C}\right)\end{array}$ & $\begin{array}{c}\text { Avg. } \\
\text { MD } \\
\text { Temp } \\
\left({ }^{\circ} \mathrm{C}\right)\end{array}$ & $\begin{array}{l}\text { Avg. } \\
\text { GD } \\
\text { Temp } \\
\left({ }^{\circ} \mathrm{C}\right)\end{array}$ & $\begin{array}{l}\text { Peak } \\
\text { BL } \\
\text { Temp } \\
\left({ }^{\circ} \mathrm{C}\right)\end{array}$ & $\begin{array}{c}\text { Maximum } \\
\text { Difference } \\
\text { Between } \\
\text { HES and } \\
\text { Baseline } \\
\left({ }^{\circ} \mathrm{C}\right)\end{array}$ & $\begin{array}{c}\text { Elapsed } \\
\text { Time to } \\
\text { Maximum } \\
\text { Temperature } \\
\text { Difference } \\
\text { (years) }\end{array}$ \\
\hline 15 & 13.5 & 120 & 13.9 & 13.9 & 10.0 & 16.9 & 1.5 \\
\hline 30 & 13.6 & 14.3 & 14.4 & 14.3 & 22.1 & 25.2 & 3.7 \\
\hline 45 & 13.8 & 14.9 & 15.1 & 14.7 & 22.7 & 26.2 & 5.0 \\
\hline
\end{tabular}

The maximum difference between temperatures $0 \mathrm{~m}$ away from HES and baseline temperatures was greatest for the $45 \mathrm{~m}$ waste height $\left(26.5^{\circ} \mathrm{C}\right)$ and 
lowest for the $15 \mathrm{~m}$ waste height $\left(16.9^{\circ} \mathrm{C}\right)$. A greater increase in the maximum difference between HES and baseline temperatures occurred between the 15 and $30 \mathrm{~m}$ waste heights than the 30 and $45 \mathrm{~m}$ waste heights. Time required to obtain the maximum difference for differing waste heights ranged from 1.5 years to 5.0 years and was longest for the $45 \mathrm{~m}$ waste height and shortest for the $15 \mathrm{~m}$ waste height.

Maximum landfill temperatures (at the time of maximum difference between HES and baseline temperatures) were determined to occur at depths of $7.5,15.5$, and $27.5 \mathrm{~m}$ for the 15,30 and $45 \mathrm{~m}$ waste heights, respectively. Peak temperatures at normalized waste depth (depth of peak landfill temperatures divided by total landfill waste mass depth) occurred at slightly higher normalized depths for increased waste heights $(0.50,0.52$, and 0.61 for the 15,30 , and $45 \mathrm{~m}$ waste heights). Temperatures did not change significantly (less than $4^{\circ} \mathrm{C}$ change) along the length of the HES. Simulated temperatures increased to within $5^{\circ} \mathrm{C}$ of baseline temperatures $2 \mathrm{~m}$ directly below the HES. Temperatures at the cover liner, shallow-depth, middle-depth, great-depth, and bottom liner locations are presented in Figure 4.33 for the $45 \mathrm{~m}$ waste height simulation. The vertical temperature profile results at the time of maximum difference between HES and baseline temperatures are presented in Figure 4.34 for the $45 \mathrm{~m}$ waste height simulation. Additional plots for all other waste height simulations are presented in Appendix A. 

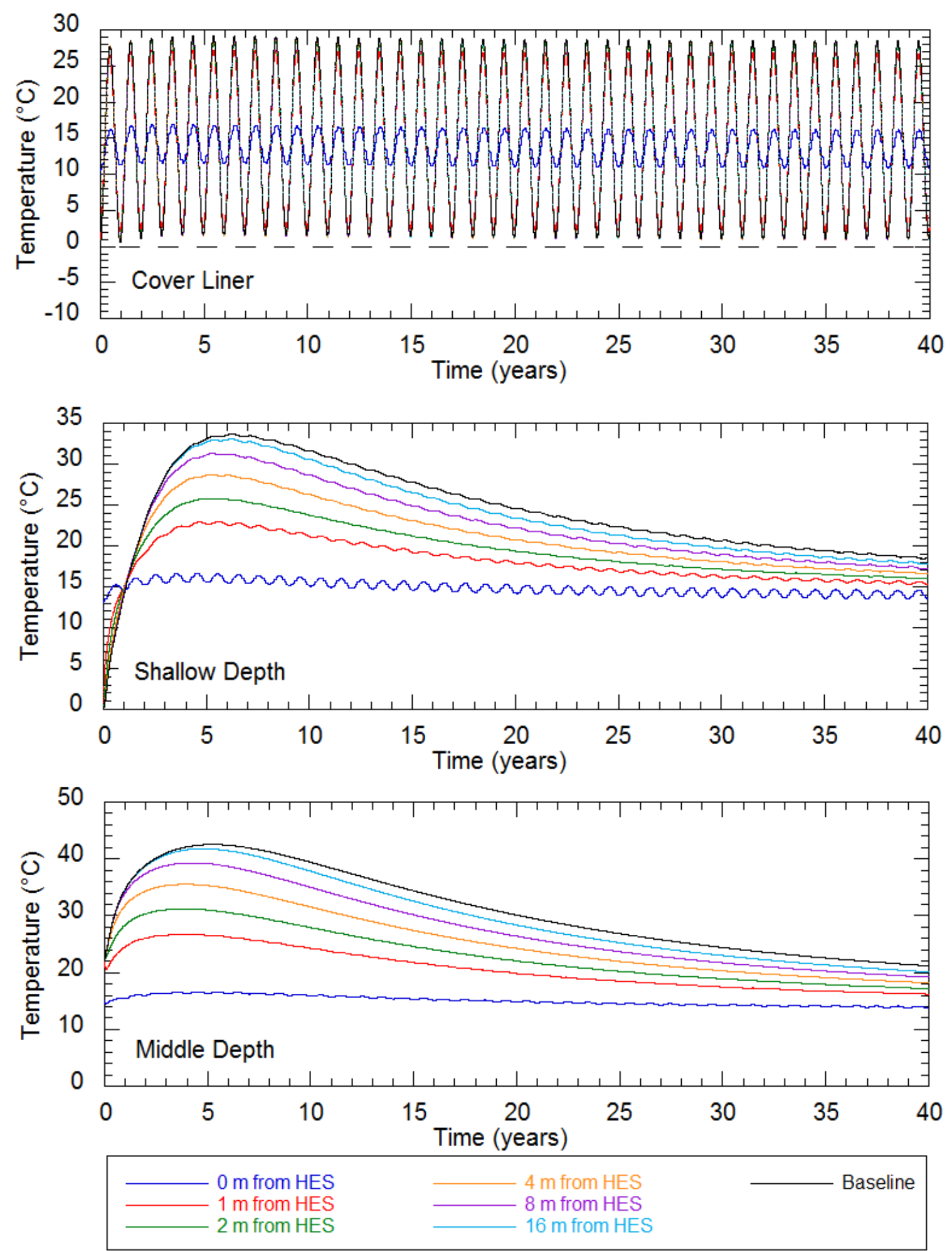

Figure 4.33a: Temperature Results: 45 m Waste Height 

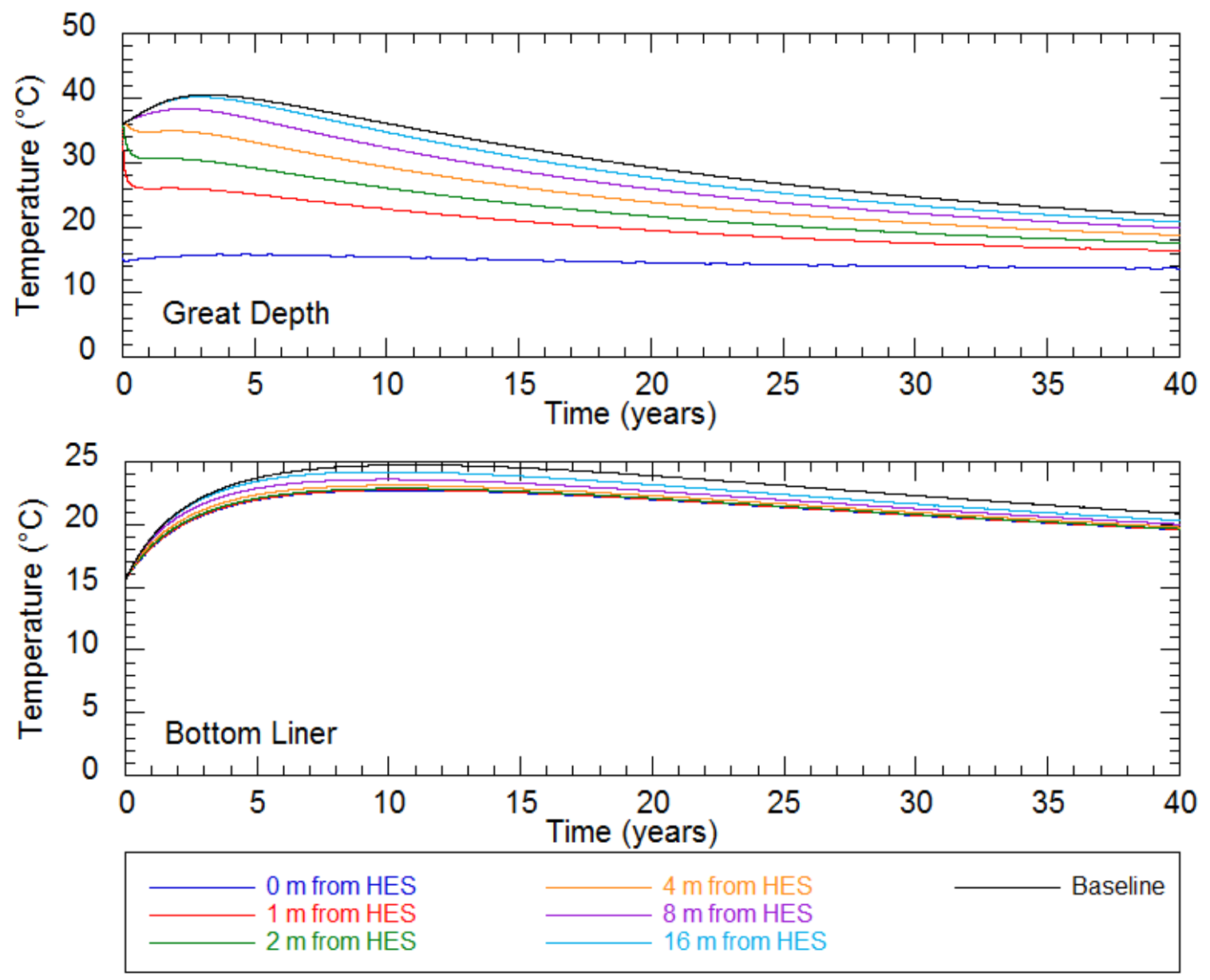

Figure 4.33b: Temperature Results: $45 \mathrm{~m}$ Waste Height

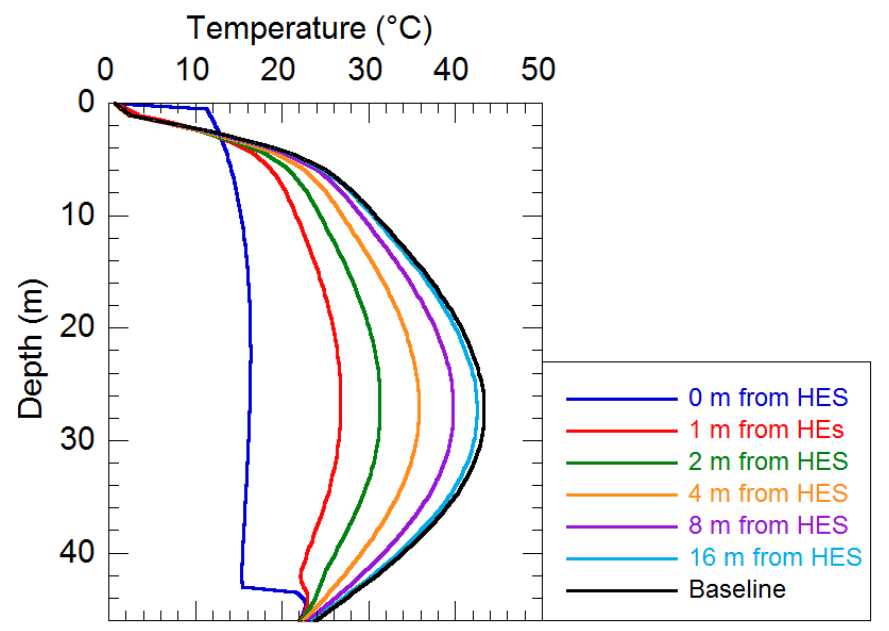

Figure 4.34: Vertical Temperature Results: 45 m Waste Height 
The heat extraction results for the waste height simulations are presented in Table 4.15. The $45 \mathrm{~m}$ waste height simulation had maximum heat extraction rates and total heat energy extracted. The $15 \mathrm{~m}$ waste height simulation had the minimum heat extraction rate and total heat energy extracted. The range in expected heat extraction rates for the waste height simulations are presented in Table 4.16. Maximum total heat energy extracted was determined to be $1,181,400 \mathrm{MJ}$ over a 40 year period for the $45 \mathrm{~m}$ waste height. Minimum total heat energy extracted was determined to be $67,400 \mathrm{MJ}$ after a 10.5 year period for the $15 \mathrm{~m}$ waste height. The heat extraction phase for the $15 \mathrm{~m}$ waste height simulation lasted for only 10.5 years and therefore, the total heat energy was calculated only for the heat extraction phase. The peak heat extraction rate occurred 1.0 to 4.4 years after start of HES operation. The average seasonal heat extraction rate amplitude ranged from 132 to $157 \mathrm{~W}$. The heat extraction rates and annual average heat extraction rates for the variable waste heights are presented in Figures 4.35 and 4.36, respectively.

Table 4.15: Waste Height Heat Extraction Results

\begin{tabular}{|c|c|c|c|c|}
\hline $\begin{array}{c}\text { Waste Height } \\
(\mathrm{m})\end{array}$ & $\begin{array}{c}\text { Peak Heat } \\
\text { Extraction } \\
\text { Rate }(\mathrm{W})\end{array}$ & $\begin{array}{c}\text { Time To } \\
\text { Peak (years) }\end{array}$ & $\begin{array}{c}\text { Average } \\
\text { Seasonal } \\
\text { Amplitude }(\mathrm{W})\end{array}$ & $\begin{array}{c}\text { Total Heat } \\
\text { Extracted } \\
(\mathrm{MJ})\end{array}$ \\
\hline 15 & 440 & 1.0 & 89 & $67,400^{\mathrm{a}}$ \\
\hline 30 & 1230 & 3.2 & 140 & 561,100 \\
\hline 45 & 1720 & 4.4 & 98 & $1,181,400$ \\
\hline
\end{tabular}

* in a 40 year period

${ }^{a}$ the heat extraction phase occurred for only 10.5 years 
Table 4.16: Expected Range of Heat Extraction Rates for Waste Height Simulations

\begin{tabular}{|c|c|c|c|c|c|c|}
\hline \multirow{2}{*}{$\begin{array}{c}\text { Waste Height } \\
(\mathrm{m})\end{array}$} & \multicolumn{2}{|c|}{$\begin{array}{c}\text { Heat Extraction } \\
\text { During 1st year } \\
\text { of Operation } \\
(\mathrm{W})\end{array}$} & \multicolumn{2}{|c|}{$\begin{array}{c}\text { Heat Extraction } \\
\text { During Year of } \\
\text { Peak Heat } \\
\text { Extraction }(\mathrm{W})\end{array}$} & \multicolumn{2}{|c|}{$\begin{array}{c}\text { Heat Extraction } \\
\text { During Last Year } \\
\text { of Operation } \\
(\mathrm{W})\end{array}$} \\
\cline { 2 - 7 } & Max & Min & Max & Min & Max & Min \\
\hline $15^{\mathrm{a}}$ & 440 & 250 & $440^{\mathrm{b}}$ & $250^{\mathrm{b}}$ & 170 & 0 \\
\hline $30^{*}$ & 950 & 680 & 1230 & 940 & 290 & 20 \\
\hline $45^{\star}$ & 1140 & 780 & 1720 & 1540 & 530 & 360 \\
\hline
\end{tabular}

* last year is year 40

a last year is year 10

${ }^{b}$ peak heat extraction occurred in 1 st year

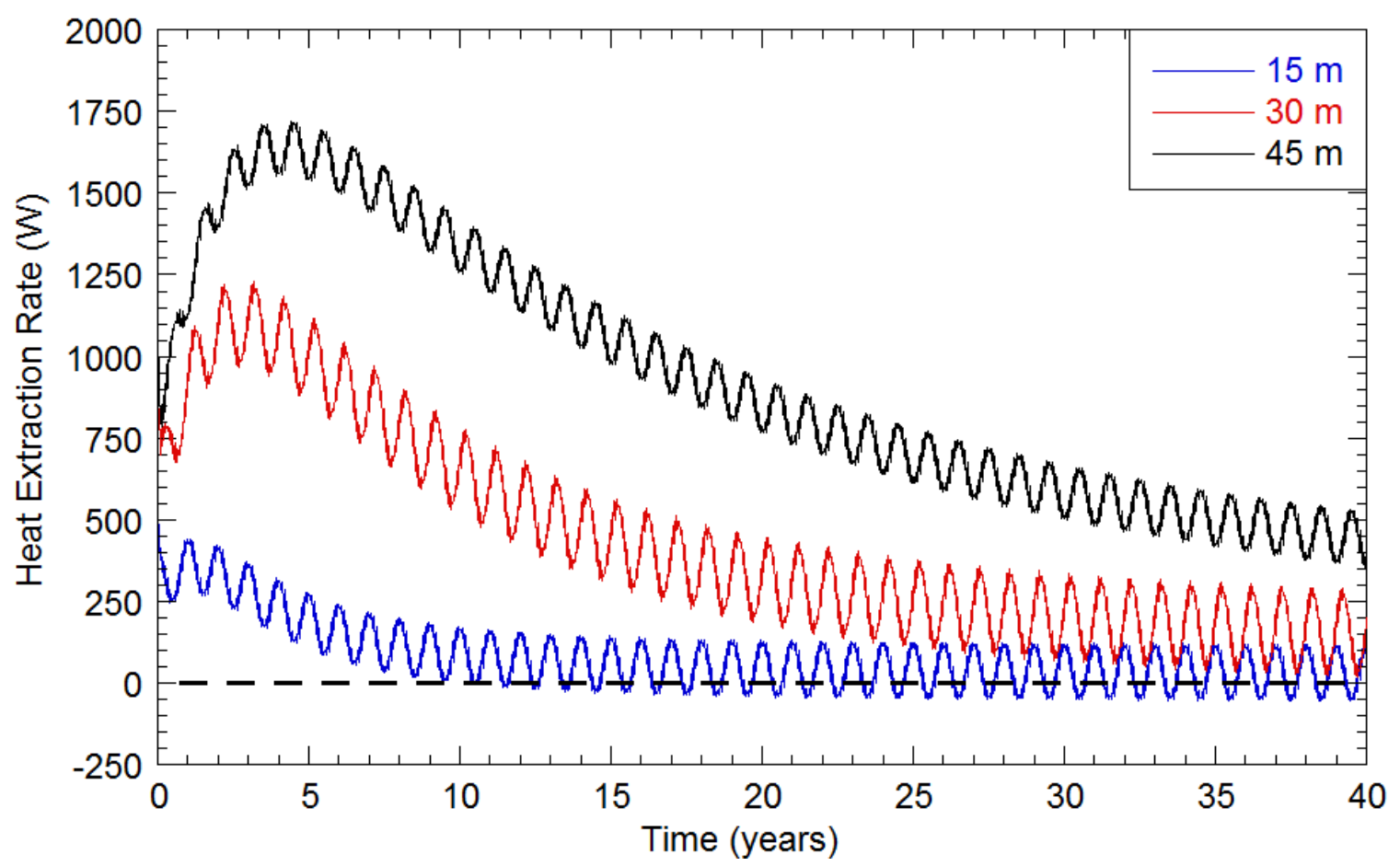

Figure 4.35: Heat Extraction Rates for Different Waste Heights 


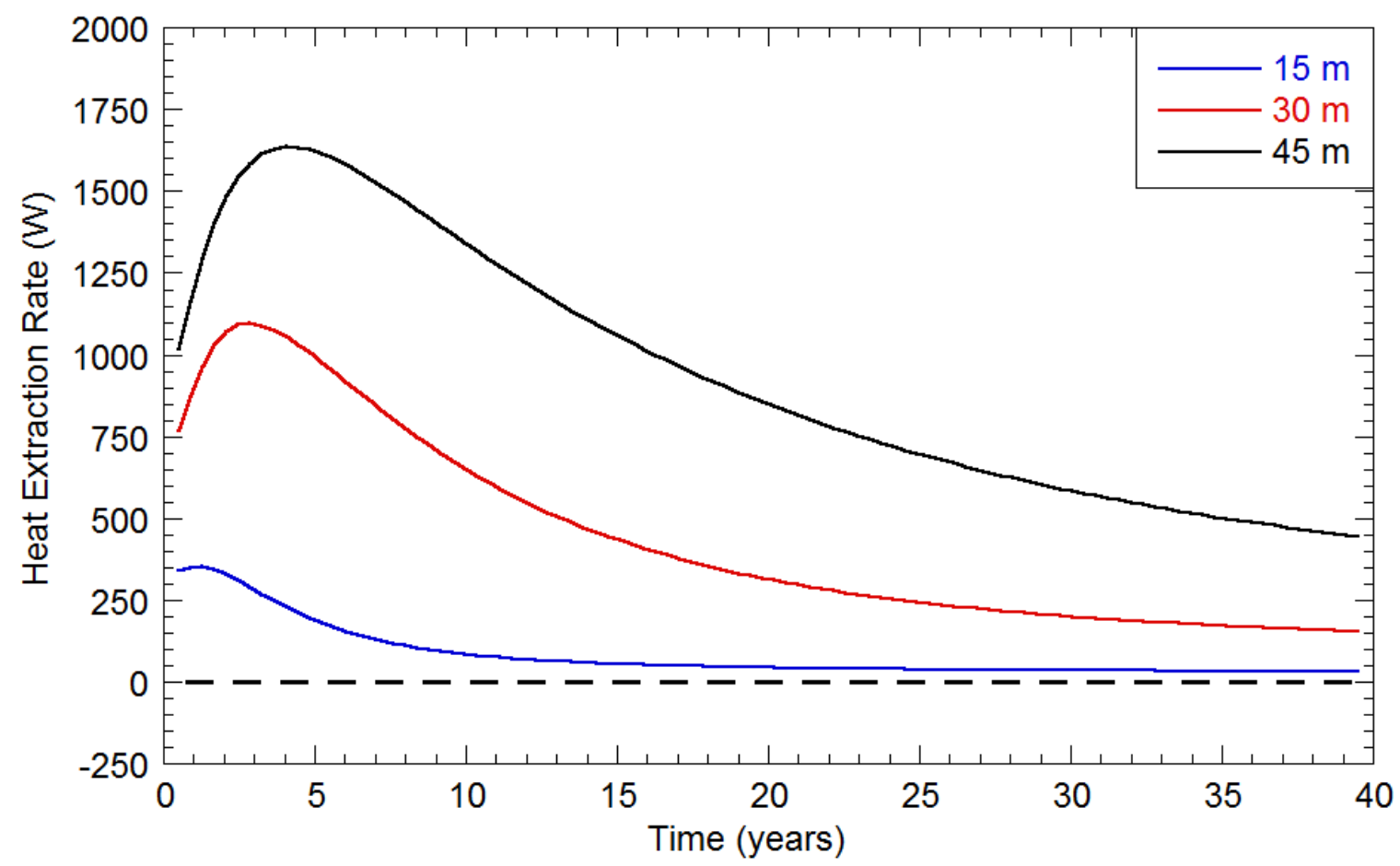

Figure 4.36: Annual Average Heat Extraction Rates for Different Waste Heights

Baseline temperatures increased as waste height increased (Table 4.13). Increased waste height caused an increase in the heat extraction rates and the amount of heat energy extracted. Peak heat extraction rates increased linearly with increasing waste weight (Figure 4.37). The peak heat extraction rate was determined to increase with waste height by $43 \mathrm{~W} / \mathrm{m}$.

The peak heat extraction rate per $1 \mathrm{~m}$ section of HES was calculated to determine the effect of the HES over a normalized depth. The depths of the HES were $13,28,43 \mathrm{~m}$ for the $15,30,45 \mathrm{~m}$ waste heights, respectively. The $30 \mathrm{~m}$ waste height was the most efficient waste height in extracting heat and the $15 \mathrm{~m}$ waste height was the least efficient waste height. The $15 \mathrm{~m}$ simulation waste height was more impacted by seasonal temperature fluctuations than the 30 or $45 \mathrm{~m}$ waste height simulations. The normalized analysis of the effects of waste 
height on peak heat extraction rate yielded a peak heat extraction rate per $1 \mathrm{~m}$ depth of HES of $33.8,43.9$, and $40.0 \mathrm{~W} / \mathrm{m}$ for the $15,30,45 \mathrm{~m}$ waste heights, respectively (Figure 4.38).

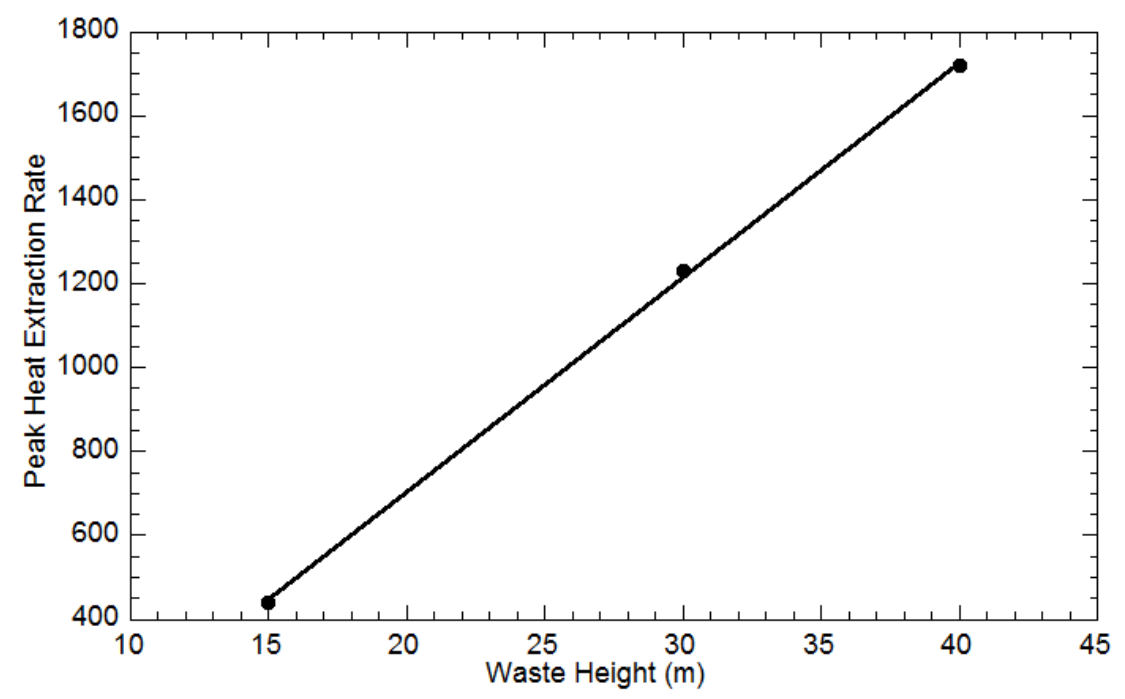

Figure 4.37: Effect of Waste Height on Peak Heat Extraction Rate

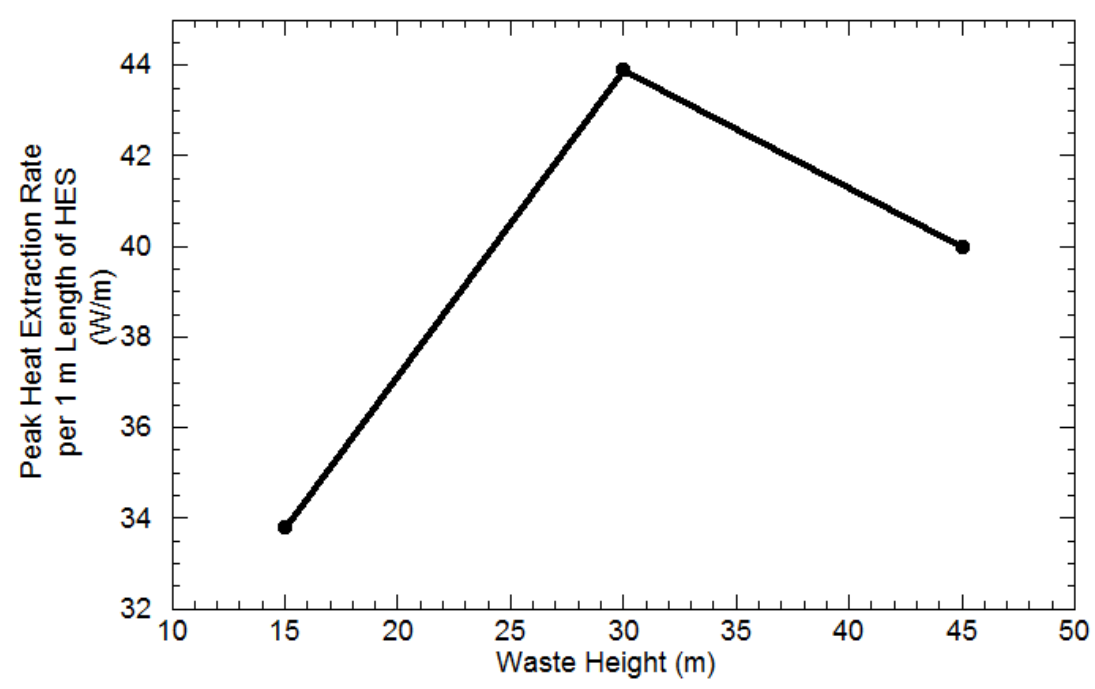

Figure 4.38: Peak Heat Extraction Rate for $1 \mathrm{~m}$ Length of HES 


\subsubsection{Waste Filling Rate Results}

Waste filling rate simulations were conducted on the template landfill model and only the waste filling rate was varied. Three filling rates were simulated to represent various scales of operation: $5 \mathrm{~m} / \mathrm{year}, 12 \mathrm{~m} / \mathrm{year}$, and 20 $\mathrm{m} /$ year. Filling times were varied based on the filling rate, such that all waste filling rate simulations had the same total waste height of $30 \mathrm{~m}$. Temperature results, heat extraction results, and trends for the waste filling rate simulations are discussed in this section. Peak baseline temperatures and temperature results of the waste filling rate simulations are summarized in Tables 4.17 and 4.18, respectively.

Table 4.17: Peak Baseline Temperatures at Locations for Different Waste Filling Rates

\begin{tabular}{|c|c|c|c|c|c|}
\hline $\begin{array}{c}\text { Waste Filling } \\
\text { Rate } \\
(\mathrm{m} / \text { year })\end{array}$ & $\begin{array}{c}\text { Peak } \\
\text { CL Temp } \\
\left({ }^{\circ} \mathrm{C}\right)\end{array}$ & $\begin{array}{c}\text { Peak } \\
\text { SD Temp } \\
\left({ }^{\circ} \mathrm{C}\right)\end{array}$ & $\begin{array}{c}\text { Peak } \\
\text { MD Temp } \\
\left({ }^{\circ} \mathrm{C}\right)\end{array}$ & $\begin{array}{c}\text { Peak } \\
\text { GD Temp } \\
\left({ }^{\circ} \mathrm{C}\right)\end{array}$ & $\begin{array}{c}\text { Peak } \\
\text { BL Temp } \\
\left({ }^{\circ} \mathrm{C}\right)\end{array}$ \\
\hline 5 & 30.3 & 35.9 & 36.4 & 30.4 & 22.1 \\
\hline 12 & 29.8 & 36.3 & 40.5 & 34.8 & 23.6 \\
\hline 20 & 29.6 & 35.1 & 40.8 & 36.1 & 23.9 \\
\hline
\end{tabular}

Table 4.18: Temperature Results for Different Waste Filling Rates $0 \mathrm{~m}$ away from the HES

\begin{tabular}{|c|c|c|c|c|c|c|c|}
\hline $\begin{array}{l}\text { Waste } \\
\text { Filling } \\
\text { Rate } \\
\text { (m/year) }\end{array}$ & $\begin{array}{c}\text { Avg. } \\
\text { CL } \\
\text { Temp } \\
\left({ }^{\circ} \mathrm{C}\right)\end{array}$ & $\begin{array}{l}\text { Avg. } \\
\text { SD } \\
\text { Temp } \\
\left({ }^{\circ} \mathrm{C}\right)\end{array}$ & $\begin{array}{c}\text { Avg. } \\
\text { MD } \\
\text { Temp } \\
\left({ }^{\circ} \mathrm{C}\right)\end{array}$ & $\begin{array}{c}\text { Avg. } \\
\text { GD } \\
\text { Temp } \\
\left({ }^{\circ} \mathrm{C}\right)\end{array}$ & $\begin{array}{c}\text { Peak } \\
\text { BL } \\
\text { Temp } \\
\left({ }^{\circ} \mathrm{C}\right)\end{array}$ & $\begin{array}{c}\text { Maximum } \\
\text { Difference } \\
\text { Between } \\
\text { HES and } \\
\text { Baseline } \\
\left({ }^{\circ} \mathrm{C}\right)\end{array}$ & $\begin{array}{l}\text { Elapsed } \\
\text { Time to } \\
\text { Maximum } \\
\text { Temperature } \\
\text { Difference } \\
\text { (years) }\end{array}$ \\
\hline 5 & 13.6 & 14.2 & 14.3 & 14.1 & 20.7 & 21.2 & 2.5 \\
\hline 12 & 13.6 & 14.3 & 14.4 & 14.3 & 21.9 & 24.8 & 3.0 \\
\hline 20 & 13.6 & 14.3 & 14.4 & 14.3 & 22.1 & 25.2 & 3.7 \\
\hline
\end{tabular}


The waste filling rates did not significantly impact the difference in temperatures $0 \mathrm{~m}$ away from HES at the same depths. A greater difference in temperatures $0 \mathrm{~m}$ from the HES was observed between the 5 and $12 \mathrm{~m} /$ year waste filling rate simulations than between the 12 and $20 \mathrm{~m} /$ year waste filling rate simulations. The highest average temperature along the length of the HES occurred in the middle of the waste mass.

Increasing the waste filling rate caused an increase in the maximum difference between the baseline landfill temperatures and temperatures $0 \mathrm{~m}$ away from HES with the maximum temperature difference ranging from 21.2 to $25.2^{\circ} \mathrm{C}$ for the 5 and $20 \mathrm{~m} /$ year waste filling rates, respectively. A greater increase in maximum difference between HES temperatures and baseline landfill temperatures occurred between the 5 and $12 \mathrm{~m} /$ year filling rate than between the 12 and $20 \mathrm{~m} /$ year filling rate. Time required to reach the maximum difference for varying waste heights was longest for the $20 \mathrm{~m} /$ year waste filling rate (3.7 years) and shortest for the $5 \mathrm{~m} /$ year waste filling rate (2.5 years).

Maximum landfill temperatures (at the time of maximum difference between HES and baseline temperatures) were determined to occur at depths of 13,15 , and $15.5 \mathrm{~m}$ for the 5,12 , and $20 \mathrm{~m} /$ year waste filling rates, respectively. Temperatures did not significantly change significantly (less than $5^{\circ} \mathrm{C}$ change in temperature) along the length of the HES. Simulated temperatures increased to within $5^{\circ} \mathrm{C}$ of baseline temperatures $2 \mathrm{~m}$ directly below the HES. Temperatures at the cover liner, shallow-depth, middle-depth, great-depth, and bottom liner locations are presented in Figure 4.39 for the $5 \mathrm{~m} /$ year waste filling rate. The 
vertical temperature profile results at the time of maximum difference between HES and baseline temperatures are presented in Figure 4.40 for the $5 \mathrm{~m} / \mathrm{year}$ waste filling rate. Additional plots for all other waste filling simulations are presented in Appendix A. 

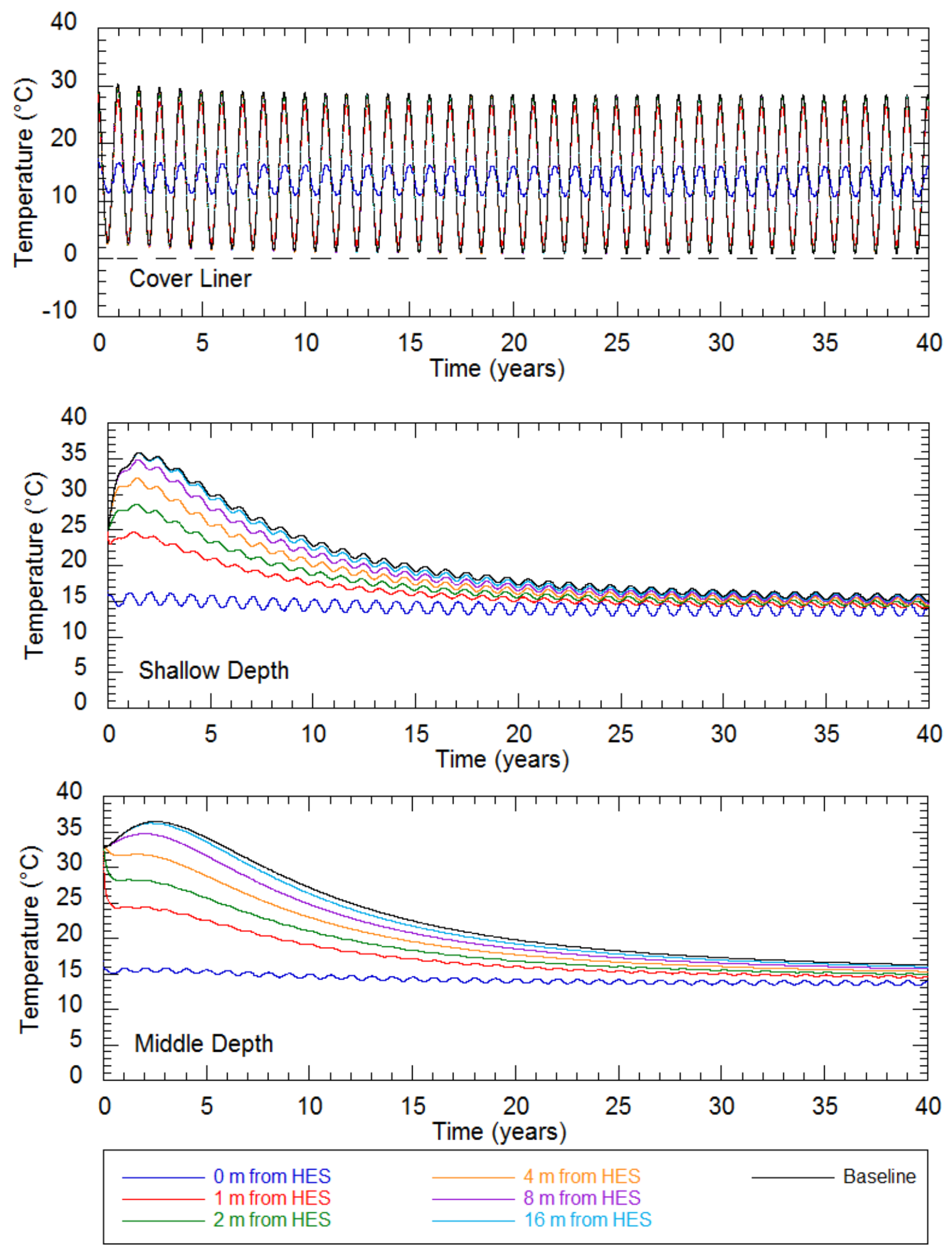

Figure 4.39a: Temperature Results: 5 m/year Waste Filling Rate 

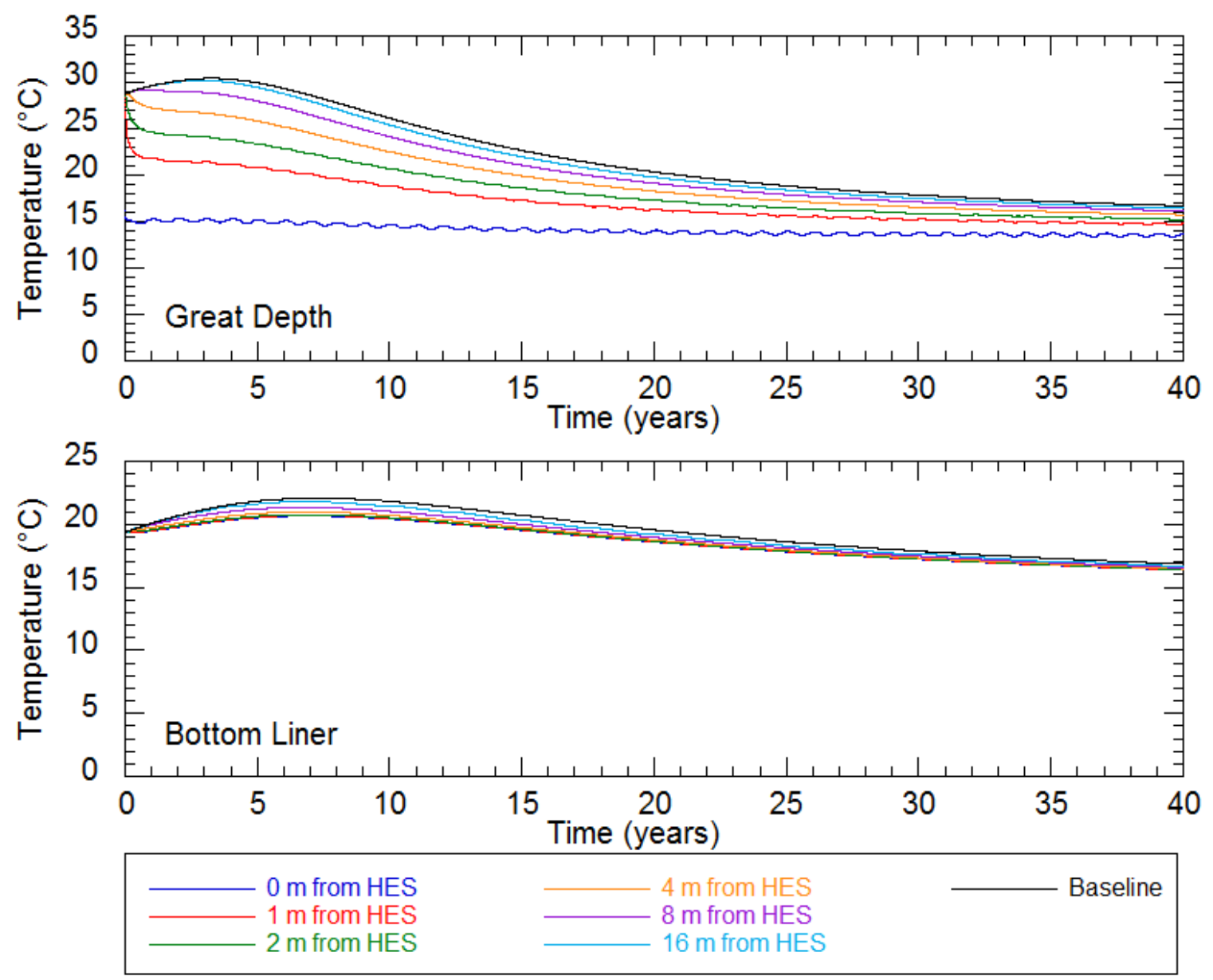

Figure 4.39b: Temperature Results: 5 m/year Waste Filling Rate

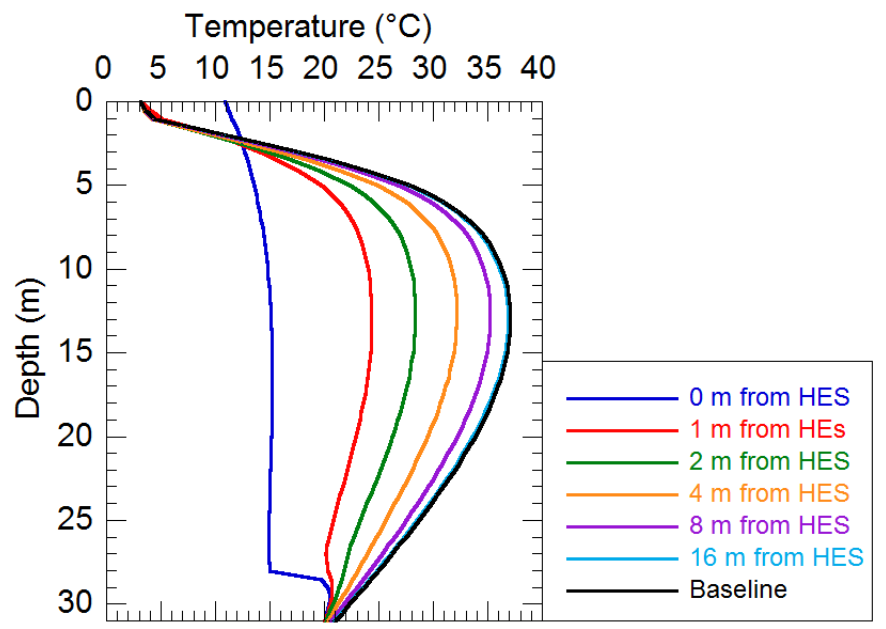

Figure 4.40: Vertical Temperature Results: 5 m/year Waste Filling Rate 
The heat extraction results for the waste filling rate simulations are presented in Table 4.19. The $20 \mathrm{~m} /$ year waste filling rate simulation had maximum heat extraction rates and total heat energy extracted. The $5 \mathrm{~m} / \mathrm{year}$ waste filling rate simulation had minimum heat extraction rates and total heat energy extracted. The range in expected heat extraction rates for the waste filling rate simulations are presented in Table 4.20. Maximum total heat energy extracted was determined to be $561,100 \mathrm{MJ}$ over a 40 year period and the minimum total heat energy extracted was determined to be $475,000 \mathrm{MJ}$ over a 40 year period. The peak heat extraction rate occurred 0.2 to 3.2 years after onset of HES operation. The average seasonal amplitude ranged from $140 \mathrm{~W}$ to 143 W. The heat extraction rates and annual average heat extraction rates for the variable waste filling rates are presented in Figures 4.41 and 4.42 , respectively.

Table 4.19: Waste Filling Rate Heat Extraction Results

\begin{tabular}{|c|c|c|c|c|}
\hline $\begin{array}{c}\text { Waste filling } \\
\text { Rate } \\
\text { (m/year) }\end{array}$ & $\begin{array}{c}\text { Peak Heat } \\
\text { Extraction } \\
\text { Rate }(\mathrm{W})\end{array}$ & $\begin{array}{c}\text { Time To } \\
\text { Peak (years) }\end{array}$ & $\begin{array}{c}\text { Average } \\
\text { Seasonal } \\
\text { Amplitude }(\mathrm{W})\end{array}$ & $\begin{array}{c}\text { Total Heat } \\
\text { Extracted }^{*} \\
(\mathrm{MJ})\end{array}$ \\
\hline 5 & 1210 & 0.2 & 143 & 475,000 \\
\hline 12 & 1230 & 2.4 & 141 & 551,900 \\
\hline 20 & 1230 & 3.2 & 140 & 561,100 \\
\hline
\end{tabular}

\footnotetext{
* over a 40 year period
} 
Table 4.20: Expected Range of Heat Extraction Rates for Waste Filling Rate Simulations

\begin{tabular}{|c|c|c|c|c|c|c|}
\hline $\begin{array}{c}\text { Waste filling } \\
\text { Rate } \\
\text { (m/year) }\end{array}$ & $\begin{array}{c}\text { Heat Extraction } \\
\text { During 1st year } \\
\text { of Operation } \\
(\mathrm{W})\end{array}$ & \multicolumn{2}{|c|}{$\begin{array}{c}\text { Heat Extraction } \\
\text { During Year of } \\
\text { Peak Heat } \\
\text { Extraction }(\mathrm{W})\end{array}$} & \multicolumn{2}{|c|}{$\begin{array}{c}\text { Heat Extraction } \\
\text { During Last Year } \\
\text { of Operation } \\
\text { (W) }\end{array}$} \\
\cline { 2 - 7 } & Max & Min & Max & Min & Max & Min \\
\hline 5 & 1210 & 930 & $1210^{\text {a }}$ & $930^{\text {a }}$ & 270 & 0 \\
\hline 12 & 950 & 710 & 1230 & 960 & 290 & 20 \\
\hline 20 & 950 & 680 & 1230 & 940 & 290 & 20 \\
\hline
\end{tabular}

* last year is year 40

a peak heat extraction occurred in 1 st year

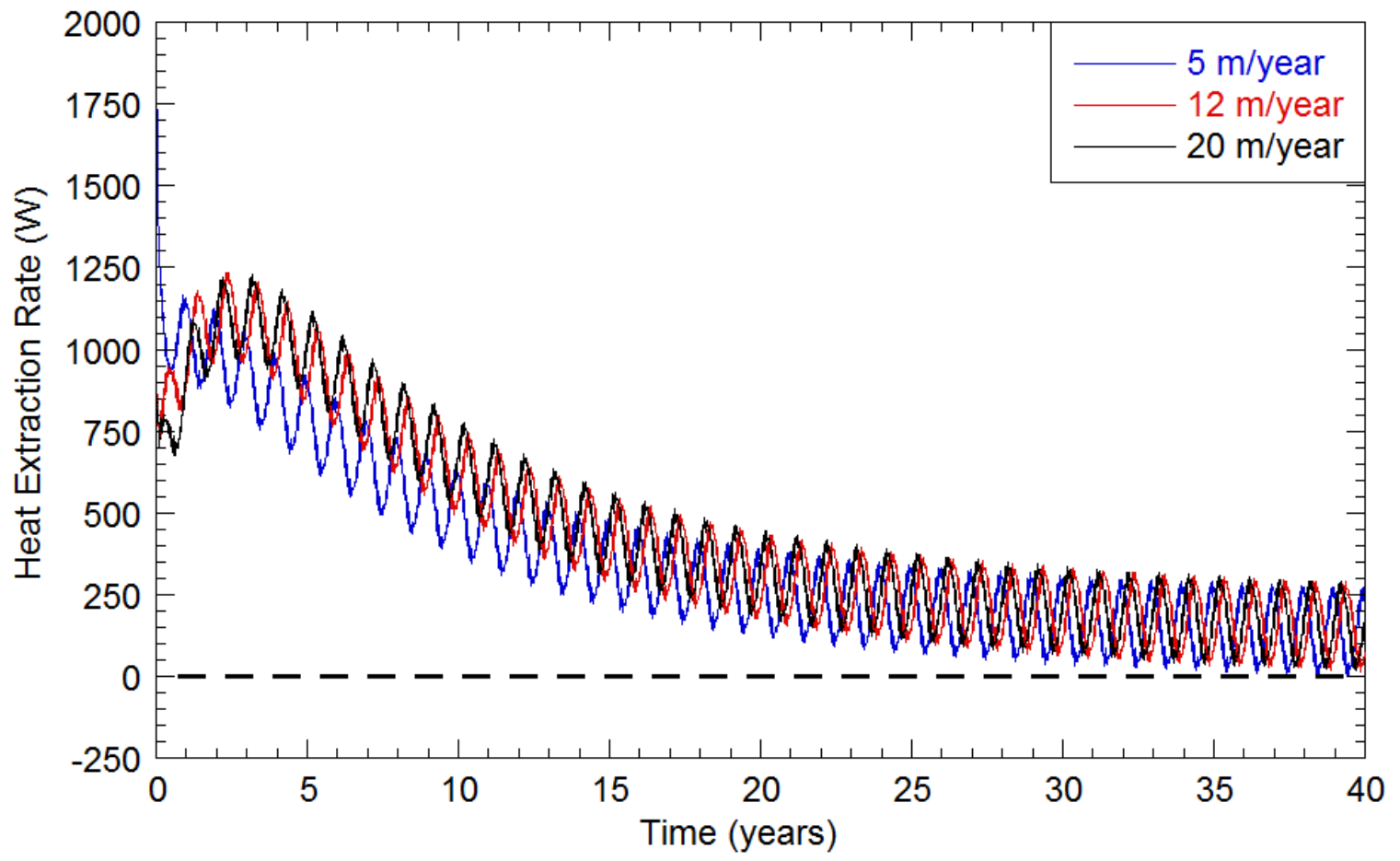

Figure 4.41: Heat Extraction Rates for Different Waste Filling Rates 


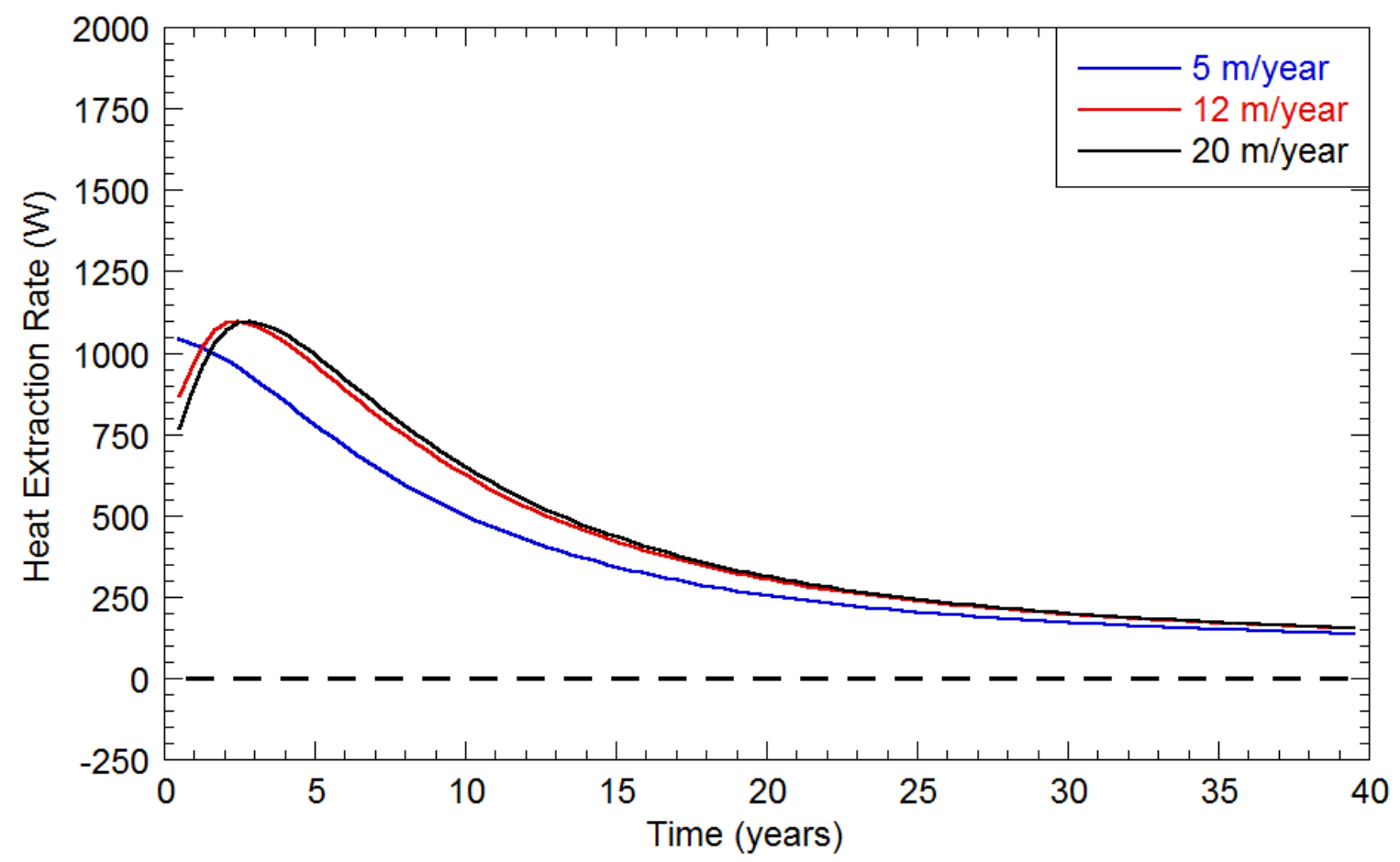

Figure 4.42: Annual Average Heat Extraction Rates for Different Waste Filling Rates

The waste filling rate affected the baseline temperatures within the landfill. Low waste filling rates $(5 \mathrm{~m} / \mathrm{year})$ yielded lower temperatures in the landfill because the heat generation from the entire $30 \mathrm{~m}$ waste height was extended over a longer time period during filling. Lower baseline temperatures yielded a lower maximum difference in baseline temperatures and temperatures $0 \mathrm{~m}$ away from HES and also total heat energy extracted compared to higher baseline temperatures. Increasing the waste filling rate caused an increase in the total heat energy extracted. The difference between the 5 and $12 \mathrm{~m} / \mathrm{year}$ filling rate was greater than the difference in total heat energy extracted between the 12 and $20 \mathrm{~m} /$ year filling rate (Figure 4.43). 


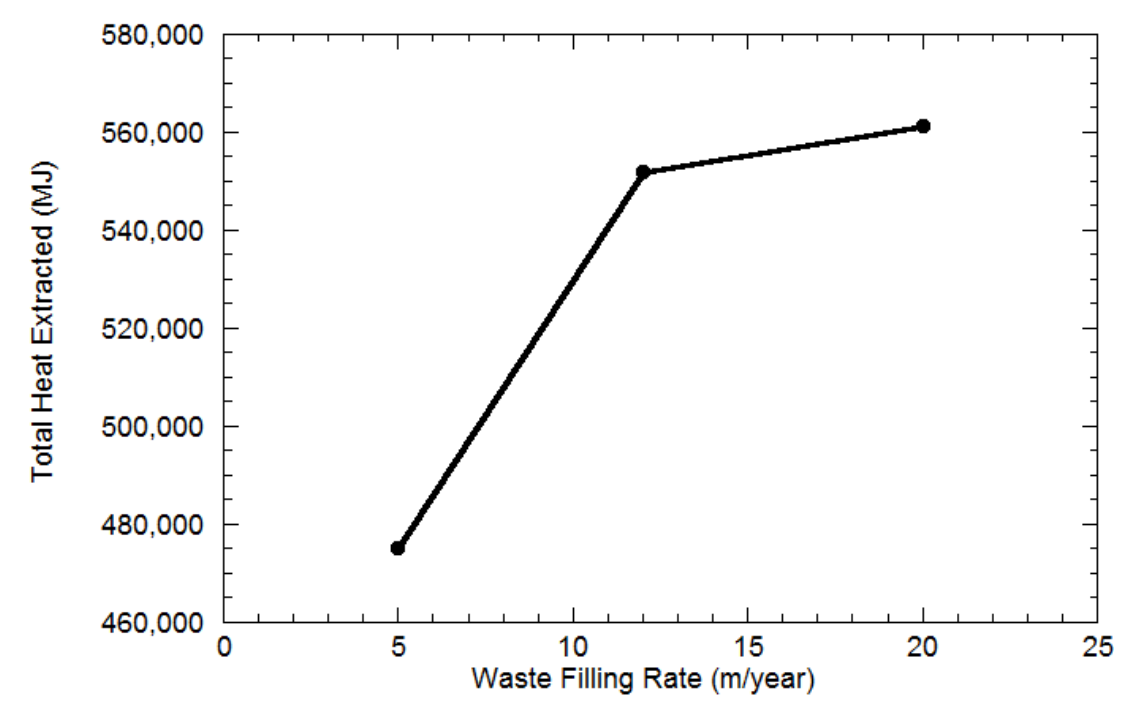

Figure 4.43: Effect of Waste Filling Rate on Total Heat Energy Extracted

\subsubsection{Vertical Landfill Expansion Results}

Vertical landfill expansion simulations were conducted on the template landfill model and only time between the original waste placement and the vertical landfill expansion was varied. Intermediate cover with a thickness of $1 \mathrm{~m}$ was placed between the two waste sections. Two vertical landfill expansions were simulated representing two different timelines: 5 and 15 years between original placement and vertical landfill expansion (Figure 4.44). The vertical landfill expansion simulations were compared to a landfill without a vertical landfill expansion. Temperature results, heat extraction results, and trends for the vertical landfill expansion simulations are discussed in this section. Peak baseline temperatures and temperature results of the vertical landfill expansion simulations are summarized in Tables 4.21 and 4.22, respectively. 


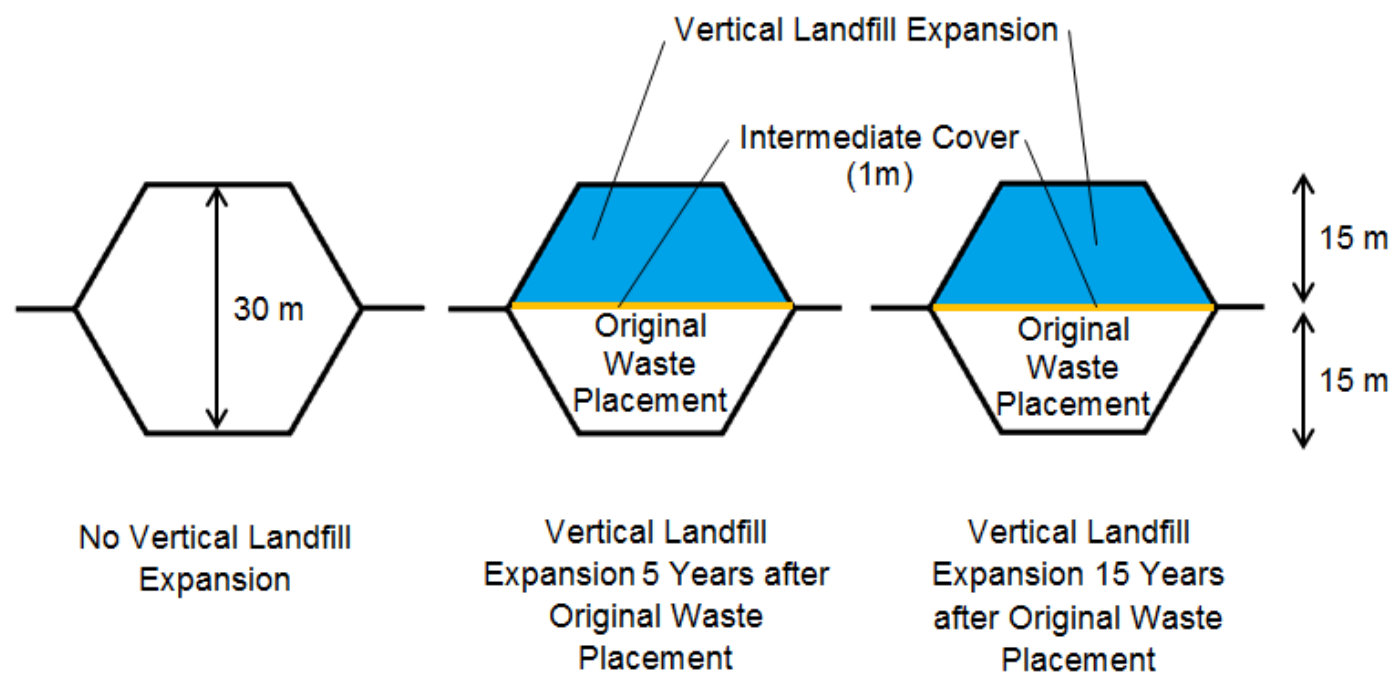

Figure 4.44: Schematic of Vertical Landfill Extraction Simulations

Temperatures along the length of the HES decreased as the time between the original waste placement and the vertical landfill expansion increased. The highest average temperature along the length of the HES occurred in the middle of the waste mass that was placed over the intermediate cover (shallow depth of the entire landfill). Longer time periods between the original waste placement and the vertical landfill expansion lead to lower temperatures in the original waste mass. Simulations with lower temperatures in the original waste mass yielded decreased temperatures in the upper waste mass. 
Table 4.21: Peak Baseline Temperatures at Locations for Different Vertical Landfill Expansions

\begin{tabular}{|c|c|c|c|c|c|}
\hline $\begin{array}{c}\text { Time Between } \\
\begin{array}{c}\text { Vertical Landfill } \\
\text { Expansions } \\
\text { (years) }\end{array}\end{array}$ & $\begin{array}{c}\text { Peak } \\
\mathrm{CL} \mathrm{Temp} \\
\left({ }^{\circ} \mathrm{C}\right)\end{array}$ & $\begin{array}{c}\text { Peak } \\
\text { SD Temp } \\
\left({ }^{\circ} \mathrm{C}\right)\end{array}$ & $\begin{array}{c}\text { Peak } \\
\text { MD Temp } \\
\left({ }^{\circ} \mathrm{C}\right)\end{array}$ & $\begin{array}{c}\text { Peak } \\
\text { GD Temp } \\
\left({ }^{\circ} \mathrm{C}\right)\end{array}$ & $\begin{array}{c}\text { Peak } \\
\text { BL Temp } \\
\left({ }^{\circ} \mathrm{C}\right)\end{array}$ \\
\hline NA & 29.6 & 35.1 & 40.8 & 36.1 & 23.9 \\
\hline 5 & 29.5 & 31.7 & 31.6 & 26.3 & 20.2 \\
\hline 15 & 29.4 & 29.6 & 27.4 & 22.1 & 18.0 \\
\hline
\end{tabular}

Table 4.22: Temperature Results for Different Timing of Vertical Landfill Expansions $0 \mathrm{~m}$ away from the HES

\begin{tabular}{|c|c|c|c|c|c|c|c|}
\hline $\begin{array}{c}\text { Time } \\
\text { Between } \\
\text { Vertical } \\
\text { Landfill } \\
\text { Expansions } \\
\text { (years) }\end{array}$ & $\begin{array}{c}\text { Avg. } \\
\text { CL } \\
\text { Temp } \\
\left({ }^{\circ} \mathrm{C}\right)\end{array}$ & $\begin{array}{c}\text { Avg. } \\
\text { SD } \\
\text { Temp } \\
\left({ }^{\circ} \mathrm{C}\right)\end{array}$ & $\begin{array}{c}\text { Avg. } \\
\text { MD } \\
\text { Temp } \\
\left({ }^{\circ} \mathrm{C}\right)\end{array}$ & $\begin{array}{l}\text { Avg. } \\
\text { GD } \\
\text { Temp } \\
\left({ }^{\circ} \mathrm{C}\right)\end{array}$ & $\begin{array}{c}\text { Peak } \\
\text { BL } \\
\text { Temp } \\
\left({ }^{\circ} \mathrm{C}\right)\end{array}$ & $\begin{array}{c}\text { Maximum } \\
\text { Difference } \\
\text { Between } \\
\text { HES and } \\
\text { Baseline } \\
\left({ }^{\circ} \mathrm{C}\right)\end{array}$ & $\begin{array}{l}\text { Elapsed } \\
\text { Time to } \\
\text { Maximum } \\
\text { Temperature } \\
\text { Difference } \\
\text { (years) }\end{array}$ \\
\hline NA & 13.6 & 14.3 & 14.4 & 14.3 & 22.1 & 25.2 & 3.7 \\
\hline 5 & 13.6 & 14.1 & 14.2 & 14.0 & 19.0 & 16.6 & 3.9 \\
\hline 15 & 135 & 14.0 & 14.0 & 13.8 & 17.2 & 12.7 & 3.9 \\
\hline
\end{tabular}

Increasing the time between the original waste placement and the vertical landfill expansion decreased the maximum difference between the baseline landfill temperatures and temperatures $0 \mathrm{~m}$ away from the HES. The maximum difference between the baseline landfill temperatures and temperatures $0 \mathrm{~m}$ away from the HES was greatest for the simulation without a vertical landfill expansion $\left(25.2^{\circ} \mathrm{C}\right)$ and smallest for the simulation with a 15 years between the original waste placement and the vertical landfill expansion $\left(12.7^{\circ} \mathrm{C}\right)$. The time required to obtain the maximum difference in baseline temperatures and temperatures $0 \mathrm{~m}$ away from the HES for differing vertical landfill expansions ranged from 3.7 to 3.9 years. 
Maximum landfill temperatures (at the time of maximum difference between HES and baseline temperatures) were determined to occur at depths of $15.5,12.5$, and $11.5 \mathrm{~m}$ for landfill with no vertical expansion, 5 years between the original waste placement and the vertical landfill expansion, and 15 years between the original waste placement and the vertical landfill expansion, respectively. Simulated temperatures increased to within $5^{\circ} \mathrm{C}$ of baseline temperatures $2 \mathrm{~m}$ directly below the HES. Temperatures at the cover liner, shallow-depth, middle-depth, great-depth, and bottom liner locations are presented in Figure 4.45 for the vertical landfill expansion 5 years after the original waste placement. The vertical temperature profile results at the time of maximum difference between HES and baseline temperatures are presented in Figure 4.46 for the vertical landfill expansion 5 years after the original waste placement. Additional plots for all other vertical landfill expansion simulations are presented in Appendix A. 

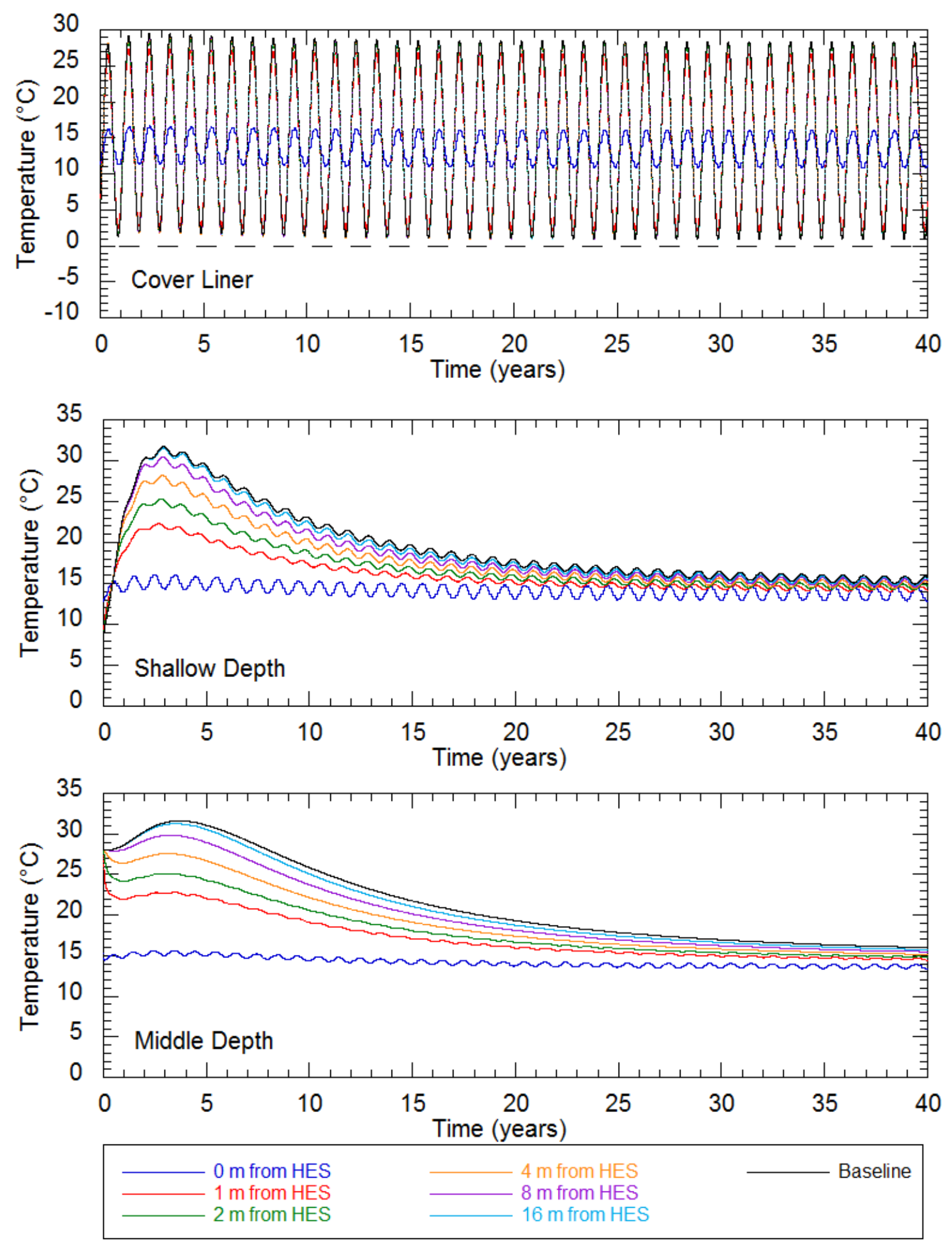

Figure 4.45a: Temperature Results: 5 Years between Original Waste Placement and Landfill Vertical Expansion 

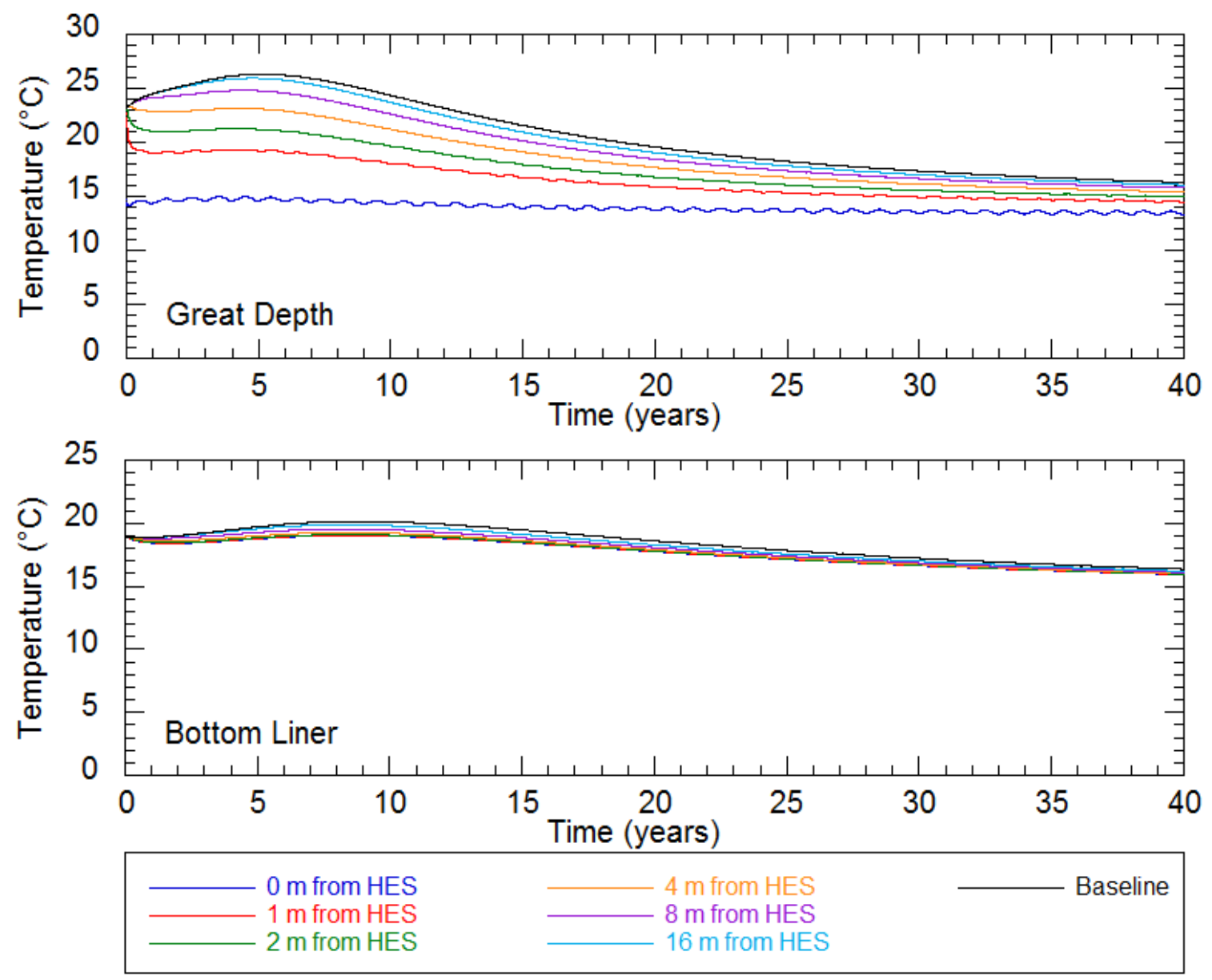

Figure 4.45b: Temperature Results: 5 Years between Original Waste Placement and Landfill Vertical Expansion

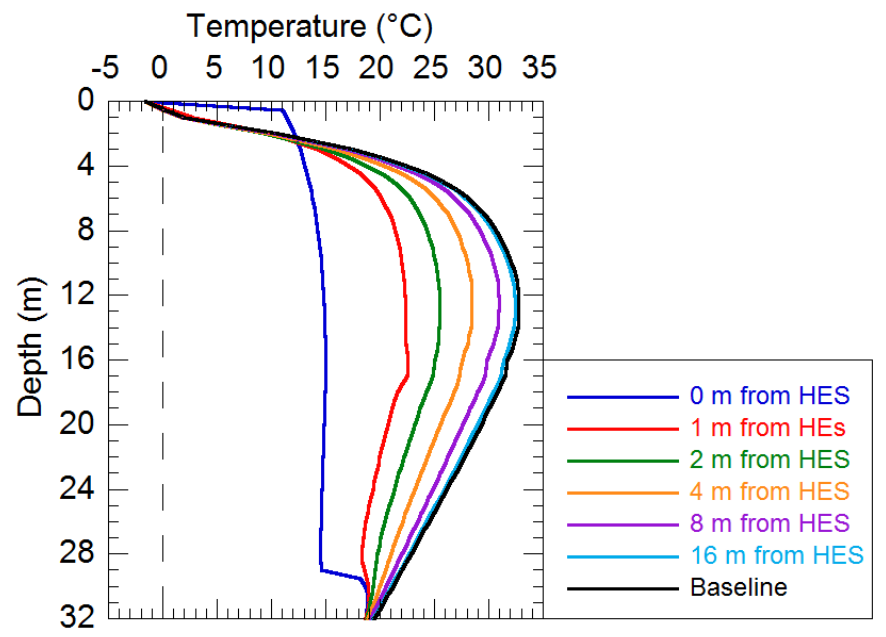

Figure 4.46: Vertical Temperature Results: 5 Years between Original Waste Placement and Landfill Vertical Expansion 
The heat extraction results for the vertical landfill expansion simulations are presented in Table 4.23. The simulation without a vertical landfill expansion had maximum heat extraction rates and total heat energy extracted. The simulation with 15 years between the original waste placement and the vertical landfill expansion had the minimum heat extraction rates and total heat energy extracted. The range in expected heat extraction rates for the vertical landfill expansion simulations are presented in Table 4.24. Maximum total heat energy extracted over a 40 year period was determined to be $561,100 \mathrm{MJ}$ and the minimum total heat energy extracted over a 40 year period was determined to be 324,400 MJ. The peak heat extraction rate occurred 2.4 to 3.2 years after start of HES operation. The average seasonal heat extraction rate amplitude ranged from 92 to $140 \mathrm{~W}$. The heat extraction rates and annual average heat extraction rates for vertical landfill expansions are presented in Figures 4.47 and 4.48, respectively.

Table 4.23: Vertical Landfill Expansion Heat Extraction Results

\begin{tabular}{|c|c|c|c|c|}
\hline $\begin{array}{c}\text { Time Between } \\
\text { Vertical Landfill } \\
\text { Expansions } \\
\text { (years) }\end{array}$ & $\begin{array}{c}\text { Peak Heat } \\
\text { Extraction } \\
\text { Rate (W) }\end{array}$ & $\begin{array}{c}\text { Time To } \\
\text { Peak (years) }\end{array}$ & $\begin{array}{c}\text { Average } \\
\text { Seasonal } \\
\text { Amplitude (W) }\end{array}$ & $\begin{array}{c}\text { Total Heat } \\
\text { Extracted* } \\
\text { (MJ) }\end{array}$ \\
\hline NA & 1230 & 3.2 & 140 & 561,100 \\
\hline 5 & 880 & 2.4 & 93 & 423,300 \\
\hline 15 & 690 & 2.4 & 92 & 324,400 \\
\hline
\end{tabular}

* over a 40 year period 
Table 4.24: Expected Range of Heat Extraction Rates for Vertical Landfill Expansion Simulations

\begin{tabular}{|c|c|c|c|c|c|c|}
\hline $\begin{array}{c}\text { Time Between } \\
\text { Vertical Landfill } \\
\text { Expansions } \\
\text { (years) }\end{array}$ & \multicolumn{2}{|c|}{$\begin{array}{c}\text { Heat Extraction } \\
\text { During 1st year } \\
\text { of Operation } \\
\text { (W) }\end{array}$} & \multicolumn{2}{|c|}{$\begin{array}{c}\text { Heat Extraction } \\
\text { During Year of } \\
\text { Peak Heat } \\
\text { Extraction }\end{array}$} & \multicolumn{2}{|c|}{$\begin{array}{c}\text { Heat Extraction } \\
\text { During Last Year } \\
\text { of Operation } \\
\text { (W) }\end{array}$} \\
\cline { 2 - 7 } & Max & Min & Max & Min & Max & Min \\
\hline NA & 950 & 680 & 1230 & 940 & 290 & 20 \\
\hline 5 & 660 & 430 & 880 & 710 & 220 & 40 \\
\hline 15 & 470 & 190 & 690 & 510 & 200 & 20 \\
\hline
\end{tabular}

* last year is year 40

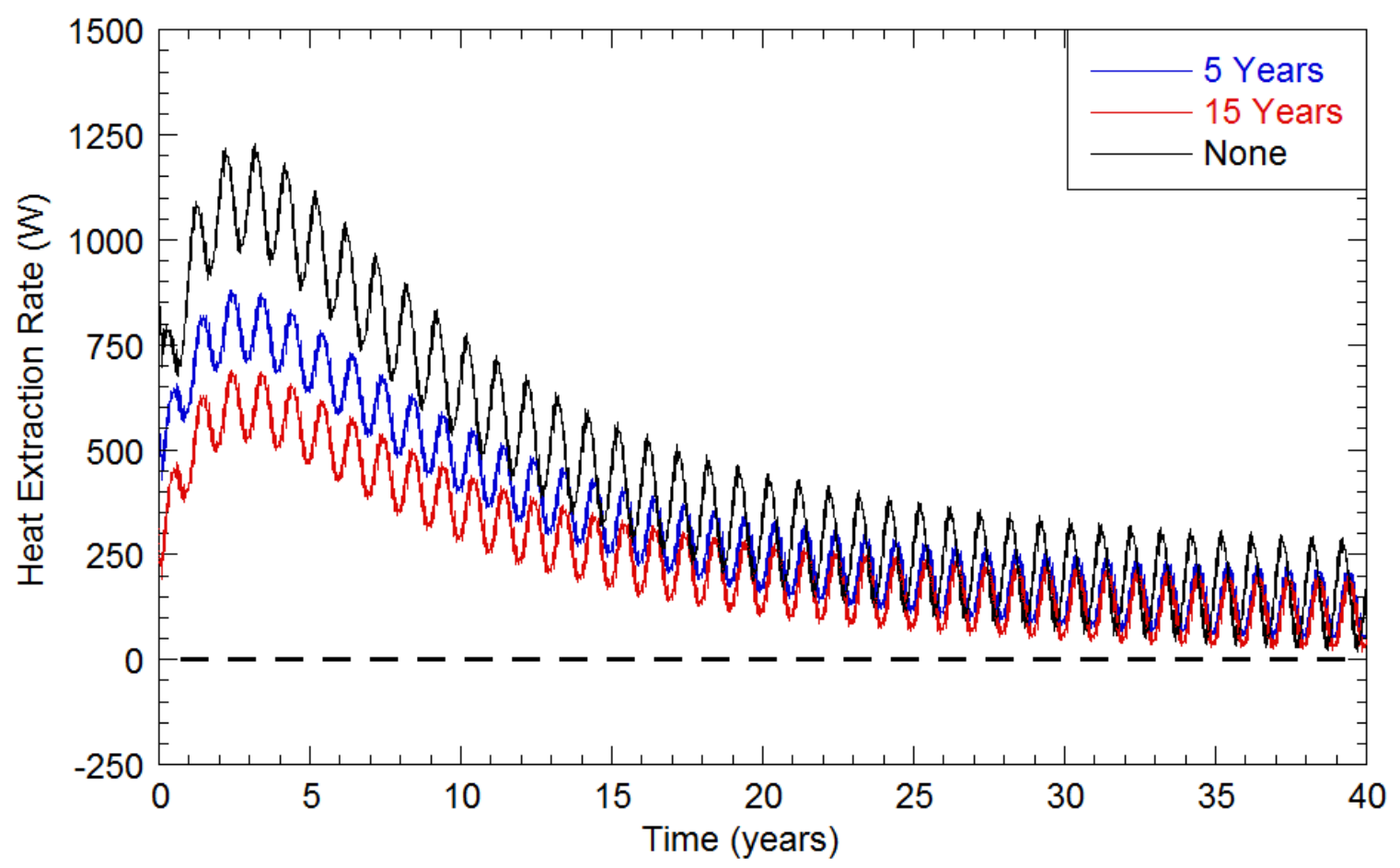

Figure 4.47: Heat Extraction Rates for Vertical Landfill Expansions 


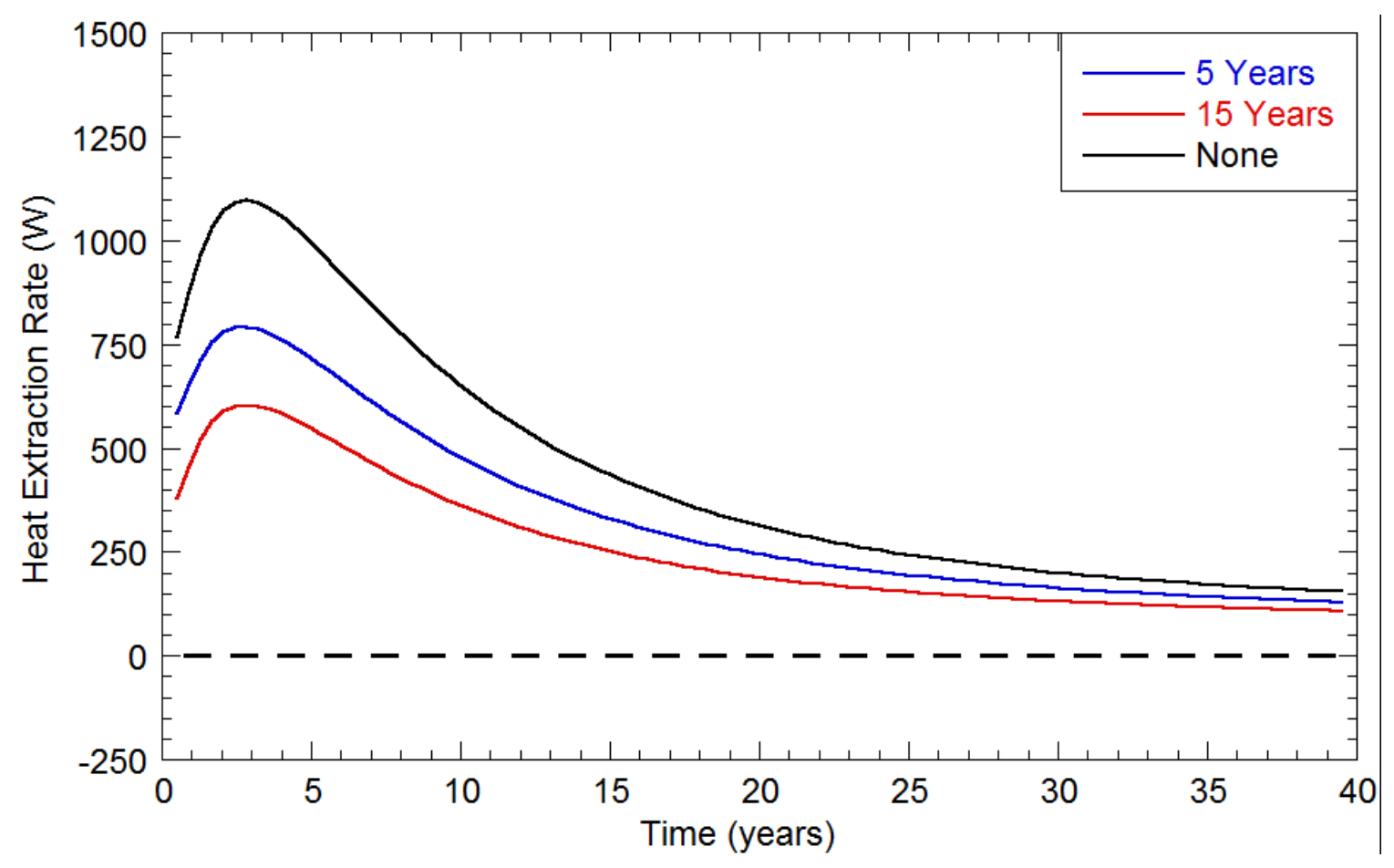

Figure 4.48: Annual Average Heat Extraction Rates for Vertical Landfill Expansions

For long time periods between the placement of the original waste mass and the vertical landfill expansion, the level of heat generation in the original waste mass was beyond the time associated with peak heat generation. Temperatures in the original waste mass were already decreasing prior to the vertical landfill expansion. The longer times between original waste mass placement and the vertical landfill expansion resulted in lower baseline temperatures. These lower baseline temperatures yielded a lower difference between baseline temperatures and temperatures $0 \mathrm{~m}$ away from the HES as temperatures $0 \mathrm{~m}$ away from the HES did not vary significantly for different vertical landfill expansion simulations. Lower temperature differences between baseline temperatures and temperatures $0 \mathrm{~m}$ away from the HES yielded lower 
peak heat generation rates and total energy extracted. A larger decrease in peak heat extraction rate was predicted between no vertical landfill expansion and the vertical expansion 5 years after the original waste placement than between vertical landfill expansions 5 and 15 years after the original waste placement (Figure 4.49).

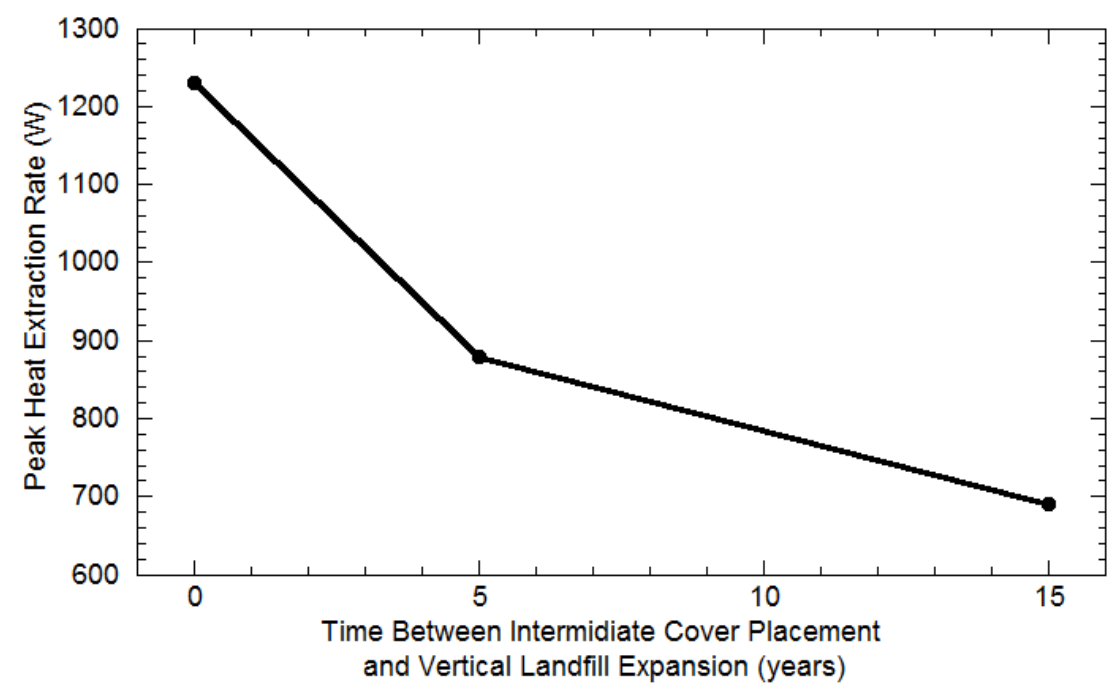

Figure 4.49: Effect of Vertical Landfill Expansions on Peak Heat Extraction

\subsubsection{HES Placement Time Results}

HES placement time simulations were conducted on the template landfill model and only the time after the final cover was placed until HES operation began was varied. Three vertical HES placement times were simulated: 1 day, 1 year, and 5 years after final cover placement. The HES placed 1 day after final cover placement was simulated for 40 years. The HES placed 1 year after final cover placement was simulated for 39 years and the HES placed 5 years after final cover placement was simulated for 35 years (for a total landfill simulation of 40 years after cover placement). Temperature results, heat extraction results, 
and trends for the HES placement time simulations are discussed in this section. Peak baseline temperatures and temperature results of the HES placement time simulations are summarized in Tables 4.25 and 4.26, respectively.

Table 4.25: Peak Baseline Temperatures at Locations for Different HES Placement Times

\begin{tabular}{|c|c|c|c|c|c|}
\hline $\begin{array}{c}\text { HES Time } \\
\begin{array}{c}\text { Placement After } \\
\text { Cover Placement }\end{array}\end{array}$ & $\begin{array}{c}\text { Peak } \\
\text { CL Temp } \\
\left({ }^{\circ} \mathrm{C}\right)\end{array}$ & $\begin{array}{c}\text { Peak } \\
\text { SD Temp } \\
\left({ }^{\circ} \mathrm{C}\right)\end{array}$ & $\begin{array}{c}\text { Peak } \\
\text { MD Temp } \\
\left({ }^{\circ} \mathrm{C}\right)\end{array}$ & $\begin{array}{c}\text { Peak } \\
\text { GD Temp } \\
\left({ }^{\circ} \mathrm{C}\right)\end{array}$ & $\begin{array}{c}\text { Peak } \\
\text { BL Temp } \\
\left({ }^{\circ} \mathrm{C}\right)\end{array}$ \\
\hline 1 day & 29.6 & 35.1 & 40.8 & 36.1 & 23.9 \\
\hline 1 year & 29.6 & 34.1 & 40.8 & 36.1 & 23.9 \\
\hline 5 years & 29.5 & 33.4 & 39.7 & 35.3 & 23.8 \\
\hline
\end{tabular}

Table 4.26: Temperature Results for Different HES Placement Times $0 \mathrm{~m}$ away from the HES

\begin{tabular}{|c|c|c|c|c|c|c|c|}
\hline $\begin{array}{c}\text { HES Time } \\
\text { Placement } \\
\text { After } \\
\text { Cover } \\
\text { Placement }\end{array}$ & $\begin{array}{c}\text { Avg. } \\
\text { CL } \\
\text { Temp } \\
\left({ }^{\circ} \mathrm{C}\right)\end{array}$ & $\begin{array}{l}\text { Avg. } \\
\text { SD } \\
\text { Temp } \\
\left({ }^{\circ} \mathrm{C}\right)\end{array}$ & $\begin{array}{c}\text { Avg. } \\
\text { MD } \\
\text { Temp } \\
\left({ }^{\circ} \mathrm{C}\right)\end{array}$ & $\begin{array}{l}\text { Avg. } \\
\text { GD } \\
\text { Temp } \\
\left({ }^{\circ} \mathrm{C}\right)\end{array}$ & $\begin{array}{l}\text { Peak } \\
\text { BL } \\
\text { Temp } \\
\left({ }^{\circ} \mathrm{C}\right)\end{array}$ & $\begin{array}{c}\text { Maximum } \\
\text { Difference } \\
\text { Between } \\
\text { HES and } \\
\text { Baseline } \\
\left({ }^{\circ} \mathrm{C}\right)\end{array}$ & $\begin{array}{l}\text { Elapsed } \\
\text { Time to } \\
\text { Maximum } \\
\text { Temperature } \\
\text { Difference } \\
\text { (years) }\end{array}$ \\
\hline & 13.6 & 4.3 & 14.4 & 14 & 22 & 25.2 & 3.7 \\
\hline & 13.6 & 14.3 & 14.4 & 14.3 & 22.1 & 25.2 & 2.7 \\
\hline 5 years & 13.6 & 14.2 & 14.3 & 14.2 & 23.2 & 23.6 & 2.9 \\
\hline
\end{tabular}

Temperatures along the length of the HES were not significantly impacted by the placement time of the HES. The highest average temperature along the length of the HES occurred in the middle of the waste mass. As the HES placement 5 years after cover construction began operation at a time beyond the occurrence of the peak landfill temperatures, average temperatures $0 \mathrm{~m}$ away from the HES were lower for this condition than placement 1 day or 1 year after cover construction. 
The maximum difference between HES temperatures and baseline landfill temperatures for the 1 day and 1 year after cover construction placement conditions occurred 1 year apart from each other (3.7 and 2.7 year, respectively) as both HES placement times were before the occurrence of peak landfill temperatures and the maximum difference between HES temperatures and baseline landfill temperatures occurred on the same day. The maximum difference between HES temperatures and baseline landfill temperatures for the placement of the HES 5 years after final cover construction occurred 2.9 years after the placement of the HES.

Maximum landfill temperatures (at the time of maximum difference between HES and baseline temperatures) were determined to occur at depths of 15.5, 16.5, and $17.5 \mathrm{~m}$ for HES placed 1 day, 1 year and 5 years after cover placement, respectively. Temperatures did not change significantly along the length of the HES. Simulated temperatures increased to within $5^{\circ} \mathrm{C}$ of baseline temperatures $2 \mathrm{~m}$ directly below the HES. Temperatures at the cover liner, shallow-depth, middle-depth, great-depth, and bottom liner locations are presented in Figure 4.50 for HES placement 1 year after cover construction. The vertical temperature profile results at the time of maximum difference between HES and baseline temperatures are presented in Figure 4.51 for HES placement 1 year after cover construction. Additional plots for all other HES placement time simulations are presented in Appendix A. 

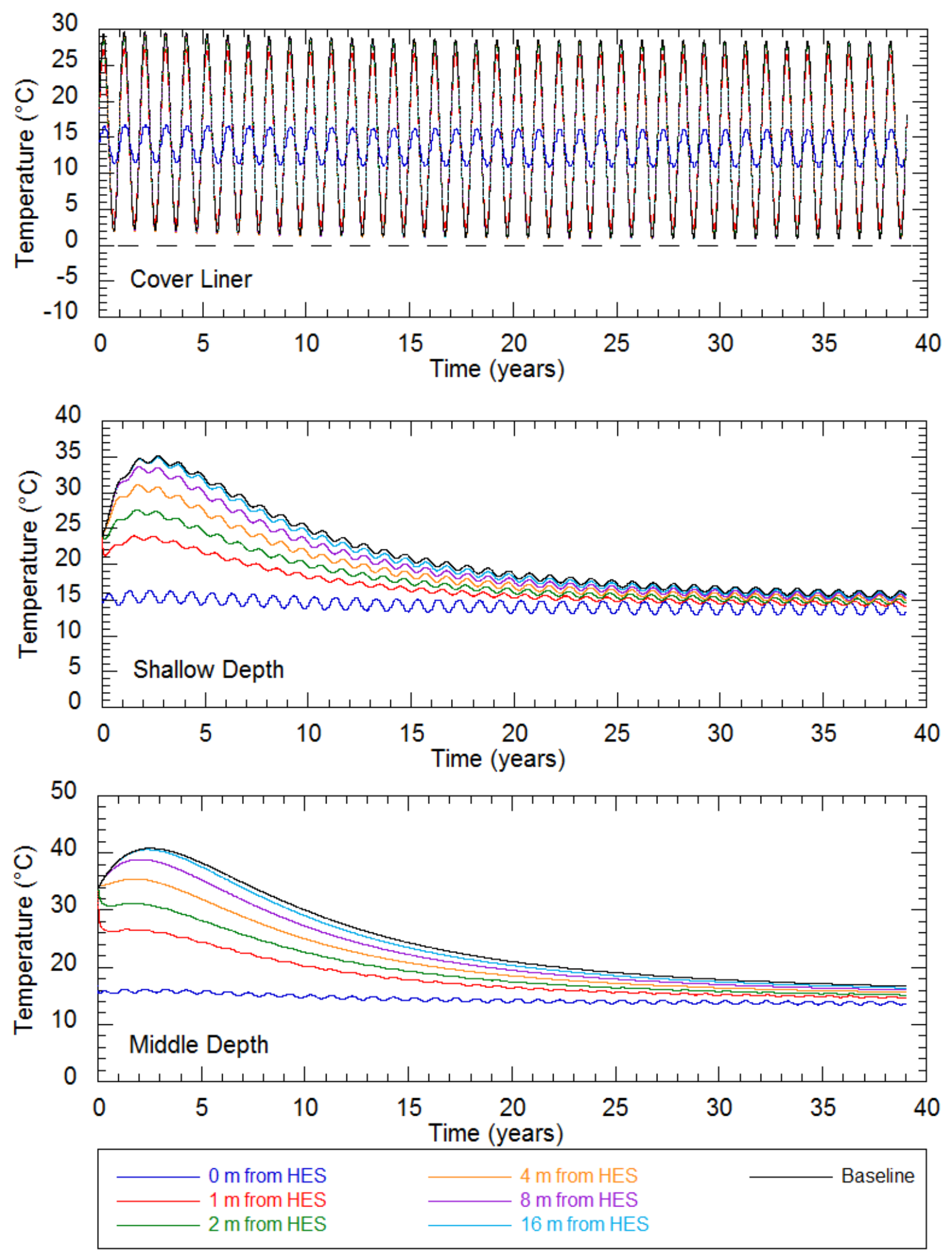

Figure 4.50a: Temperature Results: HES Placement 1 Year after Cover Construction 

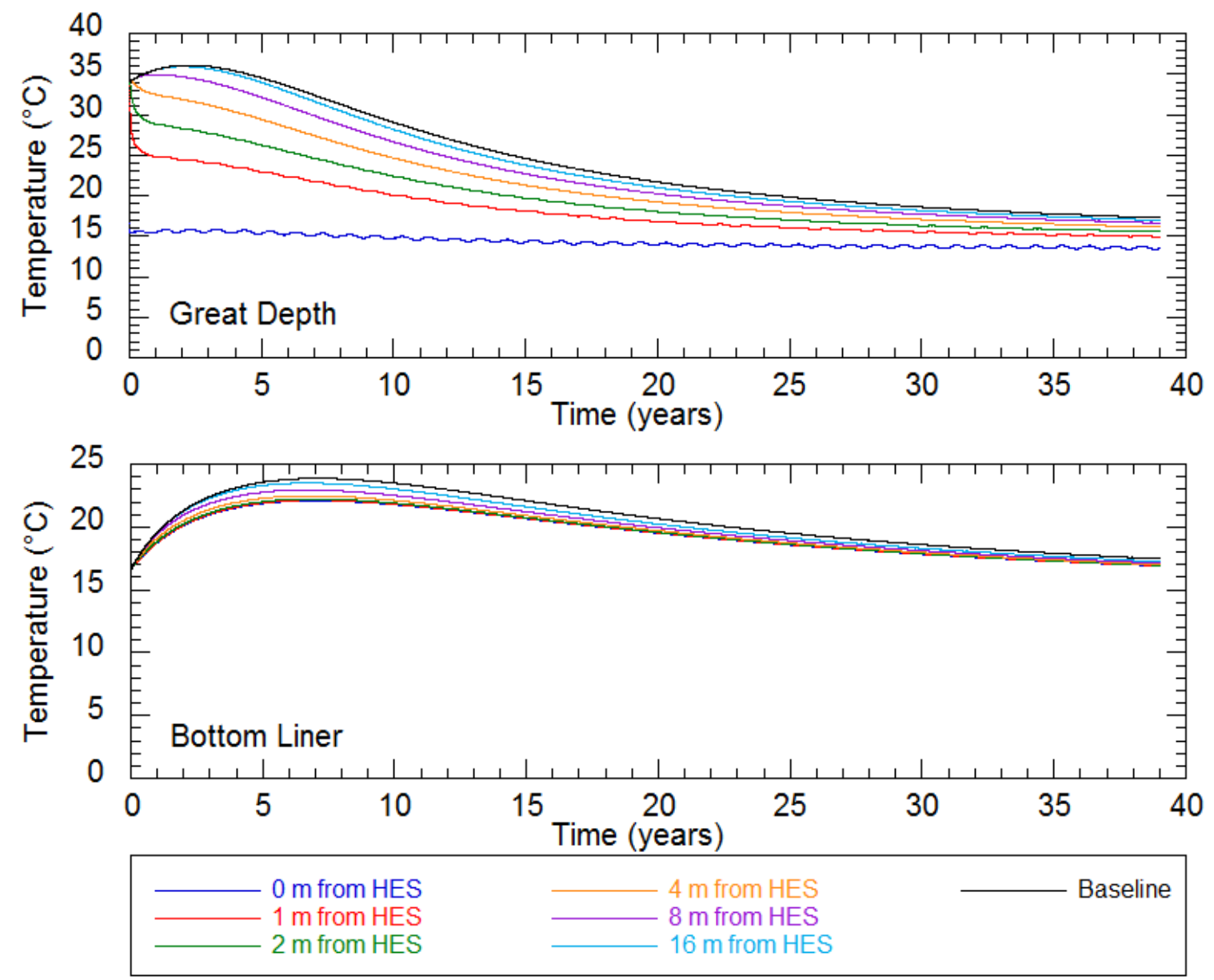

Figure 4.50b: Temperature Results: HES Placement

1 Year after Cover Construction

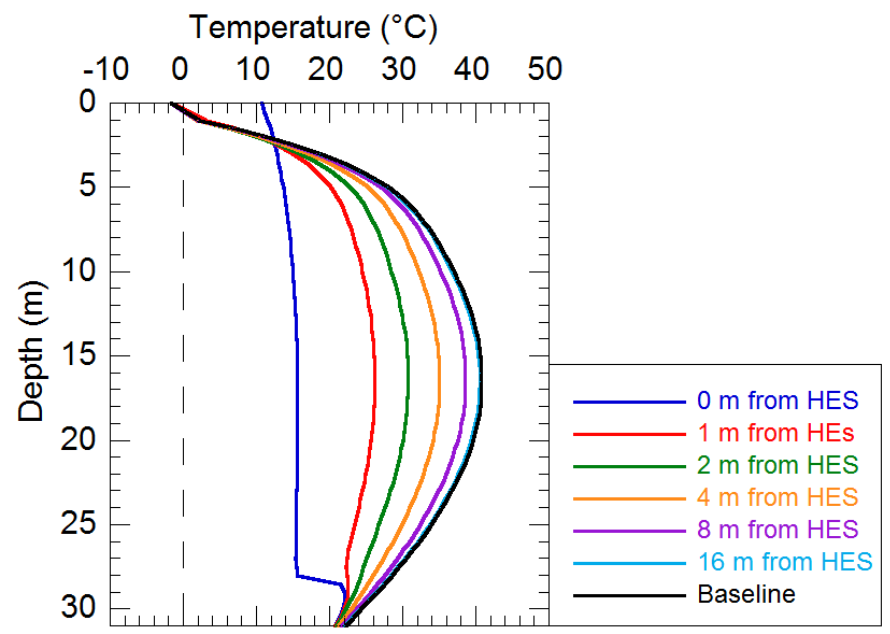

Figure 4.51: Vertical Temperature Results: HES Placement 1 Year after Cover Construction 
The heat extraction results for the HES placement time simulations are presented in Table 4.27. The range in expected heat extraction rates for the HES placement time simulations are presented in Table 4.28. Maximum total heat energy extracted was determined to be $561,100 \mathrm{MJ}$ over a 35 year period and the minimum total heat energy extracted was determined to be $428,000 \mathrm{MJ}$ over a 35 year period. To compare the total heat energy extracted, an equivalent period of time of heat extraction was required. A 35 year period was selected to compare the different HES placement time simulations, because all HES placement time simulations were conducted for at least 35 years. The peak heat extraction rate occurred 0.0 to 3.2 years after start of HES operation. The average seasonal heat extraction rate amplitude ranged from 140 to $156 \mathrm{~W}$. The heat extraction rates and annual average heat extraction rates for HES placement times are presented in Figures 4.52 and 4.53, respectively.

Table 4.27: HES Placement Time Heat Extraction Results

\begin{tabular}{|c|c|c|c|c|}
\hline $\begin{array}{c}\text { HES Time } \\
\begin{array}{c}\text { Placement After } \\
\text { Cover } \\
\text { Placement }\end{array}\end{array}$ & $\begin{array}{c}\text { Peak Heat } \\
\text { Extraction } \\
\text { Rate }(\mathrm{W})\end{array}$ & $\begin{array}{c}\text { Time To } \\
\text { Peak (years) }\end{array}$ & $\begin{array}{c}\text { Average } \\
\text { Seasonal } \\
\text { Amplitude (W) }\end{array}$ & $\begin{array}{c}\text { Total Heat } \\
\text { Energy } \\
\text { Extracted* } \\
\text { (MJ) }\end{array}$ \\
\hline 1 day & 1230 & 3.2 & 140 & 532,300 \\
\hline 1 year & 1260 & 1.2 & 148 & 520,900 \\
\hline 5 years & 1630 & 0.0 & 156 & 428,000 \\
\hline
\end{tabular}

* over a 35 year period 
Table 4.28: Expected Range of Heat Extraction Rates for HES Placement Time Simulations

\begin{tabular}{|c|c|c|c|c|c|c|}
\hline $\begin{array}{c}\text { HES Time } \\
\text { Placement After } \\
\text { Cover Placement }\end{array}$ & $\begin{array}{c}\text { Heat Extraction } \\
\text { During 1st year } \\
\text { of Operation } \\
\text { (W) }\end{array}$ & \multicolumn{2}{|c|}{$\begin{array}{c}\text { Heat Extraction } \\
\text { During Year of } \\
\text { Peak Heat } \\
\text { Extraction }(W)\end{array}$} & \multicolumn{2}{|c|}{$\begin{array}{c}\text { Heat Extraction } \\
\text { During Last Year } \\
\text { of Operation } \\
\text { (W) }\end{array}$} \\
\cline { 2 - 7 } & $\operatorname{Max}$ & Min & Max & Min & Max & Min \\
\hline 1 day & 950 & 680 & 1230 & 940 & 310 & 40 \\
\hline 1 year & 1160 & 990 & 1260 & 1000 & 310 & 40 \\
\hline 5 years & 1630 & 1010 & $1630^{\text {a }}$ & $1010^{\mathrm{a}}$ & 290 & 20 \\
\hline
\end{tabular}

* last year is year 35

a peak heat extraction occurred in 1 st year

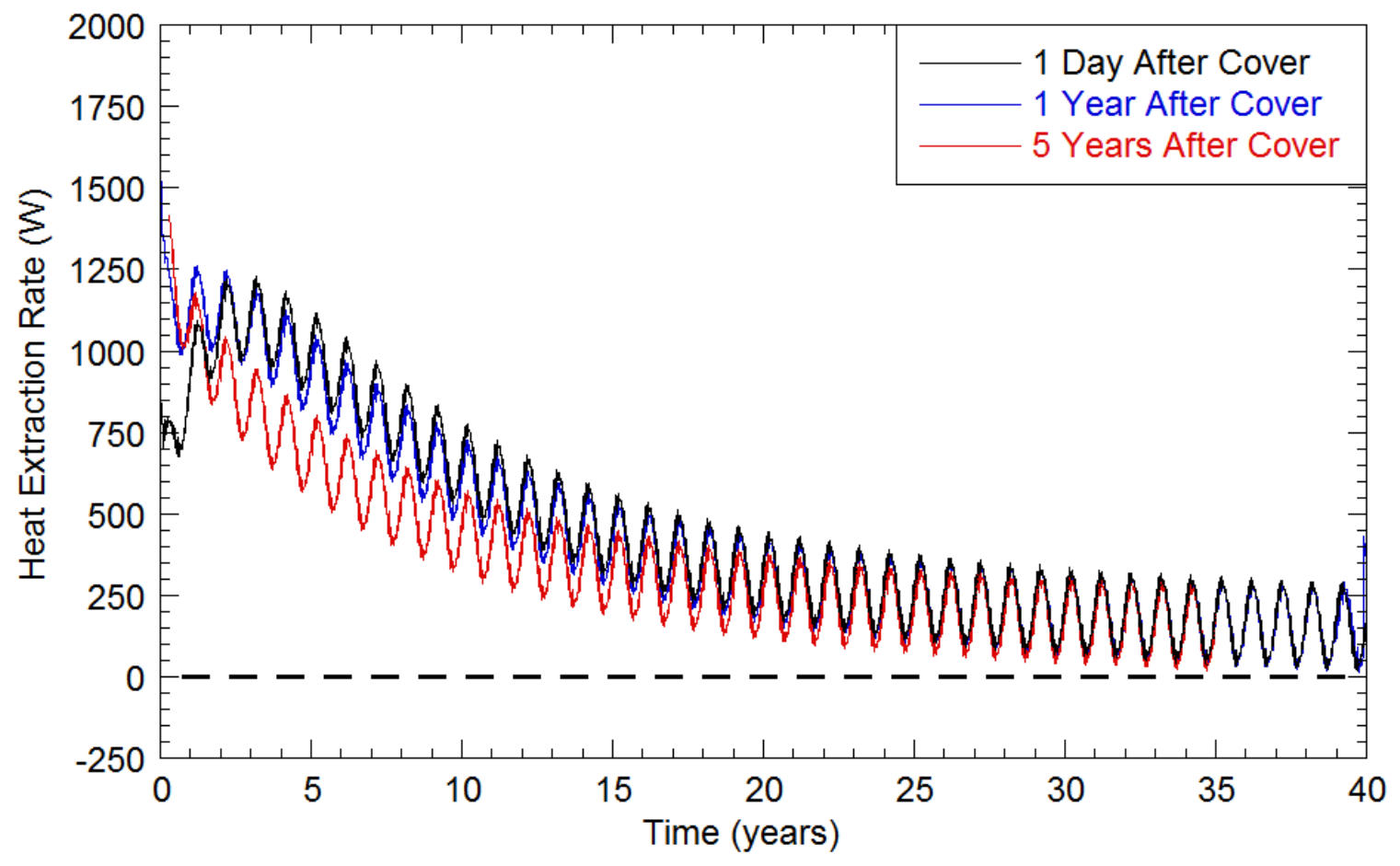

Figure 4.52: Heat Extraction Rates for Different HES Placement Times 


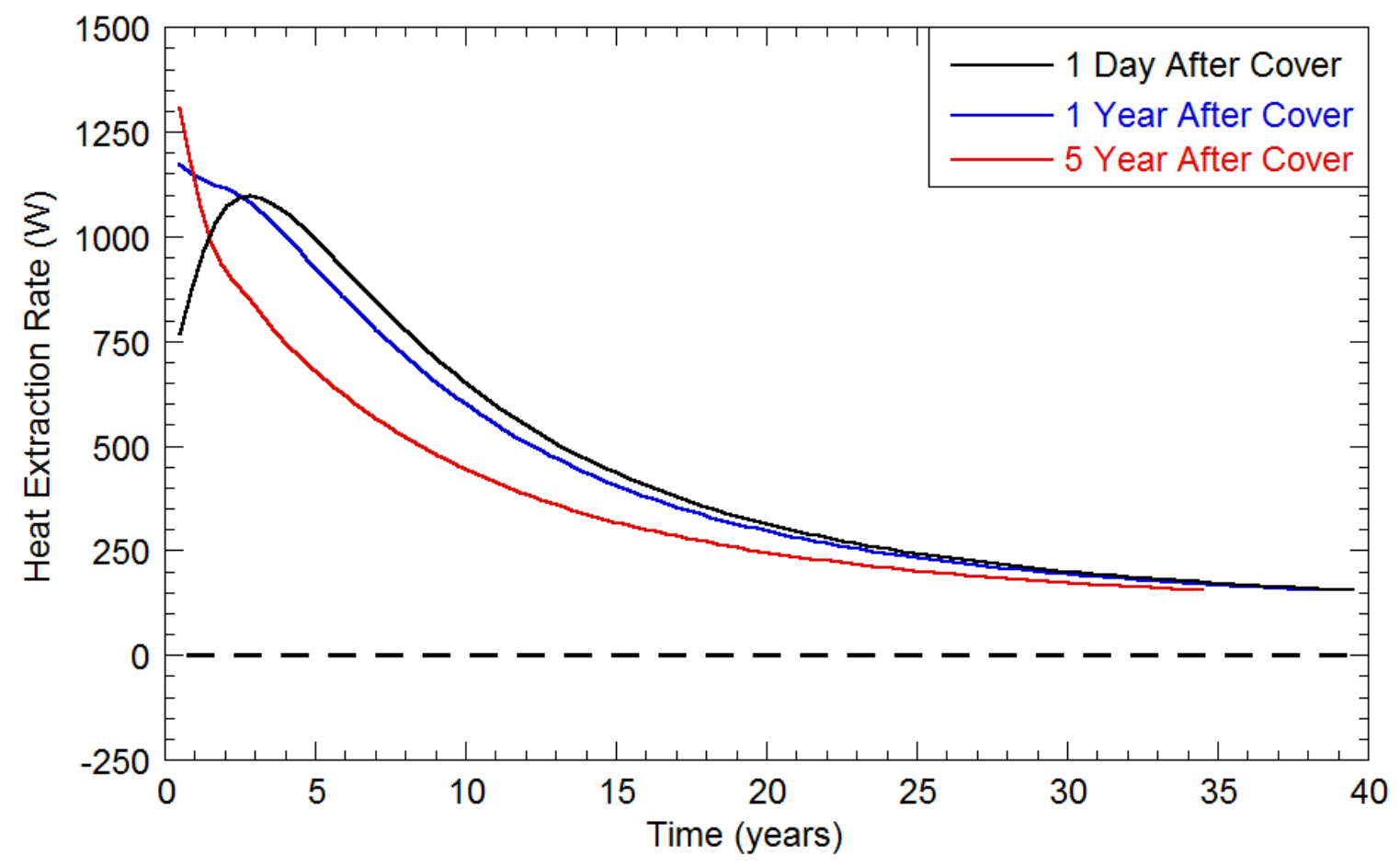

Figure 4.53: Annual Average Heat Extraction Rates for Different HES Placement Times

The maximum difference between HES temperatures and baseline landfill temperatures for the placement of the HES 1 day and 1 year after cover construction were equal as the HES were placed before peak temperatures occurred in the landfill. The HES placement 5 years after cover construction was determined to have a lower maximum difference between HES temperatures and baseline landfill temperatures as the HES was placed after peak temperatures occurred at the landfill.

The HES placement 5 years after cover construction took place after the time of peak temperatures in the landfill occurred. Therefore, heat extraction rates initially were high and decreased over time. The HES placement 1 year after cover construction occurred at a time near the occurrence of peak 
temperatures in the landfill. Therefore, heat extraction rates increased slightly before decreasing over time. The HES placement 1 day after cover construction occurred well before peak temperatures were predicted in the landfill and therefore heat extraction rates demonstrate a distinct peak. Total heat energy extracted decreased linearly with the HES placement time after final cover placement. For every year that the HES was constructed after the final cover was placed, the total heat energy extracted decreased by approximately 21,500 $\mathrm{MJ} /$ year (Figure 4.54).

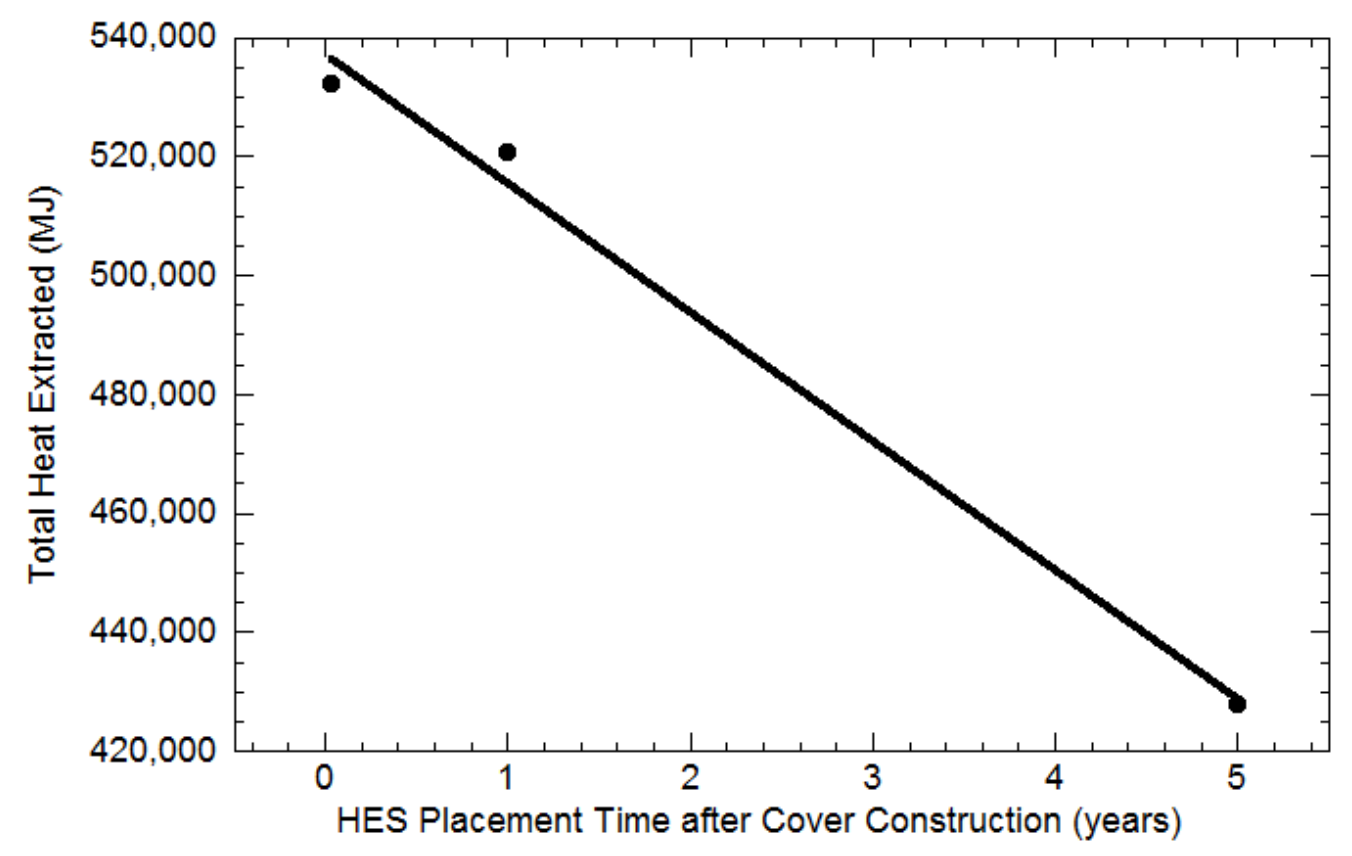

Figure 4.54: Effect of HES Placement Time on Total Heat Energy Extracted

\subsubsection{HES Operation Results}

HES operation simulations were conducted on the template landfill model and only the time when the HES was operational was varied. Vertical HES operation in only winter was simulated to represent the potential HES use of 
heating during winter. The HES was operated for 3 months each year as detailed in Chapter 3. Temperature results, heat extraction results, and trends for the HES operation simulation are discussed in this section.

Peak baseline temperatures were $29.6,35.1,40.8,36.1$, and $23.9^{\circ} \mathrm{C}$ for the cover liner, shallow-depth, middle-depth, great-depth, and bottom liner locations, respectively. For winter-only operation, temperatures along the length of the HES varied based on the season. In winter, temperatures $0 \mathrm{~m}$ away from the HES were equal to temperatures $0 \mathrm{~m}$ away from the HES for yearround operation. When the HES was not operating, temperatures $0 \mathrm{~m}$ away from the HES increased until they were within $5^{\circ} \mathrm{C}$ of the baseline landfill temperatures. The highest temperature along the length of the HES occurred in the middle of the waste mass.

The maximum difference between HES temperatures and baseline landfill temperatures were 25.2 and $25.1^{\circ} \mathrm{C}$ for the year-round operation and winter-only operation, respectively. The maximum difference between HES temperatures and baseline landfill temperatures for year-round HES operation occurred 3.7 years after the placement of the HES. The maximum difference between HES temperatures and baseline landfill temperatures for winter HES operation occurred 3.8 years after the placement of the HES.

Maximum landfill temperatures (at the time of maximum difference between HES and baseline temperatures) were determined to occur at depths of 15.5 and $16.5 \mathrm{~m}$ in a $30 \mathrm{~m}$ waste height for the year-round operation and winteronly operation, respectively. Temperatures did not change significantly (less 
than $5^{\circ} \mathrm{C}$ change in temperature) along the length of the HES during HES operation. Temperatures at the cover liner, shallow-depth, middle-depth, greatdepth, and bottom liner locations are presented in Figure 4.55 for winter-only HES operation. The vertical temperature profile results at the time of maximum difference between HES and baseline temperatures are presented in Figure 4.56 for winter-only HES operation. 

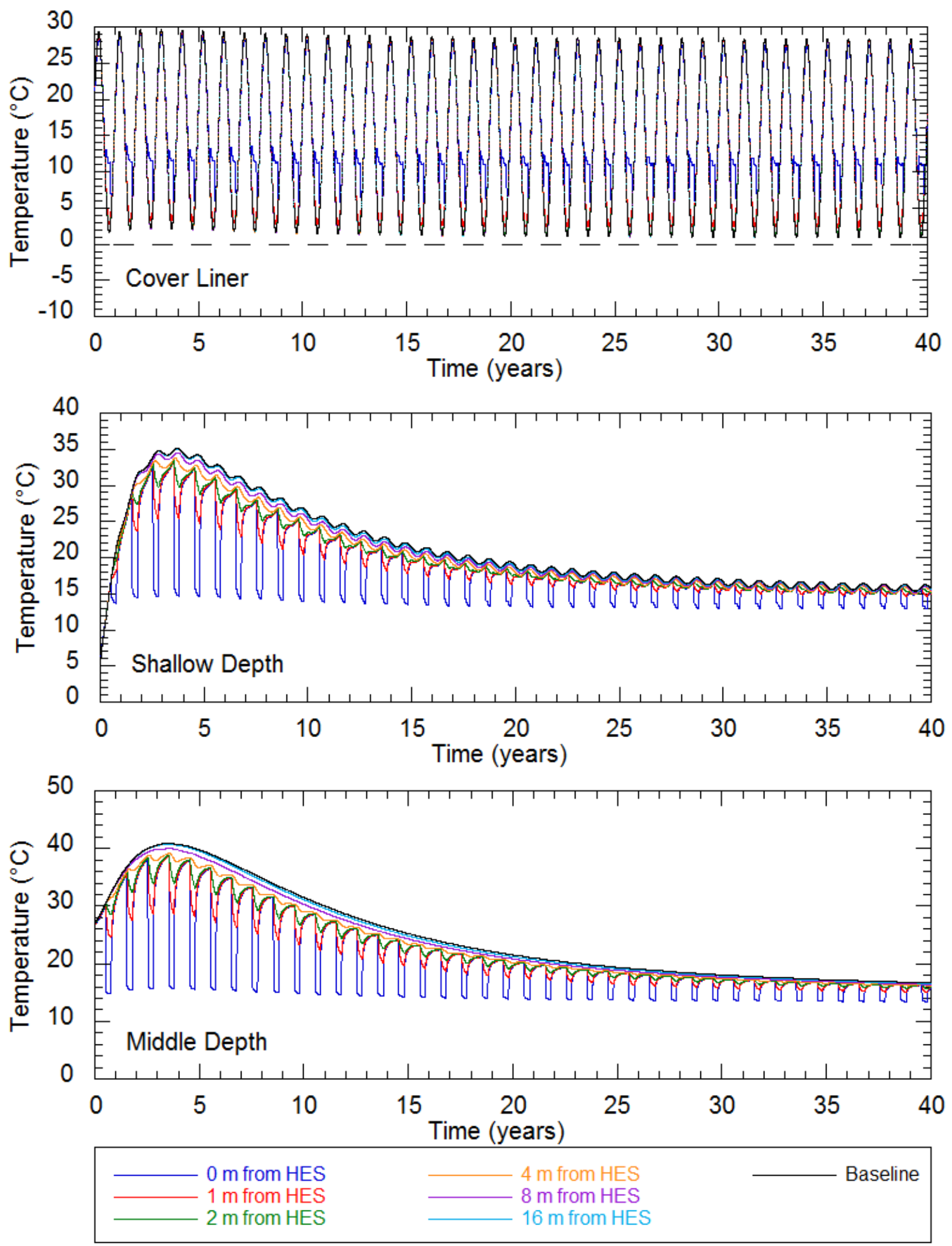

Figure 4.55a: Temperature Results: Winter-Only HES Operation 

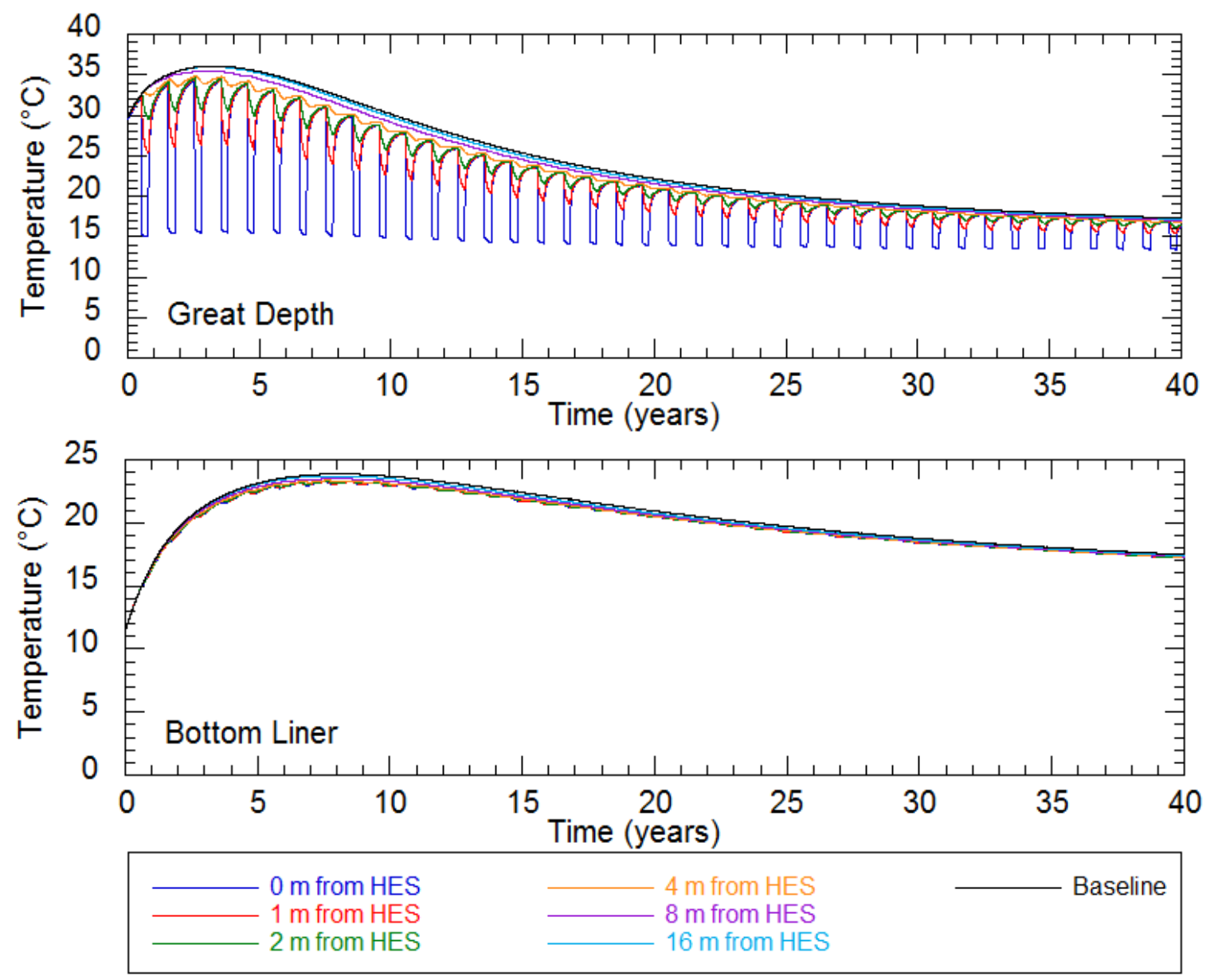

Figure 4.55b: Temperature Results: Winter-Only HES Operation

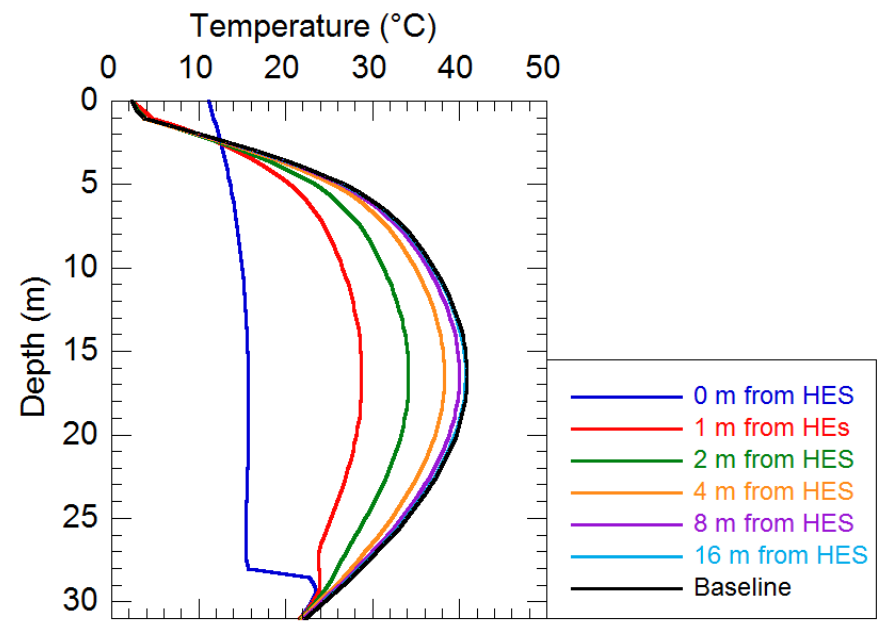

Figure 4.56: Vertical Temperature Results: Winter-Only HES 
The heat extraction results for the HES operational simulations are presented in Table 4.29. The range in expected heat extraction rates for the HES operational simulations are presented in Table 4.30. The difference in peak heat extraction rates between the year-round operation and winter-only operation was due to a high temperature difference at the start of HES operation each year in the winter-only operation. Temperatures $0 \mathrm{~m}$ away from the HES increased after the HES stopped operation. When the HES operation resumed, the large peak temperature difference caused the high initial heat extraction rates. Total heat energy extracted over a 40 year period for winter-only HES operation was determined to be $163,000 \mathrm{MJ}$ and total heat energy extracted for year-round HES operation was determined to be $561,100 \mathrm{MJ}$. The peak heat extraction rate occurred 3.6 and 3.2 years after start of HES operation for winter-only operation and year-round operation, respectively. The heat extraction rates for HES operation are presented in Figure 4.57.

Table 4.29: HES Operation Heat Extraction Results

\begin{tabular}{|c|c|c|c|c|}
\hline HES Operation & $\begin{array}{c}\text { Peak Heat } \\
\text { Extraction } \\
\text { Rate }(\mathrm{W})\end{array}$ & $\begin{array}{c}\text { Time To } \\
\text { Peak (years) }\end{array}$ & $\begin{array}{c}\text { Average } \\
\text { Seasonal } \\
\text { Amplitude }(\mathrm{W})\end{array}$ & $\begin{array}{c}\text { Total Heat } \\
\text { Extracted } \\
\text { (MJ) }\end{array}$ \\
\hline Winter-Only & 2280 & 3.6 & NA & 163,000 \\
\hline Year-Round & 1230 & 3.2 & 140 & 561,100 \\
\hline
\end{tabular}

* over a 40 year period 
Table 4.30: Expected Range of Heat Extraction Rates for HES Operation Simulations

\begin{tabular}{|c|c|c|c|c|c|c|}
\hline HES Operation & \multicolumn{2}{|c|}{$\begin{array}{c}\text { Heat Extraction } \\
\text { During 1st year } \\
\text { of Operation } \\
\text { (W) }\end{array}$} & \multicolumn{2}{|c|}{$\begin{array}{c}\text { Heat Extraction } \\
\text { During Year of } \\
\text { Peak Heat } \\
\text { Extraction (W) }\end{array}$} & \multicolumn{2}{|c|}{$\begin{array}{c}\text { Heat Extraction } \\
\text { During Last Year } \\
\text { of Operation } \\
\text { (W) }\end{array}$} \\
\cline { 2 - 7 } & Max & Min & Max & Min & Max & Min \\
\hline Winter-Only & 1350 & 850 & 2280 & 1240 & 250 & 100 \\
\hline Year-Round & 950 & 680 & 1230 & 940 & 310 & 40 \\
\hline
\end{tabular}

* last year is year 35

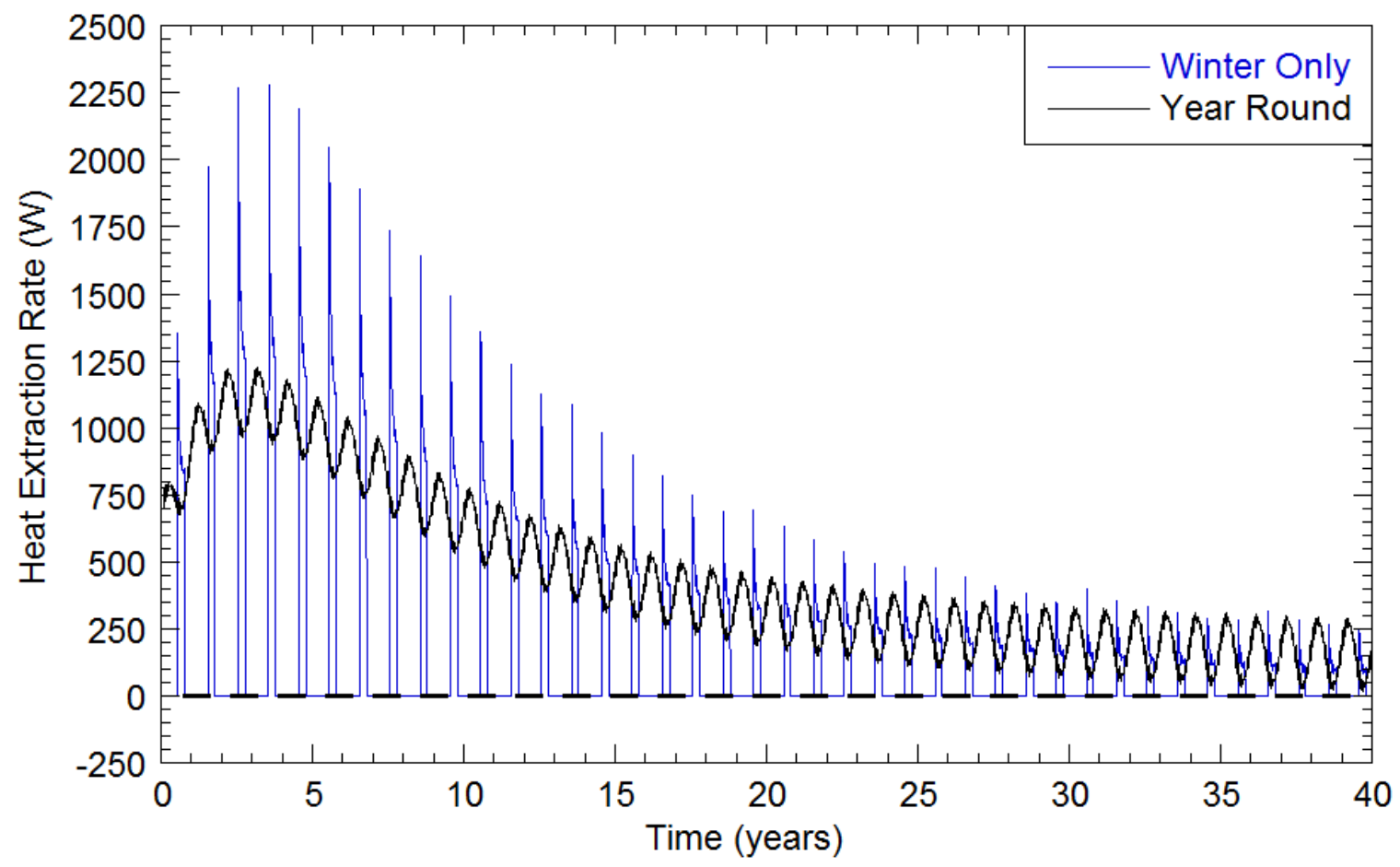

Figure 4.57: Heat Extraction Rates for Different HES Operational Times

Temperatures near the HES varied based on the HES operation. Temperatures $0 \mathrm{~m}$ away from HES deceased rapidly within the first 1 to 2 days of HES operation. After the first 1 to 2 days, temperatures decreased by $2^{\circ} \mathrm{C}$ over the rest of the HES operation period. After the HES operation stopped, 
temperatures $0 \mathrm{~m}$ away from the HES increased to within $4^{\circ} \mathrm{C}$ of the baseline temperatures (Figure 4.58).

For each winter season, the maximum heat extraction rate occurred at the beginning of the winter season and decreased exponentially over the course of the winter season (Figure 4.59). Total heat energy extracted over a year long period differed for each year and the total heat energy extracted for each year after HES placement is presented in Figure 4.60.

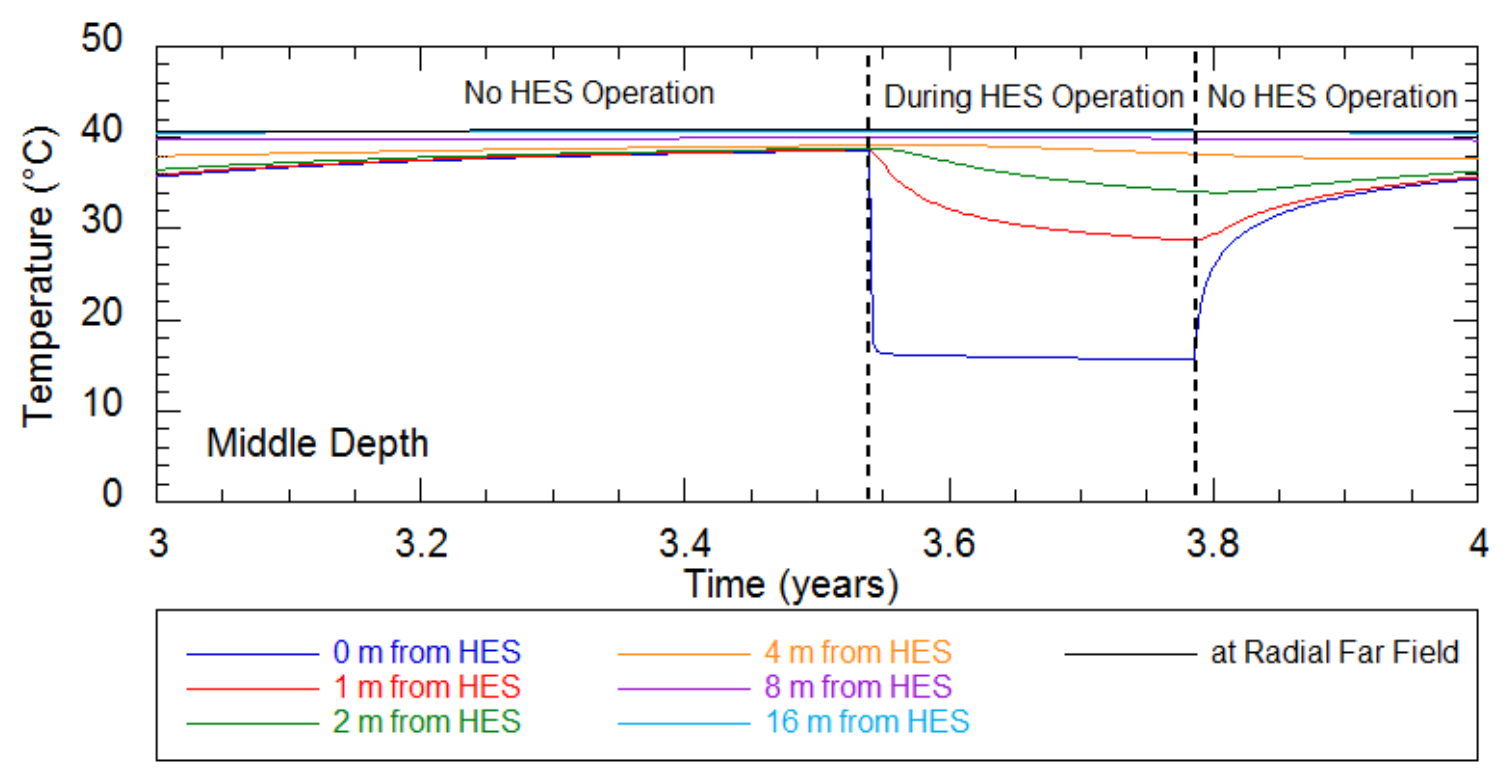

Figure 4.58: Temperatures over a 1 Year Time Period 


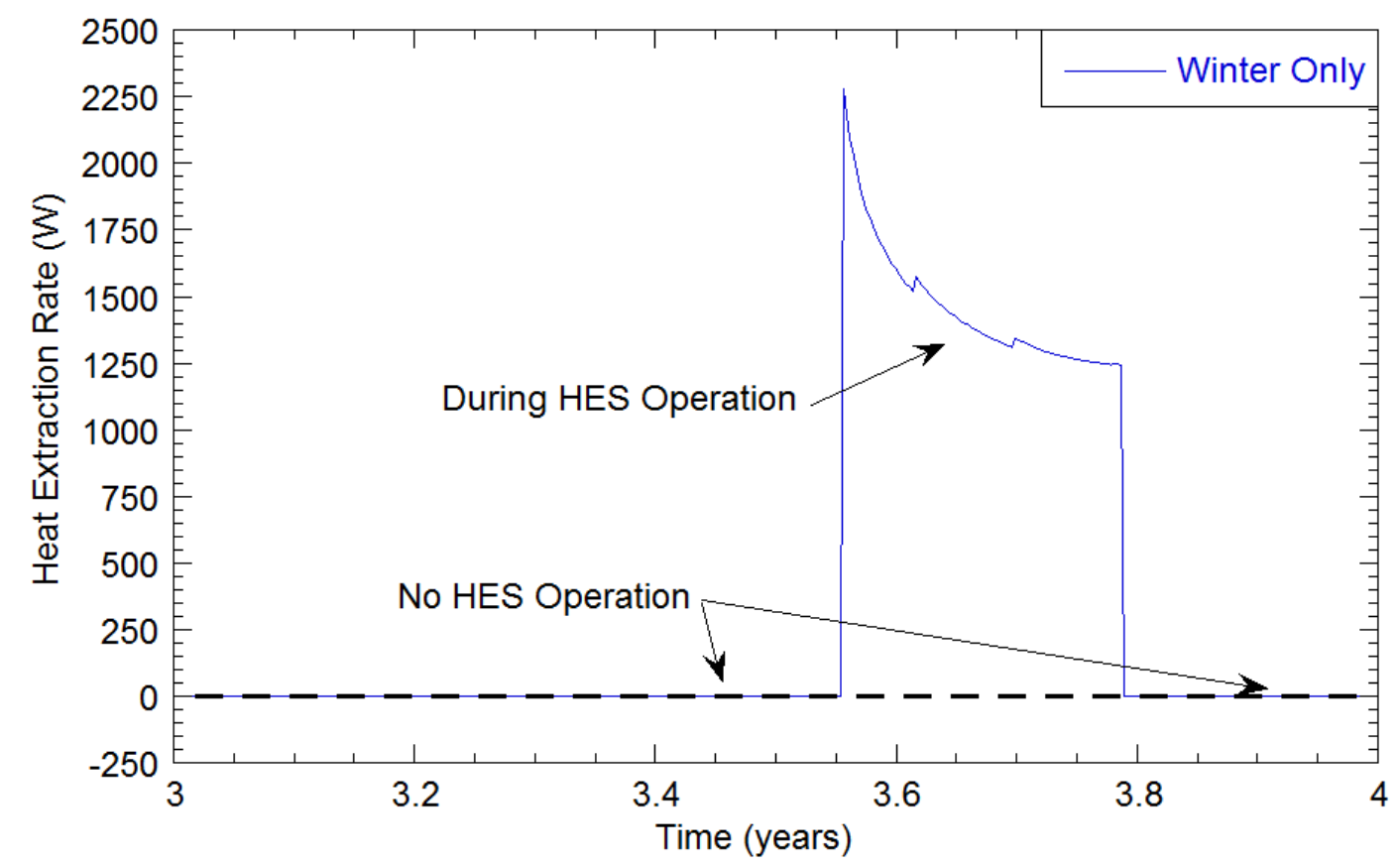

Figure 4.59: Heat Extraction Rates over a 1 Year Time Period

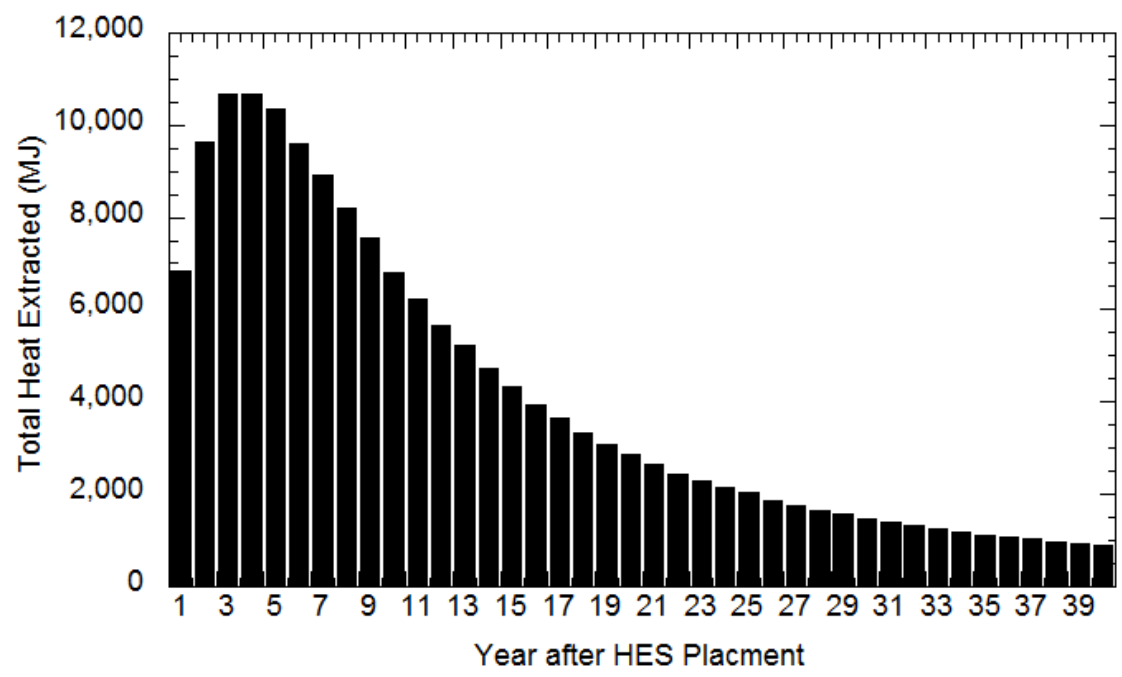

Figure 4.60: Total Heat Energy Extracted for Each Year after HES Placement

\subsubsection{Climate Results}

Climate simulations were conducted on the template landfill model and only the climate region was varied. Four climatic regions were simulated: Alaska, British Columbia, Michigan, and New Mexico. Temperature results, heat 
extraction results, and trends for the climate simulations are discussed in this section. Peak baseline temperatures and temperature results of the climate simulations are summarized in Tables 4.31 and 4.32 , respectively.

Table 4.31: Peak Baseline Temperatures at Locations for Different Climates

\begin{tabular}{|c|c|c|c|c|c|}
\hline Climate & $\begin{array}{c}\text { Peak } \\
\text { CL Temp } \\
\left({ }^{\circ} \mathrm{C}\right)\end{array}$ & $\begin{array}{c}\text { Peak } \\
\text { SD Temp } \\
\left({ }^{\circ} \mathrm{C}\right)\end{array}$ & $\begin{array}{c}\text { Peak } \\
\text { MD Temp } \\
\left({ }^{\circ} \mathrm{C}\right)\end{array}$ & $\begin{array}{c}\text { Peak } \\
\text { GD Temp } \\
\left({ }^{\circ} \mathrm{C}\right)\end{array}$ & $\begin{array}{c}\text { Peak } \\
\text { BL Temp } \\
\left({ }^{\circ} \mathrm{C}\right)\end{array}$ \\
\hline Alaska & 20.0 & 8.0 & 11.3 & 10.9 & 5.8 \\
\hline British Columbia & 33.9 & 57.6 & 63.7 & 58.5 & 45.2 \\
\hline Michigan & 29.6 & 35.1 & 40.8 & 36.1 & 23.9 \\
\hline New Mexico & 29.6 & 31.5 & 34.5 & 32.6 & 27.2 \\
\hline
\end{tabular}

Table 4.32: Temperature Results for Variable Climates $0 \mathrm{~m}$ away from the HES

\begin{tabular}{|c|c|c|c|c|c|c|c|}
\hline Climate & $\begin{array}{c}\text { Avg. } \\
\mathrm{CL} \\
\mathrm{Temp} \\
\left({ }^{\circ} \mathrm{C}\right)\end{array}$ & $\begin{array}{c}\text { Avg. } \\
\mathrm{SD} \\
\mathrm{Temp} \\
\left({ }^{\circ} \mathrm{C}\right)\end{array}$ & $\begin{array}{c}\text { Avg. } \\
\mathrm{MD} \\
\mathrm{Temp} \\
\left({ }^{\circ} \mathrm{C}\right)\end{array}$ & $\begin{array}{c}\text { Avg. } \\
\mathrm{GD} \\
\mathrm{Temp} \\
\left({ }^{\circ} \mathrm{C}\right)\end{array}$ & $\begin{array}{c}\text { Peak } \\
\mathrm{BL} \\
\mathrm{Temp} \\
\left({ }^{\circ} \mathrm{C}\right)\end{array}$ & $\begin{array}{c}\text { Maximum } \\
\text { Difference } \\
\text { Between } \\
\text { HES and } \\
\text { Baseline } \\
\left({ }^{\circ} \mathrm{C}\right)\end{array}$ & $\begin{array}{c}\text { Elapsed } \\
\text { Time to } \\
\text { Maximum } \\
\text { Temperature } \\
\text { Difference } \\
(\text { years })\end{array}$ \\
\hline Alaska & 5.9 & 6.0 & 5.9 & 5.8 & 5.6 & 5.2 & 4.8 \\
\hline $\begin{array}{c}\text { British } \\
\text { Columbia }\end{array}$ & 15.1 & 16.5 & 16.9 & 16.9 & 39.7 & 43.2 & 2.9 \\
\hline Michigan & 13.6 & 14.3 & 14.4 & 14.3 & 22.1 & 25.2 & 3.7 \\
\hline $\begin{array}{c}\text { New } \\
\text { Mexico }\end{array}$ & 19.5 & 19.7 & 19.7 & 19.6 & 25.4 & 14.1 & 3.7 \\
\hline
\end{tabular}

Temperatures along the length of the HES increased in climates with greater average ground temperatures and greater heat generation. The highest average temperature along the length of the HES occurred in the middle of the waste mass except in the Alaska climate. The Alaska site had waste placement during freezing conditions. Frozen waste caused noticeably lower temperatures 
than would otherwise be expected near the center of the waste mass. The New Mexico climate had the highest ground surface temperatures which caused the highest temperatures $0 \mathrm{~m}$ away from the HES. The British Columbia and Michigan climates had similar ground surface temperatures; however, the British Columbia climate had higher heat generation characteristics. Having higher heat generation rates caused the British Columbia simulation to have higher temperatures $0 \mathrm{~m}$ away from the HES than the Michigan simulation.

The maximum difference between HES temperatures and baseline landfill temperatures were impacted by the heat generation characteristics at the four climates. Greater heat generation characteristics resulted in a greater maximum difference between HES temperatures and baseline landfill temperatures.

Maximum landfill temperatures (at the time of maximum difference between HES and baseline temperatures) were determined to occur at depths of 19.0, 16.0, 15.5, and $16.5 \mathrm{~m}$ for the Alaska, British Columbia, Michigan, and New Mexico climates, respectively. Temperatures did not change significantly (less than $5^{\circ} \mathrm{C}$ change in temperature) along the length of the HES for the Alaska, Michigan, and New Mexico climates. Temperatures along the length of the HES for the British Columbia climate changed $5.6^{\circ} \mathrm{C}$ because of higher temperatures gradients than the other climates. Below the HES, temperatures increased to within $5^{\circ} \mathrm{C}$ of baseline temperatures within $2 \mathrm{~m}$ below the HES for the Alaska, Michigan, and New Mexico climates. Temperatures at the cover liner, shallow depth, middle depth, great depth, and bottom liner locations are presented in Figure 4.61 for the British Columbia climate. The vertical temperature profile 
results at the time of maximum difference between HES and baseline temperatures are presented in Figure 4.62 for the British Columbia climate. Additional plots for all other climate simulations are presented in Appendix A. 

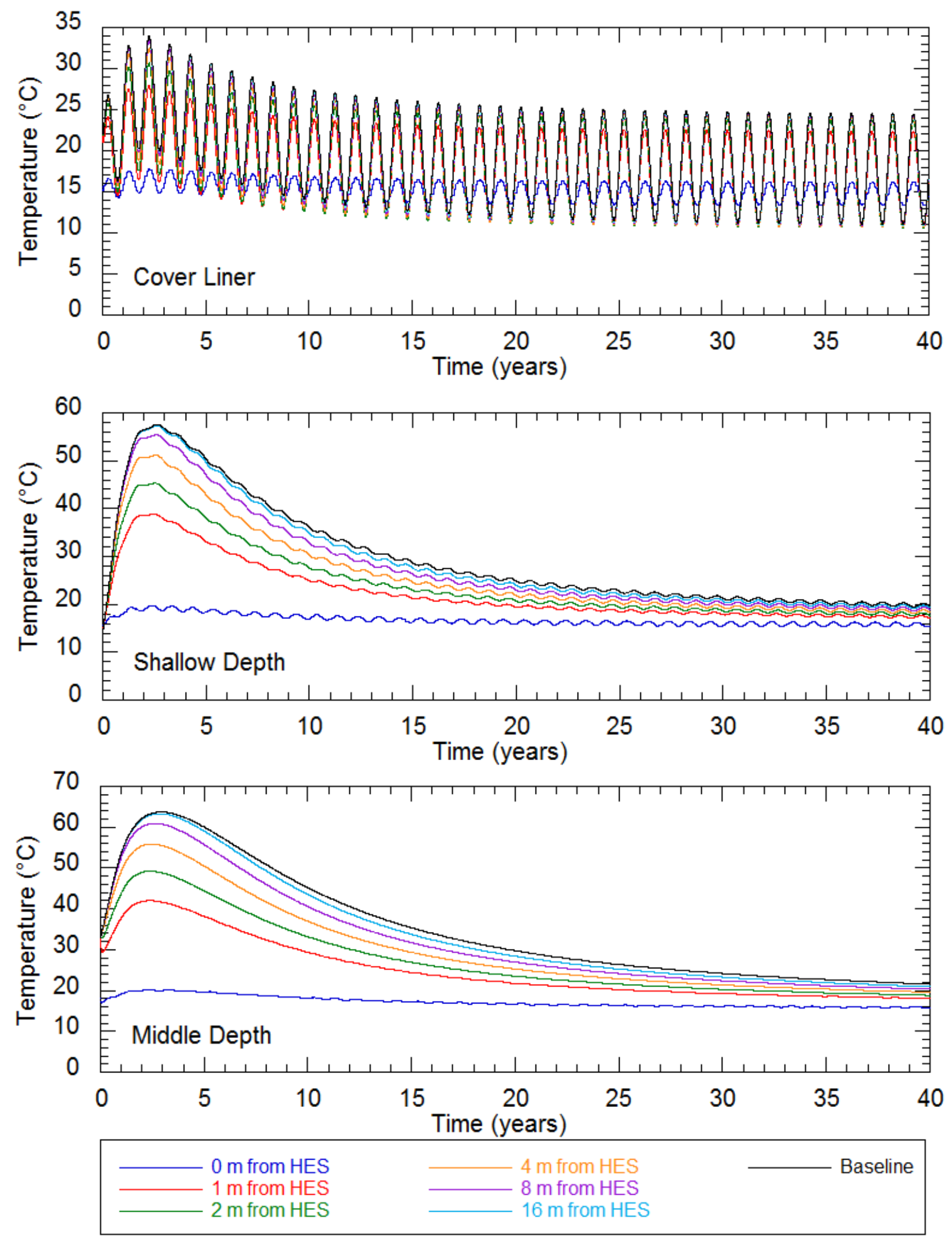

Figure 4.61a: Temperature Results: British Columbia Climate 

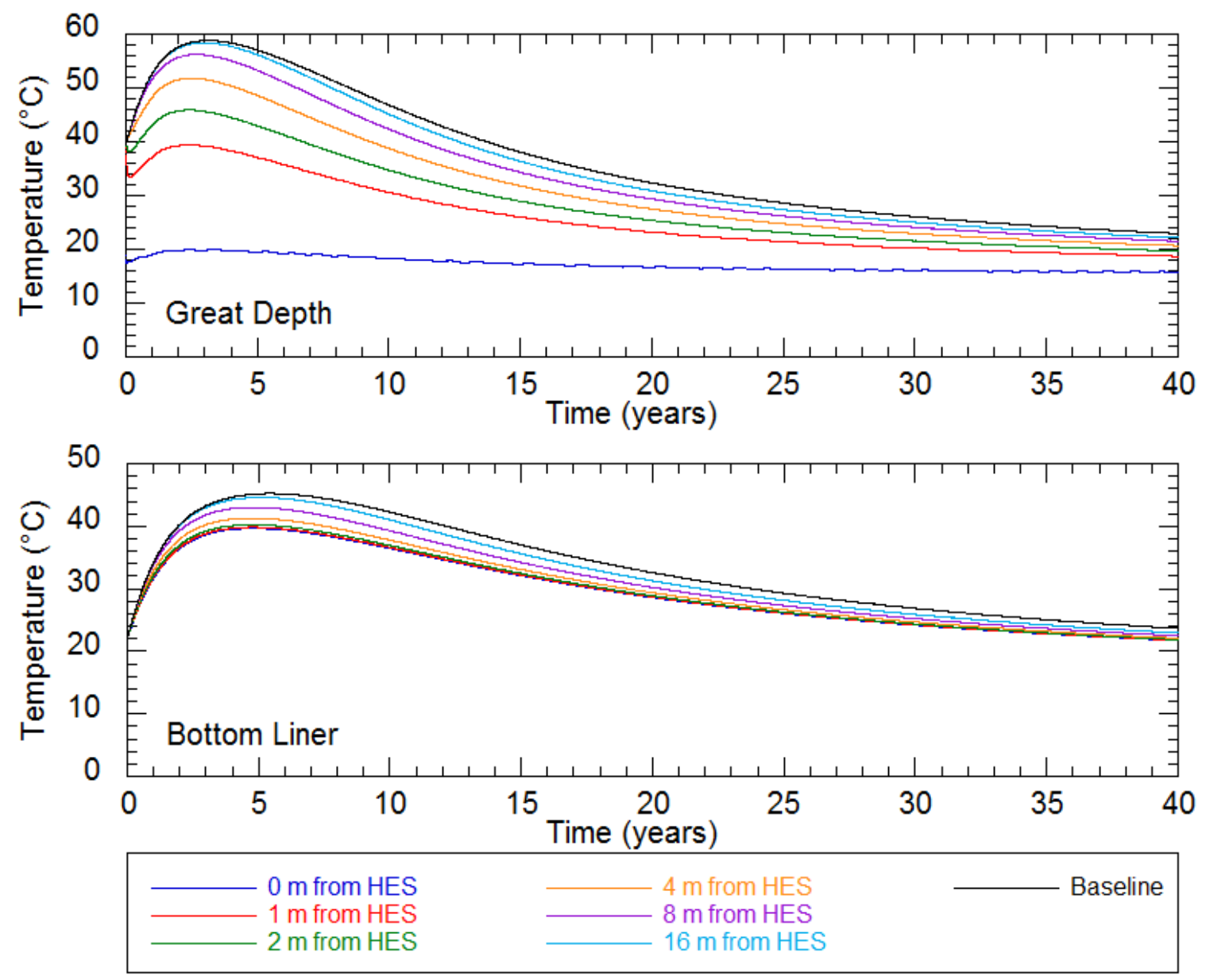

Figure 4.61b: Temperature Results: British Columbia Climate

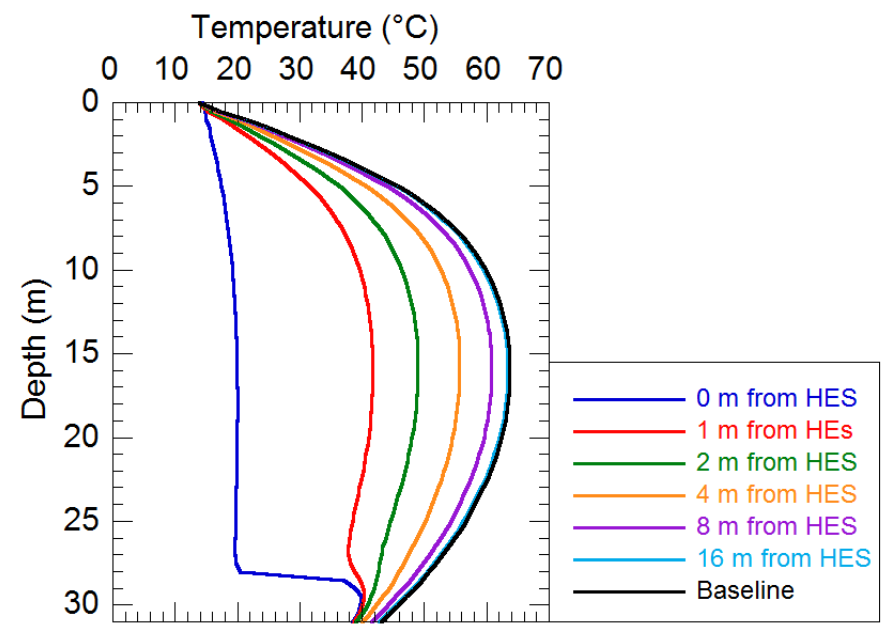

Figure 4.62: Vertical Temperature Results: British Columbia Climate 
The heat extraction results for the climate simulations are presented in Table 4.33. The British Columbia climate simulation had maximum heat extraction rates and total heat energy extracted. The range in expected heat extraction rates for the climate simulations are presented in Table 4.34. Maximum total heat energy extracted was determined to be $1,400,000 \mathrm{MJ}$ over a 40 year period. The total heat energy extracted was $220,400 \mathrm{MJ}$ over a 38.7 year period in the New Mexico climate. No heat extraction phase was present in the Alaska climate. The peak heat extraction rate occurred 2.2 to 3.2 years after start of HES operation. The average seasonal heat extraction rate amplitude ranged from 76 to $140 \mathrm{~W}$. The heat extraction rates and annual average heat extraction rates for the different climates are presented in Figures 4.63 and 4.64, respectively.

Table 4.33: Climate Heat Extraction Results

\begin{tabular}{|c|c|c|c|c|}
\hline Climate & $\begin{array}{c}\text { Peak Heat } \\
\text { Extraction } \\
\text { Rate }(\mathrm{W})\end{array}$ & $\begin{array}{c}\text { Time To } \\
\text { Peak (years) }\end{array}$ & $\begin{array}{c}\text { Average } \\
\text { Seasonal } \\
\text { Amplitude }(\mathrm{W})\end{array}$ & $\begin{array}{c}\text { Total Heat } \\
\text { Extracted } \\
\text { (MJ) }\end{array}$ \\
\hline Alaska & 170 & 3.2 & 118 & $1,200^{\mathrm{a}}$ \\
\hline British Columbia & 3080 & 2.2 & 109 & $1,400,000^{*}$ \\
\hline Michigan & 1230 & 3.2 & 140 & $561,100^{*}$ \\
\hline New Mexico & 500 & 2.2 & 76 & $220,400^{*}$ \\
\hline
\end{tabular}

${ }^{a}$ seasonally over a 6 month period (behaved as a ground source heat pump)

* over a 40 year period

${ }^{* *}$ over a 38.7 year period 
Table 4.34: Expected Range of Heat Extraction Rates for Climate Simulations

\begin{tabular}{|c|c|c|c|c|c|c|}
\hline \multirow{2}{*}{ Climate } & \multicolumn{2}{|c|}{$\begin{array}{c}\text { Heat Extraction } \\
\text { During 1st year } \\
\text { of Operation } \\
\text { (W) }\end{array}$} & \multicolumn{2}{|c|}{$\begin{array}{c}\text { Heat Extraction } \\
\text { During Year of } \\
\text { Peak Heat } \\
\text { Extraction (W) }\end{array}$} & \multicolumn{2}{c|}{$\begin{array}{c}\text { Heat Extraction } \\
\text { During Last Year } \\
\text { of Operation } \\
\text { (W) }\end{array}$} \\
\cline { 2 - 7 } & Max & Min & Max & Min & Max & Min \\
\hline Alaska $^{*}$ & 160 & -80 & 170 & -70 & 130 & -100 \\
\hline British Columbia $^{*}$ & 2550 & 1450 & 3080 & 2880 & 460 & 310 \\
\hline Michigan & 950 & 680 & 1230 & 940 & 310 & 40 \\
\hline New Mexico & 390 & 240 & 500 & 360 & 150 & 0 \\
\hline
\end{tabular}

* last year is year 40

${ }^{a}$ last year is year 38

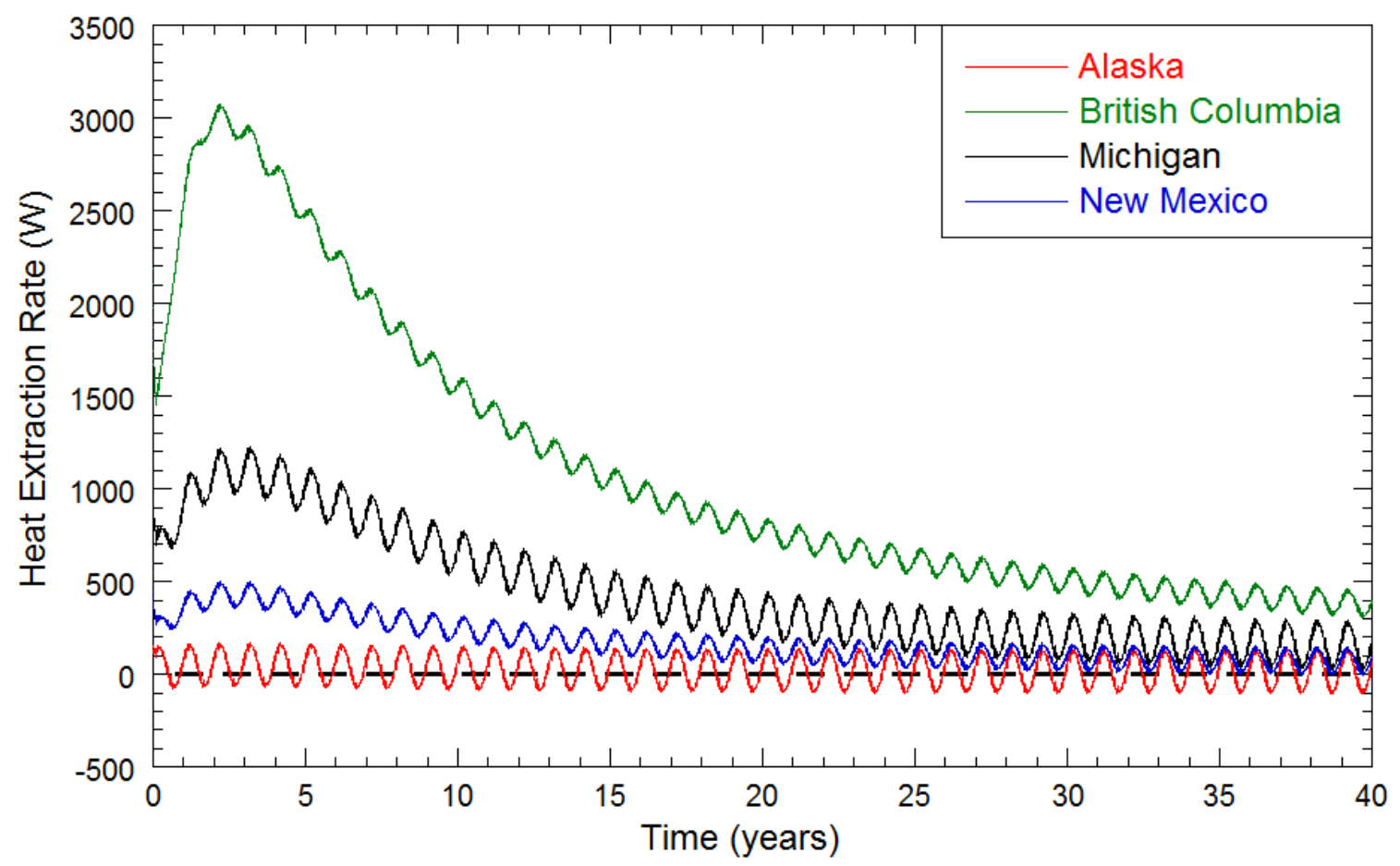

Figure 4.63: Heat Extraction Rates for Different Climates 


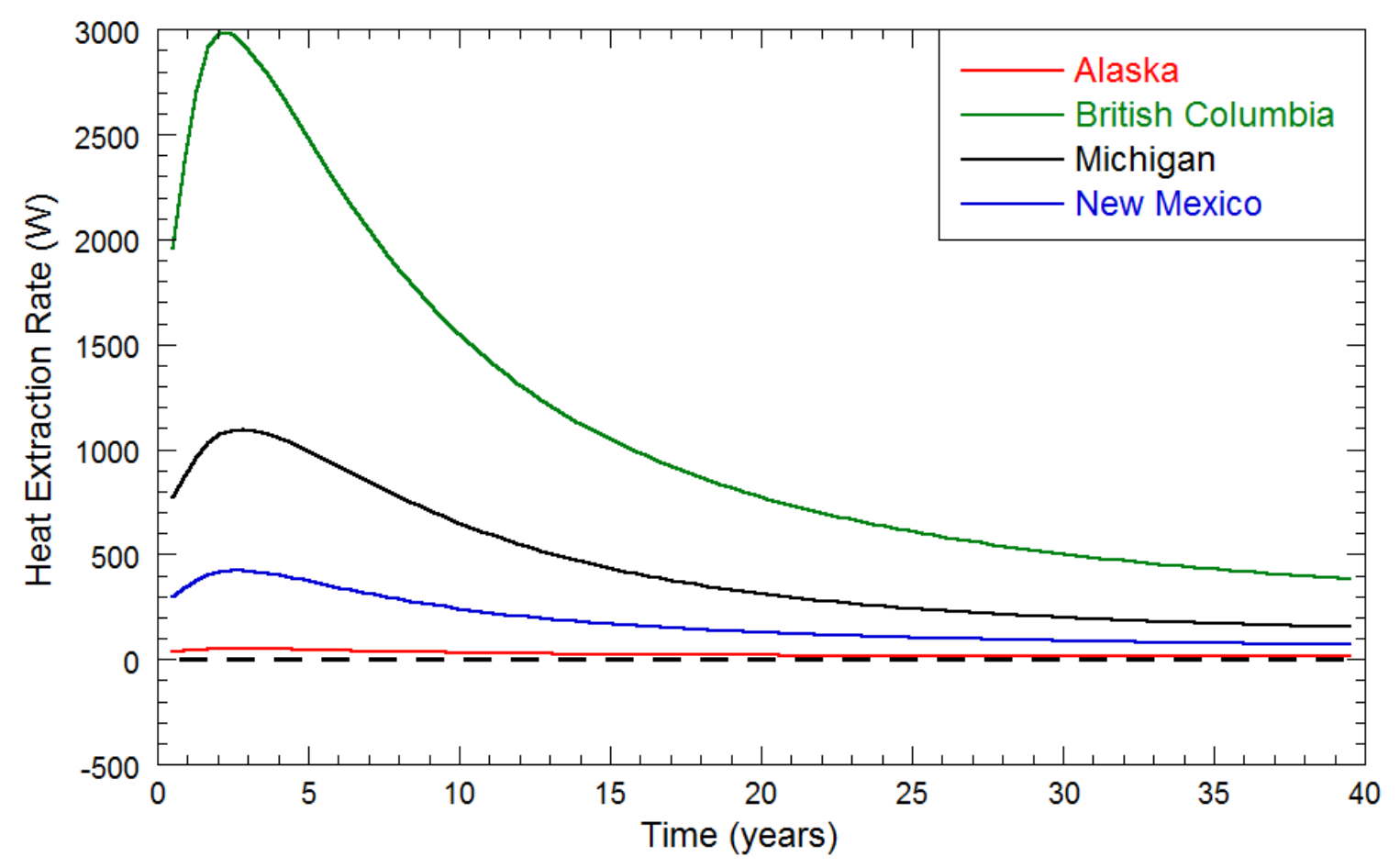

Figure 4.64: Annual Average Heat Extraction Rates for Different Climates

The Alaska simulation did not demonstrate a heat extraction phase as some of the waste was placed at temperatures below $0^{\circ} \mathrm{C}$. Frozen wastes impacted heat generation and the baseline temperatures. The heat generation function was empirically determined by Liu (2007) with temperatures not in optimum heat generating temperatures $\left(30\right.$ to $50^{\circ} \mathrm{C}$ ) and increasing waste temperatures near the HES could potentially increase the heat generation rate function. It is possible that operation of the HES would result in increased temperatures near the HES and a new heat generation function would be required. While the Alaska climate might have a higher heat generating capacity than what was simulated, the Alaska climate simulation still showed promise as a ground source heat pump (extracting and rejecting heat seasonally). 
Higher baseline temperatures were predicted in climates with higher heat generation rates (as a result of higher precipitation). Higher baseline temperatures caused an increase in the maximum differences between baseline temperatures and temperatures $0 \mathrm{~m}$ away from the HES, peak heat extraction rates, and total heat energy extracted. The maximum temperature difference between baseline temperatures and temperatures $0 \mathrm{~m}$ away from the HES increased by $16.6{ }^{\circ} \mathrm{C}$ for every $1 \mathrm{~W} / \mathrm{m}^{3}$ increase in the peak heat generation rate (Figure 4.65).

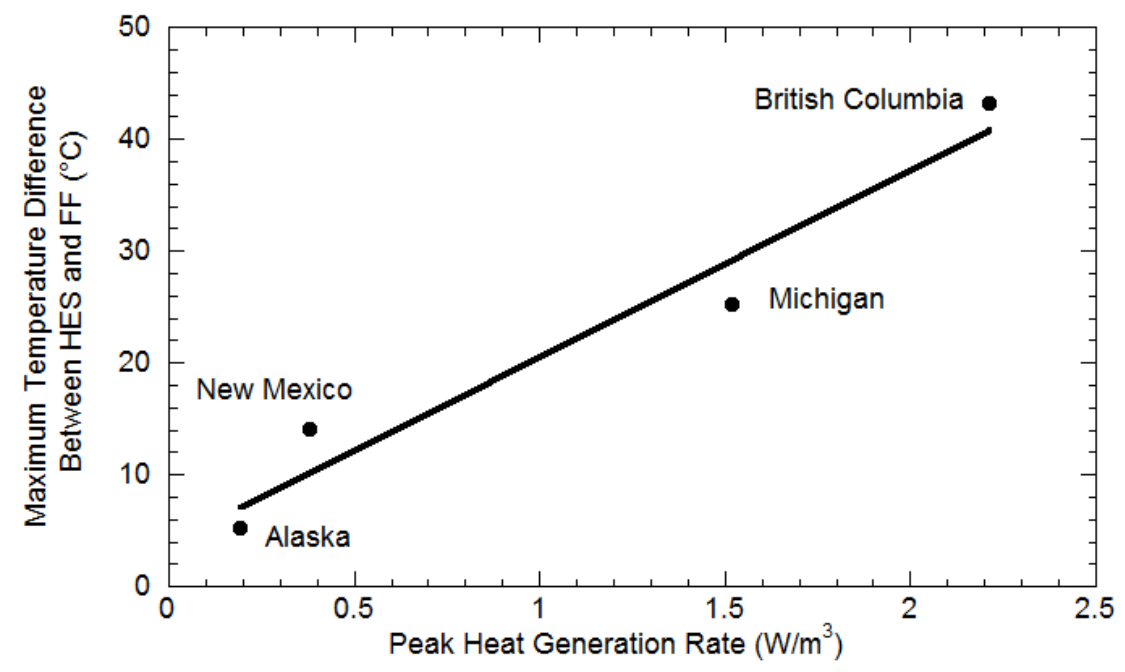

Figure 4.65: Effect of Heat Generation Rate on the Maximum Temperature Difference

\subsubsection{Waste Heating Results}

Waste heating simulations were conducted on the template landfill model and only the inlet temperature of the HES was varied. Waste heating was simulated for the Alaska climate by specifying the inlet fluid temperature to be $50^{\circ} \mathrm{C}$ when determining fluid temperatures. Temperature results, heat extraction 
results, and trends for the waste heating simulations are discussed in this section.

Peak baseline temperatures (temperatures at the radial far field boundary) were $20.0,8.0,11.3,10.9$, and $5.8^{\circ} \mathrm{C}$ for the cover liner, shallowdepth, middle-depth, great-depth, and bottom liner locations, respectively. The average temperatures along the length of the HES were 25.1, 13.9, 9.2, and $7.4^{\circ} \mathrm{C}$ for the cover liner, shallow-depth, middle-depth, and great-depth locations, respectively. Peak bottom liner temperature beneath the HES was $5.7^{\circ} \mathrm{C}$.

Waste heating occurred primarily at shallow depths within the landfill. The time to maximum waste heating was determined to be 1.4 years after the vertical HES was placed. At the time of maximum waste heating, temperatures $0 \mathrm{~m}$ away from the HES were greater than baseline temperatures at depths of 0 to $15.5 \mathrm{~m}$ and less than baseline temperatures at depths from 15.5 to $28 \mathrm{~m}$. Baseline temperatures approached mean annual earth temperatures after approximately 20 years. Temperatures in waste that was placed at higher temperatures than mean annual earth temperatures decreased over time. Temperatures in waste that was placed at lower temperatures than mean annual earth temperatures increased over time. Bottom liner temperatures beneath the HES differed from baseline bottom liner temperatures by $0.1^{\circ} \mathrm{C}$. Temperatures at the cover liner, shallow-depth, middle-depth, great-depth, and bottom liner are presented in Figure 4.66. The vertical temperature profile results at the time of maximum difference between HES and baseline temperatures are presented in Figure 4.67. 

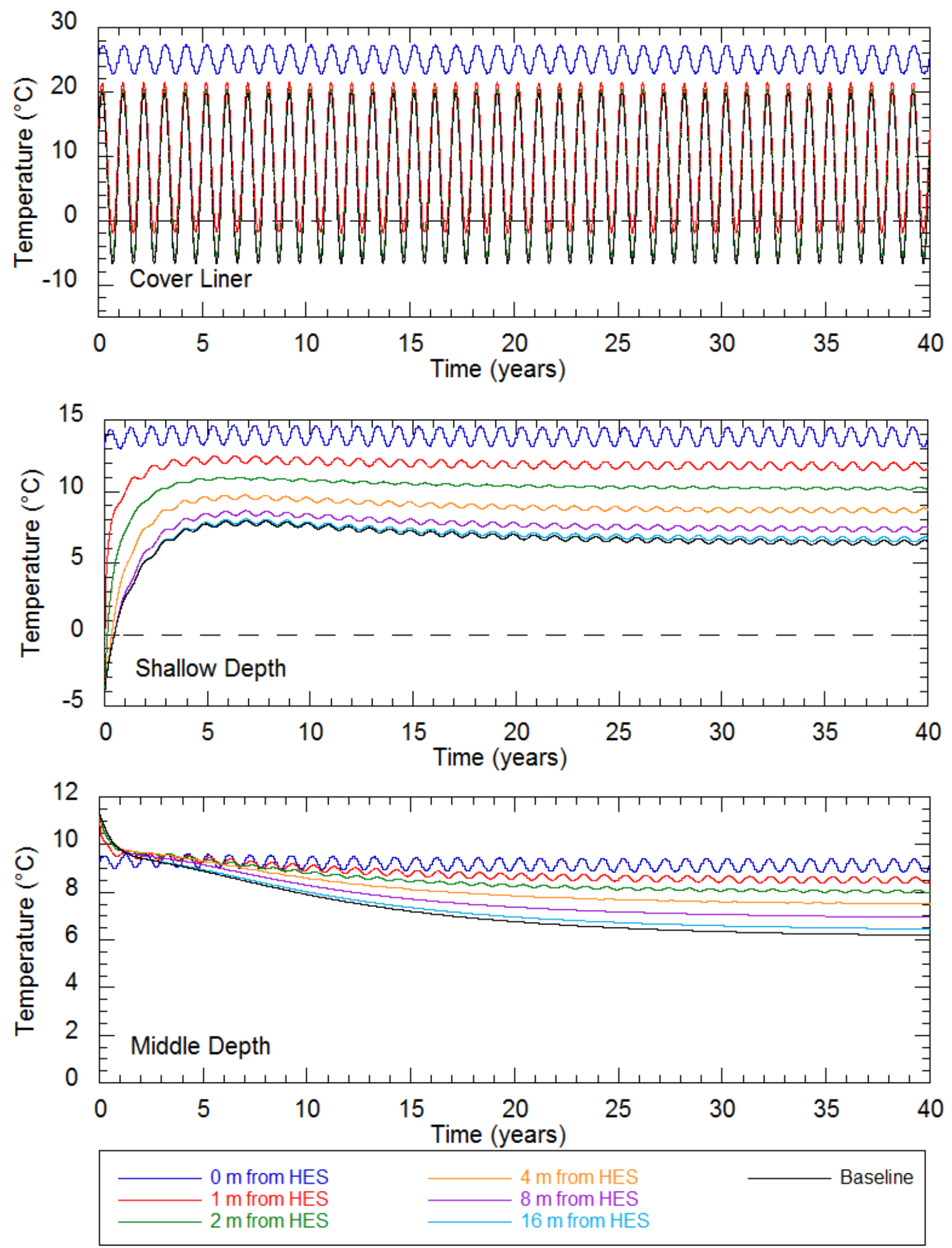

Figure 4.66a: Temperature Results: Waste Heating 

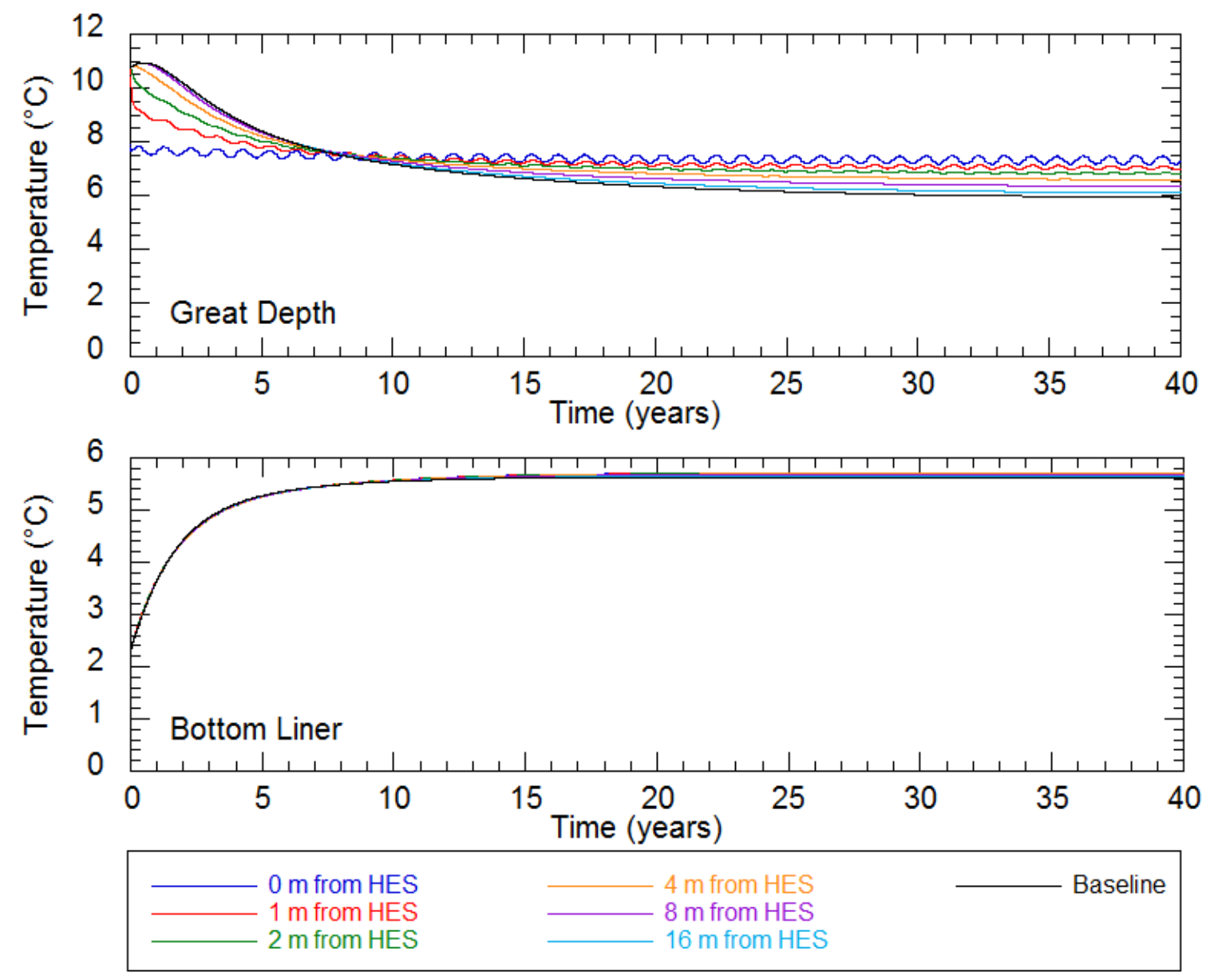

Figure 4.66b: Temperature Results: Waste Heating

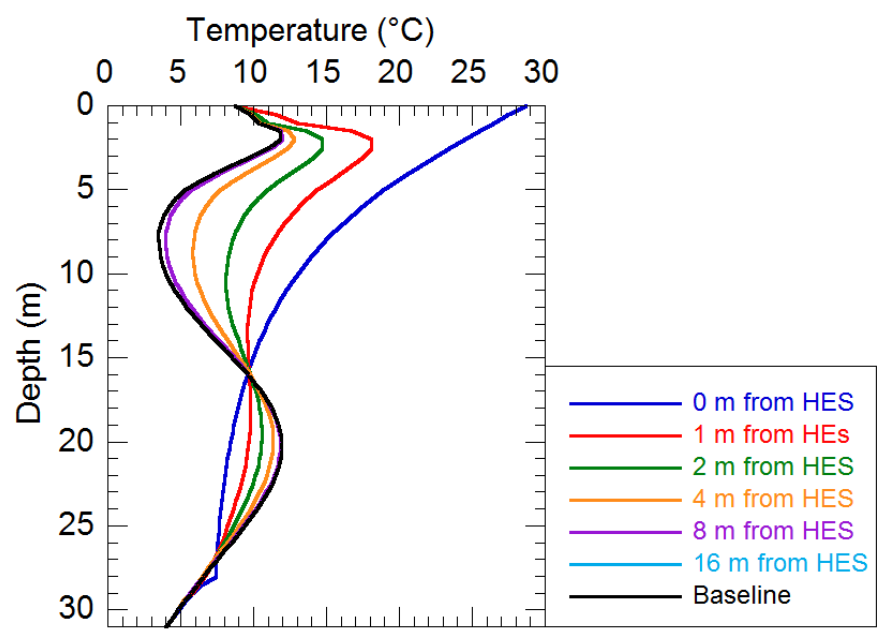

Figure 4.67: Vertical Temperature Results: Waste Heating 
For the waste heating operation, the rejection rates (i.e., heat input to the waste mass) ranged from 170 to $440 \mathrm{~W}$. Heat rejected over a 40 year period for waste heating operation was determined to be $390,000 \mathrm{MJ}$. The maximum heat rejection rate occurred 0.7 years after start of the waste heating operation. The average seasonal heat extraction rate amplitude was $119 \mathrm{~W}$. Heat rejection stabilized after 7 years to an Annual average of approximately $300 \mathrm{~W}$ as temperatures stabilized in the landfill. The heat extraction rates and annual average heat extraction rates for waste heating are presented in Figures 4.68 and 4.69 , respectively.

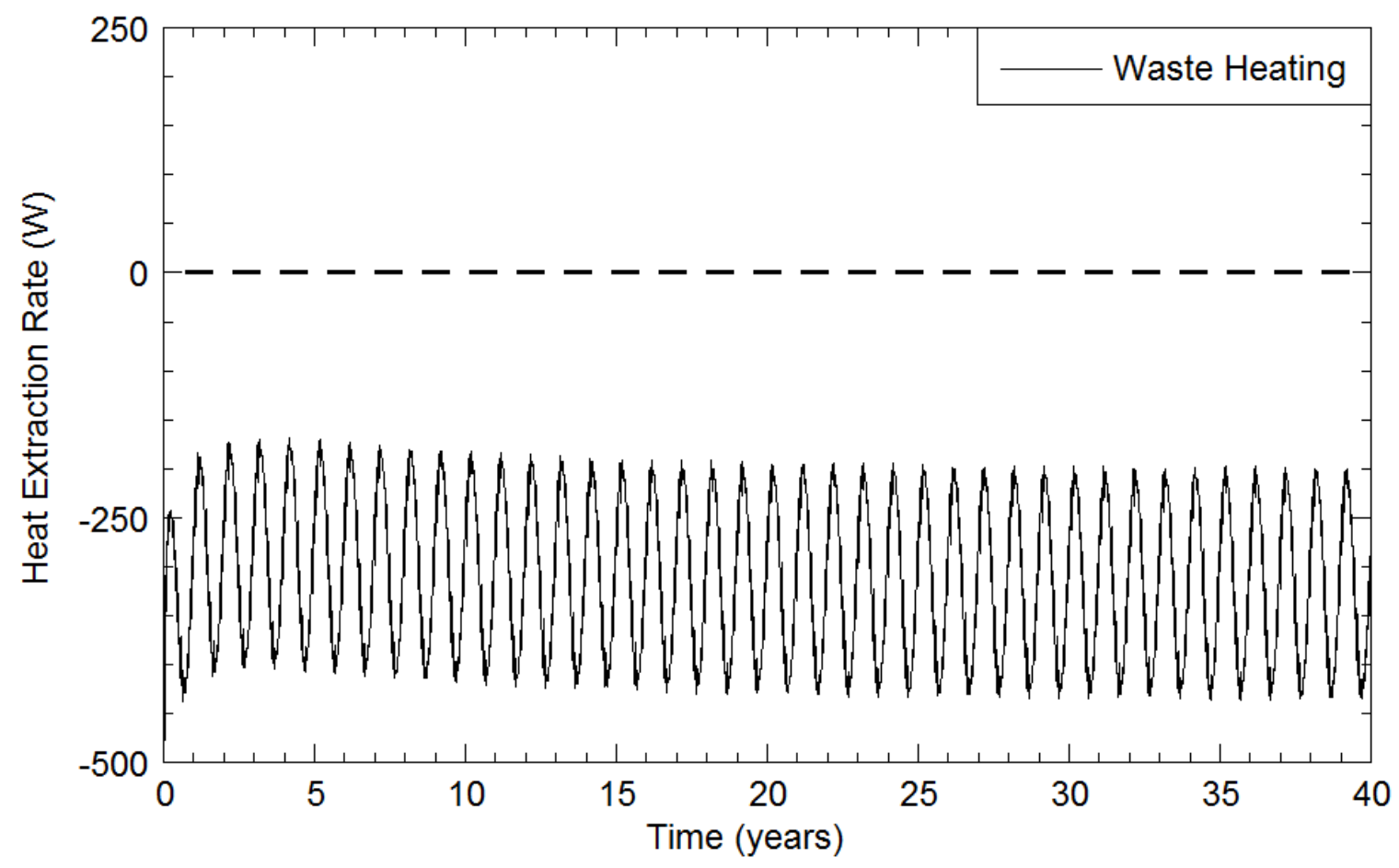

Figure 4.68: Heat Extraction Rates during Waste Heating 


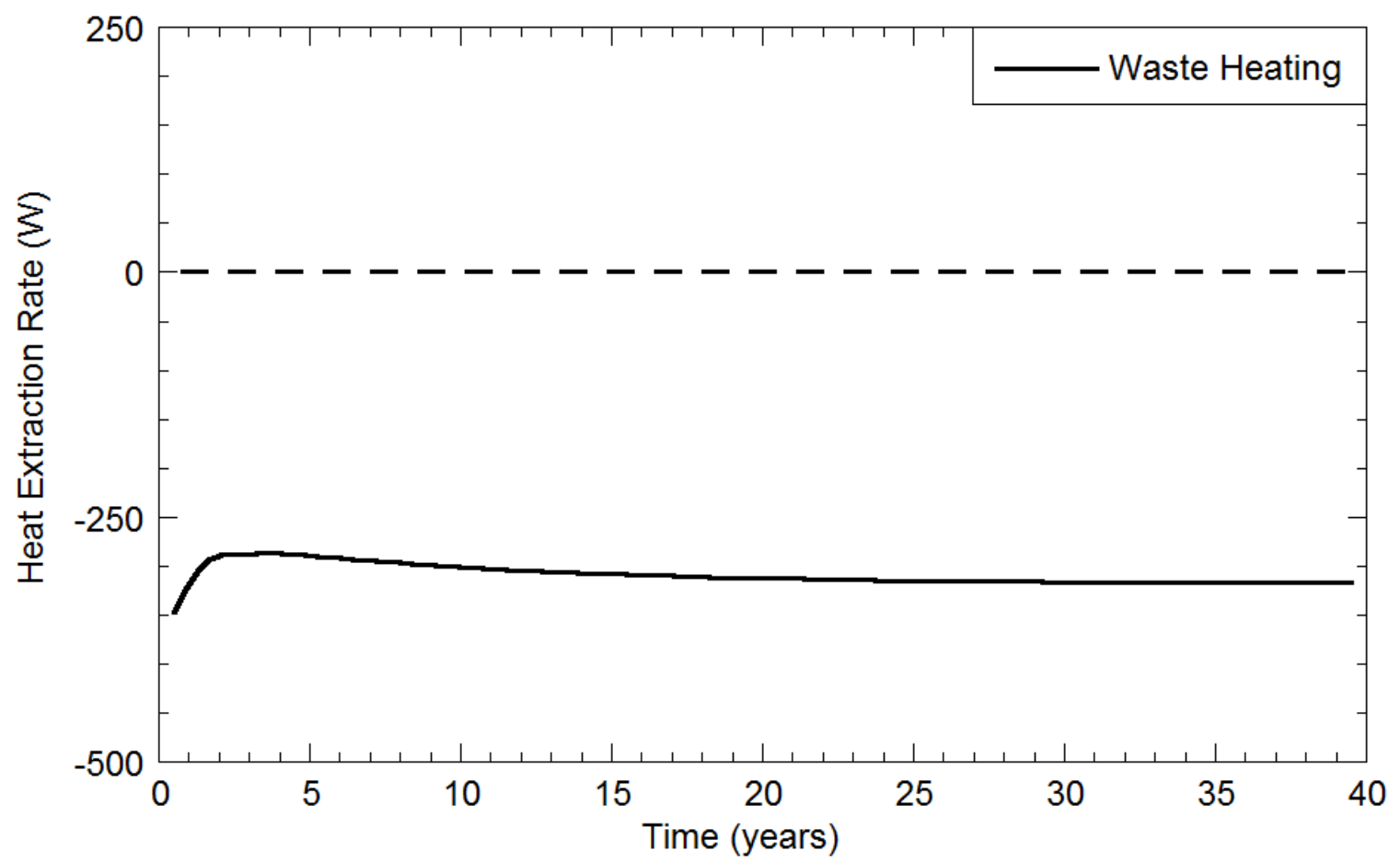

Figure 4.69: Annual Average Heat Extraction Rates during Waste Heating

The impact of the vertical HES on temperatures near the HES was most noticeable at shallow depths. The increased inlet temperature caused temperatures along the length of the HES to decrease exponentially as heat was transferred to the waste mass. At greater depths, the operation of the HES resulted in deceased temperatures for the first 7 years.

An increase in low waste temperatures (such as those determined in the Alaska climate simulations) would potentially increase gas production rates. Waste temperatures near the HES became closer to optimum temperatures for gas production than baseline waste temperatures. Inlet temperatures could be optimized such that optimum gas production is obtained. 


\section{Chapter 5: Engineering Significance}

\subsection{Introduction}

Relevant engineering considerations for implementing a vertical HES in a landfill are presented in this chapter. The order of topics discussed in this chapter is: spacing, economic considerations, and HES effect on gas production.

\subsection{Spacing}

The spacing requirements presented are determined for negligible impact of the vertical HES on surrounding wells. The wells can be configured horizontally in either a rectangular spacing or a triangular spacing configuration (Figure 5.1).

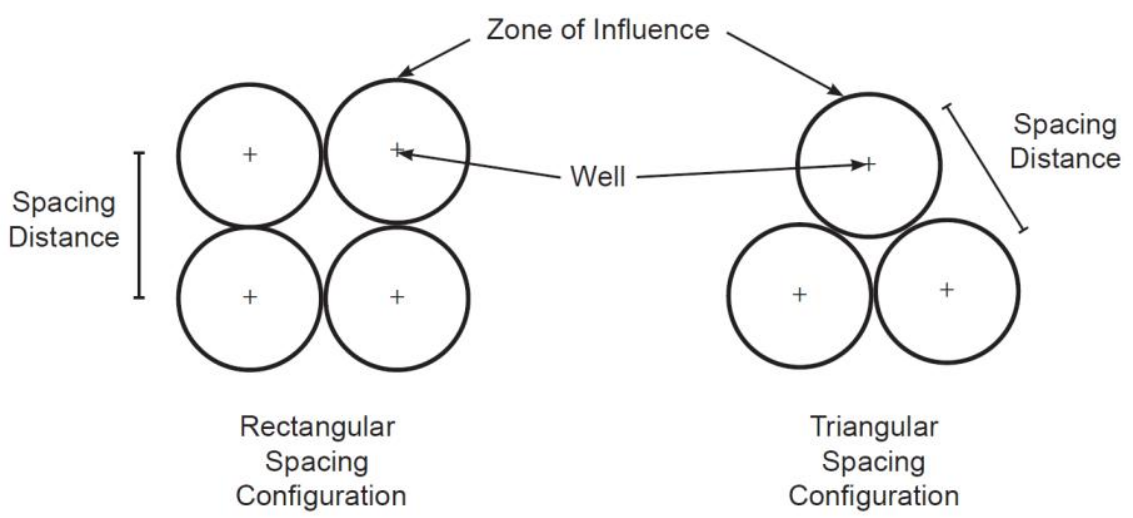

Figure 5.1: Horizontal Spacing Configurations

To determine the horizontal distance required (i.e. zone of influence for a single well) for negligible impact of the vertical HES on surrounding wells, the horizontal temperature gradients were analyzed. Horizontal temperature gradients varied based on distance away from the well and depth within the waste mass. Temperature gradients decreased as distance away from the well 
increased. Maximum temperature gradients at a given distance away from the well occurred at the midpoint along the simulated waste depth.

The zone of influence for a single well was determined for the most efficient horizontal spacing configuration (i.e., negligible impact of the well on adjacent wells). Negligible impact of the well on surrounding wells was established as smaller dimension of either the average radial temperature gradient for the entire depth of waste to be less than $0.25^{\circ} \mathrm{C} / \mathrm{m}$ or maximum radial temperature gradient to be less than $0.5^{\circ} \mathrm{C} / \mathrm{m}$. Temperature gradients were highest at the time when the maximum difference between baseline temperatures and temperatures $0 \mathrm{~m}$ away from the HES occurred. Spacing distances (the well to well distances) were calculated using the temperature profile (horizontal and vertical) from the time when the maximum difference between baseline temperatures and temperatures $0 \mathrm{~m}$ away from the HES occurred. Using the established criteria, the zone of influence for a single well was calculated for both the pipe diameter and fluid velocity simulations (Table 5.1) and the operational simulations (Table 5.2).

The most efficient spacing distance was determined to be twice the zone of influence, as multiple wells would have negligible impact on each other. The maximum difference between baseline temperatures and temperatures $0 \mathrm{~m}$ away from the HES (results can be found in Chapter 4) resulted in different spacing distances. Landfills with a higher maximum difference between baseline temperatures and temperatures $0 \mathrm{~m}$ away from the HES resulted in a higher spacing distance. Landfills with a lower maximum difference between baseline 
temperatures and temperatures $0 \mathrm{~m}$ away from the HES resulted in a lower spacing distances.

Table 5.1: Pipe Diameter and Fluid Velocity Simulations Zone of Influence Results

\begin{tabular}{|c|c|c|c|c|c|}
\hline Simulation & $\begin{array}{c}\text { Pipe } \\
\text { Diameter } \\
(\mathrm{mm})\end{array}$ & $\begin{array}{c}\text { Velocity } \\
(\mathrm{m} / \mathrm{s})\end{array}$ & $\begin{array}{c}\text { Avg. Temp. } \\
\text { Gradient } \\
\left({ }^{\circ} \mathrm{C} / \mathrm{m}\right)\end{array}$ & $\begin{array}{c}\text { Max. Temp. } \\
\text { Gradient } \\
\left({ }^{\circ} \mathrm{C} / \mathrm{m}\right)\end{array}$ & $\begin{array}{c}\text { Zone of } \\
\text { Influence } \\
\text { Radius } \\
(\mathrm{m})\end{array}$ \\
\hline 1 & 25.4 & 0.01 & 0.21 & 0.32 & 9 \\
\hline 2 & 25.4 & 0.1 & 0.24 & 0.36 & 9 \\
\hline 3 (Typ.) & 25.4 & 0.3 & 0.21 & 0.32 & 10 \\
\hline 4 & 25.4 & 0.6 & 0.21 & 0.32 & 10 \\
\hline 5 & 25.4 & 1.0 & 0.22 & 0.32 & 10 \\
\hline 6 & 38.1 & 0.01 & 0.22 & 0.34 & 9 \\
\hline 7 & 38.1 & 0.1 & 0.25 & 0.37 & 9 \\
\hline 8 & 38.1 & 0.3 & 0.22 & 0.32 & 10 \\
\hline 9 & 38.1 & 0.6 & 0.22 & 0.33 & 10 \\
\hline 10 & 38.1 & 1.0 & 0.22 & 0.33 & 10 \\
\hline 11 & 50.8 & 0.01 & 0.23 & 0.34 & 9 \\
\hline 12 & 50.8 & 0.1 & 0.25 & 0.37 & 9 \\
\hline 13 & 50.8 & 0.3 & 0.22 & 0.33 & 10 \\
\hline 14 & 50.8 & 0.6 & 0.22 & 0.33 & 10 \\
\hline 15 & 50.8 & 1.0 & 0.22 & 0.34 & 10 \\
\hline
\end{tabular}

${ }^{*}$ maximum temperature gradient over the entire depth at the distance of the zone of influence Typ. = template landfill model used to compare with operational simulations

Laminar pipe flow yielded spacing results of $18 \mathrm{~m}$, while turbulent flow yielded spacing results of $20 \mathrm{~m}$. Spacing distance for the waste placement starting month ranged from 18 to $20 \mathrm{~m}$. Waste placement that began in and ended in colder months (November and December) had smaller spacing requirements than other waste placement starting months. Spacing distance for seasonal placement in only winter and only summer were determined to be 12 and $22 \mathrm{~m}$, respectively. 
Spacing distances for the waste height simulations were determined to be 12,20 , and $22 \mathrm{~m}$ for the 15,30 , and $45 \mathrm{~m}$ waste heights, respectively. Waste filling rate spacing distances were determined to be 18,18 , and $20 \mathrm{~m}$ for the 5 , 12 and $29 \mathrm{~m} /$ year filling rates. Spacing distance results for the vertical landfill expansion simulations were determined to be 20,16 , and $14 \mathrm{~m}$ for a landfill without vertical landfill expansions, expansion 5 years after intermediate cover construction, and expansion 15 years after intermediate cover construction, respectively.

Spacing distances for the vertical HES placement time simulations were 20, 18 , and $18 \mathrm{~m}$ for the HES placed 1 day, 1 year, and 5 years after final cover placement, respectively. The HES operation only in winter was determined to have spacing requirements of $12 \mathrm{~m}$.

Spacing distances for the different climates were determined to be 4, 22, 20, and $16 \mathrm{~m}$ for the Alaska, British Columbia, Michigan, and New Mexico sites. The Alaska site resulted in a very small spacing distance due to the low maximum difference between baseline temperatures and temperatures $0 \mathrm{~m}$ away from the HES resulting from the presence of the frozen waste mass. Spacing requirements at Alaska would increase if the impact of the wells caused a change in the heat generation function at the Alaska Climate. For waste heating, a spacing of $12 \mathrm{~m}$ was determined using the same threshold as spacing for heat extraction. 
Table 5.2: Operational Simulations Zone of Influence Results

\begin{tabular}{|c|c|c|c|c|}
\hline Operational Condition & Variable & $\begin{array}{c}\text { Avg. } \\
\text { Temp. } \\
\text { Gradient* } \\
\left({ }^{\circ} \mathrm{C} / \mathrm{m}\right)\end{array}$ & $\begin{array}{c}\text { Max. } \\
\text { Temp. } \\
\text { Gradient* } \\
\left({ }^{\circ} \mathrm{C} / \mathrm{m}\right)\end{array}$ & $\begin{array}{c}\text { Zone of } \\
\text { Influence } \\
\text { Radius } \\
(\mathrm{m})\end{array}$ \\
\hline \multirow{11}{*}{$\begin{array}{c}\text { Waste Placement Starting } \\
\text { Month }\end{array}$} & Jan & 0.21 & 0.32 & 10 \\
\hline & Mar & 0.22 & 0.33 & 10 \\
\hline & Apr & 0.23 & 0.34 & 10 \\
\hline & May & 0.23 & 0.34 & 10 \\
\hline & Jun & 0.23 & 0.35 & 10 \\
\hline & Jul & 0.23 & 0.35 & 10 \\
\hline & Aug & 0.23 & 0.34 & 10 \\
\hline & Sep & 0.22 & 0.33 & 10 \\
\hline & Oct & 0.21 & 0.32 & 10 \\
\hline & Nov & 0.25 & 0.38 & 9 \\
\hline & Dec & 0.24 & 0.36 & 9 \\
\hline \multirow{2}{*}{ Seasonal Waste Placement } & WO & 0.21 & 0.32 & 6 \\
\hline & SO & 0.20 & 0.30 & 11 \\
\hline \multirow{2}{*}{ Waste Height $(\mathrm{m})$} & 15 & 0.24 & 0.38 & 6 \\
\hline & 45 & 0.22 & 0.34 & 11 \\
\hline \multirow{2}{*}{ Waste Filling Rate (m/year) } & 5 & 0.21 & 0.32 & 9 \\
\hline & 12 & 0.25 & 0.37 & 9 \\
\hline \multirow{2}{*}{$\begin{array}{c}\text { Time Between Vertical Landfill } \\
\text { Expansions (years) }\end{array}$} & 5 & 0.23 & 0.34 & 8 \\
\hline & 15 & 0.21 & 0.35 & 7 \\
\hline \multirow{2}{*}{$\begin{array}{l}\text { HES Placement Time After } \\
\text { Cover Placement (years) }\end{array}$} & 1 & 0.25 & 0.37 & 9 \\
\hline & 5 & 0.22 & 0.34 & 9 \\
\hline HES Operation & WO & 0.18 & 0.28 & 6 \\
\hline \multirow{4}{*}{ Climate } & $\mathrm{AK}$ & 0.23 & 0.40 & 2 \\
\hline & $\mathrm{BC}$ & 0.23 & 0.31 & 11 \\
\hline & $\mathrm{Ml}$ & 0.21 & 0.32 & 10 \\
\hline & NM & 0.21 & 0.31 & 8 \\
\hline Waste Heating (inlet temp. ${ }^{\circ} \mathrm{C}$ ) & 50 & 0.10 & 0.39 & 6 \\
\hline
\end{tabular}

* maximum temperature gradient over the entire depth at the distance of the zone of influence $\mathrm{WO}=$ winter-only

$\mathrm{SO}=$ summer-only

$\mathrm{AK}=$ Alaska

$\mathrm{BC}=$ British Columbia

$\mathrm{MI}=$ Michigan

$\mathrm{NM}=$ New Mexico 
A triangular spacing configuration is recommended as the volume of waste outside the zone of influence between wells is lower than for rectangular spacing. For year-round operation, if the expected maximum difference between baseline temperatures and temperatures $0 \mathrm{~m}$ away from the HES is greater than $17^{\circ} \mathrm{C}$, then a spacing of $22 \mathrm{~m}$ is recommended. For year-round operation, if the expected maximum difference between baseline temperatures and temperatures $0 \mathrm{~m}$ away from the HES is less than $17^{\circ} \mathrm{C}$, then a spacing of $16 \mathrm{~m}$ is recommended. For operation of the HES in only winter, a spacing of $12 \mathrm{~m}$ is recommended. For waste heating, a spacing of $12 \mathrm{~m}$ is recommended.

\subsection{Economics}

The approximate costs associated with of installation and operation of a vertical HES are presented in this section. Actual costs depend on intended use and landfill geometry; therefore, economic viability of the system should be assessed based on site-specific design. The example presented includes a single vertical HES well used to heat a building $600 \mathrm{~m}$ away. The cost of each of the 15 configurations was determined using recent available prices. The prices of the various components for a single well are presented in Table 5.3.

To determine the amount of electrical demands for the power required for the pump, the pump power equation (Munson et al. 2009) was used (Equation $5.1)$. 


$$
P=\frac{Q H}{\eta}
$$

Where:

$$
\begin{aligned}
& P=\text { pump power }(\mathrm{kW}) \\
& Q=\text { flow rate }\left(\mathrm{m}^{3} / \mathrm{s}\right) \\
& H=\text { pump head }(\mathrm{m}) \\
& \eta=\text { pump efficiency }
\end{aligned}
$$

Table 5.3: Costs of Components for a Single Vertical HES Well (McMaster-Carr, Ingram's Water and Air Equipment, Bureau of Labor Statistics 2013)

\begin{tabular}{|c|c|c|c|}
\hline Component & Cost/Unit & $\begin{array}{c}\text { Number of } \\
\text { Units }\end{array}$ & Total cost $(\$)$ \\
\hline Drill Rig & $\$ 148.00 / \mathrm{hr}$ & 4 hours & 592.00 \\
\hline $25.4 \mathrm{~mm}$ HDPE Pipe & $\$ 6.00 / \mathrm{m}$ & $56 \mathrm{~m}+1200 \mathrm{~m}$ & 7536.00 \\
\hline $38.1 \mathrm{~mm}$ HDPE Pipe & $\$ 5.35 / \mathrm{m}$ & $56 \mathrm{~m}+1200 \mathrm{~m}$ & 6719.60 \\
\hline $50.8 \mathrm{~mm}$ HDPE Pipe & $\$ 7.02 / \mathrm{m}$ & $56 \mathrm{~m}+1200 \mathrm{~m}$ & 8817.12 \\
\hline Insulation for 25.4 mm Pipe & $\$ 2.82 / \mathrm{m}$ & $1200 \mathrm{~m}$ & 3384.00 \\
\hline Insulation for 38.1 mm Pipe & $\$ 4.09 / \mathrm{m}$ & $1200 \mathrm{~m}$ & 4908.00 \\
\hline Insulation for 50.8 mm Pipe & $\$ 4.41 / \mathrm{m}$ & $1200 \mathrm{~m}$ & 5292.00 \\
\hline Bronze Centrifugal Pump & $\$ 448.96$ & 1 & 448.96 \\
\hline 2'x2'x1/2" Vibration Pad & $\$ 64.24$ & 1 & 62.24 \\
\hline Heat Pump & $\$ 2,429.70$ & 1 & $2,429.70$ \\
\hline Fittings and Connections & $\$ 750$ & 1 & 750.00 \\
\hline Installation Labor & $\$ 40 / \mathrm{hr}$ & $100 \mathrm{hrs}$ & $4,000.00$ \\
\hline Maintenance & $\$ 40 / \mathrm{hr}$ & $40 \mathrm{hrs} /$ year & $\$ 1,600 /$ year \\
\hline Electricity & $\$ 0.158 / \mathrm{kWh}$ & $\star$ & $\star$ \\
\hline
\end{tabular}

* depends on fluid flow rate

Flow rate was calculated for each configuration and an assumed efficiency of 0.7 was used. Pump head was assumed to be equal to frictional head losses as the fluid was flowing in a closed circuit. Equation 5.2 was used to calculate the frictional head losses (Munson et al. 2009). The friction factor was determined using the Moody Diagram (Munson et al. 2009). 


$$
H=\frac{L}{D} f \frac{v^{2}}{2 \mathrm{~g}}
$$

Where:

$$
\begin{aligned}
& H=\text { frictional head losses }(\mathrm{m}) \\
& L=\text { length of pipe }(\mathrm{m}) \\
& D=\text { pipe diameter }(\mathrm{m}) \\
& f=\text { friction factor } \\
& v=\text { velocity }(\mathrm{m} / \mathrm{s}) \\
& \mathrm{g}=\text { gravitational acceleration }\left(\mathrm{m}^{2} / \mathrm{s}\right)
\end{aligned}
$$

The electrical costs for the 0.01 and $0.1 \mathrm{~m} / \mathrm{s}$ fluid velocities were negligible as frictional losses for low flow rates were low. The costs for the pipe diameter and fluid velocity simulations are presented in Table 5.4.

The $38.1 \mathrm{~mm}$ pipe diameter and $0.3 \mathrm{~m} / \mathrm{s}$ fluid velocity was the most cost effective configuration. For all pipe sizes, cost effectiveness peaked for the 0.3 $\mathrm{m} / \mathrm{s}$ fluid velocity (Figure 5.2). The $1 \mathrm{~m} / \mathrm{s}$ fluid velocity was significantly less cost efficient as electrical costs for pumping the fluid over a 40 year period were significantly higher than other configurations. The fluid velocities in order of least cost effective to most cost effective were: $1.0,0.01,0.6,0.1$, and $0.3 \mathrm{~m} / \mathrm{s}$.

Pipe diameter did not have as large of an impact on cost efficiency as the fluid velocity (Figure 5.2). For fluid velocities of 0.1 and $0.01 \mathrm{~m} / \mathrm{s}$, larger pipe diameters were more cost efficient because associated electricity costs were negligible. For the $0.3 \mathrm{~m} / \mathrm{s}$ fluid velocity, cost efficiency peaked for the $38.1 \mathrm{~mm}$ pipe diameter. The 25.4 and $50.8 \mathrm{~mm}$ pipe diameters for the $0.3 \mathrm{~m} / \mathrm{s}$ fluid 
velocity had similar cost efficiencies. For the 0.6 and $1.0 \mathrm{~m} / \mathrm{s}$ fluid velocities, cost efficiency decreased with pipe diameter as the electrical costs increased with increasing pipe diameter. The cost of extracting heat energy could be lowered by implementing multiple vertical HES as more heat energy could be extracted for the similar costs of transporting the heat to the building.

Table 5.4: Costs for Pipe Diameter and Fluid Velocity Simulations

\begin{tabular}{|c|c|c|c|c|c|c|}
\hline $\begin{array}{c}\text { Pipe } \\
\text { Diameter } \\
(\mathrm{mm})\end{array}$ & $\begin{array}{c}\text { Fluid } \\
\text { Velocity } \\
(\mathrm{m} / \mathrm{s})\end{array}$ & $\begin{array}{c}\text { Cost for } \\
\text { Single } \\
\text { Well }(\$)^{\mathrm{a}}\end{array}$ & $\begin{array}{c}\text { Total } \\
\text { Installation } \\
\text { Costs }(\$)\end{array}$ & $\begin{array}{c}\text { Annual } \\
\text { Costs } \\
(\$)\end{array}$ & $\begin{array}{c}\text { Total } \\
\text { Costs }(\$)^{*}\end{array}$ & $\begin{array}{c}\text { Unit } \\
\text { Cost } \\
(\$ / \mathrm{MJ})\end{array}$ \\
\hline \multirow{4}{*}{25.4} & 0.01 & 2,928 & 19,200 & 1,600 & 83,200 & 0.178 \\
\cline { 2 - 7 } & 0.1 & 2,928 & 19,200 & 1,600 & 83,200 & 0.157 \\
\cline { 2 - 7 } & 0.3 & 2,928 & 19,200 & 1,630 & 84,400 & 0.150 \\
\cline { 2 - 7 } & 0.6 & 2,928 & 19,200 & 1,820 & 92,000 & 0.162 \\
\cline { 2 - 7 } & 1.0 & 2,928 & 19,200 & 2,370 & 114,000 & 0.199 \\
\hline \multirow{4}{*}{38.1} & 0.01 & 2,892 & 19,900 & 1,600 & 83,900 & 0.175 \\
\cline { 2 - 7 } & 0.1 & 2,892 & 19,900 & 1,600 & 83,900 & 0.150 \\
\cline { 2 - 7 } & 0.3 & 2,892 & 19,900 & 1,640 & 85,500 & 0.148 \\
\cline { 2 - 7 } & 0.6 & 2,892 & 19,900 & 1,850 & 93,900 & 0.161 \\
\cline { 2 - 7 } & 1.0 & 2,892 & 19,900 & 2,560 & 122,300 & 0.207 \\
\hline \multirow{4}{*}{50.8} & 0.01 & 2,985 & 22,400 & 1,600 & 86,400 & 0.175 \\
\cline { 2 - 7 } & 0.1 & 2,985 & 22,400 & 1,600 & 86,400 & 0.150 \\
\cline { 2 - 7 } & 0.3 & 2,985 & 22,400 & 1,660 & 88,800 & 0.150 \\
\cline { 2 - 7 } & 0.6 & 2,985 & 22,400 & 1,930 & 99,600 & 0.166 \\
\cline { 2 - 7 } & 1.0 & 2,985 & 22,400 & 2,880 & 137,600 & 0.227 \\
\hline
\end{tabular}

* over a 40 year period

a drilling rig, pipe, and 50 hours of labor

Heat extracted from a landfill will be economically viable if utilized on or near the site. Costs associated with piping and pumping the heated fluid as well was the heat lost during transport makes utilizing the heat extracted off site less economically feasible than using the heat extracted near the landfill. 


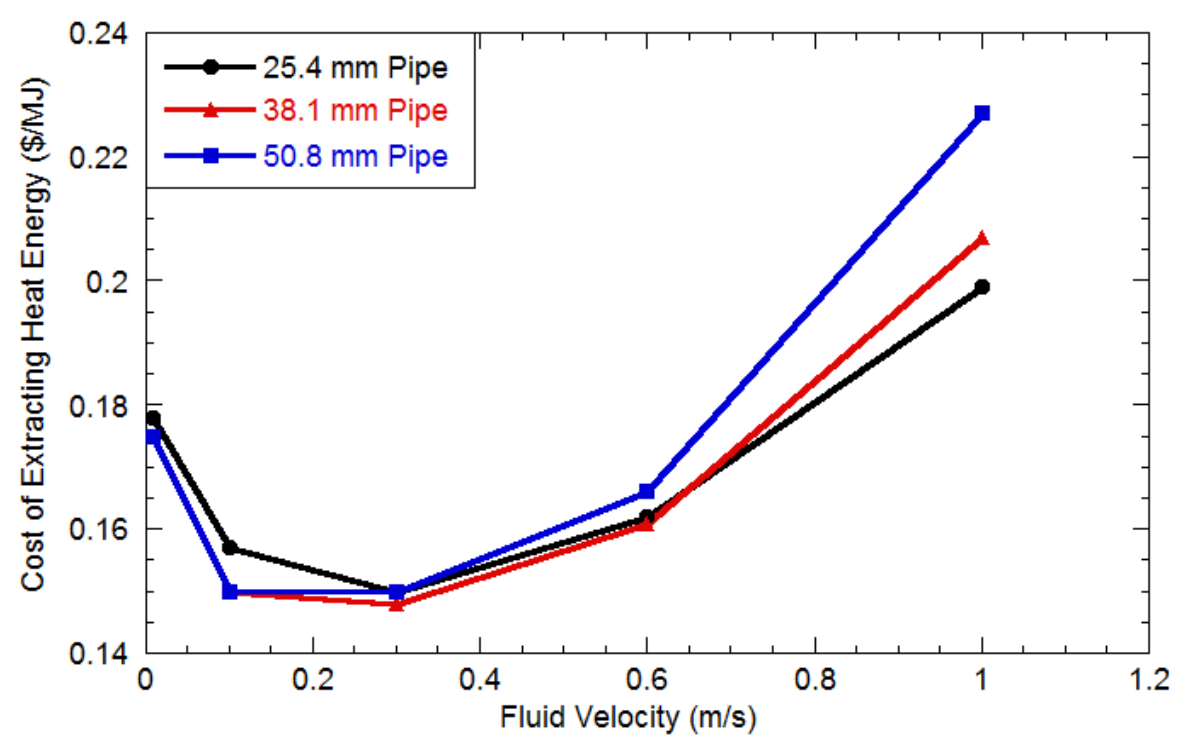

Figure 5.2: Impact of Fluid Velocity on Cost Effectiveness of an HES for Different Pipe Diameters

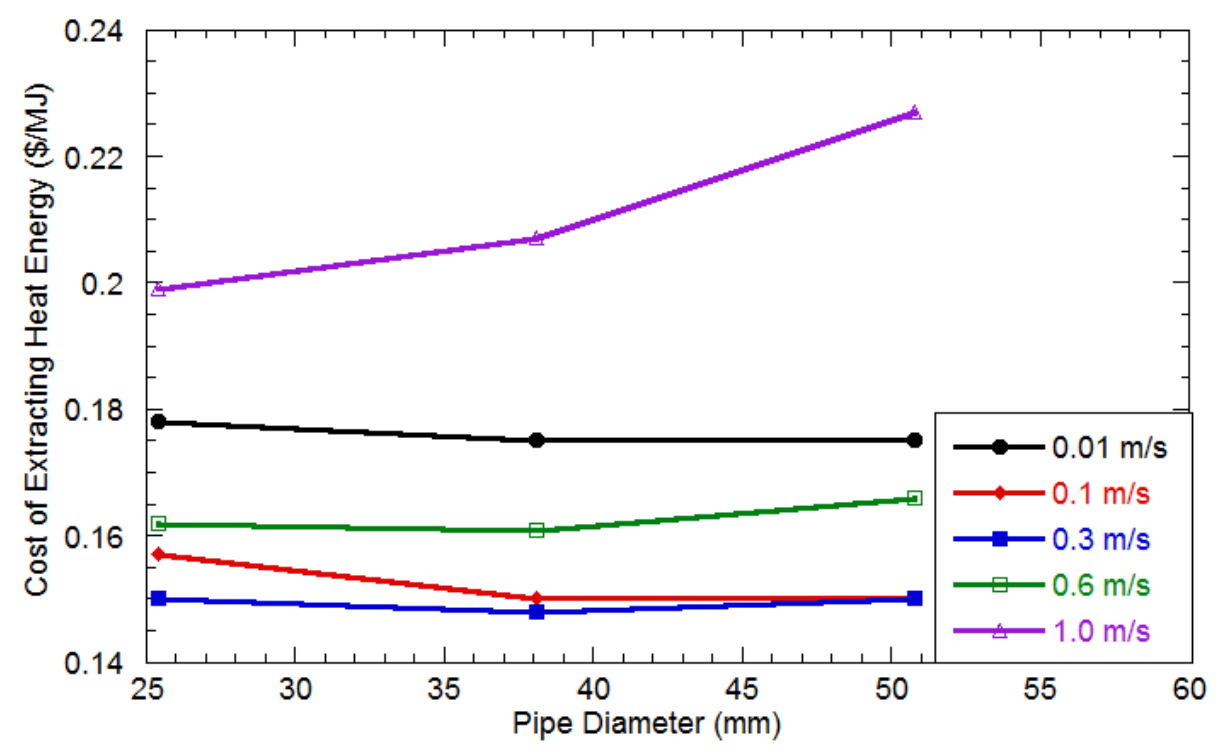

Figure 5.3: Impact of Pipe Diameter on Cost Effectiveness of an HES for Different Fluid Velocities

\subsection{HES Effect on Gas Production}

Gas production has been established to be a function of temperature (Hartz et al. 1982). By implementing a vertical HES in a landfill, gas production 
can potentially be altered. An analysis was performed to determine the increase in gas production rate at the Alaska site due to waste heating. Using the equation developed by Hartz et al. (1982) for the effect of temperature on methane production rates (Equation 5.3), the increase in methane production rate was calculated for each node in the waste mass within the vertical HES zone of influence $(12 \mathrm{~m})$ for the first 5 years of HES operation (assuming 5 years of gas production).

$$
\begin{aligned}
& k_{T_{2}}=k_{T_{1}} \mathrm{e}^{\frac{E_{a}\left(T_{2}-T_{1}\right)}{R T_{2} T_{1}}} \\
& \begin{aligned}
\text { Where: } \\
k_{T_{1}}=\mathrm{CH}_{4} \text { production rate at temperature } 1\left(\mathrm{~m}^{3} / \mathrm{d}\right) \\
k_{T_{2}}=\mathrm{CH}_{4} \text { production rate at temperature } 2\left(\mathrm{~m}^{3} / \mathrm{d}\right) \\
E_{a}=\text { energy of activation }(\mathrm{kcal} / \mathrm{mol})=20 \mathrm{kcal} / \mathrm{mol} \\
T=\text { temperature }(\mathrm{K}) \\
R=\text { ideal gas constant }=1.987 \times 10^{-3} \mathrm{kcal} /(\mathrm{K} \mathrm{mol})
\end{aligned}
\end{aligned}
$$

Once the increase in methane production rate for each node was calculated, a volumetric weighted average was taken for the entire cylinder of waste. The resulting increase in gas production rate over the 5 year period is presented in Figure 5.4. The maximum increase in gas production rate was determined to be $13.7 \%$

Currently, 560 gas energy projects exist in the United States, producing 1730 MW per year (US EPA 2012). The average landfill gas energy project produces 3.09 MW per year. For the waste heating simulations, an average 
increase in gas production rate per year of $9.1,13.5,13.2,12.5$, and $12.3 \%$ occurred in years $1,2,3,4$, and 5 , respectively. If gas production for the waste heating simulation was assumed be equal to that of the average landfill gas project, the increase in energy produced would be $0.28,0.42,0.41,0.39$, and $0.38 \mathrm{MW}$ for years $1,2,3,4$, and 5, respectively. Assuming energy prices were $\$ 0.158 / \mathrm{kWh}$ (Bureau of Labor Statistics 2013), the increase in revenue for a typical system would be $\$ 2,590,000$ for the 5 year period.

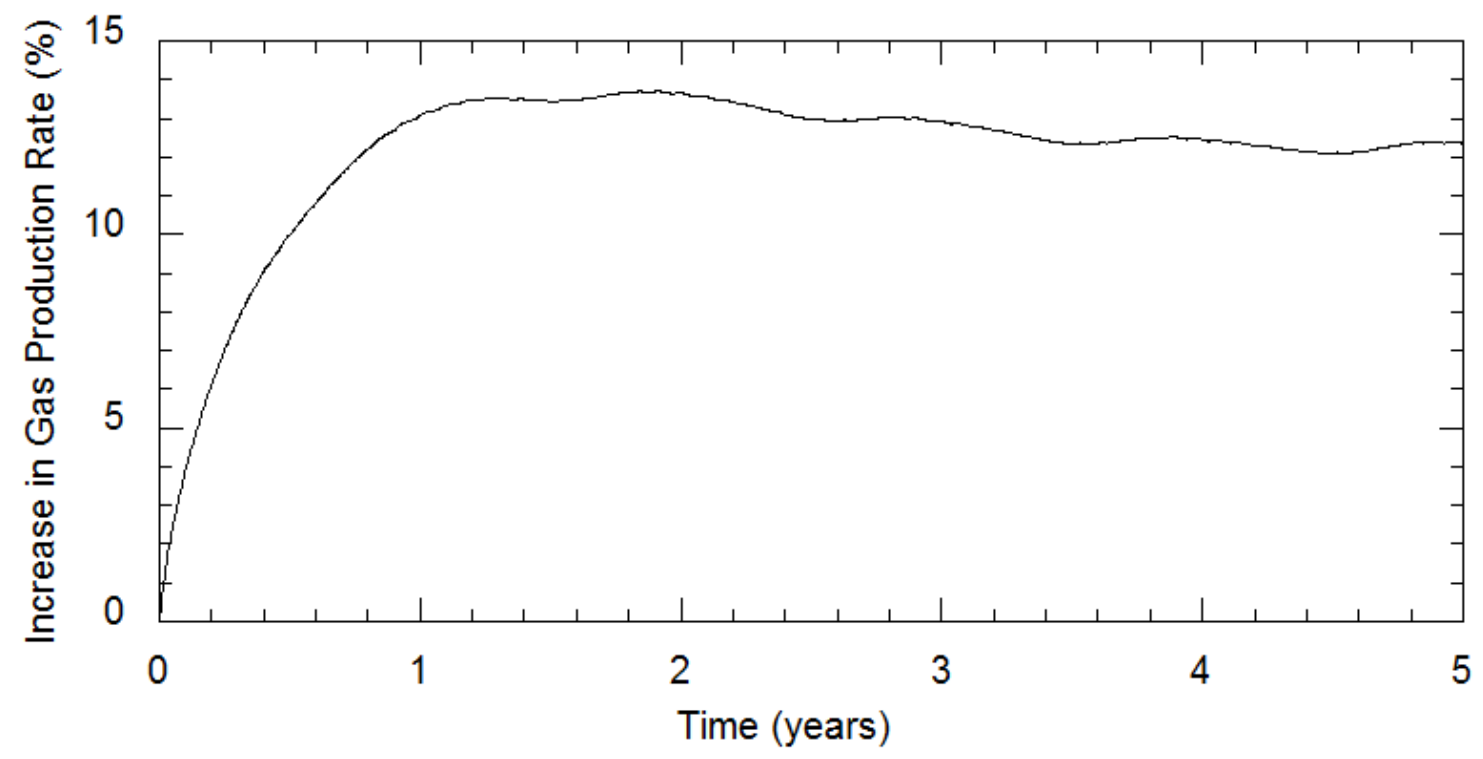

Figure 5.4: Increase in Gas Production Due to Waste Heating

Vertical HES can potentially be used to control the gas production rate. Adjusting landfill temperatures to optimum gas production temperatures would potentially increase the gas production rate. An increase in gas production rate would increase revenue from a landfill gas energy system. In addition, the gas extraction time period could potentially be accelerated. Alternatively, landfill temperatures could be intentionally cooled allowing gas extraction to occur over 
a longer time period at a lower rate. More research is necessary to quantify the effect an HES would have on gas generation. Although more research is required to quantify the effect of a vertical HES on gas production rates, initial results suggest that a vertical HES could provide a great benefit to landfill gas energy projects. 


\section{Chapter 6: Summary and Conclusions}

A numerical model was developed to investigate the impact of a vertical HES on landfill temperatures. A method for approximating fluid temperatures was developed and applied to a 2-D axisymmetric model to simulate a single vertical HES in a landfill. A total of 41 numerical simulations were conducted to investigate various vertical HES configurations and operational conditions. Parameters investigated included: fluid velocity, pipe diameter, waste placement time, waste height, waste filling rate, vertical landfill expansions, HES placement time, HES operation, climate, and waste heating. The operation of the vertical HES can be divided into 3 phases: heat extraction phase, transitional phase, and ground source heat pump phase. When total heat energy extracted is presented, the value represents the heat extraction phase only. Based on the numerical investigation of vertical HES operation in landfills, the following conclusions were drawn:

1. General trends predicted for landfill temperatures in response to vertical HES operation were: maximum baseline landfill temperatures were determined near the middle of the waste mass except when frozen waste was present (as simulated in the Alaska climate) and temperatures increased asymptotically with distance away from the HES for heat extraction and decreased exponentially with distance away from the HES for heat rejection.

2. General trends predicted for heat extraction were: increased landfill temperatures yielded increased heat extraction rates and total heat energy 
extracted; a 30-day to 40-day startup period was required for heat extraction rates to reach thermal stasis; and heat extraction underwent seasonal cycles with more heat extracted in summer than in winter due to a constant inlet temperature.

3. Liner temperatures were not significantly impacted by the presence of a vertical HES.

4. Fifteen configuration simulations were conducted varying fluid velocities of $0.01,0.1,0.3,0.6$, and $1.0 \mathrm{~m} / \mathrm{s}$ and pipe diameters of $25.4,38.1$, and 50.8 $\mathrm{mm}$. The maximum difference in baseline temperatures and temperatures 0 $\mathrm{m}$ away from the HES ranged from $21.2^{\circ} \mathrm{C}$ for a $25.4 \mathrm{~mm}$ pipe diameter with $0.01 \mathrm{~m} / \mathrm{s}$ fluid velocity to $26.7^{\circ} \mathrm{C}$ for a $50.8 \mathrm{~mm}$ pipe diameter with $1.0 \mathrm{~m} / \mathrm{s}$ fluid velocity. For the 15 configuration simulations, heat extraction rates ranged from 530 to 1000,830 to 1310 , and 20 to $340 \mathrm{~W}$ for the first year, peak year, and last year of HES operation, respectively. The total heat energy extracted ranged from $468,800 \mathrm{MJ}$ to $606,500 \mathrm{MJ}$ in a 40 year period for the a $25.4 \mathrm{~mm}$ pipe diameter with $0.01 \mathrm{~m} / \mathrm{s}$ fluid velocity and a $50.8 \mathrm{~mm}$ pipe diameter with $1.0 \mathrm{~m} / \mathrm{s}$ fluid velocity, respectively. Increasing fluid velocity caused an increase in the heat extraction rate, the total amount of heat energy extracted, and the maximum temperature difference between baseline temperatures and temperatures influenced by the HES. Increasing pipe diameter caused and increase in both the heat extraction rate, the total amount of heat energy extracted, and the maximum temperature difference between baseline temperatures and temperatures influenced by the HES. 
Turbulent flow yielded higher heat extraction rates, total energy extracted, and maximum temperature difference in the landfill than laminar flow. Once turbulent flow was reached, the increase in heat extraction rate and total amount of heat energy extracted between increasingly flow rates was negligible. Therefore, minimum turbulent fluid flow rates are recommended for HES operation.

5. Twelve year-round waste placement simulations were conducted varying the initiation of waste placement every month. For year-round waste placement simulations, the maximum difference in baseline temperatures and temperatures $0 \mathrm{~m}$ away from the HES ranged from 25.2 to $28.2^{\circ} \mathrm{C}$ for waste placement beginning in February and July, respectively. Heat extraction rates for the year-round waste placement simulations ranged from 410 to 1240,940 to 1410 , and 20 to $320 \mathrm{~W}$ for the first year, peak year, and last year of HES operation, respectively. The total heat energy extracted ranged from 554,700 to $661,700 \mathrm{MJ}$ over a 40 year period for waste placement beginning in February and July, respectively. Simulations that had more waste placed at higher temperatures yielded higher overall landfill temperatures. For wastes that were placed at the same temperatures, placement before peak seasonal temperatures resulted in increased temperatures compared to wastes placed after peak seasonal temperatures.

6. Simulations of waste placement in winter-only and summer-only were conducted. The maximum difference in baseline temperatures and 
temperatures $0 \mathrm{~m}$ away from the HES for winter-only and summer-only waste placement simulations were 10.5 and $34.4^{\circ} \mathrm{C}$, respectively. Heat extraction rates for the summer-only and winter-only waste placement simulations ranged from 0 to 1720,310 to 1750 , and 0 to $340 \mathrm{~W}$ for the first year, peak year, and last year of HES operation, respectively. The heat extraction phase lasted only 24.7 years for the winter-only waste placement simulation. Total heat energy extracted for winter-only and summer-only waste placement were $206,900 \mathrm{MJ}$ over a 24.7 year period and 766,900 MJ over a 40 year period, respectively. Winter-only waste placement yielded significantly lower landfill temperatures than summer-only waste placement as waste was placed at a lower temperature for winter-only waste placement.

7. Three waste height simulations of 15,30 , and $45 \mathrm{~m}$ were conducted. For waste height simulations, the maximum difference in baseline temperatures and temperatures $0 \mathrm{~m}$ away from the HES for waste height simulations ranged from 16.9 to $26.2^{\circ} \mathrm{C}$ for the 15 and $45 \mathrm{~m}$ waste height, respectively. The heat extraction phase lasted only 10.5 years for the $15 \mathrm{~m}$ waste height simulation. For the waste height simulations, heat extraction rates ranged from 250 to 1140,250 to 1720 , and 0 to $530 \mathrm{~W}$ for the first year, peak year, and last year of HES operation, respectively. The total heat energy extracted ranged from $67,400 \mathrm{MJ}$ over a 10.5 year period to $1,181,400 \mathrm{MJ}$ over a 40 year period, for the 15 and $45 \mathrm{~m}$ waste height, respectively. Waste height greatly contributed to simulated overall landfill temperatures 
and peak heat extraction rates increased linearly with waste depth. Peak heat extraction increased by $43 \mathrm{~W}$ for every $1 \mathrm{~m}$ of waste height. When normalized for length of the HES, peak heat extraction rates were 33.8, 43.9 , and $40.0 \mathrm{~W} / \mathrm{m}$ for the 15,30 , and $45 \mathrm{~m}$ waste heights, respectively.

8. Three waste filling rate simulations of $5 \mathrm{~m} /$ year, $12 \mathrm{~m} / \mathrm{year}$, and $20 \mathrm{~m} /$ year were conducted. For the waste filling rate simulations, the maximum difference in baseline temperatures and temperatures $0 \mathrm{~m}$ away from the HES ranged from 21.2 to $25.2^{\circ} \mathrm{C}$ for the 5 and $20 \mathrm{~m} /$ year filling rates, respectively. Heat extraction rates for the waste filling simulations ranged from 680 to 1210,930 to 1230 , and 0 to $290 \mathrm{~W}$ for the first year, peak year, and last year of HES operation, respectively. The total heat energy extracted ranged from 475,000 to $561,100 \mathrm{MJ}$ over a 40 year period for the 5 and $20 \mathrm{~m} /$ year filling rates, respectively. The time to peak heat extraction rate increased with increasing waste filling rate. Total heat energy extracted increased as waste filling rate increased. The increase in total heat energy extracted when the filling rate varied from 5 to $12 \mathrm{~m} /$ year was larger than the increase when the filling rate varied from 12 to $20 \mathrm{~m} /$.

9. Two vertical landfill expansion simulations were conducted with vertical landfill expansions occurring 5 and 15 years between the original waste placements. The maximum difference in baseline temperatures and temperatures $0 \mathrm{~m}$ away from the HES for the vertical landfill expansions simulations was 16.6 and $12.7^{\circ} \mathrm{C}$ for 5 and 15 years between original waste placement and the vertical landfill expansion simulations, respectively. For 
the vertical landfill expansion simulations, heat extraction rates ranged from 190 to 660,510 to 880 , and 20 to $220 \mathrm{~W}$ for the first year, peak year, and last year of HES operation, respectively. Total heat energy extracted for vertical landfill expansions 5 and 15 years after the original waste placement were 423,300 and 324,400 MJ over a 40 year period, respectively. Peak heat extraction decreased as the time between the original waste placement and the vertical landfill expansion increased. Overall waste temperatures decreased as time between the original waste placement and the vertical landfill expansion increased.

10. Three different HES placement time simulations of 1 day, 1 year, and 5 years after cover placement were conducted. For HES placement time simulations, the maximum difference in baseline temperatures and temperatures 0 m away from the HES for HES placement time simulations ranged from 23.6 to $25.2^{\circ} \mathrm{C}$ for the 5 years and 1 day after final cover construction simulations, respectively. Heat extraction rates for the HES placement time simulations ranged from 680 to 1630,940 to 1630 , and 20 to $310 \mathrm{~W}$ for the first year, peak year, and last year of HES operation, respectively. The total heat energy extracted ranged from 428,000 to 532,300 over a 35 year period for HES placement 5 years and 1 day after final cover construction, respectively. If the HES was placed before peak landfill temperatures, then similar heat extraction rates and temperatures were obtained for each HES placement time. If the HES was placed after peak temperatures within the landfill, the heat extraction rates were initially 
higher and then decreased exponentially. For every year that passed after the cover was constructed until the HES was placed, the total heat energy extracted decreased by approximately $21,500 \mathrm{MJ}$.

11. One simulation of winter-only HES operation was conducted. The maximum difference in baseline temperatures and temperatures $0 \mathrm{~m}$ away from the HES for winter-only HES operation simulation was $25.1^{\circ} \mathrm{C}$. Heat extraction rates for winter-only operation of the HES ranged from 850 to 1350,1240 to 2280 , and 100 to $250 \mathrm{~W}$ for the first year, peak year, and last year of HES operation, respectively. The total heat energy extracted was 163,000 MJ. The peak heat extraction rate occurred at the beginning of HES operation for each year. Heat extraction rates decreased exponentially over the course of the 3 month operational period each year. Temperatures in the vicinity of the HES, while the HES was not in operation, returned to the general temperature tends at a given depth during HES operation (i.e. decreasing temperatures with distance away from the HES). Total heat energy extracted for each winter season varied each year and the maximum total heat energy extracted occurred in the 4th year.

12. Four climate simulations were conducted for Alaska, British Columbia, Michigan, and New Mexico climatic regions. For the climate simulations, the maximum difference in baseline temperatures and temperatures $0 \mathrm{~m}$ away from the HES ranged from 5.2 to $43.2^{\circ} \mathrm{C}$ for the Alaska and British Columbia climates, respectively. The Alaska site did not have a heat extraction phase as the presence of frozen waste impacted heat generation 
and caused temperatures to be lower than required for a heat extraction phase. Heat extraction rates for the remaining climate simulations (all climates except Alaska) ranged from 240 to 2550,360 to 3080 , and 0 to 460 W for the first year, peak year, and last year of HES operation, respectively. The heat extraction rates for the Alaska climate simulation ranged from -100 to $170 \mathrm{~W}$. The total heat energy extracted ranged from $1200 \mathrm{MJ}$ seasonally to $1,400,000 \mathrm{MJ}$ in a 40 year period for the Alaska and British Columbia climates, respectively. Climate was the most significant factor impacting the heat extraction rates and amount of heat energy extracted. Climates with higher precipitation caused increased heat extraction rates and total heat extraction. The maximum difference of temperatures in the landfill increased by $16.6^{\circ} \mathrm{C}$ for every $1 \mathrm{~W} / \mathrm{m}^{3}$ increase in peak waste heat generation rate.

13. One waste heating simulation was conducted by setting the inlet temperature for the HES to $50^{\circ} \mathrm{C}$. The heat rejection rates for the waste heating simulation ranged from 170 to $440 \mathrm{~W}$. Temperatures near the HES increased from baseline temperatures from ground surface to a depth 15.5 $\mathrm{m}$ and decreased from baseline temperatures below $15.5 \mathrm{~m}$. Waste temperatures increased most notably at shallow depths. An increase in temperature could potentially increase the gas production rate in the landfill.

14. Spacing requirements were determined at the time of maximum temperature difference in the landfill. A threshold to determine the zone of influence of a single vertical HES well was established using thermal 
gradients: average gradients less than $0.25^{\circ} \mathrm{C} / \mathrm{m}$ and maximum gradients less than $0.50^{\circ} \mathrm{C} / \mathrm{m}$. A triangular spacing configuration is recommended as it is the most efficient configuration. The most efficient spacing distance was determined to be twice the zone of influence, as multiple wells would have negligible impact on each other. Spacing for all simulations with a heat extraction phase (all except the Alaska climate) ranged from $12 \mathrm{~m}$ to $22 \mathrm{~m}$. Simulations with lower maximum difference of temperatures in the landfill from the HES yielded lower spacing requirements. The same threshold established for heat extraction was used for waste heating, yielding a spacing requirement of $12 \mathrm{~m}$. For year-round operation, if maximum difference of temperatures in the landfill is greater than $17^{\circ} \mathrm{C}$, a spacing of $22 \mathrm{~m}$ is recommended. For year-round operation, if maximum difference of temperatures in the landfill is less than $17^{\circ} \mathrm{C}$, a spacing of $16 \mathrm{~m}$ is recommended. For operation of the HES in only winter and for waste heating, a spacing of $12 \mathrm{~m}$ is recommended.

15. A cost analysis for a single heat extraction well was performed for the 15 vertical HES configurations. The 15 HES configurations varied 5 fluid velocities and 3 pipe sizes. Low flow rate simulations had negligible electricity requirements for the pump. The cost of extracting heat energy ranged from $\$ 0.150$ to $\$ 0.227$ per $M J$ for the $50.8 \mathrm{~mm}$ pipe at $0.3 \mathrm{~m} / \mathrm{s}$ fluid velocity and the $50.8 \mathrm{~mm}$ pipe at $1.0 \mathrm{~m} / \mathrm{s}$ fluid velocity, respectively. The $50.8 \mathrm{~mm}$ pipe diameter with a fluid velocity of $0.3 \mathrm{~m} / \mathrm{s}$ was determined to be the most cost effective. For all pipe sizes, cost efficiency peaked at the 0.3 
$\mathrm{m} / \mathrm{s}$ fluid velocity. Fluid flow rates that yielded higher electrical costs were less cost effective for longer durations of system operation. Costs for vertical HES in landfills are highly site specific and economic viability is dependent on the specific design. The heat is extracted by the system is most economically viable if used near the landfill.

16. The temperature increase caused by waste heating was determined to result in increases methane production within zone of influence by as much as $13.7 \%$. Assuming gas production occurred over a 5 year period for the waste heating simulation, the increase methane production increased revenue by $\$ 2,590,000$ for the 5 year period. A vertical HES could be used to control the time required for gas extraction allowing landfill operators to have more control of gas extraction and associated revenue streams. More research is required to quantify the effect an HES would have on gas production. The greatest economic benefit of a vertical HES is its effect on gas production.

17. Vertical HES for landfills holds promise to provide a new form of sustainable thermal energy. Additionally, vertical HES for landfills could potentially give landfill operators more control over landfill gas production. 


\section{References}

Abaqus (2011). Abaqus Analysis User's Manual, Dassault Systems

Andersland O. B., and Ladanyi, B. (1994). An Introduction to Frozen Ground Engineering, Chapman \& Hall, Inc., New York.

Bolz, R. E., and Tuve, G. L. (1973). CRC Handbook of Tables for Applied Engineering Science, 2nd Ed., CRC Press, Boca Raton, Florida.

Bose, J. E., (1983). Closed Loop Ground Coupled Heat Pump Design Manual, Engineering Technology Extension Oklahoma State University.

Bradley, W. A., and Zarling, J. P. (1991). "MUT1D: User-Friendly OneDimensional Thermal Model." Proceedings of the Sixth International Specialty Conference: Cold Regions Engineering, West Lebanon, New Hampshire, 1-10.

Bureau of Labor Statistics (2013). "Average Energy Prices, Detroit - Ann Arbor Flint - November 2013." 13-2480-CHI, Chicago, Illinois

Carslaw, H. S., and Jaeger, J. C. (1959). Conduction of Heat in Solids, 2nd Ed., Oxford University Press, Oxford.

Cook, R. D., Malkus, D. S., Plesha, M. E., Witt, R. J. (2002). Concepts and Applications of Finite Element Analysis, 4th Ed., John Wiley and Sons Inc., Hoboken, New Jersey.

Dittus, F. W., and Boelter, L. M. K. (1930). "Heat Transfer in Automobile Radiators of Tubular Type." University of California (Berkeley) Pub. Eng., vol. 2, p. 443. 
Dixon, N., and Jones, D. R. (2005). "Engineering Properties of Municipal Solid Waste." Geotextiles and Geomembranes, 23, 205-233.

Eklund, B., Anderson, E. P., Walker, B. L., and Burrows D. B. (1998). "Characterization of Landfill Gas at the Fresh Kills Municipal Solid Waste Landfill." Environmental Science and Technology, 32(15), 2233-2237.

El-Fadel, M., Findikakis, A. N., and Leckie, J. O. (1996a). "Numerical Modelling of Generation and Transport of Gas and Heat in Landfills I. Model Formulation." Waste Management and Research, 14, 483-504.

El-Fadel, M., Findikakis, A. N., and Leckie, J. O. (1996b). "Numerical Modelling of Generation and Transport of Gas and Heat in Sanitary Landfills II. Model Application." Waste Management and Research, 14, 483-504.

Eskilson, P. (1987). "Thermal Analysis of Heat Extraction Boreholes." Ph.D. Thesis, University of Lund, Department of Mathematical Physics. Lund, Sweden.

Gnielinski, V. (1976). "New Equations for Heat and Mass Transfer in Turbulent Pipe and Channel Flow." International Chemistry Engineering, 16, 359346.

Hanson, J. L., Yesiller, N., and Kendall, L. A. (2005a). “Integrated Temperature and Gas Analysis at a Municipal Solid Waste Landfill." Proceedings of the 16th International Conference on Soil Mechanics and Geotechnical Engineering, Geotechnology in Harmony with the Global Environment, Millpress Science Publishers, Rotterdam, Netherlands, 2265-2268. 
Hanson J. L., Yesiller, N., and Swarbrick, G. E. (2005b). "Thermal Analysis of GCLs at a Municipal Solid Waste Landfill." Waste Containment and Remediation, ASCE GSP 142, 1-15.

Hanson, J. L., Liu, W., and Yesiller, N. (2008). "Analytical and Numerical Modeling of Temperatures in Landfills." Proceedings of Selected Sessions of GeoCongress 08: Geotechnics of Waste Management and Remediation, ASCE GSP No. 177, Reston, Virginia, 24-31.

Hanson, J. L., Yesiller, N., Swarbrick, G. E., and Liu, W. (2010). "New Approach for Surface $n$ Factors." Journal of Cold Regions Engineering, 24, 19-34.

Hanson, J. L., Yesiller, N., Onnen, M. T., Liu, W., Oettle, N., and Marinos, J. A. (2013). "Development of Numerical Model for Predicting Heat Generation and Temperatures in MSW Landfills." Waste Management, 33(10), 19932000.

Hart, D. P., and Couvillion, R. (1986). Earth Coupled Heat Transfer, Publication of the National Water Well Association.

Hartz, K. E., Klink, R. E., and Ham, R. K. (1982). "Temperature Effects: Methane Generation from Landfill Samples." Journal of the Environmental Engineering Division, 108, 629-638.

Hellstrom, G. (1991). Ground Heat Storage Thermal Analysis of Duct Storage Systems Part I Theory, University of Lund, Department of Mathematical Physics, Lund, Sweden. 
Hepbasli, A., Akdemir, O., and Hancioglu, E. (2003). "Experimental Study of a Closed Loop Vertical Ground Source Heat Pump." Energy Conversion Management, 44, 527-548.

Holman, J. P. (1997). Heat Transfer, 8th Ed., McGraw-Hill, Inc., United States.

Houi, D., Paul, E., and Couturier, C. (1997). "Heat and Mass Transfer in Landfills and Biogas Recovery." Proceedings Sardinia 1997, Sixth International Waste Management and Landfill Symposium, T. H. Christensen et al. (Eds.), CISA, Italy, 101-108.

Inalli, M., and Esen, H. (2004). "Experimental Thermal Performance Evaluation of a Horizontal Ground-Source Heat Pump System." Applied Thermal Engineering, 24, 2219-2232.

Ingersoll, L.R., and Plass H.J. (1948). "Theory of the Ground Pipe Heat Source for the Heat Pump." Transactions of the American Society of Heating and Ventilating Engineers.

Ingersoll, L. R., Zobel, O. J., and Ingersoll A. C. (1954). Heat Conduction with Engineering, Geological, and Other Applications McGraw-Hill, New York. Ingram's Water and Air Equipment, < http://ingramswaterandair.com/> (April 18, 2014).

Jumikis, A. R. (1966). Thermal Soil Mechanics, 2nd Ed., Rutgers University Press, New Brunswick, New Jersey.

Karunaratne, K. C., and Brun, C. R. (2004). "Relationship between Air and Surface Temperature on Discontinuous Permafrost Terrain near Mayo, Yukon Territory." Canadian Journal of Earth Science, 41, 1437-1451 
Kavanaugh, S. P. (1985). "Simulation and Experimental Verification of Vertical Groundcoupled Heat Pump Systems." Ph.D. Thesis, Oklahoma State University, Stillwater, Oklahoma.

Kavanaugh, S. P., and Rafferty, K. (1997). Ground Source Heat Pumps: Design of Geothermal Systems for Commercial and Institutional Buildings, American Society of Heating, Refrigerating and Air-Conditioning Engineers, Atlanta, Georgia.

Kaviany, M. (1995) Principles of Heat Transfer in Porous Media, 2nd Ed., Springer-Verlag, Inc., New York.

Kjeldsen, P., Barlaz, M. A., Rooker, A. P., Baun, A., Ledin, A., and Christensen, T. H. (2002). "Present and Long-Term Composition of MSW Landfill Leachate: A Review." Critical Reviews in Environmental Science and Technology, 32(4), 297-336.

Kumar, A., and Sah, G. N. (2004). Thermal Engineering, Alpha Science International Ltd., Pangbourne, U.K.

Labs, K. (1981). Regional Analysis of Ground and Above-Ground Climate, ORNL/SUB-81/4045/1, U.S. Department of Energy, Office of Buildings Energy R\&D.

Lefebvre, X., Lanini, S., and Houi, D. (2000). "The Role of Aerobic Activity on Refuse Temperature Rise, I. Landfill Experimental Study." Waste Management and Research, 18, 444-452. 
Li Z., and Zheng M. (2009). "Development of a Numerical Model for the Simulation of Vertical U-tube Ground Heat Exchangers." Applied Thermal Engineering, 29(5-6), 920-924.

Liu, W. (2007). "Thermal Analysis of Landfills." Ph.D. Thesis, Wayne State University, Detroit, Michigan.

McBean, E. A., Rovers, F. A., and Farquhar, G. J. (1995). Solid Waste Landfill Engineering and Design, Prentice Hall, New York

McMaster-Carr, <http://www.mcmaster.com> (April 18, 2014).

Mills, A. F. (1999). Basic Heat and Mass Transfer, 2nd Ed., Prentice-Hall Inc., New Jersey.

Mitchell, J. K., and Soga, K. (2005). Fundamentals of Soil Behavior, 3rd Ed., John Wiley and Sons Inc., Hoboken, New Jersey.

Morgan, M. J., and Shapiro, H. N. (2008). Fundamentals of Engineering Thermodynamics, 6th Ed., John Wiley and Sons Inc., Hoboken, New Jersey.

Munson, B. R., Young, D. F., Okiishi, T. H., and Huebsch, W. W. (2009) Fundamentals of Fluid Mechanics, John Wiley and Sons Inc., Hoboken, New Jersey.

Muraya, N. K. (1995). "Numerical Modeling of the Transient Thermal Interference of Vertical U-Tube Heat Exchangers." Ph.D. Thesis, Texas A\&M University, College Station, Texas.

Oettle, N. K. (2008). "Thermal Analysis of Landfill Barriers." M.S. Thesis, California Polytechnic State University, San Luis Obispo, California. 
Omer, A. M. (2008). "Ground-Source Heat Pumps Systems and Applications." Renewable and Sustainable Energy Reviews, 12, 344-371.

Oweis, I. S., and Khera R. P. (1998). Geotechnology of Waste Management, 2nd Ed., PWS Publishing, Boston, Massachusetts.

Ozgener, O., and Hepbasli, A. (2007). "Modeling and Performance Evaluation of Ground Source (Geothermal) Heat Pump Systems." Energy and Buildings, 39, 66-75.

Park, H., Lee, J. S., Kim, W., and Kim, Y. (2012). "Performance Optimization of a Hybrid Ground Source Heat Pump with the Parallel Configuration of a Ground Heat Exchanger and a Supplemental Heat Rejecter in the Cooling Mode." International Journal of Refrigeration, 35, 1537-1546.

Pertzborn, A., Nellis, G., and Klein, S. (2011). "Impact of Weather Variation on Ground-Source Heat Pump." HVAC\&R Research, 17(2), 174-185.

Petukhov, B. S. (1970). "Heat Transfer and Fiction in Turbulent Pipe Flow with Variable Physical Properties." Advances in Heat Transfer, Academic Press, Inc., p. 504-564.

Phetteplace, G. (2007). "Geothermal Heat Pumps." Journal of Energy Engineering, 133(1), 32-38.

Qian, X., Koerner, R. M., and Gray, D. H. (2002). Geotechnical Aspects of Landfill Design and Construction, Prentice Hall, New York.

Reay, D. A., and MacMichael, D. B. A. (1979). Heat Pumps Design and Application, William Clowes (Beccles) Limited, Beccles and London, Great Britain. 
Renou, S., Givaudan, J. G., Poulain, S., Dirassouyan, F., and Moulin, P. (2008). "Landfill Leachate Treatment: Review and Opportunity." Journal of Hazardous Materials, 150, 468-493.

Reuss, M., Beck, M., and Muller, J. P. (1997). "Design of a Seasonal Thermal Energy Storage in the Ground." Solar Energy, 59, 247-257.

Romanovsky, V. E., and Osterkamp, T. E. (1995). "Interannual Variations of Thermal Regime of the Active Layer and Near-Surface Permafrost in Northern Alaska." Permafrost and Periglacial Processes, 6, 313-315.

Rottmayer, S. P., Beckman, W. A., and Mitchell, J. W. (1997). "Simulation of a Single Vertical U-Tube Ground Heat Exchanger in an Infinite Medium." ASHRAE Transactions, 103(2), 651-659.

Sauer, H. J., and Howell, R. H. (1983). Heat Pump Systems, John Wiley \& Sons, Inc., New York.

Sharma, H. D., and Lewis, S. P. (1994). Waste Containment Systems, Waste Stabilization, and Landfills: Design and Evaluation, John Wiley and Sons Inc., New York.

Sieder, E. N., and Tate, C. E. (1936). "Heat Transfer and Pressure Drop of Liquids in Tubes." Industrial and Engineering Chemistry, 28, 1429.

Singh, H. (2002). "Ground Source Heat Pumps Selection and Pre-Installation Considerations." Heating/Piping/Air Conditioning Engineering, 74(3), 6062. 
Smith, M. W., and Riseborough, D. W. (1996). "Permafrost Monitoring and Detection of Climate Change." Permafrost and Periglacial Processes, 7, 301-309.

Stafford, A. (2011). "Long-Term Monitoring and Performance of Ground Source Heat Pumps." Building Research \& Information, 39(6), 566-573.

Tchobanoglous, G., Theisen, H., and Vigil, S. A. (1993). Integrated Solid Waste Management: Engineering Principles and Management Issues. McGrawHill, New York.

Themelis, N. J., and Uloa P. A. (2007). "Methane Generation in Landfills." Renewable Energy, 32, 1243-1257.

US EPA (2012). Landfill Gas Energy: A Guide to Developing and Implementing Green House Gas Reduction Programs, EPA 430-R-09-047, Washington D.C.

US EPA (2013). Municipal Solid Waste in the United States: 2011 Facts and Figures, EPA 530-R-13-001, Washington D.C.

Wang, X., Zheng, M., Zhang, W., Zhang, S., and Yang, T. (2010). "Experimental Study of a Solar-Assisted Ground-Coupled Heat Pump System with Solar Seasonal Thermal Storage in Severe Cold Areas." Energy and Buildings, 42, 2104-2110.

Yang, H., Cui, P., and Fang, Z. (2010). "Vertical-Borehole Ground-Coupled Heat Pumps: A Review of Models and Systems." Applied Energy, 87, 16-27. 
Yavuzturk, C. (1999). "Modeling of Vertical Ground Loop Heat Exchangers for Ground Source Heat Pump Systems." Ph.D. Thesis, Oklahoma State University, Stillwater, Oklahoma.

Yesiller, N., and Hanson, J. L. (2003). "Analysis of Temperatures at a Municipal Solid Waste Landfill." Proceedings of the Ninth International Waste Management and Landfill Symposium, Sardinia 2003, T. H. Christensen et al., Eds., CISA, Italy, 1-10.

Yesiller, N., Hanson, J. L., and Liu, W. (2005). "Heat Generation in Municipal Solid Waste Landfills." Journal of Geotechnical and Geoenvironmental Engineering, 131, 1330-1344.

Yesiller, N., Hanson, J. L., Oettle, N. K, and Liu, W. (2008). "Thermal Analysis of Cover Systems in Municipal Solid Waste Landfills." Journal of Geotechnical and Geoenvironmental Engineering, 134(11), 1655-1664

Yesiller, N., and Shackelford, C. D. (2011). "Chapter 13: Geoenvironmental Engineering." Geotechnical Engineering Handbook, B. M. Das Ed., J. Ross Publishing, Fort Lauderdale, Florida.

Yoshida, H., Hozumi, H., and Tanaka, N. (1996). "Theoretical Study on Temperature Distribution in a Sanitary Landfill." Proceedings 2nd International Congress on Environmental Geotechnics, A.A. Balkema, Osaka, Japan, 323-328.

Yoshida, H., Tanaka, N., and Hozumi, H. (1997). "Theoretical Study on Heat Transport Phenomena in a Sanitary Landfill." Proceedings, Sardinia 1997, 
Sixth International Waste Management and Landfill Symposium, T. H. Christensen et al. (Eds.), CISA, Italy, 109-120.

Yoshida, H., and Rowe, R. K. (2003). "Consideration of Landfill Liner Temperature." Proceedings, Sardinia 2003, Ninth International Waste Management and Landfill Symposium, T. H. Christensen et al. (Eds.), CISA, Italy.

Younis, M., Bolisetti, T., and Ting, D.S.-K. (2010). "Ground Source Heat Pump Systems: Current Status." International Journal of Environmental Studies, 67(3), 405-415.

Zanetti, M. C., Manna, L., and Genon, G. (1997). "Biogas Production Evaluation by Means of Thermal Balances." In T. H. Christensen et al. (Eds.), Proceedings, Sardinia 1997, Sixth International Waste Management and Landfill Symposium, T. H. Christensen et al. (Eds.), CISA, Italy.

Zekkos, D., Bray, J. D., Kavazanjian Jr., E., Matasovic, N., Rathje, E. M., Riemer, M. F., and Stokoe, K. H. (2006). "Unit Weight of Municipal Solid Waste." Journal of Geotechnical and Geoenvironmental Engineering, 132, 12501261. 


\section{Appendix A}
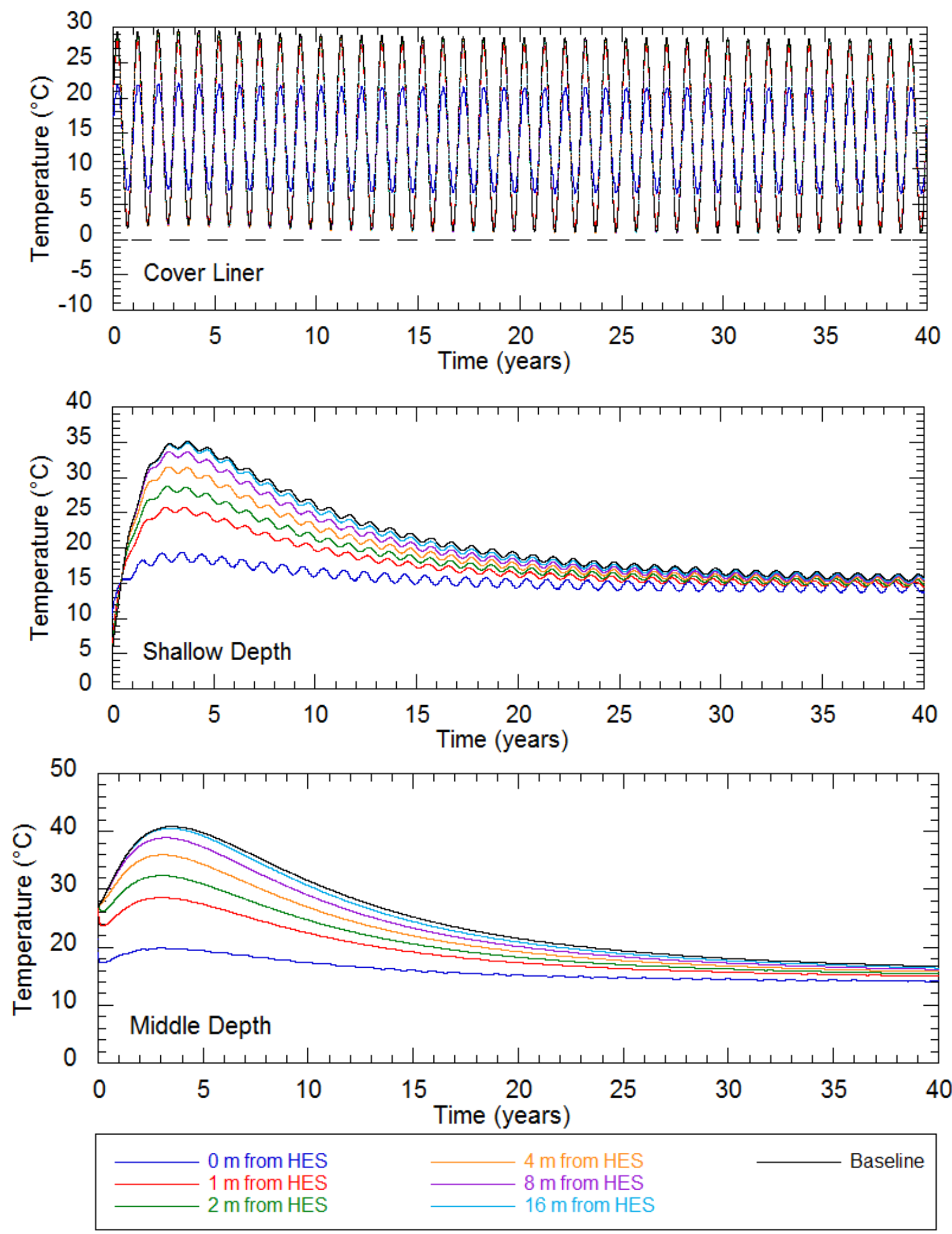

Figure A.1a: Temperature Results: 25.4 mm Diameter Pipe $0.01 \mathrm{~m} / \mathrm{s}$ Fluid Velocity 

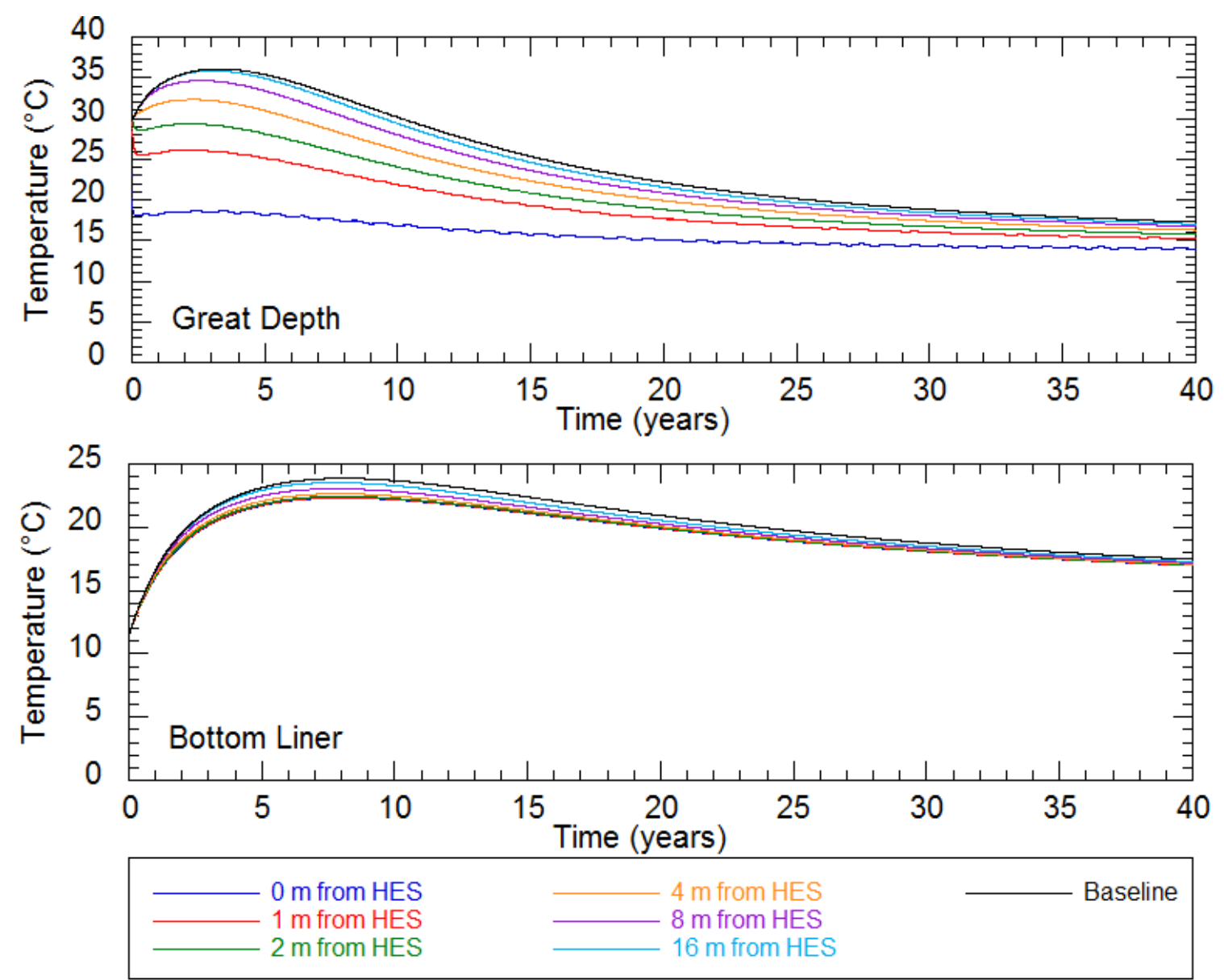

Figure A.1b: Temperature Results: $25.4 \mathrm{~mm}$ Diameter Pipe $0.01 \mathrm{~m} / \mathrm{s}$ Fluid Velocity

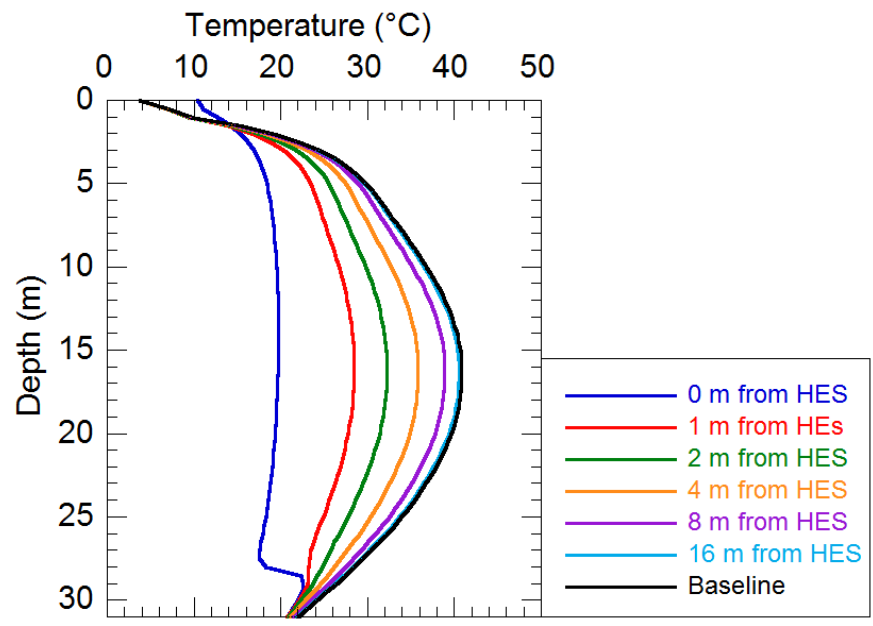

Figure A.2: Vertical Temperature Results: $25.4 \mathrm{~mm}$ Diameter Pipe $0.01 \mathrm{~m} / \mathrm{s}$ Fluid Velocity 

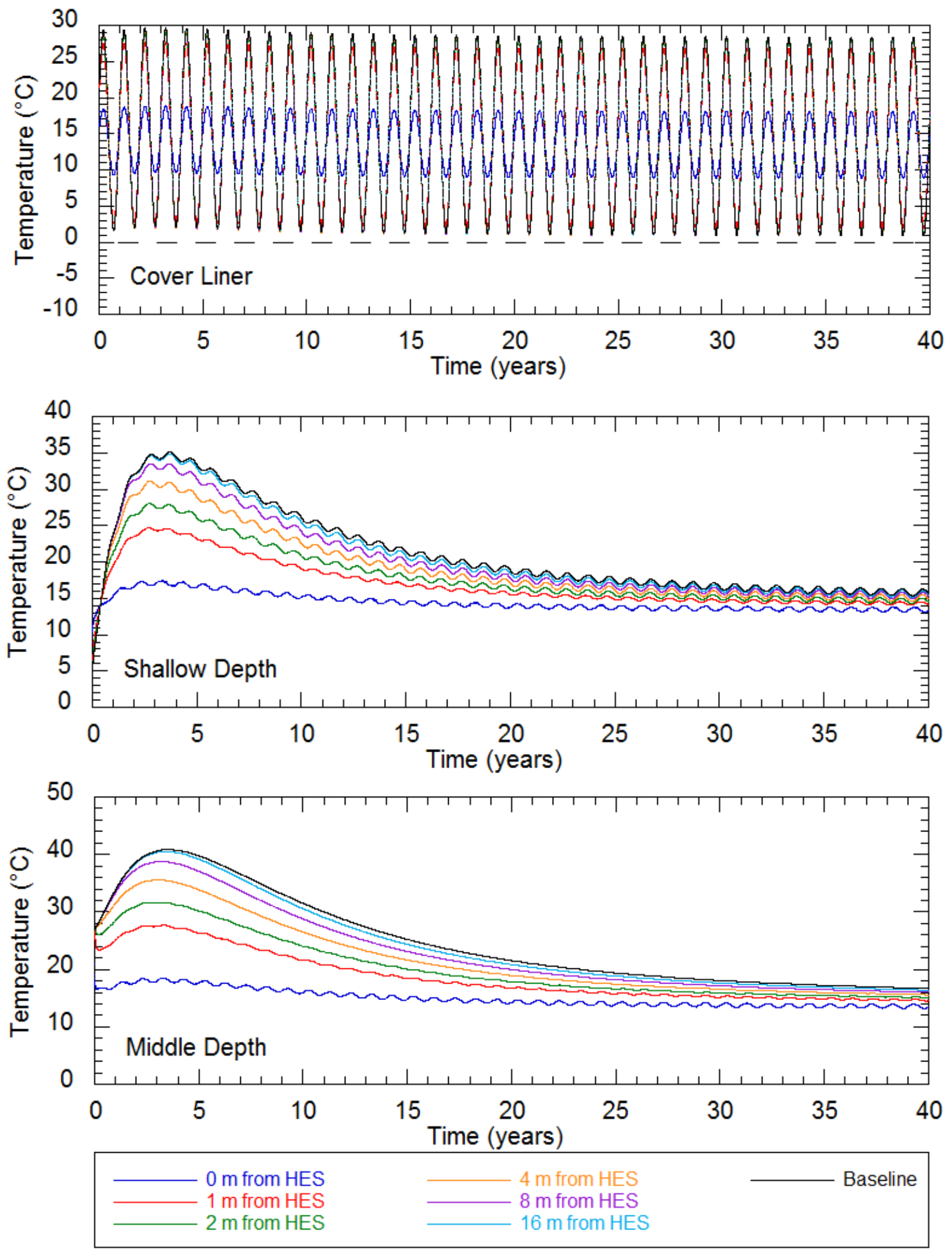

Figure A.3a: Temperature Results: 25.4 mm Diameter Pipe $0.1 \mathrm{~m} / \mathrm{s}$ Fluid Velocity 

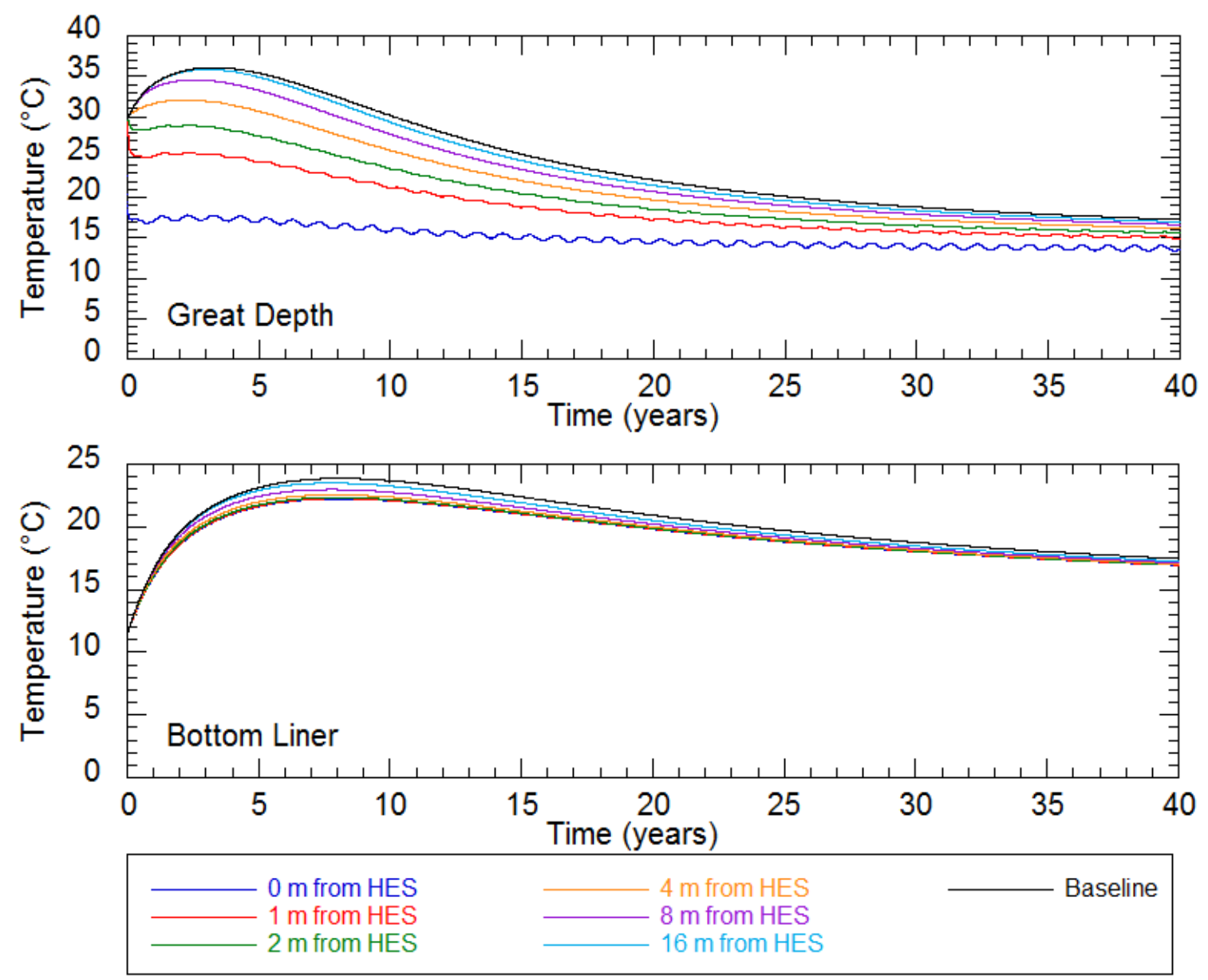

Figure A.3b: Temperature Results: $25.4 \mathrm{~mm}$ Diameter Pipe $0.1 \mathrm{~m} / \mathrm{s}$ Fluid Velocity

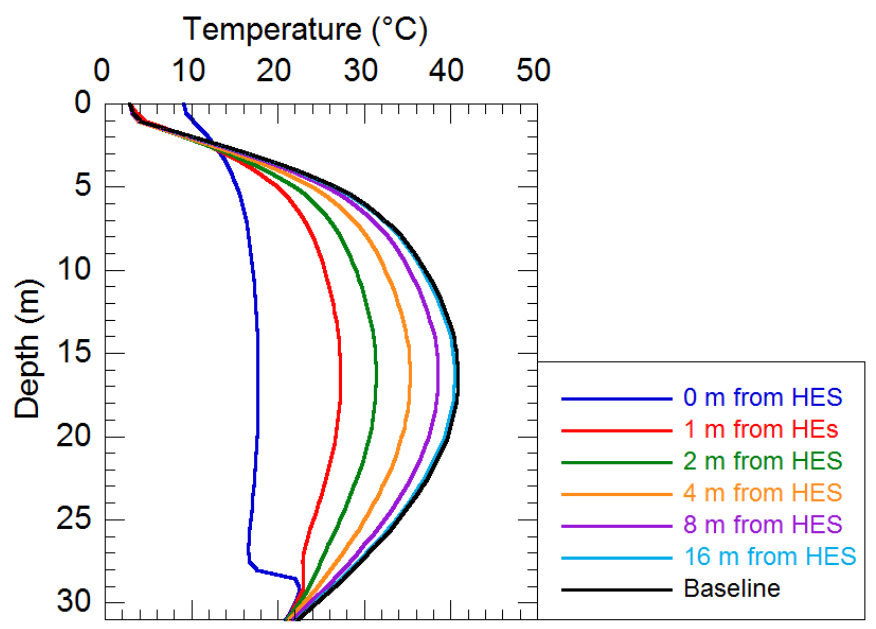

Figure A.4: Vertical Temperature Results: $25.4 \mathrm{~mm}$ Diameter Pipe $0.1 \mathrm{~m} / \mathrm{s}$ Fluid Velocity 

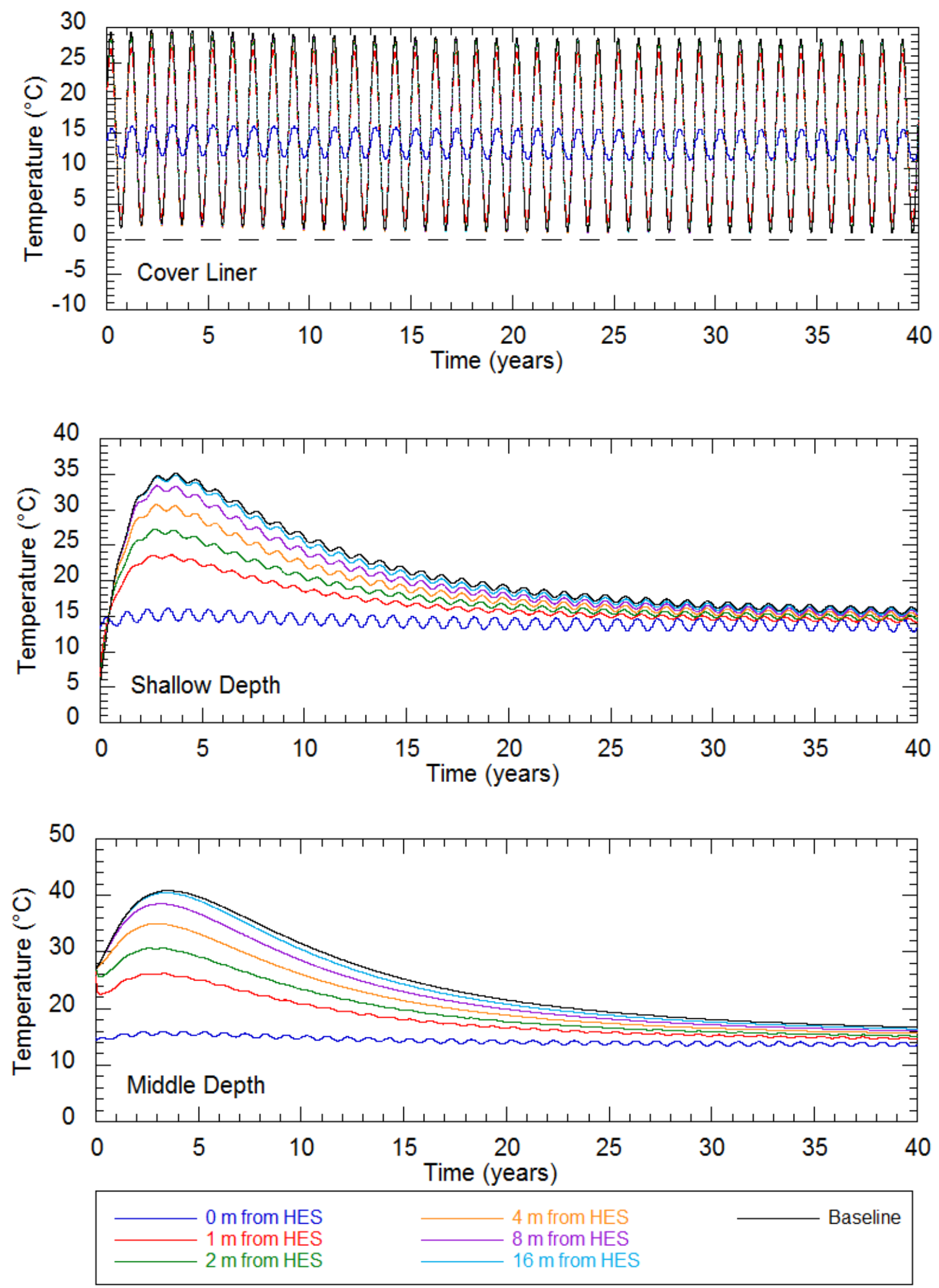

Figure A.5a: Temperature Results: $25.4 \mathrm{~mm}$ Diameter Pipe $0.6 \mathrm{~m} / \mathrm{s}$ Fluid Velocity 

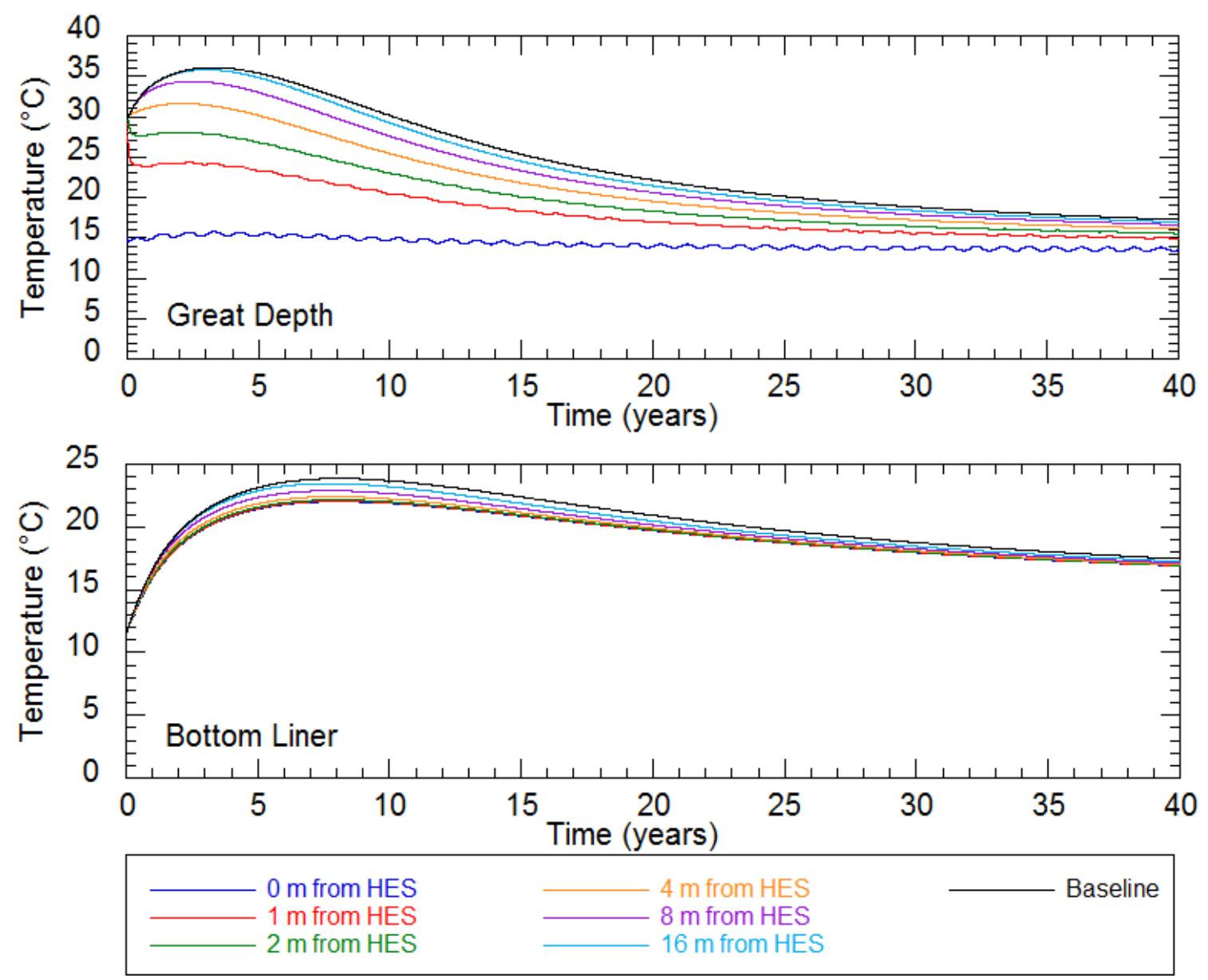

Figure A.5b: Temperature Results: 25.4 mm Diameter Pipe 0.6 m/s Fluid Velocity

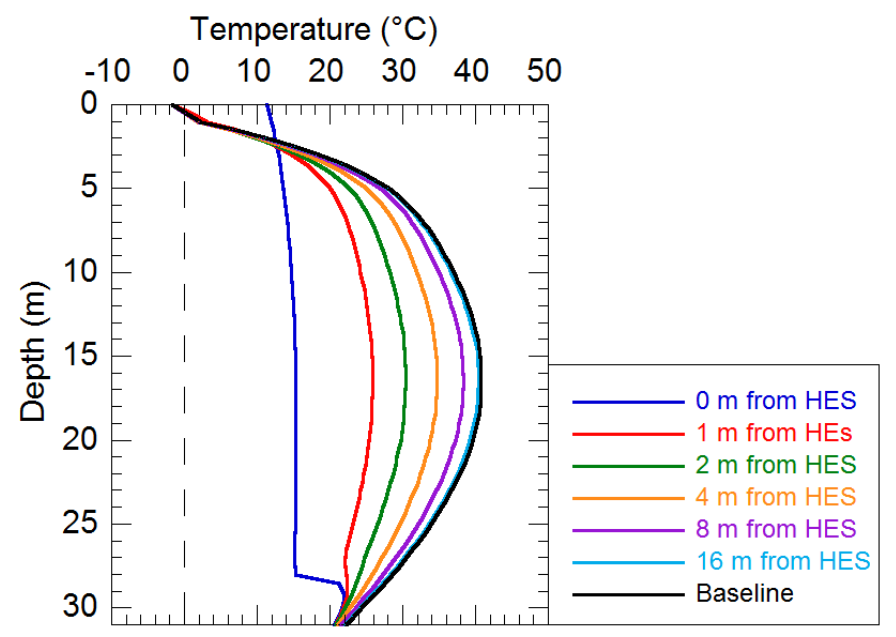

Figure A.6: Vertical Temperature Results: $25.4 \mathrm{~mm}$ Diameter Pipe $0.6 \mathrm{~m} / \mathrm{s}$ Fluid Velocity 

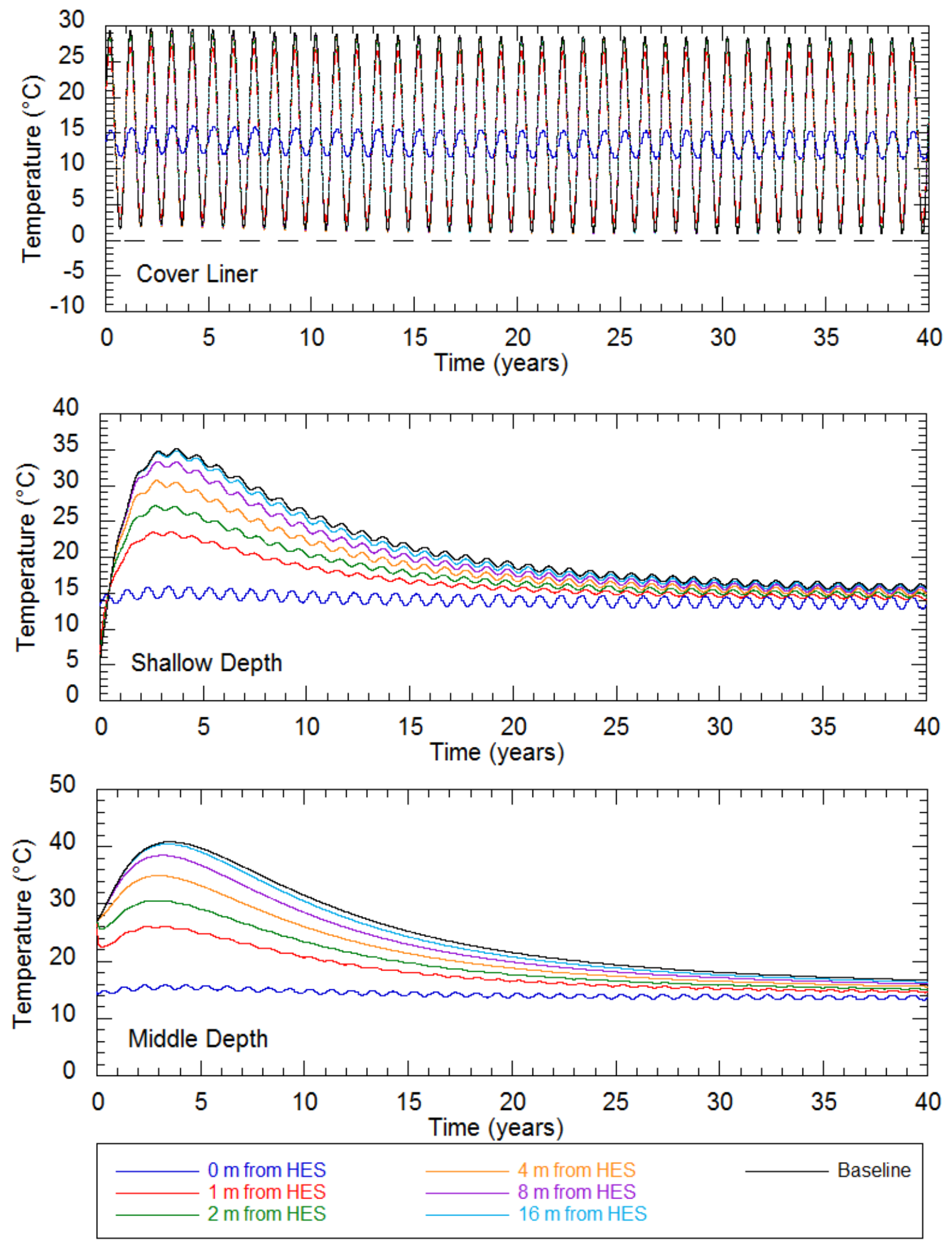

Figure A.7a: Temperature Results: 25.4 mm Diameter Pipe 1.0 m/s Fluid Velocity 

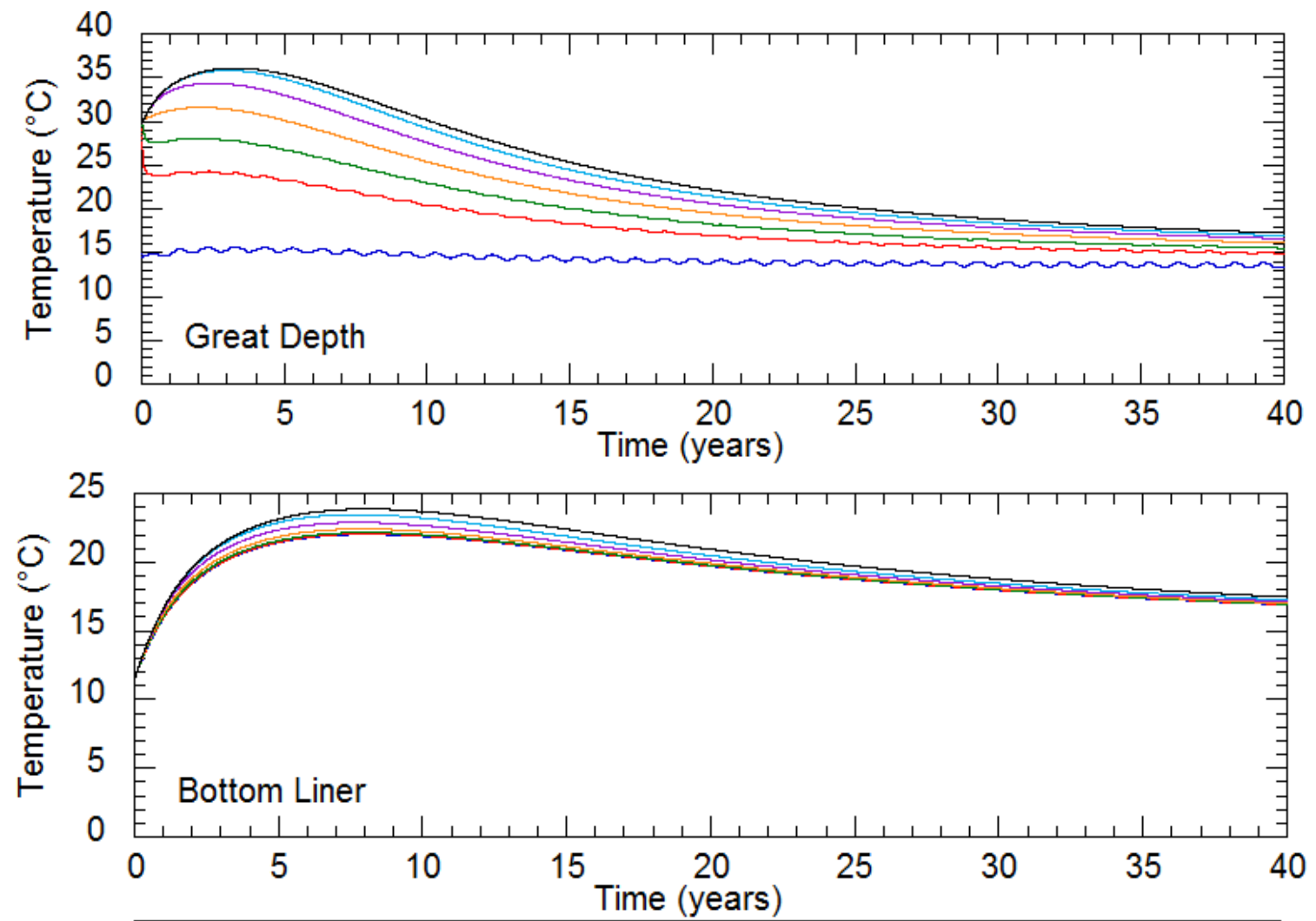

$m$ from HES

$1 \mathrm{~m}$ from HES

$4 \mathrm{~m}$ from HES

Baseline

$2 \mathrm{~m}$ from HES

- $8 \mathrm{~m}$ from HES

$16 \mathrm{~m}$ from HES

Figure A.7b: Temperature Results: 25.4 mm Diameter Pipe 1.0 m/s Fluid Velocity

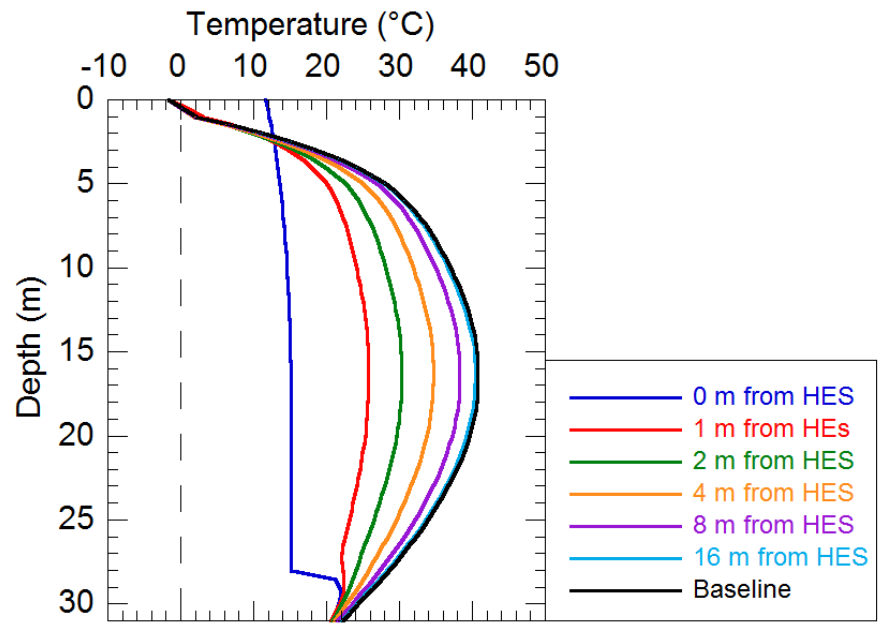

Figure A.8: Vertical Temperature Results: $25.4 \mathrm{~mm}$ Diameter

Pipe $1.0 \mathrm{~m} / \mathrm{s}$ Fluid Velocity 

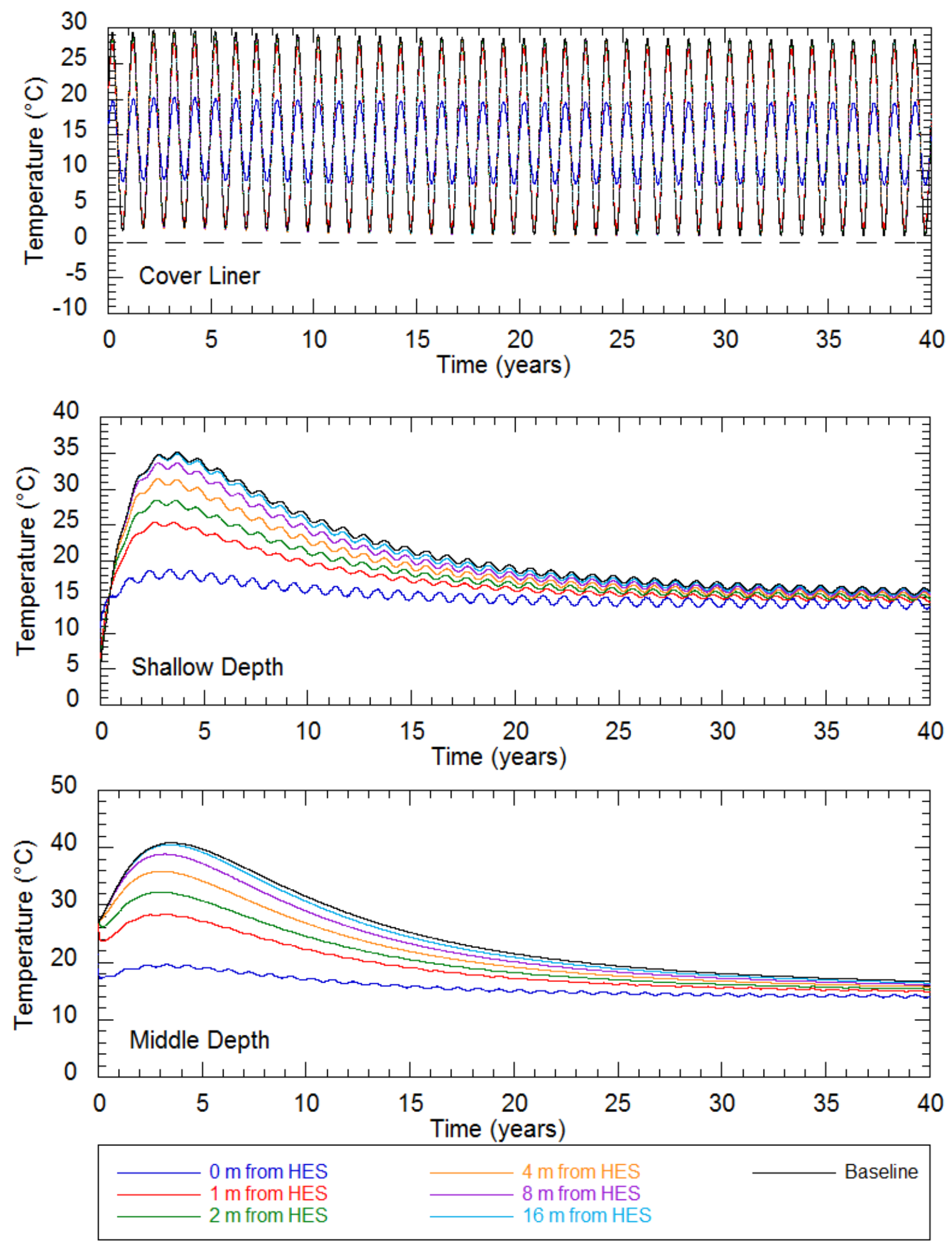

Figure A.9a: Temperature Results: $38.1 \mathrm{~mm}$ Diameter Pipe $0.01 \mathrm{~m} / \mathrm{s}$ Fluid Velocity 

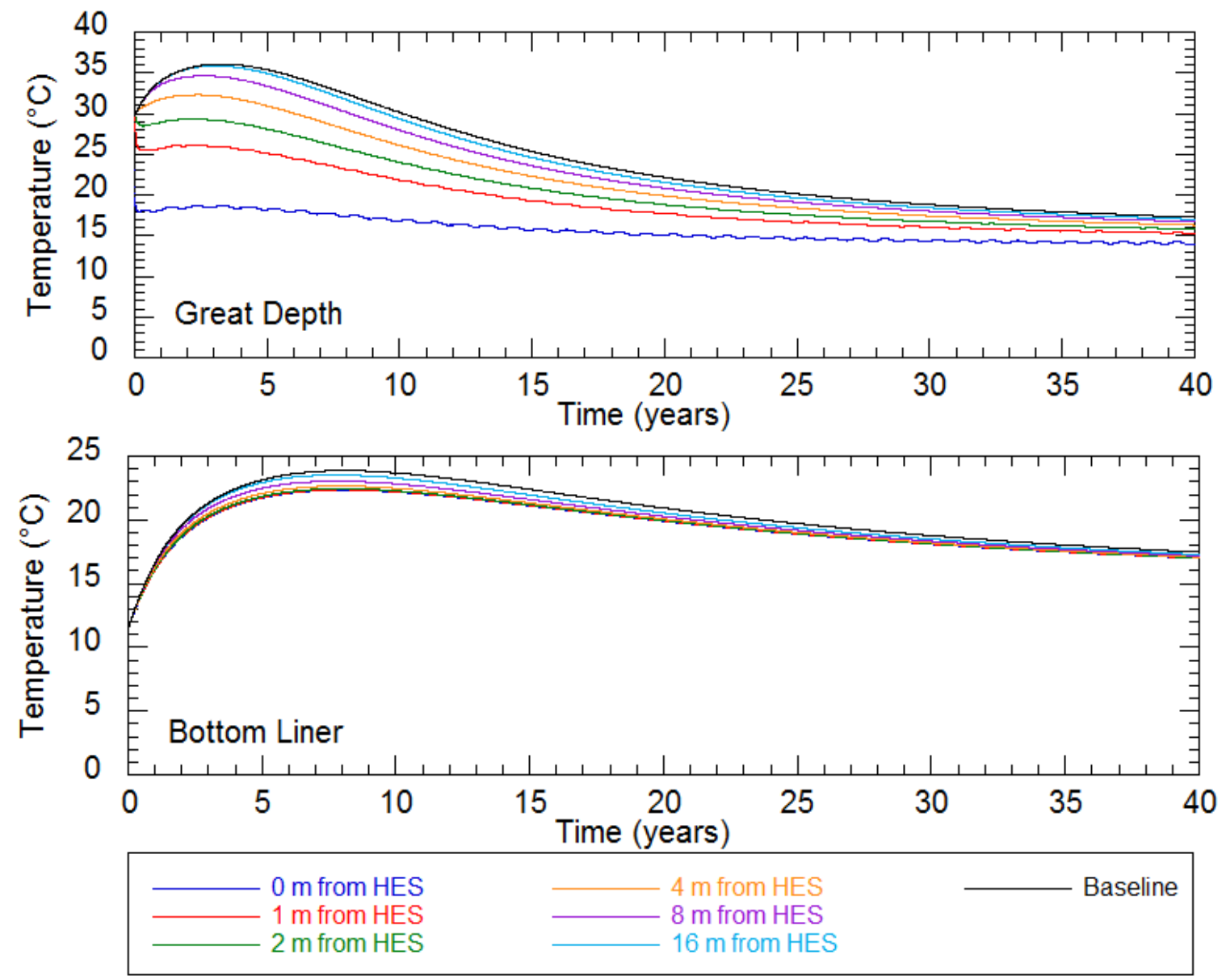

Figure A.9b: Temperature Results: $38.1 \mathrm{~mm}$ Diameter Pipe $0.01 \mathrm{~m} / \mathrm{s}$ Fluid Velocity

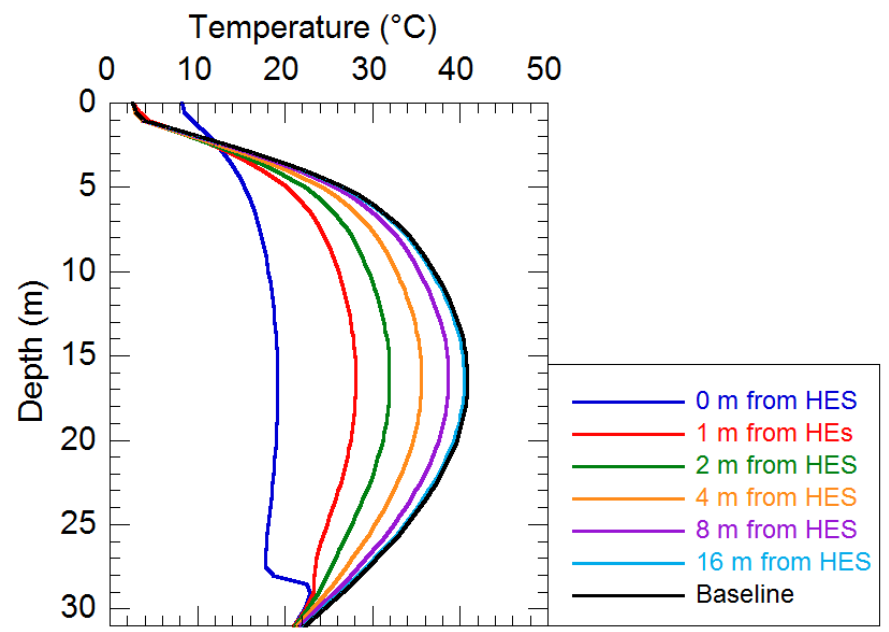

Figure A.10: Vertical Temperature Results: $38.1 \mathrm{~mm}$ Diameter Pipe $0.01 \mathrm{~m} / \mathrm{s}$ Fluid Velocity 

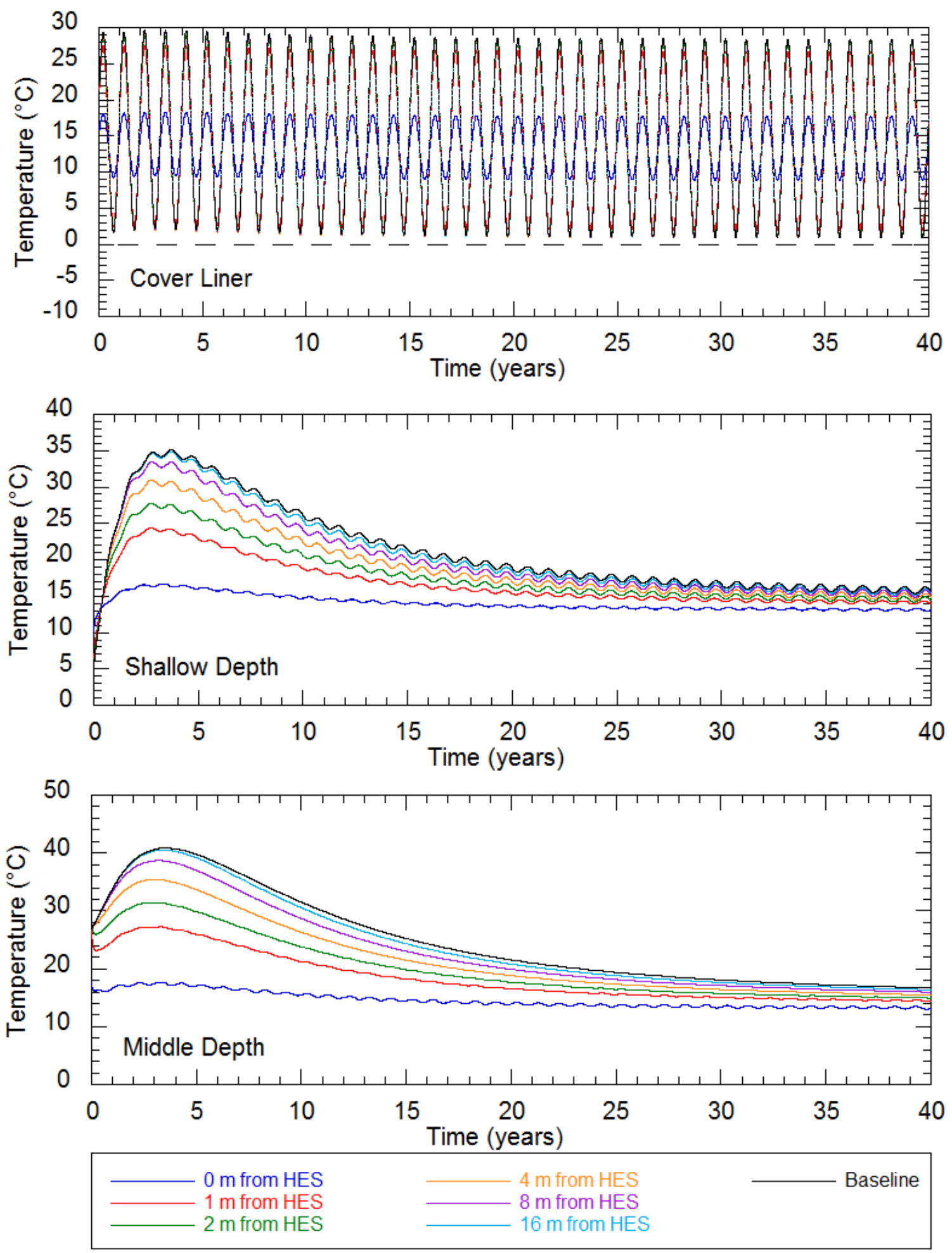

Figure A.11a: Temperature Results: $38.1 \mathrm{~mm}$ Diameter Pipe $0.1 \mathrm{~m} / \mathrm{s}$ Fluid Velocity 

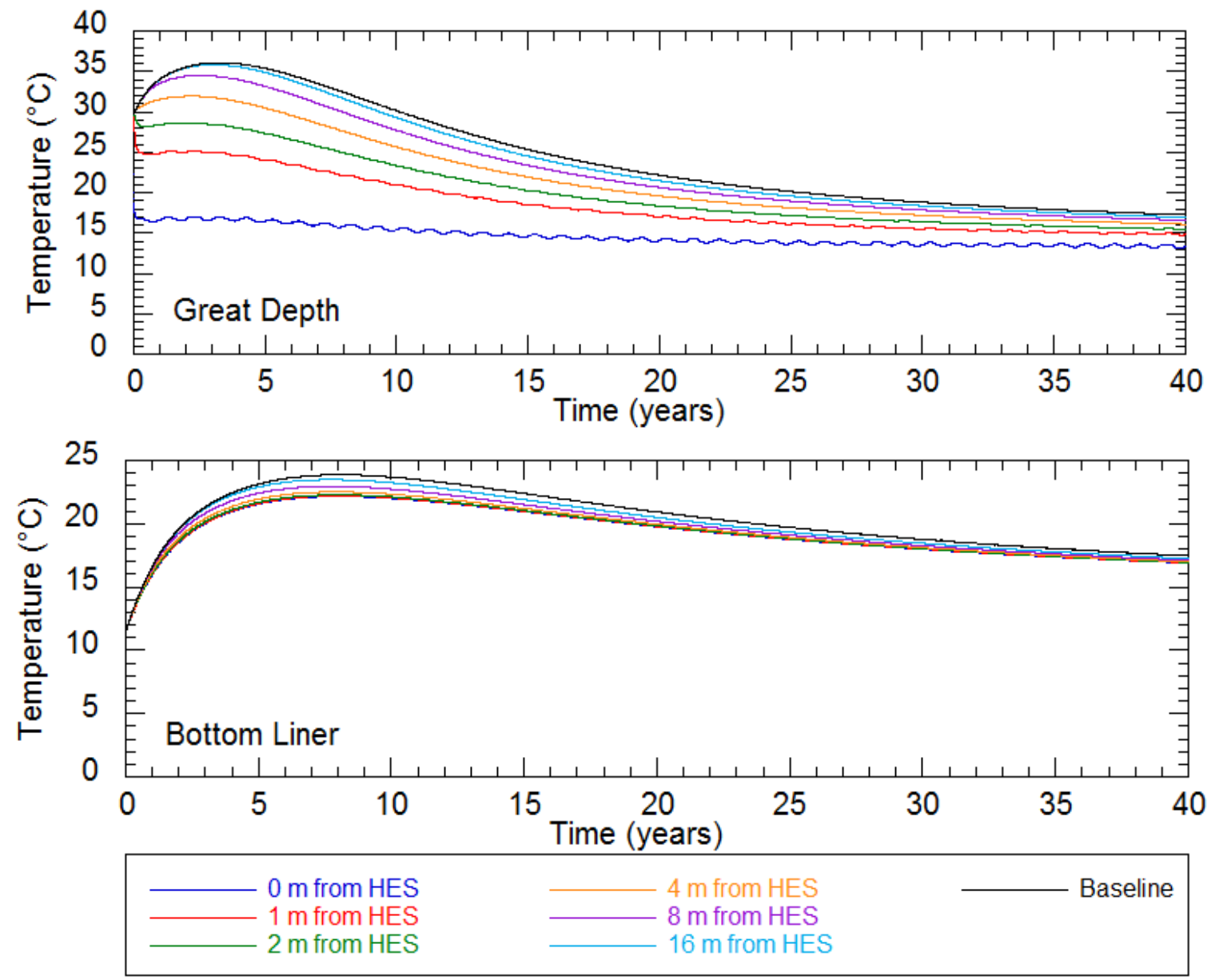

Figure A.11b: Temperature Results: $38.1 \mathrm{~mm}$ Diameter

Pipe $0.1 \mathrm{~m} / \mathrm{s}$ Fluid Velocity

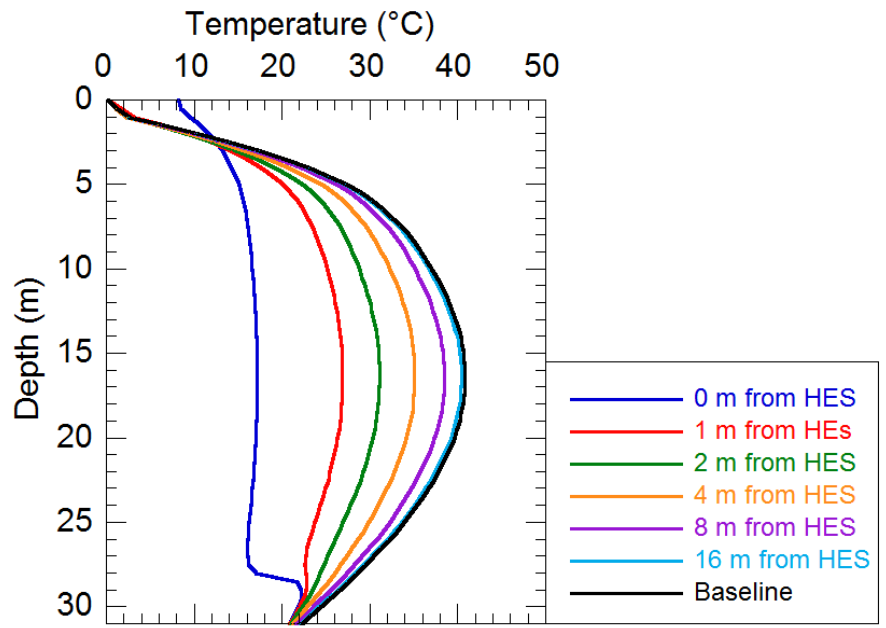

Figure A.12: Vertical Temperature Results: $38.1 \mathrm{~mm}$ Diameter Pipe $0.1 \mathrm{~m} / \mathrm{s}$ Fluid Velocity 

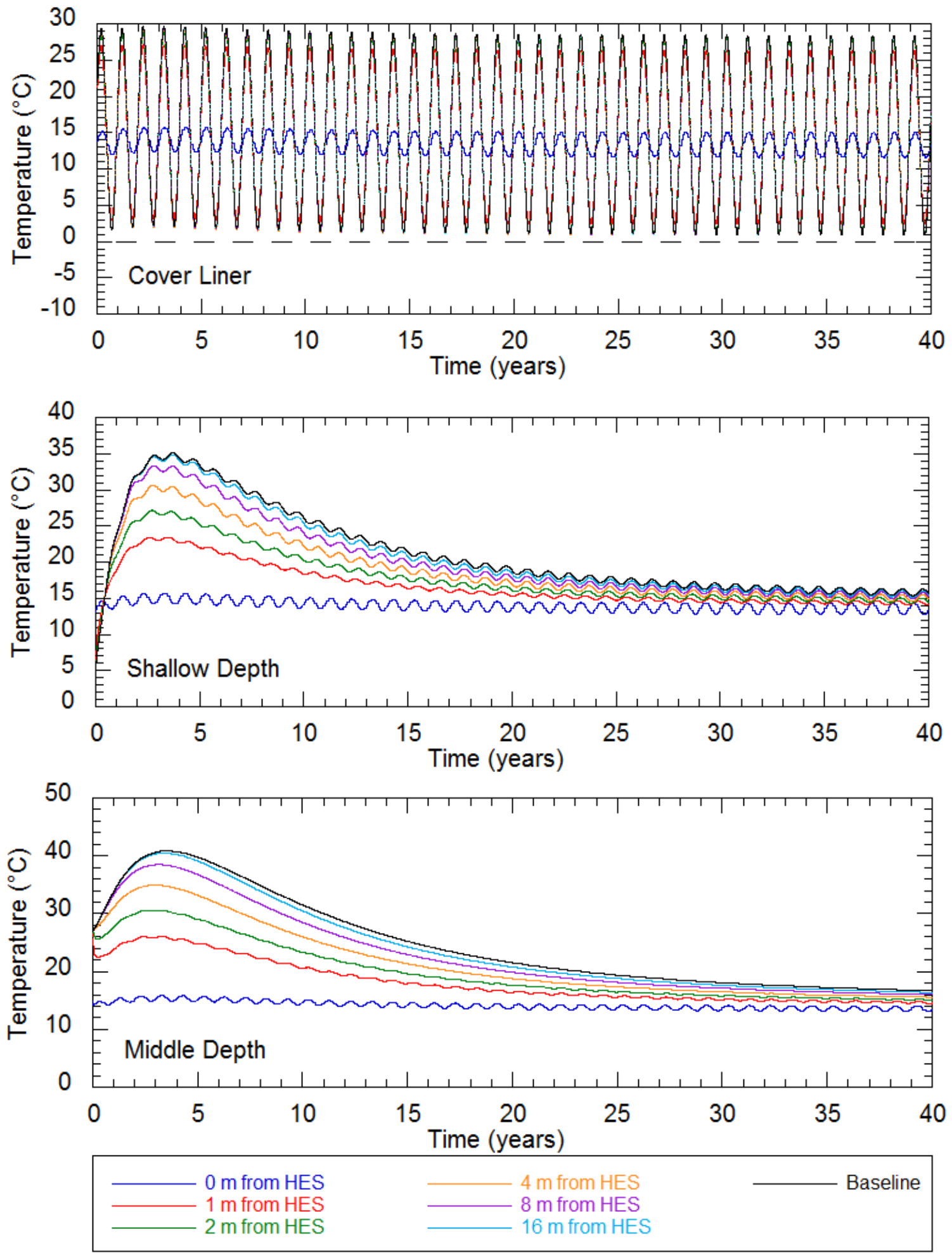

Figure A.13a: Temperature Results: $38.1 \mathrm{~mm}$ Diameter Pipe $0.3 \mathrm{~m} / \mathrm{s}$ Fluid Velocity 

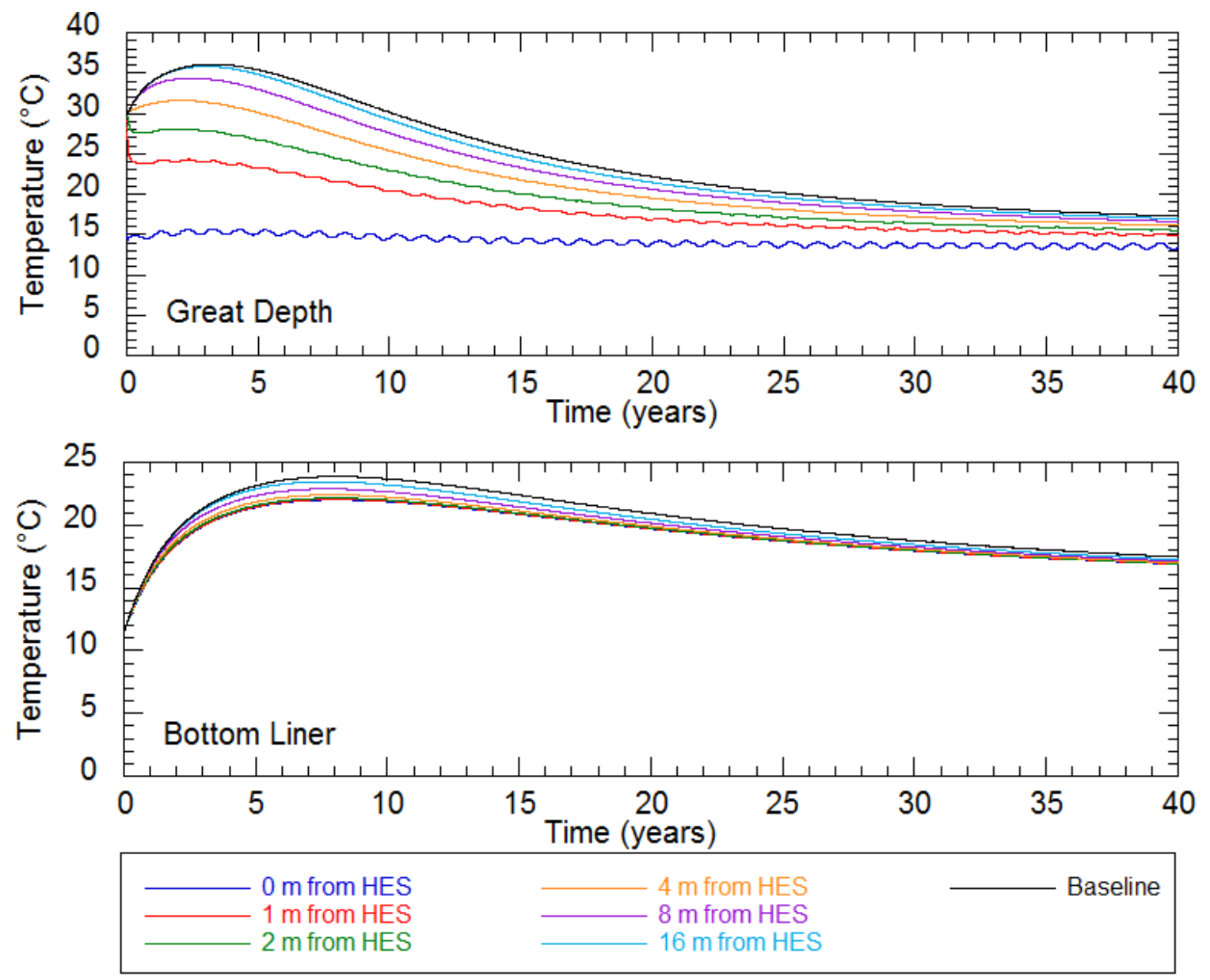

Figure A.13b: Temperature Results: $38.1 \mathrm{~mm}$ Diameter

Pipe $0.3 \mathrm{~m} / \mathrm{s}$ Fluid Velocity

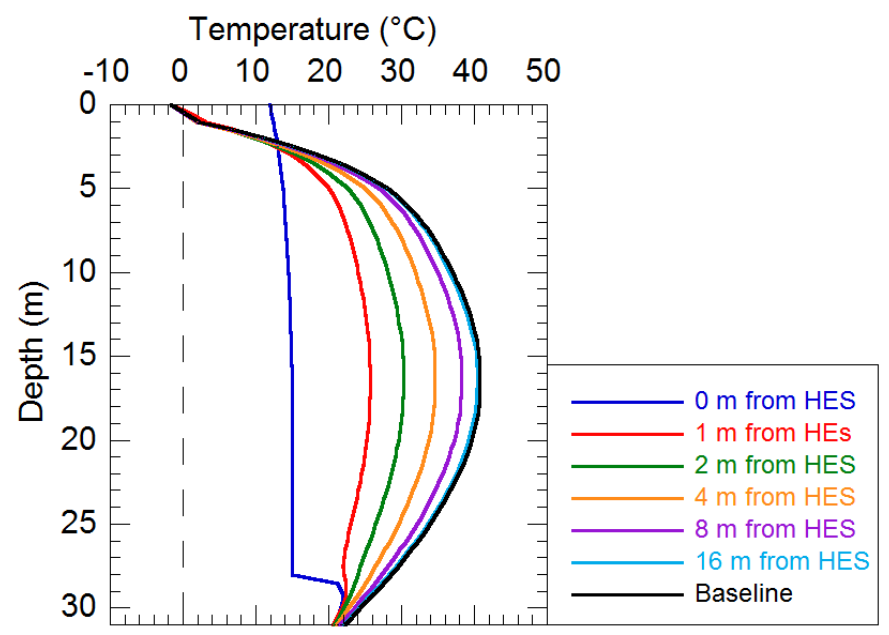

Figure A.14: Vertical Temperature Results: $38.1 \mathrm{~mm}$ Diameter Pipe $0.3 \mathrm{~m} / \mathrm{s}$ Fluid Velocity 

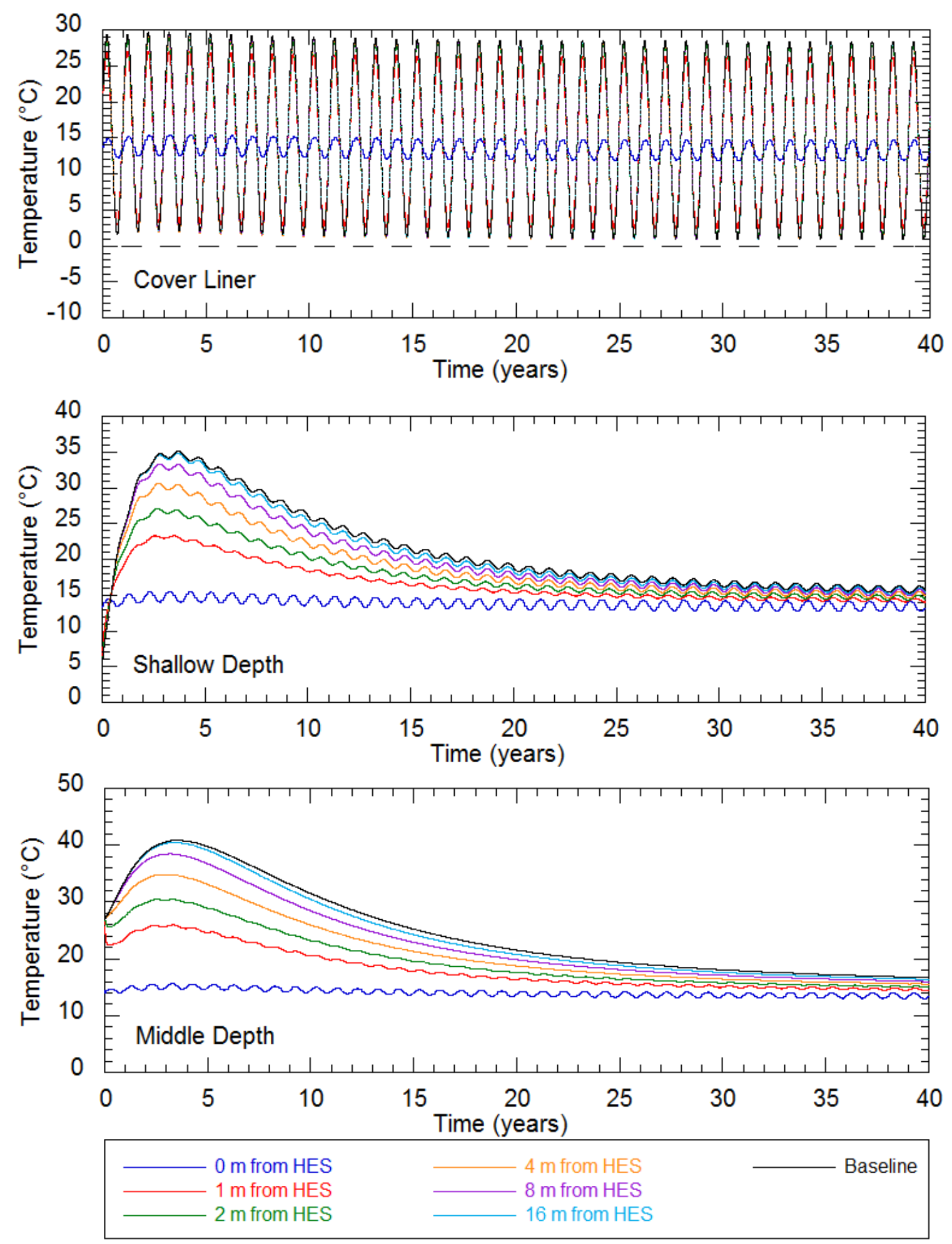

Figure A.15a: Temperature Results: $38.1 \mathrm{~mm}$ Diameter Pipe $0.6 \mathrm{~m} / \mathrm{s}$ Fluid Velocity 

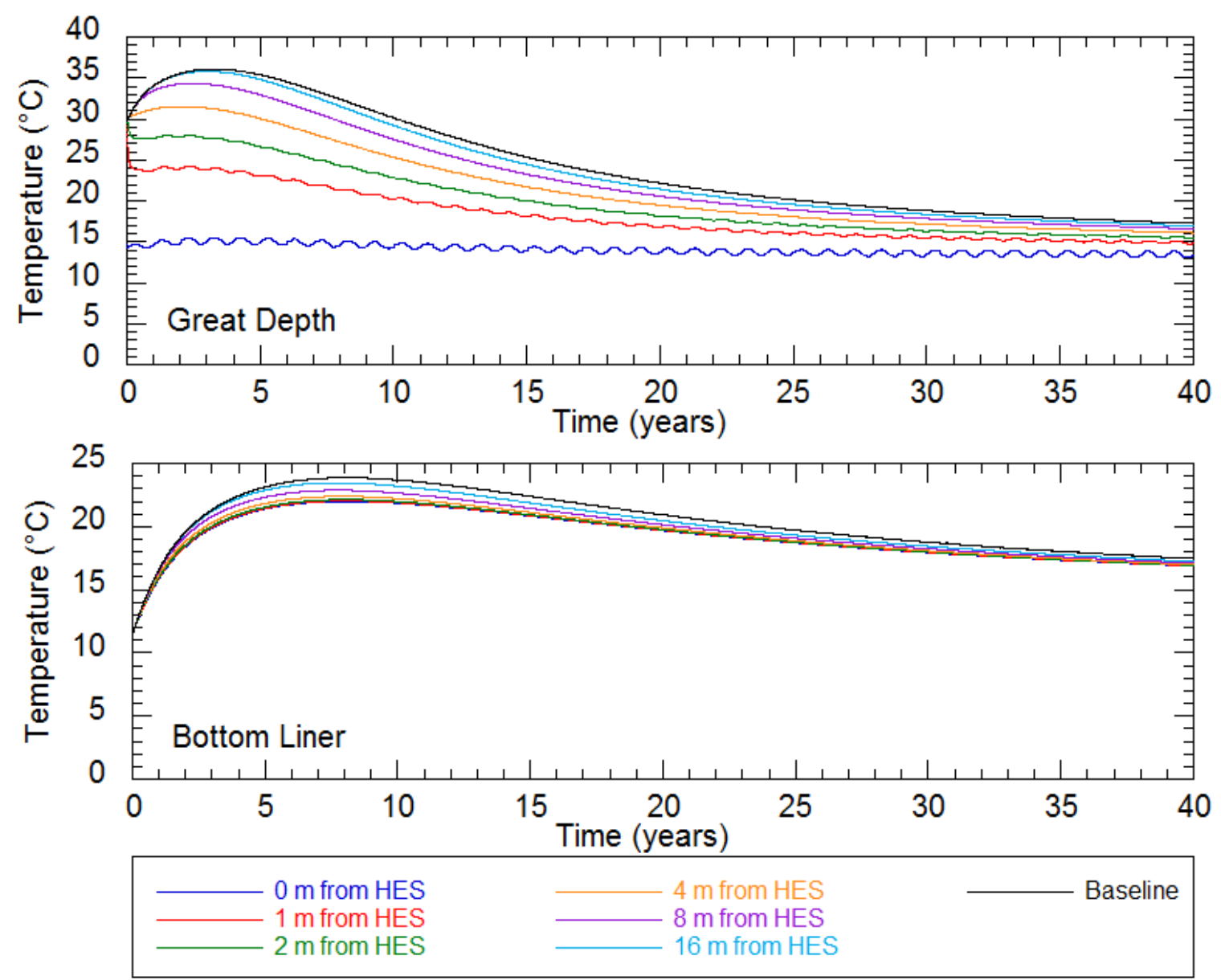

Figure A.15b: Temperature Results: $38.1 \mathrm{~mm}$ Diameter Pipe $0.6 \mathrm{~m} / \mathrm{s}$ Fluid Velocity

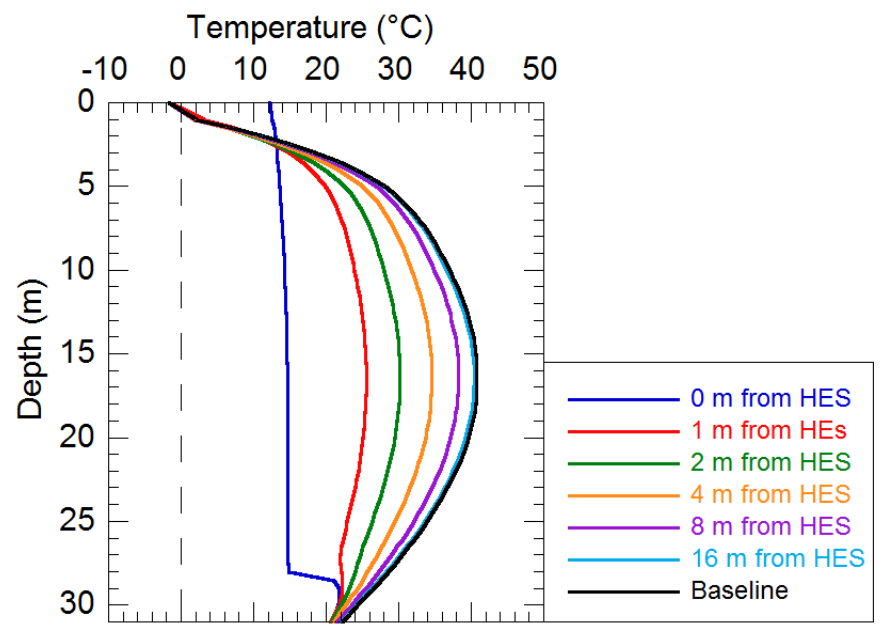

Figure A.16: Vertical Temperature Results: $38.1 \mathrm{~mm}$ Diameter Pipe $0.6 \mathrm{~m} / \mathrm{s}$ Fluid Velocity 

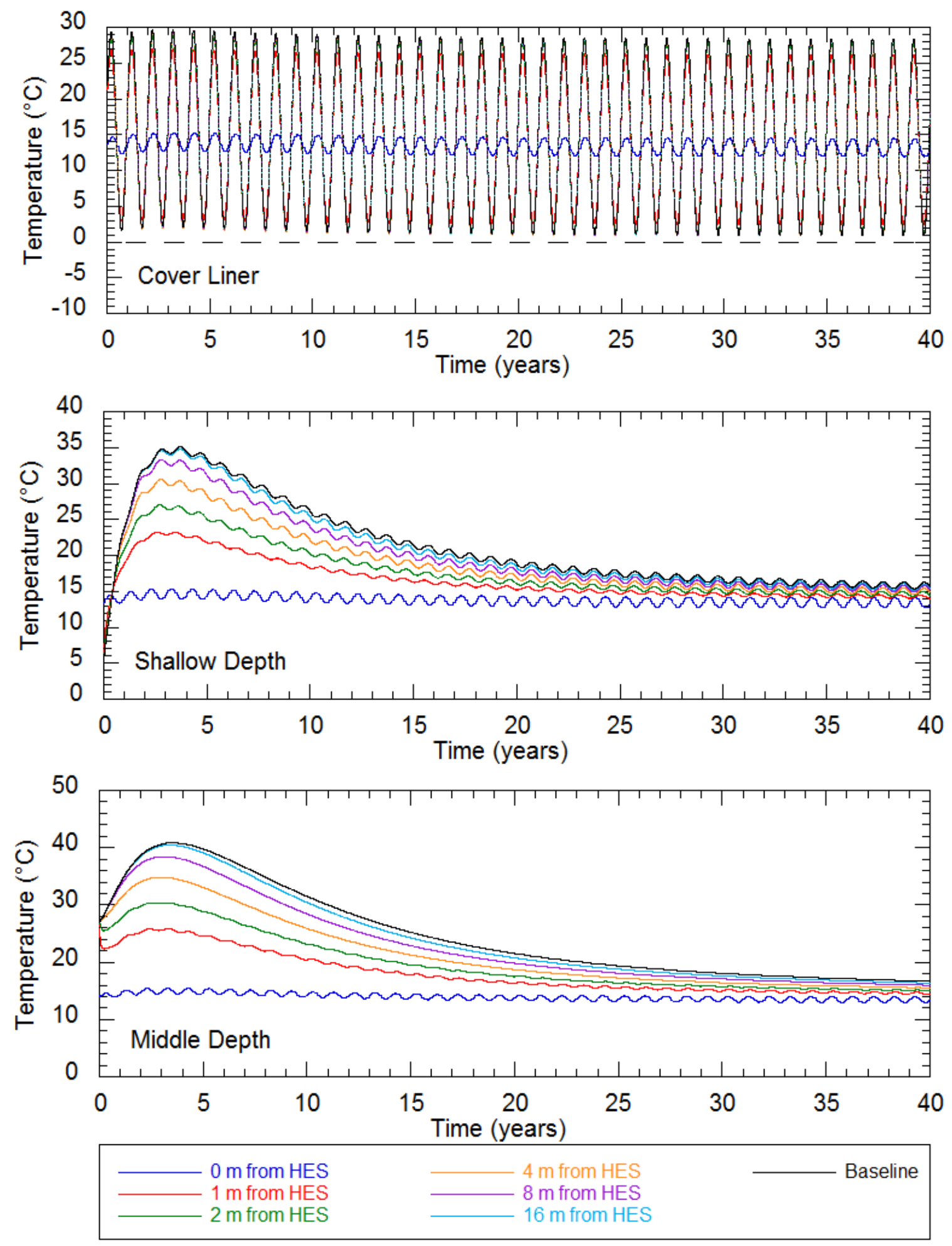

Figure A.17a: Temperature Results: $38.1 \mathrm{~mm}$ Diameter Pipe $1.0 \mathrm{~m} / \mathrm{s}$ Fluid Velocity 

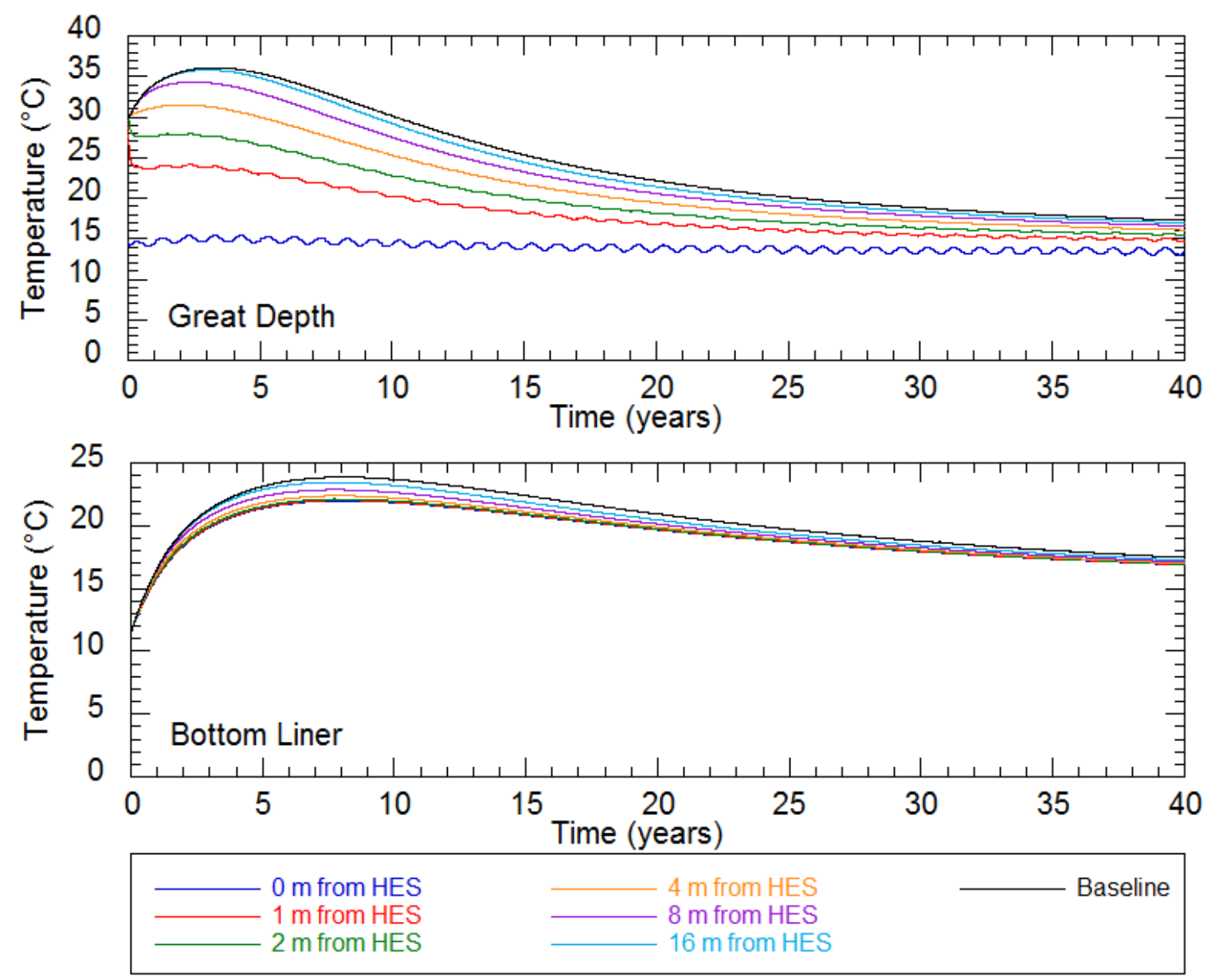

Figure A.17b: Temperature Results: $38.1 \mathrm{~mm}$ Diameter Pipe $1.0 \mathrm{~m} / \mathrm{s}$ Fluid Velocity

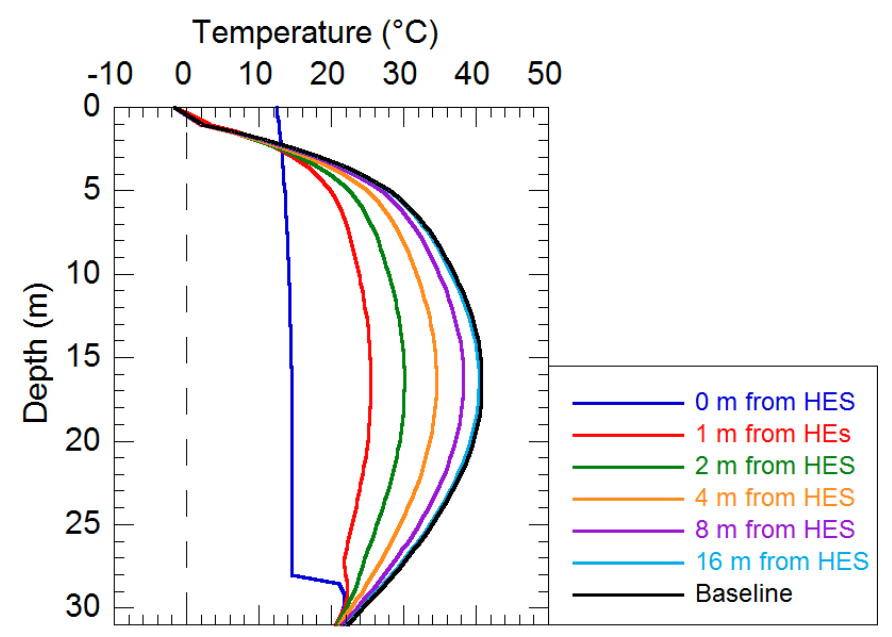

Figure A.18: Vertical Temperature Results: $38.1 \mathrm{~mm}$ Diameter Pipe $1.0 \mathrm{~m} / \mathrm{s}$ Fluid Velocity 

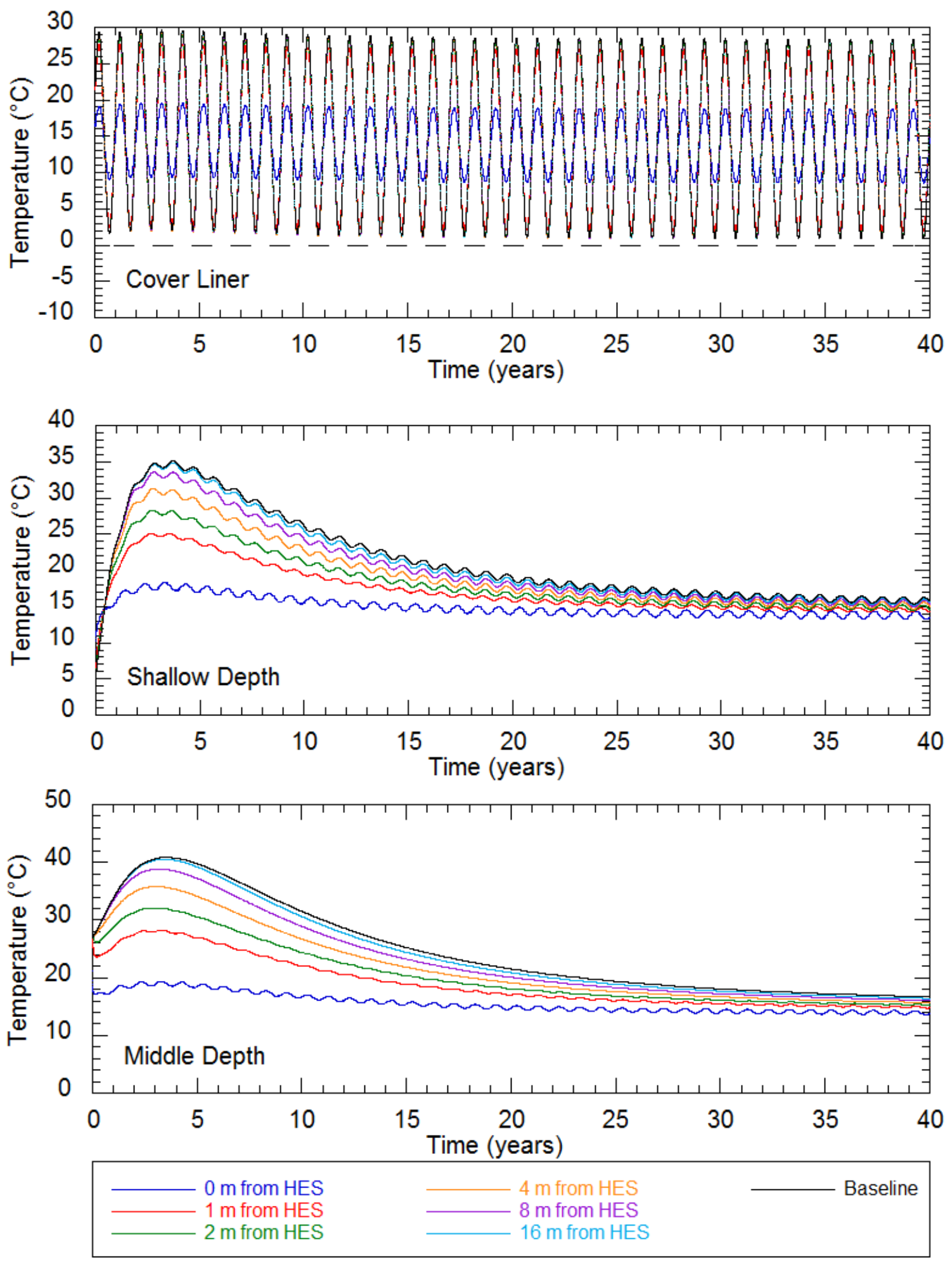

Figure A.19a: Temperature Results: $50.8 \mathrm{~mm}$ Diameter

Pipe $0.01 \mathrm{~m} / \mathrm{s}$ Fluid Velocity 

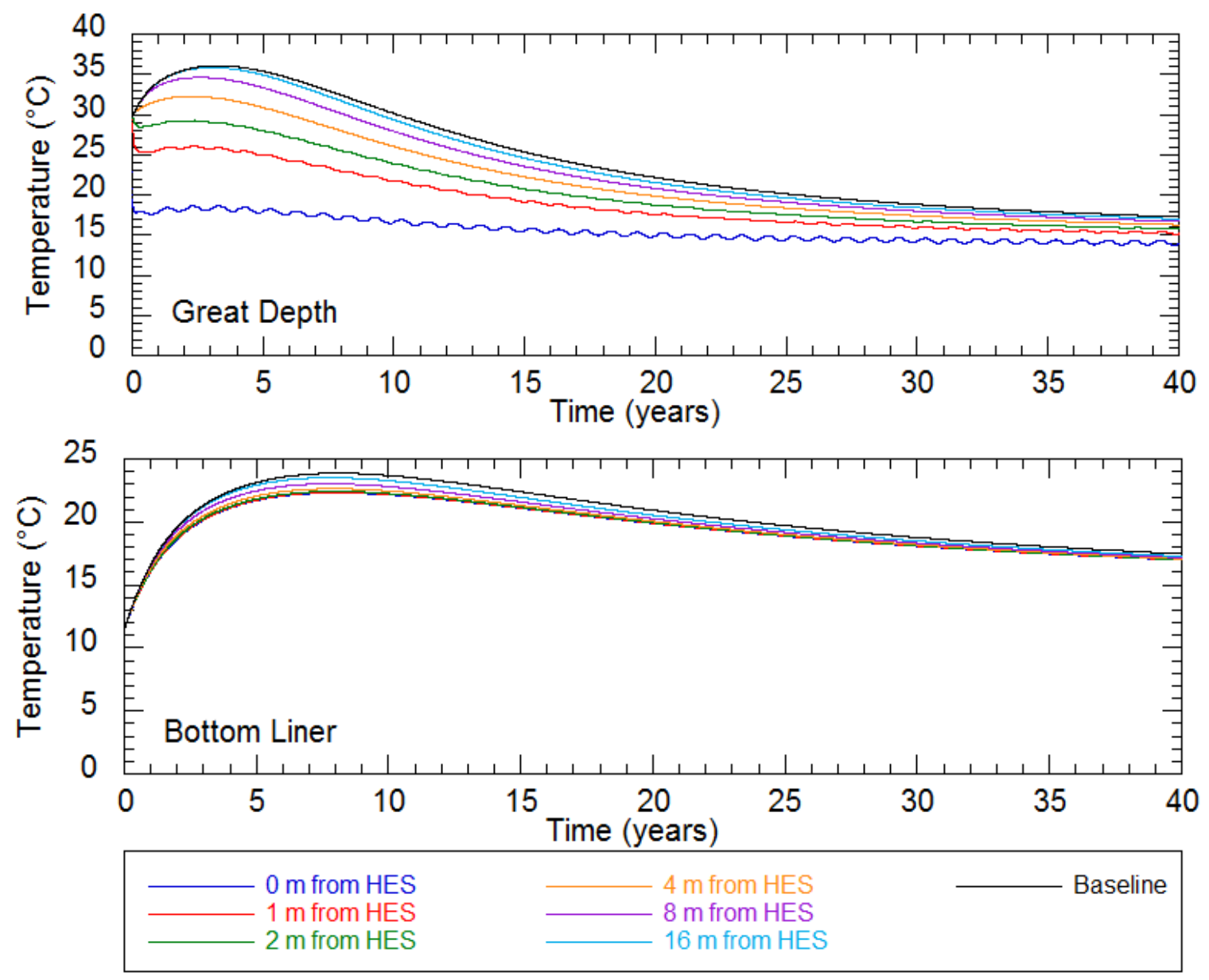

Figure A.19b: Temperature Results: $50.8 \mathrm{~mm}$ Diameter

Pipe $0.01 \mathrm{~m} / \mathrm{s}$ Fluid Velocity

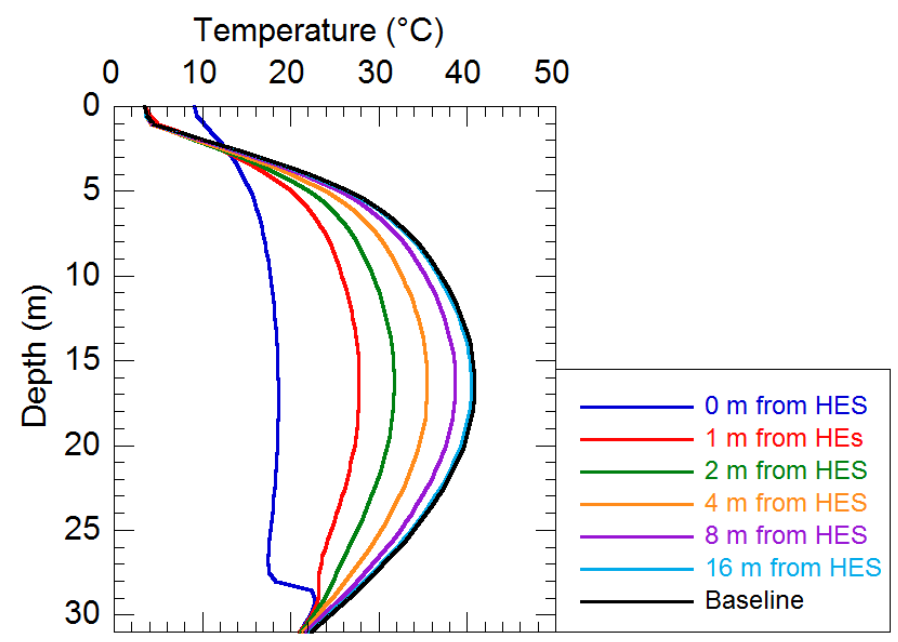

Figure A.20: Vertical Temperature Results: $50.8 \mathrm{~mm}$ Diameter Pipe $0.01 \mathrm{~m} / \mathrm{s}$ Fluid Velocity 

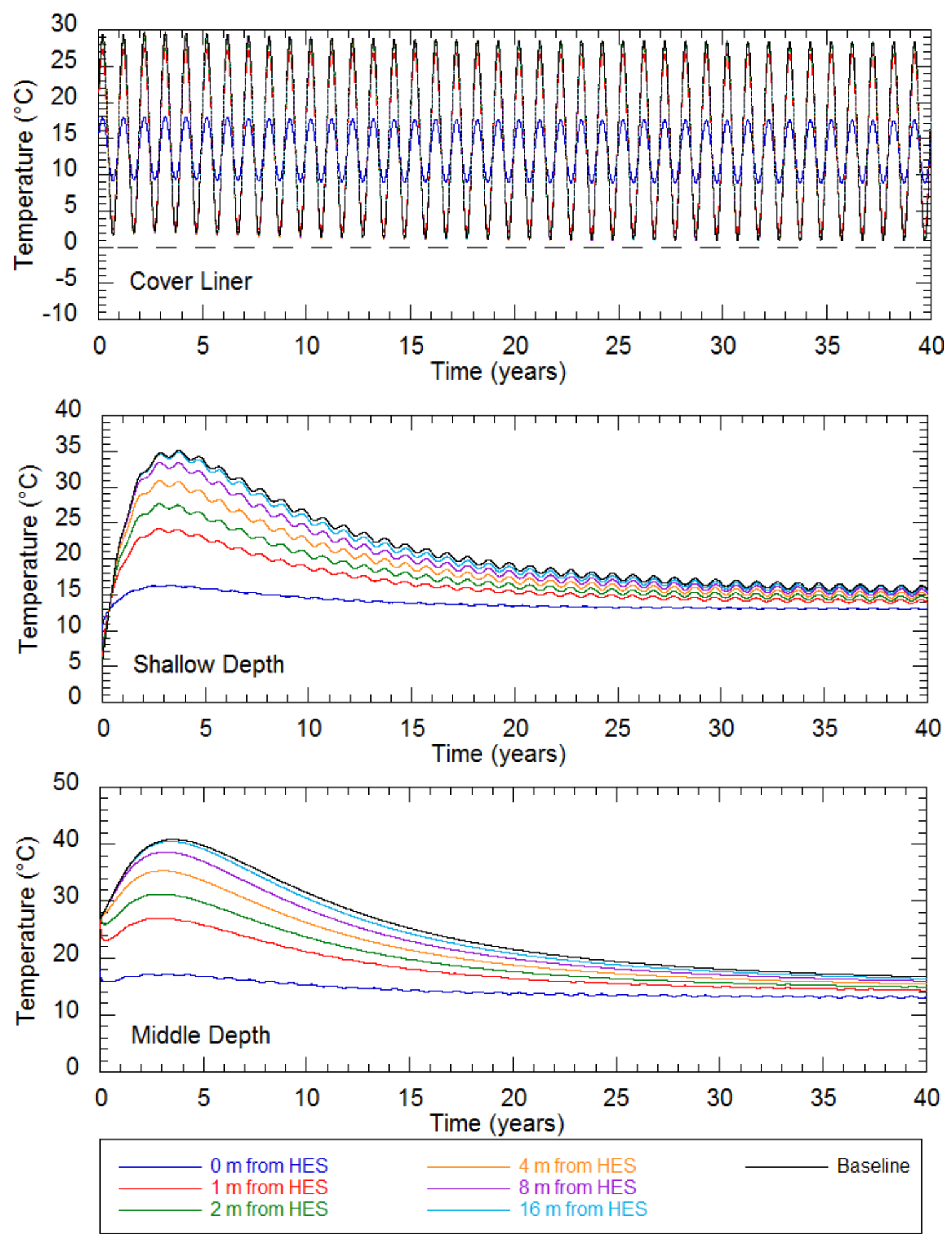

Figure A.21a: Temperature Results: $50.8 \mathrm{~mm}$ Diameter Pipe $0.1 \mathrm{~m} / \mathrm{s}$ Fluid Velocity 

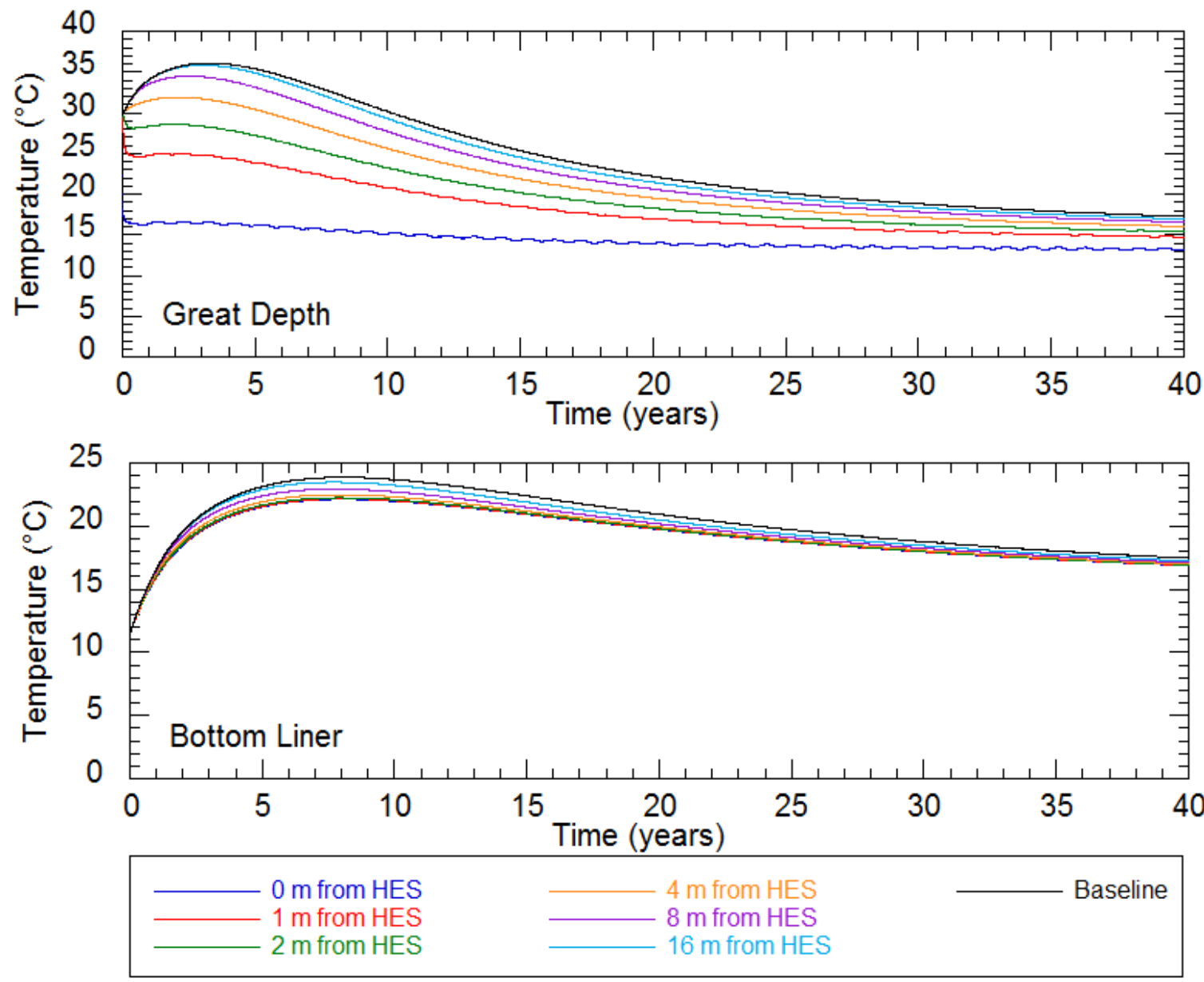

Figure A.21b: Temperature Results: $50.8 \mathrm{~mm}$

Diameter Pipe $0.1 \mathrm{~m} / \mathrm{s}$ Fluid Velocity

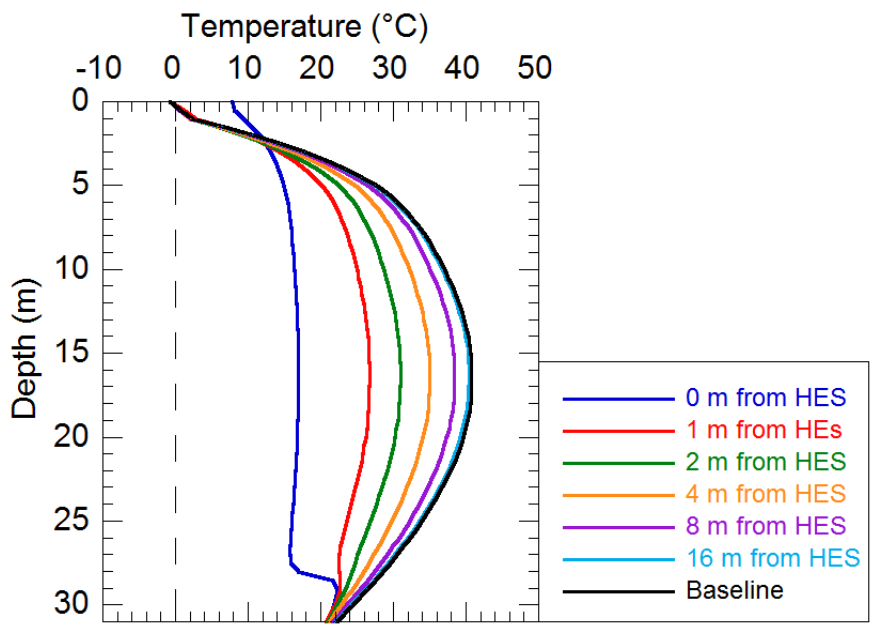

Figure A.22: Vertical Temperature Results: $50.8 \mathrm{~mm}$ Diameter Pipe $0.1 \mathrm{~m} / \mathrm{s}$ Fluid Velocity 

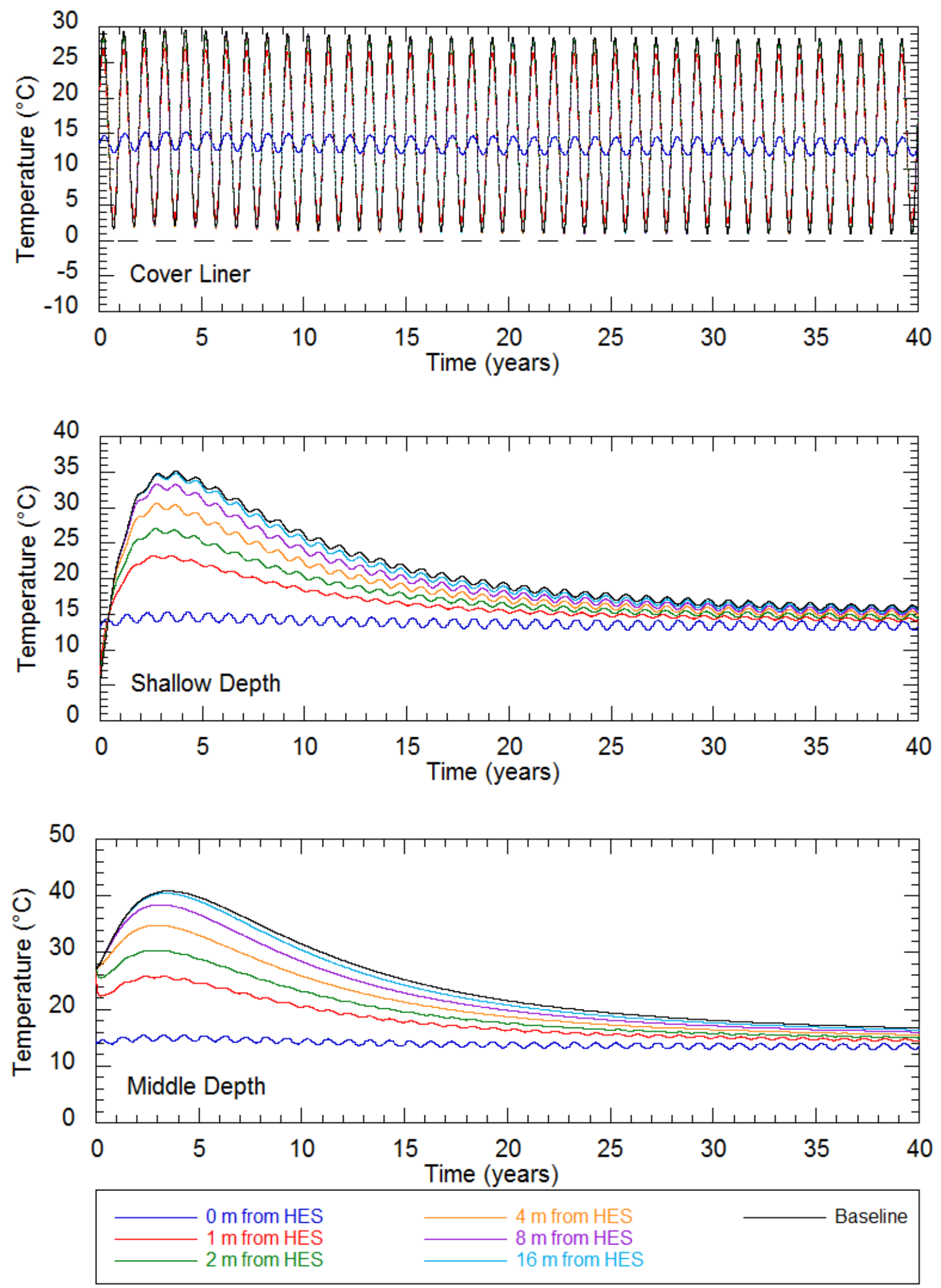

Figure A.23a: Temperature Results: $50.8 \mathrm{~mm}$ Diameter Pipe $0.3 \mathrm{~m} / \mathrm{s}$ Fluid Velocity 

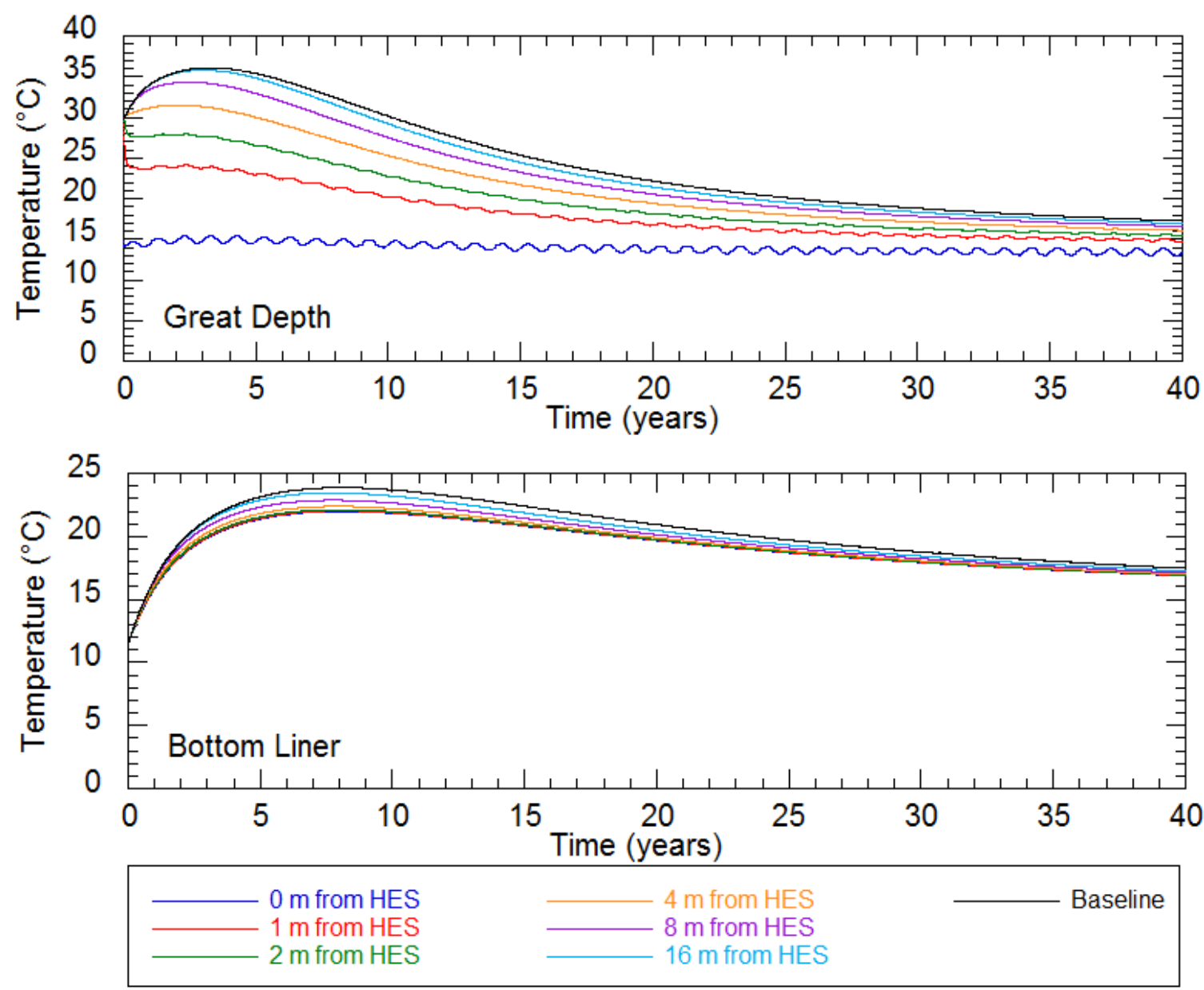

Figure A.23b: Temperature Results: $50.8 \mathrm{~mm}$ Diameter Pipe $0.3 \mathrm{~m} / \mathrm{s}$ Fluid Velocity

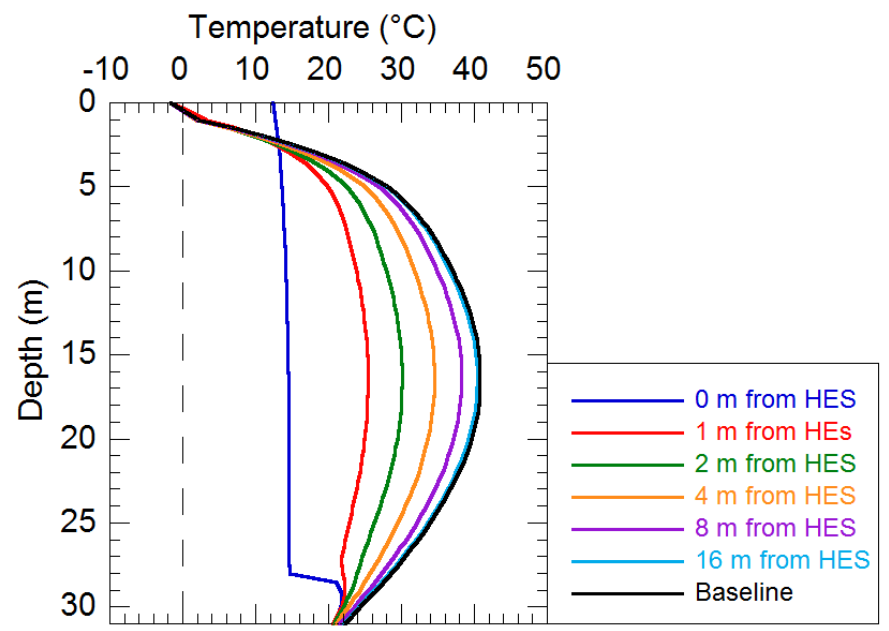

Figure A.24: Vertical Temperature Results: $50.8 \mathrm{~mm}$ Diameter Pipe $0.3 \mathrm{~m} / \mathrm{s}$ Fluid Velocity 

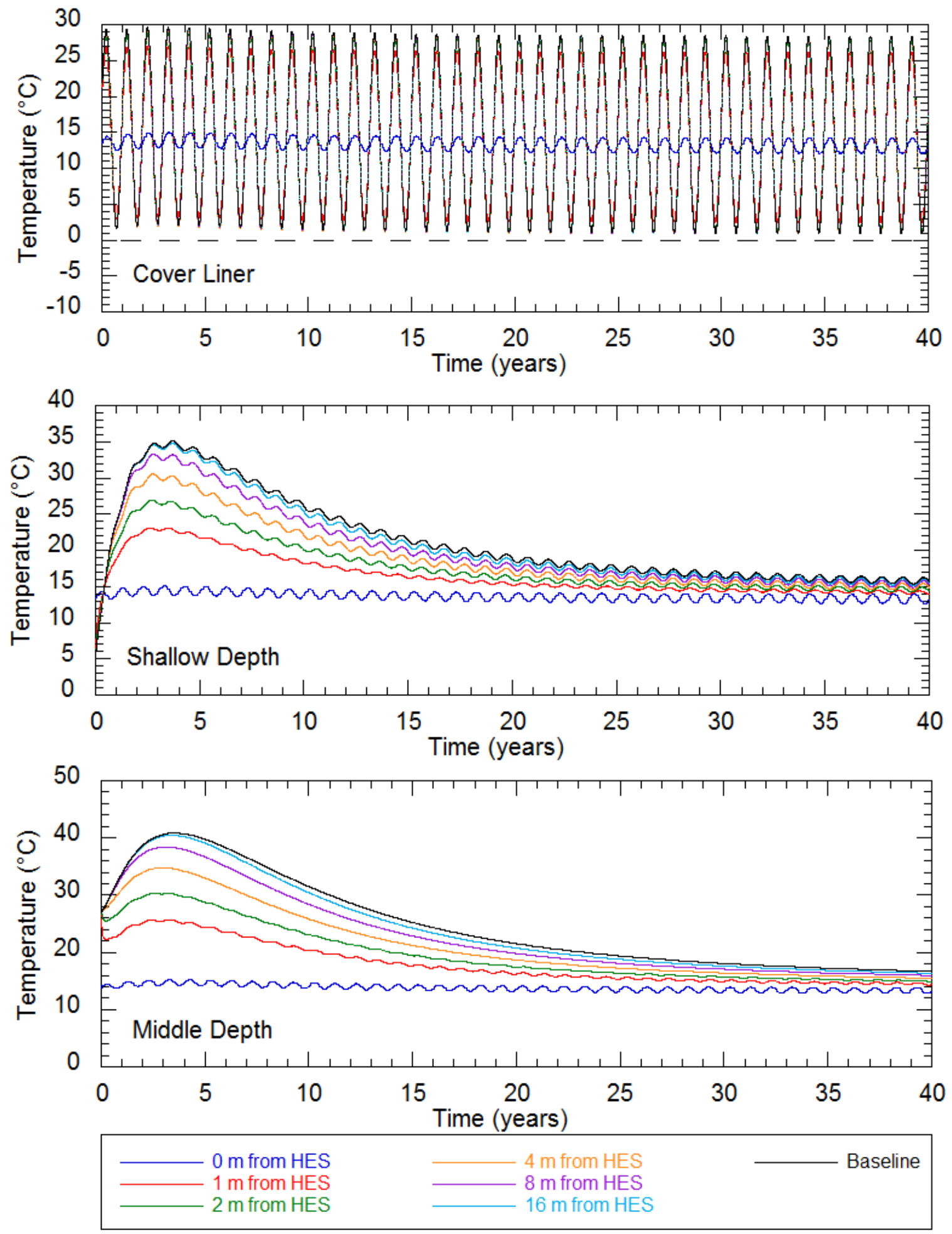

Figure A.25a: Temperature Results: $50.8 \mathrm{~mm}$ Diameter Pipe $0.6 \mathrm{~m} / \mathrm{s}$ Fluid Velocity 

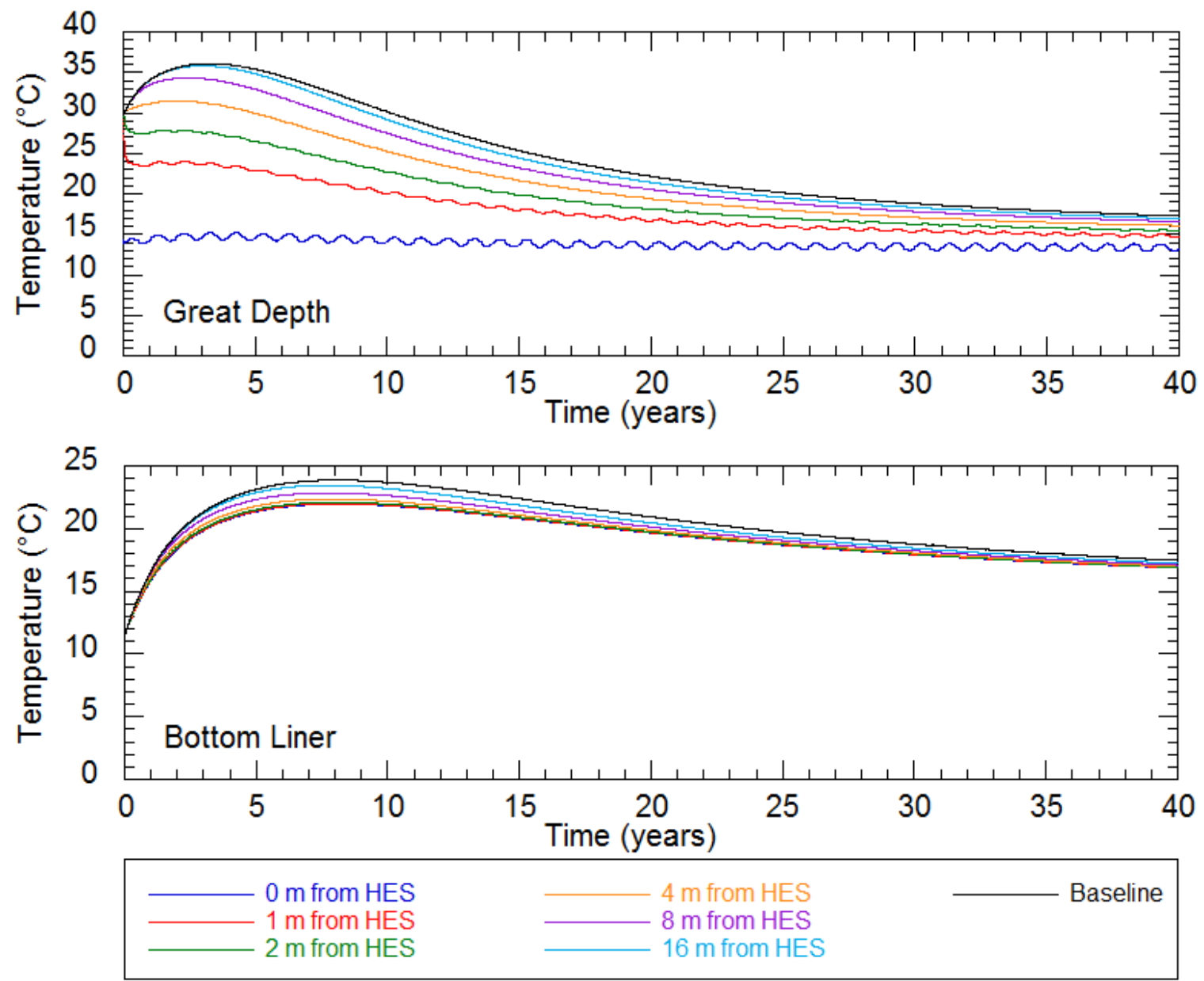

Figure A.25b: Temperature Results: $50.8 \mathrm{~mm}$ Diameter Pipe $0.6 \mathrm{~m} / \mathrm{s}$ Fluid Velocity

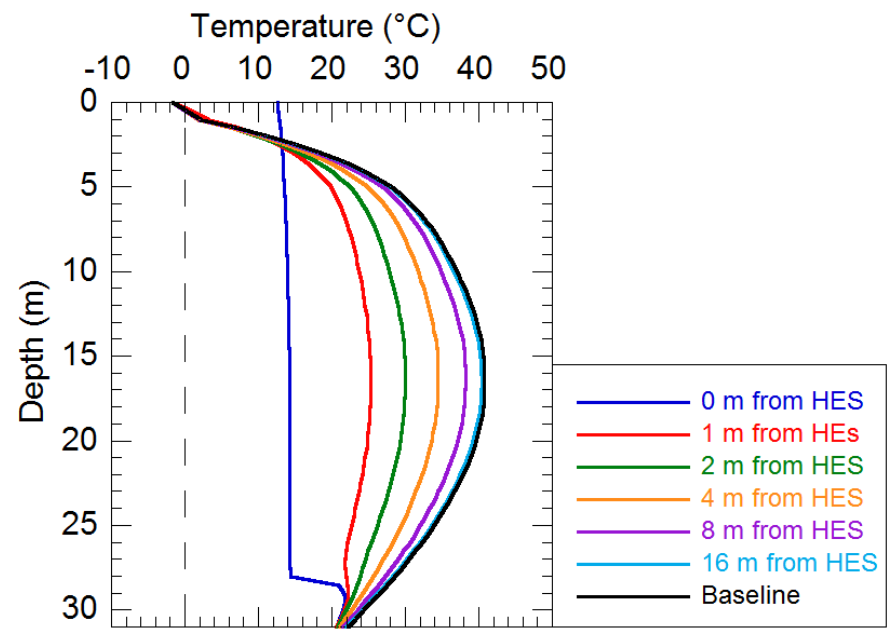

Figure A.26: Vertical Temperature Results: $50.8 \mathrm{~mm}$ Diameter

Pipe $0.6 \mathrm{~m} / \mathrm{s}$ Fluid Velocity 

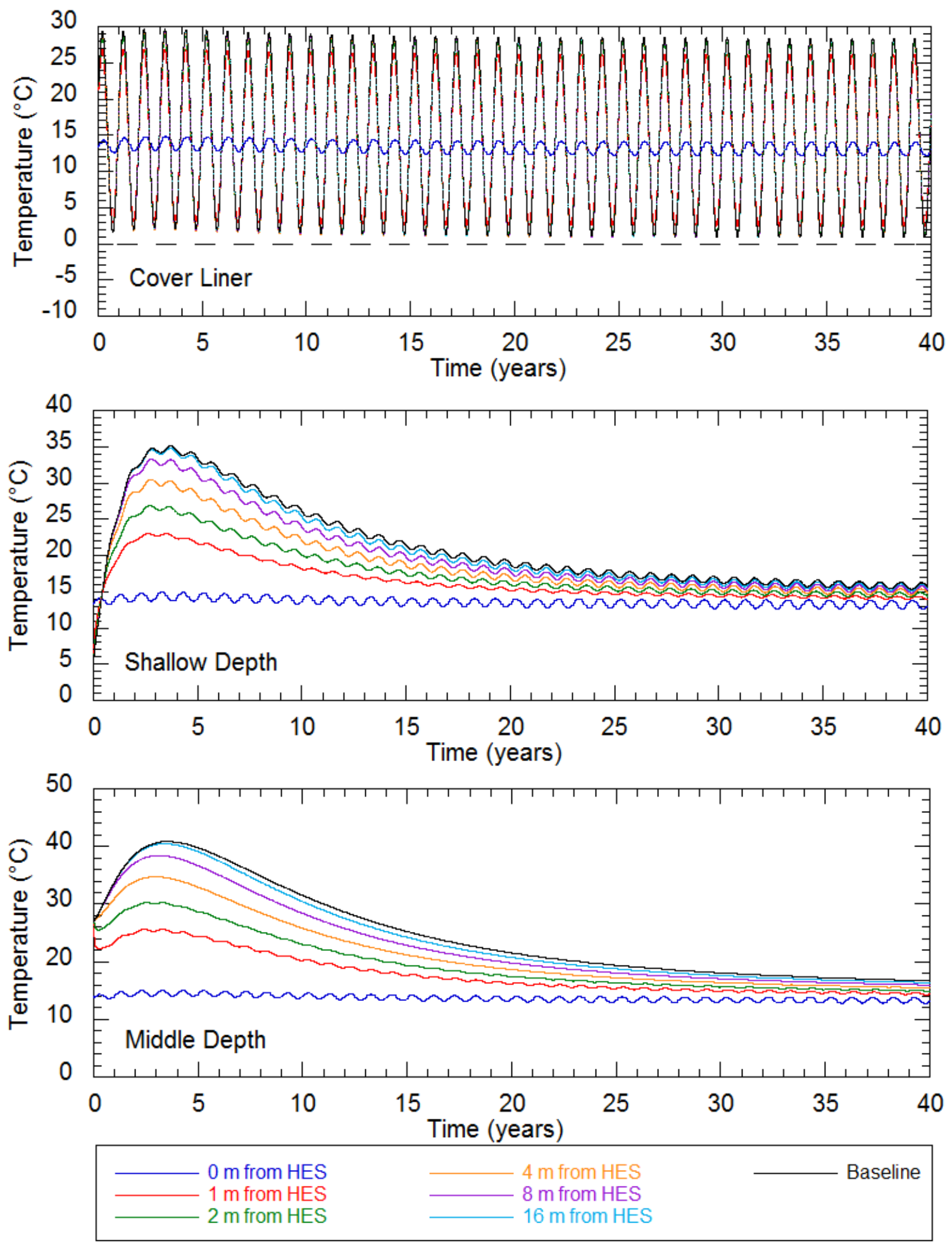

Figure A.27a: Temperature Results: $50.8 \mathrm{~mm}$ Diameter

Pipe $1.0 \mathrm{~m} / \mathrm{s}$ Fluid Velocity 

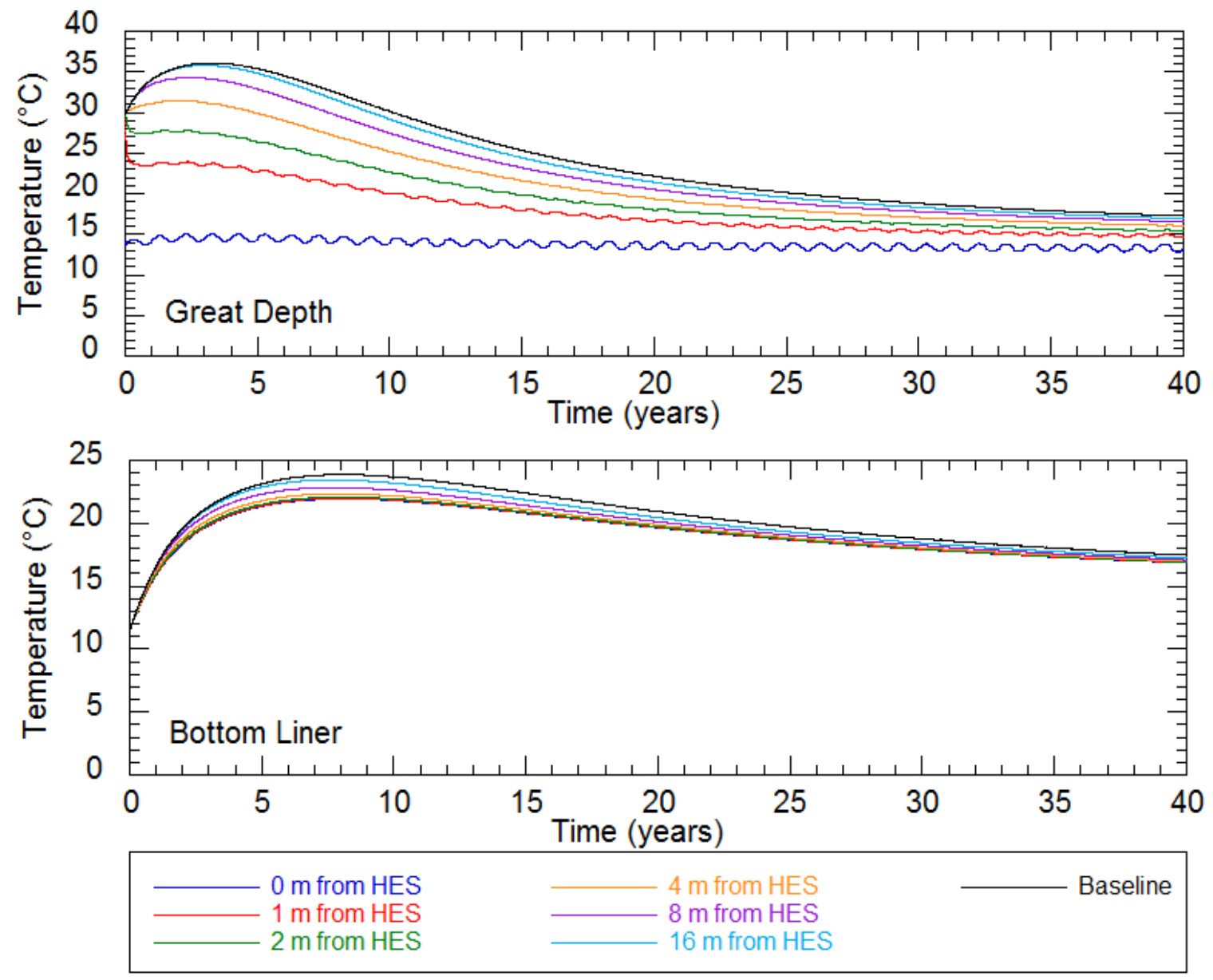

Figure A.27b: Temperature Results: $50.8 \mathrm{~mm}$ Diameter Pipe $1.0 \mathrm{~m} / \mathrm{s}$ Fluid Velocity

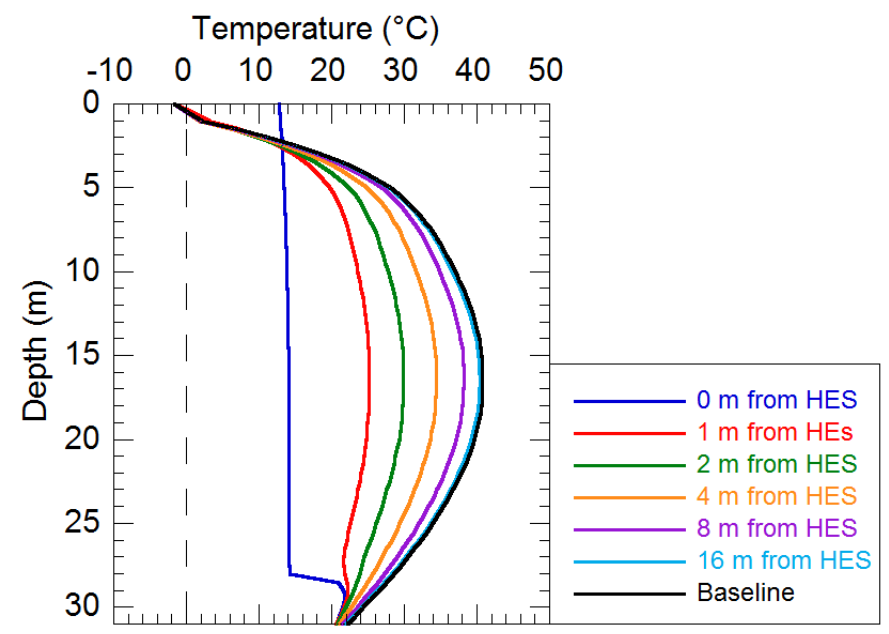

Figure A.28: Vertical Temperature Results: $50.8 \mathrm{~mm}$ Diameter Pipe $1.0 \mathrm{~m} / \mathrm{s}$ Fluid Velocity 

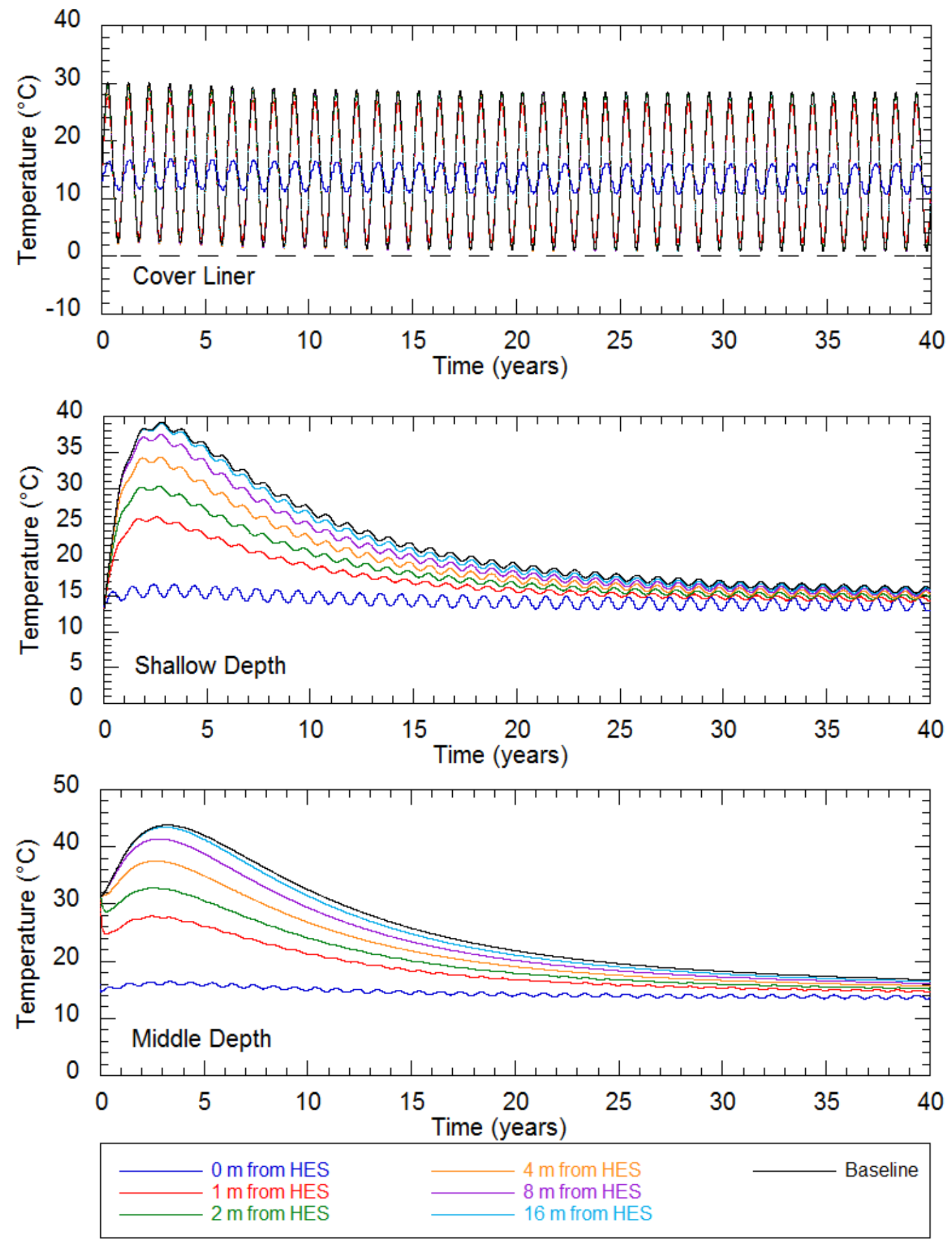

Figure A.29a: Temperature Results: Year-Round Waste Placement January Start 

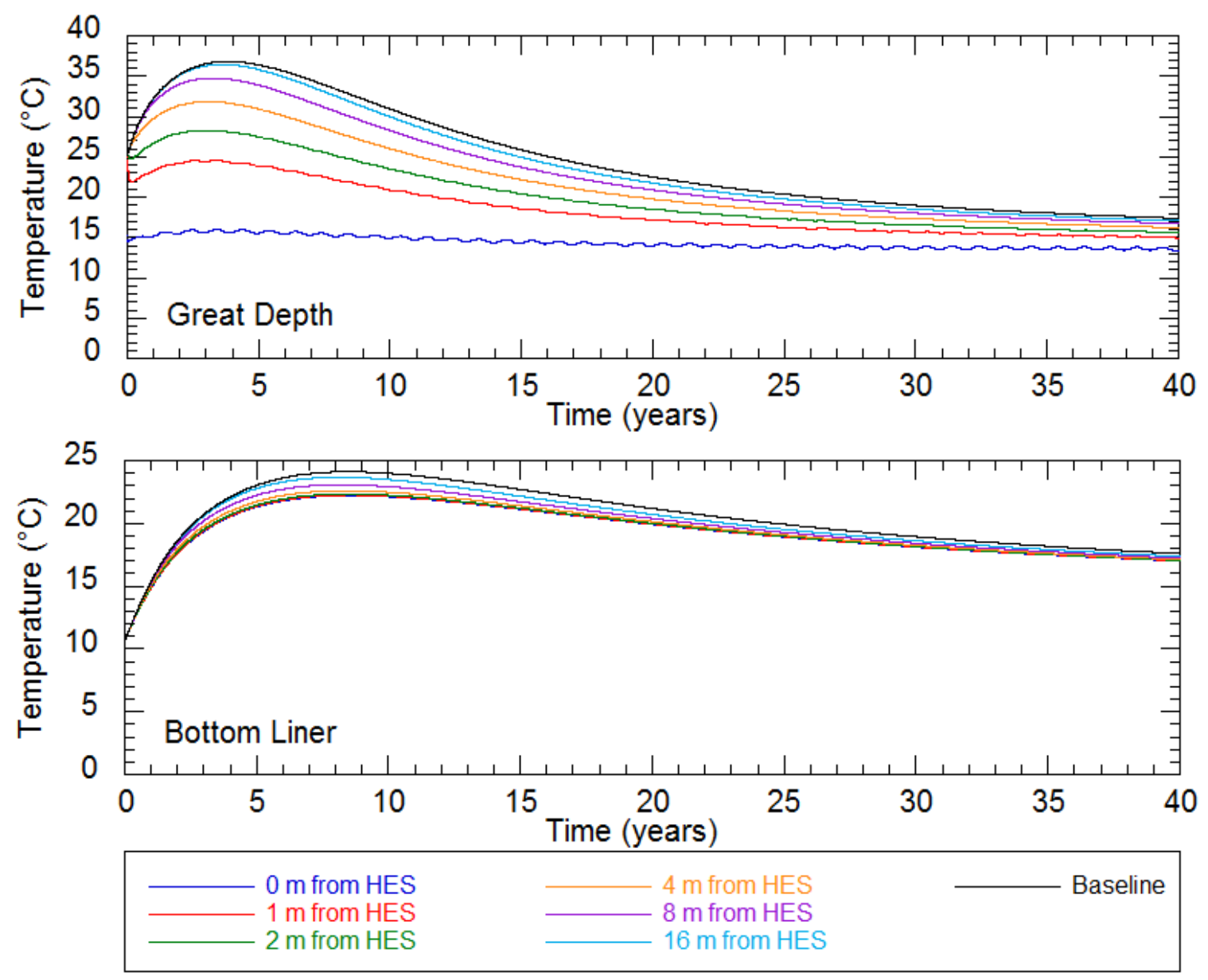

Figure A.29b: Temperature Results: Year-Round Waste Placement January Start

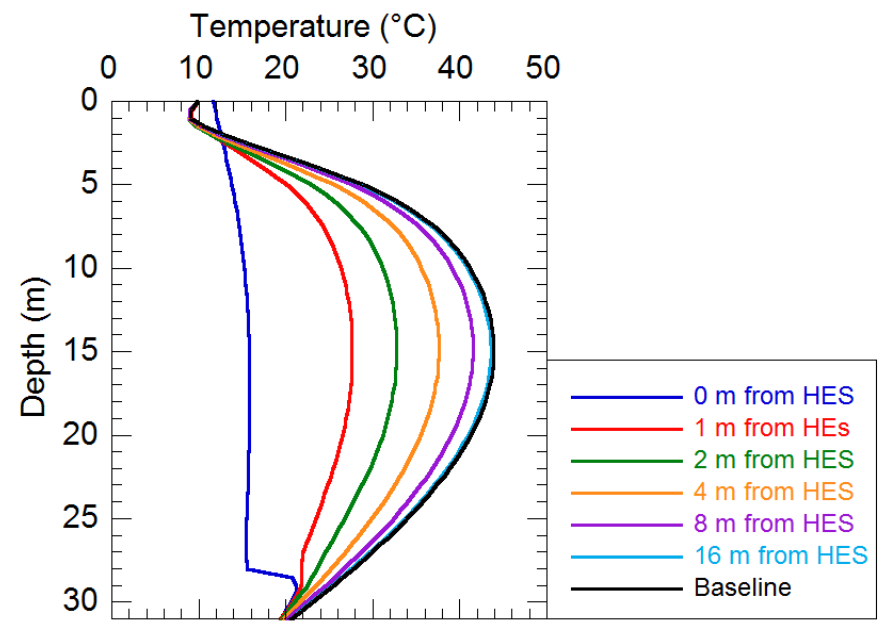

Figure A.30: Vertical Temperature Results: Year-Round Waste Placement January Start 

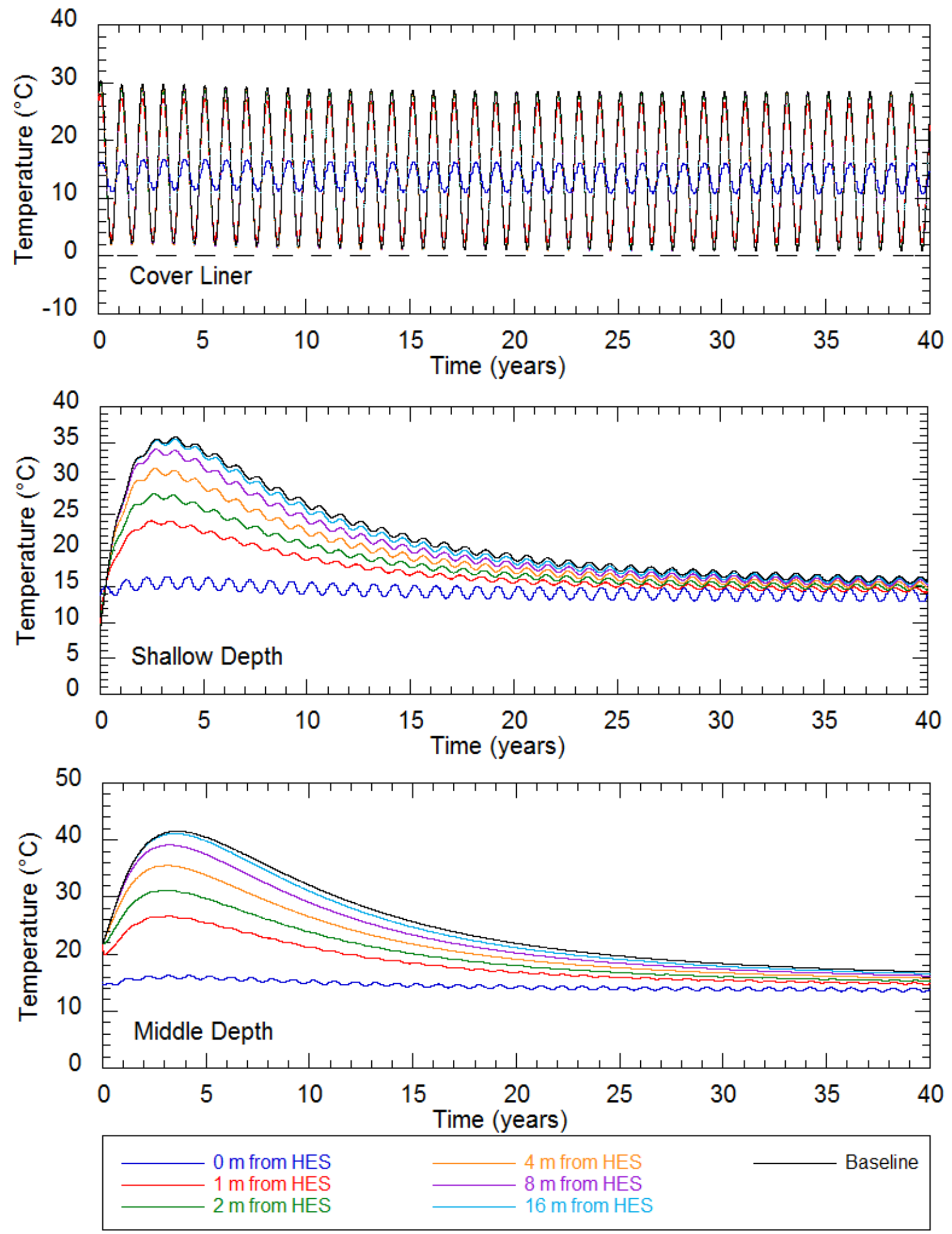

Figure A.31a: Temperature Results: Year-Round Waste Placement March Start 

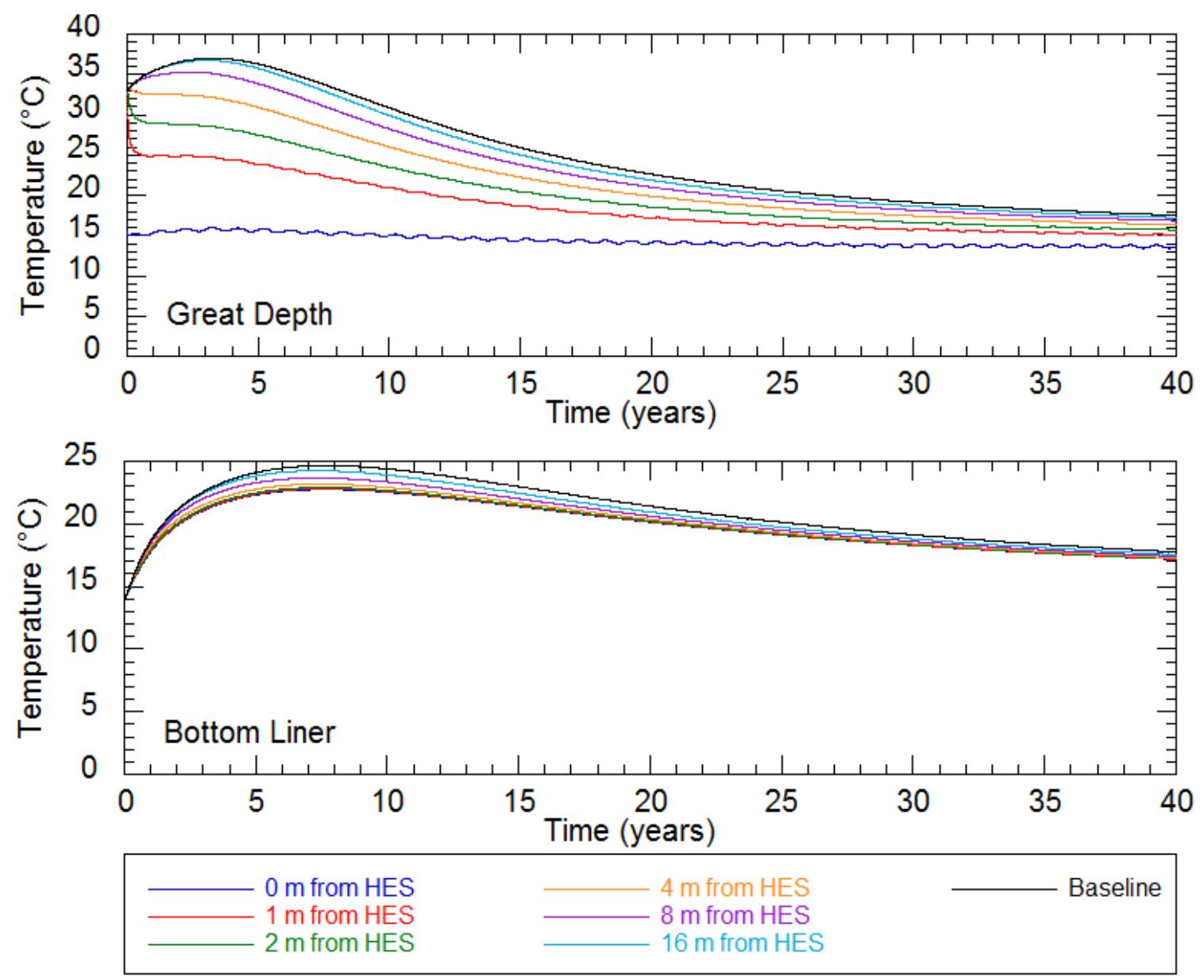

Figure A.31b: Temperature Results: Year-Round Waste Placement March Start

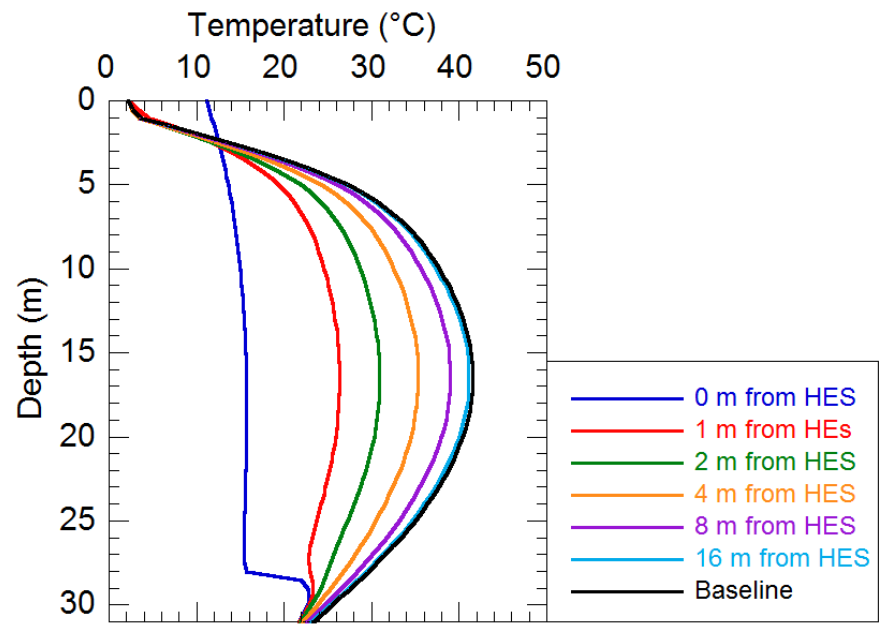

Figure A.32: Vertical Temperature Results: Year-Round Waste Placement March Start 

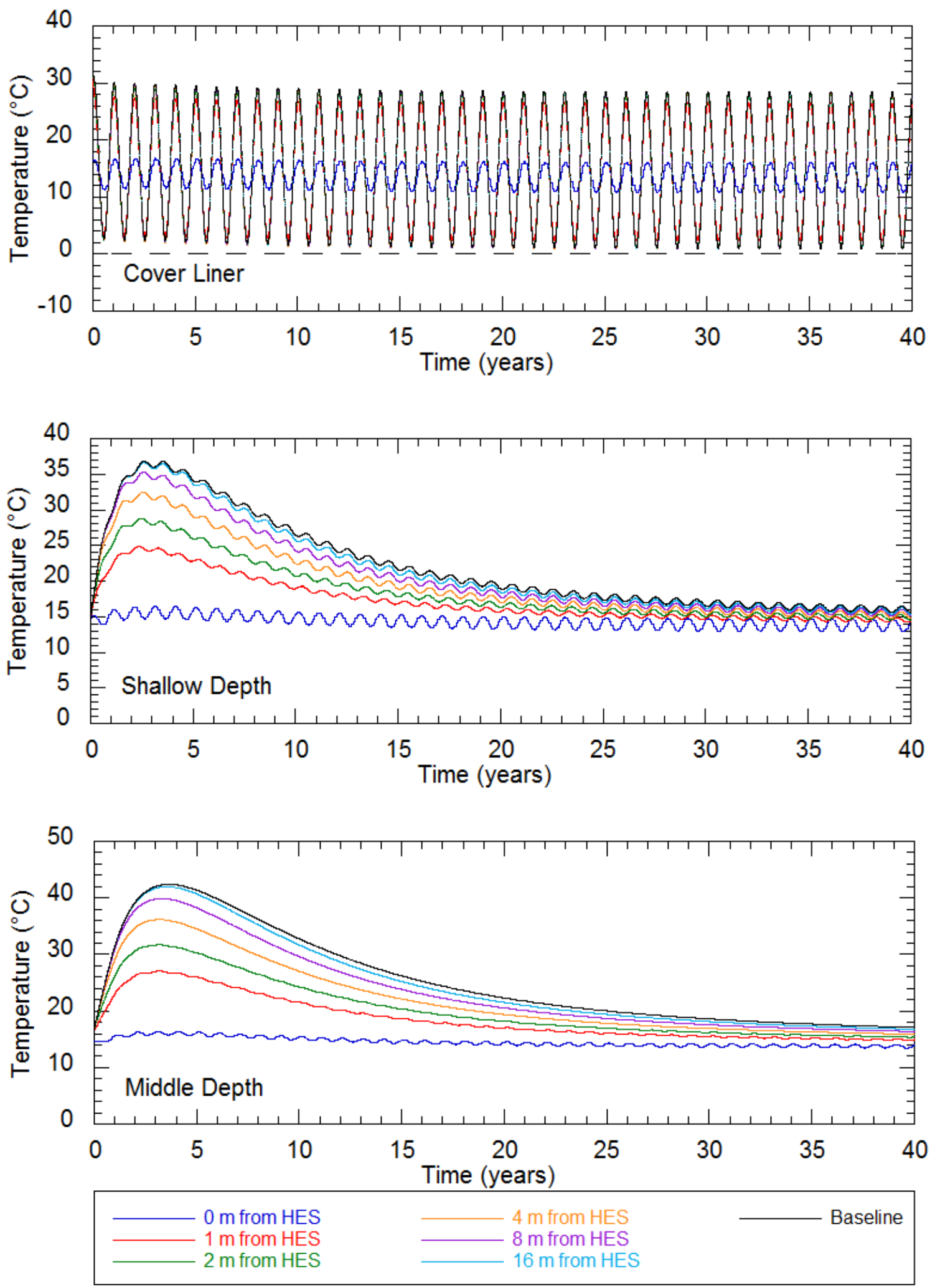

Figure A.33a: Temperature Results: Year-Round Waste Placement April Start 

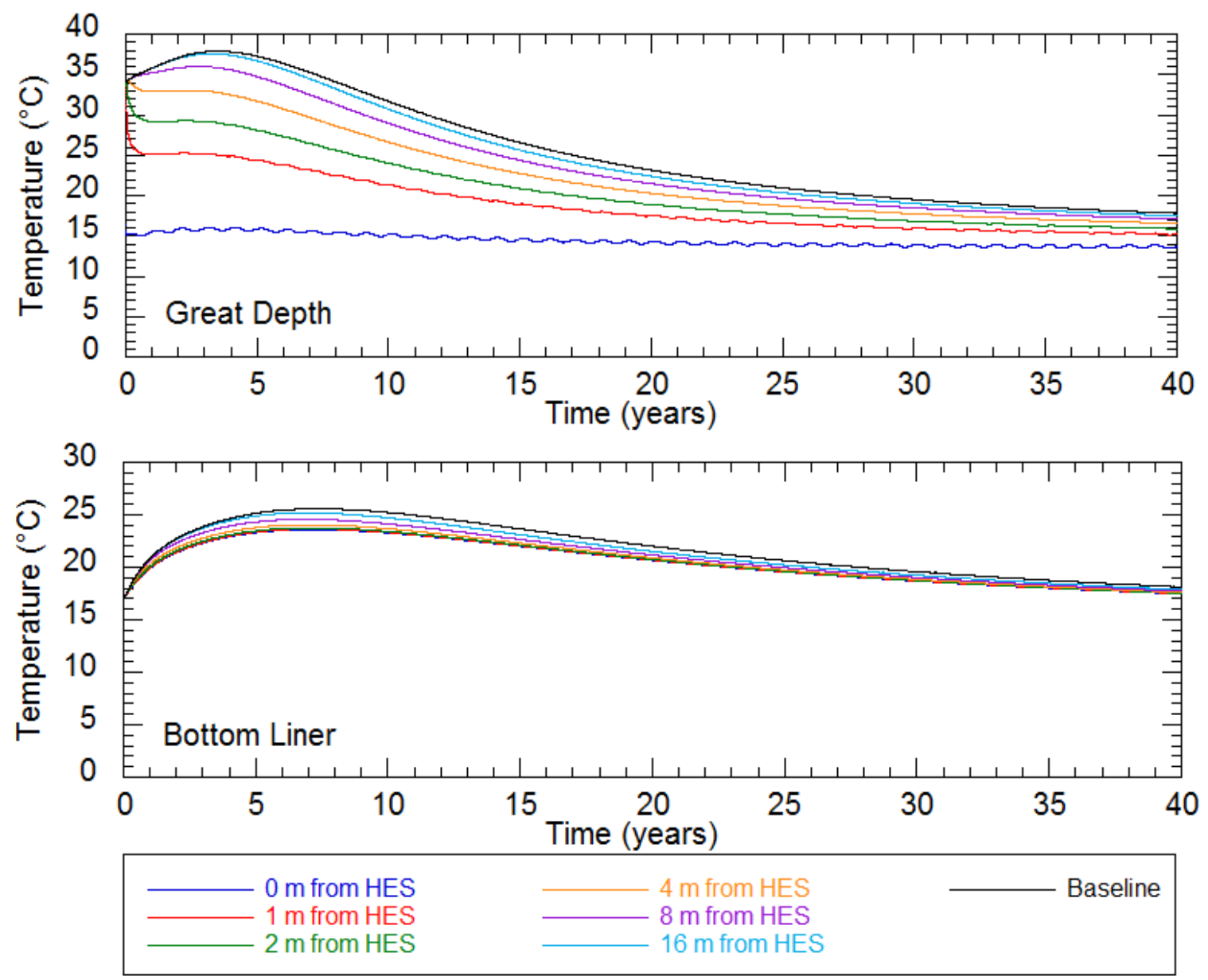

Figure A.33b: Temperature Results: Year-Round Waste Placement April Start

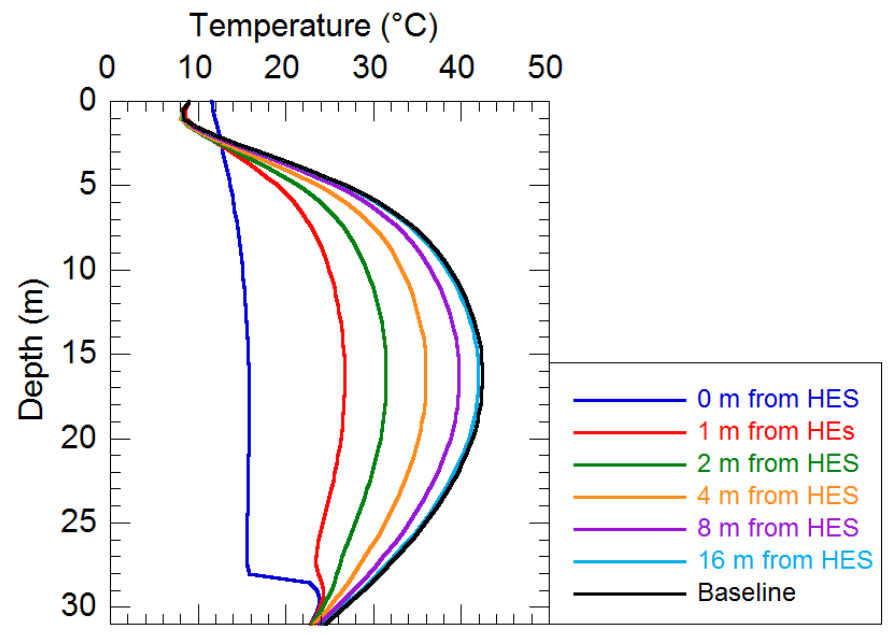

Figure A.34: Vertical Temperature Results: Year-Round Waste Placement April Start 

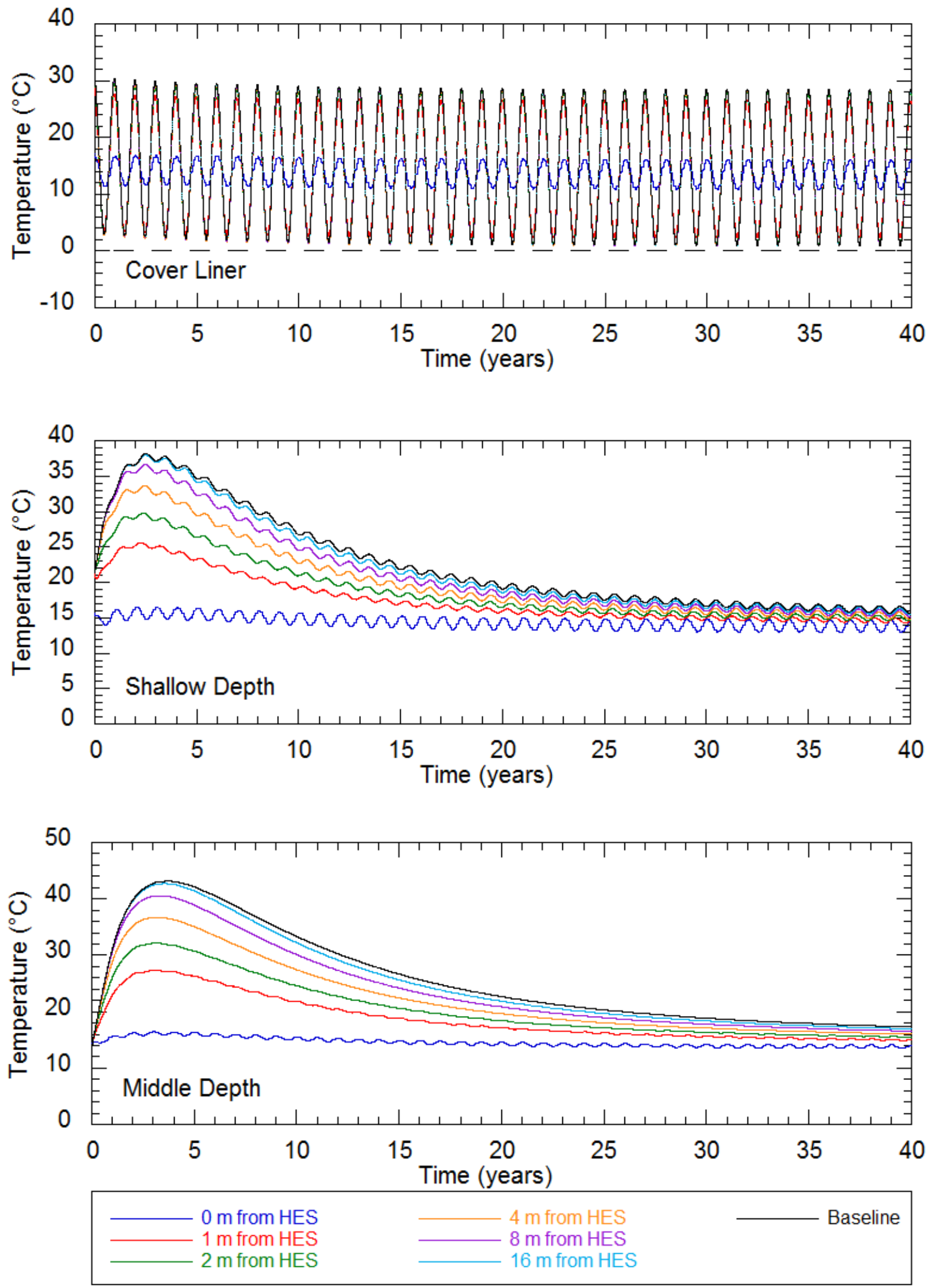

Figure A.35a: Temperature Results: Year-Round Waste Placement May Start 

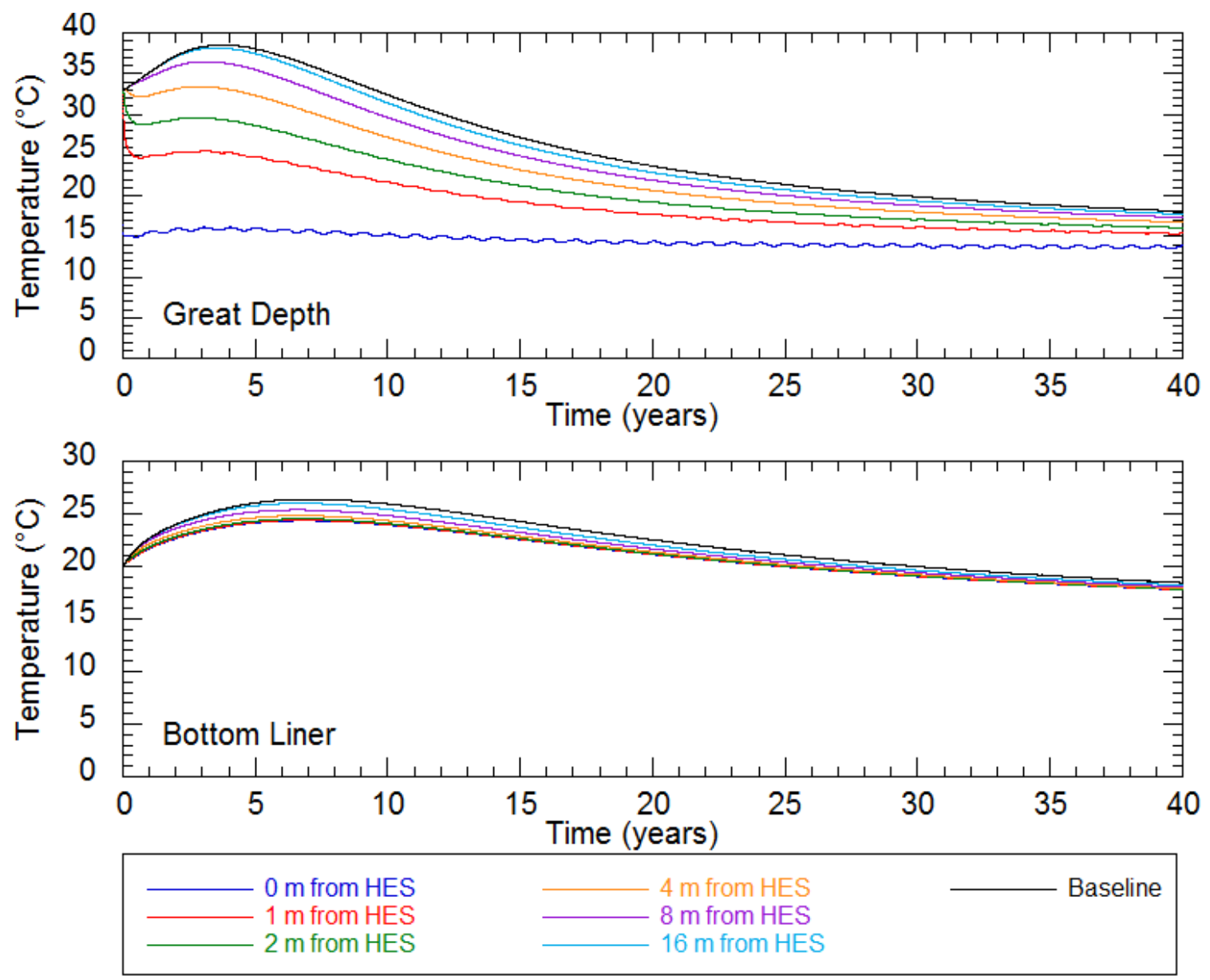

Figure A.35b: Temperature Results: Year-Round Waste Placement May Start

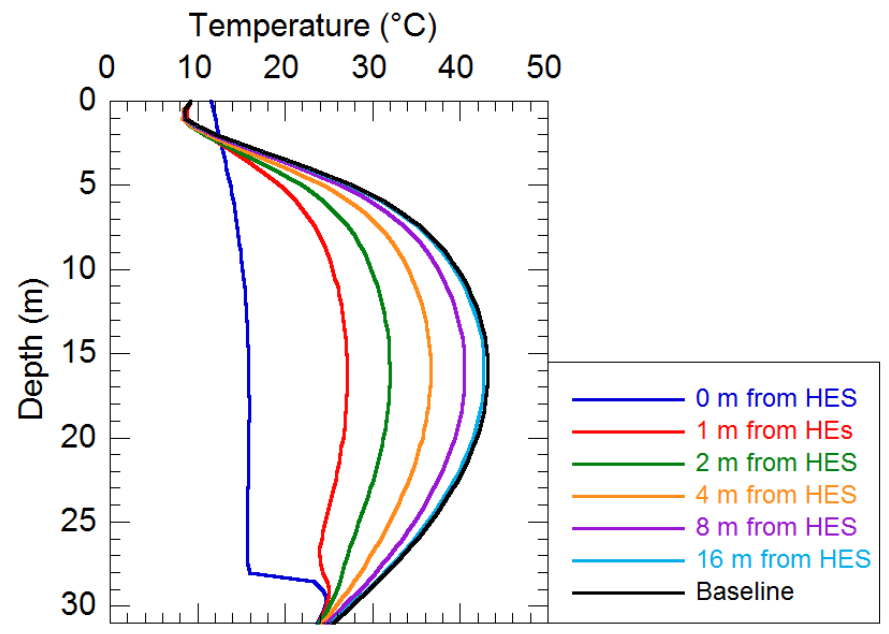

Figure A.36: Vertical Temperature Results: Year-Round Waste Placement May Start 

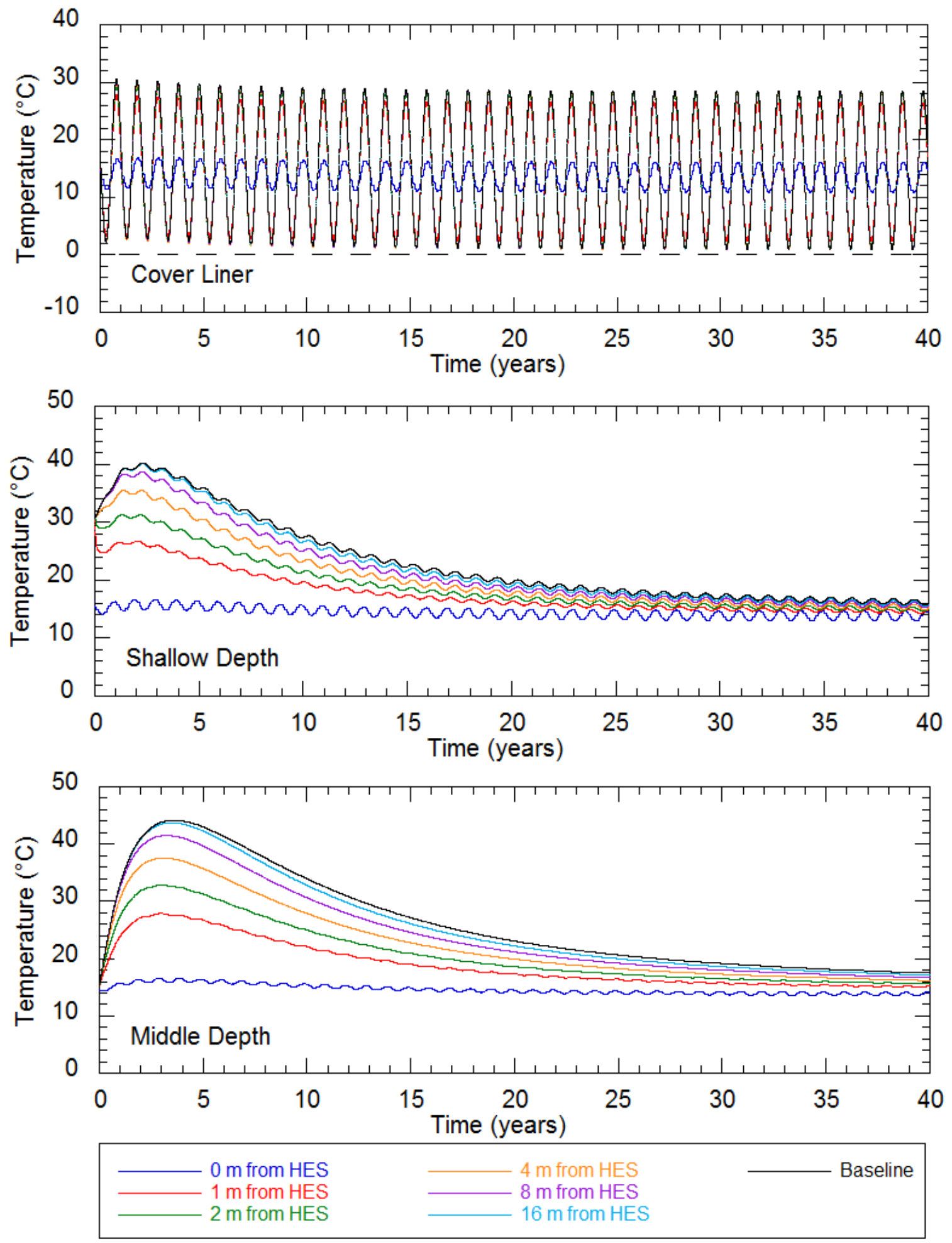

Figure A.37a: Temperature Results: Year-Round Waste Placement July Start 

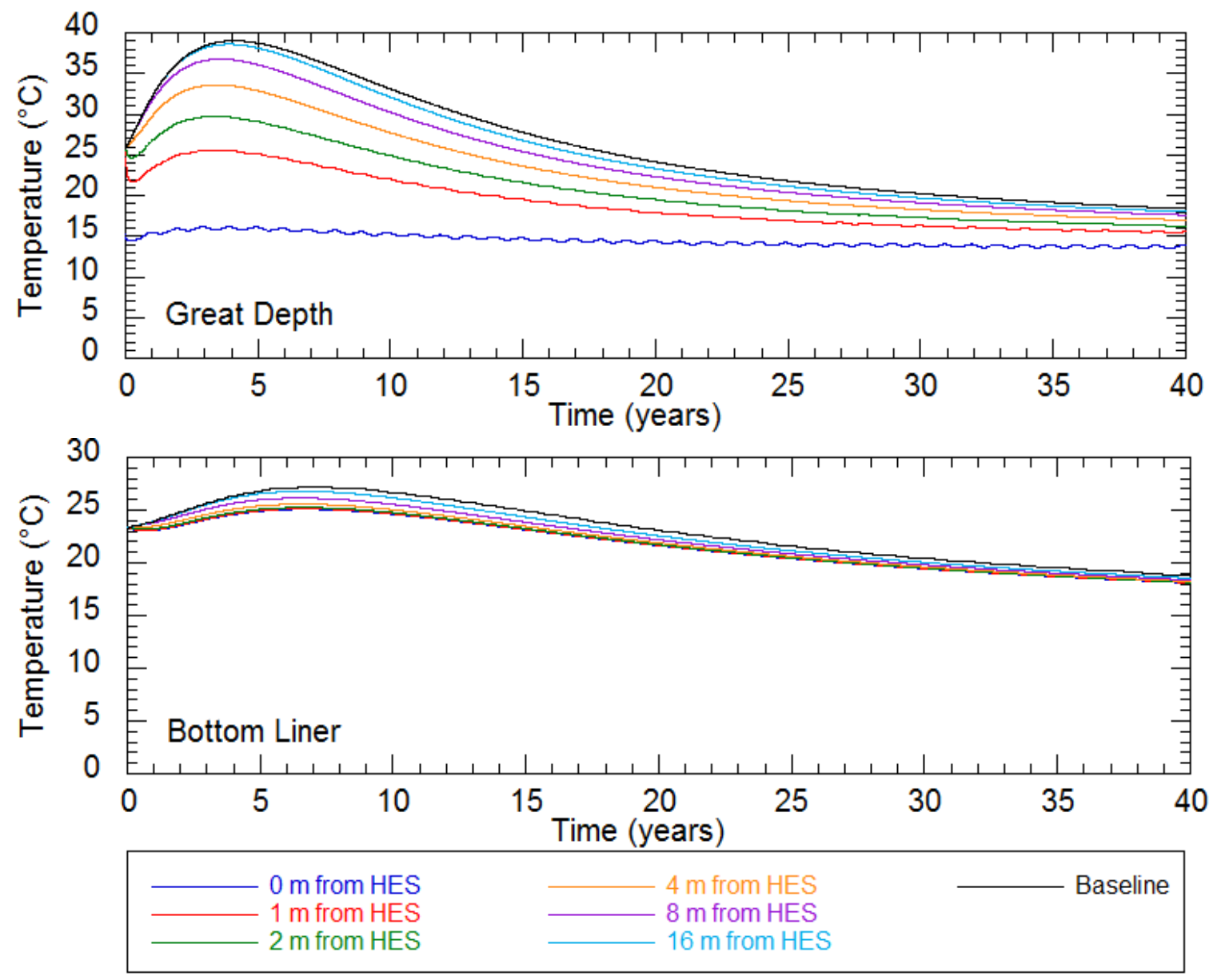

Figure A.37b: Temperature Results: Year-Round Waste Placement July Start

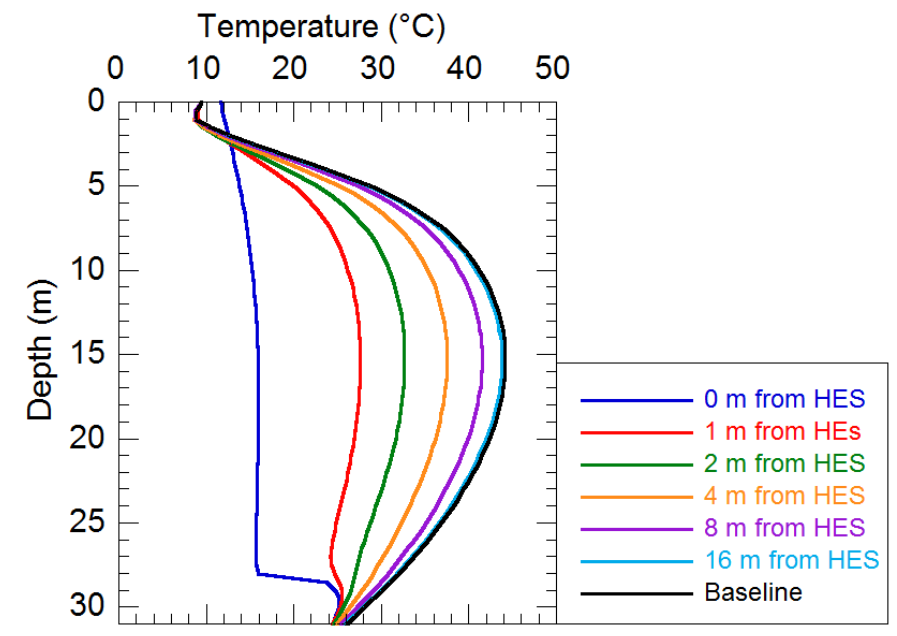

Figure A.38: Vertical Temperature Results: Year-Round Waste Placement July Start 

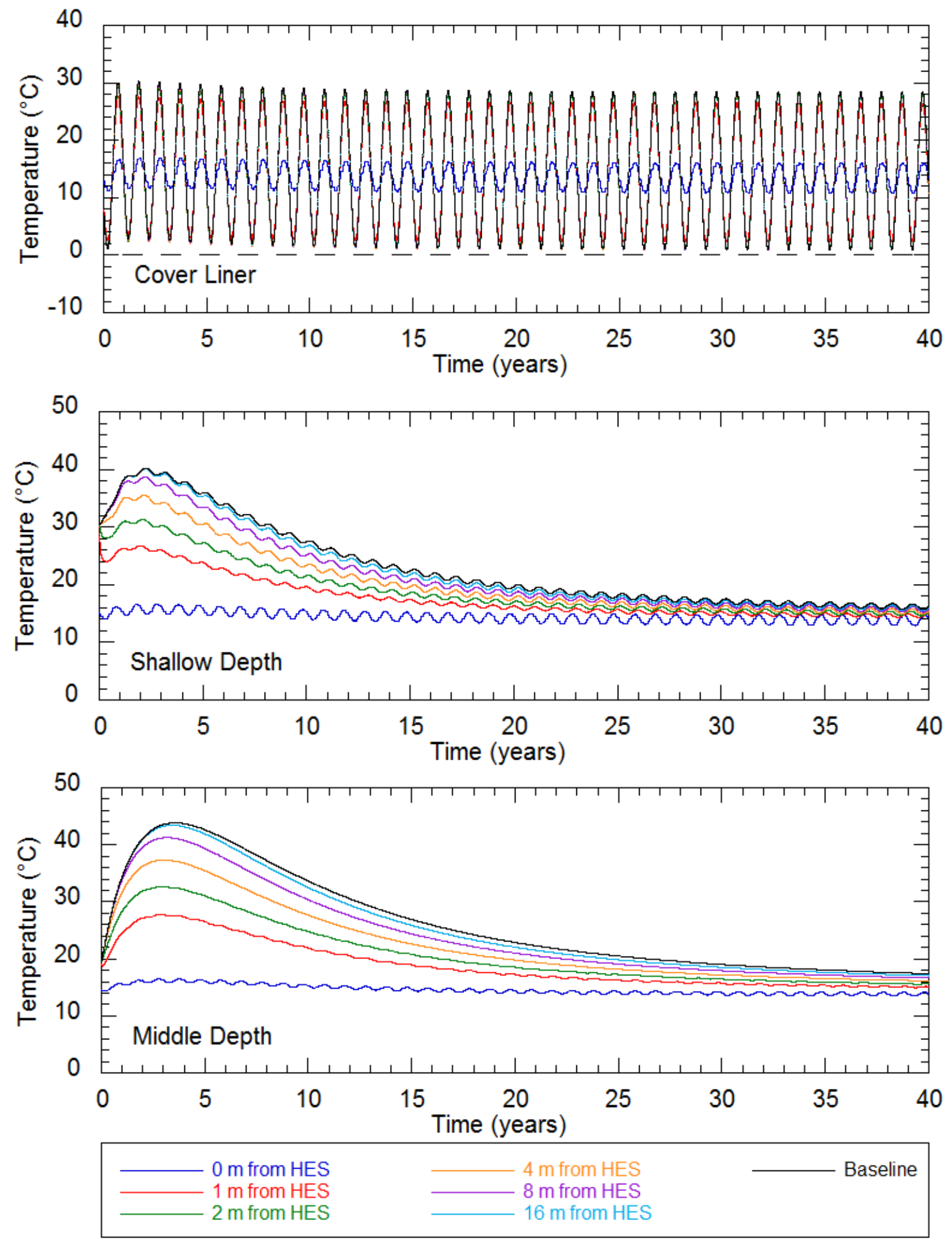

Figure A.39a: Temperature Results: Year-Round Waste Placement August Start 

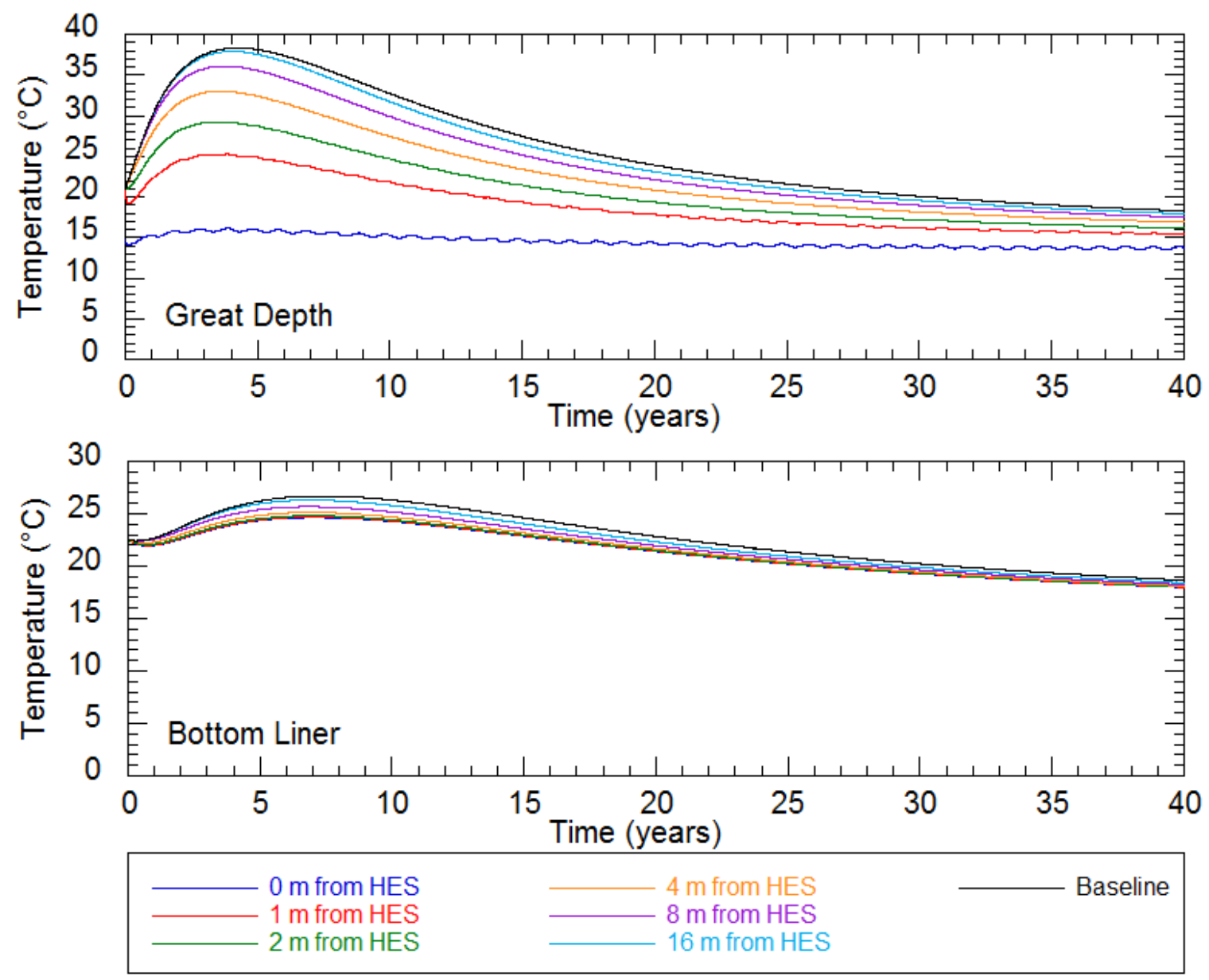

Figure A.39b: Temperature Results: Year-Round Waste Placement August Start

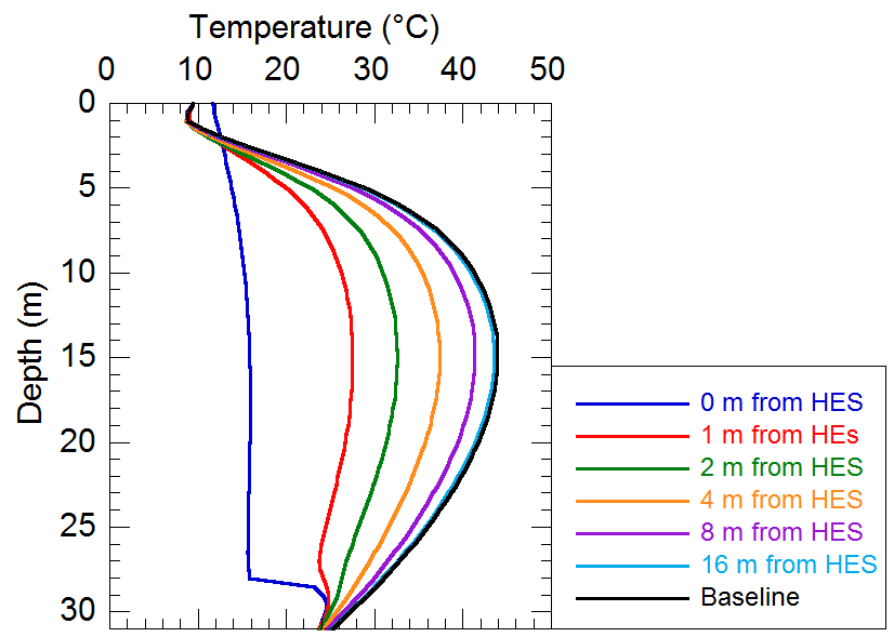

Figure A.40: Vertical Temperature Results: Year-Round Waste Placement August Start 

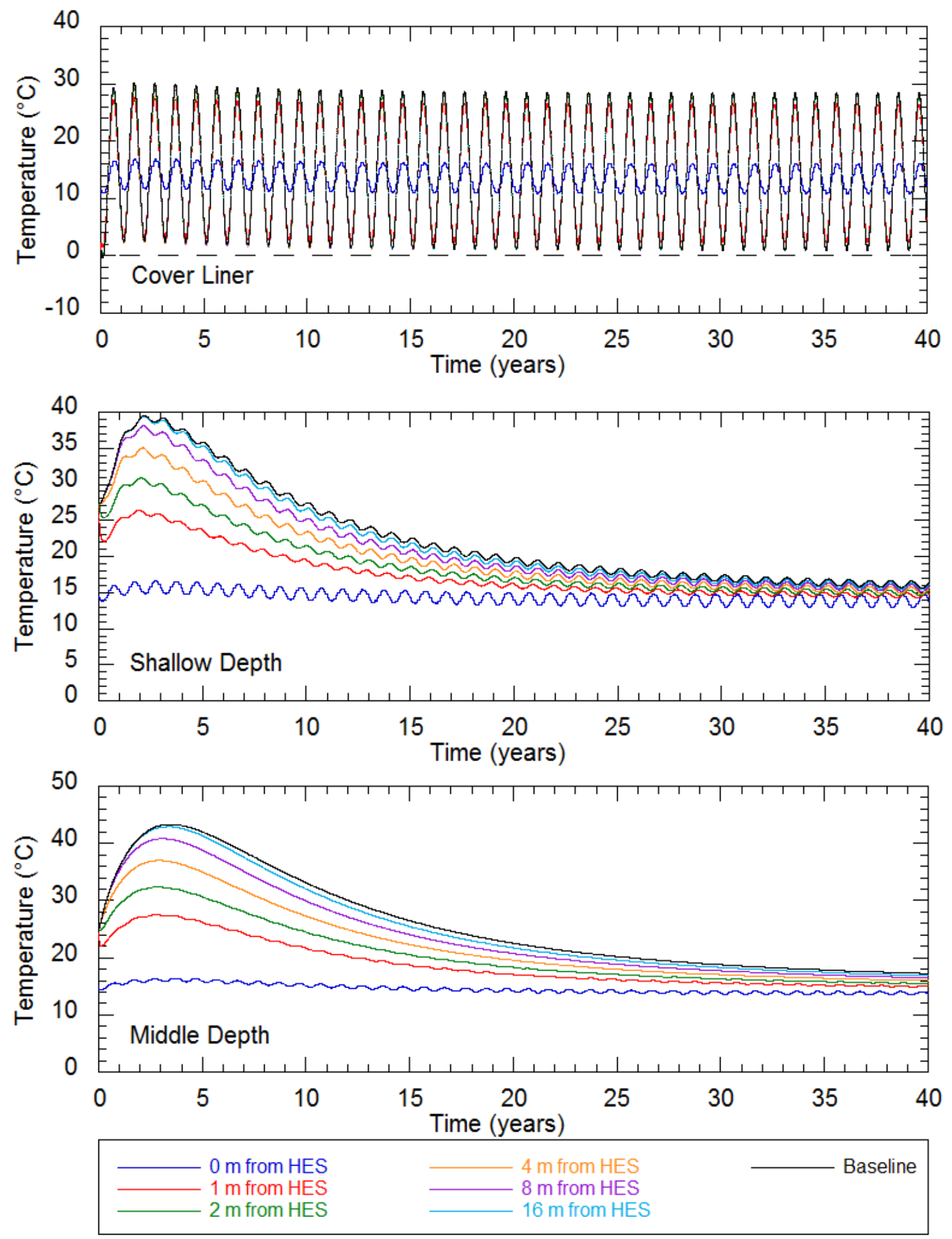

Figure A.41a: Temperature Results: Year-Round Waste Placement September Start 

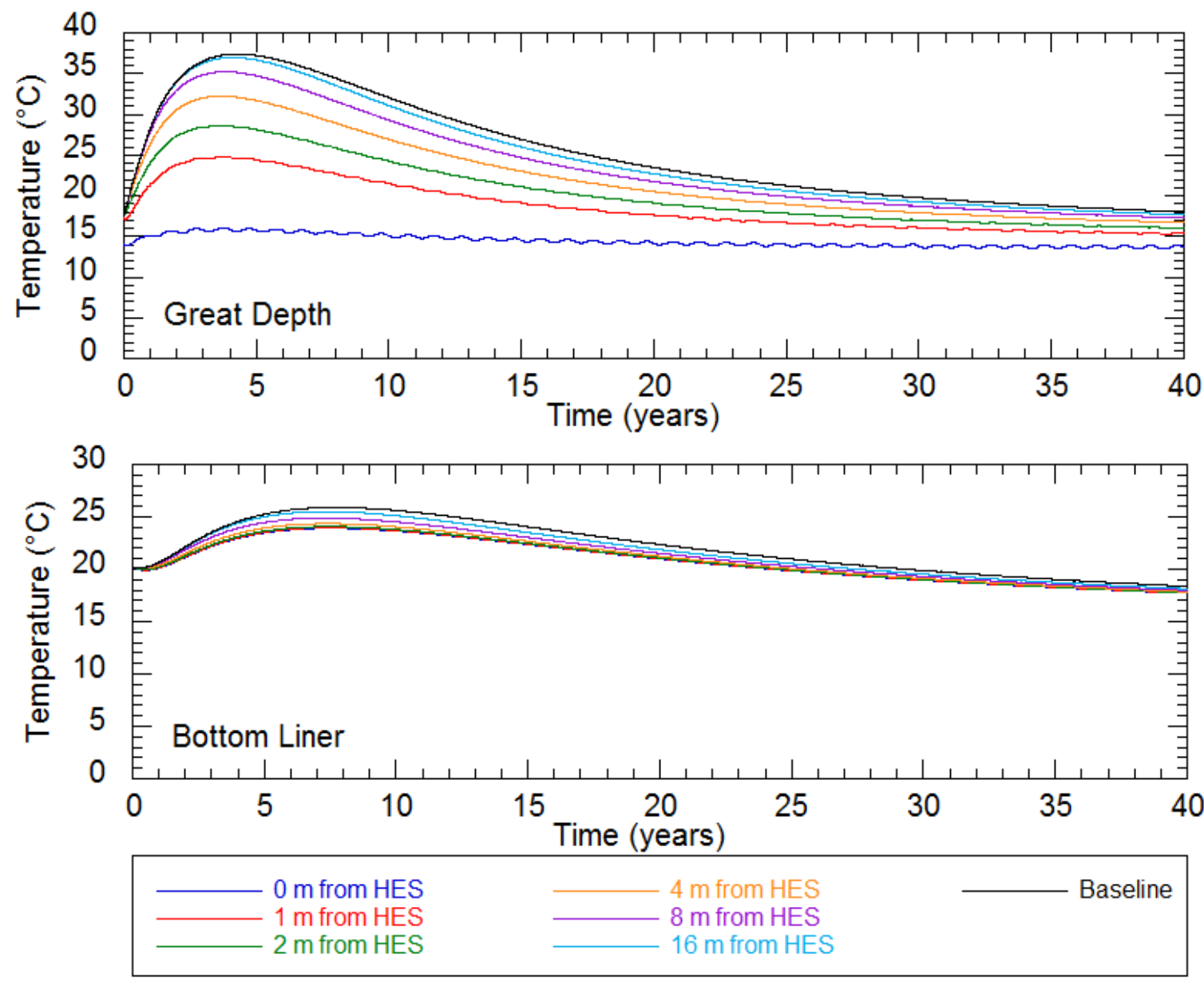

Figure A.41b: Temperature Results: Year-Round Waste Placement September Start

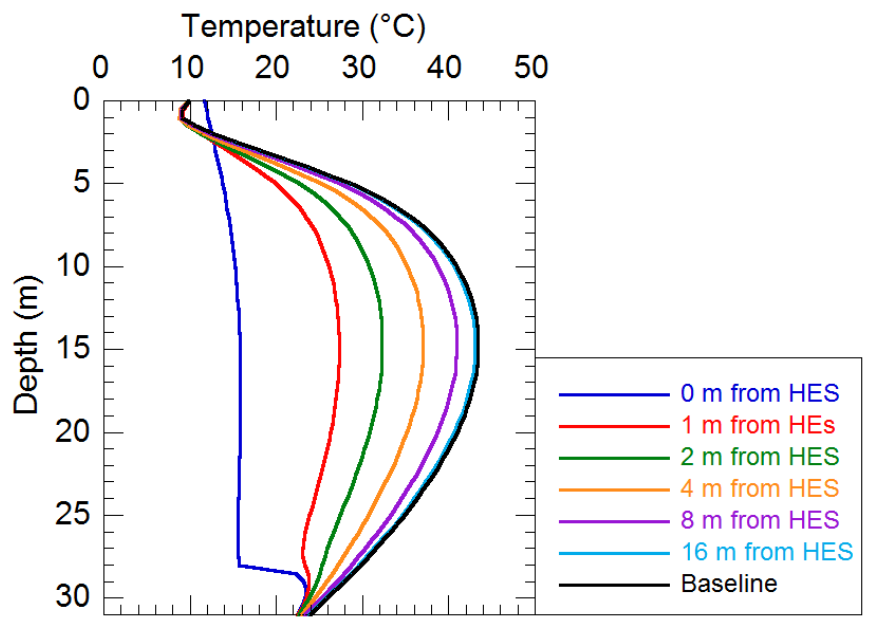

Figure A.42: Vertical Temperature Results: Year-Round Waste Placement September Start 

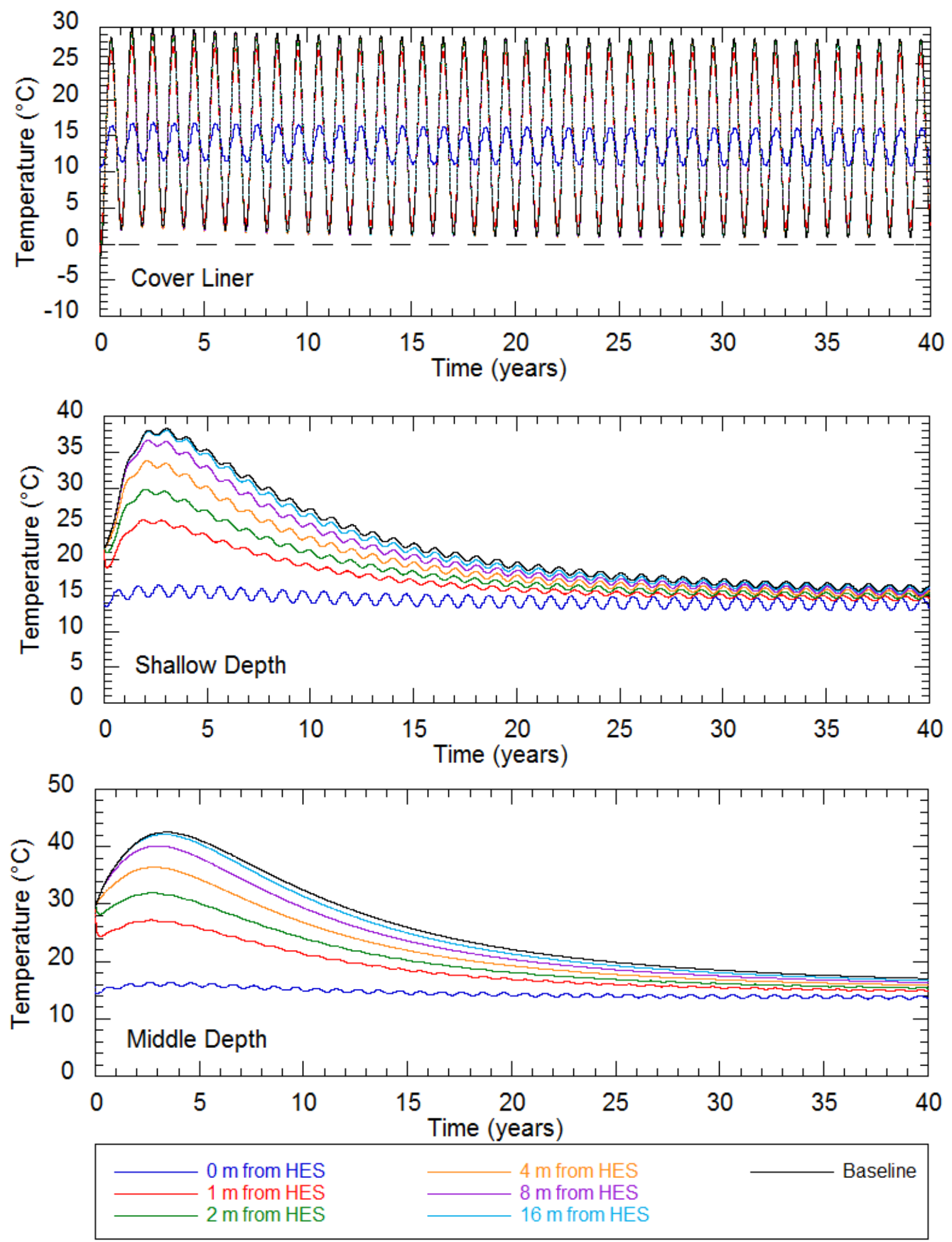

Figure A.43a: Temperature Results: Year-Round Waste Placement October Start 

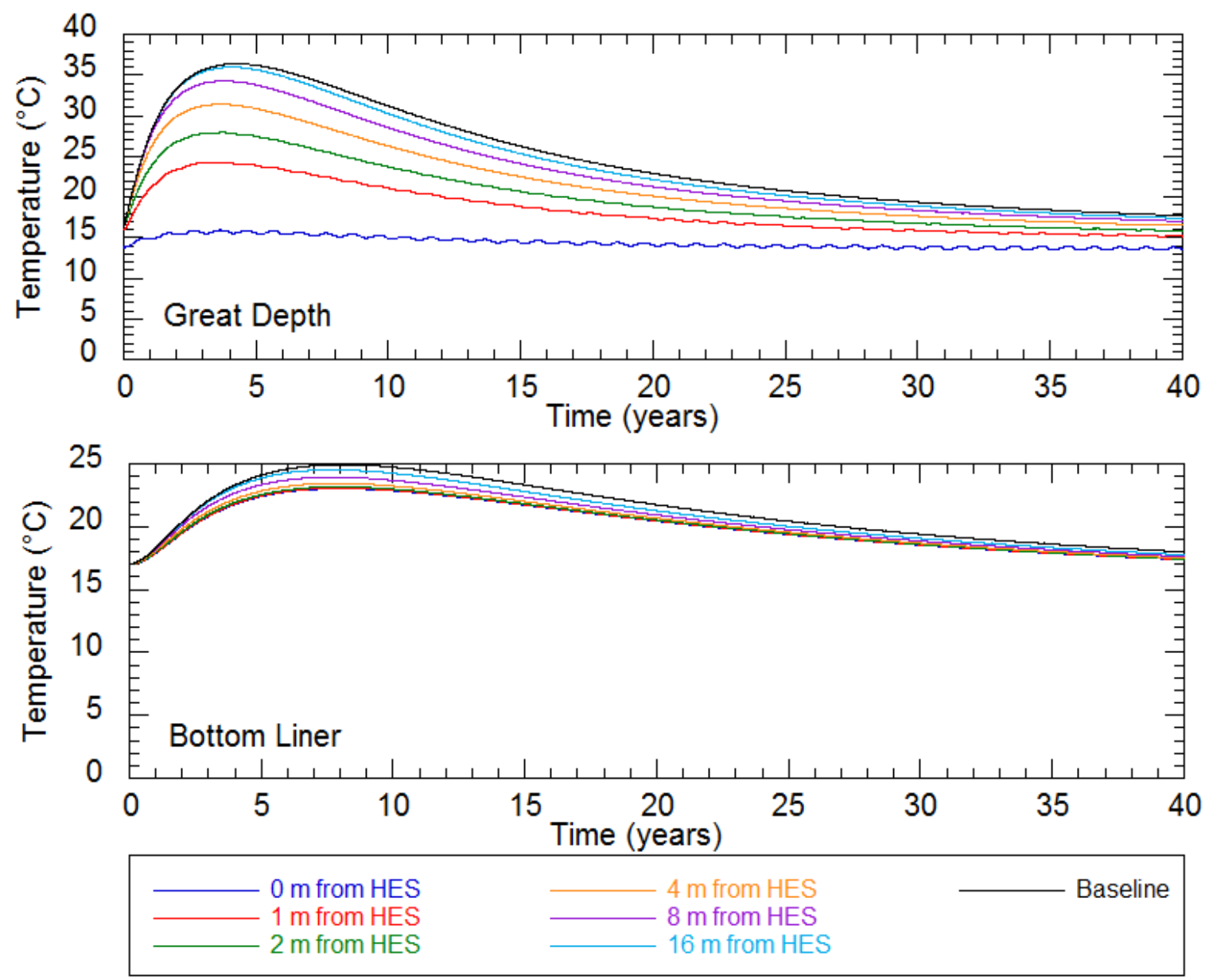

Figure A.43b: Temperature Results: Year-Round Waste Placement October Start

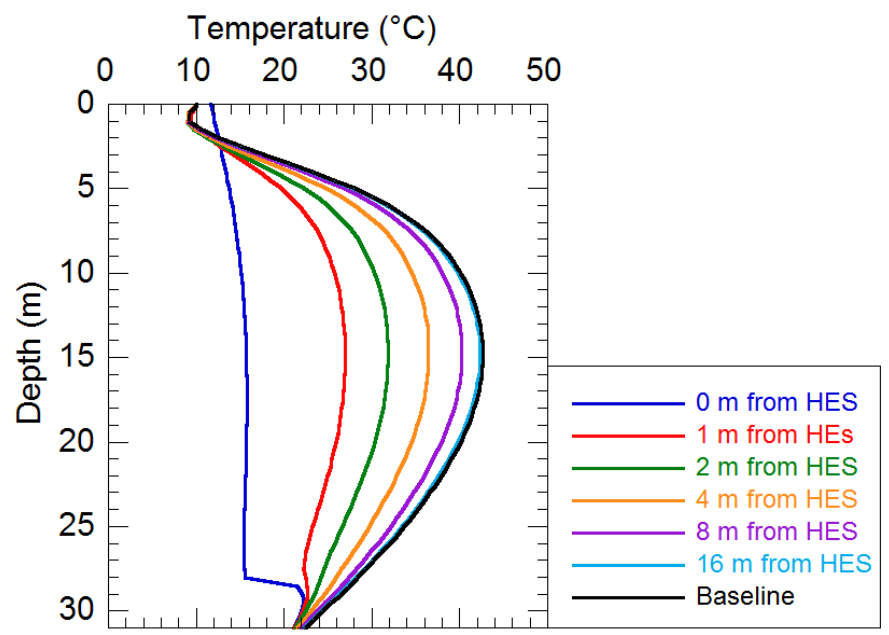

Figure A.44: Vertical Temperature Results: Year-Round Waste Placement October Start 

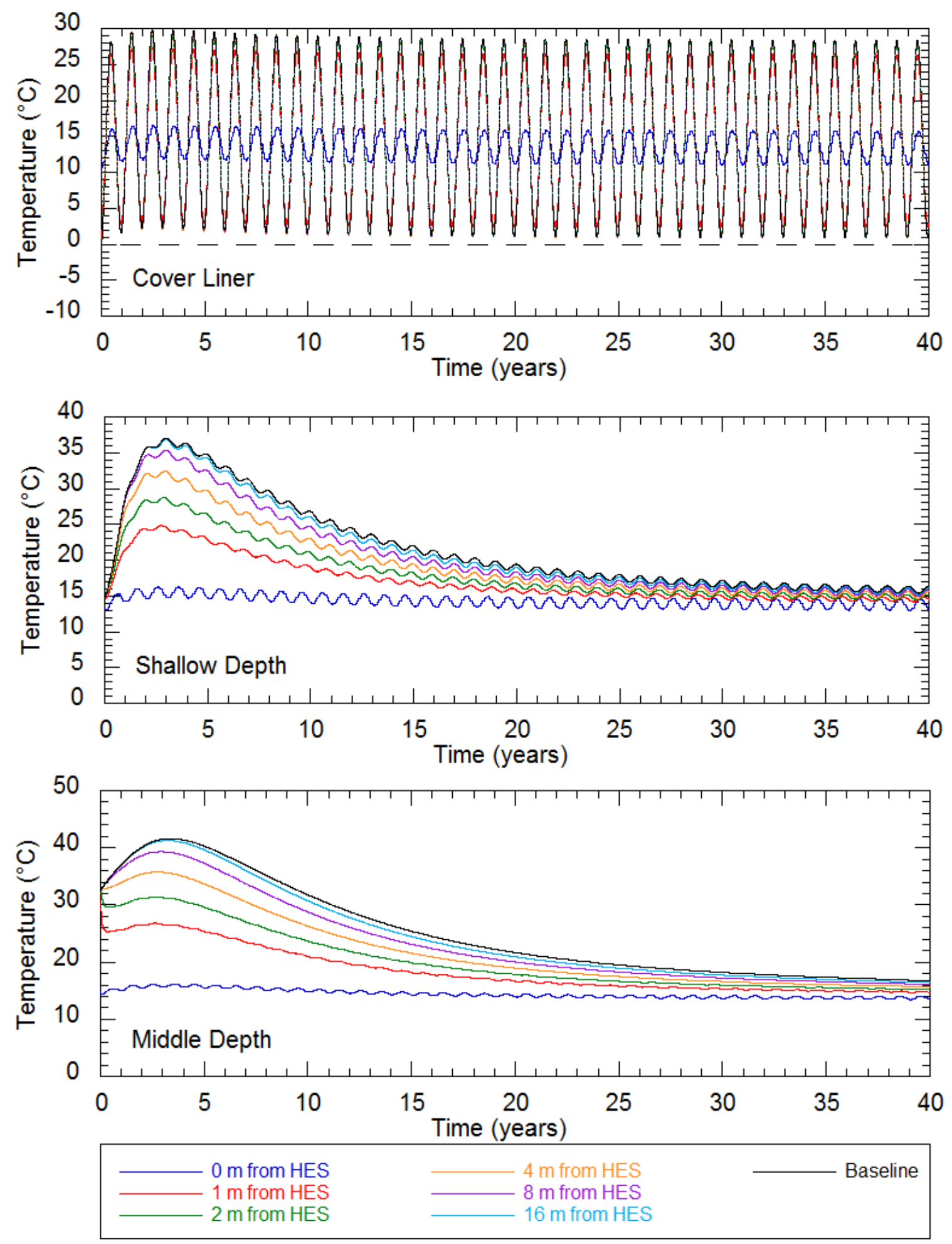

Figure A.45a: Temperature Results: Year-Round Waste Placement November Start 

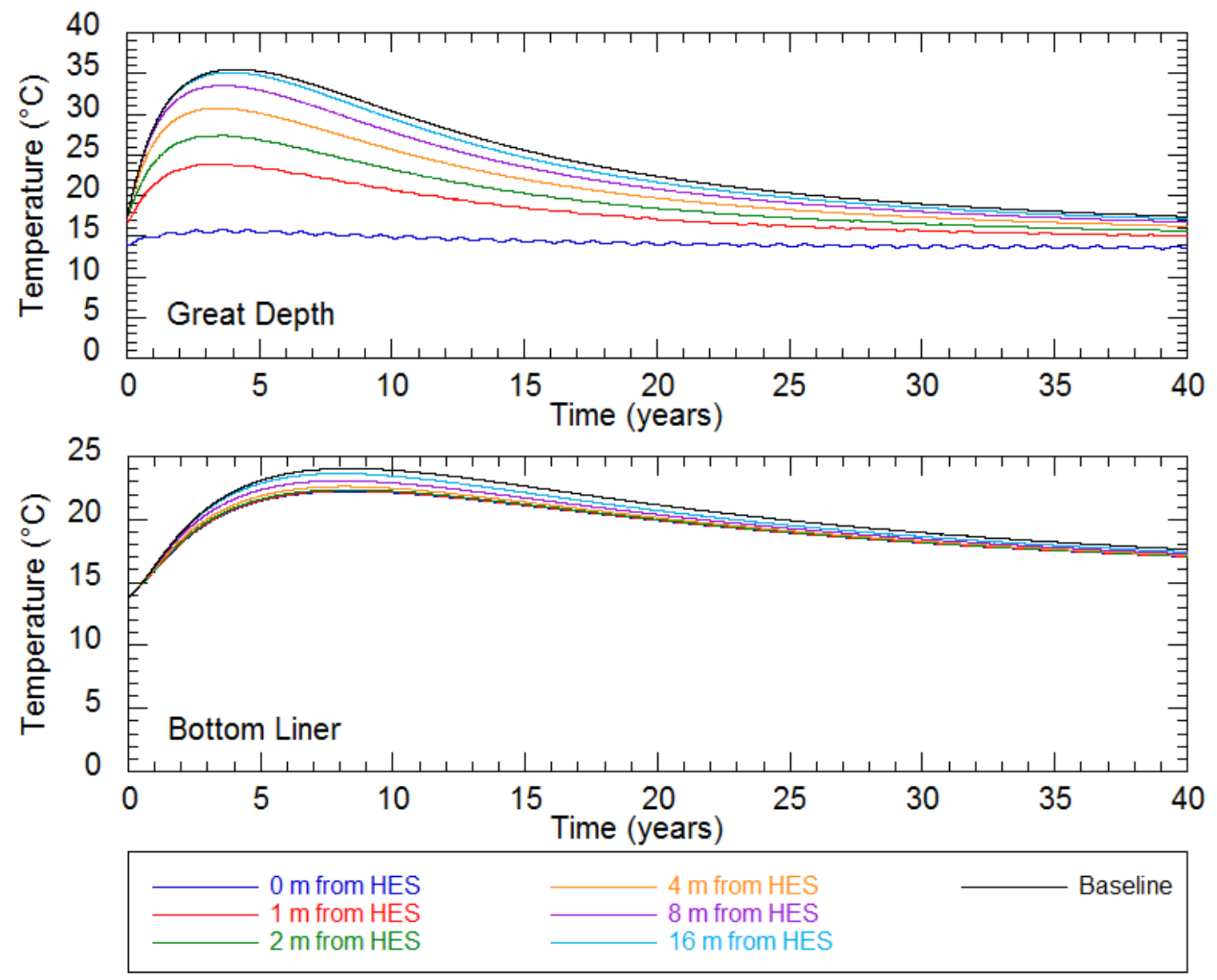

Figure A.45b: Temperature Results: Year-Round Waste Placement November Start

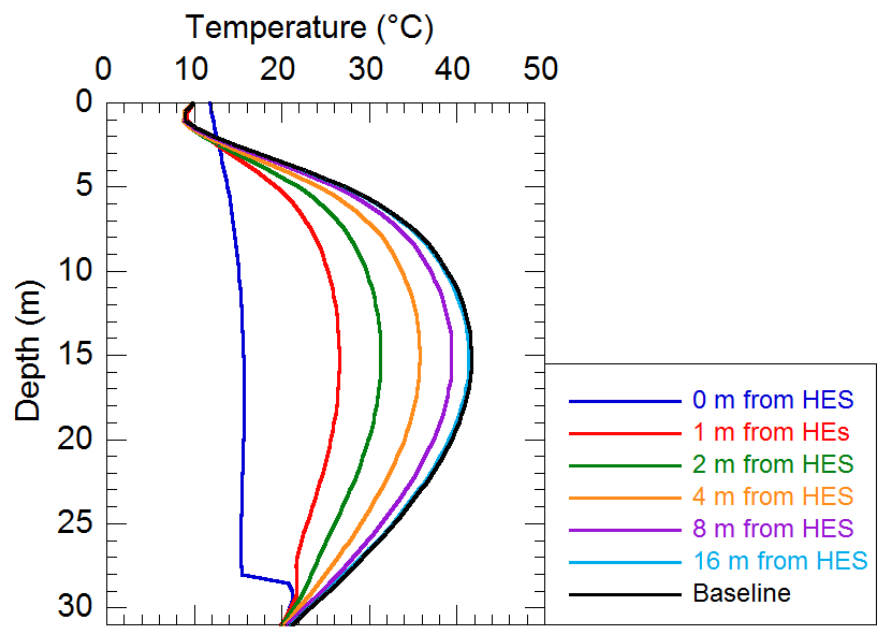

Figure A.46: Vertical Temperature Results: Year-Round Waste Placement November Start 

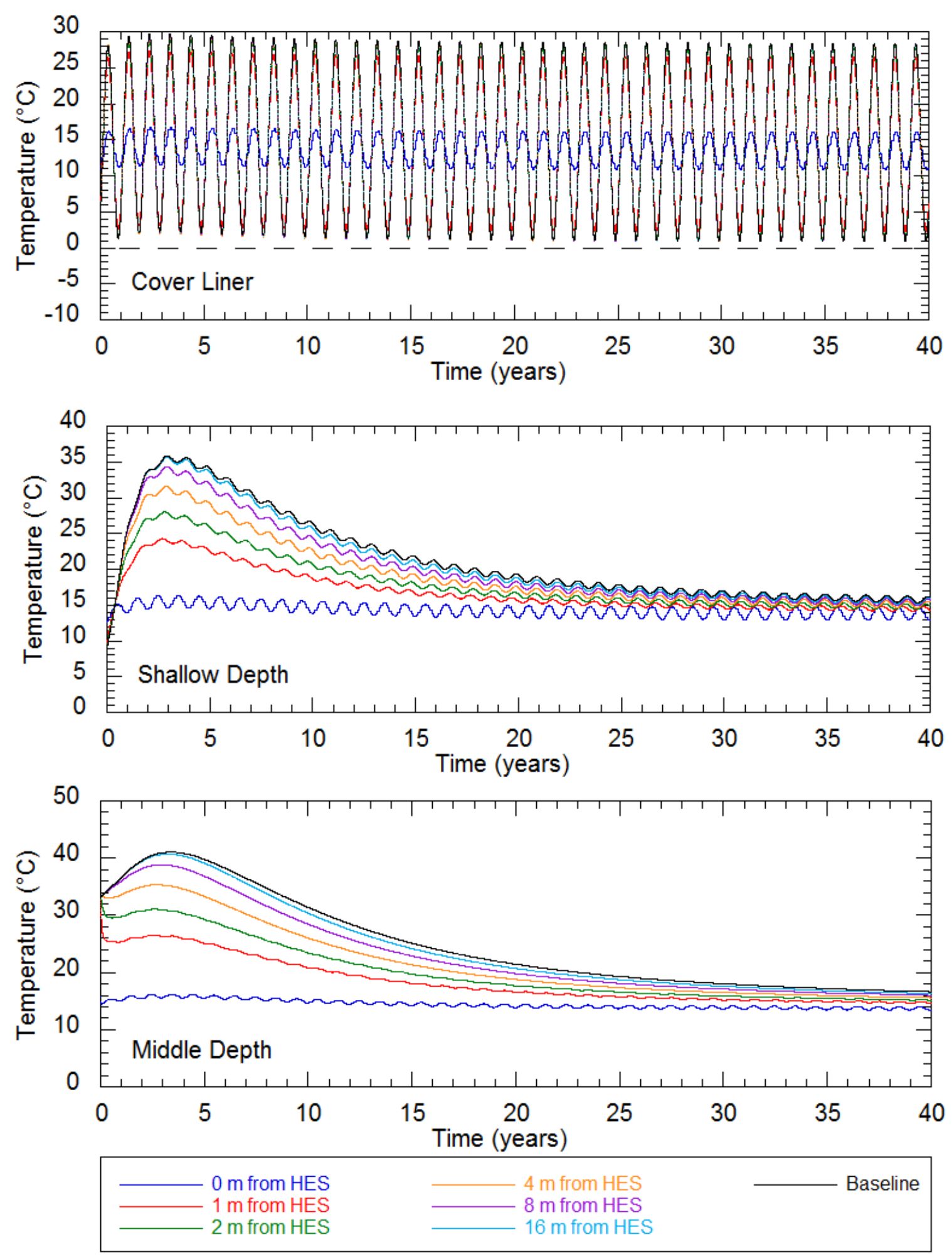

Figure A.47a: Temperature Results: Year-round Waste Placement December Start 

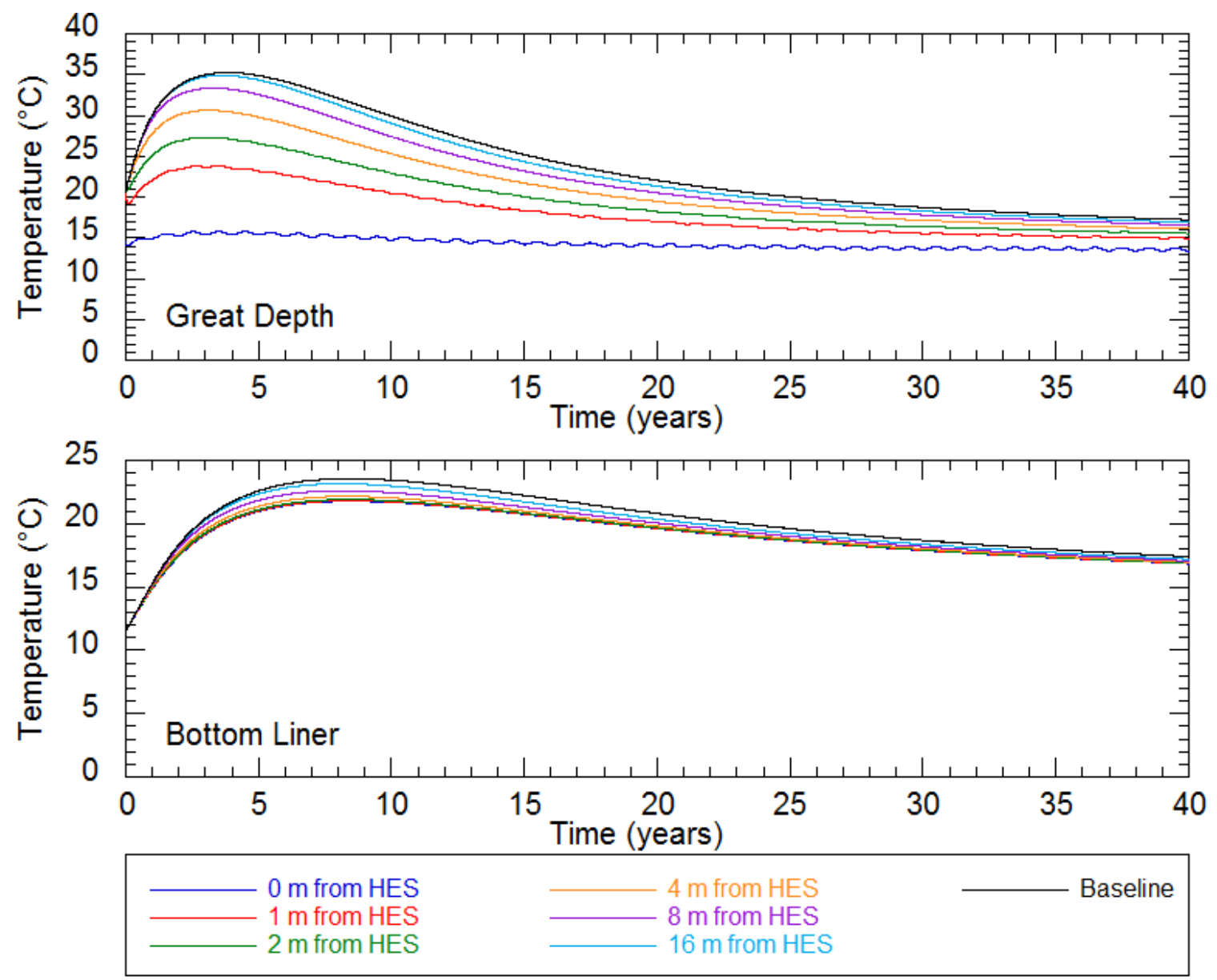

Figure A.47b: Temperature Results: Year-Round Waste Placement December Start

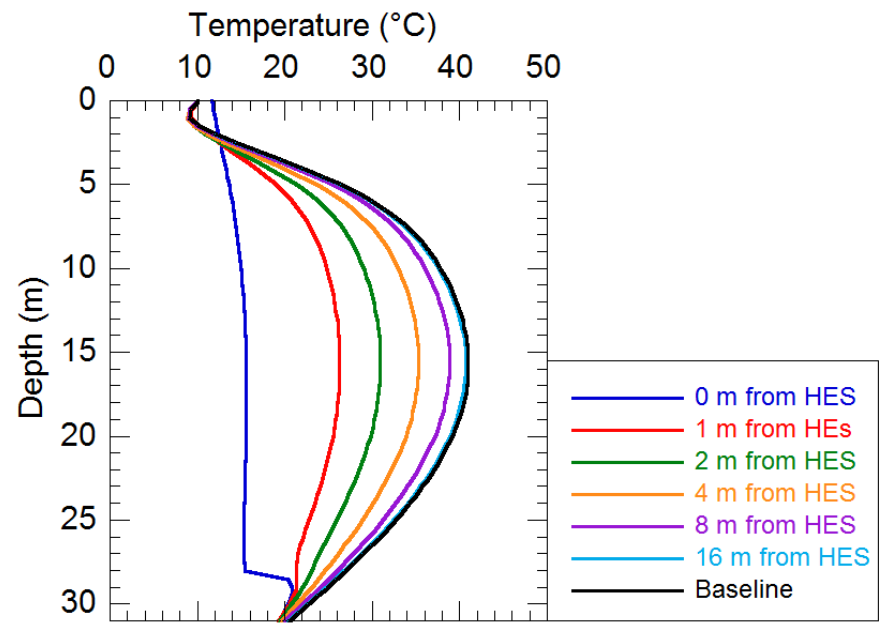

Figure A.48: Vertical Temperature Results: Year-Round Waste Placement December Start 

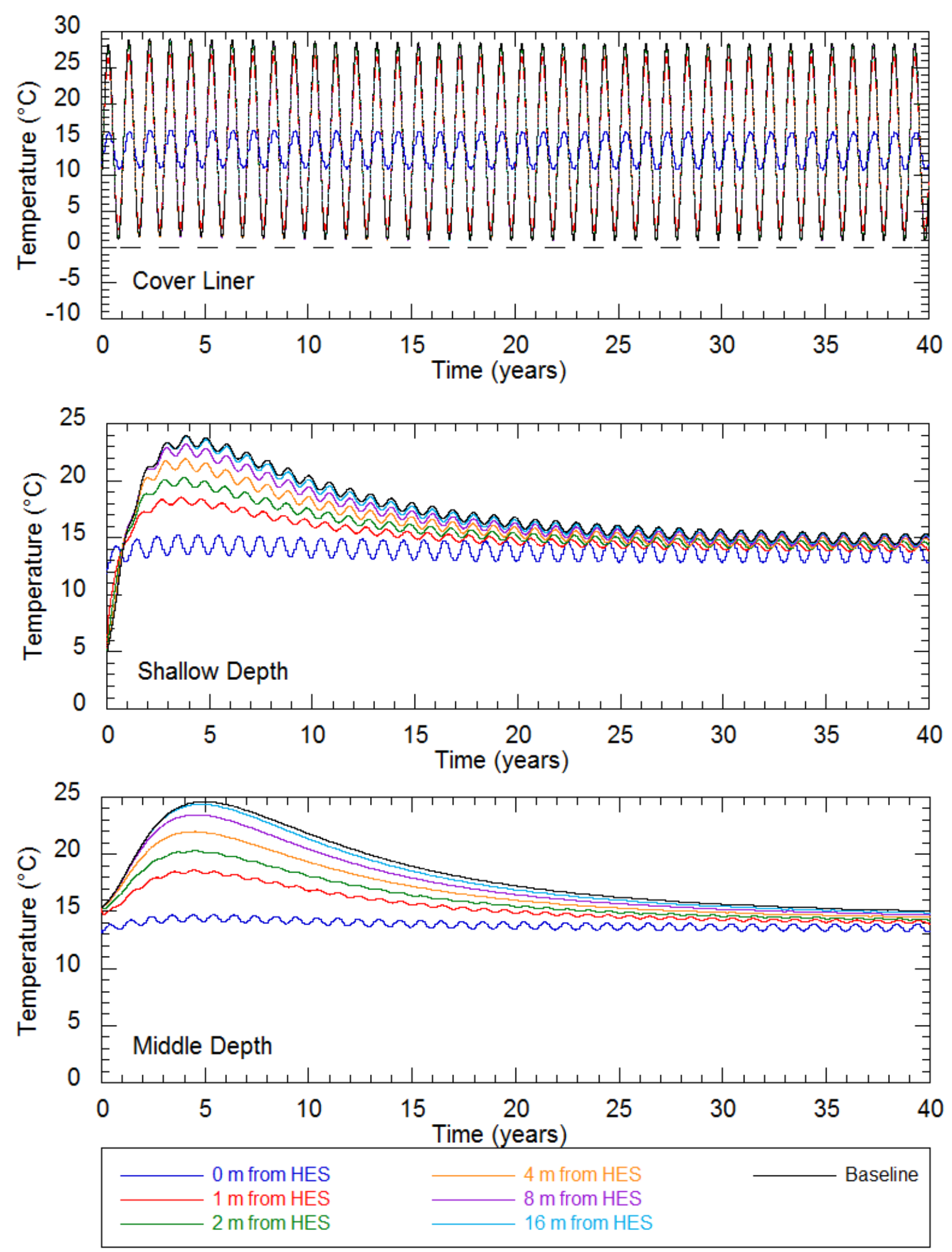

Figure A.49a: Temperature Results: Winter-Only Waste Placement 

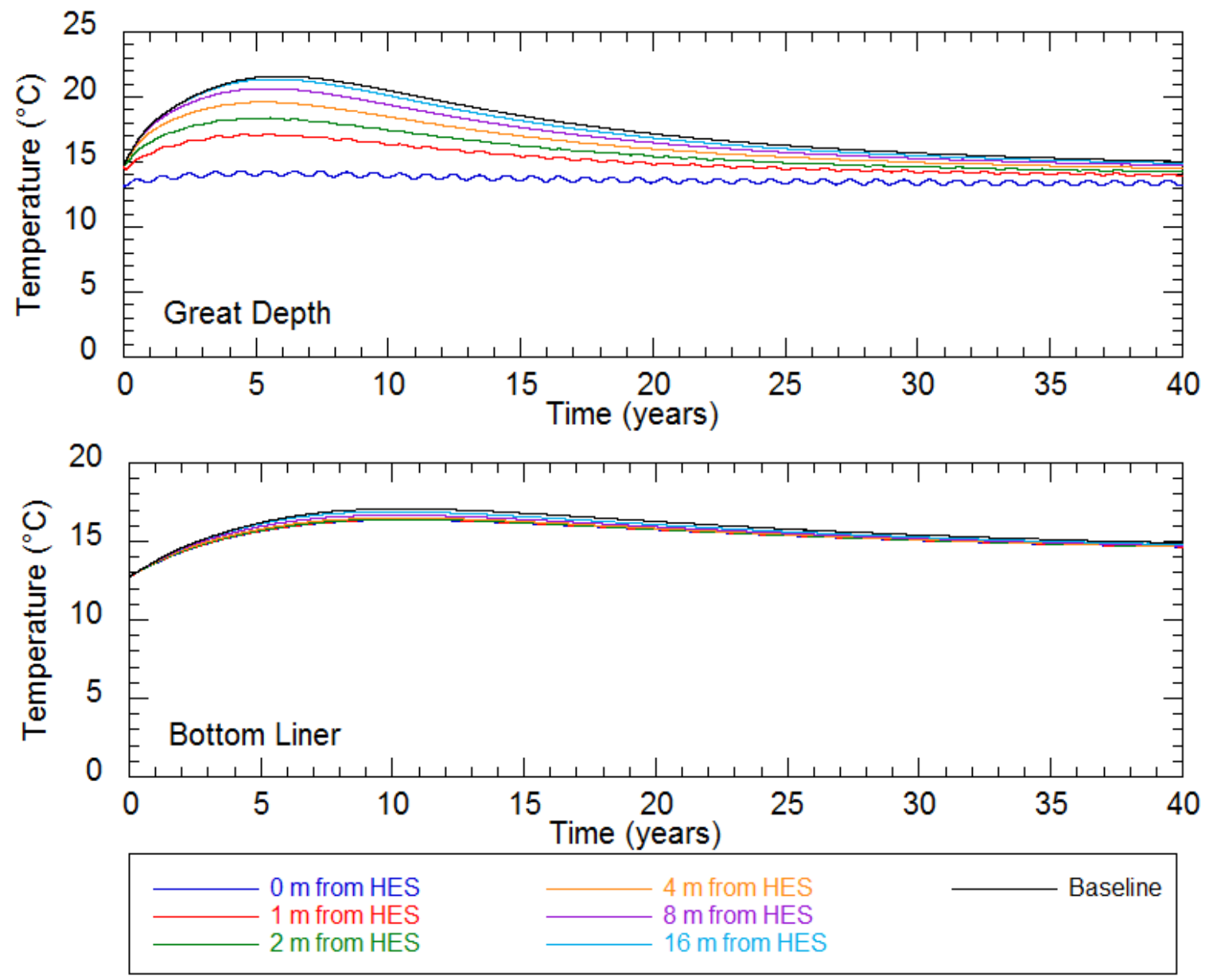

Figure A.49b: Temperature Results: Winter-Only Waste Placement

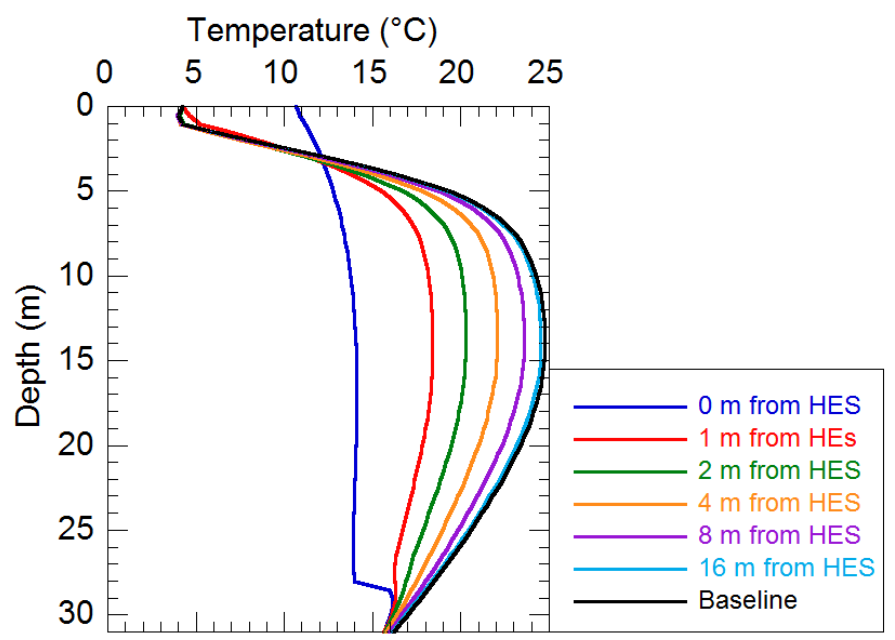

Figure A.50: Vertical Temperature Results: Winter-Only Waste Placement 

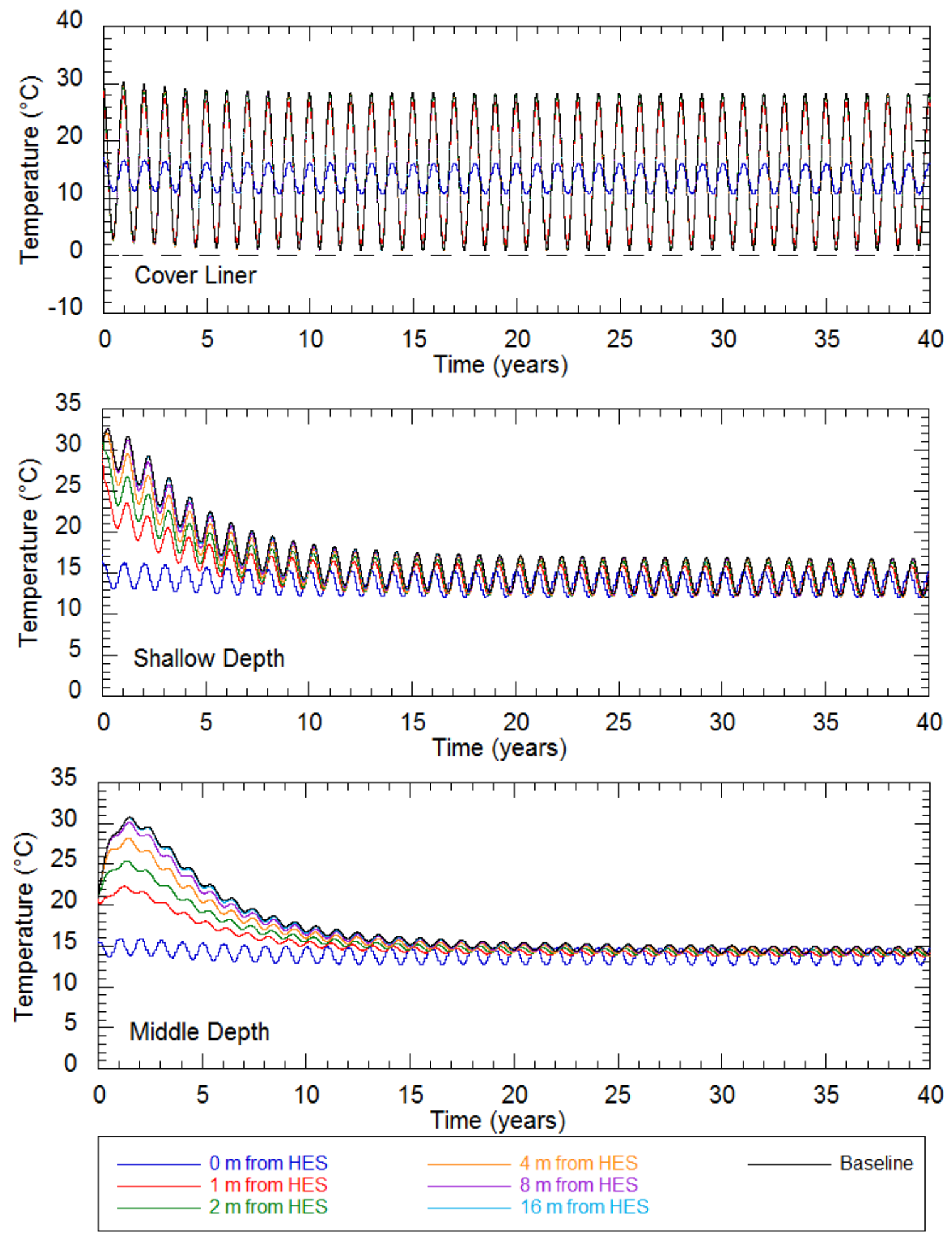

Figure A.51a: Temperature Results: 15 m Waste Height 

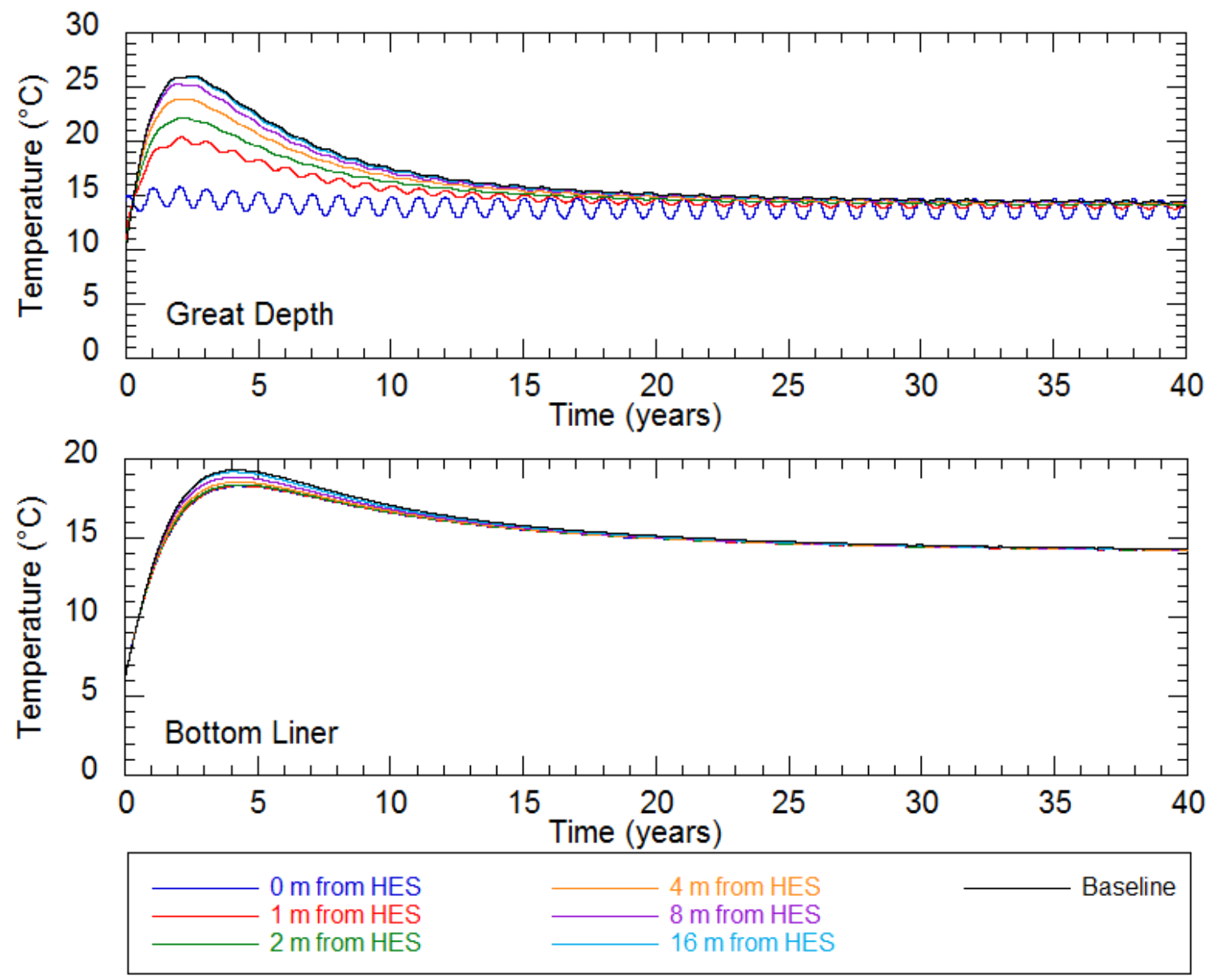

Figure A.51b: Temperature Results: 15 m Waste Height

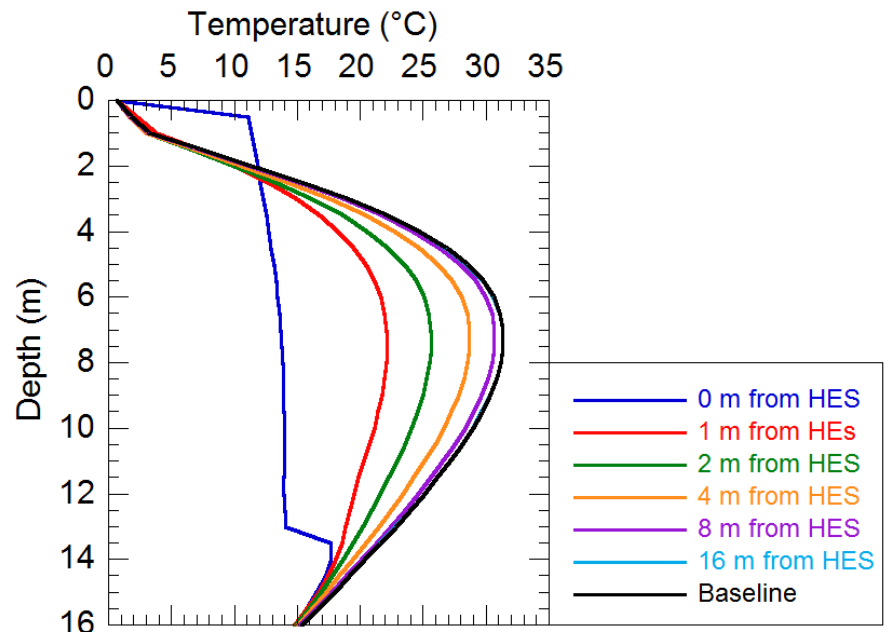

Figure A.52: Vertical Temperature Results: 15 m Waste Height 

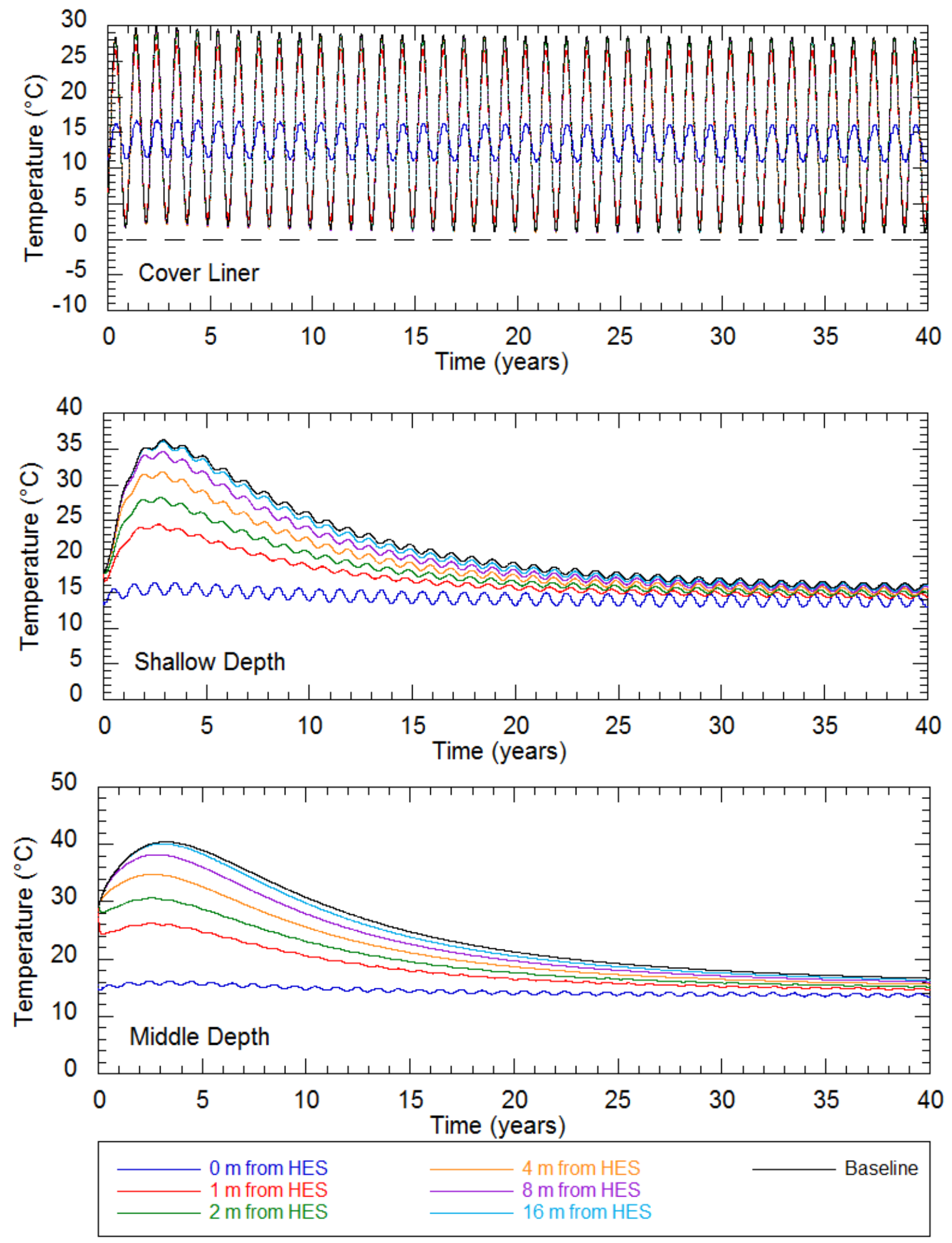

Figure A.53a: Temperature Results: 15 m/year Waste Filling Rate 

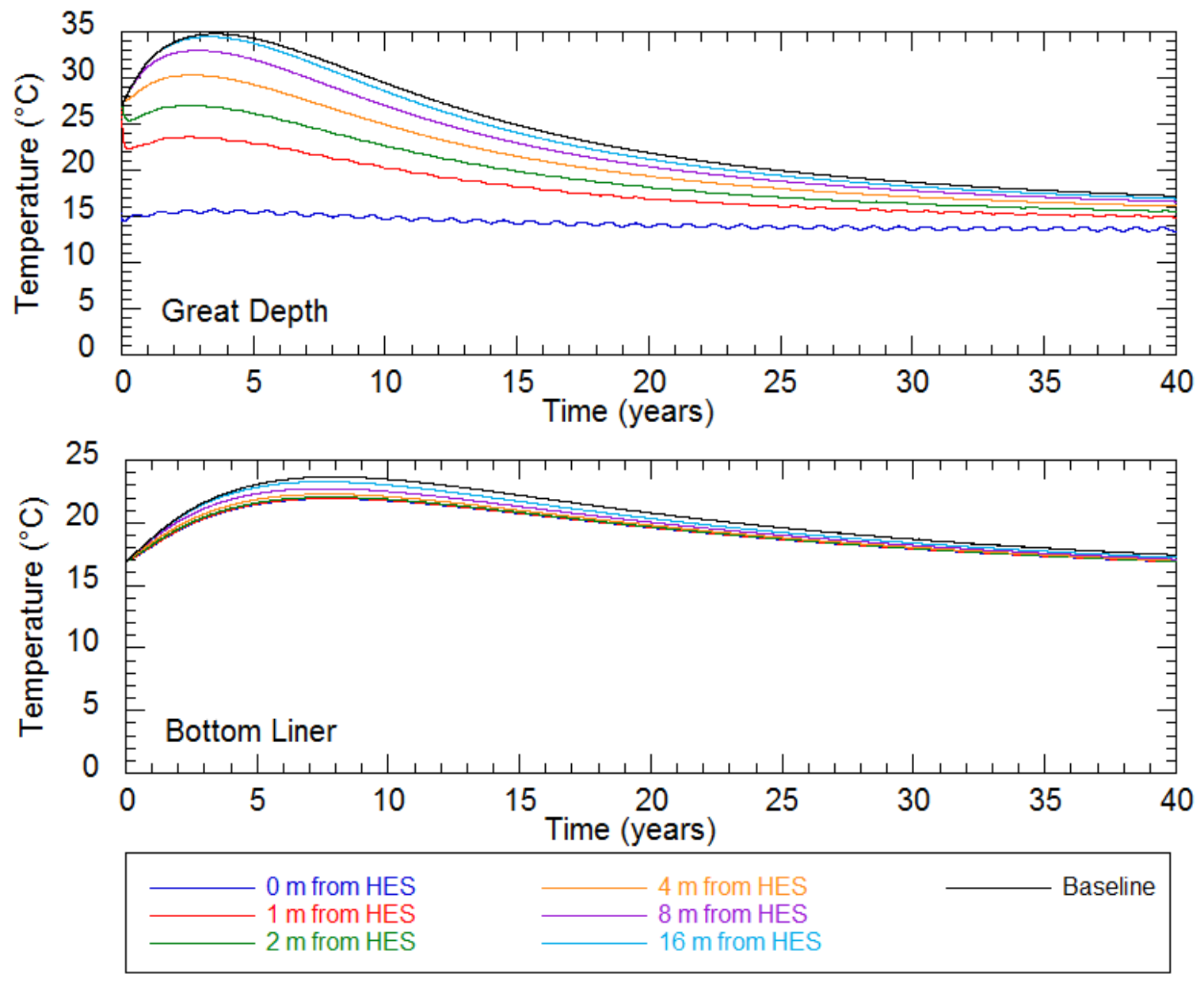

Figure a.53b: Temperature Results: 15 m/year Waste Filling Rate

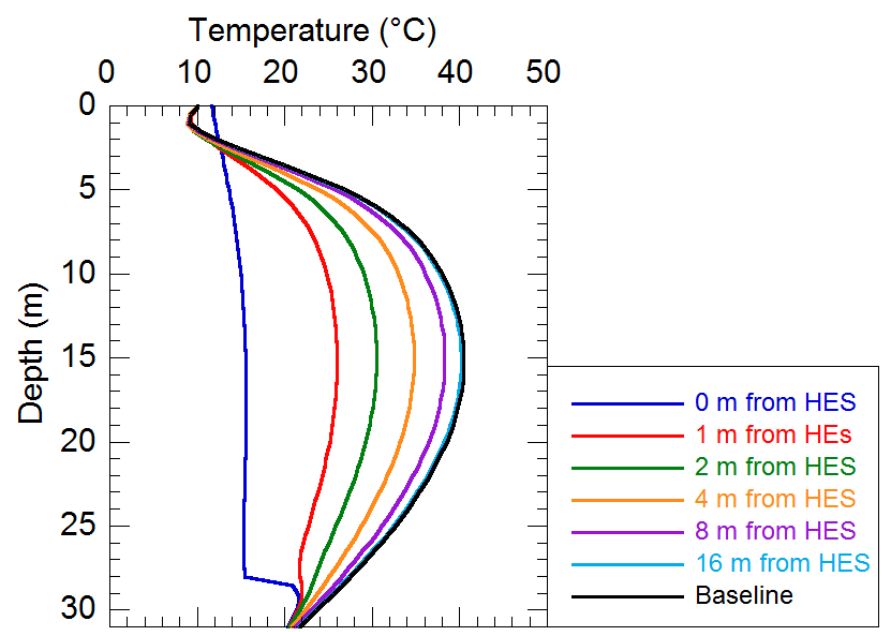

Figure A.54: Vertical Temperature Results: 15 m/year Waste Filling Rate 

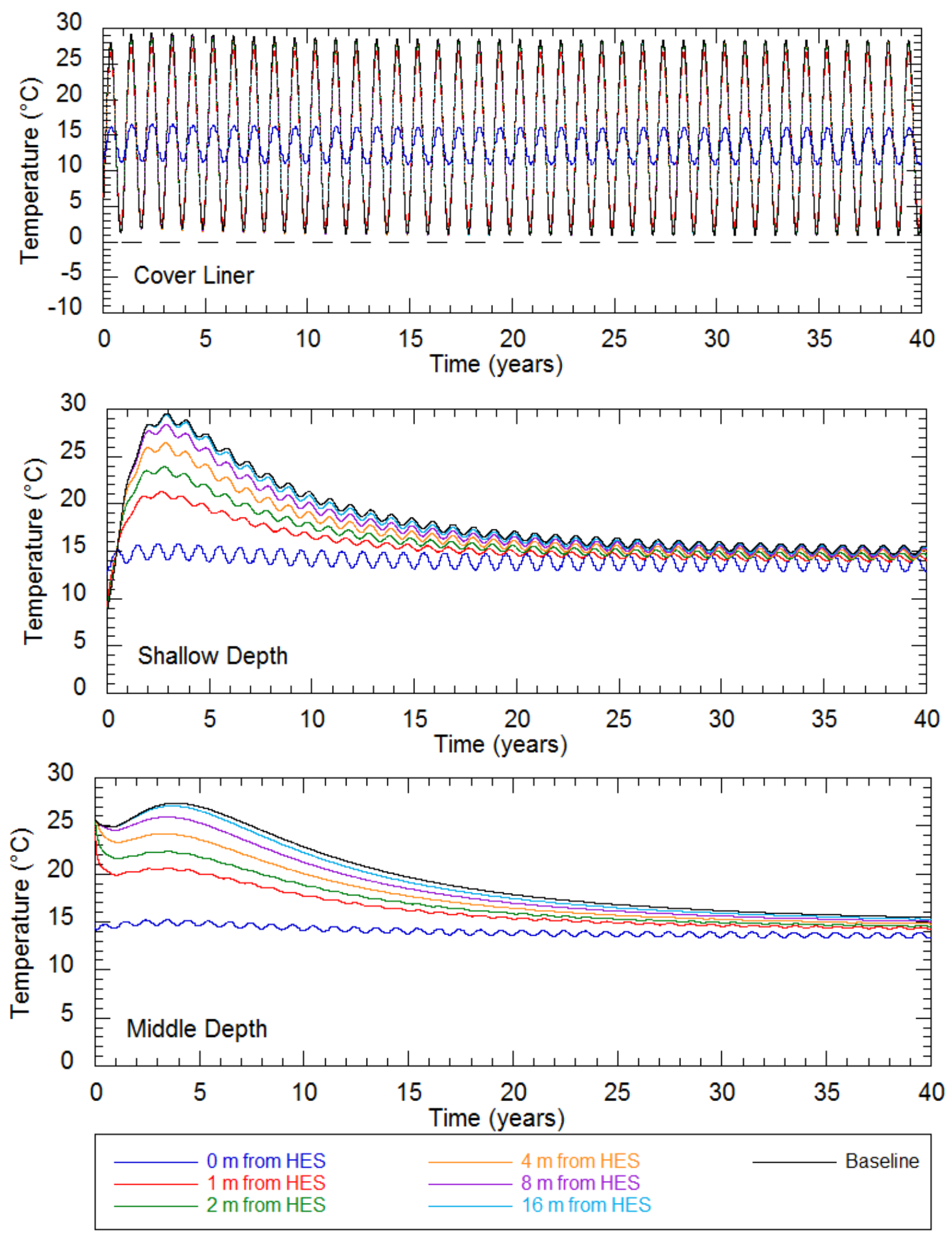

Figure A.55a: Temperature Results: 15 Years between Original Waste Placement Landfill Vertical Expansion 

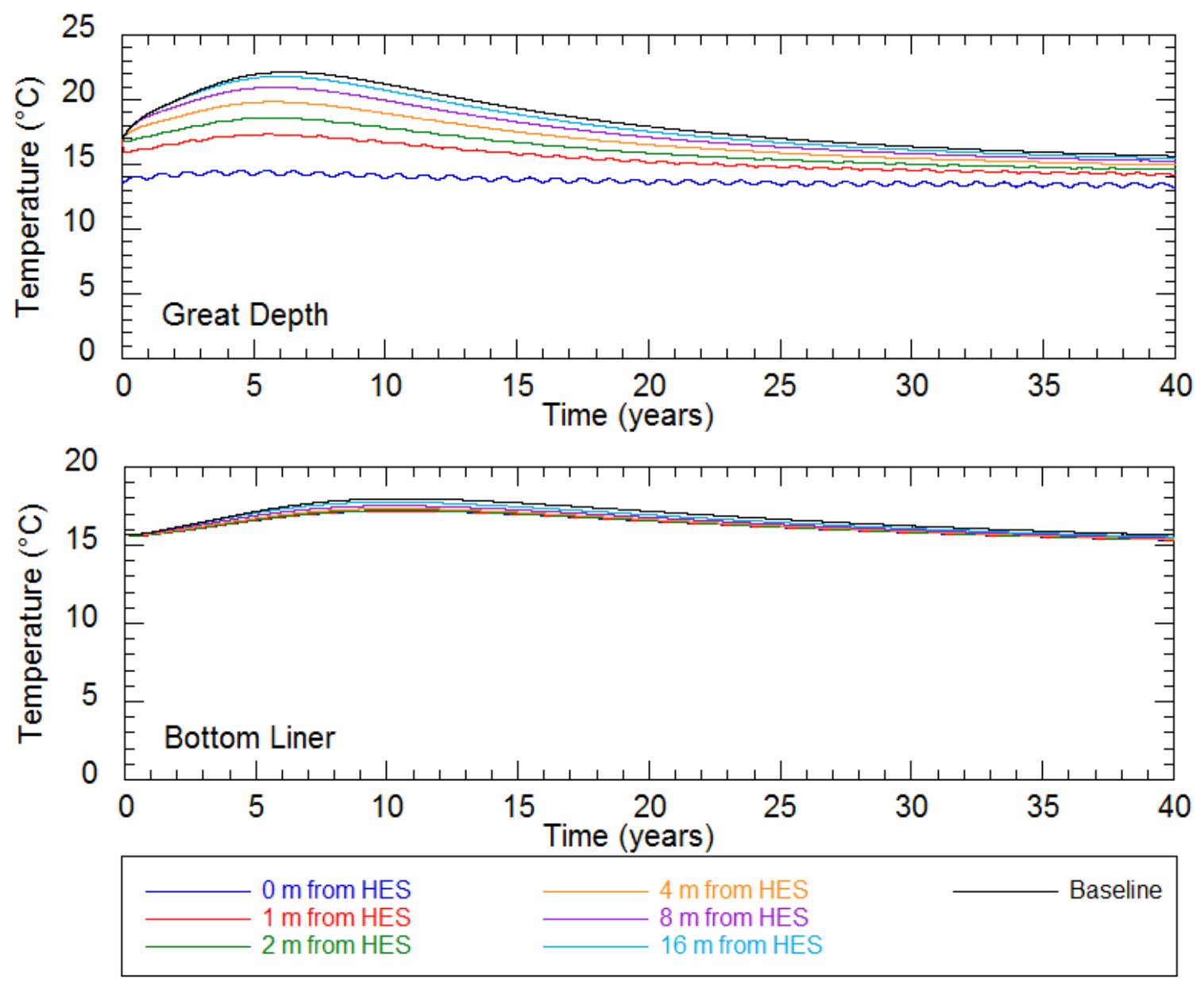

Figure A.55b: Temperature Results: 15 Years between Original Waste Placement Landfill Vertical Expansion

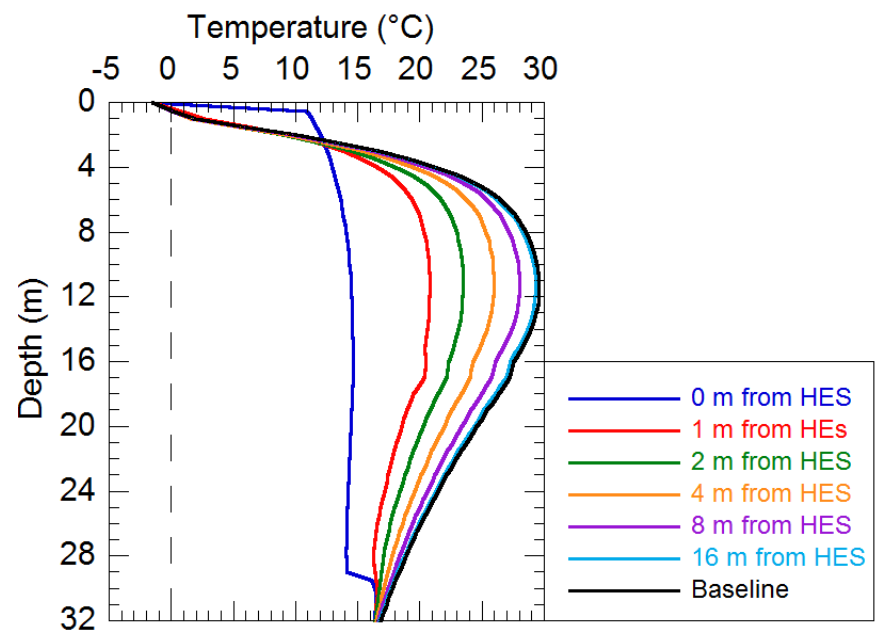

Figure A.56: Vertical Temperature Results: 15 Years between Original Waste Placement Landfill Vertical Expansion 

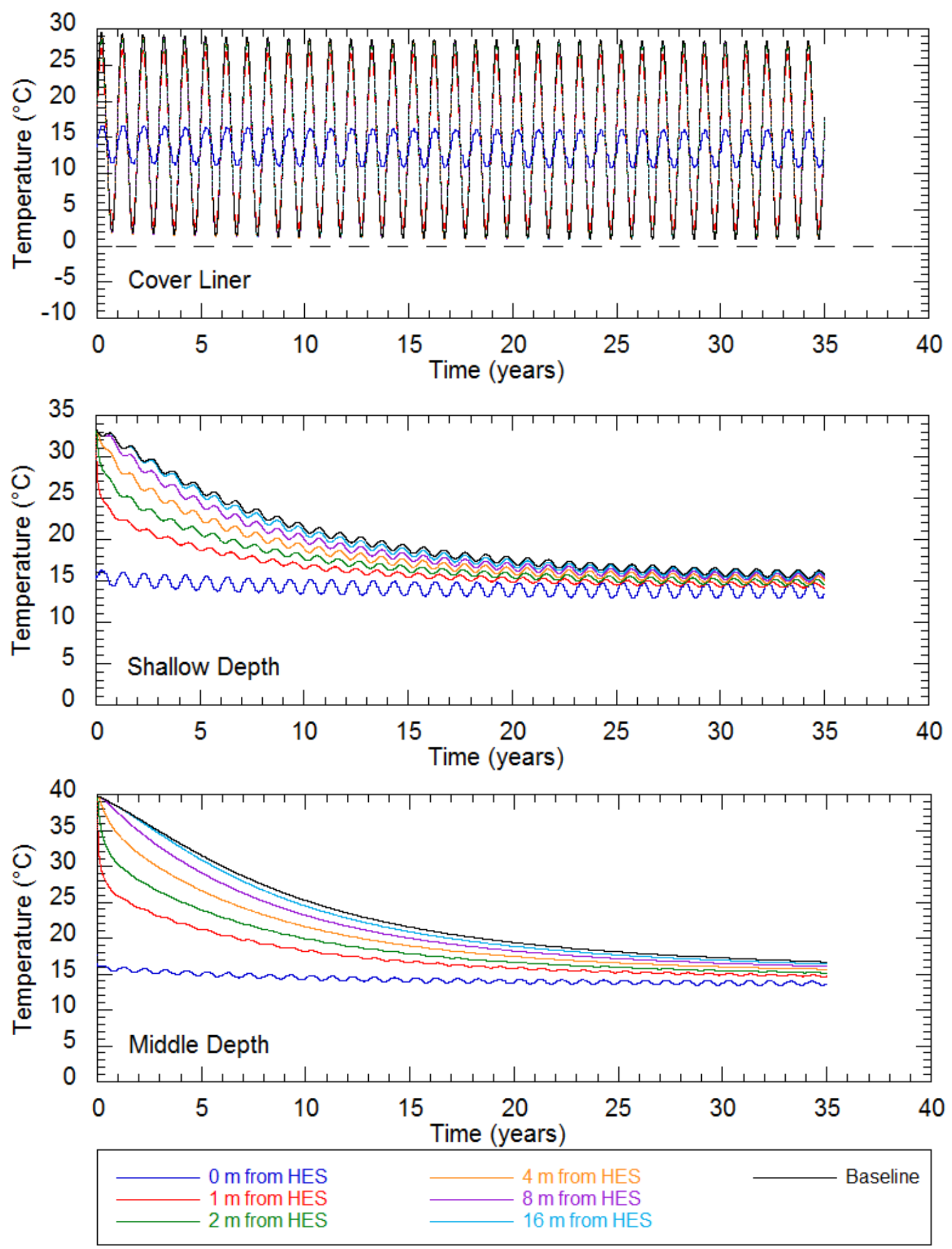

Figure A.57a: Temperature Results: HES Placement 5 Years after Cover Construction 

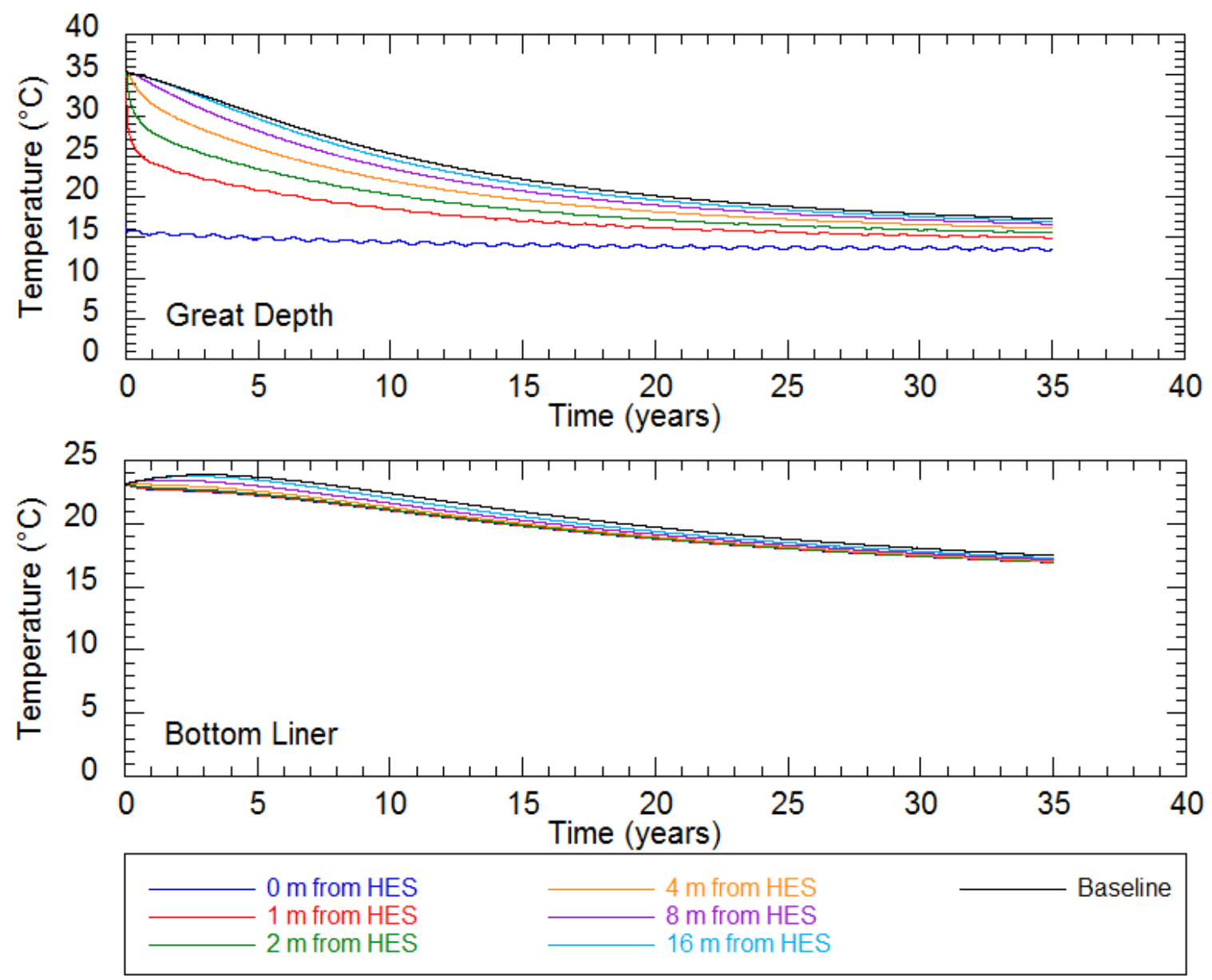

Figure A.57b: Temperature Results: HES Placement 5 years after Cover Construction

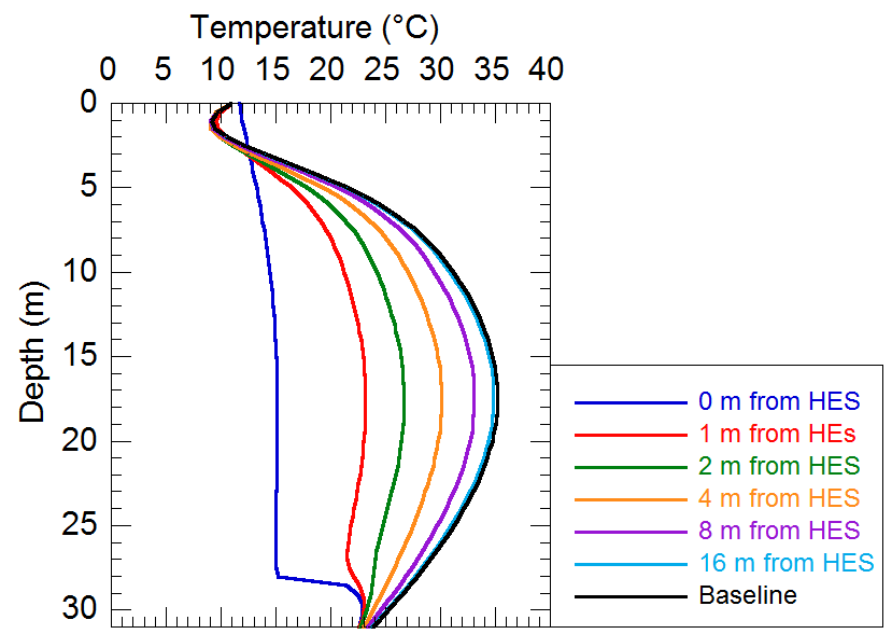

Figure A.58: Vertical Temperature Results: HES Placement 5 years after Cover Construction 

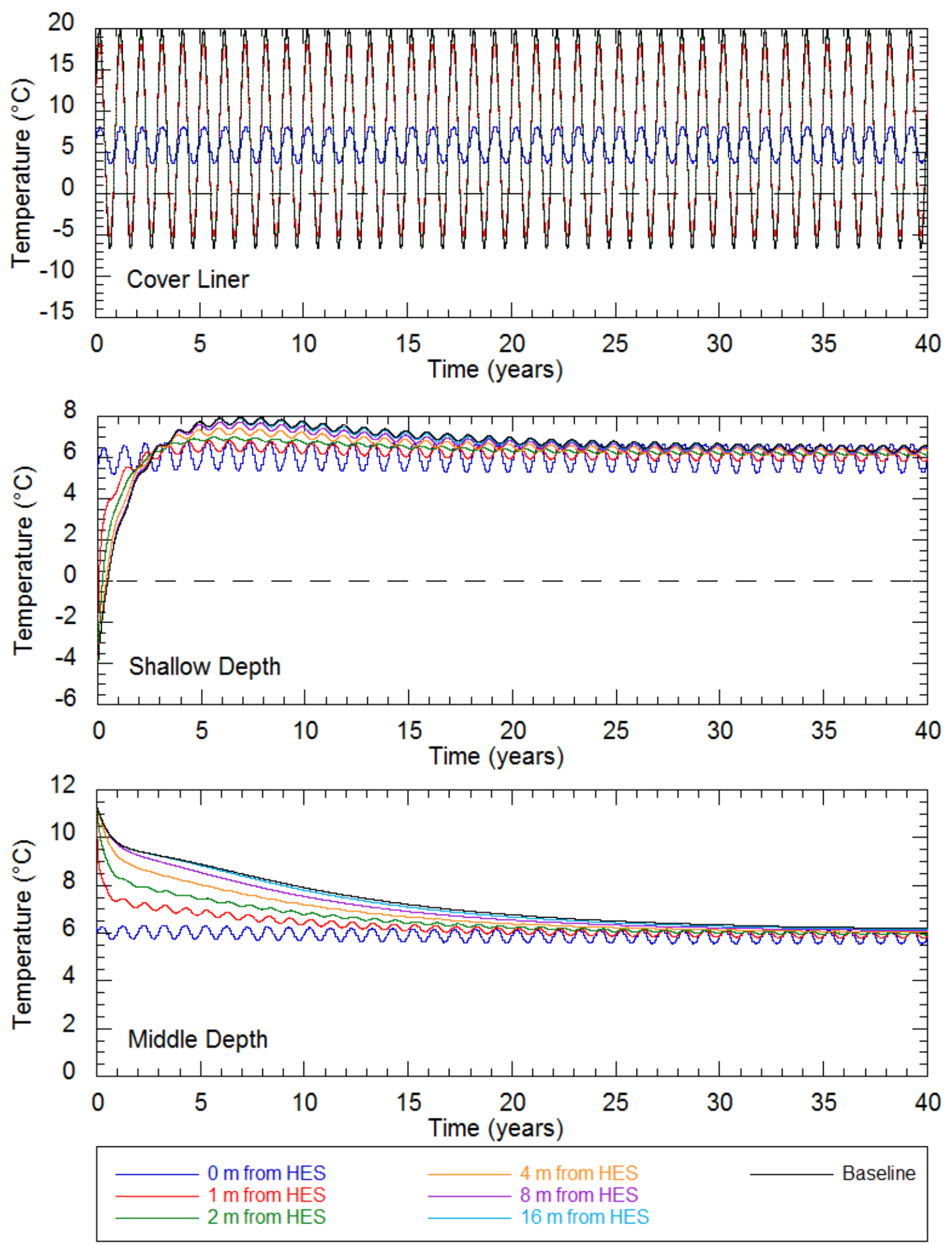

Figure A.59a: Temperature Results: Alaska Climate 

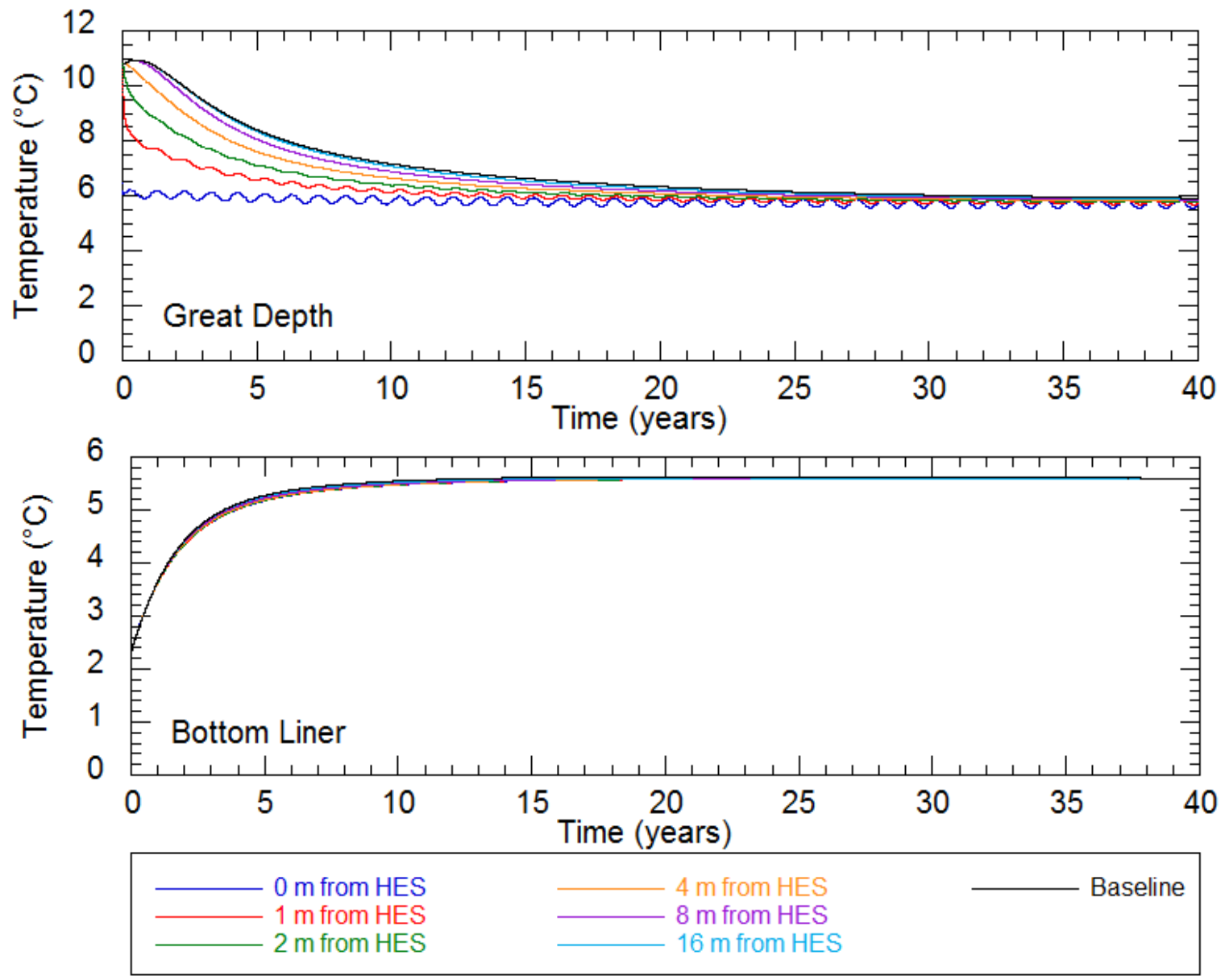

Figure A.59b: Temperature Results: Alaska Climate

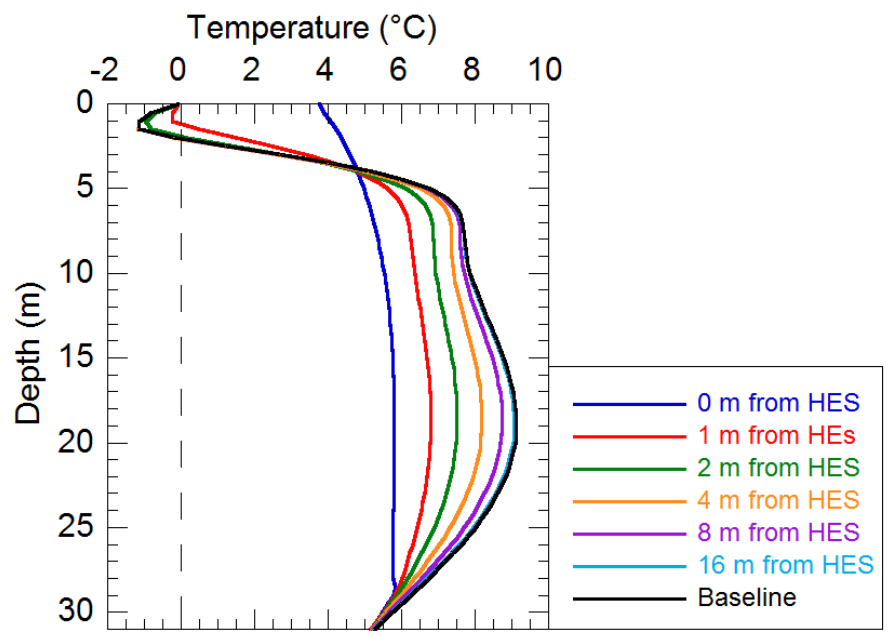

Figure A.60: Vertical Temperature Results: Alaska Climate 

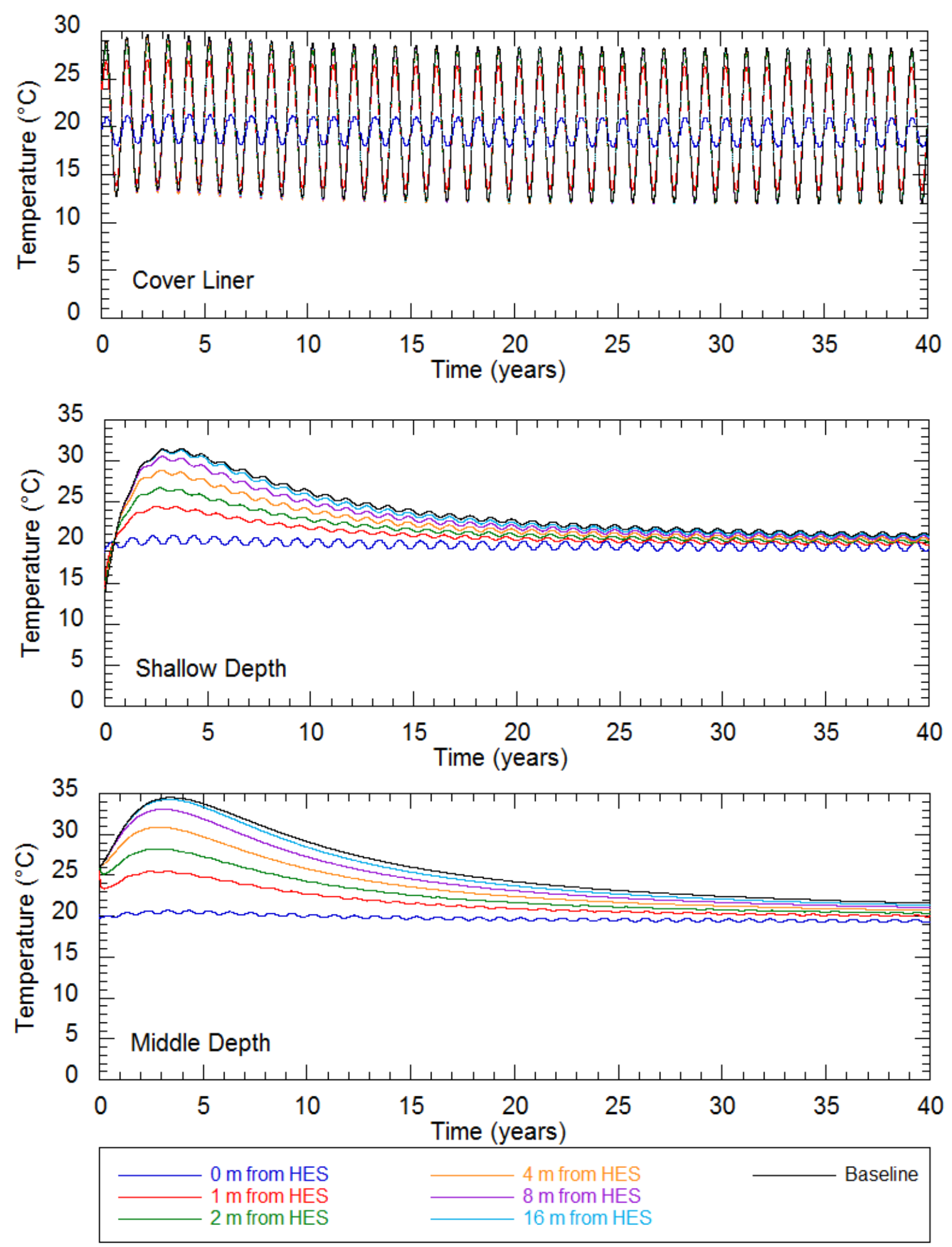

Figure A.61a: Temperature Results: New Mexico Climate 

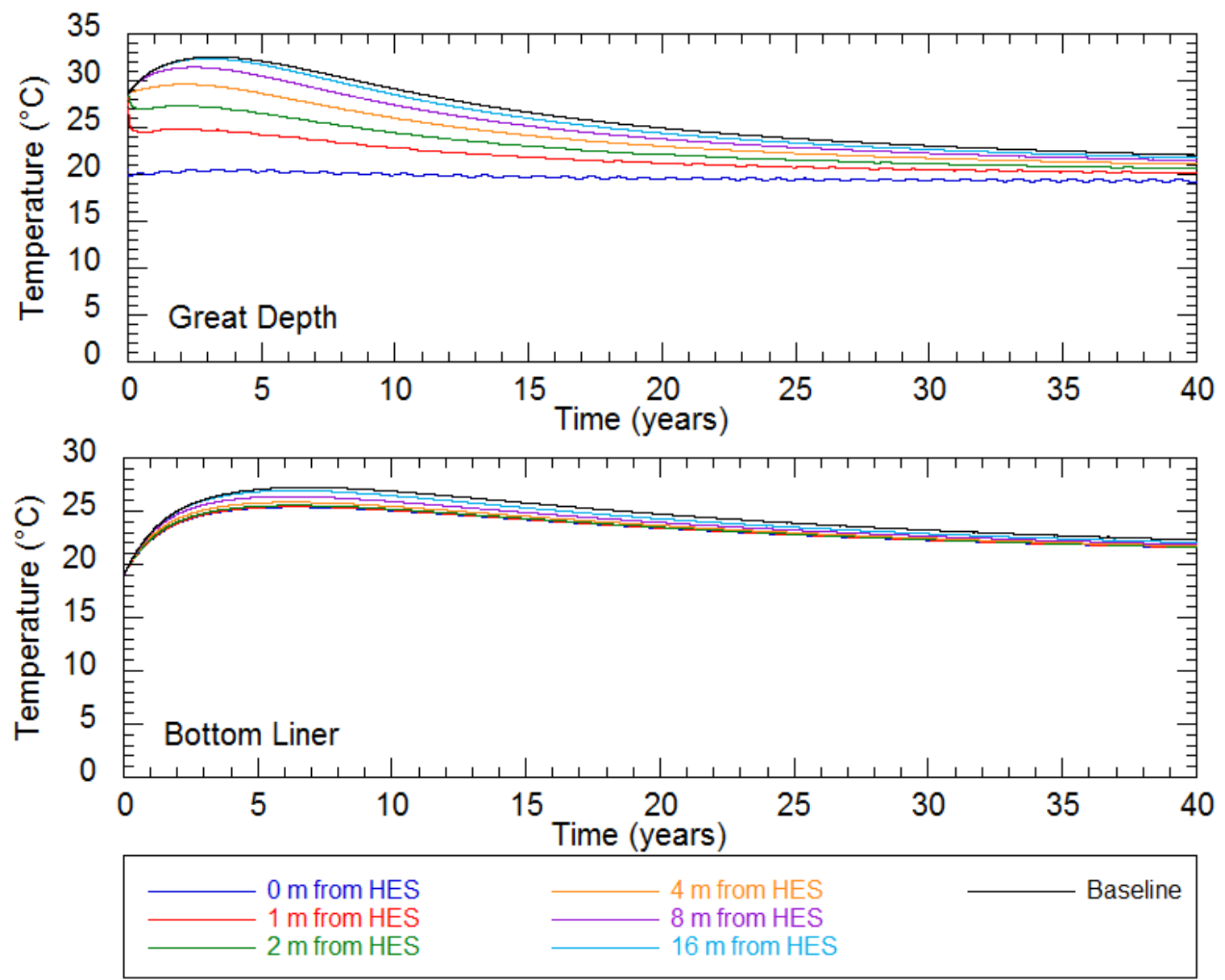

Figure A.61b: Temperature Results: New Mexico Climate

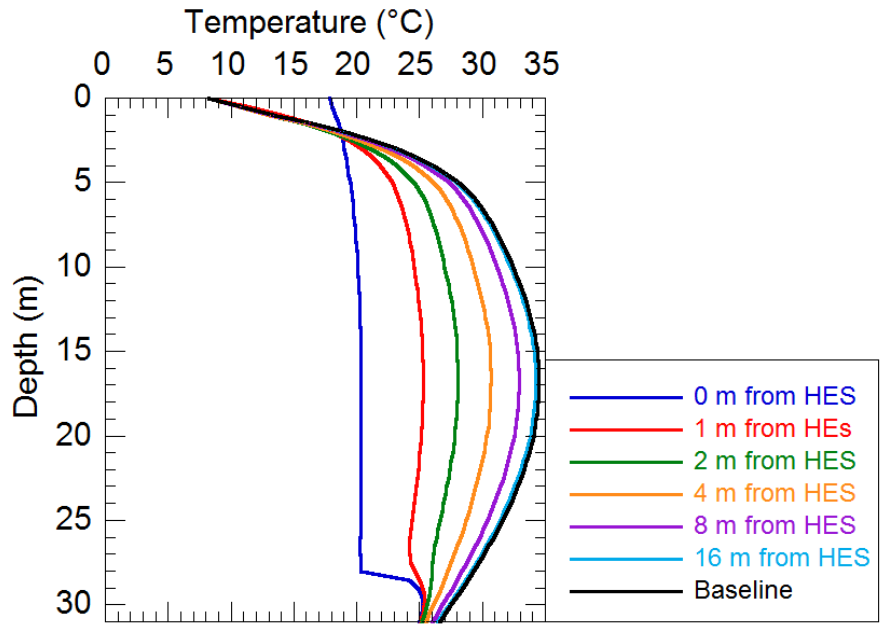

Figure A.62: Vertical Temperature Results: New Mexico Climate 